André Mendes Moreira

Tese de Doutorado

\title{
NÃO-CUMULATIVIDADE TRIBUTÁRIA NA CONSTITUIÇÃO E NAS LEIS (IPI, ICMS, PIS/COFINS, IMPOSTOS E CONTRIBUIÇÕES RESIDUAIS)
}

Orientador: Prof. Titular Paulo de Barros Carvalho

Faculdade de Direito da USP

São Paulo 
André Mendes Moreira

\section{NÃO-CUMULATIVIDADE TRIBUTÁRIA NA CONSTITUIÇÃO E NAS LEIS (IPI, ICMS, PIS/COFINS, IMPOSTOS E CONTRIBUIÇÕES RESIDUAIS)}

Tese de doutorado apresentada ao Curso de Pós-Graduação da Faculdade de Direito da Universidade de São Paulo, como requisito parcial para obtenção do título de Doutor em Direito.

Orientador: Professor Titular Paulo de Barros Carvalho Área de Concentração: Direito Econômico e Financeiro Faculdade de Direito da USP São Paulo 
Tese defendida em e pela banca examinadora constituída pelos Professores:

Prof. Dr. Paulo de Barros Carvalho (Orientador - USP)

Prof. Dr.

Prof. Dr.

Prof. Dr.

Prof. Dr. 


\section{AGRADECIMENTOS}

Longe de ser um trabalho individual, esta tese é fruto de uma experiência que tenho o privilégio de vivenciar há uma década, que é o convívio com dois baluartes do Direito Tributário Brasileiro: Professores Sacha Calmon Navarro Coêlho e Misabel Abreu Machado Derzi. Palavras seriam poucas e incipientes para descrever meu sentimento de gratidão para com ambos, que, a cada parágrafo, se fazem presentes. É aos Professores Sacha e Misabel, portanto, que quero registrar, penhoradamente, os meus agradecimentos pela consecução do trabalho.

Outrossim, recordo-me de forma vívida da primeira vez em que, pessoalmente, conheci o Prof. Paulo de Barros Carvalho, meu orientador nesta novel empreitada. Era dia 29 de junho de 2005 quando, no anexo da Sala da Congregação da Faculdade de Direito da UFMG, fui a ele apresentado, minutos antes do início de minha argüição de mestrado. Já o conhecia previamente, por meio de suas obras e de sua ímpar trajetória acadêmica. Todavia, não posso deixar de mencionar a minha satisfação com o seu aceite para conduzir-me por este novo caminho, que é a titulação perante a Faculdade de Direito do Largo de São Francisco. Tive a oportunidade de conviver mais com a ilustre figura do Prof. Paulo de Barros Carvalho, assim como de conhecer um novo círculo de pessoas, das mais variadas origens, igualmente dedicadas ao estudo do Direito Tributário Brasileiro - pelo que manifesto minha profunda gratidão.

Também quero registrar meus agradecimentos ao Prof. Eduardo Maneira. Com sua visão de mundo e inteligência absolutamente privilegiadas, o Prof. Eduardo tem sido um constante apoiador de minha carreira e meus estudos, desde o início. 
Agradeço aos meus pais, Ozires e Maria José e à minha irmã Lívia, pelo apoio e pela compreensão das minhas ausências, dadas as consabidas dificuldades de se conciliar a advocacia tributária com o crescimento acadêmico, ambos tão caros para mim.

Agradeço, outrossim, a algumas pessoas com as quais o convívio tem iluminado minha vida, cada qual à sua maneira:

Ao Prof. Igor Mauler Santiago, exemplo de dedicação e brilhantismo acadêmico;

Ao Prof. Valter Lobato, que gentilmente compartilhou comigo seus profundos conhecimentos sobre a não-cumulatividade tributária;

À querida amiga Juliana Junqueira Coelho, companheira fiel da luta diária da advocacia;

À caríssima Paula Derzi Botelho, de cuja amizade tenho a satisfação e honra de privar;

Aos Drs. Eduardo Junqueira Coelho e Sandra Maria Dias Nunes, cuja elevada expertise sobre a tributação no plano federal sempre produz diálogos inteligentes e profícuos;

Ao Dr. Antonio Reinaldo Rabelo Filho, caríssimo amigo, companheiro de batalha e exemplo de profissional;

Ao Prof. Tácio Lacerda Gama, há alguns anos incluído no rol de amigos pelas afinidades que reciprocamente encontramos, o que muito me honra;

Aos Mestres em Direito Tributário Gabriel Prado Amarante de Mendonça e Donovan Mazza Lessa, com os quais enfrento as dificuldades do labor da advocacia, sem, porém, nunca perder o bom humor - condição fundamental para o sucesso de qualquer empreitada;

A todos os advogados, paralegais, funcionários e estagiários do escritório Sacha Calmon - Misabel Derzi Consultores e Advogados, com os quais partilho a porfia diária da tributarística aplicada, que permitiram o meu afastamento para a conclusão desta tese. No- 
minalmente, permito-me citar algumas pessoas que, pela proximidade diária, tiveram fundamental participação na consecução do trabalho: Dra. Patrícia Dantas Gaia, Dr. Guilherme Camargos Quintela, Dra. Alice Gontijo Santos Teixeira, Dra. Gabriela Barroso Gonzaga Ferreira Porto, Dra. Virgínia Fontes Simões, Dr. Rafael França Savassi Longo e Dr. Fabrício Costa Resende de Campos.

Agradeço, ainda, aos Drs. Hildegard Gouvêa e Thiago Lage, pela colaboração na pesquisa doutrinária.

Por fim, mas não menos importante, agradeço à Dra. Isadora de Assis e Souza, pelo cuidado com que revisou o texto final do trabalho. 


\section{DEDICATÓRIA}

Este trabalho é dedicado àquela que me acompanha há onze anos, testemunhando tudo aquilo - de bom, em sua maioria, e de ruim, felizmente em menor parte - que tem se passado comigo desde então: minha esposa, Maria Eduarda, a quem devoto pleno amor, sempre certo de ser retribuído na mesma medida. 
“O tributo é vetusta e fiel sombra do poder político há mais de 20 séculos. Onde se ergue um governante, ela se projeta sobre o solo de sua dominação.” (ALIOMAR BALEEIRO) 


\section{RESUMO}

A tese se inicia com o delineamento das linhas mestras do instituto da nãocumulatividade, estremando-o da tributação indireta e concluindo que, no Brasil, apenas o ICMS e o IPI são tributos verdadeiramente não-cumulativos. A contribuição para o PIS e a COFINS são, sob esse prisma, dotadas da não-cumulatividade lato sensu, ou seja: de um modus operandi de apuração do tributo regido apenas em parte pela não-cumulatividade clássica. Afinal, para ser verdadeiramente não-cumulativo o tributo deve ser plurifásico, o que implica a incidência sobre diversos estádios do processo de produção de mercadorias ou prestação de serviços. Exações cujo critério material da regra-matriz de incidência consiste em atos isolados (tal como o auferimento de receitas, gravadas pelo PIS/COFINS), impassíveis de inserção no bojo de um processo de circulação jurídica de bens e serviços, não podem ser consideradas não-cumulativas em sua forma estrita.

Outrossim, a exigência de duas operações tributadas em seqüência para que o direito ao crédito seja exercido, mesmo no caso do IPI (em que inexiste tal restrição na Constituição) é também abordada. Tendo em vista que a jurisprudência do STF se consolidou nesse sentido, aponta-se, contudo, uma incoerência no raciocínio: no caso de operações isentas, em que a norma tem por objetivo reduzir a carga tributária sobre o produto ou serviço, a vedação do aproveitamento e transporte de créditos produz os efeitos contrários aos buscados pela norma. Ademais, considerando que o STF entende ser a isenção dispensa legal de tributo devido, há incidência do tributo na operação isenta, cujo pagamento é, todavia, dispensado pela atuação secundária da regra isencional ${ }^{\mathrm{i}}$. Assim, não se poderia falar em ausência de tributação e conseqüente vedação do aproveitamento e transporte do crédito.

No que tange ao conteúdo material do princípio da não-cumulatividade, a evolução legislativa e constitucional, constantemente interpretada pelos Tribunais, trouxe o instituto à sua atual conformação, que assegura o crédito sobre matérias-primas, produtos intermediários e materiais de embalagem utilizados na produção industrial ou na prestação de serviços. Para além desse núcleo mínimo de direito ao crédito, a lei poderá - sem que isso configure outorga de incentivo fiscal, pois estará dentro do escopo da não-cumulatividade - autorizar o creditamento sobre bens destinados ao ativo imobilizado e materiais de uso e

\footnotetext{
${ }^{\mathrm{i}}$ Para nós, contudo, a isenção consiste em uma mutilação no antecedente da regra-matriz de incidência, obstando o próprio nascimento da obrigação tributária. Entrementes, considerando que se está analisando o entendimento do próprio STF acerca dos efeitos da isenção nos tributos não-cumulativos, é mais coerente partir-se dos conceitos vincados pela Corte Suprema para proceder às críticas sobre sua jurisprudência.
} 
consumo que não sejam diretamente empregados no processo de produção ou prestação de serviço. Ao se fazer a opção pela ampliação do escopo da não-cumulatividade, muda-se o tipo de imposto sobre o valor acrescido (IVA) adotado no Brasil: de um IVA tipo Produto Bruto (regido pelo crédito físico) para um IVA tipo Renda ou Consumo (em que se admitem créditos, à vista ou fracionados ${ }^{\mathrm{ii}}$, sobre os bens destinados ao ativo imobilizado e ao uso e consumo).

Este é o cenário posto pela jurisprudência do Supremo Tribunal Federal, há decênios. Baseando-se nessa premissaii a tese busca conceituar adequadamente as matériasprimas, materiais de embalagem e, principalmente, os produtos intermediários que geram créditos nos tributos não-cumulativos. À míngua de um detalhamento adequado desses produtos, o núcleo mínimo da não-cumulatividade tributária tem sido mutilado pela jurisprudência. Afinal, bens intermediários, segundo definição legal em vigor desde a década de $1960^{\text {iv }}$, são aqueles consumidos no processo de produção. Portanto, requisitos como o contato físico direto com o produto fabricado, erigidos para a sua caracterização, são ilegais e devem ser afastados em atenção ao brocardo de que se a lei não distingue, não cabe ao intérprete distinguir. Outrossim, descabe a distinção entre emprego direto ou indireto do bem intermediário no processo de produção, eis que a lei tampouco opera tal diferenciação. Desde que o produto seja consumido no processo de industrialização ou prestação de serviço, dele fazendo parte como elemento essencial, será imprescindível - sob pena de ilegalidade - o reconhecimento do direito ao crédito. Os bens ditos de uso e consumo, em verdade, são aqueles alheios à produção, como, por exemplo, materiais utilizados na seção administrativa da empresa. É possível, ainda, que materiais de uso e consumo sejam também utilizados no setor operacional. Nesses casos, os bens não se relacionarão com o processo de fabricação ou prestação do serviço em si, tal como se dá com os produtos de limpeza externa das instalações, maquinário e veículos das empresas ${ }^{\mathrm{v}}$.

\footnotetext{
ii A diferença entre os IVAs tipo Renda e Consumo reside exatamente na forma de apropriação dos créditos das aquisições para o ativo imobilizado: fracionadamente, observando o período de depreciação do bem no primeiro caso; e à vista, com estorno posterior em caso de alienação antes de decorrido o período de depreciação, na segunda hipótese.

iii Apesar de não concordarmos com a restrição ao crédito perfilhada pela jurisprudência do STF, a existência de centenas de acórdãos prolatados no mesmo sentido desde a década de 1960 fez-nos optar pela consideração, para fins metodológicos, da não-cumulatividade como garantia tão-somente do crédito físico.

${ }^{\text {iv }}$ Lei ${ }^{\circ}$ 4.502, de 30 de novembro de 1964, que atualmente rege o IPI.

v Não se incluem nesse conceito, por óbvio, os produtos utilizados para limpeza e lubrificação interna das máquinas em geral, que se afiguram como essenciais ao seu funcionamento e, via de conseqüência, ao processo produtivo.
} 
A adequada conceituação dos produtos intermediários é fundamental, ainda, para que a não-cumulatividade continue operando seus efeitos quando aplicada ao segmento de prestação de serviços. Nesta atividade, como não há matérias-primas (pois nada se integra ao produto final, que é intangível) ou materiais de embalagem, apenas os produtos intermediários geram direito ao creditamento. A restrição do conceito de bem intermediário operada pela jurisprudência - que, no entanto, nunca discutiu o tema de forma aprofundada - pode, em última análise, anular a não-cumulatividade tributária para o segmento de prestação de serviços, o que, sobre ser indesejável, é inconstitucional.

Essas as balizas que, em síntese, estão assentadas no presente trabalho.

Palavras-chave: tributário - não-cumulatividade - crédito - impostos - contribuições neutralidade. 


\section{RIASSUNTO}

La tesi inizia delineando le caratteristiche principali dell'istitutuzione della non cumulatività, separandola dal tributo indiretto e concludendo che in Brasile soltanto l' ICMS e l' IPI sono tributi realmente non cumulativi. I tributi versati al PIS e alla COFINS sono, da questo punto di vista, dotati della non cumulatività lato sensu, ossia: di un modus operandi di controllo del tributo retto solo in parte dalla non cumulatività classica. Infine, per essere veramente non cumulativo, il tributo deve essere plurifasico, il che comporta l'incidenza su diversi stadi del processo di produzione di merci o prestazione di servizi. Esazioni il cui criterio materiale della regola madre di incidenza consiste in atti isolati (così come la ricevuta di entrate, gravate dal PIS/COFINS), non passibili di essere inserite all'interno di un processo di circolazione giuridica di beni e servizi, non possono essere considerate non cumulative in senso stretto.

Allo stesso modo, si approccia l'esigenza di due operazioni tributate in sequenza perché sia esercitato il diritto al credito, considerando anche il caso dell' IPI (in cui tale restrizione non esiste nella Costituzione). Tenendo in conto che la giurisprudenza del STF si è consolidata in tal senso, si segnala, nonostante tutto, una incoerenza di raziocinio: nel caso delle operazioni esenti, in cui la norma ha come obiettivo la riduzione del carico tributario sul prodotto o servizio, il divieto di profitto e trasporto di crediti produce l'effetto contrario a quello perseguito dalla norma. Non solo, considerando che il STF intende che l'esenzione sia dispensa legale di tributo dovuto, vi è incidenza del tributo sull'operazione esente, il cui pagamento è tuttavia dispensato dall'attuazione secondaria della regola di esenzione $^{\mathrm{vi}}$. In questo modo, non si potrebbe parlare di assenza di tributo e conseguente divieto di profitto e trasporto del credito.

Riguardo al contenuto materiale del principio della non cumulatività, l' evoluzione legislativa e costituzionale, costantemente interpretata dai Tribunali, ha portato l'istitutuzione alla sua attuale conformazione, che assicura il credito sulle materie prime, sui prodotti intermediari e materiali da imballo usati nella produzione industriale o nella prestazione di servizi. Oltre a questo esiguo nucleo di diritto al credito, la legge potrà senza che questo rappresenti concessione di incentivo fiscale, poiché rientrerà nello scopo della non cumulatività - autorizzare l'accredito sui beni destinati all'attivo immobilizzato e

\footnotetext{
${ }^{\text {vi }}$ A nostro avviso, tuttavia, l'esenzione consiste in una mutilazione nei precedenti della regola madre di incidenza, opponendosi all'origine stessa dell'obbligo tributario. Frattanto, considerando che si sta analizzando la concezione dello stesso STF riguardo agli effetti dell'esenzione nei tributi non cumulativi, è più coerente partire dai concetti fissati dalla Corte Suprema per procedere alle critiche sulla giurisprudenza che adotta.
} 
ai materiali d'uso e consumo che non siano direttamente impiegati nel processo di produzione o prestazione di servizi. Quando si sceglie di ampliare lo scopo della non cumulatività, si cambia il tipo di imposta sul valore aggiunto (IVA) adottato in Brasile: si passa da un' IVA tipo Prodotto Lordo (retto dal credito fisico) ad un' IVA tipo Reddito o Consumo (in cui si ammettono crediti, in contanti o a rate ${ }^{\text {vii }}$, sui beni destinati all' attivo immobilizzato e all'uso e consumo).

È questo lo scenario proposto da decenni dalla giurisprudenza del Supremo Tribunale Federale. Basandosi su questa premessa ${ }^{\text {viii }}$, la tesi cerca di definire un concetto adeguato di materie prime, materiali da imballo e, soprattutto, di prodotti intermedi che generano credito nei tributi non cumulativi. In mancanza di una adeguata specificazione di tali prodotti, il nucleo minimo della non cumulatività tributaria viene ad essere mutilato dalla giurisprudenza. Infine, beni intermedi, secondo definizione legale in vigore dagli anni ' 60 ix , sono quelli consumati nel processo di produzione. Pertanto, requisiti come il contatto fisico diretto con il prodotto fabbricato, eretti per la loro caratterizzazione, sono illegali e devono essere rinnegati secondo il principio che sentenzia che se la legge non distingue, non spetta all' interprete distinguere. Allo stesso modo, non è opportuna la distinzione tra impiego diretto o indiretto del bene intermedio nel processo di produzione, dato che nemmeno la legge non opera tale differenziazione. Dal momento che il prodotto sia consumato nel processo di industrializzazione o prestazione di servizi, facendone parte come elemento essenziale, sarà imprescindibile - pena l'illegalità - il riconoscimento del diritto al credito. I cosidetti beni di uso e consumo, in verità, sono quelli estranei alla produzione, come, ad esempio, materiali usati nella sezione amministrativa dell'azienda. È anche possibile che materiali di uso e consumo siano pure usati nel settore operazionale. In questo caso, i beni non saranno messi in relazione al processo di fabbricazione o prestazione di servizio in sé, così come succede con i prodotti di pulizia esterna degli stabilimenti, macchinari e veicoli aziendali ${ }^{\mathrm{x}}$.

\footnotetext{
vii La differenza tra l' IVA del tipo Reddito e Consumo consiste esattamente nel modo di appropriazione dei crediti delle acquisizioni per l'attivo immobilizzato: ratealmente, osservando il periodo di deprezzazione del bene, nel primo caso; e in contanti, con storno posteriore, in caso di alienazione prima che sia scaduto il periodo di deprezzazione, nella seconda ipotesi.

viii Pur discordando sulla restrizione al credito adottata dalla giurisprudenza del STF, l' esistenza di centinaia di accordi differiti nello stesso senso a partire dagli anni ' 60 ha fatto sí che scegliessimo di considerare, per fini metodologici, la non cumulatività come garanzia unicamente del credito fisico.

${ }^{\text {ix }}$ Legge $\mathrm{n}^{\circ}$ 4.502, del 30 novembre 1964, attualmente vigente nell' IPI.
} 
Un'adeguata concezione dei prodotti intermedi è ancora fondamentale perché la non cumulatività continui ad operare i suoi effetti quando applicata al segmento di prestazione di servizi. In tale attività, non essendoci materie prime (visto che non si integra nulla al prodotto finale, che è intangibile) o materiali da imballo, soltanto i prodotti intermedi generano diritto all'accredito. La restrizione del concetto di bene intermedio operato dalla giurisprudenza - che intanto non ha mai discusso l'argomento a fondo - può in ultima analisi annullare la non cumulatività tributaria per il segmento di prestazione di servizi, cosa che, oltre a non essere desiderabile, è anticostituzionale.

Questo è in sintesi il traguardo che si propone il presente lavoro.

Parole chiave: tributario - non cumulatività - credito - imposte - contributi - neutralità.

\footnotetext{
${ }^{\mathrm{x}}$ Non sono inclusi in questo concetto, ovviamente, i prodotti impiegati per la pulizia e lubrificazione interna delle macchine in generale, che si configurano essenziali al loro funzionamento e, conseguentemente, al processo produttivo.
} 


\section{ABSTRACT}

The thesis starts with the delineation of the non-compounding tax principle and its difference from the indirect taxation and ends with the conclusion that, in Brazil, only the "ICMS" (value added tax upon sales and some kinds of services) and "IPI" (tax upon industrialized products) fully apply the principle. On the other hand, the PIS and COFINS (contributions to social security) don't apply the principle on its entire extent. To be fully applied the principle demands that the tax be imposed on values of products/services in multiple phases of its production/sale chain. Taxes that are imposed once in a chain of events such as the PIS and COFINS - don't apply fully to the principle of the non-compounding tax.

The thesis also analyses the right to compensate the tax paid in the purchase of inputs (materials) with the tax paid with the sale of the output (products/services) regarding the case when the output is exempt.

The thesis also considers the Federal Supreme Court's ruling on the compensation right to criticize the judicial decision of not recognizing this right when one of the phases of a chain of products/services is exempt. The problem is the effect of this decision, which neutralizes the exemption and contradicts with the judicial understanding that the exemption does not change the nature of the taxed operation ${ }^{\mathrm{xi}}$. After all, if the operation is taxed it should imply the right to compensate.

The historical and judicial evolution of the non-compounding principle has brought it to an outline which recognizes the right to compensate the tax paid in the purchase of raw materials, intermediary products and packing used in industries and services.

Beyond the core of this principle the law can establish the right to compensate the tax paid in the purchase of equipments and, also, of consumer goods that are not directly applied in the production process or in the services. By editing this law the Legislative alters the nature of the Brazilian IVA: from a tax upon physical credit into a tax upon financial credit - in this last case the compensation of the tax paid with purchase of equipments and consumer goods is assured though a credit divided into one or more fractions ${ }^{\mathrm{xii}}$.

\footnotetext{
${ }^{x i}$ In our opinion the exemption changes the nature of the taxed operation into a non-taxed operation. However, since the thesis analyses the Federal Supreme Court's ruling on this case, it has to consider the understanding of the Court as the premises of the thesis.

${ }^{\text {xii }}$ In spite of our disagreement with the understanding of the Federal Supreme Court, the unanimous Jurisprudence regarding the non-compounding principle, have made us agree - for the purpose if this work with its more restricted concept - limited by its core.
} 
That's the current understanding in the Federal Supreme Court. Based on this understanding ${ }^{\text {xiii }}$ the thesis intend to identify the raw materials, packing and - mainly - the intermediary products that allow the tax compensation.

The non existence of a deep study on these materials results in an incorrect application of the non-compounding principle by the Judges. Intermediary products, according to the regulation set in $1960^{\mathrm{xiv}}$, are those consumed in the production process. Therefore, the claimed necessity of the physical contact between the intermediary and the final product, to characterize the first one, is illegal and ought to be avoided - as the legal principle establishes ubi lex non distinguit nec interpres dis.

Moreover, the separation of the intermediary products into directly and indirectly applicable into the production process is also illegal. Since the intermediary product is consumed in the production process or during the services in a essential way, the right to compensate ought to be assured. The consumer goods are the ones not directly applied to the production process or to the services, as for example, the goods used in the Administrative Department. It's also possible to find consumer goods in the production; in this case it differs from the intermediary product for not being directly applied to the production process, such as the cleaning products used in the equipments and vehicles ${ }^{\mathrm{xv}}$.

The correct characterization of the intermediary products is essential to assure that the non-compounding principle take effect when applied to services. In this case there are no raw materials - since there is no final product - nor packing, only intermediary products. The restriction of the concept of intermediary product set by the Jurisprudence - although incipient in this quaestio - can culminate in neutralizing the effects of the noncompounding principle regarding the services - what, we believe, is unconstitutional.

These are, synthetically, the main points analyzed in the present thesis.

Key-words: taxation - non-compounding principle - credit - tax - contribution - neutrality.

\footnotetext{
xiii The main difference between the two types of IVA can be verified in the method of compensating the tax on equipments, which can be in one fraction (the tax is entirely compensated in one month) or various fractions (the tax is compensated throughout the months).

${ }^{\text {xiv }}$ Law 4.502 edited on November $30^{\text {th }}$, 1964, that regulates the IPI.

${ }^{\mathrm{xv}}$ The cleaning and lubrication products used in the interior of the equipments, for being essential to is functioning, do not fall into this category.
} 


\section{SUMÁRIO}

Introdução......................................................................................................................................01

\section{Título I}

Tributação indireta e não-cumulatividade: os necessários distínguos

Capítulo I. Considerações iniciais... .06

Capítulo II. Tributos diretos e indiretos.

2.1. Origem histórica dos conceitos sub examine: a tributação indireta e a repercussão econômica.

2.2. As classificações possíveis.

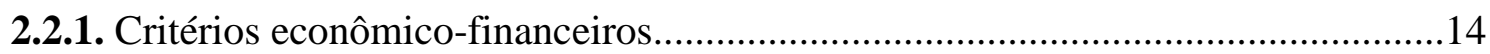

2.2.1.1. Teoria fisiocrática da repercussão econômica..................................................14

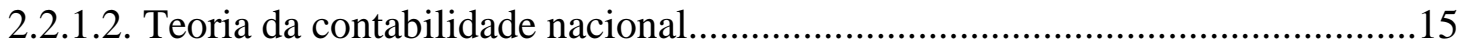

2.2.1.3. A teoria da capacidade contributiva...............................................................

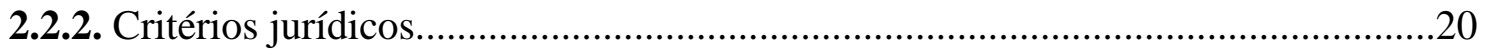

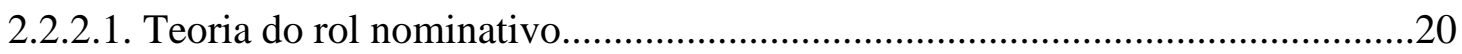

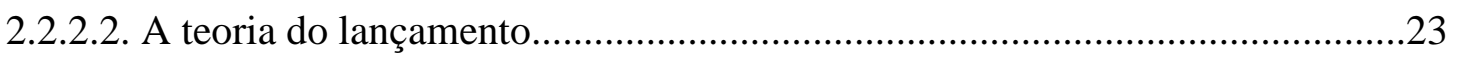

2.2.2.3. A teoria da natureza do fato tributável....................................................24

2.3. A definição adotada pelo ordenamento jurídico brasileiro.................................27

2.3.1. A tributação indireta à luz da jurisprudência........................................................29

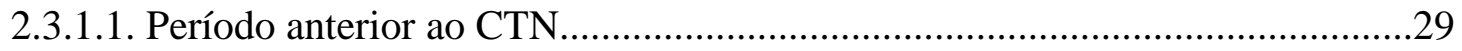

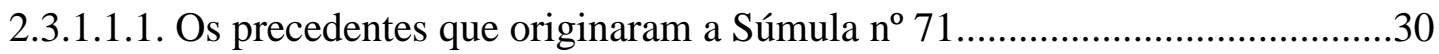

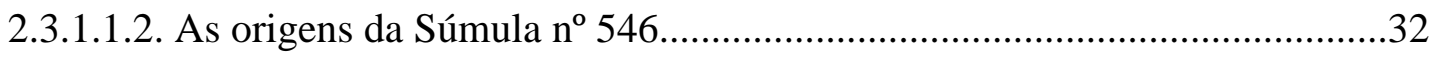

2.3.1.2. O art. 166 do Código Tributário e as Cortes Superiores....................................34

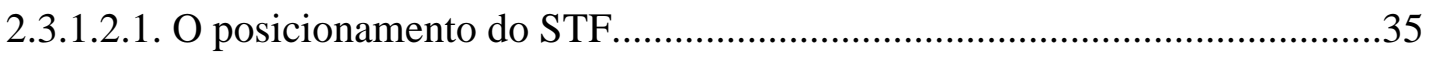

2.3.1.2.2. A jurisprudência do Superior Tribunal de Justiça........................................37

2.3.2. As correntes doutrinárias acerca da tributação direta e indireta no Brasil............43

2.3.2.1. A corrente pela invalidade, no direito brasileiro, da divisão de tributos em diretos e indiretos. 
2.3.2.2. A corrente que pugna pela validade da classificação diretos/indiretos, desde que moldada pelo critério do art. 166 do CTN (repercussão jurídica)

2.3.2.3. A nossa opinião.

2.3.3. O conceito brasileiro de tributo indireto: teoria da repercussão jurídica......

Capítulo III. A não-cumulatividade tributária. .56

3.1. Considerações preliminares .56

3.2. Origens .61

3.3. Técnicas .68

3.3.1. Métodos de adição e subtração. 68

3.3.2. Número de operações gravadas (plurifasia necessária) e direito ao crédito sobre bens do ativo imobilizado .71

3.3.3. O creditamento sobre insumos .73

3.3.4. A amplitude do direito ao crédito .75

3.3.5. Apuração por produto e por período .76

3.4. Neutralidade fiscal, tributação do consumo e a problemática das isenções........77

3.5. A não-cumulatividade e a regra-matriz de incidência tributária.........................82

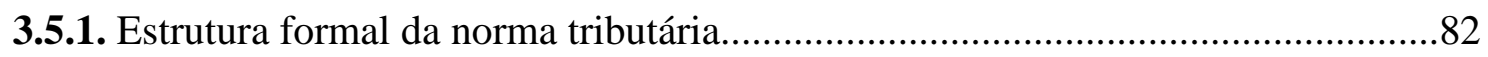

3.5.2. O instituto da não-cumulatividade em face da norma tributária............................84

3.6. Pressupostos da não-cumulatividade: plurifasia e direito ao abatimento............86

Capítulo IV. Relações entre tributação indireta e não-cumulatividade. .94

Capítulo V. Tributos não-cumulativos no ordenamento jurídico brasileiro..................97

5.1. Advertência.

5.2. Não-cumulatividade em sentido amplo e estrito. .98

Título II

A não-cumulatividade no altiplano constitucional

Capítulo VI. A não-cumulatividade do ICMS e do IPI................................................104

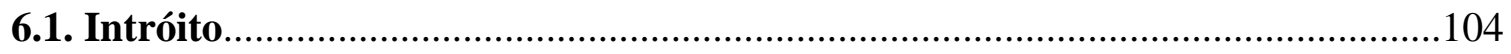

6.2. A não-cumulatividade como norma de eficácia plena......................................107 
6.3. Crédito sobre imposto "cobrado" na operação anterior: sentido do vocábulo constitucional

6.4. A “compensação" do ICMS e do IPI prescrita pela CR/88 (substituindo o termo “abatimento”, utilizado pelas cartas anteriores)

6.5. A apuração imposto-contra-imposto versus a base-contra-base.

6.6. A apuração por período de tempo, com transporte de créditos não utilizados para competências subseqüientes.

6.7. As tentativas de restrição da não-cumulatividade por leis estaduais e a jurisprudência do STF: o crédito é sempre integral, independentemente do valor da saída

6.8. Os efeitos da isenção ou não-incidência intercalar no ICMS. 119

6.8.1. A vedação ao transporte de créditos para as operações e prestações posteriores à isenta ou não-tributada.

6.8.2. O dever de estorno dos créditos das operações anteriores à etapa isenta ou nãotributada.

6.8.3. O direito à manutenção do crédito das prestações anteriores à etapa isenta ou nãotributada. 128

6.9. Não-incidência, isenção, alíquota zero e direito ao crédito do IPI. 131

6.9.1. Definição dos institutos

6.9.2. O direito à manutenção dos créditos de IPI nas saídas isentas, não-tributadas e sujeitas à alíquota zero. $\mathrm{O}$ art. 11 da Lei no 9.779/99.

6.9.2.1. A quaestio juris.

6.9.2.2. A decisão da Suprema Corte: inexistência de direito ao aproveitamento dos créditos de IPI sobre insumos quando o produto final for isento, não-tributado ou sujeito à alíquota zero do imposto.

6.9.2.3. O nosso entendimento. 137

6.10. A concessão de créditos presumidos de IPI aos adquirentes de insumos isentos, não-tributados e sujeitos à alíquota zero. 140

6.11. O diferimento e não-cumulatividade.

6.11.1. A ausência de direito a créditos presumidos pelo adquirente dos produtos com tributação postergada.

6.11.2. O direito à manutenção dos créditos pelos alienantes dos produtos com tributação diferida. Impossibilidade, todavia, de transferência dos créditos a terceiros sem lei autorizativa. 148 
6.13. A exportação e o direito à manutenção dos créditos escriturais de IPI e ICMS

6.14. O ICMS e a problemática da equiparação, à isenção, da redução de base de cálculo.

6.14.1. A Constituição e a interpretação das regras restritivas de direitos 161

6.14.2. A inexistência da intitulada "isenção parcial". Definições ontológico-jurídicas de isenção e redução de base de cálculo .162

6.15. Crédito físico versus crédito financeiro. 164

6.15.1. As regras aplicáveis ao IPI. 165

6.15.2. As normas do ICMS. 167

6.15.2.1. O crédito físico do convênio $\mathrm{ICM} \mathrm{n}^{\circ} 66 / 88$. 167

6.15.2.2. O crédito financeiro da $\mathrm{LC}^{\circ}{ }^{\mathrm{o}} 87 / 96$ e o regresso ao crédito físico operado pela $\mathrm{LC} \mathrm{n}^{\circ} 102 / 00$

6.15.3. Comentários sobre o crédito físico como o minimum minimorum da nãocumulatividade plasmado na Constituição.

6.16. A importação de mercadorias por não-contribuintes: sistemáticas distintas para o IPI e o ICMS 178

6.16.1. A evolução jurisprudencial. 178

6.16.2. Nossa opinião: necessária incidência de ICMS e IPI nas importações por nãocontribuintes. Inexistência de ferimento à não-cumulatividade.

6.17. A substituição tributária para frente e o direito à restituição do tributo pago a maior. 185

6.17.1. Origens. 185

6.17.2. Conceito. 187

6.17.3. A jurisprudência do STF à luz da Constituição de 1988 . 189

6.18. A monofasia do ICMS incidente sobre combustíveis em face da nãocumulatividade: análise da Emenda Constitucional no 33/01. 195

6.19. O cálculo "por dentro" do ICMS: ferimento à não-cumulatividade?.

6.19.1. Cálculo "por fora" versus cálculo "por dentro".

6.19.2. A forma de cálculo ("por dentro" ou "por fora") do tributo não possui relação com a operacionalização da não-cumulatividade tributária.

6.20. $\mathrm{O}$ diferencial de alíquotas do ICMS e o direito à sua compensação. .203 
Capítulo VII. A não-cumulatividade do PIS/COFINS.

7.1. A previsão constitucional

7.2. A não-cumulatividade da contribuição ao PIS e da COFINS, inclusive quando devidas na importação de mercadorias e serviços.

7.2.1. A eficácia das normas constitucionais: conceito e modalidades.

7.2.2. A não-cumulatividade do PIS/COFINS: norma de eficácia limitada de princípio institutivo facultativo.

7.3. A não-cumulatividade do PIS/COFINS que grava as receitas brutas se amolda apenas em parte à do ICMS e IPI

7.4. O PIS e a COFINS devidos na importação de bens e serviços.

Capítulo VIII. Não-cumulatividade dos impostos e contribuições residuais. 218

8.1. As normas da Lei Maior. 218

8.2. A jurisprudência 219

8.3. Conclusões 220

Capítulo IX. O núcleo constitucional mínimo da não-cumulatividade à luz da jurisprudência do Supremo Tribunal Federal. . .222

9.1. A exigência de duas etapas gravadas pelo tributo. 222

9.2. $O$ crédito escritural. .224

9.3. A substituição tributária para frente e para trás .225

9.4. O núcleo inatacável do direito ao crédito. 226

Capítulo X. Não-cumulatividade: Princípio ou regra? .228

10.1. Princípios e regras: Distinções fundamentais .228

10.2. A não-cumulatividade enquanto princípio constitucional 230

10.3. O princípio da não-cumulatividade somente encontra condições de atingir seus fins quando aplicado a exações plurifásicas (que gravem a circulação de riquezas)

\section{Título III}

A não-cumulatividade e as normas infraconstitucionais

Capítulo XI. Imposto sobre Produtos Industrializados. 
11.2. A não-cumulatividade do IPI no Código Tributário Nacional.........................242

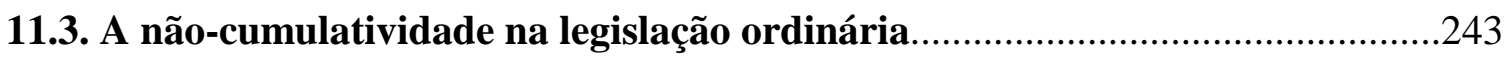

11.3.1. O art. 25 da Lei $n^{\circ} 4.502 / 64$ e suas demais disposições sobre o tema...............243

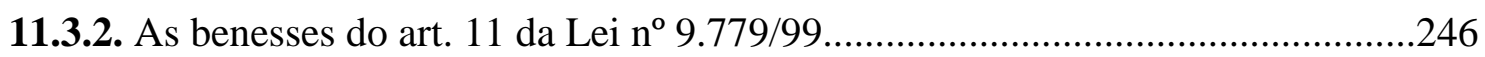

11.3.2.1. Direito aos créditos do IPI quando os produtos finais forem isentos ou tributados à alíquota zero.

11.3.2.2. Direito à compensação dos créditos de IPI acumulados ao longo de um trimestre com outros tributos federais

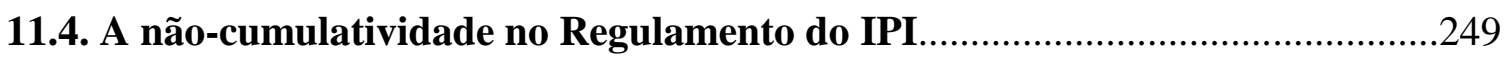

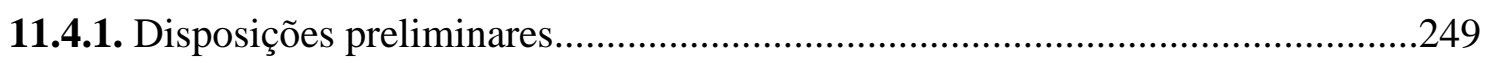

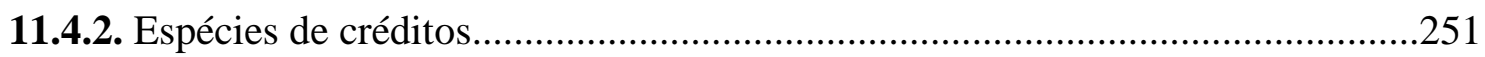

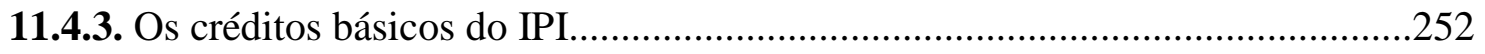

11.4.3.1. A vedação ao crédito sobre bens do ativo imobilizado................................253

11.4.3.2. Matérias-primas, produtos intermediários e materiais de embalagem.........255

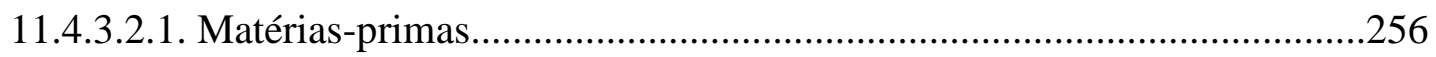

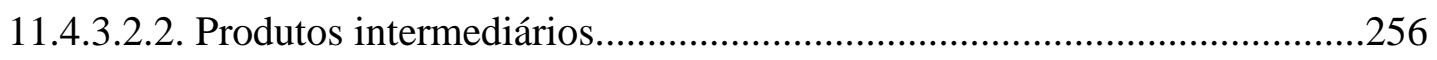

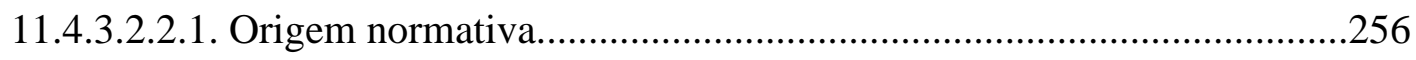

11.4.3.2.2.2. A jurisprudência das Cortes Superiores...........................................262

11.4.3.2.2.3. Conceito de bem intermediário.....................................................267

11.4.3.2.2.4. A energia elétrica utilizada na produção..........................................268

11.4.3.2.2.4.1. A impossibilidade de cálculo de créditos do IPI sobre as despesas com energia elétrica: efeito da imunidade do art. $155, \S 3^{\circ}$ da CR/88..................272

11.4.3.2.3. Material de embalagem.....................................................................2. 273

11.4.3.3. A manutenção do crédito em caso de quebras............................................274

11.4.3.4. Manutenção do crédito nas saídas de sucata, resíduos e assemelhados.......274

11.4.3.5. Manutenção dos créditos relativos aos insumos tributados utilizados no fabri-

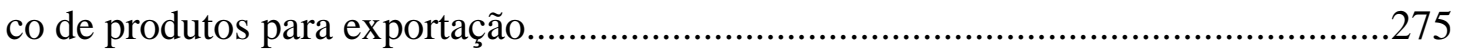

11.4.4. Créditos por devolução ou retorno de produtos................................................276

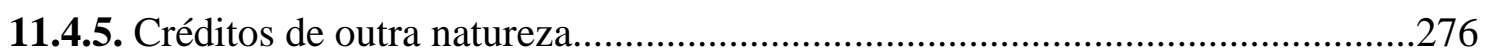

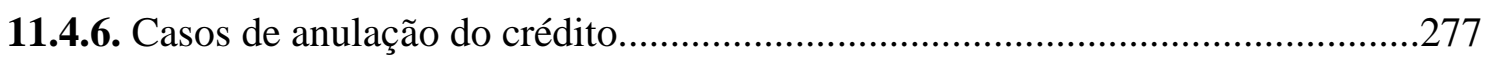

11.4.6.1. As saídas não-tributadas ou com suspensão do imposto..............................277

11.4.6.2. O estorno dos créditos de insumos no caso de perecimento dos produtos finais. 
11.4.6.3. A obrigação de estornar os créditos quando da devolução de produtos.

11.4.6.4. Estorno, pelo estabelecimento importador, do crédito de IPI-importação quando da remessa do bem diretamente da repartição aduaneira para outro estabeleci-

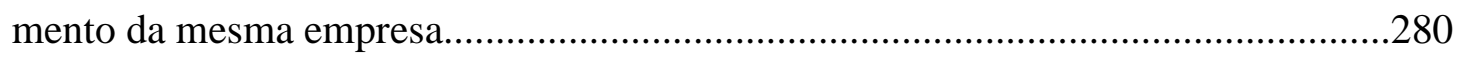

11.4.7. Créditos decorrentes de incentivos fiscais previstos no Regulamento do IPI...280 11.4.7.1. Créditos incentivados para as áreas da SUDAM, SUDENE e Amazônia Ocidental. 280

11.4.7.1.1. Crédito ficto de IPI para empresas isentas de IRPJ inscritas no Programa de Alimentação do Trabalhador.

11.4.7.1.2. Isenção de IPI para produtos elaborados a partir de insumos agrícolas e vegetais (exceto fumo e bebidas alcoólicas).. 282

11.4.7.2. Créditos presumidos para compensação do PIS e da COFINS suportados pelo exportador (Leis $\mathrm{n}^{\circ} \mathrm{s}$ 9.363/96 e 10.276/01). 282

11.4.7.2.1. Direito ao cômputo dos dispêndios com energia elétrica no cálculo do crédito presumido do IPI previsto na Lei $\mathrm{n}^{\circ}$ 9.363/96. .285

11.5. O crédito-prêmio de IPI plasmado no Decreto-lei no 491/69. .286

Capítulo XII. O Imposto sobre Operações de Circulação Jurídica de Mercadorias e Prestações de Serviço de Transporte Interestadual e Intermunicipal e de Comunicação. .292

12.1. A ampla regra-matriz de incidência do ICMS .292

12.2. As normas infraconstitucionais sobre a não-cumulatividade do ICMS 296

12.2.1. Disposições gerais sobre a não-cumulatividade. 296

12.2.1.1. Período de apuração do imposto e transporte do saldo credor acumulado para competências subseqüentes. 297

12.2.1.2. Autonomia dos estabelecimentos. 297

12.2.1.3. A transferência do saldo credor a outros contribuintes dentro do mesmo Estata-

do. .298

12.2.1.4. Formas de apuração do imposto. .299

12.2.1.5. A apuração por estimativa. .299

12.2.2. O crédito financeiro mitigado autorizado pela $\mathrm{LC} \mathrm{n}^{\circ} 87 / 96$. 300 
12.2.2.1. Créditos de ICMS sobre matérias-primas, produtos intermediários e bens de uso e consumo. 301

12.2.2.1.1. Origem normativa dos termos em questão..............................................301

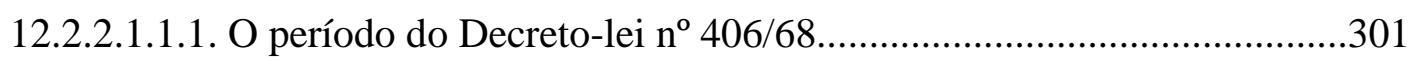

12.2.2.1.1.2. O Convênio ICM n ${ }^{\circ}$ 66/88 e a Lei Complementar $n^{\circ} 87 / 96 \ldots \ldots . . . . . . . .306$

12.2.2.1.2. A jurisprudência do Superior Tribunal de Justiça...................................309

12.2.2.1.2.1. Consumo versus desgaste: diferenciação entre produtos intermediários e partes e peças de reposição integrantes do ativo imobilizado..............................310

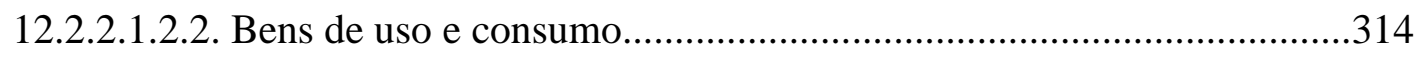

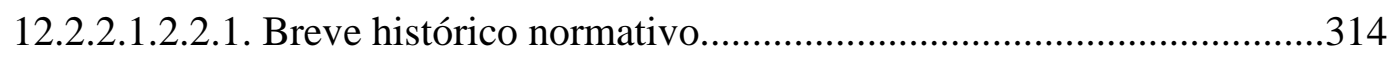

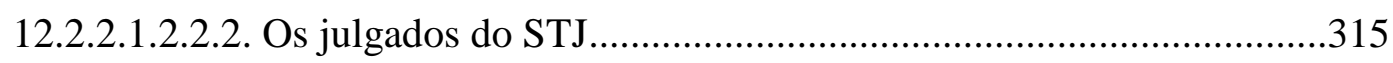

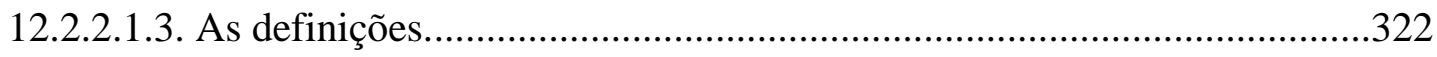

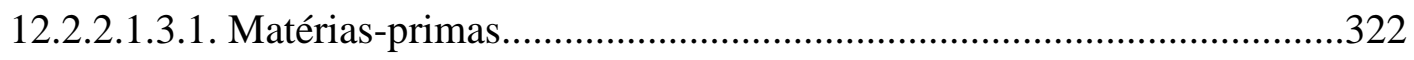

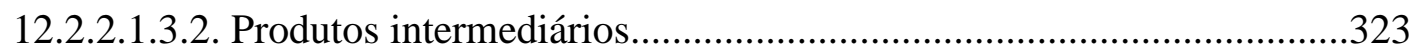

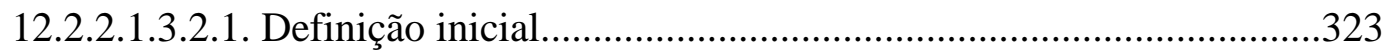

12.2.2.1.3.2.2. Consumo versus desgaste e a inexigência de contato direto com o

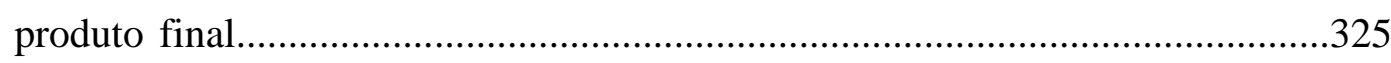

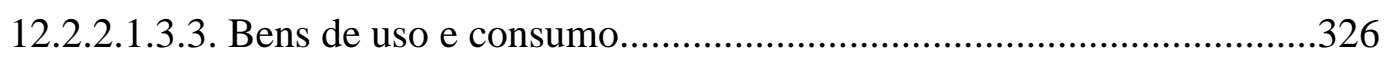

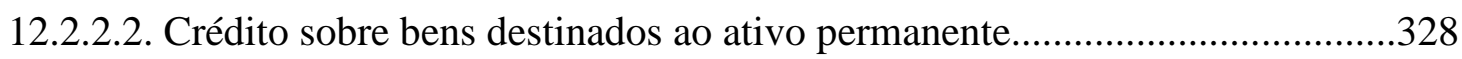

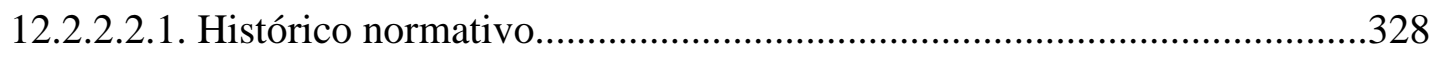

12.2.2.2.2. O conceito de ativo permanente.........................................................330

12.2.2.2.3. Bens do ativo permanente alheios à atividade fim do contribuinte.........333

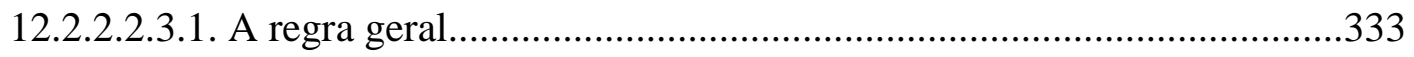

12.2.2.2.3.2. Crédito sobre materiais utilizados na construção de imóveis.............336

12.2.2.2.3.3. Veículos destinados ao transporte pessoal.......................................339

12.2.2.2.4. A mitigação do crédito conferido sobre os bens do ativo permanente: cumulatividade residual determinada pela lei..........................................................340

12.2.2.2.4.1. O cancelamento dos créditos remanescentes após o decurso de quatro

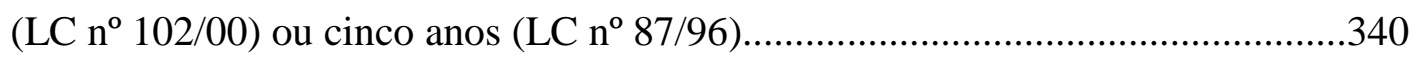

12.2.2.2.4.2. A alienação do ativo antes de decorrido o prazo legal e o estorno dos

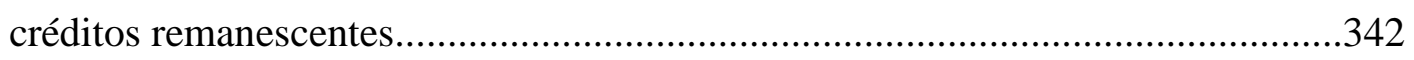

12.2.2.2.5. Bens cedidos em comodato: possibilidade de manutenção do crédito...344

12.2.2.3. Crédito sobre serviços de transporte e comunicação....................................347

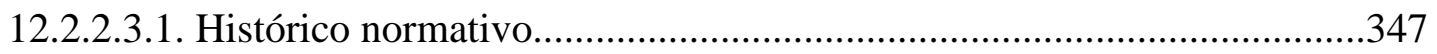


12.2.2.3.2. O tratamento jurisprudencial. .348

12.2.2.4. Os créditos sobre a energia elétrica consumida .352

12.3. A não-cumulatividade na prestação de serviços e a teoria do crédito físico.....353

12.3.1. A prestação de serviços de transporte interestadual e intermunicipal. 353

12.3.1.1. O direito ao crédito sobre os insumos utilizados no transporte de mercadorias.

12.3.1.2. O transporte de produtos não-tributados não afeta o direito ao crédito sobre insumos utilizados na prestação do serviço. .357

12.3.2. Não-cumulatividade e prestação de serviços de comunicação. 357

12.3.2.1. Os créditos de energia elétrica utilizados na área operacional das empresas.

12.3.2.2. O crédito sobre os serviços de comunicação utilizados no call center obrigatoriamente mantido pela operadora de telefonia. 361

12.4. O direito de transferência a terceiros do saldo credor de ICMS acumulado.

12.4.1. A transferência mandatória em decorrência da exportação de mercadorias e serviços.

12.4.2. A norma especial para o saldo credor decorrente de exportação acumulado até 31 de dezembro de 1999. 366

12.4.3. As transferências condicionadas pela lei 367

12.5. Idoneidade da documentação e escrituração regular: limites formais para o

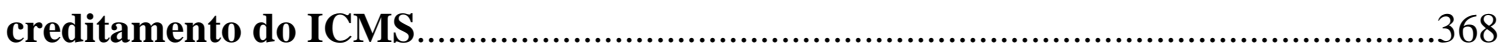

12.6. O lustro decadencial para utilização do crédito do ICMS ................................372

12.7. O estorno dos créditos incentivados e o art. $8^{\circ}$ da Lei Complementar $n^{\circ}$ $24 / 75$. .373

Capítulo XIII. PIS/COFINS incidentes sobre a receita bruta.....................................377

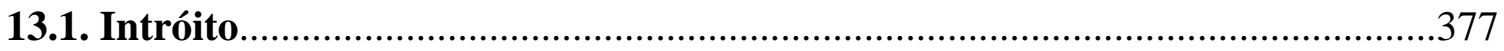

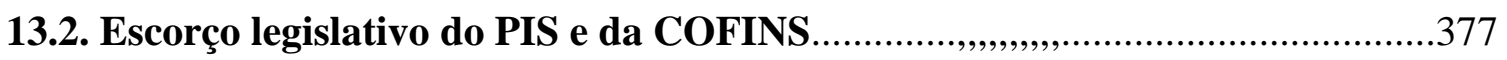

13.3. A regra-matriz de incidência do PIS/COFINS não-cumulativos.....................383

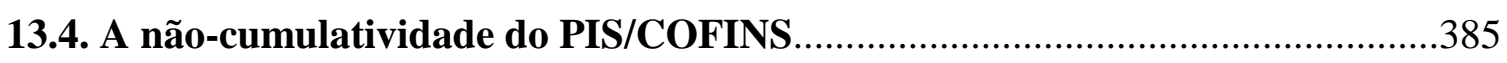

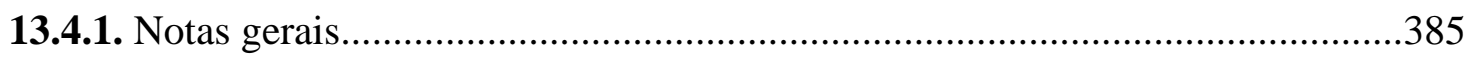

13.4.1.1. A natureza escritural dos créditos do PIS/COFINS......................................385 
13.4.1.2. Apuração imposto-contra-imposto, por período de tempo, com transporte de saldo credor para competências posteriores.

13.4.1.3. O direito do exportador de compensar os créditos de PIS/COFINS com débitos de outros tributos federais ou de pedir o ressarcimento em espécie. .386

13.4.1.4. O adquirente de produtos e serviços tributados pelo PIS/COFINS cumulati$\operatorname{vos}(3,65 \%)$ faz jus ao crédito regular $(9,25 \%)$ sobre as suas despesas. .388

13.4.1.5. A exigência de duas "etapas" tributadas e as benesses da não-cumulatividade legal do PIS/COFINS. 389

13.4.1.5.1. A vedação do crédito sobre aquisições não-tributadas pelo PIS/COFINS. 390

13.4.1.5.2. Direito aos créditos do PIS/COFINS quando as saídas forem abrigadas pela isenção, suspensão, alíquota zero ou não-incidência. 391

13.4.2. Os contribuintes sujeitos à não-cumulatividade e as exceções à regra. .391

13.4.2.1. As disposições legais 392

13.4.2.2. A apuração do IRPJ pelo lucro real como critério para sujeição à nãocumulatividade do PIS/COFINS: violação ao princípio da isonomia. 395

13.4.3. A monofasia do PIS/COFINS e a não-cumulatividade tributária.. .398

13.4.3.1. O regime monofásico das contribuições. 398

13.4.3.2. A sujeição dos contribuintes monofásicos à não-cumulatividade do PIS/COFINS.

13.4.4. Empresas sujeitas ao regime misto (cumulativo e não-cumulativo): apuração direta ou proporcional dos créditos .401

13.4.5. As espécies de créditos do PIS/COFINS 403

13.4.5.1. Os créditos de bens adquiridos para revenda. 404

13.4.5.2. Bens e serviços utilizados como insumos 405

13.4.5.3. Energia térmica e elétrica. 407

13.4.5.4. Aluguéis de prédios, máquinas e equipamentos. 408

13.4.5.5. Leasing (arrendamento mercantil). 408

13.4.5.6. Bens do ativo imobilizado. .409

13.4.5.7. Edificações e benfeitorias em imóveis. 409

13.4.5.8. Bens recebidos em devolução. 409

13.4.5.9. Armazenagem de mercadoria e frete na operação de venda. 410 
13.4.5.10. Vale-transporte, vale-alimentação ou refeição, uniformes e fardamentos fornecidos por empresa prestadora de serviços de conservação, limpeza e manutenção aos seus empregados.

13.4.5.11. Imóveis prontos e em construção: forma de creditamento. 411

13.4.5.12. Créditos presumidos sobre o estoque de abertura. 412

13.4.5.12.1. As previsões legais. 412

13.4.5.12.2. A discussão judicial acerca da alíquota aplicável aos créditos sobre o estoque de abertura.

13.4.5.12.3. O estoque de abertura dos contribuintes sujeitos à apuração monofásica do PIS/COFINS que passaram, a partir da lei $\mathrm{n}^{\circ} 10.865 / 04$, ao regime nãocumulativo.

13.4.5.13. O crédito presumido nas subcontratações feitas pelas empresas de transporte de cargas

13.4.6. O estorno de créditos 415

13.4.7. Créditos expressamente vedados pela legislação. 416

13.4.8. As vicissitudes da não-cumulatividade do PIS/COFINS para os prestadores de serviço: uma proposta de lege ferenda.

13.4.8.1. A proposta.

13.4.8.2. A justificativa.

Capítulo XIV. PIS/COFINS incidentes sobre a importação de bens e serviços 420

14.1. A regra-matriz de incidência do PIS/COFINS-importação .420

14.2. A não-cumulatividade do PIS/COFINS-importação

14.2.1. O abatimento do PIS/COFINS-importação somente é permitido aos contribuintes do PIS/COFINS não-cumulativo: restrição que fere a isonomia. 424

14.2.2. Os créditos do PIS/COFINS-importação .426

14.2.2.1. Origem dos créditos 426

14.2.2.2. O cálculo do crédito .427

14.2.2.3. O transporte do saldo credor para os períodos subseqüentes. .427

14.2.2.4. Importações isentas e direito ao crédito. .428

14.2.2.5. Importações por conta e ordem de terceiros .428

Capítulo XV. Temas comuns à não-cumulatividade do IPI, ICMS e PIS/COFINS. 
15.1.1. A regra geral: vedação de aproveitamento e transferência de créditos pelas empresas optantes do Simples

15.1.2. Os créditos de PIS/COFINS

15.1.3. A não-cumulatividade do ICMS .432

15.1.4. A problemática do IPI. 434

15.2. Restituição do indébito versus creditamento escritural: prazos prescricionais 435

15.2.1. O CTN e a repetição do indébito nos tributos sujeitos a lançamento por homologação.

15.2.2. O decreto $n^{\circ} 20.910 / 32$ e o creditamento escritural de IPI, ICMS e PIS/COFINS não-cumulativos.

15.3. Prazo decadencial para escrituração, em conta gráfica, de créditos de IPI, ICMS e PIS/COFINS. 440

15.4. A correção monetária dos créditos escriturais. 440

Conclusões. .444

Bibliografia. .451 


\section{INTRODUÇÃO}

O presente estudo possui o escopo de delinear as bases da não-cumulatividade tributária, focando nos pontos em que o referido instituto merece ser revisitado:

(a) do ponto de vista doutrinário, para acompanhar a evolução jurisprudencial; e

(b) sob o prisma da jurisprudência, para sanar suas próprias incoerências.

Expliquemos.

Quando de sua criação, por meio das Leis $\mathrm{n}^{\circ} \mathrm{s} 2.974 / 56$ e 3.520/58, a nãocumulatividade aplicava-se tão-somente ao vetusto Imposto de Consumo (IC), cujos contribuintes eram os industriais e os importadores. Posteriormente, a Lei $n^{\circ} 4.502 / 64$ - último diploma legal regente do IC - consolidou o disposto nas referidas Leis $n^{\circ}$ s 2.974/56 e 3.520/58, operando ainda uma pequena ampliação no alcance da não-cumulatividade. Entretanto, como a sujeição passiva do IC continuou a mesma, a não-cumulatividade se manteve restrita aos industriais e importadores.

$\mathrm{O}$ advento do Imposto sobre Produtos Industrializados (IPI), por meio da EC $\mathrm{n}^{\circ}$ 18/65, não modificou sensivelmente o cenário em questão. A lei-base do IPI era a mesma do IC (Lei $\left.n^{\circ} 4.502 / 64\right)$, com poucas adaptações pontuais. E a não-cumulatividade, apesar de ter adquirido status constitucional, já tinha as suas principais notas delineadas pela referida legislação.

Por conseguinte, quando os primeiros casos envolvendo a não-cumulatividade chegaram aos Tribunais Superiores, as decisões tomadas laboraram sobre a realidade das indústrias, as únicas (além dos importadores) contribuintes do IC. Como o IPI sucedeu o IC, os conceitos sedimentados à luz deste imposto foram simplesmente transplantados para o IPI pela jurisprudência. Afinal, os fundamentos das lides eram praticamente os mesmos em ambos os impostos, assim como o eram as questões fáticas. Estas envolviam quase sempre a atividade industrial e, eventualmente, algum questionamento dos importadores.

As conseqüências desse momento inicial de implantação da não-cumulatividade são perceptíveis até hoje. Apesar de a EC no 18/65 ter estendido a não-cumulatividade para o Imposto sobre Circulação de Mercadorias (ICM), cujos sujeitos passivos, para além dos industriais e importadores, eram também os comerciantes, a jurisprudência que se firmara para o IC (e, em seguida, para o IPI) foi simplesmente aplicada para o ICM, sem maiores digressões. 
Assim, em que pesem as dessemelhanças entre o IPI e o ICM (que possuía maior amplitude), a jurisprudência das Cortes Superiores tratou da mesma forma a nãocumulatividade de ambos os impostos - sob as luzes dos fundamentos assentados quando ainda vigorava o Imposto de Consumo!

Quando da edição da Constituição de 1988, a competência tributária dos Estadosmembros foi ampliada para permitir que o então novel ICMS incidisse sobre duas modalidades de serviços: comunicação e transporte interestadual e intermunicipal. A ampliação do espectro de incidência do ICM, agora ICMS, deveria necessariamente implicar uma readaptação da não-cumulatividade. Afinal, a compensação do imposto pago nas operações e prestações anteriores, tal como pugna a Constituição, não pode ser pautada pelas mesmas amarras que envolviam o Imposto de Consumo, exação menos abrangente e complexa que o hodierno ICMS.

Tal mudança na regra-matriz do mais importante imposto estadual, contudo, ainda não foi assimilada no que pertine à não-cumulatividade. As premissas estabelecidas à época do IC, vertidas sem maiores discussões para o IPI e depois para o ICM, continuam, por ausência de enfrentamento do tema pela jurisprudência, a reger a não-cumulatividade do ICMS. O problema se agrava pois, agora, existem prestações de serviço integrando o critério material da hipótese de incidência do ICMS - e serviços não possuem nenhuma relação com a indústria, em torno da qual os Tribunais construíram o conceito de nãocumulatividade tributária.

Outrossim, nos anos de 2002 e 2003 um novo capítulo sobre o tema foi iniciado. Criou-se para o PIS e a COFINS incidentes sobre a receita das empresas um regime nãocumulativo. Como essas contribuições gravam fatos isolados (auferimento de receitas) ${ }^{1}$, muito se tem questionado acerca de sua natureza jurídica. Afinal, seria mesmo possível aplicar a não-cumulatividade a tributos que não gravam operações e prestações mercantis? Caso positivo, a não-cumulatividade teria transformado o PIS/COFINS em exações indiretas, aplicando-se-lhes o disposto no art. 166 do Código Tributário Nacional ${ }^{2}$ ? Tais indagações permanecem em aberto.

\footnotetext{
${ }^{1}$ O IPI e o ICMS, ao contrário, tributam operações de circulação de riquezas interligadas entre si (vendas realizadas da fábrica para o distribuidor e deste para o varejista, v.g.).

${ }^{2}$ CTN:

“Art. 166. A restituição de tributos que comportem, por sua natureza, transferência do respectivo encargo financeiro somente será feita a quem prove haver assumido o referido encargo, ou, no caso de tê-lo transferido a terceiro, estar por este expressamente autorizado a recebê-la."
} 
Como complemento, em 2004 advém o PIS/COFINS-importação, também pugnando - com respaldo constitucional - ser dotado do atributo da não-cumulatividade.

Dessarte, apesar de contar mais de meio século de existência no direito positivo brasileiro, a não-cumulatividade possui basicamente as mesmas linhas-mestras que a regiam quando de sua instituição.

Por esses motivos o presente trabalho tenciona revisitar a não-cumulatividade e, ao fazê-lo, assestar os pontos em que se entende necessária a sua adaptação aos atuais IPI e ICMS e, ainda, ao PIS/COFINS. Sem descurar da jurisprudência do Supremo Tribunal Federal e do Superior Tribunal de Justiça, buscar-se-á formular propostas para a solução dos desafios enfrentados pela tributação não-cumulativa no País.

Para tanto, o texto foi estruturado em três partes:

- A primeira, que compreende os capítulos I a V, cura das distinções entre tributação indireta e não-cumulatividade. Uma análise histórico-evolutiva de ambos os conceitos é resenhada, com o intuito de, ao cabo, estremar-se um do outro, isolando o objeto de estudo que é a não-cumulatividade tributária propriamente dita;

- A segunda, que perpassa os capítulos VI a X, bosqueja as normas constitucionais da não-cumulatividade tributária desde os primórdios de sua instituição no País. Para fins didáticos, são analisadas em conjunto as disposições atinentes ao IPI e ao ICMS, dadas as proximidades - mas não identidade completa - existentes entre ambas. Outrossim, curam-se dos aspectos constitucionais do PIS/COFINS incidentes sobre a receita bruta e sobre a importação de bens e serviços. Os impostos e contribuições residuais, mandatoriamente não-cumulativos por força da $\mathrm{CR} / 88$, também são analisados. Ao cabo, define-se o conteúdo material do princípio da não-cumulatividade tributária, arrimando-se para tanto na jurisprudência consolidada do Supremo Tribunal Federal;

- A terceira e última parte abarca os capítulos XI a XV, nos quais os aspectos infraconstitucionais da não-cumulatividade tributária são analisados com vagar. As normas do IPI, do ICMS, do PIS/COFINS sobre receitas e do PIS/COFINSimportação são tratadas separadamente. A natureza dos bens geradores de créditos é analisada, com enfoque no posicionamento dos Tribunais Superiores, em especial, nesta parte, do STJ. No último capítulo, temas comuns à não-cumulatividade do IPI, ICMS e PIS/COFINS são examinados, sem descurar das nuanças que, mesmo em tópicos de comum tratamento, possam eventualmente distinguir as referidas exações. 
Buscar-se-á, desta forma, edificar uma abordagem diferençada sobre a nãocumulatividade, que, apesar de vetusta, ainda possui diversos questionamentos não respondidos. Por essas razões se espera, com este trabalho, ofertar alguma contribuição para os estudos sobre o tema. 
TÍTULO I - TRIBUTAÇÃO INDIRETA E NÃO-CUMULATIVIDADE: OS NECESSÁRIOS DISTÍNGUOS 


\section{CONSIDERAÇÕES INICIAIS.}

Os conceitos de tributo direto e indireto sempre sofreram censuras de parcela da doutrina, que os classifica como atécnicos e desprovidos de sustentação científica ${ }^{3}$. Segundo os críticos, o melhor a fazer seria abandonar tal distinção que, nas palavras de BEC$\mathrm{KER}^{4}$, é "falsa e impraticável”.

Todavia, o alerta de BALEEIRO $^{5}$ contra tal radicalismo soa adequado, posto que dita classificação não é mais ou menos imperfeita do que outras existentes.

De fato, a expressão "tributação indireta" tornou-se referência e consiste em uma das principais formas de classificação dos tributos em todo o mundo ${ }^{6}$ (tendo merecido, em diversas ocasiões, análises aprofundadas das Cortes Superiores brasileiras ${ }^{7}$, dado o alto grau de relevância que as exações indiretas, também nominadas sobre o consumo, possuem no País $\left.{ }^{8}\right)$.

${ }^{3}$ E. SELIGMAN assim discorre sobre a classificação:

"É verdade, de fato, que a distinção entre tributos diretos e indiretos perdeu muito o seu valor, pois vários tributos intitulados diretos podem ser transferidos da mesma forma que os tributos nominados indiretos. Em palavras simples, a distinção entre tributos diretos e indiretos foi praticamente relegada à mente do legislador: aquilo que ele pretende seja suportado pelo contribuinte original é denominado tributo direto, aquilo que ele pretende seja suportado por outrem que não o contribuinte original é intitulado tributo indireto. Infelizmente a intenção do legislador não equivale aos resultados verdadeiros. Nós precisamos, então, revisar a nomenclatura ou declarar que a presente distinção é de pouca valia." (SELIGMAN, Edwin Robert Anderson. The Shifting and Incidence of Taxation, $3^{\text {rd }}$ ed. New York: Columbia University Press, 1910, p. 390 - tradução livre do original em inglês).

${ }^{4}$ BECKER, Alfredo Augusto. Teoria Geral do Direito Tributário, 4ª ed. São Paulo: Noeses, 2007, p. 568.

${ }^{5}$ Averba o autor, após criticar o posicionamento dos que condenam a classificação em análise:

"Esse agnosticismo não nos parece defensável, porque aquela classificação não é menos defeituosa do que outras sobre os vários fenômenos financeiros. Todavia, elas são instrumentos úteis de comparação e análise." (BALEEIRO, Aliomar. Uma Introdução à Ciência das Finanças, 16 ed. Atualizado por DEJALMA DE CAMPOS. Rio de Janeiro: Forense, 2006, p. 281).

ATALIBA também compartilha desse entendimento. (ATALIBA, Geraldo. Hipótese de Incidência Tributária, $6^{\text {a }}$ ed. São Paulo: Malheiros, 2006, p. 143).

${ }^{6}$ FERREIRO LAPATZA, Jose Juan. Curso de Derecho Financiero Español, $12^{\mathrm{a}}$ ed. Madrid: Marcial Pons, 1990, p. 243.

${ }^{7}$ No âmbito do Supremo Tribunal Federal, vale citar a paradigmática decisão nos Embargos no Recurso Extraordinário $\mathrm{n}^{\circ}$ 47.624/ES, na qual o então Ministro ALIOMAR BALEEIRO - apesar de ter sido voto vencido - averbou que "o mesmo tributo poderá ser direto ou indireto, conforme a técnica de incidência e até conforme as oscilantes e variáveis circunstâncias do mercado ou a natureza da mercadoria ou a do ato tributado" (STF, Segunda Turma, RE no 47.624/ES, Relator Min. VICTOR NUNES, DJ 28.09.1961, p. 2.062).

Já no âmbito do Superior Tribunal de Justiça, o acórdão nos Embargos de Divergência em Recurso Especial $\mathrm{n}^{\circ}$ 168.469/SP, onde a Corte assentou que tributo indireto é aquele cuja lei estabeleça a transferência do ônus financeiro ao contribuinte de fato, consiste no primeiro e, até hoje, principal precedente sobre o tema naquele Sodalício (STJ, Primeira Seção, EREsp no 168.469/SP, Relator Min. JOSÉ DELGADO, DJ 17.12.1999, p. 314). 
O estudo da classificação mencionada se faz necessário para o presente trabalho. Afinal, quando a doutrina trata dos tributos indiretos, em variadas ocasiões a nãocumulatividade é apontada como característica essencial de tais exações ${ }^{9}$. Se a assertiva procede, então:

(a) todo tributo indireto (é dizer, juridicamente criado para ter seu ônus repassado ao consumidor final) deve necessariamente ser não-cumulativo; e

(b) a não-cumulatividade teria, dentre os seus escopos, o de permitir a tributação do consumo.

${ }^{8}$ Entidades como o Unafisco Sindical (Sindicato Nacional dos Auditores-Fiscais da Receita Federal do Brasil - www.unafisco.org.br) e a Fenafisco (Federação Nacional dos Fiscos Estaduais e Distrital www.fenafisco.org.br) têm, periodicamente, divulgado estudos nos quais alertam para a proporção desmesurada que a tributação sobre o consumo tem atingido no País.

De fato, a tributação da renda - tanto das pessoas físicas como das jurídicas - é mais consentânea com a justiça fiscal, posto que permite atingir com maior precisão a capacidade contributiva dos pagantes. A incidência sobre o consumo, ainda que permeada pela seletividade (gravando mais os produtos supérfluos e menos os essenciais), é, sob tal prisma, menos justa, pois não fornece meios para diferençar-se a capacidade contributiva dos diversos consumidores de produtos e serviços.

IVES GANDRA, contudo, oferta-nos visão distinta sobre o paradigma, demonstrando que a justiça fiscal reside na tributação direta (entendida esta como a incidente sobre o patrimônio e a renda) e não na indireta (que grava o consumo). Ao analisar o art. $145, \S 1^{\circ}$ da $\mathrm{CR} / 88$ (segundo o qual os impostos, sempre que possível, serão graduados conforme a capacidade econômica do contribuinte), o jurista averba:

"A utilização pelo legislador da expressão 'sempre que possível', à nitidez, só pode estar relacionada à espécie 'imposto', sendo que nos indiretos a graduação não tem como ser pessoal. A progressividade perderia sentido e razão de ser, no máximo permanecendo o princípio da seletividade, que nem por isso transformaria um tributo indireto em pessoal.

Esta é a razão pela qual o constituinte fez uma opção. O ideal seria a tributação direta - a experiência tem demonstrado que na prática o ideal é pobre de resultados - e não a indireta, tida por regressiva, em posições ideológicas. Se não for possível, contudo, admitir-se-á a tributação indireta e, portanto, não pessoal.

O fundamento ideológico de tal postura é que o tributo indireto é regressivo e injusto socialmente, e o direto é justo e distributivo. A tendência dos países em reverter tal concepção ideológica e idealística, ao utilizar-se da tributação indireta, prevalecendo sobre a direta, reside em constatações práticas. É que a tributação direta desestimula a poupança, o investimento, gerando menor desenvolvimento, menos emprego e, portanto, menor arrecadação. Por ser a tributação indireta neutra, a maior disponibilidade que a reduzida tributação direta produz gera maiores estímulos aos investimentos e poupanças. Por decorrência, há progresso econômico e nível de volume arrecadatório superiores." (MARTINS, Ives Gandra da Silva. O Sistema Tributário na Constituição, $6^{a}$ ed. São Paulo: Saraiva, 2007, p. 109).

${ }^{9} \mathrm{O}$ excerto a seguir demonstra o grau de vinculação e, até certo ponto, de confusão da não-cumulatividade com a tributação indireta por vezes existente na doutrina:

“(...) Somente no que diz respeito ao ICMS e ao IPI é possível falar em impostos que por sua natureza jurídica comportam transferência do encargo financeiro. É que nesse assaz superior patamar jurídico está consagrado o princípio da não-cumulatividade, assim para o IPI (CF, art. 153, §3º, II) como para o ICMS (CF, art. 155, §2 $2^{\circ}$, I)". (RABELLO FILHO, Francisco Pinto. Consideração do ISS como Imposto Direto ou Indireto, para Efeito de Repetição do Indébito Tributário: Breve Revisitação do Tema. Revista Tributária e de Finanças Públicas, nº 55. São Paulo: Revista dos Tribunais, mar.-abr./2004, p. 145).

Da passagem resta claro que o autor, para firmar sua conclusão de que o ISSQN não é tributo indireto (ou seja, para sustentar que ele não comporta a transferência jurídica do seu ônus para o consumidor final), opta pela linha de que o imposto indireto deve, mandatoriamente, ser não-cumulativo, sob pena de ser direto (rectius, sob pena de não repercutir juridicamente). Data maxima venia, dita ponderação parece-nos demasiado simplista. 
Em que pese a última assertiva ser correta, a primeira não o é. Em outras palavras, a exação indireta poderá ou não ser não-cumulativa. Trata-se de uma faculdade. Todavia, sendo não-cumulativa ${ }^{10}$, a exação será, obrigatoriamente, indireta. Veja-se o porquê.

${ }^{10}$ A não-cumulatividade aqui referida é a aplicada em impostos sobre a circulação de bens e serviços. Tratase da não-cumulatividade que nominamos stricto sensu, conforme será explanado infra, no Capítulo V. 


\section{TRIBUTOS DIRETOS E INDIRETOS.}

Não são recentes as discussões sobre a classificação dos tributos em diretos e indiretos $^{11}$. Como ocorre em toda e qualquer classificação (que é, per se, arbitrária, posto que remanesce ao alvedrio de cada intérprete), há dificuldades em saber:

(a) se ela é necessária (do ponto de vista dogmático); e, ainda,

(b) se é possível estabelecer regras estáveis e rígidas, porém ao mesmo tempo abrangentes o suficiente para abarcar a totalidade dos objetos passíveis de classificação.

No caso in examen, pode-se sustentar que há interesse - para além do meramente didático - em se proceder à dicotomização entre tributos diretos e indiretos. Isso porque, no direito pátrio, tal distinção importa para saber se o contribuinte de jure é parte legítima para pleitear a compensação ou restituição de tributo indevidamente pago. Em se tratando de exação indireta, o pagante (rectius, o que recolhe o tributo às burras estatais) somente poderá proceder à repetição se:

(a) estiver autorizado pelo terceiro que arcou com o ônus da exação; ou

(b) provar que o encargo não foi repassado a outrem, tendo sido suportado pelo próprio pagante.

Caso seja direto, tais óbices inexistirão, haja vista haver, neste caso, uma presunção juris et de jure de que o gravame financeiro é, in totum, absorvido pelo contribuinte ${ }^{12}$. Trata-se, como se dessume, da aplicação da regra inserta no art. 166 do Código Tributário Nacional $^{13}$, para a qual se faz necessário diferençar tributos diretos e indiretos.

Ademais, a conceituação de tributação indireta é imprescindível para a verificação da não-cumulatividade como:

(a) elemento indissociável e conditio sine qua non para sua existência (o que, desde já, adiantamos não ser correto); ou

${ }^{11}$ VILLEGAS informa que a categoria diretos/indiretos é a mais antiga no mundo ocidental. (VILLEGAS, Hector Belisario. Curso de Finanzas, Derecho Financiero y Tributario, $8^{\mathrm{a}}$ ed. Buenos Aires: Astrea, 2003, p. $161)$.

${ }^{12}$ Em um passado não muito distante, a jurisprudência pátria chegava ao ponto de obstar toda e qualquer tentativa de repetição ou compensação do indébito caso o tributo fosse indireto. A Súmula no 71 do Supremo Tribunal Federal, editada em 1963, assentava que "embora pago indevidamente, não cabe restituição de tributo indireto". Seis anos depois, o STF flexibilizou seu entendimento, passando a entender cabível, por meio da Súmula $\mathrm{n}^{\circ} 546$, "a restituição do tributo pago indevidamente quando reconhecido por decisão que o contribuinte de jure não recuperou do contribuinte de facto o quantum respectivo".

${ }^{13}$ Dispõe o Código Tributário Nacional:

"Art. 166. A restituição de tributos que comportem, por sua natureza, transferência do respectivo encargo financeiro somente será feita a quem prove haver assumido referido encargo, ou, no caso de tê-lo transferido a terceiro, estar por este expressamente autorizado a recebê-la." 
(b) instituto que, presente na exação, qualifica-a como indireta - porém, se ausente, não impede que o tributo, ainda assim, seja qualificado como indireto (assertiva com a qual concordamos).

Confira-se.

\subsection{ORIGEM HISTÓRICA DOS CONCEITOS SUB EXAMINE: A TRIBUTAÇÃO INDIRETA E A REPERCUSSÃO ECONÔMICA.}

Foram as Ciências da Economia e das Finanças que primeiro postularam a existência de tributos diretos e indiretos. A difusão dessa categorização, entretanto, é atribuída aos fisiocratas, que, no século XVIII ${ }^{14}$, arrimados no critério da repercussão econômica, classificaram as exações conforme seu ônus financeiro fosse arcado exclusivamente pelo contribuinte ou repassado a terceiros ${ }^{15}$.

Segundo essa teoria, existiriam duas espécies tributárias:

(a) tributos diretos: aqueles nos quais o peso fiscal não era economicamente trasladado ao consumidor final (ou melhor, ao adquirente final ${ }^{16}$ de produtos e serviços). Com isso, o encargo era suportado exclusivamente pelo contribuinte, ou seja, pelo próprio obrigado ao recolhimento da quantia para os cofres públicos. Nessa modalidade, o pagante do tributo era a mesma pessoa que, de fato, suportava o seu ônus financeiro;

${ }^{14}$ BALEEIRO, Aliomar. Uma Introdução à Ciência das Finanças, $16^{\mathrm{a}}$ ed. Atualizado por DEJALMA DE CAMPOS. Rio de Janeiro: Forense, 2006, p. 279.

Os fisiocratas entendiam que a classe agricultora era a verdadeira produtora de riquezas, gravitando a classe urbana (por eles intitulada de classe "estéril") e a dos proprietários de terras em torno da única classe produtiva (a dos agricultores). GARCÍA BELSUNCE atribui aos fisiocratas, liderados por FRANÇOIS QUESNAY, o mérito de terem estudado a economia como um sistema pela primeira vez na história dessa ciência. (GARCÍA BELSUNCE, Horacio A. El Concepto de Crédito en la Doctrina y en el Derecho Tributario. Buenos Aires: Depalma, 1967, p. 10).

${ }^{15}$ BECKER, em tom crítico, discorre sobre o critério proposto pelos fisiocratas para classificação dos tributos em diretos e indiretos:

"A antiguidade e simplicidade desta classificação, bem como a natureza político-fiscal de seu critério, com o decorrer do tempo, foram imprimindo a cada espécie de tributo o batismo de direto ou indireto, de tal modo que, pela simples enunciação do nome, uns tributos são imediatamente considerados diretos e outros indiretos. Por sua vez, a repercussão econômica do tributo indireto é aceita como um fato necessário e óbvio."

Prosseguindo, o mesmo autor pontifica:

"A erronia das decisões dos tribunais em matéria tributária e a irracionalidade das leis tributárias são devidas, em grande parte, à classificação dos tributos em diretos e indiretos segundo o critério da repercussão econômica." (BECKER, Alfredo Augusto. Teoria Geral do Direito Tributário, $4^{\mathrm{a}}$ ed. São Paulo: Noeses, 2007, pp. 568-9).

${ }^{16} \mathrm{O}$ termo adquirente final é mais adequado haja vista que, em muitos casos, agentes produtores compram mercadorias para uso interno (e não como insumos para o processo de produção). Tais bens são nominados “de uso e consumo", é dizer: não se vinculam à atividade-fim da empresa, porém são por esta utilizados em suas atividades-meio. 
(b) tributos indiretos: estes tinham o seu gravame financeiro trasladado para terceiros, posto que compunham o preço de mercadorias ou serviços vendidos pelo contribuinte.

A distinção apregoada amparou o surgimento dos institutos do contribuinte de jure e do contribuinte de facto, que perduram até os dias atuais. O primeiro é aquele situado no pólo passivo da norma jurídico-tributária, a qual grava um fato ou ato por ele praticado, obrigando-o a fazer a recolha do numerário à burra estatal. Já o de facto não está diretamente envolvido na relação obrigacional tributária ${ }^{17}$. O contribuinte de fato, por adquirir bens ou serviços do contribuinte de direito, permite que este lhe repasse o ônus financeiro da exação. Com isso, assume o primeiro a tarefa de suportar o peso fiscal, sem, todavia, caracterizar-se como sujeito passivo da norma exacional.

A translação do gravame financeiro-fiscal do contribuinte de direito para o de facto era a pedra de toque da proposta classificatória dos fisiocratas ${ }^{18}$. Dessarte, em tributos como o imposto sobre a renda e os ditos impostos reais (como os que gravam a propriedade imóvel), inexistiria possibilidade de repercussão econômica, pelo que seriam diretos. Haveria, em ambos, uma coincidência entre os contribuintes de jure e de facto. Já a incidência sobre os negócios jurídicos em geral era indireta, posto que o contato entre o contribuinte de direito e o de fato (ambos partes no negócio) permitia ao primeiro verter para este último o peso da exação.

Desde cedo, todavia, os próprios fisiocratas perceberam que o critério utilizado para suportar dita categorização se demonstrava falho. Em certos casos, tributos tidos como diretos eram, por razões de mercado, economicamente transferidos aos contribuintes de

\footnotetext{
${ }^{17} \mathrm{O}$ alheamento do contribuinte de fato da relação jurídico-tributária fez surgir grande controvérsia jurisprudencial e doutrinária quanto à sua legitimidade para ingressar em juízo contra a exigência de tributo suportado pelo contribuinte de jure. Hodiernamente, a jurisprudência do Superior Tribunal de Justiça possui entendimento assentado de que, provado cabalmente o repasse do ônus tributário para o contribuinte de fato, este pode ingressar autonomamente em juízo para pedir a restituição do indébito fiscal, desde que não tenha, a seu turno, repassado dito ônus a terceiros. (STJ, Primeira Seção, EREsp nº 648.288/PE, Relator Min. TEORI ALBINO ZAVASCKI, DJ 11.09.2006, p. 224).

${ }^{18}$ Conforme apregoa VILLEGAS:

"A classificação mais antiga se baseia na possibilidade de translação (...). Por translação se entende a transferência econômica da carga impositiva daquele que paga a um terceiro.

Então, impostos diretos são aqueles que não podem transladar-se. (...). Impostos diretos são transladáveis; isso significa que são cobrados de uma pessoa tomando-se como certo ou supondo que provavelmente esta se indenizará às expensas de outra pessoa).” (VILLEGAS, Hector Belisario. Curso de Finanzas, Derecho Financiero e Tributario, $8^{\mathrm{a}}$ ed. Buenos Aires: Astrea, 2003, p. 161 - tradução livre do original em espanhol).
} 
facto; da mesma forma, tributos indiretos não tinham seu custo repassado ao consumidor final quando a conjuntura econômica assim não permitia ${ }^{19}$.

Realmente, todo e qualquer tributo pode repercutir economicamente, é dizer, ser arcado pelo consumidor final e não pelo contribuinte ${ }^{20}$. Aliás, essa é a lógica do mercado: assim como as despesas com salários dos empregados e matérias-primas, os tributos são computados como custos da produção e embutidos no preço das mercadorias ou serviços. Indiretamente, portanto, até mesmo o Imposto sobre a Renda, o IPTU do imóvel-sede da empresa e o IPVA dos veículos de sua propriedade são economicamente repassados a terceiros. Isso porque o preço cobrado pelo empresário-contribuinte deve ser suficiente para fazer face a todos os seus gastos (que incluem os tributários) e, ainda, permitir-lhe o auferimento de lucro. Se assim não fosse, o industrial, comerciante ou prestador de serviço estaria fadado ao fechamento de suas portas, posto que a atividade empresarial não seria auto-sustentável.

A análise do ônus econômico do IPTU incidente sobre o imóvel locado ${ }^{21}$ é pródiga para demonstrar a insuficiência do critério fisiocrático. Em que pese tratar-se de tributo direto por excelência, ele será suportado pelo locatório quando o contrato de aluguel contiver tal previsão. Como o locador é necessariamente o contribuinte de jure, este irá ressarcir-se do ônus fiscal (tendo-se, nesta hipótese, tributo direto com garantia contratual de repasse do ônus econômico, o que subverte a lógica da proposta fisiocrática).

Lado outro, em eventual momento de dificuldades mercadológicas, poderá o contribuinte optar pela venda dos seus produtos ou serviços com prejuízo, o que importará no

${ }^{19}$ A doutrina de ATALIBA reforça tal crítica. Segundo o autor, a classificação de impostos em diretos e indiretos com base no critério da translação econômica "nada tem de jurídica". E pontifica:

"Pode inclusive acontecer de um imposto qualificável como direto, numa dada conjuntura econômica, se transformar em indireto e vice-versa, sem que em nada se altere a lei e sem que se modifique o sistema jurídico.” (ATALIBA, Geraldo. Hipótese de Incidência Tributária, $6^{\mathrm{a}}$ ed. São Paulo: Malheiros, 2006, p. 143).

${ }^{20}$ Neste ponto se apropositam as lições de ULHÔA CANTO, in verbis:

"Mesmo em sentido meramente econômico, a transferência do encargo financeiro de qualquer tributo é uma mera conjectura dos especialistas, que já escreveram algumas centenas, senão alguns milhares de trabalhos, basicamente de matemática financeira e não de direito, procurando mostrar como se comportam as cifras nos casos em que certos tributos - principalmente os tributos sobre a circulação de bens, direitos ou valores - podem ser transferidos a terceiros. Predomina entre tais autores o entendimento de que a transferência, mesmo se o tributo de que se trate é expresso numa percentagem de certo valor e calculado como acréscimo ao preço, constitui sempre uma incógnita, porque depende das condições de mercado." (CANTO, Gilberto de Ulhôa. A Repetição do Indébito. MARTINS, Ives Gandra da Silva (coord.). Caderno de Pesquisas Tributárias, no 8 - Repetição do Indébito. São Paulo: Resenha Tributária, 1983, pp. 7-8).

${ }^{21}$ COÊLHO, Sacha Calmon Navarro. Curso de Direito Tributário Brasileiro, $9^{\mathrm{a}}$ ed. Rio de Janeiro: Forense, 2007, p. 817. 
não-repasse de nenhum tributo, nem mesmo daqueles considerados indiretos por natureza por incidirem sobre operações mercantis ${ }^{22}$. Aliás, nesta hipótese as figuras do contribuinte de direito e de fato se confundem, estando ambas consolidadas na pessoa do comerciante, que chama para si o gravame financeiro da tributação.

Nessa toada, pode-se assertar que a repercussão econômica somente é passível de ser verificada no caso concreto, independente da natureza da exação ou de qualquer característica que esta possua. Portanto, ela não pode ser tomada como base para a dicotomização dos tributos em diretos e indiretos - constatação à qual a doutrina desde cedo chegou ${ }^{23}$. Afinal, a volubilidade e a instabilidade da repercussão financeira - que varia ao sabor do mercado e de cada negócio jurídico praticado - impedem que a taxonomia jurídica nela busque fundamento.

Em face disso, novos critérios foram propostos para fundamentar a bipartição entre tributos diretos e indiretos, originando um extenso rol de teorias que, apesar de distintas, guardam entre si alguma correlação.

${ }^{22}$ Sobre o tema preleciona MISABEL DERZI:

"Pode se dar (...) que o contribuinte tenha adquirido a mercadoria em condições tão favoráveis, que, apesar do imposto lhe ter sido destacado na fatura de compra, o encargo econômico foi transferido para trás, contra o seu fornecedor, que lhe cedeu o bem pelo custo ou abaixo do custo." (BALEEIRO, Aliomar. Direito Tributário Brasileiro, $11^{\mathrm{a}}$ ed. Atualizado por MISABEL ABREU MACHADO DERZI. Rio de Janeiro: Forense, 2001, p. 890).

Exemplifiquemos: uma mercadoria é comprada pelo comerciante por $\mathrm{R} \$ 100,00$ (cem reais). Após seis meses, porém, ela ainda não teve saída. Decide então o empresário aliená-la por $\mathrm{R} \$ 80,00$ (oitenta reais), em uma promoção. A venda será concretizada e na nota fiscal será destacado o ICMS de R \$ 14,40 (quatorze reais e quarenta centavos) considerando uma alíquota de $18 \%$. Pode-se dizer que o contribuinte de facto arcou com o ônus tributário destacado na nota fiscal? Obviamente que não.

${ }^{23}$ Neste particular, vale conferir a lição de FONROUGE:

"Os autores antigos, fundando-se nas teorias fisiocráticas, baseavam a distinção [entre tributos diretos e indiretos] na possibilidade de translação do gravame, considerando direto o suportado definitivamente pelo contribuinte de jure e indireto o que se traslada sobre outra pessoa; mas os estudos modernos demonstraram a incerteza das regras de incidência e como alguns impostos (...) considerados antes intransferíveis resultam em verdadeiro traslado [do ônus financeiro] para terceiros." (FONROUGE, Carlos María Giuliani. Derecho Financiero, v. I, $8^{\text {a }}$ ed. Buenos Aires: Depalma, 2003, p. 324 - tradução livre do original em espanhol).

COCIVERA segue o mesmo sendeiro:

"Este critério de distinção (o econômico) não pode ser utilizado pelo jurista porque, além das dúvidas, legítimas, que suscitam em relação à possibilidade da total translação do imposto, não oferece nenhum critério formal para uma distinção dos impostos sob o aspecto jurídico." (COCIVERA, Benedeto. Principi di Diritto Tributario, v. I. Milano: Giuffrè, 1959, p. 245 - tradução livre do original em italiano).

Na doutrina pátria, calha à fiveleta a cita de BOTTALLO e MELO, para quem os fundamentos da classificação em análise "repousam em noções e princípios que, embora relevantes no campo da Economia e da Ciência das Finanças, são absolutamente estranhos ao Direito Tributário". (BOTTALLO, Eduardo Domingos e MELO, José Eduardo Soares de. Comentários às Súmulas Tributárias do STF e do STJ. São Paulo: Quartier Latin, 2007, p. 87). 


\subsection{AS CLASSIFICAÇÕES POSSÍVEIS.}

Sabedora da insuficiência do critério da repercussão econômica, a doutrina - acedendo aos reclames de segurança para ditar-se a natureza do tributo - partiu em busca de novos sustentáculos para a dicotomia diretos/indiretos.

As diversas escolas que se foram sucedendo ao longo do tempo podem ser sumariadas em duas grandes categorias: as que apregoam um critério econômico-contábil para tal mister e aquelas que buscam o respaldo em sistematizações jurídicas. A nota que as separa é a radicação ou não, em lei, do elemento diferenciador apreendido pelos teóricos. Dessarte, quando se fala em repercussão econômica, a dicotomização será guiada pela economia. Já quando se invoca a lei para identificar elementos que permitam ultimar a classificação em tela, está-se diante de uma análise jurídica da questão. Dentro de cada macro-divisão, podemos apontar as seguintes subcategorias:

\begin{tabular}{|l|ll|}
\hline \multicolumn{1}{|c|}{ Critérios econômico-contábeis } & \multicolumn{1}{c|}{ Critérios jurídicos } \\
\hline (a) teoria clássica da repercussão econô- & (a) teoria do rol nominativo; \\
mica (critério dos fisiocratas); & (b) teoria do lançamento; \\
(b) teoria da contabilidade nacional; & (c) teoria da natureza do fato tributável. \\
(c) teoria da capacidade contributiva. & & \\
\hline
\end{tabular}

Vejamo-las, uma a uma.

\subsubsection{CRITÉRIOS ECONÔMICO-FINANCEIROS.}

\subsubsection{TEORIA FISIOCRÁTICA DA REPERCUSSÃO ECONÔMICA.}

Como já foi visto, trata-se da tese que deitou as bases para a classificação das exações em diretas e indiretas. Ao sustentar que toda riqueza provinha da terra, apregoavam os fisiocratas (dentre os quais destacamos QUESNAY ${ }^{24}$ ) que os tributos diretos seriam aqueles recolhidos pelo proprietário rural. Já os indiretos traduziam-se em três modalidades: os pagos pelos agricultores (não-proprietários); os incidentes sobre os lucros obtidos com o capital e a indústria; e, por fim, a tributação sobre as commodities vendidas ou consumidas. Assim, o termo tributo indireto correspondia a toda incidência fiscal, exceto aquela suportada diretamente pelo dono da terra ${ }^{25}$ (de todo modo, o ônus da tributação indireta era sempre trasladado ao proprietário rural, pilar fundante de toda a sociedade).

\footnotetext{
${ }^{24}$ QUESNAY, François. The Economical Table. Honolulu: University Press of the Pacific, 2004.

${ }^{25}$ SELIGMAN, Edwin Robert Anderson. The Shifting and Incidence of Taxation, $3^{\text {rd }}$ ed. New York: Columbia University Press, 1910, p. 138.
} 
Assim, para os adeptos desta corrente, tributo indireto era o que repercutia economicamente; já o direto inadmitia o repasse do ônus econômico, posto que gravava diretamente aquele que suportava o peso fiscal (no caso, o senhor da terra).

Não obstante, desde cedo a teoria foi tida por insuficiente dado que, como alerta SACHA CALMON ${ }^{26}$, todos os tributos são passíveis de repercussão econômica. Nada mais verdadeiro. Por ser um dado da realidade mutável em cada caso concreto - passando, dessarte, ao largo da Ciência do Direito, única hábil a proporcionar um "critério verdadeiramente jurídico para classificar as exações fiscais", como salienta BARROS CARVA$\mathrm{LHO}^{27}$ - a repercussão meramente financeira não se presta, em definitivo, a vôos mais al$\operatorname{tos}^{28}$.

\subsubsection{TEORIA DA CONTABILIDADE NACIONAL.}

Estoutro critério apregoa que os impostos indiretos agregam-se aos preços das mercadorias e serviços, ao passo que os diretos representam custos suportados pelos próprios agentes econômicos. Em outras palavras: os indiretos são tributos repassados adiante nos preços; os diretos, não. Sob essa ótica, o ICMS seria indireto, sendo inclusive destacado na nota fiscal para indicar ao adquirente que o ônus do imposto está sendo trasladado no preço do produto ou serviço adquirido; já o IPTU seria imposto direto, por não integrar o valor de qualquer bem fabricado ou revendido, sendo devido pelo simples fato de o contribuinte deter a propriedade de bem imóvel.

A denominação "teoria da contabilidade nacional" decorre do fato de a ciência contábil, para calcular o produto nacional ${ }^{29}$ dos países, acrescer ao valor dos bens produzidos o montante dos impostos indiretos, por serem tributos que - consoante o critério in examense agregam aos preços. Lado outro, os indiretos devem ser excluídos ao se calcular a renda nacional $^{30}$, pois esta corresponde aos valores pagos aos agentes produtores para remunerar

\footnotetext{
${ }^{26}$ COÊLHO, Sacha Calmon Navarro. Curso de Direito Tributário Brasileiro, $9^{\mathrm{a}}$ ed. Rio de Janeiro: Forense, 2007, p. 817.

${ }^{27}$ CARVALHO, Paulo de Barros. Teoria da Norma Tributária. São Paulo: Lael, 1974, p. 169.

${ }^{28}$ Para ulteriores considerações, remetemos o leitor ao Item 2.1, introdutório a este subtópico.

${ }^{29}$ O Produto Nacional corresponde ao valor de todos os bens e serviços finais produzidos na economia em determinado período (WONNACOT, Paul e WONNACOT, Ronald. Introdução à Economia. Trad. por CRUSIUS, Yeda e CRUSIUS, Carlos Augusto. São Paulo: McGraw-Hill do Brasil, 1985, p. 87).

${ }^{30}$ A Renda Nacional equivale ao valor dos pagamentos que foram feitos aos meios de produção para fins de obtenção do Produto Nacional (WONNACOT, Paul e WONNACOT, Ronald. Introdução à Economia. Trad. por CRUSIUS, Yeda e CRUSIUS, Carlos Augusto. São Paulo: McGraw-Hill do Brasil, 1985, p. 101).
} 
as riquezas produzidas em determinado período de tempo. Como os indiretos não são suportados pelos contribuintes de jure $e^{31}$ - em que pese integrarem os preços das mercadorias e serviços - devem ser, como dito, excluídos do cálculo da renda nacional ${ }^{32}$.

Neste ponto, vale conferir, sob o prisma macroeconômico, como é visualizada a produção de riquezas no âmbito das nações, para melhor compreensão do critério sub examine:

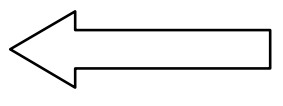

PRODUTOS

(bens e serviços)

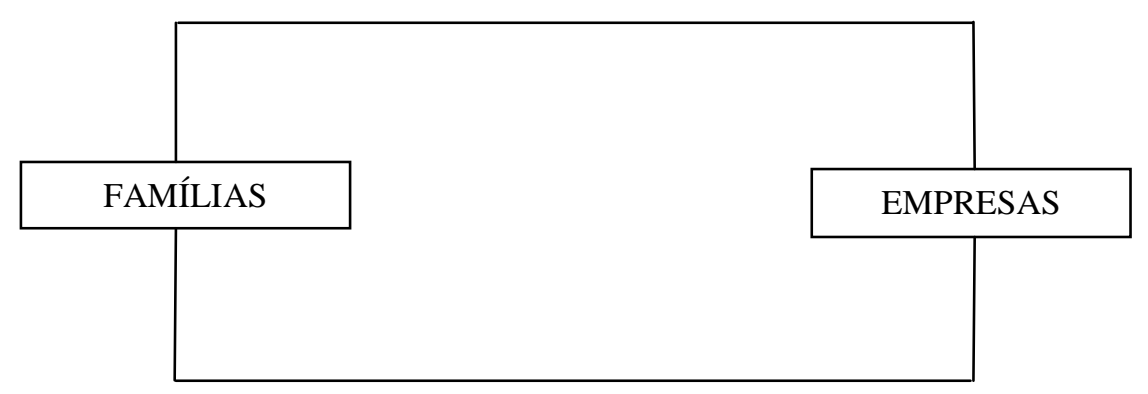

FATORES PRODUTIVOS

(terra, trabalho, capital)

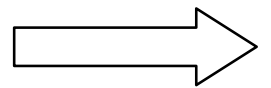

É sob tal ótica, portanto, que a contabilidade diferencia os tributos diretos dos indi$\operatorname{retos}^{33}$.

Entretanto, consoante averbado anteriormente, esta teoria não possui aplicação jurídica, servindo apenas às ciências econômicas e contábeis, em que pesem as suas conclusões coincidirem em parte com aquelas derivadas de outros critérios classificatórios (como as teorias da natureza do fato tributável e da capacidade contributiva, que, apesar de finca-

${ }^{31} \mathrm{O}$ papel do contribuinte de direito no imposto indireto seria, nessa visão, apenas o de recolher numerário do contribuinte de facto para fins de repasse ao Estado.

${ }^{32}$ NABAIS assim explica o critério da contabilidade nacional, ao qual também atribui a nomenclatura de critério econômico stricto sensu:

“(...) Enquanto os impostos directos, porque não integram os preços dos bens e serviços, não são tidos nem havidos no apuramento do produto e rendimento nacionais, os impostos indirectos, porque integram os referidos preços, são deduzidos do produto nacional (bruto ou líquido) para apurar o rendimento nacional (bruto ou líquido). É que, o rendimento nacional é igual ao produto nacional menos os impostos directos ou impostos sobre o consumo. O que significa que os impostos indirectos neste sentido correspondem aos impostos sobre o consumo." (NABAIS, José Casalta. Direito Fiscal, $2^{\mathrm{a}}$ ed. Coimbra: Almedina, 2004, p. 42).

${ }^{33}$ A tributação sobre o consumo de bens e serviços será sempre a indireta, ao passo que as propriedades e rendas sofrerão a incidência dos diretos. 
das noutras premissas, predicam que a tributação direta grava patrimônio e renda, ao passo que a indireta grava o consumo e, também, manifestações isoladas de capacidade contributiva, como a transferência da propriedade imóvel).

Não obstante, como dito, a premissa da teoria da contabilidade nacional não se apresenta como válida, posto que guarda estreita semelhança com a da repercussão econômica. Parece-nos, aliás, que se trata do mesmo critério dos fisiocratas, porém formulado em outros termos. Afinal, parte-se do pressuposto da existência de tributos que, pagos pelo agente econômico, não trariam nenhum ônus à mercadoria vendida ou ao serviço prestado; e de outros que, ao contrário, comporiam os respectivos preços.

Ora, é cediço que todo e qualquer tributo suportado pelos agentes produtores é economicamente repassado ao próximo elo da cadeia produtiva, salvo situações excepcionais, como práticas de dumping ou dificuldades mercadológicas. Dessarte, o critério sub examine perde, por esta razão, serventia jurídica.

\subsubsection{A TEORIA DA CAPACIDADE CONTRIBUTIVA.}

Segundo este critério (também intitulado financeiro $^{34}$ ), os tributos diretos atingem manifestações imediatas ${ }^{35}$ da capacidade contributiva ${ }^{36}$ dos cidadãos, a saber: seus patrimônios e suas rendas. Trata-se de uma forma bastante eficaz de se tributar adequadamente quem tem mais posses, alcançando-se, com maior precisão, a riqueza na medida de sua disponibilidade. Apesar de, eventualmente, a traslação do ônus financeiro ser passível de ocorrer mesmo nos tributos diretos (o que é reconhecido pelas premissas do critério em

\footnotetext{
${ }^{34}$ NABAIS, José Casalta. Direito Fiscal, 2a ed. Coimbra: Almedina, 2004, p. 41.

${ }^{35}$ RIBEIRO, José Joaquim Teixeira. Lições de Finanças Públicas, 5ª ed. Coimbra: Coimbra Editora, 1995, p. 309.

${ }^{36}$ Note-se que o termo capacidade contributiva não se confunde com capacidade econômica, em que pese muitas vezes serem utilizados como sinônimos. Sobre a distinção entre eles, confira-se a lição de IVES GANDRA:

"Capacidade contributiva e capacidade econômica não se confundem (...). Contributiva é a capacidade do contribuinte relacionada com a imposição específica ou global, sendo, portanto, dimensão econômica particular de sua vinculação ao poder tributante, nos termos da lei. Capacidade econômica é a exteriorização da potencialidade econômica de alguém, independentemente de sua vinculação ao referido poder."

O seguinte exemplo melhor clarifica a diferença exposta pelo autor:

"Um cidadão que usufrui renda tem capacidade contributiva perante o país em que a recebeu, desde que nos limites adequados e vinculados à sua produção de renda, se a imposição for aquela do imposto sobre a renda.

Um cidadão rico, de passagem pelo país, tem capacidade econômica, mas não tem a contributiva, para efeitos dos tributos específicos exigidos de cidadãos e residentes." (MARTINS, Ives Gandra da Silva. O Sistema Tributário na Constituição, $6^{\text {a }}$ ed. São Paulo: Saraiva, 2007, pp. 106-7).
} 
questão), a sua verificação ou não, no caso concreto, é irrelevante nesta proposta classificatória.

Já os indiretos atingem manifestações mediatas da capacidade contributiva, gravando operações de compra-e-venda de bens, prestações de serviços e celebração de negócios jurídicos. São situações, em regra, ligadas ao consumo de riqueza ${ }^{37}$, ou, noutras palavras, à aquisição ou transferência de bens e serviços ${ }^{38}$. Em todas essas hipóteses, está-se diante de manifestações de capacidade contributiva, porém não tão objetivas quanto aquelas gravadas pela tributação direta. Afinal, a aquisição de um bem de consumo, em que pese a priori ser um signo presuntivo de riqueza, eventualmente falseia, aos olhos do Fisco, a real disponibilidade financeira do contribuinte (cuja capacidade de recolha à burra estatal pode ser bem menor do que a exteriorizada por um ato isolado). De toda forma, quando incidente sobre atos de consumo de bens e serviços, a tributação é considerada indireta pela teoria em questão - pouco importando se há ou não a traslação econômica do ônus físcal.

NABAIS $^{39}$, contudo, insurge-se contra este critério, tachando-o de superficial e afirmando que ele se encontra em desuso, não sendo observado pelas legislações tributárias hodiernas. Entretanto, não nos parece que o jurista português, nesse particular, esteja com toda a razão. Vejamos, para tanto, o seguinte sumário das conclusões da teoria da capacidade contributiva:

(a) tributos diretos: gravam a riqueza estática (patrimônio) ou o acréscimo patrimonial (renda);

(b) tributos indiretos: incidem sobre a riqueza gasta (consumo de bens e serviços) ou transferida (compra-e-venda de imóveis, v.g.).

Ora, esta é a classificação que predomina nos sistemas jurídicos atuais. FERREIRO LAPATZA $^{40}$, analisando o direito positivo espanhol, conclui que os tributos diretos gravam a riqueza em si mesma, diretamente considerada. E enumera como integrantes desta categoria o imposto de renda das pessoas físicas, o imposto sobre sociedades (que, na Europa, grava a renda das pessoas jurídicas), o imposto extraordinário sobre o patrimônio das pessoas físicas e o imposto sobre sucessões e doações.

\footnotetext{
${ }^{37}$ FERREIRO LAPATZA, José Juan. Direito Tributário - Teoria Geral do Tributo. Barueri: Manole; Madrid: Marcial Pons, 2007, pp. 164-5.

${ }^{38}$ GRIZIOTTI, Benvenuto. Principios de Ciencia de las Finanzas. Buenos Aires: Depalma, 1959, p. 161.

${ }^{39}$ NABAIS, José Casalta. Direito Fiscal, 2a ed. Coimbra: Almedina, 2004, p. 41.

${ }^{40}$ FERREIRO LAPATZA, José Juan. Curso de Derecho Financiero Español, 12a ed. Madrid: Marcial Pons, 1990, pp. 286-353.
} 
Ainda segundo o jurista catalão ${ }^{41}$, os indiretos atingem manifestações indiretas da capacidade contributiva. $\mathrm{O}$ rol pertencente a este quadrante compreende, na Espanha: o imposto sobre transmissões patrimoniais e atos jurídicos documentados, o imposto sobre o valor agregado (IVA), os impostos especiais (que, na Europa, gravam o consumo de bebidas alcoólicas e tabaco em geral), os impostos aduaneiros, os impostos das comunidades autônomas e das entidades locais. Ora, se o critério é empregado até os dias de hoje não se pode dizer que esteja em desuso - ao contrário. No Brasil, R. B. NOGUEIRA ${ }^{42}$ foi um dos únicos autores a sustentar dita classificação, que, todavia, não teve aplicação prática por confrontar-se com a linha adotada pelo CTN (que esposou o critério da repercussão jurídica).

A nosso sentir, a teoria em análise peca por não se pautar em regras jurídicas, mas sim em premissas econômicas. Analisa-se apenas a forma de apreensão da riqueza tributável (mediata ou imediata) e nenhum outro elemento que possa trazer juridicidade ao critério.

Expliquemo-nos melhor. A referência pura e simples à capacidade contributiva, apesar de indicar o critério extrajurídico que pautou a atuação do legislador, nada diz sobre a origem da obrigação tributária, tampouco sobre o seu objeto e a sua natureza. Apenas versa sobre um escopo do legislador, exógeno à norma tributária.

Ora, a adequada formulação de uma teoria classificatória das espécies de tributos deve passar, necessariamente, pela análise da hipótese de incidência, em especial do seu critério material, que, consoante averba BARROS CARVALHO ${ }^{43}$, designa o comportamento passível de atrair os efeitos fiscais previstos em abstrato no antecedente da norma.

Dessarte, por não se ocupar do estudo da natureza do fato imponível para concluir pelo caráter direto ou indireto das exações, o critério da capacidade contributiva - arrimado

${ }^{41}$ FERREIRO LAPATZA, José Juan. Curso de Derecho Financiero Español, $12^{\mathrm{a}}$ ed. Madrid: Marcial Pons, 1990, pp. 354-392.

${ }^{42}$ Assim leciona R. B. NOGUEIRA:

"O imposto direto tem a virtude de poder graduar diretamente a soma devida por um contribuinte, de conformidade com a sua capacidade contributiva. Exemplo típico de imposto direto é o imposto sobre a renda pessoal.

O imposto indireto, diferentemente, liga o ônus tributário a um evento jurídico ou material e não dispõe de um parâmetro direto para apurar a capacidade econômica do contribuinte. (...) São impostos indiretos, entre outros, o IPI e o ICMS, o imposto de importação." (NOGUEIRA, Ruy Barbosa. Curso de Direito Tributário, 10ª ed. São Paulo: Saraiva, 1990, p. 163).

${ }^{43}$ CARVAlHO, Paulo de Barros. Curso de Direito Tributário, 17 a ed. São Paulo: Saraiva, 2005, pp. 257-60. 
em fundamentos financeiros e extrajurídicos - sucumbe quando contrastado com a necessidade de segurança e método ínsita à Ciência do Direito ${ }^{44}$.

\subsubsection{CRITÉRIOS JURÍDICOS.}

\subsubsection{TEORIA DO ROL NOMINATIVO.}

O critério do rol nominativo (também intitulado critério administrativo ${ }^{45}$ ou $\mathrm{gal}^{46}$ ), originou-se na Itália em fins do século XIX. O mesmo propugnava que tributos diretos seriam aqueles nos quais os dados do contribuinte e da respectiva riqueza tributável constariam de um cadastro público, o qual seria acessado pela autoridade administrativa sempre que necessário. Assim, contribuinte da exação direta seria aquele individualmente inscrito, cujo nome constava do rôle nominatif (como era referido pelos franceses ${ }^{47}$ ).

Já os indiretos não seriam cobrados com base em rol constante dos cadastros públicos, mas sim quando verificada a prática, pelo contribuinte, de atos que a Administração tivesse competência para gravar, tais como a prestação de serviços, a compra-e-venda de mercadorias, et caterva.

Os impostos sobre a propriedade eram - e alguns ainda são - exemplos clássicos de tributos diretos exigidos com base no cadastro administrativo. A Administração Tributária oficiava aos contribuintes por ela cadastrados, notificando-os do valor do tributo a pagar. Como os órgãos efetivamente mantinham um cadastro individual dos contribuintes para esse tipo de exação, de fato o rol nominativo era uma característica formal comum aos impostos sobre a propriedade. Transplantando para os dias de hoje a classificação, temos como exemplo dessa modalidade de tributo o IPVA. A Administração Tributária possui em seu banco de dados as informações sobre cada um dos veículos automotores em circulação e seus respectivos proprietários. Com base no valor venal dos automóveis, o imposto é

\footnotetext{
${ }^{44}$ Sobre a invalidade do critério financeiro, GIANNINI apregoa:

"A referência genérica (...) à capacidade contributiva não basta para determinar nem a origem nem a extensão da obrigação tributária, uma e outra dependendo de mais específicos e concretos elementos de fato, mas serve apenas para exprimir o conceito que guiou o legislador ao instituir cada tributo; isso indica a razão, não o conteúdo da norma, e constitui portanto uma noção extrajurídica." (GIANNINI, Achille Donato. I Concetti Fondamentali del Diritto Tributario. Torino: Torinese, 1956, p. 84 - tradução livre do original em italiano).
}

45 BALEEIRO, Aliomar. Uma Introdução à Ciência das Finanças, 16 ${ }^{\mathrm{a}}$ ed. Atualizado por DEJALMA DE CAMPOS. Rio de Janeiro: Forense, 2006, p. 280.

${ }^{46}$ BOUCHER, Hércules. Estudo da Mais-Valia no Direito Tributário Brasileiro, tomo I. Rio de Janeiro: Freitas Bastos, 1964, p. 86.

${ }^{47}$ BALEEIRO, Aliomar. Uma Introdução à Ciência das Finanças, $16^{\mathrm{a}}$ ed. Atualizado por DEJALMA DE CAMPOS. Rio de Janeiro: Forense, 2006, p. 280. 
lançado pelo Executivo e o contribuinte-proprietário é informado do montante que deve pagar - tributo indireto, portanto, haja vista ser cobrado com base no rôle nominatif.

Apesar da tese não nos convencer, consoante demonstraremos infra, é digno de nota que BERLIRI ${ }^{48}$ foi um de seus defensores. Para o jurista, a legislação italiana efetivamente havia adotado essa fórmula para distinção dos tributos em diretos e indiretos. Tal posicionamento lhe rendeu críticas por parte de GIANNINI ${ }^{49}$ e COCIVERA $^{50}$. O primeiro, após tecer loas a BERLIRI por exercer o mister classificatório com base no direito positivo (e não na economia), dissente do sendeiro perfilhado pelo autor. Para GIANNINI, critérios meramente formais, ainda que escorados na lei, não são adequados para a diferenciação dos tributos conforme a sua natureza. Já COCIVERA invalida a teoria do rol nominativo ao expor que diversos impostos de titularidade das comunas italianas - à mesma época em que BERLIRI defendia seu posicionamento - eram tidos como indiretos, porém cobrados com base na inscrição do contribuinte em cadastros públicos (como exemplo, cita os impostos incidentes sobre locações e serviços de transporte prestados por carruagens).

Atualmente o critério em tela está superado, pois $95 \%$ dos tributos são sujeitos a lançamento por homologação, é dizer, são pagos sem que haja qualquer interferência esta$\operatorname{tal}^{51}$. Tirante os precitados IPVA e IPTU, a Administração não possui "rol nominativo" (ou individualizado) que informe, ao contribuinte, o valor do débito e a data do vencimento de qualquer tributo. O imposto sobre a renda é lançado por homologação, assim como também o são o ITR (típico imposto sobre a propriedade, no caso rural) e as diversas contribuições para financiamento da seguridade social, inter alii. Cientes da subjugação da teoria pela passagem do tempo, LAFERRIÉRE e WALINE ${ }^{52}$ chegaram a sustentar que, à época de sua criação, o critério era válido pois a arrecadação fiscal dos tributos diretos não era possível sem o recurso ao rol nominativo de contribuintes (assertiva que contrasta com a de

${ }^{48}$ Assim dispõe o jurista:

“(...) $\mathrm{O}$ critério diferenciador entre impostos diretos e indiretos resulta dos métodos de lançamento e cobrança: são diretos todos aqueles lançados sob o regime de rol nominativo. Todos os demais são indiretos." (BERLIRI, Antonio. Corso Istituzionale di Diritto Tributario. Milano: Giuffré, 1965, p. 55 - tradução livre do original em italiano).

${ }^{49}$ GIANNINI, Achille Donato. I Concetti Fondamentali del Diritto Tributario. Torino: Torinese, 1956, pp. $81-9$.

${ }^{50}$ COCIVERA, Benedeto. Principi di Diritto Tributario, v. I. Milano: Giuffrè, 1959, pp. 244-50.

${ }^{51}$ COÊLHO, Sacha Calmon Navarro. Liminares e Depósitos antes do Lançamento por Homologação Decadência e Prescrição, $2^{\mathrm{a}}$ ed. São Paulo: Dialética, 2002, p. 2.

${ }^{52}$ LAFERRIÉRE, Julien e WALINE, Marcel. Traité Élémentaire de Science et de Législation Financiéres. Paris: Librairie generale de droit et de jurisprudence, 1952, p. 259. 
COCIVERA $^{53}$ ), dada a forma de organização das Administrações Tributárias italiana e francesa, onde, respectivamente, a teoria surgiu e se desenvolveu.

Todavia, não nos parece que o fundamento de LAFERRIÉRE e WALINE seja apto a confirmar a validade do critério objurgado. Ainda que assim fosse, a nosso sentir continuaria faltando respaldo jurídico à tese. Tomar-se como parâmetro para estabelecer a distinção entre tributos diretos e indiretos a mera forma administrativa de cobrança das exações significa olvidar-se por completo das premissas metodológicas que devem pautar qualquer classificação que se pretenda científica. Por não se tratar de um critério fundado na natureza do tributo, não é possível atribuir-lhe validade suficiente para enquadrar a exação em uma ou outra categoria ${ }^{54}$. Vale repisar: a dicotomia diretos/indiretos refere-se à natureza das exações e não à sua forma de cobrança, por meio de um cadastro ou não. A categorização em análise exacerba a importância dos elementos burocráticoadministrativos constantes da legislação tributária e olvida-se por completo da busca da essentialia dos tributos diretos e indiretos. Um exemplo clarifica a nossa dissonância com a teoria em comento: se, a partir do próximo ano, o IPTU passasse a ser pago por conta e risco do contribuinte, dispensando-se a inscrição individual deste no cadastro da prefeitura e seguindo-se as regras aplicáveis aos demais tributos sujeitos a lançamento por homologação, tal mudança na forma de pagamento e cobrança importaria na sua descaracterização de tributo direto para indireto? A resposta é negativa! A proposta classificatória em xeque possui caráter excessivamente mecânico ${ }^{55}$, não constituindo critério apropriado para o estudo das espécies exacionais.

Assim, duplamente superada está a teoria do rol nominativo: pela ação inexorável do tempo, a retirar-lhe as premissas em que se fundava; e pela imperfeição de seu critério,

${ }^{53}$ COCIVERA, Benedeto. Principi di Diritto Tributario, v. I. Milano: Giuffrè, 1959, pp. 244-50.

${ }^{54}$ Sobre método e ciência, vale conferir as lições de BARROS CARVALHO:

"Toda ciência pressupõe um corte metodológico. Ao analisarmos o homem do ângulo histórico, por exemplo, colocamos entre parênteses as conotações propriamente técnico-jurídicas, econômicas, sociológicas, éticas, antropológicas etc., para concentrar o estudo prioritário na evolução dos fatos que se sucedem no tempo, e que apresentam a criatura humana como entidade central. Qualquer especulação científica que pretendamos empreender trará consigo essa necessidade irrefragável, produto das ínsitas limitações do ser cognoscente." (CARVALHO, Paulo de Barros. Curso de Direito Tributário, $17^{\mathrm{a}}$ ed. São Paulo: Saraiva 2005, p. 12).

Não vislumbramos, na teoria do cadastro administrativo, um corte metodológico adequado. Se o que se busca é estudar a natureza do tributo, como é possível sustentar que a forma administrativa de sua cobrança tem o condão de definir sua espécie? A nosso sentir, em vista dessa falha a teoria estava condenada desde a sua origem.

${ }^{55}$ ZANOBINI, Guido. Corso di Diritto Amministrativo, v. IV. Milano: Giuffrè, 1955, p. 359. 
que se baseia nas práticas adotadas pelos agentes fiscais para cobrança dos tributos e não na natureza propriamente dita do tributo.

\subsubsection{A TEORIA DO LANÇAMENTO.}

Trata-se de critério derivado da teoria do rol nominativo. Tributos diretos seriam aqueles em que o lançamento é mandatório (essencial para permitir-se o pagamento do tributo), ao passo que os indiretos dispensariam tal figura ${ }^{56}$. Nessa linha, seriam diretos os impostos sobre a propriedade e a renda ${ }^{57}$ e indiretos aqueles incidentes sobre atos e negócios jurídicos (circulação e consumo de riqueza), pagos pelo contribuinte sem o prévio accertamento por parte da autoridade administrativa.

Entretanto, a teoria - desenvolvida no início do século XX por O. MAYER ${ }^{58}$ - não teve longa vida útil, haja vista a constatação de que diversos tributos diretos não reclamam lançamento (caso típico, no Brasil, do imposto sobre a renda), ao passo que vários outros tidos como indiretos muitas vezes o exigem (como, por exemplo, o IPI devido na importação, que somente pode ser pago após o despacho aduaneiro). Mesmo na Europa do início do século XX - ou seja, contemporânea à criação da teoria - o imposto sobre a renda, quando retido na fonte, dispensava o lançamento, fato que levou O. MAYER a defender seu ponto de vista argumentando que a regra geral por ele proposta comportava algumas exceções.

O caráter estritamente formalista rendeu a O. MAYER as mesmas objeções que a doutrina fizera a BERLIRI e aos demais adeptos do critério do rol nominativo. Se um tributo passasse, por opção do legislador, a ser lançado de ofício, tornar-se-ia de imediato uma exação direta? Certamente que não.

Outrossim, é cediço que na hipótese de não pagamento do imposto indireto o contribuinte fica sujeito a lançamentos de ofício (que exigirão o tributo acrescido de juros e multa). Exsurge de tal consideração a seguinte dúvida: o ICMS quitado após eventual lançamento de ofício possui natureza distinta do mesmo imposto pago regularmente pelo con-

\footnotetext{
${ }^{56}$ NABAIS assim discorre sobre o tema:

"Segundo este critério (...) seriam impostos directos ou impostos com lançamento aqueles em cujo procedimento fiscal houvesse lugar a um acto administrativo de lançamento ou acto tributário, e impostos indirectos ou impostos sem lançamento aqueles em que esse acto administrativo não tivesse lugar." (NABAIS, José Casalta. Direito Fiscal, $2^{a}$ ed. Coimbra: Almedina, 2004, pp. 43-4).

${ }^{57}$ No século passado, França, Itália e outros países da Europa exigiam o lançamento para a recolha aos cofres públicos do imposto sobre a renda.

${ }^{58}$ MAYER, Otto. Deutsches Verwaltungsrecht, v. I, $3^{\text {a }}$ ed. Miinchen: Duncker \& Humblot, 1914, pp. 200-15.
} 
tribuinte, sem necessidade de lançamento? A aplicação do critério de O. MAYER nos levaria ao absurdo de concluir que o ICMS recolhido espontaneamente seria indireto, ao passo que o imposto quitado em razão do lançamento de ofício seria direto. E está-se falando, por óbvio, do mesmo tributo.

A tais constatações adicione-se o fato de que, nas legislações tributárias hodiernas, o lançamento é figura tributária em extinção, sendo desnecessária inclusive em impostos sobre o patrimônio (caso, em nossas plagas, do ITR) e na tributação da renda. Em face disso, a teoria do lançamento para os fins em análise está superada ${ }^{59}$.

\subsubsection{A TEORIA DA NATUREZA DO FATO TRIBUTÁVEL.}

Os dois critérios jurídicos postos até o momento (cadastro administrativo e lançamento), além de inválidos por erro de premissa metodológica (prendem-se à forma, e não à essência dos tributos), não possuem aplicação prática nos dias atuais.

Já a Teoria da Natureza do Fato Tributável, em que pese ter surgido na segunda metade do século XIX, ainda encontra respaldo e aplicabilidade em diversos sistemas jurídicos contemporâneos. Segundo o seu criador, DE FOVILLE, para se perquirir se o tributo é direto ou indireto, deve-se analisar o critério material de sua hipótese de incidência ${ }^{60}$. A tributação direta gravaria fenômenos permanentes no tempo, como a propriedade de um imóvel ou o exercício de indústria ou profissão que gerasse rendimentos (fatos perenes, que tendem a se perpetuar). A seu turno, a indireta alcançaria fatos instantâneos, ou seja, que pudessem ser isoladamente considerados, como a prestação de serviços, transferência da propriedade, importação de produtos ${ }^{61}$, inter alii.

A dicotomia entre tributos diretos e indiretos, com base na permanência ou intermitência do fato gerador, conquistou a simpatia da doutrina ${ }^{62}$. Prova disso é que a Liga das

${ }^{59}$ COSTA, José Manuel Moreira Cardoso da. Curso de Direito Fiscal, $2^{\mathrm{a}}$ ed. Coimbra: Almedina, 1972, p. 29.

${ }^{60}$ DE FOVILLE não utiliza a terminologia critério material da hipótese de incidência, que adotamos apenas para melhor esclarecer os fundamentos de sua doutrina. Além disso, ressalta-se que a proposta metodológica da presente classificação já demonstra as razões pelas quais ela não foi superada pelo decurso do tempo. $\mathrm{O}$ direito posto é sempre analisado hic et nunc pela ciência jurídica, porém esta deve pautar-se em elementos que, dentro do possível, transcendam uma simples mudança legislativa. E a única forma de fazê-lo é perquirir a natureza, os elementos intrínsecos e verdadeiramente essenciais do objeto estudado, o que permitirá não somente uma análise mais acurada do fenômeno do direito positivo, mas, também, maior sobrevida das lições propostas.

${ }^{61}$ BOUCHER, Hércules. Estudo da Mais-Valia no Direito Tributário Brasileiro, tomo I. Rio de Janeiro: Freitas Bastos, 1964, p. 88. 
Nações, ao fim da I Guerra Mundial, propôs que o modelo de impostos a ser adotado pelos

Países se dividisse em diretos (incidentes sobre propriedade e renda) e indiretos (gravando a produção, utilização e transações econômicas) - exatamente nos moldes do que DE FOVILLE propusera meio século antes ${ }^{63}$. E, consoante averbado anteriormente, a utilização dos tributos diretos para tributação da renda e propriedade e dos indiretos para o consumo e transferência de patrimônio é regra, hoje, em vários sistemas jurídicos (o próprio Tratado de Roma, em seus arts. 92 e 93, opera a distinção dessa forma ${ }^{64}$ ).

Assim, pode-se sustentar que, sob o prisma classificatório em análise, os verbos ser e ter vinculam-se à imposição direta e o verbo fazer à indireta. Dessarte, o núcleo do crité-

${ }^{62}$ A teoria mereceu os aplausos de A. FALCÃO:

"A velha e surrada classificação dos impostos (...) em diretos e indiretos se revitaliza quando toma como ponto de referência, num desdobramento ou aplicação do critério de FOVILLE, a natureza do fato gerador:

- no imposto direto, o fato gerador é um fato, estado de fato ou situação jurídica de caráter permanente, continuado ou, pelo menos, durável no tempo;

- no imposto indireto, o fato gerador é um fato, estado de fato ou situação jurídica de caráter intermitente, isolado no tempo ou instantâneo." (FALCÃO, Amílcar de Araújo. Fato Gerador da Obrigação Tributária, $2^{a}$ ed. Atualizado por GERALDO ATALIBA. São Paulo: Revista dos Tribunais, 1971, p. 137).

Analisando um artigo publicado por DE FOVILLE no Economiste Français de $1^{\circ}$ de setembro de 1883, ALLIX e LECERCLÉ averbaram:

"O imposto direto - diz De Foville - visa e atinge no contribuinte aqueles elementos impositivos que oferecem um caráter durável, constante, ou pelo menos contínuo, como a existência, a profissão ou a posse. Existir, possuir, exercer um comércio ou uma indústria, eis aí os dados permanentes que a Administração pode tributar por meio de impostos nominativos e periódicos. Ao contrário, os impostos indiretos incidem não sobre as qualidades (individuais) ou a posse, mas sobre fatos particulares, sobre atos intermitentes. O verbo fazer remete ao imposto indireto; o verbo ser ou haver invoca o imposto direto." (ALLIX, Edgard e LECERCLÉ, Marcel. L'Impôt sur Le Revenú, Impôts Cédulaires et Impôt Général. Les Nouvelles Dispositions Législatives, v. I. Paris: Rousseau, 1926, p. 20 tradução livre do original em francês).

${ }^{63}$ BALEEIRO, Aliomar. Uma Introdução à Ciência das Finanças, $16^{\mathrm{a}}$ ed. Atualizado por DEJALMA DE CAMPOS. Rio de Janeiro: Forense, 2006, p. 280.

${ }^{64}$ NABAIS, ao analisar o Tratado de Roma (Tratado CE), especificamente seus arts. 92 e 93, conclui que a referência à tributação indireta contida nos dispositivos tem sido utilizada pelos Estados-Membros da Comunidade para harmonizar a tributação sobre o consumo, notadamente o IVA (Imposto sobre Valor Agregado) e os impostos especiais (típicos dos países europeus, que buscam tributar, de forma diferenciada, bebidas alcoólicas, tabaco e derivados de petróleo). Vale conferir o Tratado:

“Art. 92. Relativamente às imposições que não sejam os impostos sobre o volume de negócios, os impostos especiais de consumo e outros impostos indirectos, só podem ser concedidas exonerações e reembolsos na exportação para outros Estados-Membros (...), desde que as medidas projectadas tenham sido previamente aprovadas pelo Conselho (...).

Art. 93. O Conselho, deliberando por unanimidade (...), adopta as disposições respeitantes à harmonização das legislações relativas aos impostos sobre o volume de negócios, aos impostos especiais de consumo e a outros impostos indirectos (...)." (destaques nossos)

Analisando tais disposições, concluiu o Professor de Coimbra que o Tratado da Comunidade Européia adotou a imposição indireta como sinônimo de tributação sobre o consumo. No que se alinha, vale acrescer, com a classificação predominante em nível mundial. (NABAIS, José Casalta. Direito Fiscal, $2^{\mathrm{a}}$ ed. Coimbra: Almedina, 2004, pp. 42-9). 
rio material da norma tributária (que é um verbo seguido pelo seu complemento, como esclarece BARROS CARVALHO ${ }^{65}$ ), pautará a definição da espécie do tributo.

Essa a razão pela qual juristas do porte de H. VILLEGAS ${ }^{66}$ e GIANNINI ${ }^{67}$ defendem - baseados no direito positivo de seus respectivos países - a prevalência do critério da natureza do fato gerador, sem deixar, contudo, de advertir que a matéria é efetivamente polêmica $^{68}$.

A força de tal classificação pode ainda ser constatada pela sua utilização por R. G. DE SOUSA no Anteprojeto de Código Tributário Nacional ${ }^{69}$ (o qual, todavia, cedeu lugar

${ }^{65}$ Exemplo: ser (verbo) proprietário de bem imóvel (complemento predicativo). Este o critério material da regra-matriz de incidência do IPTU. (CARVALHO, Paulo de Barros. Direito Tributário - Fundamentos Jurídicos da Incidência, $4^{\mathrm{a}}$ ed. São Paulo: Saraiva, 2006, p. 89).

${ }^{66}$ VILLEGAS, Hector Belisario. Curso de Finanzas, Derecho Financiero y Tributario, $8^{\mathrm{a}}$ ed. Buenos Aires: Astrea, 2003, pp. 162-3.

${ }^{67}$ Leciona GIANNINI:

"No ordenamento jurídico italiano não há dúvidas (...) de que a distinção entre impostos diretos e indiretos constitua a base de múltiplas disposições legislativas, o que basta para demonstrar-nos a sua relevância jurídica (cf. art. $6^{\circ}$ da lei sobre o contencioso administrativo; arts. 2752, 2758, 2771 e 2772 do Código Civil). Sobretudo no mais recente desenvolvimento do direito internacional a distinção entre as duas categorias de impostos (...) se tornou de fundamental importância para a determinação dos impostos devidos pelos que residem ou possuem bens ou exercem sua atividade no território de mais de um Estado (...). Assim o art. $1^{\circ}$ da convenção entre a Itália e a Alemanha (...) declaram que devem ser considerados impostos diretos aqueles que 'são extraídos diretamente dos rendimentos brutos ou líquidos o dos patrimônios' por parte do Estado ou dos entes públicos menores (...).

Os impostos diretos, portanto, atingem uma manifestação imediata, os indiretos uma manifestação mediata da capacidade contributiva."

Ao cabo, porém, o jurista italiano traz o seguinte alerta, advertindo para a falta de critério jurídico nessa classificação que é, antes de mais nada, financeira:

"A referência genérica, de fato, à capacidade contributiva não basta para determinar nem a origem nem a extensão da obrigação tributária, uma e outra dependendo de pressupostos de fato mais específicos e concretos, mas serve para exprimir o conceito que guiou o legislador para instituir cada um dos tributos; isso indica a razão, não o conteúdo da norma, e constitui portanto uma noção extrajurídica." (GIANNINI, Achille Donato. I Concetti Fondamentali del Diritto Tributario. Torino: Torinese, 1956, pp. 83-4 - tradução livre do original em italiano).

${ }^{68}$ Mas a polêmica é, obviamente, ínsita a todo e qualquer processo classificatório. Vale aqui relembrar EINAUDI que, com propriedade e lucidez, averbou que "toda classificação é arbitrária, e não é preciso exagerar sua importância, atribuindo-lhe mais do que a de corresponder a útil instrumento de estudo e esclarecimento". (Apud FONROUGE, Carlos María Giuliani. Conceitos de Direito Tributário. Trad. por ATALIBA, Geraldo e GRECO, Marco Aurélio. São Paulo: Lael, 1973, p. 23).

${ }^{69}$ Analisando a teoria defendida por R. G. DE SOUSA, BARROS CARVALHO averbou:

"Rubens Gomes de Sousa afirmou que impostos diretos seriam os suportados em definitivo pelo contribuinte obrigado por lei ao seu pagamento; ao passo que os indiretos configurariam os que são ou podem ser transferidos por aquele contribuinte para outra pessoa que por sua vez os transferirá ou suportará em definitivo (...).

Vê-se que se tratava de perfil mais econômico do que jurídico, certamente pela influência desagregadora que a Ciência das Finanças provocava no desenvolvimento do raciocínio jurídico." (CARVALHO, Paulo de Barros. Isenções Tributárias do IPI, em face do Princípio da Não- 
a outro texto final). Entretanto, no Brasil, dita teoria não foi perfilhada pelo CTN. Este adotou o critério da repercussão positivada na lei como elemento diferenciador entre a tributação direta (criada para não repercutir) e a indireta (que pressuporia - do ponto de vista legal - a translação do ônus financeiro), como se verá nos itens subseqüentes.

\subsection{A DEFINIÇÃO ADOTADA PELO ORDENAMENTO JURÍDICO BRASILEI- RO.}

Antes do advento do Código Tributário Nacional, a restituição de tributos indevidamente pagos - para a qual classificação diretos/indiretos é essencial - era, como lembra MISABEL DERZI ${ }^{70}$, regida pelo Código Civil.

Foi por meio do CTN que a restituição de tributos e, via de conseqüência, a problemática da tributação direta e indireta, recebeu tratamento sistemático e uniforme ${ }^{71}$, em seus arts. 165 a 168. Para o que interessa ao presente estudo, basta-nos a análise de um dispositivo, o art. 166, que vem assim redigido:

"Art. 166. A restituição de tributos que comportem, por sua natureza, transferência do respectivo encargo financeiro somente será feita a quem prove haver assumido o referido encargo, ou, no caso de tê-lo transferido a terceiro, estar por este expressamente autorizado a recebê-la." (destaques nossos)

Uma leitura rápida do texto pode levar o hermeneuta ao equívoco de concluir que o legislador prestigiou a teoria da repercussão econômica (tese clássica dos fisiocratas) ao dispor sobre tributos que comportem "a transferência do respectivo encargo financeiro". Afinal, o vocábulo repercussão, isoladamente considerado, remete à translação do ônus financeiro para o contribuinte de fato.

Entretanto, a expressão "por sua natureza", constante do dispositivo in examen, alude a algo além do mero critério econômico. Isso porque os fisiocratas propugnavam a análise caso-a-caso da transferência do ônus financeiro - mas não perquiriam se o tributo comportava dita repercussão por características que lhe fossem inerentes (ou "por sua natureza", como quer o CTN). Apenas a constatavam e, por isso, aplicavam a classificação - a

Cumulatividade. Revista Dialética de Direito Tributário, no 33. São Paulo: Dialética, jun./1998, pp. 149-50).

70 BALEEIRO, Aliomar. Direito Tributário Brasileiro, $11^{\mathrm{a}}$ ed. Atualizado por MISABEL ABREU MACHADO DERZI. Rio de Janeiro: Forense, 2001, p. 882.

${ }^{71}$ SILVEIRA, Lindemberg da Mota. Repetição do Indébito. MARTINS, Ives Gandra da Silva (coord.). Caderno de Pesquisas Tributárias, no 8 - Repetição do Indébito. São Paulo: Resenha Tributária, 1983, p. 67. 
qual, justamente por se calcar em dados fático-econômicos (logo, injurídicos e mutáveis ao sabor das condições mercadológicas), não logrou êxito.

A locução do CTN, que merece toda a atenção, lembra-nos a consideração de S. $\mathrm{MILL}^{72}$. O filósofo e economista inglês sugeriu que indiretos seriam os tributos nos quais o legislador tencionava arrecadar os valores do contribuinte de fato ${ }^{73}$. A assertiva é um indicador de que os tributos indiretos seriam não aqueles nos quais houvesse a translação do ônus financeiro, mas sim aquelas exações que, devido à sua conformação legislativa, possuíssem esse escopo (em que pese o critério da repercussão econômica nunca ter admitido a inclusão de qualquer elemento jurídico para a sua conformação ${ }^{74}$ ). Também HENSEL sob a ótica privilegiada de jurista - já havia atentado para tal fato, atribuindo valor à distinção diretos/indiretos tão-somente se "a intenção do legislador em relação à questão da translação tenha encontrado uma expressão normativa"75 (no Brasil, SACHA CALMON ${ }^{76}$ também versou o tema, perfilhando posicionamento similar ao de HENSEL, em lição à qual nos reportaremos adiante).

Conforme apregoa o art. 166 do CTN, são indiretos (rectius: dotados da característica da repercussão) os tributos que, por sua natureza, comportem a transferência do encargo financeiro a terceiro. Como se deve interpretar dita locução? Adoção pura e simples

\footnotetext{
${ }^{72}$ Segundo MILL, tributos indiretos são aqueles "antecipados [pagos] por uma pessoa para, como esperado e pretendido, ser reembolsada por outra", situada no elo subseqüiente da cadeia, até o consumidor final. (MILL, John Stuart. Principles of Political Economy. New York: Prometheus Books, 2004, p. 764 - tradução livre do original em inglês).

${ }^{73}$ Neste ponto, em que há expressa remissão à intenção do legislador (a qual é muitas vezes criticada quando inserida como elemento do processo interpretativo), vale repisar a lição de HURD, que, com clarividência e objetividade, averba que "apesar da tentativa de exorcismo, a interpretação jurídica é assombrada pelo intencionalismo". (HURD, Heidi M. Interpretando as Autoridades. MARMOR, Andrei (coord.). Direito e Interpretação. São Paulo: Martins Fontes, 2004, p. 609).
}

${ }^{74}$ Partilhando deste entendimento, averba NABAIS:

“(...) A distinção em apreço tende a assentar não na simples susceptibilidade de repercussão econômica, mas antes na repercussão econômica tida em conta e querida pelo legislador fiscal quando do recorte legal do pressuposto de facto do respectivo imposto." (NABAIS, José Casalta. Direito Fiscal, $2^{\text {a }}$ ed. Coimbra: Almedina, 2004, p. 43).

Advertimos, contudo, que a repercussão econômica (enquanto método classificatório dos tributos em diretos e indiretos) pauta-se, apenas, no critério financeiro, como visto no Item 2.1. O acréscimo de um elemento jurídico à mesma é fruto da evolução doutrinária - o que, contudo, transmuda por completo o critério financeiro clássico, não sendo correto sustentar-se que, desde sempre, a teoria da repercussão econômica já atentava para a vontade do legislador. Sabedor disso, o próprio NABAIS conclui, após a explanação acima transcrita, que a análise da vontade do legislador "exprime mais um critério jurídico do que econômico". (NABAIS, José Casalta. Direito Fiscal, 2ª ed. Coimbra: Almedina, 2004, p. 43).

75 HENSEL, Albert. Diritto Tributario. Trad. para o italiano de DINO JARACH. Milano: Giuffrè, 1956, p. 342 - tradução livre do original em italiano.

${ }^{76}$ COÊLHO, Sacha Calmon Navarro. Liminares e Depósitos antes do Lançamento por Homologação - Decadência e Prescrição, $2^{\mathbf{a}}$ ed. São Paulo: Dialética, 2002, pp. 39-42. 
da tese econômica (de resto imprestável, como já salientado alhures) ou uma nova proposta classificatória, que parte de um dado econômico (translação do ônus) porém o transforma em instituto jurídico (existência de norma criada para possibilitar a translação - independendo se, do ponto de vista financeiro, ela ocorrerá ou não)? Inclinamo-nos pela segunda, porém, antes de ofertar nossas conclusões, vale conferir o que os Tribunais Superiores e a doutrina pátria averbam sobre o tema.

\subsubsection{A TRIBUTAÇÃO INDIRETA À LUZ DA JURISPRUDÊNCIA. 2.3.1.1. PERÍODO ANTERIOR AO CTN.}

Até o advento do Código Tributário, inexistia na legislação vigente dispositivo que autorizasse a devolução de tributos indevidamente pagos. Na ausência de normatização, o Supremo Tribunal Federal aplicava o art. $964^{77}$ do Código Civil de 1916, determinando a restituição dos tributos indevidamente $\operatorname{pagos}^{78}$ (fossem estes diretos ou indiretos ${ }^{79}$ ).

Após esse primeiro posicionamento (que era bastante liberal, pois não erigia óbices para a restituição de tributos indiretos), a teoria da repercussão econômica (em sua visão fisiocrática) foi adotada pelo STF, que passou a vedar a devolução de todo e qualquer tributo indireto (conforme deliberação da Sessão Plenária de 13/12/1963, que culminou com a edição da Súmula $\mathrm{n}^{\mathrm{o}} 71 / \mathrm{STF}^{80}$ ). Segundo o Supremo, como a exação indireta pressupunha a translação do ônus econômico, o contribuinte de jure não estaria nunca legitimado a pleitear a sua devolução. Lado outro, o consumidor final, por não integrar a relação jurídico-tributária, tampouco poderia postular a repetição.

\footnotetext{
${ }^{77}$ Assim dispunha o hoje revogado Código de 1916:

"Art. 964. Todo aquele que recebeu o que lhe não era devido fica obrigado a restituir."
}

78 BOTTALlO, Eduardo Domingos. Restituição de Impostos Indiretos. Revista de Direito Público, $\mathrm{n}^{\circ} 22$. São Paulo: Revista dos Tribunais, out-dez./1972, p. 316.

${ }^{79}$ Esse posicionamento do STF, que autorizava a restituição de todo e qualquer tributo, inclusive os indiretos (sem qualquer tipo de condicionante quanto à legitimidade ativa para pleitear a repetição), não prosperou. $\mathrm{O}$ Ministro CARLOS MEDEIROS DA SILVA, nos autos do RE $\mathrm{n}^{\circ}$ 58.290/SP, faz breve remissão aos poucos acórdãos nesse sentido:

"Antes mesmo da Súmula 71 e quando a jurisprudência deste egrégio Tribunal ainda era vacilante quanto à restituição do imposto indireto, tive oportunidade de publicar um modesto trabalho na Revista de Direito Administrativo, sustentando a tese que hoje está consagrada.

Recordo-me que existia, anteriormente, somente um acórdão, em caso do Estado do Espírito Santo, relatado pelo saudoso Ministro Ari Franco, que permitia a restituição; depois houve mais um ou dois acórdãos." (STF, Terceira Turma, RE no 58.290/SP, Relator Min. LUIZ GALLOTTI, DJ 23.11.1966, destaques nossos).

80 "Embora pago indevidamente, não cabe restituição de tributo indireto". 
Posteriormente, nova modificação no entendimento sumulado - desta vez para favorecer os contribuintes - ocorreu em 03.12.1969. A Súmula $n^{\circ} 71$ foi revogada ${ }^{81}$ e substituída pela de $\mathrm{n}^{\mathrm{o}} 546^{82}$. Esta autorizou a devolução do tributo indevidamente pago desde que o contribuinte de direito provasse ter arcado com o ônus financeiro da exação (ou, caso não tivesse suportado o gravame, possuísse autorização do contribuinte de fato para solicitar a repetição).

Mas, afinal, o que era - sob a ótica do STF - tributo indireto (cuja restituição chegou a ser totalmente vedada em um período ${ }^{83}$ ) anteriormente à edição do $\mathrm{CTN}^{84}$ ? O estudo dos acórdãos que pautaram a edição de ambas as Súmulas que curam da restituição tributária (a de $n^{\circ} 71$, utilizando de forma expressa o termo "tributo indireto", e a n ${ }^{\circ} 546$, referindo-se às figuras do contribuinte de direito e de fato, ínsitas à tributação indireta) lança luzes sobre o tema. Confira-se.

\subsection{OS PRECEDENTES QUE ORIGINARAM A SÚMULA N 71.}

São quatro os arestos que embasaram a súmula em análise.

No Recurso Extraordinário $\mathrm{n}^{\mathrm{o}} 46.450 / \mathrm{RS}^{85}$, julgado em 10 de janeiro de 1961, o Ministro Relator VILAS BOAS averbou que tributo indireto seria aquele no qual houvesse a percussão econômica. O Ministro VICTOR NUNES, em voto-vista, acompanhou o raciocínio do Relator, sustentando que, no tributo indireto, o contribuinte de direito incorpora o valor da exação ao preço da mercadoria vendida a terceiros. Este foi o primeiro precedente analisado na sessão plenária que erigiu a Súmula nº 71 . Dele já se denota que o STF,

\footnotetext{
${ }^{81}$ Para alguns a Súmula no 71/STF não teria sido revogada, mas apenas "esclarecida" pela de no 546 . Não nos parece que seja assim, posto que a mera leitura de ambas, aliada à análise dos precedentes que as originaram, já denota a contrariedade de suas disposições.

82 "Cabe a restituição do tributo pago indevidamente, quando reconhecido por decisão, que o contribuinte de jure não recuperou do contribuinte de facto o quantum respectivo."

${ }^{83}$ Por refugir ao escopo deste trabalho, não adentraremos no mérito do erro ou acerto das decisões judiciais sobre o direito do contribuinte à restituição do tributo indireto. Sobre aludido tema, sugerimos as seguintes obras: MARTINS, Ives Gandra da Silva (coord.). Caderno de Pesquisas Tributárias $n^{o} 8$ - Repetição do Indébito. São Paulo: Resenha Tributária, 1983; MACHADO, Brandão. Repetição do Indébito no Direito Tributário. MACHADO, Brandão (coord.). Direito Tributário - Estudos em Homenagem ao Prof. Ruy Barbosa Nogueira. São Paulo: Saraiva, 1984, pp. 61-106; TORRES, Ricardo Lobo. Restituição dos Tributos, $1^{\mathrm{a}}$ ed. Rio de Janeiro: Forense, 1983; MORSHBACHER, José. Repetição do Indébito Tributário Indireto. São Paulo: Revista dos Tribunais, 1984.
}

${ }^{84}$ A Súmula no 546, em que pese ter vindo a lume em 1969, originou-se de precedentes que curavam de casos anteriores à edição do Código Tributário (logo, ainda regidos pela sistemática do art. 964 do CC/1916).

${ }^{85}$ STF, Segunda Turma, RE no 46.450/RS, Relator Min. VILAS BOAS, DJ 21.08.1961, p. 284. 
nesta época, adotava pura e simplesmente o critério econômico ${ }^{86}$ para classificação de tributos em diretos e indiretos.

É interessante notar que tal entendimento padece de uma perversidade singela: na oportunidade em que concluiu pela impossibilidade do contribuinte de jure pleitear em nome próprio eventual restituição, o STF também assentou que o contribuinte de facto, por não integrar a relação jurídico-tributária, tampouco poderia requerer, em juízo ou fora dele, a repetição do tributo indireto. E a conclusão final, constante do voto do Ministro VICTOR NUNES, foi, no mínimo, heterodoxa: entre o locupletamento ilícito do contribuinte de jure e o do Estado, é preferível o deste último, que presumivelmente utilizará os recursos em prol do bem comum. Para não haver dúvidas de que o STF decidiu exatamente isso, damos à transcrição o voto do Ministro VICTOR NUNES, no RE n 46.450/RS:

"Se o dilema é sancionar um enriquecimento sem causa, quer em favor do Estado (...), quer em favor do contribuinte (...), não há que hesitar: impõe-se a primeira alternativa, pois o Estado representa, por definição, o interesse coletivo, a cuja promoção se destina, no conjunto da receita pública, a importância reclamada pelo particular, para sua fruição pessoal. Esta solução é que corresponde à eqüidade, fundamento básico da ação proposta."

O Estado Robin Hood, que rouba dos ricos (ou melhor, se apropria indevidamente de valores por estes pagos) para dar aos pobres seria até uma consideração jocosa - se não tivesse sido realmente autorizado perante nossa Corte Maior.

Os outros três arestos que serviram de base à Súmula $n^{\circ} 71$ confirmam a utilização pelo Supremo da teoria da repercussão criada pelos fisiocratas.

De fato, nos autos dos Recursos Extraordinários $\mathrm{n}^{\circ} \mathrm{s} 45.678 / \mathrm{SP}^{87}$ (julgado em 26.06.1961) e 47.069/SP ${ }^{88}$ (julgado em 30.06.1961), decididos respectivamente pela Primeira e Segunda Turmas, resta claro a mais não poder que tributo indireto é aquele que repercute sobre terceiro, ou seja, cujo ônus não é arcado pelo solvens, que apenas recolhe o tributo aos cofres públicos. Vale conferir a ementa do primeiro aresto mencionado:

"Não se restitui tributo indireto, pois que seu montante incorpora-se no custo da produção da mercadoria, ao ser vendida. Jurisprudência do Supremo Tribunal."

\footnotetext{
${ }^{86}$ Sobre o aludido critério, vide Capítulo I, Item 1.1.1, supra.

${ }^{87}$ STF, Primeira Turma, RE no 45.678/SP, Relator Min. GONÇALVES DE OLIVEIRA, DJ 27.11.1961, p. 431.

${ }^{88}$ STF, Segunda Turma, RE no 47.069/SP, Relator Min. VICTOR NUNES, DJ 05.12.1962, p. 63.
} 
É dizer: pelo fato de o tributo integrar o custo do produto final, ao contribuinte de direito não seria lídimo pleitear a restituição da exação paga a maior ou indevidamente, posto que lhe faltaria legitimatio ad causam. Afinal, como o ônus fora trasladado a terceiro, se a restituição fosse deferida ao contribuinte de jure este iria enriquecer-se indevidamente.

Por derradeiro, o Recurso Extraordinário n ${ }^{\circ} 44.115 / \mathrm{ES}^{89}$, julgado pelo Pleno em 02 de outubro de 1961, restou assim ementado:

"A restituição dos tributos indiretos, pagos pelo produtor à conta do $1^{\circ}$ consumidor, somente por este ou mediante sua autorização, pode ser reclamada."

O Min. GONÇALVES DE OLIVEIRA, ao votar, pontuou que os impostos indiretos são aqueles que "se incorporam ao preço da mercadoria", seguindo a linha tracejada pela ementa do aresto, que, como visto, classificou os indiretos como tributos pagos pelo contribuinte de jure às expensas do consumidor.

\subsection{AS ORIGENS DA SÚMULA N 546 .}

A Súmula $\mathrm{n}^{\circ} 546$, editada quase seis anos após a de $\mathrm{n}^{\circ} 71$, foi lavrada pelo Plenário do STF com base em três acórdãos pretéritos daquela mesma Corte. Vejamo-las, lembrando que a análise in casu perquire a conceituação de tributo direto e indireto ofertada pela Corte Suprema.

No Recurso Extraordinário n ${ }^{\text {o }} 58.290 / \mathrm{SP}^{90}$ (j. em 17.06.1966), nenhuma mudança na concepção de tributo indireto ocorreu. A decisão apenas sustentou que, se em determinado caso fosse impossível ao contribuinte de direito repassar o ônus do tributo a terceiro, não haveria que se falar em aplicação da Súmula ${ }^{\circ} 71$ (que vedava a restituição de tributos que repercutissem). Aliás, tanto não houve qualquer mudança na concepção de tributo indireto que o acórdão, referindo-se a outra decisão do STF (Recurso Extraordinário $n^{\circ}$ 50.892), qualifica como indireto o tributo "de larga e imediata repercussão". Clara invocação do critério classificatório dos fisiocratas, baseado na repercussão financeira.

Foi sob a pena do Ministro ALIOMAR BALEEIRO que, no Recurso Extraordinário $n^{\circ} 45.977 / \mathrm{ES}^{91}$ (julgado em 27.09.1966), adveio a rediscussão, no âmbito do STF, sobre a

\footnotetext{
${ }^{89}$ STF, Pleno, RE no 44.115/ES, Relator Min. AFRÂNIO COSTA, DJ 17.09.1962, p. 421.

${ }^{90}$ STF, Terceira Turma, RE no 58.290/SP, Relator Min. LUIZ GALLOTTI, DJ 23.11.1966.

${ }^{91}$ STF, Segunda Turma, RE no 45.977/ES, Relator Min. ALIOMAR BALEEIRO, DJ 22.02.1967.
} 
classificação técnico-jurídica de tributação direta e indireta. A ementa do aresto vale ser lida:

\section{"REPETIÇÃO DE IMPOSTO INCONSTITUCIONAL.}

Em princípio, não se concede a do tributo indireto no pressuposto de que ocasionaria o locupletamento indébito do contribuinte de jure.

Mas essa regra, consagrada pela Súmula $\mathrm{n}^{\circ} 71$, deve ser entendida em caso concreto, pois nem sempre há critério científico para diagnosticar-se esse locupletamento.

Financistas e juristas ainda não assentaram um standard seguro para distinguir impostos diretos e indiretos, de sorte que, a transferência do ônus, às vezes, é matéria de fato, apreciável em caso concreto."

Como se dessume da última parte da ementa, por primeira vez passou o STF a questionar a validade do critério econômico para distinção dos tributos em diretos e indiretos. A lucidez de BALEEIRO sobre a insuficiência do critério até então adotado pelo Supremo pode ser conferida nos seguintes excertos de seu voto:

"O mesmo tributo poderá ser direto ou indireto, conforme a técnica de incidência e até conforme as oscilantes e variáveis circunstâncias do mercado (...).

À falta de um conceito legal, que seria obrigatório ainda que oposto à evidência da realidade dos fatos, o Supremo Tribunal Federal inclina-se a conceitos econômico-financeiros baseados no fenômeno da incidência e da repercussão dos tributos indiretos, no pressuposto errôneo, data venia, de que, sempre, eles comportam transferência do ônus do contribuinte de jure para o contribuinte de facto."

Com base em tais considerações, acolhidas à unanimidade pela Segunda Turma, o STF julgou, naquele caso, ser legítima a repetição de tributo indireto, posto que demonstrado, no caso concreto, que não houve o repasse do ônus econômico a terceiros.

Seguindo o sendeiro aberto por BALEEIRO, o terceiro paradigma (Embargos de Divergência no Recurso Extraordinário $\mathrm{n}^{\mathrm{o}} 58.660 / \mathrm{SP}^{92}$, julgado em 10.04.1969) utilizado na Sessão Plenária de 03.12.1969 para firmar o novo entendimento sumulado repete as razões expostas acima. Na hipótese, reconheceu-se o direito à restituição de imposto indireto em face das circunstâncias do caso concreto, que impediram a translação econômica da exação. Do relatório do Ministro AMARAL SANTOS, extraímos as seguintes considerações:

"Ficou expressamente afirmado nas decisões proferidas na justiça local e nos laudos periciais constantes dos autos que a embargante não incluiu no preço de seus produtos a parcela do tributo que indevidamente pagou."

\footnotetext{
${ }^{92}$ STF, Pleno, RE-embargos no 58.660/SP, Relator Min. AMARAL SANTOS, DJ 30.05.1969.
} 
Com base nestes precedentes, operou-se a reformulação do entendimento do STF acerca da restituição de tributos indiretos. Ao fazê-lo, sustentou o Supremo que não há presunção juris et de jure de que o seu ônus financeiro é sempre transferido ao consumidor final - tal dependeria de verificação, in concreto, das condições econômicas que pautaram a operação tributada.

Dita evolução foi seguida também de uma modificação nas premissas classificatórias das exações em diretas e indiretas. Estas passaram a ser qualificadas não mais conforme a existência ou não de transferência econômica, mas sim de acordo com a repercussão juridicamente objetivada - ou não - pelo legislador. É o que nos demonstra a jurisprudência que sucedeu à Súmula no 546/STF.

\subsubsection{O ART. 166 DO CÓDIGO TRIBUTÁRIO E AS CORTES SUPERIORES.}

Após a edição do CTN, a classificação dos tributos em diretos e indiretos, que era feita com base no critério (reconhecidamente falho) da translação do ônus econômico, sofreu mudanças. O Código Tributário passa a exigir expressamente a prova do não-repasse na "restituição de tributos que comportem, por sua natureza, transferência do respectivo encargo financeiro". Tal disposição, inserta em seu art. 166, modificou sensivelmente a normatização do tema "repetição do indébito tributário", que, consoante averbado anteriormente, encontrava guarida no Código Civil de 1916 (art. 964).

O que o CTN dispôs assemelhou-se (embora não coincidisse por completo) com o apregoado pelo STF na Súmula n ${ }^{\circ} 546$. Vejamos ambos os textos:

\begin{tabular}{|c|l|}
\hline CÓDIGO TRIBUTÁRIO NACIONAL & \multicolumn{1}{|c|}{ SUPREMO TRIBUNAL FEDERAL } \\
\hline $\begin{array}{l}\text { Art. 166. A restituição de tributos que com- } \\
\text { portem, por sua natureza, transferência do } \\
\text { respectivo encargo financeiro somente será }\end{array}$ & $\begin{array}{l}\text { Súmula 546. Cabe a restituição do tributo } \\
\text { pago indevidamente, quando reconhecido } \\
\text { feita a quem prove haver assumido o referi- } \\
\text { po encargo, ou, no caso de tê-lo transferido o contribuinte de jure não } \\
\text { recuperou do contribuinte de facto o quan- } \\
\text { a terceiro, estar por este expressamente au- } \\
\text { torizado a recebê-la. }\end{array}$ \\
\hline
\end{tabular}

Da análise das transcrições, extrai-se que:

(a) nem o CTN nem o STF utilizam o termo "tributo indireto" (ao contrário da extinta Súmula $\left.\mathrm{n}^{\mathrm{o}} 71\right)$;

(b) o critério para exigir-se a ou não a prova da repercussão é:

(b.1) para o CTN, a natureza do tributo, que determinará a translação do ônus econômico; 
(b.2) para o STF, a existência de duas modalidades de contribuinte: o de jure e o de facto.

Então, diante dessa nova realidade, pode-se afirmar que a distinção entre diretos e indiretos foi definitivamente abandonada, abrindo espaço para um novo critério classificatório? Temos que não. O que houve foi uma modificação do conceito de tributo indireto, que passou a ser permeado por critérios jurídicos - e não mais puramente econômicos.

A análise da jurisprudência e, em seguida, da doutrina pós-CTN, lança luzes sobre o tema.

\subsection{O POSICIONAMENTO DO STF.}

Após as modificações legais e jurisprudenciais supracitadas, podemos apontar a existência de duas correntes no Supremo Tribunal Federal quanto à caracterização dos tributos em diretos e indiretos e à aplicação do art. 166 do CTN.

Uma primeira, que acabou se limitando a alguns votos prolatados no bojo de acórdãos que decidiam o direito (ou não) à restituição, assevera que a distinção diretos/indiretos deixou de ter serventia no direito brasileiro. É o que constou do voto do Ministro OSWALDO TRIGUEIRO, prolatado nos Embargos de Divergência no Recurso Extraordinário $\mathrm{n}^{\mathrm{o}} 73.173 / \mathrm{SP}^{93}$. Ao analisar o argumento da parte interessada de que o conceito de tributo indireto não seria aplicável à taxa de despacho aduaneiro (cobrada, à época, como um adicional do imposto de importação), averbou o Ministro TRIGUEIRO:

“(...) O Código Tributário Nacional, quando trata do pagamento indevido, não faz a distinção entre imposto direto ou indireto. Ele reconhece que a restituição do tributo é cabível 'seja qual for a modalidade de seu pagamento' (art. 165). É certo que o art. 166 condiciona a restituição à prova de que o tributo não foi transferido, mas essa exigência somente tem lugar na restituição de tributos que, por sua natureza, comportem a transferência do respectivo encargo financeiro.

Como ressalta da discussão do presente caso, trata-se de tributo que - seja direto, seja indireto - não comporta a translação prevista na lei."

Esse, contudo, não foi o mesmo entendimento perfilhado pelo Ministro Relator ANTONIO NEDER. Em que pese ter sido voto vencido - por ter decidido pela impossibilidade de restituição da taxa aduaneira ${ }^{94}$ - assentou NEDER:

93 STF, Pleno, RE-Embargos $n^{\circ}$ 73.173/SP, Relator p/ o acórdão Min. RODRIGUES ALCKMIN, DJ 29.03.1974.

${ }^{94}$ A decisão foi assim ementada:

"Embargos de divergência. Acórdão que determina a restituição de taxa de despacho aduaneiro, arrecadada ilegalmente sobre importação de mercadoria isenta. Alegado dissídio com a Súmula 546 e 
"O segundo fundamento (da empresa que buscava a restituição do indébito) é o de que o conceito de tributo indireto irrestituível não é aplicável à taxa de despacho aduaneiro.

Dá-se, todavia, que, neste ponto, o acórdão embargado está em divergência não só com os verbetes 308 e 309 da súmula, que sustentam que a referida taxa é adicional do imposto de importação, como, também em certo ponto, do verbete 546 do mesmo Ementário, que se refere à restituição de tributo, palavra que abrange o imposto e a taxa, como sabemos."

Os demais votos no Recurso Extraordinário $n^{\circ}$ 73.173/SP (julgado em 14.11.1973) não trouxeram considerações sobre o tema acima, que, de fato, remanesceu como obter dictum nos dois votos mencionados.

Em outra oportunidade, e em que pese estar ciente de que a distinção diretos/indiretos era doutrinariamente insegura, o Supremo Tribunal Federal demonstrou maior inclinação para reconhecer que, mesmo após a Súmula nº 546 e o art. 166 do CTN, a classificação dos tributos em uma dessas duas espécies continuou a importar para o direito tributário. Os trechos do voto do Ministro Relator no Recurso Extraordinário $\mathrm{n}^{\circ}$ 76.597/SP ${ }^{95}$ (julgado em 30.08.1974), RODRIGUES ALCKMIN, demonstram o que se está a afirmar:

"Improcedente é a alegação de não tratar-se, no caso, de tributo indireto. A taxa de despacho aduaneiro é adicional de imposto de importação e imposto indireto como tal, sendo a distinção doutrinariamente insegura. Basta, porém, a falta de demonstração de que o encargo fiscal não se transferiu para que a ação devesse ser tida como improcedente."

Com a evolução jurisprudencial, a expressão "tributação indireta" passou a designar as exações que, por sua natureza, comportassem a transferência do respectivo encargo financeiro, sendo abandonadas as digressões sobre a invalidade do critério diretos/indiretos. Em voto de Relatoria do Ministro ALDIR PASSARINHO, este efetivamente vinculou o conceito de tributo indireto àquele de tributo passível de repercussão por sua natureza (art. $166 \mathrm{CTN})$ :

"A questão é (...) saber-se se, em se tratando de imposto indireto, caberia ou não a restituição sem prova de que o contribuinte de fato é que não arcara com o ônus tributário.",96

com julgados que excluem a repetição de tributos indiretos sem a prova da repercussão, restituição admitida por ser tabelada a mercadoria. Divergência inexistente. Embargos não conhecidos." (STF, Pleno, RE-Embargos $\mathrm{n}^{\circ}$ 73.173/SP, Relator p/ o acórdão Min. RODRIGUES ALCKMIN, DJ 29.03.1974).

${ }^{95}$ STF, Primeira Turma, RE no 76.597/SP, Relator Min. RODRIGUES ALCKMIN, DJ 27.09.1974, p. 7017.

96 STF, Primeira Turma, RE $\mathrm{n}^{\circ}$ 105.340/RJ, Relator p/ o acórdão Min. CORDEIRO GUERRA, DJ 14.03.1986, p. 3390. 
No mesmo sendeiro confiram-se, inter alii, as seguintes ementas:

"ICM. Restituição de tributo pago indevidamente. Se a carga tributária resultante de imposto indireto é absorvida na margem de lucro bruto do comerciante, por não haver integrado a formação do custo sobre o qual foi calculado o lucro, recai ela sobre o contribuinte de jure. Súmula 546. Recurso extraordinário não conhecido."97

“1) Imposto de consumo. Empresa de energia elétrica. Tributo excluído da isenção geral do art. $1^{\circ}$ do Decreto-lei n. 2.281/40. 2) Ação de repetição do indébito. Tributo indireto. Aplicação da Súmula 546. Fundamento inatacado. 3) Recurso extraordinário não conhecido."98

Dessarte, no âmbito do Supremo Tribunal Federal, sedimentou-se o entendimento de que tributo indireto é aquele que, por natureza, tem o seu ônus trasladado para o contribuinte de fato. E a natureza referida, por óbvio, é a jurídica (qual seja, a existência de lei que ordena a translação) e não a econômica, que em nada interessa ao direito.

\subsection{A JURISPRUDÊNCIA DO SUPERIOR TRIBUNAL DE JUSTIÇA.}

O STJ, ao aplicar o art. 166 do CTN nos casos que lhe foram apresentados, sempre observou o posicionamento pós-CTN da Corte Suprema no que tange à caracterização dos tributos indiretos.

Um julgado paradigmático, por ter sido um dos primeiros nos quais o Superior Tribunal de Justiça discutiu a fundo a problemática da restituição de tributos diretos e indiretos, foram os Embargos de Divergência no Recurso Especial no 168.469/SP. No aludido aresto assentou-se que a contribuição previdenciária incidente sobre a remuneração paga a autônomos, empregadores e avulsos (e que fora declarada inconstitucional pelo STF $^{99}$ )

\footnotetext{
${ }^{97}$ STF, Segunda Turma, RE no 87.055/SP, Relator Min. MOREIRA ALVES, DJ 13.06.0977, p. 3901.

${ }^{98}$ STF, Primeira Turma, RE no 93.616/SP, Relator Min. XAVIER DE ALBUQUERQUE, DJ 20.02.1981, p. 1062.
}

${ }^{99}$ O Supremo Tribunal Federal, na sessão Plenária de 12.05.1994, julgou inconstitucional, por não ter sido instituída por lei complementar, a contribuição social exigida sobre pagamentos feitos pelas empresas a autônomos e administradores sem vínculo empregatício, que havia sido criada pelo art. $3^{\circ}$, I da Lei $n^{\circ} 7.787 / 89$. Vale conferir o seguinte trecho da ementa do aresto:

"CONTRIBUIÇÃO SOCIAL. TOMADOR DE SERVIÇOS. PAGAMENTOS A ADMINISTRADORES E AUTÔNOMOS. REGÊNCIA.

A relação jurídica mantida com administradores e autônomos não resulta de contrato de trabalho e, portanto, de ajuste formalizado à luz da Consolidação das Leis do Trabalho. Daí a impossibilidade de se dizer que o tomador dos serviços qualifica-se como empregador e que a satisfação do devido ocorra via folha de salários. Afastado o enquadramento no inciso I do artigo 195 da Constituição Federal, exsurge a desvalia constitucional da norma ordinária disciplinadora da matéria. A referência contida no par. $4^{\circ}$ do artigo 195 da Constituição Federal ao inciso I do artigo 154 nela insculpido, 
poderia ser compensada pelo contribuinte de jure, haja vista tratar-se de tributo direto. Antes de prosseguirmos, vale ofertar à transcrição trechos iniciais do relatório do Ministro ARI PARGENDLER (que, no mérito, restou vencido, pois não reconheceu o direito à compensação):

"A repetição dos tributos indevidamente recolhidos está, no nosso ordenamento jurídico, indelevelmente conformada pela jurisprudência.

Num primeiro momento, o Supremo Tribunal Federal distinguiu entre tributos diretos e indiretos, só admitindo a devolução dos primeiros (Súmula 71). (...).

Depois, o Supremo Tribunal mudou de orientação, admitindo a restituição dos tributos indiretos, desde que 'reconhecido por decisão que o contribuinte de jure não recuperou do contribuinte de fato o quantum respectivo' (Súmula 546).

O leading case que inspirou essa modificação foi o RE 45.977/ES, Relator o eminente Ministro ALIOMAR BALEEIRO (...).

Destaquem-se nos julgados:

a) o enfoque econômico, em face da inexistência de critério legal, para distinguir os tributos cuja carga é repassada aos consumidores (...);

b) a irremediabilidade do recolhimento indevido quando o tributo repercute nos consumidores;

c) a irrelevância de o recolhimento resultar de lei mal interpretada ou de lei inconstitucional (...).

Sobreveio a esta construção jurisprudencial o Código Tributário Nacional, cujo artigo 166 dispõe, a propósito, do seguinte modo:

'Art. 166. A restituição de tributos que comportem, por sua natureza, transferência do respectivo encargo financeiro somente será feita a quem prove haver assumido referido encargo, ou, no caso de tê-lo transferido a terceiro, estar por este expressamente autorizado a recebê-la.'

Agora havia um critério legal, e seria de esperar que ele prevalecesse sobre o enfoque econômico. Mas 'tributos que comportem, por sua natureza, transferência do respectivo encargo financeiro' são, numa análise econômica, todos aqueles que podem ser repassados a terceiros."

A perplexidade manifestada pelo Ministro PARGENDLER no último parágrafo de seu voto possui razão de ser. Afinal, se visualizado sob o prisma econômico, o comando do art. 166 do CTN em nada esclarecia, ou melhor, mantinha a mesma incerteza da classificação dos tributos em diretos e indiretos feita pela Ciência das Finanças com base em critérios financeiros. 
Neste ponto se apropositam as considerações do Ministro JOSÉ DELGADO, em voto-vista no mesmo processo (que logrou êxito perante a maioria da Primeira Seção do STJ):

"O meu entender a respeito é que a contribuição previdenciária ora examinada é de natureza direta. Apresenta-se com essa característica porque a sua exigência se concentra, unicamente, na pessoa de quem a recolhe, no caso, uma empresa que assume a condição de contribuinte de fato e de direito. (...).

Registro, nesta oportunidade, que o então egrégio Tribunal Federal de Recursos, pela sua $5^{\text {a }}$ Turma, Apelação Cível no $70.545 / \mathrm{MG}$, firmou a compreensão de que a contribuição previdenciária é tributo que, pela sua própria natureza, apresenta-se com características de direto, tendo em vista não comportar transferência do respectivo encargo financeiro.

Esse entendimento consolidou-se por se considerar que o art. 166, do CTN, só tem aplicação aos tributos indiretos, isto é, que se incorporam explicitamente aos preços, como é o caso do ICMS, do IPI, etc. (...).

Verifico, em conseqüência de tudo o quanto já foi exposto, que o fenômeno da substituição legal no cumprimento da obrigação, do contribuinte de fato pelo contribuinte de direito, não ocorre na exigência do pagamento das contribuições previdenciárias quanto à parte da responsabilidade das empresas.

Destaco, também, o assinalado por Ives Gandra da Silva Martins no sentido de que o art. 166 do CTN tem recebido, por parte dos Tribunais, uma interpretação restritiva, por só se aplicar aos tributos indiretos que, no Sistema Tributário Nacional, são, apenas, o IPI e o ICMS (in 'Repetição de Indébito', Caderno de Pesquisas Tributárias, nº 8, pág. 176, Edit. Resenha Tributária, SP, 1983)."

Assim é que a dúvida interpretativa do art. 166 apontada anteriormente pelo Ministro PARGENDLER foi solucionada. Consoante se infere do voto-vista (vencedor) do Ministro DELGADO, os tributos mencionados no art. 166 do CTN são apenas os indiretos. É dizer: são tributos que o legislador cria com o intuito de ver seu ônus repassado para terceiros. E esses tributos, segundo o STJ no citado aresto, seriam apenas o ICMS e o IPI.

Neste ponto, merece cuidadosa leitura a ementa do julgado nos Embargos de Divergência no Recurso Especial n ${ }^{\circ} 168.469 / \mathrm{SP}$ :

“2. Tributos que comportem, por sua natureza, transferência do respectivo encargo financeiro são somente aqueles em relação aos quais a própria lei estabeleça dita transferência.

3. Somente em casos assim aplica-se a regra do art. 166, do Código Tributário Nacional, pois a natureza, a que se reporta tal dispositivo legal, só pode ser a jurídica, que é determinada pela lei correspondente e não por meras circunstâncias econômicas que podem estar, ou não, presentes, sem que se disponha de um critério seguro para saber quando se deu, e quando não se deu, aludida transferência.

4. Na verdade, o art. 166, do CTN, contém referência bem clara ao fato de que deve haver pelo intérprete sempre, em casos de repetição de indébito, 
identificação se o tributo, por sua natureza, comporta a transferência do respectivo encargo financeiro para terceiro ou não, quando a lei, expressamente, não determina que o pagamento da exação é feito por terceiro, como é o caso do ICMS e do IPI. A prova a ser exigida na primeira situação deve ser aquela possível e que se apresente bem clara, a fim de não se colaborar para o enriquecimento ilícito do poder tributante. Nos casos em que a lei expressamente determina que o terceiro assumiu o encargo, necessidade há, de modo absoluto, que esse terceiro conceda autorização para a repetição de indébito."

Veja-se que a solução dada pelo STJ à problemática dos impostos diretos/indiretos e do art. 166 do CTN baseia-se nas seguintes premissas:

(a) tributos indiretos são aqueles cujo ônus financeiro é suportado pelo contribuinte de fato e não pelo contribuinte de direito;

(b) ao mencionar "tributos que comportem, por sua natureza, transferência do respectivo encargo financeiro", o art. 166 está se referindo exatamente aos tributos indiretos, e não a toda e qualquer espécie tributária;

(c) ademais, a repercussão mencionada no art. 166 do CTN é a juridicamente perseguida pelo legislador, ou seja: somente é passível de translação do ônus o tributo cuja lei de instituição assim o preveja;

(d) unificando os conceitos, pode-se afirmar que para o STJ a transferência do encargo financeiro somente ocorre na tributação indireta, a qual tem como elementos essenciais as figuras dos contribuintes de jure e de facto - ou seja, exige-se uma dualidade de sujeitos que estarão unidos pela prática da operação ou prestação que consistirá no fato gerador do tributo - além da previsão, em lei, de mecanismo para o repasse do ônus financeiro do solvens ao consumidor final.

Dessarte, não somente o critério de classificação dos tributos em diretos e indiretos sobreviveu ao CTN, como ainda passou a agregar - via interpretação jurisprudencial - o próprio conceito de "tributo criado para repercutir" posto no art. 166 do Código.

Em decisões posteriores, o STJ vem, cada vez mais, reafirmando a importância da distinção de tributos em diretos e indiretos. Confira-se o que já decidiram:

(a) a Primeira Seção do STJ, em sede de Embargos de Divergência:

"Declarada a inconstitucionalidade da contribuição previdenciária a cargo da empresa sobre os pagamentos a administradores, autônomos e empregados avulsos, os valores recolhidos a esse título são compensáveis com contribuições da mesma espécie, independente do cumprimento da exigência 
contida na Lei 9.032/95 e no art. 166 do CTN, por isso que não se trata de tributo indireto, inocorrendo o fenômeno da repercussão ou repasse."100

“TRIBUTÁRIO. EMBARGOS DE DIVERGÊNCIA. ICMS. REPETIÇÃO DE INDÉBITO. TRIBUTO INDIRETO. TRANSFERÊNCIA DE ENCARGO FINANCEIRO AO CONSUMIDOR FINAL. ART. 166 DO CTN. ILEGITIMIDADE ATIVA. PRECEDENTES.

1. A respeito da repercussão, a $1^{a}$ Seção desta Corte (EREsp n $\left.{ }^{\circ} 168.469 / S P\right)$, pacificou posição de que ela não pode ser exigida nos casos de repetição ou compensação de contribuições, tributo considerado direto, especialmente, quando a lei que impunha a sua cobrança foi julgada inconstitucional. (...).

(...)

4. O tributo examinado (ICMS) é de natureza indireta. Apresenta-se com essa característica porque o contribuinte real é o consumidor da mercadoria objeto da operação (contribuinte de fato) e a empresa (contribuinte de direito) repassa, no preço da mercadoria, o imposto devido, recolhendo, após, aos cofres públicos o imposto já pago pelo consumidor de seus produtos. Não assume, portanto, a carga tributária resultante dessa incidência."101

(b) a Primeira Turma do STJ:

"6. O tributo examinado (ISS), no caso concreto, é de natureza indireta. Apresenta-se com essa característica porque o contribuinte real é o consumidor da mercadoria objeto da operação (contribuinte de fato) e a empresa (contribuinte de direito) repassa, no preço da mercadoria, o imposto devido, recolhendo, após, aos cofres públicos o imposto já pago pelo consumidor de seus produtos. Não assume, pois, a carga tributária resultante dessa incidência. O fenômeno da substituição legal no cumprimento da obrigação, do contribuinte de fato pelo contribuinte de direito, em conseqüência, ocorre na exigência do pagamento do ISS. A repetição do indébito e a compensação do tributo questionado não podem ser deferidas sem a exigência do repasse. 7. '1. O ISS é espécie tributária que pode funcionar como tributo direto ou indireto. 2. Hipótese dos autos que encerra espécie de tributo indireto, porque recolhido sobre as receitas oriundas de cada encomenda, sendo suportado pelo tomador do serviço. 3. Como imposto indireto, tem aplicações, em princípio, o teor do art. 166 do CTN e o verbete 71 do STF, atualmente 546.' (REsp no 426.179/SP, DJ de 20/09/2004, Rel ${ }^{\mathrm{a}}$. Min ${ }^{\mathrm{a}}$. Eliana Calmon)."102

“TRIBUTÁRIO. ICMS. MAJORAÇÃO DA ALÍQUOTA DE 17\% PARA 18\%. COMPENSAÇÃO. REPETIÇÃO DE INDÉBITO. TRIBUTO INDI-

\footnotetext{
100 STJ, Primeira Seção, EREsp no $191.402 /$ RS, Relator Min. FRANCISCO PEÇANHA MARTINS, DJ 05.03.2001, p. 120. No mesmo sentido e do mesmo relator, citem-se ainda: EREsp $\mathrm{n}^{\circ}$ 223.853/RS, DJ 05.02.2001, p. 68; EREsp no 149.860/BA, DJ 18.12.2000, p. 150; EREsp nº 191.867/SP, DJ 18.12.2000, p. 151. No mesmo sentido e de relatoria do Min. LUIZ FUX: EREsp nº 187.481/RS, DJ 03.11.2004, p. 122.

${ }^{101}$ STJ, Primeira Seção, EREsp nº 699.292/SP, Relator Min. JOSÉ DELGADO, DJ 22.05.2006, p. 143, destaques nossos. No mesmo sentido e do mesmo relator: EREsp nº 664.374/SP, DJ 02.10.2006, p. 215.
}

${ }^{102}$ STJ, Primeira Turma, REsp n ${ }^{\circ}$ 657.707/RJ, Relator Min. JOSÉ DELGADO, DJ 16.11.2004, p. 211. 
RETO. TRANSFERÊNCIA DE ENCARGO FINANCEIRO AO CONSUMIDOR FINAL. ART. 166 DO CTN. ILEGITIMIDADE ATIVA.

I - A respeito da repercussão, a Primeira Seção desta Corte, em 10/11/1999, julgando os Embargos de Divergência $n^{\circ} 168.469 / \mathrm{SP}$, Rel. para acórdão Min. JOSÉ DELGADO, pacificou o entendimento de que não pode ser exigida quando se trata de repetição ou compensação de contribuições, tributo considerado direto, especialmente, quando a lei que impunha a sua cobrança foi julgada inconstitucional.

II - O art. 166 do CTN contém referência bem clara ao fato de que deve haver pelo intérprete, sempre, em casos de repetição de indébito, identificação se o tributo, por sua natureza, comporta a transferência do respectivo encargo financeiro para terceiro ou não, quando a lei, expressamente, não determina que o pagamento da exação é feito por terceiro, como é o caso do ICMS e do IPI.

III - Essa posição consolidou-se por considerar que o art. 166 do CTN só tem aplicação aos tributos indiretos, isto é, que se incorporam explicitamente aos preços, como é o caso do ICMS, do IPI etc."103

(c) A Segunda Turma do STJ:

“TRIBUTÁRIO. FINSOCIAL. DECLARAÇÃO DE INCONSTITUCIONALIDADE PELO STF. COMPENSAÇÃO. TRANSFERÊNCIA DO ENCARGO. ART. 166 DO CTN. INAPLICABILIDADE.

Declarada a inconstitucionalidade da alteração do regime legal do Finsocial, promovida a partir do art. $9^{\circ}$ da Lei 7.689/88, com implicações sobre a sucessiva majoração das alíquotas, a partir da Lei $n^{\circ} 7.787 / 89$, os valores a esse título recolhidos, ao serem compensados, não estão sujeitos ao fenômeno da repercussão ou repasse, haja vista não se tratar de tributo indireto." ${ }^{104}$

“2. É pacífica a jurisprudência do Superior Tribunal de Justiça no sentido de que o adicional de imposto de renda, por se tratar de tributo direto, não comporta repercussão, sendo dispensável a prova do não-repasse ao contribuinte de fato.

3. Para a restituição dos valores indevidamente recolhidos a título de adicional de imposto de renda, é inaplicável o teor do art. 166 do CTN, que se dirige aos tributos indiretos." 105

A coletânea de decisões demonstra de modo insofismável que a classificação dos tributos em diretos/indiretos passou a ser baseada não mais no antigo critério de repasse econômico, mas sim nos seguintes elementos:

103 STJ, Primeira Turma, AgRg no REsp no 787.015/SP, Relator Min. FRANCISCO FALCÃO, DJ 25.05.2006, p. 176.

104 STJ, Segunda Turma, REsp no 352.468/SP, Relator Min. FRANCISCO PEÇANHA MARTINS, DJ 19.12.2004, p. 304.

105 STJ, Segunda Turma, REsp no 255.213/SP, Relator Min. JOÃO OTÁVIO DE NORONHA, DJ 01.02.2006, p. 470. 
(a) na existência de um contribuinte de jure e outro de facto, que se relacionam por meio de uma operação ou prestação que envolva ambas as partes;

(b) na previsão, em lei, do repasse econômico do tributo - não mais bastando ou mesmo importando a mera constatação in concreto, sob o prisma estritamente financeiro, da repercussão.

É também certo que o Superior Tribunal de Justiça chegou a tais conclusões amparado pela ampla doutrina que se desenvolveu em torno da tributação direta e indireta e do art. 166 do CTN, como se verá a seguir.

\subsubsection{AS CORRENTES DOUTRINÁRIAS ACERCA DA TRIBUTAÇÃO DIRETA E INDIRETA NO BRASIL.}

Da análise das decisões de nossas Cortes Superiores resta claro que a divisão de tributos em diretos e indiretos subsiste e importa para a definição das regras aplicáveis em caso de restituição do indébito. A dificuldade, portanto, não reside em aceitar-se a existência dessa classificação, mas sim em definir-se o conceito jurídico de tributos diretos e indiretos.

Na doutrina pátria, podem ser divisadas duas correntes acerca do tema:

(a) uma primeira, para a qual a classificação diretos/indiretos é injurídica e, por ser pautada em critérios econômicos, não se aplica ao direito brasileiro;

(b) uma segunda que, apesar de reconhecer que o critério econômico é inválido, apregoa efetivamente existir a referida divisão dos tributos sob o prisma do direito. E o critério de identificação de conceito de tributo indireto seria aquele plasmado no art. 166 do CTN, é dizer: os tributos indiretos seriam aqueles criados para, juridicamente, repercutir (via de conseqüência, os diretos seriam aqueles nos quais não está presente a repercussão jurídica).

Para nós, a razão assiste à segunda corrente. Todavia, antes de ofertar nossas conclusões, vale conferir o que apregoam alguns expoentes de cada uma das posições citadas.

\subsubsection{A CORRENTE PELA INVALIDADE, NO DIREITO BRASILEIRO, DA DIVISÃO DE TRIBUTOS EM DIRETOS E INDIRETOS.}

As mais acerbas críticas na doutrina nacional à propalada diferenciação entre tributos diretos e indiretos foram aquelas formuladas por BECKER ${ }^{106}$. Em tom grave, o autor

\footnotetext{
${ }^{106}$ BECKER, Alfredo Augusto. Teoria Geral do Direito Tributário, $4^{\mathrm{a}}$ ed. São Paulo: Noeses, 2007, p. 569.
} 
rejeita a classificação, por entendê-la "artificial e errada". Para ele, nem mesmo sob outros critérios que não o da repercussão econômica (tido como insuficiente por toda a doutrina, como já foi visto) seria possível conferir sustentação científica à distinção ${ }^{107}$.

ATALIBA $^{108}$ seguiu o mesmo sendeiro, propugnando que, no Brasil, não há que se falar na aludida diferenciação. Outrossim, alertou para o fato de que, como a classificação possui importância em outros sistemas nos quais há referência expressa à translação do ônus econômico, "a literatura de direito comparado deve ser recebida com cautela". E conclui que, como o critério de distinção entre diretos e indiretos é puramente econômico, o mesmo é irrevelante para os juristas brasileiros.

BOTTALLO e MELO 109 também o rejeitam, assentando que "o critério da repercussão econômica não conta com respaldo jurídico bastante para determinar a classificação de tributos em diretos e indiretos".

CARRAZZA $^{110}$ igualmente predica que a aludida classificação não seria jurídica e sim econômica, com o que se alinha aos doutrinadores precitados.

MACHADO $^{111}$, com arrimo em SCHMÖLDERS ${ }^{112}$, propaga a ausência de critério científico na divisão, que, segundo o catedrático alemão, seria "mais desorientadora do que proveitosa para uma exposição séria do imposto."

\footnotetext{
${ }^{107}$ Novamente BECKER investe contra a classificação dos tributos em diretos e indiretos, ainda que por fundamentos distintos daquele da repercussão econômica:

"A classificação dos tributos em diretos e indiretos com fundamento num critério diferente do da repercussão econômica, ainda hoje, alguns autores admitem-na, alegando razões didáticas ou conveniência orientadora para administração pública, embora todos esses autores continuem a achar tal classificação, sob qualquer critério, imperfeita, artificial e sem fundamento científico." (BECKER, Alfredo Augusto. Teoria Geral do Direito Tributário, $4^{\mathrm{a}}$ ed. São Paulo: Noeses, 2007, pp. 569-70).
}

${ }^{108}$ ATALIBA, Geraldo. Hipótese de Incidência Tributária, 6 ${ }^{\mathrm{a}}$ ed. São Paulo: Malheiros, 2006, p. 143

${ }^{109}$ O critério da repercussão econômica não conta com respaldo jurídico bastante para determinar a classificação de tributos em diretos e indiretos." (BOTTALLO, Eduardo Domingos e MELO, José Eduardo Soares de. Comentários às Súmulas Tributárias do STF e do STJ. São Paulo: Quartier Latin, 2007, p. 87).

${ }^{110}$ CARRAZZA, Roque Antonio. Curso de Direito Constitucional Tributário, $23^{\mathrm{a}}$ ed. São Paulo: Malheiros, 2007, p. 511.

${ }^{111}$ MACHADO, Hugo de Brito. Imposto Indireto, Restituição do Indébito e Imunidade Subjetiva. Revista Dialética de Direito Tributário, nº 2. São Paulo: Dialética, nov./1995, p. 33.

Ainda segundo MACHADO, o CTN teria, propositalmente, não adotado a expressão tributo indireto no seu art. 166, "em face da dubiedade de seu significado". (MACHADO, Hugo de Brito. Repetição do Indébito Tributário. MARTINS, Ives Gandra da Silva (coord.). Caderno de Pesquisas Tributárias, $\mathrm{n}^{\circ} 8$ - Repetição do Indébito. São Paulo: Resenha Tributária, 1983, p. 240).

112 SCHMÖLDERS, Günter. Teoria General del Impuesto. Trad. por MERINO, Luiz a. Martin. Madrid: Editorial de Derecho Financiero, 1962, p. 245, apud MACHADO, Hugo de Brito. Imposto Indireto, Restituição do Indébito e Imunidade Subjetiva. Revista Dialética de Direito Tributário, $\mathrm{n}^{\circ}$ 2. São Paulo: Dialética, nov./1995, p. 33 - tradução livre do original em espanhol. 
NEVIANI ${ }^{113}$ não discrepa, afirmando que a distinção entre tributos diretos e indiretos, baseada na traslação do ônus econômico do tributo, não é segura "e, por isso mesmo, não pode se prestar a orientar a administração da Justiça".

ULHÔA CANTO ${ }^{114}$, a seu turno, sustenta que não é possível qualquer divisão dos tributos em categorias ou tipos, baseada na transferência a terceiro do montante exigido do contribuinte.

Em suma: a corrente dos que rejeitam a classificação diretos/indiretos no direito brasileiro funda-se em uma só premissa: como todo e qualquer tributo pode, em tese, ser financeiramente repassado a terceiro que não o contribuinte, é inviável dividi-los em diretos e indiretos com base nesse critério. Logo, por tal motivo, é impossível adotar dita classificação no direito brasileiro. O CTN, quando da positivação do seu art. 166, teria abandonado essa distinção, para adotar a dos tributos "criados para repercutir", que não guarda correlação com os diretos ou indiretos.

Entretanto, como se viu no item precedente, a jurisprudência - que é também fonte do direito, ao lado da doutrina - cuidou de manter a aludida distinção mesmo após o advento do art. 166. E, ao invés de identificar uma nova classificação dos tributos operada pelo Código, como pretendem os ilustrados juristas supracitados, nossas Cortes Superiores adotaram o critério segundo o qual os tributos indiretos seriam aqueles aos quais o art. 166 se aplicaria, sendo certo que o dispositivo fala em repercussão jurídica, e não puramente econômica como pretendiam os financistas clássicos ao criar a divisão em análise.

Em sendo assim, a linha de raciocínio que prega o abandono da divisão diretos/indiretos pelo CTN e, via de conseqüência, pelo direito brasileiro, está em descompasso com a orientação jurisprudencial de decênios, tanto do STF como do STJ. Contudo, um elemento merece ser repisado: em momento algum os Tribunais adotaram a repercussão econômica, critério diferenciador insuficiente e, de resto, injurídico - com o que nos colocamos de acordo com aqueles que refugam a classificação em análise quando feita sob tal

\footnotetext{
${ }^{113}$ NEVIANI, Tarcísio. Repetição do Indébito. MARTINS, Ives Gandra da Silva (coord.). Caderno de Pesquisas Tributárias, nº 8 - Repetição do Indébito. São Paulo: Resenha Tributária, 1983, p. 308.

${ }^{114}$ Vale conferir a cita de ULHÔA CANTO:

"Ainda com referência à própria incerteza que emoldura as teorias econômicas sobre a transferência, nas suas múltiplas modalidades e descrita sob diferentes designações (translação, repercussão, percussão, etc...), falha também é a regra de direito que presume a possibilidade de se determinar com certeza a existência da transferência do montante do tributo e supõe que ela seja definível por categorias ou tipos de impostos." (CANTO, Gilberto de Ulhôa. A Repetição do Indébito. MARTINS, Ives Gandra da Silva (coord.). Caderno de Pesquisas Tributárias, nº 8 - Repetição do Indébito. São Paulo: Resenha Tributária, 1983, pp. 8-9).
} 
prisma. A jurisprudência, de forma clara, identificou o art. 166 do CTN como balizador do conceito de tributo indireto em razão da repercussão jurídica, a qual, segundo SACHA $\mathrm{CALMON}^{115}$, é a única passível de ser adotada, pois todos os tributos, em tese, comportam a repercussão puramente econômica.

Nesse compasso, passemos a analisar o posicionamento dos autores que pregam ser o conceito de tributo indireto o mesmo posto no Código Tributário, ou seja: o de tributo que comporte, "por sua natureza", a transferência do ônus econômico a terceiro.

\subsubsection{A CORRENTE QUE PUGNA PELA VALIDADE DA CLASSIFICAÇÃO DIRETOS/INDIRETOS, DESDE QUE MOLDADA PELO CRITÉRIO DO ART. 166 DO CTN (REPERCUSSÃO JURÍDICA).}

Em contraponto à plêiade de juristas mencionada no item precedente, existem aqueles que se posicionam favoravelmente à classificação sub examine, porém arrimados no conceito de tributo indireto plasmado no art. 166 do Código Tributário. O critério adotado é, então, o da repercussão jurídica do tributo, e não o do mero repasse financeiro do ônus fiscal.

É dizer: se o tributo é legalmente criado para repercutir (rectius: para ter o seu ônus repassado ao contribuinte de fato), então se faz presente a repercussão jurídica e o mesmo será indireto. Diz-se jurídica a repercussão, estremando-a da econômica, pois, conforme alerta MISABEL DERZI ${ }^{116}$, “se a repercussão jurídica corresponde à econômica, essa é uma coincidência provável mas não certa, que muitas vezes poderá não ocorrer”. Ou seja: para repercutir, nos termos do art. 166 do CTN, a norma legal criadora do tributo deve prever a translação do seu ônus financeiro - que, se ocorrer, atingirá os fins previstos na lei, porém, mesmo não se concretizando, em nada modificará a natureza do tributo.

\footnotetext{
${ }^{115}$ Sobre a repercussão jurídica enquanto critério orientador do art. 166 do CTN, a lição de SACHA CALMON é definitiva:

"Quando o CTN se refere a tributos que, pela sua própria natureza, comportam a transferência do respectivo encargo financeiro, está se referindo a tributos que, pela sua constituição jurídica, são feitos para obrigatoriamente repercutir, casos do IPI e do ICMS, entre nós, idealizados para serem transferidos ao consumidor final. A natureza a que se refere o artigo é jurídica. A transferência é juridicamente possibilitada. A abrangência do art. 166, portanto, é limitada, e não ampla." (COÊLHO, Sacha Calmon Navarro. Curso de Direito Tributário Brasileiro, $9^{\mathrm{a}}$ ed. Rio de Janeiro: Forense, 2007, p. 816).

116 BALEEIRO, Aliomar. Direito Tributário Brasileiro, $11^{\mathrm{a}}$ ed. Atualizado por MISABEL ABREU MACHADO DERZI. Rio de Janeiro: Forense, 2001, p. 891.
} 
Nos tributos ditos indiretos (segundo este ponto de vista), ou seja, criados para repercutir, se faz presente a dualidade de sujeitos passivos: contribuinte de direito e de fato, sendo este último o que, segundo a determinação legal, deverá suportar o custo da exação.

Esse o posicionamento esposado por MORSHBACHER ${ }^{117}$, um dos pioneiros no estudo dessa matéria no Brasil. Averba o autor:

"No caso de impostos diretos, ou melhor, de imposições diretas, o próprio contribuinte legal é, ao mesmo tempo, o contribuinte de fato; diversamente, nos casos de imposição indireta, o contribuinte de fato, em regra não corresponde ao contribuinte legal."

A lição de MORSHBACHER identifica-se com a de SAINZ DE BUJANDA ${ }^{118}$. O autor espanhol também se refere a tributo instituído por método impositivo direto e indireto, refutando a simples adjetivação diretos/indiretos. Segundo ele, pertencem à primeira categoria (tributo instituído por método impositivo direto) aqueles tributos nos quais a norma jurídica atribua a responsabilidade ao contribuinte sem conceder-lhe direito a repassar o custo a terceiro estranho à obrigação tributária; já o método impositivo indireto caracteriza-se quando a norma atribui ao contribuinte o direito de ressarcir-se de outrem (um não-partícipe da relação jurídico-tributária).

Já DENARI ${ }^{119}$ é mais objetivo, adotando a terminologia tributação direta e indireta - sempre a vinculando, ainda que de forma implícita, à repercussão jurídica (objetivada pela lei), com esforço inclusive na precitada lição de SAINZ DE BUJANDA e na jurisprudência dos Tribunais pátrios.

${ }^{117}$ MORSHBACHER, José. Repetição do Indébito Tributário Indireto, $3^{\mathrm{a}}$ ed. São Paulo: Dialética, 1998, p. 49.

${ }^{118}$ SAINZ DE BUJANDA, Fernando. Lecciones de Derecho Financiero, $6^{\mathrm{a}}$ ed. Madrid: Facultad de Derecho Universidad Complutense, 1998, p. 158.

${ }^{119}$ Averba o autor:

“(...) Estamos convencidos de que o traço distintivo entre os impostos diretos e indiretos repousa, mesmo, no fenômeno da repercussão. (...).

Também para Sainz de Bujanda todas as dificuldades relacionadas com a definição dos impostos indiretos ficam superadas pondo-se em evidência o aspecto da translação da carga tributária. Assim, o imposto é indireto 'quando a norma jurídica tributária faculta ao sujeito passivo obter de quem não é parte na relação jurídica tributária, o reembolso do imposto pago ao ente público'.

(...) De resto, a jurisprudência pátria já consagrou, como critério diferenciador, o fenômeno da repercussão da carga tributária." (DENARI, Zelmo. Curso de Direito Tributário, $2^{\mathrm{a}}$ ed. Rio de Janeiro: Forense, 1991, p. 86).

Ousamos interpretar o texto do autor: em que pese ele se referir tão-somente à repercussão, sem adjetivá-la, temos que seu raciocínio gira em torno da repercussão juridicamente perseguida pela norma jurídica. Tal é dessumível: (a) da cita de SAINZ DE BUJANDA, que vislumbra na lei instituidora do tributo a base para diferenciação da espécie de exação, direta ou indireta; (b) na referência à "jurisprudência pátria", que consagrou a classificação em comento pautada pelo critério da repercussão econômica. 
SZLAROWSKY ${ }^{120}$, por sua vez, é taxativo: tributo indireto é aquele enquadrável no art. 166 do CTN; os demais são diretos.

CASSONE $^{121}$ utiliza-se das figuras do contribuinte de jure e de facto para diferençar a exação direta da indireta. Naquela, tais figuras se confundem, ao passo que nesta temse, em regra ${ }^{122}$, um contribuinte de jure e outro de facto. CASSONE visualiza a questão a partir da legislação de regência e não sob a ótica puramente econômica, de resto imprestável.

Outros tantos autores aludem à distinção entre diretos e indiretos, sempre analisando-a em face do art. 166 do $\mathrm{CTN}^{123}$.

Por derradeiro, faz-se mister relembrar o posicionamento divergente e isolado (na doutrina pátria) de R. B. NOGUEIRA ${ }^{124}$, que não se enquadra em nenhuma das duas correntes teóricas precitadas. Para o ex-catedrático da USP, tributo direto é aquele cuja hipótese de incidência consiste em uma apreensão imediata da capacidade contributiva do pa-

${ }^{120}$ Eis a sua preleção:

"Os tributos diretos, no que diz respeito à repetição do indébito, não apresentam maiores problemas, pois o contribuinte suporta o ônus da tributação; entretanto, o complicador surge exatamente ao se cuidar dos tributos indiretos, face ao ordenamento do art. 166 do Código Tributário." (SZKLAROWSKY, Leon Frejda. Repetição do Indébito. MARTINS, Ives Gandra da Silva (coord.). Repetição do Indébito - Caderno de Pesquisas Tributárias, nº 8. São Paulo: Resenha Tributária, 1983, p. 22).

${ }^{121}$ Vale conferir a cita:

"Direto é o imposto que assim se caracteriza quando, numa só pessoa, reúnem-se as condições de contribuinte de direito (aquele que é responsável pela obrigação tributária) e contribuinte de fato (aquele que suporta o ônus do imposto).

(...)

Indireto é o imposto que comporta, na operação, dualidade de pessoas: contribuinte de direito (...) e contribuinte de fato."

O recurso à ótica legal (e não econômica) para classificar-se o tributo em direto ou indireto pode ser apreendido da seguinte passagem:

"Há certos tributos, tais como o ISS, em que é preciso verificar não só a legislação, como, também (se a legislação permitir), se na nota fiscal de serviços foi acrescentado o valor do imposto (caso em que se verifica uma dualidade de pessoas." (CASSONE, Vittorio. Direito Tributário, $17^{\mathrm{a}}$ ed. São Paulo: Atlas, 2006, pp. 82-3).

${ }^{122}$ A advertência é necessária pois, em alguns casos, a figura do contribuinte de direito se confunde com a do contribuinte de fato. A importação de um automóvel para uso próprio, por exemplo, tem um sujeito (importador) que é, ao mesmo tempo, contribuinte de jure e de facto.

${ }^{123}$ Interplures, cite-se o Desembargador VOLKWEISS:

“(...) Somente o chamado contribuinte de direito (aquele que, por determinação da lei, recolheu o tributo) pode, nos chamados impostos indiretos (como o IPI, o ICMS e o ISSQN), requerer diretamente a restituição do tributo indevidamente pago, ou, caso o tenha transferido, estar por este expressamente (por escrito) autorizado a requerer a restituição." (VOLKWEISS, Roque Joaquim. Direito Tributário Nacional, $2^{a}$ ed. Porto Alegre: Livraria do Advogado, 1998, pp. 246-7, destaques nossos).

${ }^{124}$ NOGUEIRA, Ruy Barbosa. Curso de Direito Tributário, 10ª ed. São Paulo: Saraiva, 1990, p. 163. 
gante, gravando seu patrimônio ou renda. Já a tributação indireta, segundo o mesmo autor, abriga as exações cuja hipótese de incidência alcance manifestações mediatas da capacidade contributiva, como o consumo de riqueza. Trata-se da aplicação do critério financeiro ou da capacidade contributiva, como visto no item 2.2.1.3, ao qual remetemos o leitor neste ponto. Para nosso direito positivo, contudo, tal classificação possui apenas valor didático.

\subsubsection{A NOSSA OPINIÃO.}

Estamos com a corrente que pugna pela validade da classificação dos tributos em diretos em indiretos, mediante utilização do critério da repercussão jurídica. Isso porque:

(a) o entendimento de decênios dos Tribunais Superiores sustenta tal dicotomia. Sendo a jurisprudência fonte do direito - conseqüentemente, também, do direito tributário - e tendo influenciado parcela considerável da doutrina nacional, parece-nos lícito apregoar que há, sim, no direito brasileiro, a figura jurídica dos tributos diretos e dos indiretos;

(b) a teoria dos tributos diretos/indiretos acolhida pela jurisprudência não foi a dos fisiocratas, cuja imperfeição já restou demonstrada à saciedade e com a qual, de fato, não teríamos como concordar. A tese adotada foi a da repercussão jurídica, já defendida por HENSEL ${ }^{125}$ há mais de cinquienta anos: para aceitar como jurídicos os institutos da tributação direta e indireta, avalia-se a existência ou não da repercussão na legislação tributária, nunca nos fatores econômicos subjacentes à cobrança da exação. Afinal, o tributo é instituto do Direito e não da economia ${ }^{126}$.

Assim, com a mudança de premissas do Supremo Tribunal Federal que, desde o advento do CTN, passou a adotar a teoria da repercussão plasmada no art. 166 do Codex mesmo sendeiro perfilhado posteriormente pelo Superior Tribunal de Justiça - a jurisprudência pátria adotou, a nosso sentir de forma correta e válida, os institutos em questão, tornando-os elementos integrantes do direito tributário brasileiro.

Portanto, somos levados a asseverar que existe, sim, um conceito de tributação direta e indireta no Brasil, que tem o condão de influenciar o direito à restituição do tributo

\footnotetext{
${ }^{125}$ HENSEL, Albert. Diritto Tributario. Trad. para o italiano de DINO JARACH. Milano: Giuffrè, 1956, p. 342.

${ }^{126}$ A advertência é também posta por SACHA CALMON ao tratar da dicotomia em questão e, ao final, aplaudir o art. 166 do Código Tributário por ter positivado a teoria da repercussão jurídica. (COÊLHO, Sacha Calmon Navarro. Curso de Direito Tributário Brasileiro, $9^{\mathrm{a}}$ ed. Rio de Janeiro: Forense, 2007, p. 816-7).
} 
indevidamente pago (exigindo, no caso de tributo indireto, a prova do não-repasse do ônus ou, pelo menos, a autorização do contribuinte de facto para legitimar-se o pleito repetitório).

Livres das amarras das teorias há muito superadas, cumpre-nos então identificar os elementos que integram as definições sub examine. Afinal, como já alertara COCIVE$\mathrm{RA}^{127}$, para se chegar a um conceito satisfatório de tributação direta e indireta é necessário levar em consideração não uma, mas sim um rol de premissas.

\subsubsection{O CONCEITO BRASILEIRO DE TRIBUTO INDIRETO: TEORIA DA RE- PERCUSSÃO JURÍDICA.}

Sem fazer uso de qualquer dos métodos clássicos para tanto, e considerando o art. 166 como sua norma fundante, a doutrina nacional exige, para a caracterização de um tributo indireto, a repercussão jurídica. É dizer: será indireto o tributo cuja lei tributária instituidora possua como objetivo a manutenção da neutralidade fiscal do pagante da exação, livrando-o do peso econômico do tributo, que deverá ser repassado a terceiro.

Pois bem. E quando se poderá dizer que há repercussão jurídica de um tributo? Baseando-se na lei, na doutrina e na jurisprudência, bem como na observação do próprio instituto em análise, podem ser extraídas as seguintes características indicativas do interesse do legislador em fazê-lo:

(a) a hipótese de incidência do tributo deverá ser um negócio jurídico bilateral que envolva a interação direta do contribuinte e do terceiro que suportará a carga fiscal. Não se pode presumir que o legislador objetive a translação do ônus financeiro quando a lei não delinear uma situação tributável que envolva as duas modalidades de contribuintes (de facto e de jure). Afinal, se assim não for, será impossível dizerse que, sob o prisma jurídico (único que interessa ao direito, como lembra SACHA CALMON $^{128}$ ), existe possibilidade de o contribuinte de direito ressarcir-se do ônus do tributo.

\footnotetext{
${ }^{127}$ COCIVERA, Benedetto. Principi di Diritto Tributario, v. I. Milano: Giuffré, 1959, p. 250.

${ }^{128}$ Antes de explanar o alcance do art. 166 do CTN, discorrendo sobre a necessidade de se compreender a repercussão nele prevista como sendo jurídica e nunca financeira, SACHA CALMON adverte, em boa hora, que "o tributo é uma criação do Direito, e não uma entidade econômica". (COÊLHO, Sacha Calmon Navarro. Curso de Direito Tributário Brasileiro, $9^{\mathrm{a}}$ ed. Rio de Janeiro: Forense, 2007, p. 816).
} 
Recorrendo à analogia ${ }^{129}$, pode-se sustentar que os ditames do art. 128 do CTN ${ }^{130}$ são de observância obrigatória quando o legislador pretenda criar um tributo indireto ou, noutro giro verbal, tributo que repercuta juridicamente. Explicamos: o 128 do Codex trata da responsabilidade tributária, na qual se permite à lei excluir - no todo ou em parte - a obrigação do contribuinte, atribuindo-a a terceiro. Todavia, para que isso ocorra, é essencial que esta terceira pessoa (que assumirá o múnus) esteja vinculada ao fato gerador da obrigação principal. Afinal, não seria racional, por exemplo, atribuir-se responsabilidade pelo pagamento do IPTU ao vizinho mais próximo do proprietário do imóvel. Inexistiria fundamento lógico e, menos ainda, jurídico para tal imputação. No entanto, quando a lei atribui ao novo proprietário o dever de pagar o IPTU dos anos anteriores caso não tenha constado da escritura pública que todo o imposto predial vencido fora quitado pelo antigo proprietário, existe, nessa hipótese, fundamento para a exigência. $\mathrm{O}$ limite máximo para a responsabilidade insculpida no art. 128 é a vinculação meramente indireta do terceiro ao fato gerador (como é comum ocorrer com empresas de transporte, que ficam solidariamente obrigadas ao pagamento do ICMS devido pela compra-e-venda da mercadoria que está sendo transportada se a documentação fiscal acobertadora do transporte da carga estiver irregular).

A razão de o Código exigir, na atribuição da responsabilidade tributária a terceiro, que este seja vinculado ao fato gerador da obrigação tributária, é exatamente para permitir que as partes, na relação negocial sobre a qual incide a norma tributária, possam ressarcir-se, uma da outra, em face da transferência de responsabilidade. No exemplo da substituição tributária, que se aproposita para o que pretendemos demonstrar, tal ressarcimento ocorre com perfeição, ao menos sob a ótica jurídica: o substituto já prevê que terá que pagar o tributo e reflete esse dever tributário no preço cobrado ou pago pela mercadoria, conforme se trate de substituição para frente ou para trás.

\footnotetext{
${ }^{129} \mathrm{O}$ uso da analogia é franqueado e inclusive indicado pelo Código Tributário Nacional (art. 108, I), posto que não se visa, com a hermenêutica ora proposta, a criar ou a aumentar tributo.

${ }^{130}$ Reza o CTN:

"Art. 128. Sem prejuízo do disposto neste capítulo, a lei pode atribuir de modo expresso a responsabilidade pelo crédito tributário a terceira pessoa, vinculada ao fato gerador da respectiva obrigação, excluindo a responsabilidade do contribuinte ou atribuindo-a a este em caráter supletivo do cumprimento total ou parcial da referida obrigação."
} 
Para nós, a mesma lógica que orienta o art. 128 do CTN é a que deve pautar, por interpretação sistemática, o art. 166 do Código e, conseqüentemente, o conceito de tributo indireto: somente será jurídica a repercussão se a exação tiver, por fato gerador, uma realidade negocial que permita a vinculação entre o contribuinte de direito e o contribuinte de facto, ou melhor, entre o contribuinte e o terceiro para o qual a lei transfira ${ }^{131}$ o ônus financeiro. Sem dito liame, que se constrói no momento da eleição do fato tributável pelo legislador, não se pode, a nosso sentir, falar-se em repercussão jurídica.

Dessarte, o primeiro requisito para a caracterização de um tributo indireto é a existência de dois contribuintes (de jure e de facto), que estarão conectados por um negócio jurídico no qual ambos sejam partes;

(b) é imprescindível, ainda, que o contribuinte de fato seja passível de identificação. Tal exigência não passou despercebida ao Supremo Tribunal Federal. Em voto prolatado no Recurso Extraordinário $\mathrm{n}^{\mathrm{o}} 105.340 / \mathrm{RJ}^{132}$, o Ministro FRANCISCO REZEK pontuou:

“(...) Ao contribuinte identificado como de direito só falece a prerrogativa de reaver o que recolheu indevidamente quando um contribuinte de fato, certo e individualizável, pudesse teoricamente entrar em cena, chamando a si o reembolso."

\footnotetext{
${ }^{131}$ O comando legal que determina o repasse do ônus, via de regra, não é expresso. A conclusão de que a lei objetiva a repercussão defluirá da verificação, no caso, da existência dos quatro requisitos ora mencionados, que constituem notas essenciais da tributação indireta.

${ }^{132}$ STF, Segunda Turma, RE no 105.340/RJ, Relator Min. CORDEIRO GUERRA, DJ 14.03.1986, p. 3390. Um alerta, todavia, cumpre ser feito. Não compactuamos com a posição dos que sustentam que, na venda de mercadorias em massa, o contribuinte de fato seria indeterminável. Ora, se assim for, um negócio em larga escala, dirigido a uma pluralidade de consumidores, ficará ao abrigo da incidência do art. 166 pelo simples fato de trabalhar com grandes volumes. Dessarte, não podemos concordar, data venia, com as assertivas de MELO, que predica:

"Inaplicável o art. 166 do CTN no caso de não ser identificado o terceiro, como acontece com os negócios realizados com consumidores finais das mercadorias e dos serviços, porque acabaria sendo inviabilizada a restituição ao sujeito passivo, o que caracteriza o locupletamento da Fazenda, que receberá valores sem causa jurídica." (MELO, José Eduardo Soares de. ICMS: Majoração Inconstitucional de Alíquotas. Repertório IOB de Jurisprudência/98, Verbete 1/11961)

O problema de locupletamento indevido da Fazenda, apontado na cita, foi há muito resolvido pelo STF. Entre pagar-se a um contribuinte não-legitimado (de jure) e deixar-se o dinheiro com o Estado, a opção a ser feita é em prol deste último, que, apesar de enriquecer-se indevidamente, presumidamente utilizará o numerário em prol do bem comum (inter alii, cite-se o voto do Min. VICTOR NUNES, compondo a Segunda Turma do Supremo, no RE no 46.450/RS, Relator Min. VILAS BOAS, DJ 21.08.1961, p. 284). De mais a mais, parecenos metodologicamente inapropriado pretender-se modificar a natureza jurídica do tributo (ou seja, aplicarlhe a regulamentação dos tributos diretos, sendo o mesmo indireto) pela simples razão de os seus fatos geradores ocorrerem em larga escala.
} 
(c) por fim, como requisito formal (ou seja: sua ausência não implica a descaracterização do tributo como indireto, constituindo-se apenas em um indício da natureza da exação ${ }^{133}$ ), pode-se apontar o destaque, em documento fiscal, do valor arrecadado pelo contribuinte de direito e repassado (juridicamente) ao de facto. A lei instituidora, em regra, determina a obrigatoriedade do destaque do mesmo na nota fiscal que acoberte a operação. Em casos onde o tributo pode ou não ser destacado (como ocorre, verbi gratia, com o ISSQN, que ora é recolhido per capita, como no caso da prestação de serviços profissionais - não sendo, portanto, destacado em nota ora incide em um percentual sobre o valor do serviço contratado, como, v.g., nas atividades de assistência técnica - havendo, nessa hipótese, o destaque), dito elemento auxilia na identificação da espécie de tributo em questão (se direto ou indireto) ${ }^{134}$.

A partir do exposto, é interessante notar dois pontos, merecedores de destaque.

O primeiro é que a não-cumulatividade tributária não é requisito essencial para a caracterização do tributo indireto. É, decerto, um mecanismo que, por ter como escopo manter a neutralidade fiscal e não onerar o contribuinte de jure, provavelmente estará presente em boa parte dos tributos indiretos (como ocorre no ICMS e no IPI). Mas, frisa-se, não é imprescindível a estes. O exemplo do ISSQN, que é tido como tributo indireto (passível de repercussão jurídica) quando incidente sobre o valor do serviço e suportado pelo

${ }^{133}$ A assertiva é comprovada pela jurisprudência do Supremo Tribunal Federal, que, desde a época do ICM, assegurava o direito de crédito ao adquirente dos produtos tanto na hipótese de inexistir destaque do imposto na nota fiscal (STF, Primeira Turma, RE $\mathrm{n}^{\circ} 78.589 / \mathrm{SP}$, Relator Min. ALIOMAR BALEEIRO, DJ 04.11.1974), como nas situações em que o remetente estivesse desobrigado de emitir o documento. Est'último exemplo consiste no caso das aquisições de café no Instituto Brasileiro do Café, que geraram porfias judiciais, solucionadas pelo STF com a seguinte ementa:

"1. Constituição, art. 23, II, DL. n. 406-68, 3. Princípio de que o ICM não é cumulativo.

2. Café comprado ao IBC para torrefação, moagem e venda. O fato de essa autarquia não expedir nota fiscal para o comprador do seu produto, não impede que tal adquirente inscreva, como crédito seu, no livro fiscal, a quantia do ICM referente a essa operação.

3. Precedentes do Supremo Tribunal.

4. Recurso Extraordinário provido para restabelecer sentença concessiva da segurança de tal direito." (STF, Primeira Turma, RE n 75.439/SP, Relator Min. ANTONIO NEDER, DJ 19.09.1975).

${ }^{134}$ Sobre a obrigatoriedade do destaque em nota fiscal, previsto em lei, para a determinação da natureza indireta do tributo, SACHA CALMON nos oferta a seguinte cita de CASSONE:

"Assim, quando o art. 166 fala em tributos que comportem, por sua natureza, transferência do respectivo encargo financeiro, está referindo-se aos tributos lançados (efetivamente destacados) no documento fiscal em que o contribuinte (de direito) arrecada-o do adquirente (ou do chamado contribuinte de fato) e o recolhe ao sujeito ativo." (CASSONE, Vittorio. Aspectos práticos do ICM em sua Atualidade. DCI de 14.01.1983, apud COÊLHO, Sacha Calmon Navarro. Curso de Direito Tributário Brasileiro, $9^{\mathrm{a}}$ ed. Rio de Janeiro: Forense, 2007, p. 817).

O destaque, per se, não pode ser tomado como característica do tributo indireto, a nosso sentir. Entretanto, é um indício da natureza da exação (em que pese não contribuir para a própria conformação da espécie tributária). 
tomador (hipótese na qual é feito o destaque em nota fiscal), é lapidar: apesar de ser um imposto cumulativo, não gerando créditos para aproveitamento em eventuais etapas posteriores, é considerado indireto pela jurisprudência remansosa do STJ, como indica, interplures, a ementa abaixo:

\section{“TRIBUTÁRIO. ISS. REPETIÇÃO DE INDÉBITO. REPERCUSSÃO ECONÔMICA.}

1. O ISS é espécie tributária que pode funcionar como tributo direto ou indireto.

2. Hipótese dos autos que encerra espécie de tributo indireto, porque recolhido sobre as receitas oriundas de cada encomenda, sendo suportado pelo tomador do serviço.

3. Como imposto indireto, têm aplicações, em princípio, o teor do art. 166 do CTN e o verbete 71 do STF, atualmente 546.

4. Recurso especial improvido." $" 135$

A mesma conclusão é válida, dessarte, para o instituto da plurifasia. Tributo indireto não é necessariamente plurifásico. Além do exemplo nacional do ISSQN, o retail sales tax norte-americano é outro clássico modelo de tributo criado para repercutir (juridicamente), incidindo monofasicamente sobre as operações de venda de mercadorias a consumidor final nos Estados norte-americanos.

Lado outro, resta-nos o seguinte questionamento: um tributo não-cumulativo (que, mandatoriamente, deve ser plurifásico) será necessariamente indireto? Se assim for, a nãocumulatividade, para existir, deverá ter como pontos imprescindíveis:

(a) o alcance apenas de tributos que incidam sobre negócios jurídicos passíveis de vincular o contribuinte e o terceiro que suportará o ônus da exação;

(b) a existência de dois contribuintes: de jure e de facto;

(c) um contribuinte de fato passível de identificação;

Afinal, como visto acima, o tributo será indireto, a ele se aplicando a regra do art. 166 do CTN, se os três requisitos mencionados se fizerem presentes. Dessarte, se para a existência da não-cumulatividade houver uma coincidência de critérios, poder-se-á dizer que todo tributo não-cumulativo é indireto. Contudo, inexistindo referida identidade, a nãocumulatividade não terá o condão, de per se, de modificar a natureza do tributo para tornálo indireto (ou seja, sujeito às regras de restituição do indébito previstas no art. 166 do Código Tributário).

${ }^{135}$ STJ, Segunda Turma, REsp n ${ }^{\circ}$ 426.179/SP, Relatora Min. ELIANA CALMON, DJ 20.09.2004, p. 228. 
Para logo, cumpre anotar que, a nosso sentir, a não-cumulatividade está indissociavelmente imbricada com o conceito de tributo indireto. De todo modo, para espancar qualquer dúvida, faz-se necessária uma análise daquele instituto. É o que se fará no próximo capítulo. 


\section{A NÃO-CUMULATIVIDADE TRIBUTÁRIA.}

\subsection{CONSIDERAÇÕES PRELIMINARES.}

Quando se fala em cumulação de tributos, pode-se estar referindo a três realidades distintas, a saber:

(a) exigência de dois ou mais tributos sobre o mesmo fato, que admite duas subespécies:

(a.1) bitributação; e

(a.2) bis in idem.

(b) inclusão de tributos na base de cálculo de outras exações, majorando artificialmente a riqueza tributável;

(c) incidência do tributo em dois ou mais estádios da cadeia produtiva.

Vejamo-las, uma a uma.

A primeira é a incidência de tributos idênticos sobre o mesmo fato gerador, caracterizando a bitributação (se dois entes distintos exigirem gravame idêntico sobre uma só realidade) ou o bis in idem (se ambas as exações forem cobradas pelo mesmo ente estatal).

Tem-se bitributação, verbi gratia, quando dois Estados soberanos intentam cobrar imposto de renda sobre os mesmos valores (ex.: executivo alemão, residente e domiciliado naquele país, que se desloca temporariamente para o Brasil e aqui aufere rendimentos, prestando consultoria a empresa sediada em solo pátrio). O conflito entre os princípios da fonte e da renda mundial (que orientam a tributação internacional das rendas) faz surgir tais questões, solucionadas muitas vezes pelos tratados contra dupla tributação internacional. À míngua de convenção entre países ou de soluções unilaterais eventualmente adotadas pelos Estados (como isenções, outorga de créditos presumidos, et caterva), a bitributação será inevitável ${ }^{136}$. Não obstante, existe orientação mundial no sentido de se evitar essa dupla incidência, criadora de barreiras para o desenvolvimento das nações. Tanto é que a Organização das Nações Unidas e a Organização para a Cooperação e Desenvolvimento Econômico (OCDE) possuem modelos de convenção contra a dupla tributação internacio-

\footnotetext{
${ }^{136}$ XAVIER menciona algumas situações em que a problemática da dupla tributação (cumulação de incidências) no âmbito internacional se faz presente:

"Pense-se na tributação de empresa de navegação marítima cuja sede social esteja no Panamá, cuja administração efetiva esteja em Londres, cujo capital social seja controlado por residentes nos Estados Unidos e cujos lucros advenham de tráfego marítimo realizado nas Ilhas Gregas. (...). Ou na tributação de dividendos auferidos por holding com sede no Luxemburgo, pagos por subsidiária com sede na Austrália e que exerce a sua atividade de mineração na Nova Zelândia, através de estabelecimento estável neste país." (XAVIER, Alberto Pinheiro. Direito Tributário Internacional do Brasil, $4^{\mathrm{a}}$ ed. Rio de Janeiro: Forense, 1998, p. 4).
} 
nal, destinados a orientar os Estados que pretendam eliminar esse entrave ao livre comércio.

No plano interno de um Estado federado, a bitributação ocorre quando dois Estados ou Municípios intentam gravar a mesma realidade (o exemplo mais característico, no Brasil, é o do ISSQN, no qual existe constante conflito entre as municipalidades na exigência do imposto sobre serviços - cada qual adotando, conforme seus próprios interesses, o critério da situação do estabelecimento prestador ou o do local da prestação dos serviços ${ }^{137}$ ).

O bis in idem, a seu turno, é menos usual. Afinal, o ente federado pode exercer livremente sua competência para gravar determinada situação fática, desde que respeite os princípios constitucionais tributários. Logo, conclui-se que, havendo interesse em incrementar a receita, basta ao ente público aumentar a alíquota do tributo existente. Por essa razão, o bis in idem ocorre, em regra, quando a carga tributária já é muito elevada sobre certas realidades e, mesmo assim, o Estado pretende majorá-la. Para refugir à caracterização do confisco - mais claramente visualizável quando um único tributo é utilizado com alíquotas excessivas - o ente estatal se utiliza do subterfúgio de adotar outra exação para gravar a mesma realidade. Essa situação é repelida pelos sistemas tributários ${ }^{138}$.

${ }^{137}$ O conflito iniciou-se a partir da interpretação conferida pelo Superior Tribunal de Justiça ao art. 12 do Decreto-lei $n^{\circ} 406 / 68$, que predicava ser o ISSQN devido no local da prestação do serviço, assim definindo este último:

“Art. 12. Considera-se local da prestação do serviço:

a) o do estabelecimento prestador ou, na falta de estabelecimento, o do domicílio do prestador;

b) no caso de construção civil, o local onde se efetuar a prestação;

c) no caso do serviço a que se refere o item 101 da lista anexa [exploração de concessão de rodovias pedagiadas], o Município em cujo território haja parcela da estrada explorada."

De acordo com o STJ, a alínea $a$ do art. 12 não deve ser interpretada de forma literal. Assim, apesar de estar expresso no dispositivo que o ISSQN é devido ao Município em que estiver situado o estabelecimento prestador, esse não seria o verdadeiro sentido da norma. Esta, em verdade, determinaria a recolha do ISSQN ao Município no qual o serviço foi prestado. Tal jurisprudência sedimentou-se no âmbito do STJ e não foi infirmada (posto que não analisada) pela Suprema Corte. Em face disso, a tributação municipal sobre serviços transformou-se em verdadeira algaravia, com inúmeros casos de cumulação de exigências de dois Municípios (pois a orientação do Tribunal diverge da interpretação literal do DL nº 406/68).

Com a $\operatorname{LC~}^{\circ}{ }^{\circ} 116 / 03$, que aumentou o número de casos nos quais o ISSQN seria devido no local da prestação (à época do DL n 406/68, as exceções à regra geral - pagamento no local do estabelecimento prestador eram apenas as referidas nas alíneas $b$ e $c$ do art. 12, supratranscrito), entendeu-se que o problema estaria resolvido. Entretanto, pelas decisões prolatadas até o momento pelo STJ, o entendimento anterior permanece (exigindo-se, em todos os casos, o pagamento do imposto no local da prestação, independentemente da localização do estabelecimento prestador). Persistem, assim, os problemas de dupla tributação em matéria de ISSQN.

${ }^{138}$ Caso paradigmático, que já foi analisado pelo STF, referia-se à suposta ocorrência de bis in idem pela exigência de imposto sobre a renda (cuja alíquota chega a 27,5\%), contribuição previdenciária fixa (alíquota de $11 \%$ ) e um adicional de contribuição previdenciária variável (entre 9\% e 14\%, a depender do valor do salário) sobre os vencimentos dos servidores públicos federais.

Embora não reconhecendo a existência de bis in idem, dado o caráter autônomo e específico das contribuições previdenciárias, o STF afastou a contribuição progressiva (entre $9 \%$ e 14\%) ao argumento de que a soma desta ao IR e à contribuição previdenciária já cobrada (alíquota de 11\%) determinaria, em alguns casos, 
A segunda hipótese em que há superposição contributiva ocorre quando se incluem na base de cálculo das exações o valor de outros tributos. Essa prática, pouco comum noutras plagas, tem sido adotada amiúde pelas leis tributárias brasileiras. Apesar de ter legitimado tal procedimento quando da análise do intitulado "cálculo por dentro" do ICMS, o STF não o fez por unanimidade. Vale ler o seguinte trecho do voto do Min. MARCO AURÉLIO, vencido por ser fiel a seu ponto de vista:

"Elucide-se a forma engendrada para, de forma indireta, chegar-se à majoração do tributo: as notas fiscais relativas às operações de circulação de mercadorias consignam, em parcelas destacadas, o preço de venda e, considerada a percentagem a incidir sobre este, a quantia devida pelo vendedor (contribuinte de direito) ao fisco a título de Imposto de Circulação de Mercadorias. Pois bem, em que pese esse destaque, iniludivelmente o meio de controle do recebimento do tributo, passou o fisco (...) a exigir do vendedor não o recolhimento do valor decorrente da incidência da alíquota sobre o preço do negócio mercantil, mas o resultante do somatório das parcelas, criandose, assim, uma segunda base de cálculo estranha, a mais não poder, à premissa de que os tributos pressupõem, em geral, uma vantagem, um ganho para aquele que está compelido a satisfazê-lo. Em última análise, a forma consagrada conflita com a assertiva de que compete aos Estados e ao Distrito Federal instituir imposto sobre o valor das operações relativas à circulação de mercadorias, e não de novo tipo que derivaria da incidência de alíquota própria, é certo, ao ICMS, sobre o valor que já representa este último." 139

As acerbas críticas do Ministro à sistemática do "cálculo por dentro" merecem atenção:

"Veja-se a que ponto é dado chegar quando se parte para elucubrações visando a refazer o equilíbrio dos caixas, arrecadando-se tributos mediante sutis artifícios, como se não houvesse um figurino constitucional rígido a respeito (...)."140

a recolha de quase metade do salário do servidor aos cofres públicos federais. Confira-se a ementa de um dos acórdãos que gizou o tema:

"RECURSO EXTRAORDINÁRIO. AGRAVO REGIMENTAL. CONTRIBUIÇÃO PREVIDENCIÁRIA. ALÍQUOTA PROGRESSIVA.

1. O acórdão recorrido está em consonância com o entendimento do Plenário deste Supremo Tribunal que, no julgamento da ADI 2.010-MC, assentou que a instituição de alíquotas progressivas para a contribuição previdenciária dos servidores públicos ofende o princípio da vedação à utilização de qualquer tributo com efeito de confisco (art. 150, IV, da Constituição). Tal entendimento estende-se aos Estados e Municípios.” (STF, Primeira Turma, RE-AgR n 414.915/PR, Relatora Min. ELLEN GRACIE, DJ 20.04.2006, p. 31).

Em outras palavras: apesar de, em tese, não se ter reconhecido o bis in idem, na prática os tributos cobrados pelo mesmo ente foram somados (mesmo sendo de espécies diversas, na visão do STF), autorizando a conclusão pela existência do confisco.

${ }^{139}$ STF, Pleno, RE no 212.209/RS, Relator p/ acórdão Min. NELSON JOBIM, DJ 14.02.2003, p. 60.

${ }^{140}$ STF, Pleno, RE no 212.209/RS, Relator p/ acórdão Min. NELSON JOBIM, DJ 14.02.2003, p. 60. 
Para além do "cálculo por dentro" referido, tem-se ainda cumulação de incidências com a inclusão do ICMS nas bases de cálculo do IPI e do PIS/COFINS; a inclusão da CSLL na base tributável pelo IRPJ, inter alii. Ou seja: verdadeira superposição em que as exações são expandidas, abarcando mais do que a riqueza gerada na operação. Com isso, a alíquota real do tributo torna-se superior àquela nominalmente constante da lei. Inobstante os equívocos de tal sistemática, a jurisprudência pátria tem admitido inclusões de valores tributários no cálculo do quantum debeatur de outras exações ${ }^{141}$.

A terceira e última modalidade de cumulação de tributos consiste na incidência do mesmo gravame em mais de uma etapa da cadeia produtiva. Essa realidade é passível de ocorrer apenas nos tributos incidentes sobre a produção e comercialização de bens e serviços. Afinal, somente nesses casos tem-se um liame lógico-operacional desde a primeira incidência tributária, no início da cadeia, até a aquisição do bem ou serviço pelo consumidor final. Tributos cujas hipóteses de incidência sejam fatos estanques, não situados no bojo de um processo de circulação de riquezas, não permitem a visualização desta modalidade de superposição exacional.

Ao exposto, podemos classificar as três formas de cumulação tributária existentes, a saber:

Acúmulo exógeno de tributos $\left\{\begin{array}{l}\text { Dupla imposição sobre o mesmo fato (bitributação ou } \\ \text { bis in idem) }\end{array}\right.$
Acúmulo endógeno de tributos $\left\{\begin{array}{l}\text { Imposições sucessivas da mesma exação em um } \\ \text { processo de produção/circulação de bem ou } \\ \text { prestação de serviço }\end{array}\right.$
$\begin{aligned} & \text { Inclusão do mesmo ou de outros gravames na base } \\ & \text { tributável }\end{aligned}$

${ }^{141}$ Além do RE no 212.209/RS, que legitimou o cálculo "por dentro" do ICMS, as Súmulas nº 258/TFR e 68/STJ admitem que o ICMS integre a base de cálculo do PIS (conclusão extensível à COFINS).

Entrementes, duas ações atualmente em curso no Supremo Tribunal Federal pretendem rediscutir o tema da inclusão de tributos na base de cálculo de outras exações. A ADC no 18/DF (Relator Min. MENEZES DIREITO) cura da possibilidade de inclusão do ICMS na base de cálculo do PIS e da COFINS, ao passo que o RE $\mathrm{n}^{\circ}$ 582.525/SP (Relator Min. JOAQUIM BARBOSA) trata do pleito dos contribuintes de dedução da CSLL da base de cálculo do IRPJ. 
A diferenciação proposta entre formas endógenas e exógenas de superposição tributária se faz com base na localização, dentro ou fora da regra-matriz de incidência, da situação que gera o acúmulo impositivo. Quando na base de cálculo (que integra o critério quantitativo do conseqüente da norma) incluem-se outros tributos, tem-se cumulação endógena. Quando o acúmulo é visualizável a partir da observância dos vários gravames incidentes sobre fatos determinados, a cumulação é exógena, posto que não integra a regramatriz.

Dessarte, para averiguar a existência de cumulatividade decorrente da superposição de incidências da mesma exação ao longo da cadeia de produção e/ou circulação de um bem ou serviço não basta analisar a norma em si. Esta, a depender de seu critério material, poderá ofertar um indício desse fato. Entrementes, somente quando de sua aplicação prática haverá a possibilidade de se confirmar a hipótese - visualizando-se, como um todo, o processo de produção dos bens ou serviços.

É nesta modalidade de superposição contributiva que se insere a nãocumulatividade sub examine. Portanto, não se tratarão, aqui, das normas que vedam a inclusão de tributos na base de cálculo de outros, tampouco das hipóteses de bis in idem ou bitributação. Interessam-nos apenas os casos em que houver cumulação decorrente da incidência, da mesma exação, em etapas variadas da cadeia de produção e circulação de riquezas.

A não-cumulatividade pertence à seara do direito tributário, em que pese ser também objeto de estudo dos economistas ${ }^{142}$. Sua função é atuar no cálculo do quantum devido às burras estatais pelo contribuinte. Trata-se de um mecanismo pelo qual se admitem abatimentos $^{143}$ ou compensações ${ }^{144}$ no valor do tributo devido ou na sua base de cálculo conforme se adotem, respectivamente, os métodos de apuração intitulados tax on tax (imposto-contra-imposto) ou basis on basis (base-contra-base) ${ }^{145}$. Com isso, busca-se gravar apenas a riqueza agregada pelo contribuinte ao bem ou serviço. Por essa razão, a não-

\footnotetext{
${ }^{142}$ Dentre vários, mencione-se o importante estudo do Professor de Economia da Universidade de Princeton, em especial o capítulo 20 de sua obra: ROSEN, Harvey S. Public Finance, $4^{\mathrm{a}}$ ed. Chicago: Irwin, 1995, pp. 475-503. No Brasil, a seguinte obra traz considerações - sob o viés econômico - acerca das vantagens e desvantagens dos tributos cumulativos e não-cumulativos: ALBUQUERQUE, Marcos Cintra Cavalcanti. $A$ Verdade sobre o Imposto Único. São Paulo: LCTE, 2003, pp. 63-142.

${ }^{143}$ Termo utilizado no direito pátrio desde o advento dos tributos não-cumulativos até a promulgação da Constituição de 1988.

${ }^{144}$ Terminologia empregada pela atual Carta Constitucional.

${ }^{145}$ Os métodos de apuração do IVA são explanados no Item 3.3.1, infra.
} 
cumulatividade admite, também, o método da adição (somam-se os dispêndios do contribuinte para a produção ou venda do bem ou serviço e tributa-se a medida exata da adição de valor ao objeto tributável).

A origem da não-cumulatividade está imbricada à dos tributos sobre o valor agregado, sendo a nota característica mais importante dos mesmos, consoante se demonstrará a seguir.

\subsection{ORIGENS.}

A não-cumulatividade tributária passou a ganhar contornos de instituto autônomo com o advento dos impostos sobre valor acrescido, os IVAs, a partir da segunda metade do século XX.

Até então, os tributos que gravavam o comércio e a prestação de serviços assemelhavam-se à Alcabala, exigida pela Espanha medieval em suas colônias, que incidia sobre todas as transações mercantis por meio de alíquotas que chegavam a 14\% (quatorze por cento), sem qualquer possibilidade de dedução do tributo pago nas operações anteriores.

Tal sistemática gerava gravames elevados sobre os produtos, que se tornavam mais caros - pela incidência reiterada do imposto - a cada etapa de circulação. Isso fazia com que as mercadorias não circulassem livremente, haja vista que tal implicaria em perda de competitividade, dado o maior valor a recolher ao erário quanto mais estádios houvesse entre a produção e a venda ao consumidor final. Essa forma de tributação, intitulada em cascata (à cascade), era a utilizada pela maior parte dos países - com todas as vicissitudes inerentes a essa opção - antes do advento do IVA.

A problemática da tributação à cascade era tão patente que A. $\mathrm{SMITH}^{146}$, já no século XVIII, creditou à Alcabala a culpa pelo declínio econômico do império espanhol.

${ }^{146}$ Leciona o economista sobre a origem dos impostos plurifásicos cumulativos:

"Em conseqüência da noção de que as taxas sobre bens de consumo eram taxas sobre os lucros dos mercadores, aqueles impostos, em alguns países, foram repetidos sobre cada venda sucessiva dos artigos. (...). A famosa alcabala da Espanha parece ter sido estabelecida sobre este princípio. Primeiro foi uma taxa de dez por cento, depois de catorze por cento, e atualmente é de apenas seis por cento sobre a venda de toda espécie de propriedade, móvel ou imóvel, e é repetida cada vez que a propriedade é vendida."

E acentua as vicissitudes da Alcabala:

"Sujeita não só os negociantes (...) [mas também] todo lavrador, todo manufatureiro, todo comerciante e lojista, às visitas contínuas e exame dos coletores de taxas. Pela maior parte de um país onde uma taxa dessa espécie é estabelecida, nada pode ser produzido para venda à distância. (...). É à alcabala, por conseguinte, que Ustaritz imputa a ruína das manufaturas de Espanha. Ele poderia ter imputado analogamente o declínio da agricultura, sendo o imposto não só sobre as manufaturas, mas sobre o produto bruto da terra." (SMITH, Adam. Uma Investigação sobre a Natureza e Causas da 
De fato, a tributação multifásica cumulativa desfavorece a circulação de riquezas, desencorajando a livre organização econômica dos agentes do mercado (que, para evitar várias incidências sobre o mesmo produto, tendem a se verticalizar) e incitando a sonegação, devido ao seu ônus excessivo.

Entretanto, mesmo em face desses contratempos, a tributação plurifásica cumulativa difundiu-se no mundo moderno. A principal diferença em relação à vetusta Alcabala reside no fato de os países que a adotaram no século XX terem se utilizado de alíquotas baixas, como ocorreu com as Filipinas em 1904, com o Umsatzteuer alemão em 1918, com a França (que a adotou em 1920, eliminou-a em 1936, retomou-a em 1939 e abandonou-a definitivamente em 1954), com a Espanha (que retomou a tributação multifásica cumulativa em 1964, com alíquotas de $1,5 \%$ e $3 \%$, conforme a exigência coubesse à nação ou às províncias), além do Chile $^{147}$, México e Canadá (este, somente entre 1920 e 1923), inter alii $^{148}$.

A vantagem da plurifasia cumulativa - que facilitou sua difusão pelo mundo - é a sua relativa simplicidade, haja vista que o quantum a ser pago ao Estado é obtido pela mera aplicação do percentual previsto em lei ao valor da operação ou prestação, sem necessidade de quaisquer adições ou deduções. Outrossim, como incide em cascata nas várias etapas da cadeia produtiva, a alíquota não precisa ser alta para assegurar-se uma arrecadação satisfatória ao Estado ${ }^{149}$ - o que contribui para a resignação dos contribuintes ao seu pagamento. Entretanto, as desvantagens superaram, ao longo dos anos, os benefícios obtidos com a sua utilização ${ }^{150}$. São elas, em rol enumerado por J. DUE ${ }^{151}$ :

Riqueza das Nações, $2^{\text {a }}$ ed. Trad. por LIMA, Norberto de Paula. São Paulo: Hemus, 1981, p. 475, destaques nossos).

${ }^{147}$ O Chile adotou a tributação plurifásica em cascata sobre bens e serviços em 1954, com alíquota básica de 3\%. Entretanto, após sucessivas majorações, em 1969 a alíquota inicial havia quase triplicado, para atender às exigências arrecadatórias do Estado Chileno.

${ }^{148}$ DUE, John F. Indirect Taxation in Developing Economies. Baltimore, London: Johns Hopkins, 1970, pp. $117-20$.

${ }^{149}$ DUE, John F. Indirect Taxation in Developing Economies. Baltimore, London: Johns Hopkins, 1970, pp. 117-20.

${ }^{150}$ No Brasil, a tributação plurifásica cumulativa foi adotada sob a forma dos vetustos impostos sobre vendas e consignações - IVC - e sobre o consumo, substituídos, respectivamente, pelo ICM e IPI.

${ }^{151}$ DUE, John F. Indirect Taxation in Developing Economies. Baltimore, London: Johns Hopkins, 1970, pp. 120-3. 
(a) a verticalização dos agentes econômicos: afinal, quanto mais etapas do processo produtivo e comercial uma única empresa conseguir abarcar, menor será a carga fiscal sobre o seu produto;

(b) a conseqüente discriminação tributária oriunda da incidência à cascade, haja vista que as maiores empresas, além do ganho normal pela produção em escala (ínsito a qualquer mercado), também obterão vantagens fiscais por alcançarem vários estádios da produção, refugindo a diversas incidências da exação à cascade. Tal discriminação se dá, portanto, em detrimento das pequenas e médias empresas, que em qualquer economia moderna respondem pela maior parte dos empregos gerados;

(c) a impossibilidade de efetiva desoneração das exportações: como o tributo é plurifásico e cumulativo, a mercadoria não exportada diretamente pelo seu produtor sofre uma ou mais incidências na cadeia produtiva, sem possibilidade de recuperação ou abatimento deste montante quando da venda ao exterior. Com isso subverte-se a lógica mundial de não exportar tributos, ocasionando a perda de competitividade dos bens nacionais;

(d) o ferimento à isonomia na tributação dos bens importados, que, na maior parte dos casos, estarão sujeitos a uma carga menor que a do produto nacional. Este usualmente passa pela cadeia produtor > distribuidor-atacadista > varejista até chegar ao consumidor final, ao passo que os importados, se diretamente adquiridos pelo comprador final, terão incidência única no desembaraço aduaneiro. Com isso, mercadorias advindas do estrangeiro terão um benefício tributário sobre as nacionais ${ }^{152}$, que perderão competitividade;

(e) falta de transparência: não fica claro o peso do tributo no preço final da mercadoria vendida, pois esse dado irá variar conforme o número de etapas da circulação. Assim, o comprador não tem ciência do montante que está sendo destinado ao governo - fato que não coaduna com a transparência fiscal ${ }^{153}$;

\footnotetext{
${ }^{152} \mathrm{E}$ nem se argumente que o imposto de importação serviria para mitigar tal diferença. O II é tributo que deve ser utilizado como instrumento de política desenvolvimentista do Estado e não como subterfúgio para reduzir problemas criados em desfavor das empresas nacionais por força de um sistema tributário inadequado.

${ }^{153}$ Em observância ao princípio de que a tributação sobre o consumo deve ser feita às claras, a Constituição de 1988 predica:

"Art. 150. (...).

$\S 5^{\circ}$. A lei determinará medidas para que os consumidores sejam esclarecidos acerca dos impostos que incidam sobre mercadorias e serviços."
} 
(f) em comparação com impostos como a retail sales $\operatorname{tax}^{154}$ (incidência única na etapa final de vendas, sobre o preço da mercadoria), há um número muito elevado de contribuintes que, ademais, não têm interesse em se auto-fiscalizar, já que o tributo pago por um não é dedutível do valor devido pelo outro. Esse dado gera dois problemas:

(f.1) incentivo à sonegação: nenhum agente produtor se beneficia do tributo pago anteriormente (ao contrário do que ocorre nos IVAs, em que, havendo destaque da exação na nota fiscal, o adquirente pode abater tal montante do imposto por ele devido);

(f.2) dificuldades na fiscalização: a ampla base de contribuintes tendente a sonegar torna o labor da Administração Fazendária excessivamente oneroso, fato que levou A. SMITH a sustentar que a sua fiscalização "requer uma multidão de funcionários fazendários"155;

(g) apesar de ser um tributo aparentemente simples, na prática - com a necessidade de concessão de isenções para determinadas classes de commodities ou mercadorias e de diferenciação das alíquotas conforme a natureza do produto (em atenção à essencialidade dos mesmos ou a circunstâncias de mercado) - sua aplicação torna-se complexa. Esse fator acarreta a perda de um de seus poucos atributos.

Em face de tais problemas e à procura de alternativas para dinamizar o crescimento econômico sem prejudicar a arrecadação tributária, os países europeus intentaram, na primeira metade do século XX, buscar uma nova forma de tributação das operações com bens e serviços que não impactasse tão fortemente o consumo e, via de conseqüência, permitisse o desenvolvimento mais acentuado das economias, então fortemente combalidas pelas duas guerras mundiais. A solução adveio com a adoção de uma proposta do economista C. F.

${ }^{154}$ A história da tributação sobre as vendas no varejo (a popular retail sales tax) foi assim resenhada por J. DUE:

"A sales tax na venda a varejo foi primeiramente utilizada pelos Estados das Federações NorteAmericana e Canadense. Desenvolvida a partir de um tributo que incidia sobre o comércio em alíquotas baixas, a primeira sales tax estadual foi imposta pelo Mississipi em 1932. Onze Estados a adotaram no ano seguinte; em 1937, vinte e dois Estados a utilizavam e, em janeiro de 1970, apenas cinco Estados não a tinham imposto. (...).

Em nível nacional o tributo veio mais lentamente e, no início, em países mais desenvolvidos: Noruega em 1940 (...); Suécia e Irlanda em 1960; Eire em 1963. Na década de 1960 vários países menos desenvolvidos impuseram o tributo: Honduras, 1964; Rodésia, 1965; Costa Rica, 1967; Paraguai, 1969." (DUE, John F. Indirect Taxation in Developing Economies. Baltimore, London: Johns Hopkins, 1970, p. 101 - tradução livre do original em inglês).

${ }^{155}$ SMITH, Adam. Uma Investigação sobre a Natureza e Causas da Riqueza das Nações, $2^{\mathrm{a}}$ ed. Trad. por LIMA, Norberto de Paula. São Paulo: Hemus, 1981, p. 475. 
VON SIEMENS, feita inicialmente ao governo alemão em $1918^{156}$ porém somente implementada em 1954, na França: a tributação sobre o valor acrescido.

Quando instituída, em 10 de abril 1954, a Taxe sur La Valeur Ajoutée ${ }^{157}$ se apresentou como um tributo extremamente complexo em comparação com as antigas exações cumulativas que gravavam o consumo de bens e serviços na França ${ }^{158}$. Seu método de apuração era absolutamente distinto de tudo o que fora utilizado até então: calculava-se o imposto devido sobre as transações comerciais realizadas pelo contribuinte em determinado período. No entanto, deduzia-se do valor a pagar o imposto suportado na aquisição de mercadorias utilizadas no processo produtivo. Em outras palavras: para cálculo do quantum debeatur lançava-se mão de uma sistemática de débitos e créditos que, abatidos uns dos outros, apontavam o tributo a ser efetivamente recolhido aos cofres públicos.

A TVA, inicialmente, tributava apenas as operações mercantis realizadas pelos atacadistas e varejistas. Foi somente em 1968, com a extinção de dois outros impostos que incidiam sobre os serviços e o comércio varejista, que se criou uma TVA de larga incidên-

\footnotetext{
${ }^{156}$ Há controvérsias quanto à paternidade do IVA, sendo ela também reivindicada pelos americanos (TIPKE, Klaus. Über Umsatzsteuer: Gerechtigkeit. Steuer und Wirtschaft, v. 69, n. 2, 1992, p. 106, Apud TÔRRES, Ricardo Lobo. É Possível a Criação do IVA no Brasil?. SARAIVA FILHO, Oswaldo Othon Pontes de; VASQUES, Sérgio; GUIMARÃES, Vasco Branco (org.). IVA para o Brasil - Contributos para a Reforma da Tributação do Consumo. Belo Horizonte: Fórum, 2007, p. 21).

Na Alemanha, a tributação sobre o valor agregado é nominada Mehrwertsteuer (BALEEIRO, Aliomar. Direito Tributário Brasileiro, $11^{\mathrm{a}}$ ed. Atualizado por MISABEL ABREU MACHADO DERZI. Rio de Janeiro: Forense, 2001, p. 352).

${ }^{157}$ Na França, a Taxe sur La Valeur Ajoutée (TVA) é classificada por MERCIER e PLAGNET como La Taxe Unique à Paiements Fractionnés, denotando pela própria nomenclatura ("tributo único que incide de forma fracionada") o método impositivo que a distingue dos tributos cumulativos. (MERCIER, Jean-Yves e PLAGNET, Bernard. Les Impôts em France, 29a ed. Levallois: Francis Lefebvre, 1997, pp. 298-301).
}

${ }^{158}$ Os tributos indiretos na França dividem-se em dois grandes grupos: as taxes déterminées, que gravam produtos ou operações especiais (como a venda de álcool) e as taxes sur le chiffre d'affaires, incidentes sobre a venda de mercadorias e serviços em geral. Estas últimas se subdividem em três categorias, pela ordem de adoção na França:

(a) taxes cumulatives ou à cascade: tributos plurifásicos cumulativos, adotados em 1920 com alíquotas baixas (em torno de 1\%), porém abandonados por força de uma reforma levada a cabo por lei publicada em 31 de dezembro de 1936, devido aos problemas que a tributação em cascata apresentou;

(b) taxes uniques: adotadas a partir de 1937, com a grande reforma do sistema tributário francês ocorrida no ano anterior. Incidiam uma única vez, na produção, a uma alíquota de $6 \%$ (logo, seis vezes maior, em média, que a alíquota da taxe cumulative). Entretanto, os altos índices de sonegação dessa espécie de tributo aliados a problemas de orçamento enfrentados pelo Estado francês levaram ao seu abandono em pouco tempo. Com isso, a incidência à cascade foi retomada em 1939, por meio da taxe sur le transactions e de impostos locais. Estes prevaleceram até 1968, data em que a TVA de larga abrangência foi adotada;

(c) taxe sur la valeur ajoutée: adotada em 1954, para vigorar a partir de 1955. Também conhecida como la taxe unique à paiements fractionnés, teve o mérito de conciliar as vantagens arrecadatórias do sistema cumulativo com a neutralidade da tributação, que passou a ter mecanismos eficientes para sua transferência ao consumidor final. 
cia, alcançando as operações com bens (inclusive locações e arrendamentos mercantis) e prestações de serviços em geral.

O novel mecanismo tributário tornou-se, desde cedo, um sucesso. Em 1962, o Relatório NEUMARK (um dos maiores influenciadores da tributação européia ${ }^{159}$ ) recomendou a adoção do IVA pelos países do mercado comum europeu, o que passou a ocorrer a partir do final da década de 1960. O relatório salientou o fato de que a incidência sobre o valor acrescido viabiliza a liberdade de circulação de mercadorias e serviços, um dos princípios basilares do Tratado de Roma ${ }^{160}$. Assim, apesar de a apuração ser um tanto mais complexa (em comparação com a plurifasia cumulativa, que era o padrão então vigente) e de as alíquotas dos IVAs serem necessariamente mais elevadas que as dos tributos cumulativos, as vantagens superam os defeitos, tanto sob a ótica dos agentes produtores como sob a do Estado-arrecadador. Afinal:

(a) o mecanismo de abatimento do tributo pago na etapa anterior gera uma fiscalização cruzada entre os próprios contribuintes. Diferentemente do que ocorre na plurifasia cumulativa, em que a sonegação do vendedor beneficia o adquirente do bem ou serviço (pois este fica mais barato), no IVA o ônus tributário para o adquirentecontribuinte é maior caso o produto adquirido não esteja acobertado por nota fiscal (posto que, nesta, o destaque ${ }^{161}$ do imposto pago pelo vendedor legitima o contribuinte-adquirente a compensá-lo do IVA a pagar) - fato que, de per se, é um grande aliado das fiscalizações tributárias;

${ }^{159}$ GUIMARÃES, Vasco Branco. A Tributação do Consumo no Brasil - uma Visão Européia. SARAIVA FILHO, Oswaldo Othon; VASQUES, Sérgio; GUIMARÃES, Vasco Branco (org.). IVA para o Brasil - Contributos para a Reforma da Tributação do Consumo. São Paulo: Fórum, 2007, p. 51.

${ }^{160}$ O Tratado de Roma, primeiro pilar fundante da atual União Européia, assenta-se sobre quatro liberdades fundamentais, a saber:

(a) liberdade de circulação de pessoas;

(b) liberdade de circulação de bens;

(c) liberdade de circulação de serviços;

(d) liberdade de circulação de capitais.

O IVA, por ser neutro, acaba permitindo o alcance dos quatro objetivos, como leciona GUIMARÃES:

“(...) O IVA é percebido como o imposto sobre o consumo que propicia liberdade de circulação, liberdade de concorrência, liberdade e mobilidade do trabalho e dos capitais; enfim, os pressupostos constitutivos da idéia de unidade européia." (GUIMARÃES, Vasco Branco. A Tributação do Consumo no Brasil - uma Visão Européia. SARAIVA FILHO, Oswaldo Othon; VASQUES, Sérgio; GUIMARÃES, Vasco Branco (org.). IVA para o Brasil - Contributos para a Reforma da Tributação do Consumo. São Paulo: Fórum, 2007, p. 54).

${ }^{161}$ Obviamente não se imputa ao adquirente o dever de fiscalizar o efetivo pagamento do imposto pelo vendedor, bastando, para se ter direito ao crédito, que a nota fiscal de aquisição seja idônea e contenha o destaque do tributo. Todavia, a simples exigência, pelo adquirente, do documento fiscal, consiste em importante auxílio no combate à evasão fiscal. 
(b) a dedução em cada etapa do tributo pago na anterior, de forma a não permitir que o ônus tributário seja superior à aplicação da alíquota sobre o preço final, faz com que o número de etapas na circulação da mercadoria ou prestação do serviço não influa no quantum devido. Dessarte, fala-se que o tributo é neutro ou proporcional (seu ônus independe do número de operações tributadas);

(c) com a neutralidade fiscal, ganham os agentes produtores, que não têm que se verticalizar para minimizar os custos tributários, podendo concentrar-se na atividade para a qual tenham maior aptidão (produção, distribuição ou venda a varejo);

(d) no comércio internacional, as vantagens são expressivas: a exportação pode ser efetivamente desonerada (a par da não-incidência quando da venda ao estrangeiro, o método de apuração em comento permite a devolução ao contribuinte ${ }^{162}$ do imposto que gravou os insumos utilizados na produção das mercadorias exportadas - o que não é passível de ser feito no caso de tributos plurifásicos cumulativos, nos quais é bastante difícil determinar o montante exato do gravame que incidiu no processo produtivo). Ademais, os produtos estrangeiros, quando tributados no desembaraço aduaneiro, serão efetivamente equiparados - sob o prisma tributário - ao produto nacional $^{163}$;

(e) a forma de cobrança confere transparência ao imposto, eis que em todos os estádios de circulação do bem é possível saber quanto está sendo pago a título de tributo, que vem devidamente destacado na nota fiscal.

Dessarte, em que pesem as suas vicissitudes (apuração complexa e alíquota mais elevada), a experiência francesa difundiu-se na Europa e em praticamente todos os países

\footnotetext{
${ }^{162}$ Sobre a sistemática européia de desoneração das exportações, leciona TÔRRES:

"Segundo o regime tributário vigente na União Européia, as operações típicas de exportação de bens conferem aos sujeitos produtores dos bens ou responsáveis pela exportação dois direitos subjetivos bem marcados: i) não-incidência tributária e, ao mesmo tempo, ii) reconhecimento do direito de devolução dos tributos incidentes nas distintas operações de aquisições de bens ou tomadas de serviços para obter o produto a ser exportado como resultado. Assim, os países exportadores não aplicam nenhum imposto e, ao mesmo tempo, devolvem todo o volume de IVA que tenha sido assumido pelo sujeito passivo, em reconhecimento ao princípio de destino, como critério para aplicação de tributos no comércio internacional." (TÔRRES, Heleno Taveira. O IVA na Experiência Estrangeira e a Tributação das Exportações no Direito Brasileiro. SARAIVA FILHO, Oswaldo Othon Pontes de; VASQUES, Sérgio; GUIMARÃES, Vasco Branco (org.). IVA para o Brasil - Contributos para a Reforma da Tributação do Consumo. Belo Horizonte: Fórum, 2007, p. 76).
}

${ }^{163}$ Isso porque, como a alíquota real do imposto equivalerá à nominal, independentemente do número de operações de circulação da mercadoria, os produtos nacionais sofrerão, sempre, uma incidência definida: o valor da alíquota do IVA prevista em lei. Assim, basta aplicar essa mesma alíquota no desembaraço aduaneiro da mercadoria estrangeira para equipará-la à nacional. 
do globo ${ }^{164}$. E a nota característica da TVA - sua peculiar forma de apuração - é o seu elemento diferenciador nas mais de 120 nações ${ }^{165}$ que a adotam hodiernamente, sob a nomenclatura de imposto sobre o valor agregado. E, como se demonstrará a seguir, a técnica mais usual de tributação do IVA (método de subtração) não o caracteriza - apesar do nome - como um imposto incidente sobre o valor acrescido. Em verdade, sua base de cálculo é o preço total da operação de venda (contudo, a posteriori, o quantum debeatur é reduzido por meio da utilização de uma conta gráfica onde são computados os débitos e créditos do contribuinte).

\subsection{TÉCNICAS.}

\subsubsection{MÉTODOS DE ADIÇÃO E SUBTRAÇÃO.}

Consoante salientado, em que pese o nome, o imposto sobre valor acrescido não tributa - em regra - o valor que se agrega ao bem ou serviço em cada etapa de circulação ${ }^{166}$. Em sua técnica de apuração mais comumente utilizada, a incidência do IVA se dá, inicialmente, sobre o valor da venda da mercadoria ou do serviço ${ }^{167}$. Em um segundo momento, deduz-se do imposto a ser pago (calculado, repise-se, mediante aplicação da alíquo-

\footnotetext{
${ }^{164}$ O Brasil adotou-o em 1958, constitucionalizando-o em 1965; a Dinamarca, em 1967; a Alemanha, em 1968; Suécia e Holanda, em 1969; Luxemburgo e Noruega, em 1970; Bélgica em 1971; Itália e Inglaterra, em 1973; Argentina em 1975; Turquia em 1985; Portugal, Nova Zelândia e Espanha em 1986; Grécia em 1987; Hungria em 1988, et caterva.

165 Atualmente mais de $70 \%$ (setenta por cento) da população mundial vive em países que adotam a tributação sobre o valor acrescido (EBRILL, Liam; KEEN, Michael; BODIN, Jean-Paul; SUMMERS, Victoria. The Modern VAT. Washington: International Monetary Fund, 2001, p. xiv).
}

${ }^{166}$ Vale conferir a cita de F. TESAURO sobre o Imposta sul Valore Aggiunto italiano, em tradução livre de V. CASSONE:

"O IVA é, portanto, assim denominado não porque o valor acrescido constitua, de modo específico, a base imponível do tributo (na aplicação a cada uma das operações imponíveis), mas porque, para efeito de dedução (o IVA assumido sobre as aquisições do IVA devido sobre as vendas), o tributo tem como objeto econômico o valor acrescido: o 'quid pluris' que cada protagonista do processo econômico produtivo e distributivo acrescenta ao preço do bem ou serviço.” (TESAURO, Francesco. Compendio di Diritto Tributario. Torino: UTET, 2002, pp. 343-75, Apud CASSONE, Vittorio. A Não-Cumulatividade no Direito Brasileiro e no Direito Italiano. MARTINS, Ives Gandra da Silva (coord.). Caderno de Pesquisas Tributárias no 10 (nova série) - O Princípio da Não-Cumulatividade. São Paulo: Revista dos Tribunais/Centro de Extensão Universitária, 2004, p. 436).

${ }^{167}$ A essa conclusão chegaram os partícipes do Simpósio de Estudos Tributários realizado pelo Centro de Extensão Universitária em 1978. Ao analisar o fato gerador do ICM, cuja nota essencial é a nãocumulatividade, o Plenário formou opinião de que "o valor acrescido não é circunstância componente da hipótese de incidência do ICM. O princípio constitucional da não-cumulatividade consiste, tão-somente, em abater do imposto devido o montante exigível nas operações anteriores, sem qualquer consideração à existência ou não de valor acrescido". (MARTINS, Ives Gandra da Silva (coord). Caderno de Pesquisas Tributárias $n^{o} 4$ (nova série) - Sanções Tributárias. São Paulo: Resenha Tributária/Centro de Extensão Universitária, 1990, p. 642). 
ta sobre o preço cheio) o montante de tributo que incidiu na operação anterior. É neste ponto que atua a não-cumulatividade. Abatendo-se, do tributo devido, aquele recolhido na etapa anterior, consagra-se a modalidade de apuração intitulada invoice credit $^{168}$ (crédito sobre a fatura) ou tax on tax (imposto-contra-imposto). As nomenclaturas são autoexplicativas: na fatura (nota fiscal) o imposto que incidiu na operação vem destacado, sendo abatido do IVA a pagar pelo contribuinte-adquirente que realiza operações utilizando-se de insumos previamente gravados.

Uma derivação desse método é o intitulado base-contra-base (basis on basis). Neste, deduz-se da base de cálculo do IVA (preço total da operação ou prestação) o valor de insumos e serviços adquiridos pelo contribuinte (cujo abatimento seja autorizado pela lei). Sobre a base apurada mediante a subtração, aplica-se a alíquota. Assim é que a nãocumulatividade, nestoutro processo, se presta para alcançar a base de cálculo do tributo - e não o seu valor devido, que será obtido com a mera incidência da alíquota sobre a base.

Estes dois métodos - tax on tax e basis on basis - estabelecem critérios de subtração para alcance do valor agregado. E é somente no método subtrativo que atua a nãocumulatividade.

A outra técnica utilizada para cálculo do IVA é a da adição. Ela operacionaliza a não-cumulatividade de outra forma. A obtenção do quantum debeatur se dá com a simples soma (daí o nome adição) dos salários pagos pela empresa e dos lucros obtidos em um mesmo período. A partir desses montantes obtém-se o valor acrescido em determinada etapa do processo produtivo, que é submetido à tributação (aplicando-se a alíquota sobre a base de cálculo).

Sumariando o exposto, o IVA pode ser apurado mediante:

(a) métodos subtrativos:

(a.1) base-contra-base (basis on basis) ou subtração direta;

(a.2) imposto-contra-imposto (tax on tax ou invoice credit), também nominado subtração indireta;

\footnotetext{
${ }^{168}$ O método "invoice credit" (adotado, no Brasil, para o ICMS e o IPI) é assim descrito pelos especialistas em IVA do Fundo Monetário Internacional:

'Sob o método 'invoice credit', o vendedor aplica a alíquota a cada venda e entrega ao comprador uma fatura (invoice) que demonstra o valor do tributo cobrado. O comprador, se sujeito ao IVA em suas próprias vendas, fica autorizado a creditar o tributo suportado em suas compras sobre o tributo cobrado em suas vendas (...)." (EBRILL, Liam; KEEN, Michael; BODIN, Jean-Paul; SUMMERS, Victoria. The Modern VAT. Washington: International Monetary Fund, 2001, p. 20 - tradução livre do original em inglês).
} 
(b) método de adição: aplicação da alíquota sobre o somatório dos salários e lucros auferidos em dado período ${ }^{169}$.

O valor agregado stricto sensu é calculado apenas no método de adição. Assim, pode-se dizer que a forma mais adequada para o cálculo do IVA (do ponto de vista puramente teórico) é a soma dos dispêndios do contribuinte para a produção de mercadoria ou prestação de um serviço - que, acrescidos do seu lucro, informarão o valor que o mesmo acresceu à operação ou prestação. Este acréscimo corresponderá ao valor agregado sendo, então, submetido à alíquota prevista em lei. Todavia, as dificuldades práticas na implantação do método de adição tornaram-no pouco utilizado. Não há IVA de abrangência nacional calculado pela sistemática aditiva (exceto para setores específicos, como é o caso do IVA devido pelas instituições financeiras em Israel e na Argentina). Em nível estadual, podemos apontar os Estados norte-americanos de Michigan e New Hampshire, que o adotam desde 1976 e 1993, respectivamente ${ }^{170}$.

A evolução demonstra terem os métodos subtrativos conquistado a preferência das Administrações Tributárias. E é apenas nestes que a não-cumulatividade se opera. PÉREZ DE AYALA ${ }^{171}$ sustenta que, dentre as duas opções existentes (subtração direta ou indireta - que, respectivamente, correspondem aos métodos base-contra-base e imposto-contraimposto), a dedução das bases tributáveis é mais adequada a um imposto que se pretende sobre o valor agregado. No entanto, reconhece o jurista que, por ser de mais difícil consecução prática, a técnica basis on basis cede espaço ao método tax on tax, utilizado na Europa, Américas e na maior parte dos países que adotam o IVA.

De fato, apenas o Japão possui um IVA nacional que se utiliza do método subtrativo direto. No Vietnã o sistema base-contra-base também existe, mas apenas para cálculo

${ }^{169}$ Alguns autores subdividem o método da adição em direto e indireto, conforme o quadro esquemático abaixo:

Método direto: alíquota $\mathrm{x}$ (salários + lucros)

Método indireto: alíquota $\mathrm{x}$ (salários) + alíquota $\mathrm{x}$ (lucros)

Como, a nosso sentir, a simples ordem aritmética dos fatores não tem o condão de alterar a forma de incidência do IVA, optamos por não adotar tal subdivisão do critério da adição. Em sentido contrário, confira-se OGLEY, Adrian. Principles of Value Added Tax - a European Perspective. London: Interfisc Publishing, 1998, p. 5. O autor justifica a classificação argumentando que, no método indireto, "a incidência tributária é calculada em relação aos componentes do valor agregado e não diretamente ao valor agregado, em si mesmo considerado" (tradução livre do original em inglês).

${ }^{170}$ EBRILL, Liam; KEEN, Michael; BODIN, Jean-Paul; SUMMERS, Victoria. The Modern VAT. Washington: International Monetary Fund, 2001, p. 20.

${ }^{171}$ PÉREZ DE AYALA, José Luis. Explicación de la Técnica de los Impuestos, $3^{\text {a }}$ ed. Madrid: Editoriales de Derecho Reunidas, 1981, p. 179. 
do imposto pago pelas firmas individuais. As Filipinas chegaram a adotar o método basis on basis, porém abandonaram-no em favor do imposto-contra-imposto ${ }^{172}$.

O sistema tax on tax prevaleceu por ter se revelado operacionalmente mais viável (o tributo a creditar é o destacado em nota fiscal, não demandando maiores esforços aritméticos). O seguinte exemplo clarifica esta vantagem: para desoneração completa das exportações, o tributo suportado pelo contribuinte-exportador na aquisição de mercadorias e serviços estará informado nas notas fiscais que acobertaram as suas compras. Assim, bastará à Administração restituir ao exportador aquele montante registrado em seus livros fiscais por ter sido objeto de destaque nas notas fiscais de aquisição. Se a sistemática fosse a subtração direta, ter-se-ia a necessidade de apuração, dentre as compras feitas pelo exportador, daquelas que na origem foram gravadas pelo imposto - processo bastante complexo - para, somente então, proceder-se à restituição do IVA ao contribuinte-exportador.

No Brasil, como já referido, o sistema imposto-contra-imposto foi utilizado desde os primórdios da implantação da não-cumulatividade, quando ainda vigorava o vetusto imposto sobre consumo, no final da década de 1950. E, tal como prescreve o aludido método, o Supremo Tribunal Federal sempre afastou leis estaduais que exigiam do adquirente a prova do pagamento do imposto pelo vendedor como conditio sine qua non para o abatimento do tributo devido ${ }^{173}$. Afinal, como já dito, o método tax on tax parte do pressuposto de que, havendo destaque do imposto em nota fiscal, o adquirente faz jus ao crédito. A não ser assim, restaria inviabilizada a prática em tela. E o aproveitamento do crédito, como já averbou o Ministro CÉLIO BORJA ${ }^{174}$, "não é faculdade do contribuinte, mas dever para com a ordem jurídica objetiva, tanto que não lhe é possível renunciar ao lançamento do crédito do imposto, ainda quando isto lhe fosse conveniente. Nem a lei poderia autorizá-lo a tanto, sob pena de inconstitucionalidade".

\subsubsection{NÚMERO DE OPERAÇÕES GRAVADAS (PLURIFASIA NECESSÁRIA) E DIREITO AO CRÉDITO SOBRE BENS DO ATIVO IMOBILIZADO.}

O IVA admite ainda classificações conforme:

\footnotetext{
${ }^{172}$ EBRILL, Liam; KEEN, Michael; BODIN, Jean-Paul; SUMMERS, Victoria. The Modern VAT. Washington: International Monetary Fund, 2001, p. 20.

${ }^{173}$ Interplures, vale citar o seguinte acórdão, que julgou inconstitucional regime especial criado pelo Estado de São Paulo que somente autorizava o creditamento quando o imposto pago pelo contribuinte-vendedor fosse efetivamente pago: STF, Segunda Turma, RE $n^{\circ}$ 114.878/SP, Relator Min. CÉLIO BORJA, DJ 29.04.1988, p. 9.851 .

${ }^{174}$ STF, Segunda Turma, RE no 111.757/SP, Relator Min. CÉLIO BORJA, DJ 26.02.1988, p. 3.195.
} 
(a) o número de estádios do processo produtivo alcançados pelo imposto; e

(b) o tratamento tributário conferido aos bens do ativo fixo.

No primeiro caso, pode-se ter o IVA gravando: a produção, distribuição e comercialização (ciclo completo, como ocorre com o ICMS); apenas a produção e a distribuição (caso do IPI, que pode também ser exigido do distribuidor quando este for equiparado a industrial); ou apenas a distribuição e a venda. Se o tributo grava uma única etapa em toda a cadeia circulatória (sendo monofásico), não nos parece possível nominá-lo imposto sobre valor agregado, no que alinhamo-nos com J. DUE ${ }^{175}$. Assim, a plurifasia é elemento ínsito e indissociável do imposto sobre valor agregado e, via de conseqüência, da nãocumulatividade. Afinal, o método de deduções operado por esta última somente é possível se existente mais de uma operação tributável na cadeia produtiva. Para logo, é correto asseverar que sem plurifasia inexiste não-cumulatividade e, portanto, é impossível falar-se em tributação sobre valor acrescido.

Já na classificação conforme o tratamento dispensado aos bens do ativo imobilizado utilizados na produção ou prestação de serviços, a técnica da não-cumulatividade apresenta algumas variações.

A priori, dois caminhos podem ser trilhados pelo legislador: negar-se a dedução do imposto que grava os investimentos em bens do ativo fixo empregados no processo produtivo, hipótese na qual se tem o IVA Bruto (também nominado IVA tipo produto); ou autorizar-se a dedução, adotando-se o IVA Líquido ${ }^{176}$. Este último, a seu turno, poderá assumir duas formas:

(a) IVA tipo consumo (adotado pela União Européia ${ }^{177}$ e pela maior parte dos países): a compra de bens do ativo imobilizado gera crédito integral a ser abatido do IVA, sem qualquer restrição;

(b) IVA tipo renda (adotado no Brasil, em matéria de ICMS, e na China): a dedução do imposto incidente sobre bens do ativo é admitida fracionadamente, conforme a sua vida útil.

\footnotetext{
${ }^{175}$ Segundo o autor, "um tributo que utiliza o princípio do valor agregado em um só estágio (usualmente a produção) não é comumente designado imposto sobre valor agregado”. (DUE, John F. Indirect Taxation in Developing Economies. Baltimore, London: Johns Hopkins, 1970, p. 126, nota de rodapé no 16 - tradução livre do original em inglês).

${ }^{176}$ PÉREZ DE AYALA, José Luis. Explicación de la Técnica de los Impuestos, $3^{\mathrm{a}}$ ed. Madrid: Editoriales de Derecho Reunidas, 1981, p. 179.

${ }^{177}$ A UE, como visto alhures, vale-se da sistemática de subtração indireta para cálculo do IVA, ou seja, do método imposto-contra-imposto.
} 
O IVA tipo produto é assim nominado porque sua base de incidência equivale à soma da venda das mercadorias e das aquisições, pelo contribuinte-produtor, de bens de capital. Ou seja: economicamente o gravame recai sobre o produto bruto das vendas (valor destas somado aos gastos com os ativos necessários à produção).

Já o IVA tipo consumo, mais usual, possui este nome porque, sob o prisma econômico, sua base de cálculo equivale às despesas dos consumidores. Afinal, como o comerciante poderá creditar-se integralmente dos bens instrumentais por ele adquiridos, a incidência se dará apenas sobre o valor do consumo, ou seja, sobre o preço das vendas (produto líquido).

Por fim, a nomenclatura IVA tipo renda se deve ao fato de que, apesar de a incidência se dar sobre o produto líquido das vendas, o crédito dos bens do ativo é feito na medida em que estes forem gerando rendimentos para o contribuinte (e, por conseguinte, impostos para o Estado).

Em qualquer das três hipóteses, vale salientar que os bens do ativo imobilizado não afetados à atividade-fim do contribuinte nunca irão gerar direito ao abatimento nos IVAs tipos consumo e renda ${ }^{178}$. Usualmente, v.g., automóveis adquiridos para a frota da empresa são qualificados como bens alheios à atividade-fim (exceto no caso de locadoras de veículos e empresas transportadoras), impedindo o aproveitamento pelo contribuinte-adquirente do IVA suportado na aquisição do veículo ${ }^{179}$.

Portanto, a não-cumulatividade terá maior ou menor amplitude conforme a espécie de IVA (produto, consumo ou renda), sendo certo que, em termos mundiais, o IVA tipo consumo é a modalidade mais adotada.

\subsubsection{O CREDITAMENTO SOBRE INSUMOS.}

Diferentemente dos bens adquiridos para revenda, os insumos são comprados pelos produtores ou prestadores de serviços para consumo em suas atividades. Essas, ao cabo, possibilitarão a venda de uma mercadoria ou serviço tributado pelo IVA. Na indústria, ora servirão para alimentação de máquinas (como no caso de combustíveis), ora para sua manutenção (graxas, peças sobressalentes), ora integrarão o próprio produto final (para pro-

\footnotetext{
${ }^{178}$ No IVA tipo produto, como mencionado anteriormente, veda-se qualquer crédito sobre a compra de bens para o ativo imobilizado, ainda que diretamente destinados à atividade empresarial.

${ }^{179}$ No Brasil há, inclusive, disposição expressa neste sentido. A Lei Complementar $\mathrm{n}^{\circ} 87$, de 13 de setembro de 1996, ao regular a não-cumulatividade do ICMS, apregoa que "salvo prova em contrário, presumem-se alheios à atividade do estabelecimento os veículos de transporte pessoal” ( $\operatorname{art.} 20, \S 2^{\circ}$ ).
} 
dução do aço, por exemplo, são utilizados, além do minério de ferro, centenas de produtos que, fundidos, se transformam na mercadoria pronta e acabada). Da mesma forma, produtos utilizados na prestação de serviços também geram - nos IVAs em geral - direito ao abatimento. Afinal, é da lógica do imposto que o ônus seja trasladado ao consumidor final. Portanto, se o contribuinte suportou IVA na compra de bens necessários à produção ou prestação de serviço, nada mais correto do que conferir-lhe o direito de crédito.

Todavia, nem toda aquisição de bens não-duráveis será caracterizada como compra de insumo. Despesas de executivos com restaurantes, em muitos países, são associadas (em presunção juris et de jure) ao lazer, impedindo a tomada do crédito. Outro exemplo - bastante pitoresco - vem da Nova Zelândia, onde a atividade de prostituição é legalizada e tributada pelo IVA. As profissionais podem deduzir o imposto incidente na compra de lingeries rendadas e bordadas, pois se presume que estejam ligadas à atividade-fim por elas exercida; contudo, as roupas íntimas cor da pele, sem rendas ou assemelhados, não são consideradas insumos, inexistindo direito ao creditamento pela sua aquisição ${ }^{180}$. Essas restrições ocorrem porque, como já referido, o IVA busca atingir o consumidor final de bens e serviços. Dessarte, quando contribuintes do imposto adquirem bens para utilização na qualidade de consumidores finais, como se dá nos exemplos mencionados, a regra é a negativa do creditamento ${ }^{181}$.

Conforme o país, existe maior ou menor restrição para o crédito sobre insumos. No Brasil, tem-se a dicotomia entre o intitulado crédito físico - que permite o abatimento do imposto suportado na aquisição de matérias-primas e bens intermediários consumidos no processo industrial - e o crédito financeiro - que, pelo menos em tese, autorizaria a compensação do imposto que grava todo e qualquer bem destinado à atividade-fim do contribuinte.

Confira-se, para tanto, o próximo tópico.

\footnotetext{
${ }^{180}$ EBRILL, Liam; KEEN, Michael; BODIN, Jean-Paul; SUMMERS, Victoria. The Modern VAT. Washington: International Monetary Fund, 2001, p. 17.

${ }^{181}$ A explanação de OGLEY para a restrição ao crédito merece leitura:

"Apesar dos contribuintes (...), em regra, poderem recuperar o IVA que suportaram em suas despesas, eles somente poderão fazê-lo quando se tratar de uma despesa de negócio. Isso é para prevenir que despesas pessoais, quando realizadas por meio de uma empresa-contribuinte, gerem direito à devolução do IVA incidente sobre o consumo final. A maioria dos países restringe, em graus variados, o direito à recuperação do IVA relacionado a certas categorias de despesas que são automaticamente consideradas como sendo de consumo final, como as incorridas em artigos de luxo, diversões e entretenimento." (OGLEY, Adrian. Principles of Value Added Tax - a European Perspective. London: Interfisc Publishing, 1998, p. 8).
} 


\subsubsection{A AMPLITUDE DO DIREITO AO CRÉDITO.}

A doutrina pátria convencionou distinguir o direito ao abatimento dos créditos nos impostos plurifásicos não-cumulativos em duas modalidades ${ }^{182}$ :

(a) crédito financeiro, que permite ampla dedução dos investimentos em ativo imobilizado, insumos e, ainda, em bens de uso e consumo (que são empregados de forma indireta no processo produtivo da empresa, sendo consumidos em suas atividades diárias);

(b) crédito físico, que somente concede o crédito às matérias-primas e aos intitulados bens intermediários (insumos que se consomem no processo produtivo, ainda que não se agreguem fisicamente ao produto final).

Nos países europeus o modelo é o financeiro, pois toda aquisição tributada gera direito ao creditamento - exceto a compra de bens alheios à atividade empresarial ${ }^{183}$. Portanto, o insumo ou bem de uso e consumo ${ }^{184}$ (conforme esteja ou não diretamente afetado à produção) somente não possibilitará a dedução se as atividades da empresa independerem de tais produtos.

Já no Brasil, a legislação de regência do ICM sempre se orientou pelo crédito físico. Autorizava-se o abatimento dos insumos que, utilizados no processo industrial, fossem consumidos e transformados em mercadorias. Não obstante, o reconhecimento do direito à dedução do imposto estadual suportado na compra de bens do ativo imobilizado somente adveio com a LC no 87/96 ${ }^{185}$. Esta igualmente outorgou o crédito na aquisição de mercadorias para uso e consumo, em que pese tê-lo diferido no tempo (e, até o presente momento, não ter sido implementado, por sucessivas postergações do dies a quo para exercício desse direito).

182 BALEEIRO, Aliomar. Direito Tributário Brasileiro, $11^{\mathrm{a}}$ ed. Atualizado por MISABEL ABREU MACHADO DERZI. Rio de Janeiro: Forense, 2001, p. 421.

${ }^{183}$ Se determinado produto é utilizado parte para fins pessoais e parte para fins empresariais, a jurisprudência européia tem admitido o crédito integral (se a utilização não-empresarial é residual) ou proporcional (quando esta mensuração for possível).

${ }^{184}$ Exemplos de bens de uso e consumo são papéis e cartuchos de impressoras utilizados no setor administrativo de uma fábrica. Diferenciam-se dos insumos, que são empregados na atividade industrial, mas nem por isso deixam de legitimar o aproveitamento dos créditos incidentes em sua aquisição consoante a teoria do crédito financeiro.

${ }^{185}$ As leis de normas gerais do ICM (Decreto-lei no 406/68) e ICMS (Convênio ICM no ${ }^{\circ}$ 66/88) que antecederam a Lei Kandir não permitiam o crédito sobre bens do ativo imobilizado. Até então, o ICMS era um IVA tipo produto, tendo, com a LC n ${ }^{\circ} 87 / 96$, passado à categoria de IVA tipo renda. No direito pátrio, tal evolução é tratada como a passagem do crédito físico para o crédito financeiro (ainda que, por haver restrições ao aproveitamento de crédito de alguns insumos e de bens de uso e consumo, se trate de um creditamento mitigado, posto que não implementado em sua integralidade). 


\subsubsection{APURAÇÃO POR PRODUTO E POR PERÍODO.}

O IVA permite o abatimento do imposto pago nas etapas anteriores por meio de duas fórmulas: a dedução produto a produto (em que há a vinculação do crédito à mercadoria adquirida) e a dedução por período (na qual as saídas tributadas dentro de um determinado lapso temporal são cotejadas com as entradas geradoras de crédito, ocorridas nesse mesmo período).

Exemplificando: em uma exação apurada por produto, o crédito de imposto referente à aquisição de mercadoria para revenda somente será dedutível do débito gerado por essa mesma mercadoria quando de sua saída do estabelecimento comprador. Caso o bem não seja alienado, não haverá crédito a aproveitar. Se o débito na saída for inferior ao crédito da entrada, o montante que superar o valor do débito será indedutível (afinal, não haverá com o que compensar o crédito). São decorrências lógicas do sistema de apuração por produto.

Já a apuração por período de tempo pressupõe a contabilização, em conjunto, de todos os créditos oriundos da entrada de bens em determinado período de tempo. E o controle, também de forma unificada, dos débitos gerados pelas saídas tributadas nesse mesmo período $^{186}$. Da operação aritmética (créditos - débitos) obtém-se o quantum debeatur a ser recolhido aos cofres públicos relativo a determinada competência. Quando tal sistemática é adotada, perdem sentido as considerações sobre o valor do tributo incidente na saída de determinada mercadoria (se maior ou menor que aquele correspondente ao crédito lançado pelo contribuinte quando da entrada da mercadoria no estabelecimento comercial ou industrial).

O método mais consentâneo com a neutralidade fiscal perseguida pela nãocumulatividade é a apuração por período de tempo. Afinal, como dito, em tal sistema não há margens - ou, pelo menos, não deveria haver - para questionamentos quanto à necessidade de anulação do crédito caso a saída não tenha gerado débito em valor pelo menos idêntico ao da entrada. Esse estorno proporcional do crédito gera cumulatividade residual, laborando em desfavor dos objetivos de um imposto sobre valor acrescido.

A maior parte dos países adota a sistemática de apuração por período de tempo, haja vista as dificuldades operacionais encontradiças em uma eventual utilização do método produto a produto. É o caso do IVA europeu, no qual há determinação expressa para

${ }^{186}$ A competência de apuração dos IVAs é, usualmente, decendial, quinzenal ou mensal. 
que todos os países da União Européia adotem esse sistema ${ }^{187}$. No Brasil, a legislação acompanha a regra mundial (com o aval da jurisprudência ${ }^{188}$ ), porém alternativamente permite a opção pelo método produto a produto ${ }^{189}$ (o qual, todavia, está em franco desuso).

\subsection{NEUTRALIDADE FISCAL, TRIBUTAÇÃO DO CONSUMO E A PROBLE- MÁTICA DAS ISENÇÕES.}

O imposto sobre valor agregado (dotado, como visto, das notas da plurifasia e nãocumulatividade) é qualificado pelos estudiosos como uma exação sobre o consumo. A nãocumulatividade faz com que, do ponto de vista jurídico, o tributo perpasse por todas as etapas em que é exigido e, ao cabo, recaia sobre o adquirente final de bens e serviços.

A afirmação causa espécie em um primeiro momento pois, diferentemente da retail sales tax (tributo monofásico cobrado na venda a varejo e, claramente, criado para ser integralmente suportado pelo consumidor final), o IVA incide em diversas etapas da cadeia, sendo fracionadamente pago pelos agentes produtores e comerciantes. No entanto, devido à não-cumulatividade, tem-se uma neutralidade do ônus tributário em razão do número de operações (noutro giro verbal, o imposto final será o mesmo independentemente da quantidade de etapas de circulação da mercadoria). Outrossim, a não-cumulatividade atua como um facilitador para que o ônus financeiro do gravame seja transportado para as etapas subseqüentes, até alcançar o consumidor (contribuinte de facto do IVA). Em suma: a nãocumulatividade existe, sim, para permitir:

(a) a neutralidade do IVA;

(b) a transferência do ônus tributário ao consumidor final.

Dessarte, quando se permite a dedução do IVA pago na etapa anterior e se determina o destaque em nota fiscal do imposto incidente na operação (para que o adquirente tenha ciência do valor da exação que deverá suportar), está-se buscando - consoante leciona

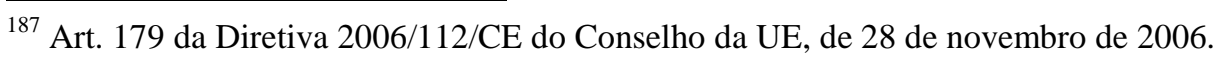

${ }^{188}$ É ver a seguinte ementa de aresto do STF:

"ICM. Princípio da não-cumulatividade. Atos sucessivos de circulação de mercadorias. O princípio da não-cumulatividade é observado sem especificidade, prescindindo da vinculação a uma certa mercadoria. Considera-se o sistema de conta-corrente em que lançados débitos e créditos." (STF, Segunda Turma, RE nº 161.257/SP, Relator Min. MARCO AURÉLIO, DJ 17.14.1998, p. 16).

${ }^{189} \mathrm{O}$ art. $4^{\text {o }}$ do Decreto-lei no 406/68 (que regulamentou o ICM até o advento da Constituição de 1988) permitia aos Estados criar um sistema alternativo de tributação, adotando a apuração por produto para as operações de venda dos vendedores ambulantes, para os estabelecimentos com existência transitória (como as feiras) e para o comércio de produtos agrícolas in natura.

Já o art. 29 do Convênio ICM n 66/88 facultava a apuração por período de tempo; por mercadoria ou serviço dentro de determinado período; e, finalmente, por mercadoria ou serviço em face de cada operação ou prestação. As mesmas alternativas são conferidas pelo art. 26 da LC n 87/96. 
MISABEL DERZI ${ }^{190}$ - que o industrial ou comerciante não arque, ele próprio, com o ônus financeiro do tributo, repassando-o adiante. Essa neutralidade do IVA possui a vantagem de evitar discriminações tributárias (afinal, como foi visto, a carga tributária será sempre a mesma independentemente do número de operações gravadas pelo imposto). Assim, a competitividade entre os agentes econômicos será determinada tão-somente pelos fatores eficiência, custo e qualidade do produto ou serviço, não sendo afetada pela tributação ${ }^{191}$. Trata-se de qualidade única do IVA, que explica sua ampla aceitação em nível mundial ${ }^{192}$.

Não obstante, em que pesem os atributos mencionados, a prática tem revelado a existência de uma cumulatividade residual do IVA, fazendo com que, em maior ou menor grau, os agentes produtores e comerciantes também arquem com o ônus do imposto. $\mathrm{O}$ XIX Relatório do Conselho de Impostos da França informa que, no ano de 1999, a carga total da TVA foi suportada pelos consumidores finais (68\%), mas também pelas empresas $(16 \%)$ e pelos órgãos governamentais $(16 \%)^{193}$. Estes últimos arcam com a TVA na quali-

${ }^{190}$ Com arrimo em sólida doutrina francesa, averba MISABEL DERZI:

“(...) A Constituição brasileira assegura, como de resto fazem os países europeus e latinoamericanos, que o contribuinte, nas operações de venda que promova, transfira ao adquirente o ônus do imposto que adiantará ao Estado e, ao mesmo tempo, possa ele creditar-se do imposto que suportou em suas aquisições (embora na posição de adquirente apenas tenha sofrido a transferência e nada tenha pessoalmente recolhido aos cofres públicos). Tal tributo não onera, assim, a força econômica do empresário que compra e vende ou industrializa, porém a força econômica do consumidor, segundo ensina Herting. A rigor, quer do ponto de vista jurídico (...) quer do ponto de vista econômico, o imposto foi modelado para ser suportado pelo consumidor, jamais pelo contribuintecomerciante." (BALEEIRO, Aliomar. Direito Tributário Brasileiro, $11^{\mathrm{a}}$ ed. Atualizado por MISANEL ABREU MACHADO DERZI. Rio de Janeiro: Forense, 2001, pp. 370-1).

${ }^{191}$ Sobre a neutralidade do IVA, GUIMARÃES averba:

"Podemos aumentar o número de transacções que o resultado final será sempre idêntico, não se altera o valor do bem por via do imposto, isto é, o consumidor final pagará efetivamente a alíquota estabelecida. Existe uma neutralidade no imposto. Este imposto, além de garantir a receita, faz também que a decisão econômica não dependa do factor tributação. Ou seja, para o agente econômico (exceptuando-se o consumidor final) é indiferente a alíquota incidente e o montante do gravame, porque transmite o valor do imposto pago à operação e, no final, quem paga é o consumidor, todos, sem excepção. Isto permite ao agente econômico estruturar sua produção independentemente do factor tributário." (GUIMARÃES, Vasco Branco. A Tributação do Consumo no Brasil - uma Visão Européia. SARAIVA FILHO, Oswaldo Othon; VASQUES, Sérgio; GUIMARÃES, Vasco Branco (org.). IVA para o Brasil - Contributos para a Reforma da Tributação do Consumo. São Paulo: Fórum, 2007, p. 52).

${ }^{192}$ Nas palavras de C. PALMA, "uma das grandes vantagens do IVA relativamente aos demais impostos sobre as transacções assenta na sua neutralidade, quer no plano interno, quer ao nível internacional. Eis, pois, a explicação para este grande mistério que é o "fenómeno IVA"”. (PALMA, Clotilde Celorico. A Harmonização Comunitária do Imposto sobre o Valor Acrescentado: Quo Vadis. SARAIVA FILHO, Oswaldo Othon; VASQUES, Sérgio; GUIMARÃES, Vasco Branco (org.). IVA para o Brasil - Contributos para a Reforma da Tributação do Consumo. São Paulo: Fórum, 2007, p. 176).

193 CONSELHO DE IMPOSTOS DA FRANÇA. XIX Relatório ao Presidente da República - Imposto sobre o Valor Agregado. Trad. por DERZI, Misabel Abreu Machado e LOBATO, Valter de Souza. Revista Internacional de Direito Tributário n 2. Belo Horizonte: Del Rey, jul.-dez./2004, p. 469. 
dade de consumidores de bens e serviços; as empresas, outrossim, suportam-na quando da aquisição de bens para consumo (que não geram direito de crédito por serem alheios ao processo empresarial) e, também, por força dos seguintes mecanismos jurídicos que obstruem a ação plena da não-cumulatividade:

(a) a existência de operações ou agentes que não se submetem ao IVA (seja por norma isencional, seja porque estão fora do campo de aplicação do imposto): nessas hipóteses, a aquisição de mercadorias não-tributadas (por terem isenção própria ou serem vendidas por agentes não sujeitos à tributação) implica na indedutibilidade do IVA incidido anteriormente;

(b) a proibição da dedução de créditos oriundos de determinadas categorias de bens e serviços.

No que tange ao primeiro fator apontado como responsável pela cumulatividade residual do IVA, a conclusão a que se chega é a de que a técnica do valor adicionado inadmite - para a manutenção integral da não-cumulatividade - isenções ou nãoincidências, exceto se estas forem concedidas na última etapa de circulação da mercadoria. $\mathrm{Na}$ prática, tal favor fiscal (quando não concedido na venda ao consumidor final, mas sim em etapa anterior da cadeia) importa em aumento de carga tributária (pois os créditos deixam de ser aproveitáveis quando a operação é não-tributada; como o IVA incide sobre o valor integral da saída, tem-se, nessas hipóteses, inexorável aumento da carga). Diferente seria se o tributo em tela fosse plurifásico cumulativo, na qual efetivamente as isenções (concedidas em qualquer etapa do processo produtivo) reduzem o quantum tributário a pagar. Confira-se, para tanto, os quadros esquemáticos abaixo, que melhor clarificam o que se está a expor:

1. Imposto sobre valor agregado ${ }^{194}$ :

1.1. Operação normal.

\begin{tabular}{|l|l|l|l|}
\hline & FABRICANTE & ATACADISTA & VAREJISTA \\
\hline $\begin{array}{l}\text { Valor de venda da } \\
\text { mercadoria }\end{array}$ & 100 & 300 & 600 \\
\hline $\begin{array}{l}\text { IVA incidente na } \\
\text { operação (18\%) }\end{array}$ & 18 & 54 & 108 \\
\hline $\begin{array}{l}\text { Valor total da ope- } \\
\text { ração }\end{array}$ & 118 & 354 & 708 \\
\hline Créditos & 0 & 18 & 54 \\
\hline $\begin{array}{l}\text { Valor do IVA a pa- } \\
\text { gar }\end{array}$ & 18 & 36 & 54 \\
\hline
\end{tabular}

${ }^{194}$ Nos IVAs em geral o tributo é sempre calculado "por fora", ou seja, não integrando o preço da mercadoria. O ICMS, com a sua forma de cálculo "por dentro", é uma exceção a esta regra. 
IVA TOTAL: $108(18+36+54)$

1.2. Isenção concedida na última etapa de circulação da mercadoria.

\begin{tabular}{|l|l|l|l|}
\hline & FABRICANTE & ATACADISTA & VAREJISTA \\
\hline $\begin{array}{l}\text { Valor de venda da } \\
\text { mercadoria }\end{array}$ & 100 & 300 & 600 \\
\hline $\begin{array}{l}\text { IVA incidente na } \\
\text { operação (18\%) }\end{array}$ & 18 & 54 & Isento \\
\hline $\begin{array}{l}\text { Valor total da ope- } \\
\text { ração }\end{array}$ & 118 & 354 & 600 \\
\hline Créditos & 0 & 18 & 0 \\
\hline $\begin{array}{l}\text { Valor do IVA a pa- } \\
\text { gar }\end{array}$ & 18 & 36 & 0 \\
\hline
\end{tabular}

IVA TOTAL: $54(18+36)$

1.3. Isenção concedida na distribuição por atacado.

\begin{tabular}{|l|l|l|l|}
\hline & FABRICANTE & ATACADISTA & VAREJISTA \\
\hline $\begin{array}{l}\text { Valor de venda da } \\
\text { mercadoria }\end{array}$ & 100 & 300 & 600 \\
\hline $\begin{array}{l}\text { IVA incidente na } \\
\text { operação (18\%) }\end{array}$ & 18 & Isento & 108 \\
\hline $\begin{array}{l}\text { Valor total da ope- } \\
\text { ração }\end{array}$ & 118 & 300 & 708 \\
\hline Créditos & 0 & 0 & 0 \\
\hline $\begin{array}{l}\text { Valor do IVA a pa- } \\
\text { gar }\end{array}$ & 18 & 0 & 108 \\
\hline
\end{tabular}

IVA TOTAL: $126(18+108)$

2. Imposto cumulativo

2.1. Operação normal.

\begin{tabular}{|l|l|l|l|}
\hline & FABRICANTE & ATACADISTA & VAREJISTA \\
\hline $\begin{array}{l}\text { Valor de venda da } \\
\text { mercadoria }\end{array}$ & 100 & 300 & 600 \\
\hline $\begin{array}{l}\text { Imposto incidente na } \\
\text { operação (18\%) }\end{array}$ & 18 & 54 & 108 \\
\hline $\begin{array}{l}\text { Valor do imposto a } \\
\text { pagar }\end{array}$ & 18 & 54 & 108 \\
\hline
\end{tabular}

IMPOSTO (CUMULATIVO) TOTAL: $180(18+54+108)$

2.2. Isenção concedida na última etapa de circulação

\begin{tabular}{|l|l|l|l|}
\hline & FABRICANTE & ATACADISTA & VAREJISTA \\
\hline $\begin{array}{l}\text { Valor de venda da } \\
\text { mercadoria }\end{array}$ & 100 & 300 & 600 \\
\hline $\begin{array}{l}\text { Imposto incidente na } \\
\text { operação (18\%) }\end{array}$ & 18 & 54 & Isento \\
\hline $\begin{array}{l}\text { Valor do imposto a } \\
\text { pagar }\end{array}$ & 18 & 54 & 0 \\
\hline
\end{tabular}


IMPOSTO (CUMULATIVO) TOTAL: $72(18+54)$

2.3. Isenção concedida na distribuição por atacado.

\begin{tabular}{|l|l|l|l|}
\hline & FABRICANTE & ATACADISTA & VAREJISTA \\
\hline $\begin{array}{l}\text { Valor de venda da } \\
\text { mercadoria }\end{array}$ & 100 & 300 & 600 \\
\hline $\begin{array}{l}\text { Imposto incidente na } \\
\text { operação (18\%) }\end{array}$ & 18 & Isento & 108 \\
\hline $\begin{array}{l}\text { Valor do imposto a } \\
\text { pagar }\end{array}$ & 18 & 0 & 108 \\
\hline
\end{tabular}

IMPOSTO (CUMULATIVO) TOTAL: $126(18+108)$

Como se dessume dos quadros, o IVA não coaduna com regime de isenções, alíquota zero ou não-incidência ao longo da cadeia. Somente se o favor fiscal ocorrer na última etapa da circulação é que haverá vantagem para o contribuinte (e, via de conseqüência, para o consumidor final). Do contrário, ter-se-á aumento de carga tributária - realidade não encontrada nos impostos cumulativos plurifásicos que, pela sua natureza, aceitam a isenção em qualquer momento da cadeia de produção.

Outrossim - e adentrando no segundo fator que labora em desfavor da aplicação plena da não-cumulatividade - quanto maiores as restrições ao aproveitamento de créditos (seja de bens do ativo, seja de insumos utilizados na atividade-fim da empresa), maior será a cumulatividade residual do imposto. Um IVA tipo produto, por exemplo - como era o ICMS no Brasil até o advento da Lei Complementar no 87/96 - gera cumulatividade ao vedar o crédito sobre aquisições para o ativo imobilizado das sociedades. Esses bens passam a ser tratados como se fossem de consumo final. Da mesma forma, restrições ao aproveitamento de créditos relativos ao IVA incidente sobre determinados insumos (como se tem, no Brasil, com a energia elétrica e os serviços de comunicação, cujo creditamento do ICMS suportado em sua aquisição é autorizado apenas em tópicas exceções previstas na legislação ${ }^{195}$ ), também contribuem para que o contribuinte de jure seja onerado com a exação, contrariando a lógica da não-cumulatividade ${ }^{196}$.

195 A LC no 87/96 inicialmente assegurava amplo direito ao crédito sobre tais insumos. Todavia, após alteração pela Lei Complementar $n^{\circ} 102$, de 11 de julho de 2000, passou a permitir o abatimento apenas em hipóteses específicas, tais como o consumo da energia em processo de industrialização.

${ }^{196}$ SACHA CALMON é taxativo ao se insurgir contra tais restrições ao crédito:

“(...) É necessário desonerar o custo da produção e da comercialização de todo o imposto pago nas aquisições (seja relativo a insumos, produtos intermediários ou bens do ativo fixo), sob pena de se ter nova tributação sobre esses bens, pois o custo deles integrará o preço do produto no momento da saída. A indedutibilidade dos créditos relativos à aquisição de bens de capital, máquinas e insumos diretamente utilizados na atividade econômica configura um rompimento com o princípio da nãocumulatividade." (COÊLHO, Sacha Calmon Navarro. O IVA Brasileiro. SARAIVA FILHO, Os- 
De toda sorte, em que pese a eventual cumulatividade encontradiça nos IVAs em geral, decorrente dos fatores acima referidos, pode-se asseverar que a exação nãocumulativa é neutra ${ }^{197}$ e atinge a ponta final (consumidor) do processo produtivo. Os recolhimentos fracionados realizados ao longo do percurso pelos contribuintes apenas antecipam aos cofres estatais o imposto que será suportado, do ponto de vista jurídico, pelo adquirente final.

Note-se, por derradeiro, que se está a falar aqui em repercussão jurídica, nunca econômica. Em outros termos: a não-cumulatividade é um instrumento que, juridicamente, viabiliza a translação do ônus financeiro da exação. Entretanto, sob a ótica econômica tal assertiva é impossível de ser feita, haja vista que depende da análise pontual de cada caso concreto, como já demonstrado no Capítulo 1.

\subsection{A NÃO-CUMULATIVIDADE E A REGRA-MATRIZ DE INCIDÊNCIA TRI- BUTÁRIA.}

A não-cumulatividade é um princípio técnico de apuração do quantum debeatur e translação do ônus fiscal ao contribuinte de facto. Todavia, há discussão sobre a sua relação com a regra-matriz da incidência tributária: trata-se de instituto externo ou de elemento integrante desta? Para melhor deslinde do tema - que, adiante-se, dependerá tão-somente do modelo de regra-matriz adotado - confira-se, ab initio, a evolução doutrinária sobre a estrutura da norma de tributação.

\subsubsection{ESTRUTURA FORMAL DA NORMA TRIBUTÁRIA.}

A norma tributária foi, desde sempre, objeto de candentes discussões doutrinárias. As escolas de A. FALCÃO ${ }^{198}$, D. JARACH ${ }^{199}$ e ATALIBA $^{200}$ estudaram-na apenas sob o

waldo Othon; VASQUES, Sérgio; GUIMARÃES, Vasco Branco (org.). IVA para o Brasil - Contributos para a Reforma da Tributação do Consumo. São Paulo: Fórum, 2007, p. 580).

${ }^{197}$ A neutralidade está diretamente imbricada com o princípio da isonomia. Uma vez que a carga tributária global sobre a operação será sempre a mesma independente do número de operações, os diferentes competidores no mercado passam a atuar - sob o prisma tributário - em condições de igualdade (ao contrário dos impostos cumulativos, nos quais quanto maior o número de operações abarcado pela mesma empresa - desde a produção até a venda ao consumidor final - menor será o seu custo tributário).

${ }^{198}$ FALCÃO, Amílcar de Araújo. O Fato Gerador da Obrigação Tributária. São Paulo: Revista dos Tribunais, 1973.

${ }^{199}$ JARACH, Dino. El Hecho Imponible, $2^{\mathrm{a}}$ ed. Buenos Aires: Abeledo-Perrot, 1971.

${ }^{200}$ ATALIBA, Geraldo. Hipótese de Incidência Tributária, 6ª ed. São Paulo: Malheiros, 2006. 
prisma da hipótese de incidência (na nomenclatura adotada por A. FALCÃO e ATALIBA, que se contrapunham à expressão "fato gerador") ou fato imponível (termo utilizado por JARACH). Desse modo, não curavam da diferenciação entre o antecedente e o conseqüente da norma, tendo sofrido críticas por "glorificarem" o fato gerador tributário.

Foram BARROS CARVALHO ${ }^{201}$ e, em seguida, SACHA CALMON ${ }^{202}$, que deram à norma tributária a conformação estrutural hoje vigente.

Propondo uma primeira evolução, BARROS CARVALHO, com esforço em COSSIO e L. VILANOVA, dividiu a norma tributária (à qual intitulou endonorma) em hipótese endonormativa (antecedente) e conseqüência endonormativa (conseqüente). Situou na hipótese de incidência (previsão em abstrato do fato tributável) os critérios material, temporal e espacial, que descrevem, respectivamente: o fato tributável em si (verbo + complemento), as condições de tempo dentro das quais a norma atua e a delimitação territorial do fato. Já no conseqüente BARROS CARVALHO inseriu os elementos que permitem a quantificação do tributo devido (critério quantitativo, composto por base de cálculo e alíquota) e a identificação dos sujeitos ativo e passivo (critério pessoal).

O descritivo abaixo, que retrata a norma de incidência do IPTU à luz da teoria Carvalheana é, nas palavras de SACHA CALMON ${ }^{203}$, "a mais aguda percepção da estrutura da norma tributária":

\begin{tabular}{|l|l|}
\hline \multicolumn{1}{|c|}{$\begin{array}{c}\text { Hipótese de incidência } \\
\text { (hipótese endonormativa) }\end{array}$} & \multicolumn{1}{c|}{$\begin{array}{c}\text { Conseqüência ou comando } \\
\text { (consequiência endonormativa) }\end{array}$} \\
\hline $\begin{array}{l}\text { 1) critério material: ser (verbo) proprietário } \\
\text { de bem imóvel (complemento predicativo); }\end{array}$ & $\begin{array}{l}\text { 1) critério pessoal: sujeito ativo é o Municí- } \\
\text { pio e o sujeito passivo o proprietário; }\end{array}$ \\
$\begin{array}{l}\text { 2) critério espacial: no perímetro urbano do } \\
\text { Município; }\end{array}$ & $\begin{array}{l}\text { 2) critério quantitativo: a base de cálculo é } \\
\text { o valor venal do bem imóvel, sobre que se } \\
\text { 3) critério temporal: computado o aconte- } \\
\text { cimento no dia } 1^{\circ} \text { de janeiro do ano civil. }\end{array}$
\end{tabular}

O modelo proposto por BARROS CARVALHO foi objeto de estudo por SACHA CALMON que, adotando-o, propôs algumas modificações. A par de utilizar a nomenclatura "aspectos" em vez de "critérios", acresceu o aspecto pessoal no antecedente, ao lado dos

\footnotetext{
${ }^{201}$ CARVALHO, Paulo de Barros. Teoria da Norma Tributária. São Paulo: Lael, 1974.

${ }^{202}$ COÊLHO, Sacha Calmon Navarro. Teoria Geral do Tributo e da Exoneração Tributária. São Paulo: Revista dos Tribunais, 1982.

${ }^{203}$ COÊLHO, Sacha Calmon Navarro. Curso de Direito Tributário Brasileiro, $9^{\mathrm{a}}$ ed. Rio de Janeiro: Forense, 2007 , p. 425.
} 
aspectos material, espacial e temporal ${ }^{204}$. Outrossim - e este ponto é primordial para a análise da não-cumulatividade no bojo da norma de tributação - SACHA CALMON apregoou a inserção, no conseqüente endonormativo, de outros elementos que se prestam para a apuração do quantum debeatur. Além da base de cálculo e alíquota (que já compunham o critério quantitativo da endonorma Carvalheana), foram incluídos no conseqüente: adições e subtrações (as primeiras necessárias, v.g., à apuração do imposto sobre a renda, e as últimas à apuração do ICMS e IPI); valores fixos (para o caso de taxas como a cobrada pela emissão de passaporte, fixada sem qualquer recurso a base de cálculo ou alíquota, inaplicáveis ao caso); além de dados sobre como pagar, quando pagar e onde pagar (preservando, outrossim, os sujeitos ativo e passivo que já integravam o conseqüente na estrutura formal proposta por BARROS CARVALHO). Vale conferir este modelo normativo:

\begin{tabular}{|l|l|}
\hline \multicolumn{1}{|c|}{ Hipótese de incidência } & \multicolumn{1}{c|}{ Conseqüência jurídica } \\
\hline Aspecto material: o fato em si & A quem pagar (sujeito ativo) \\
Aspecto temporal: condições de tempo & Quem deve pagar (sujeito passivo) \\
Aspecto espacial: condições de lugar & Quanto se deve pagar (base de cálculo e \\
Aspecto pessoal: condições e qualificações & alíquotas ou valor fixo, adições e subtra- \\
relativas às pessoas envolvidas com o fato & ções) \\
& Como pagar \\
& Quanto pagar \\
& Onde pagar \\
\hline
\end{tabular}

Assim, a não-cumulatividade poderá integrar ou não a estrutura da norma tributária em função do modelo de regra-matriz adotado pelo exegeta - e não por alguma de suas características próprias. É o que se demonstrará a seguir.

\subsubsection{O INSTITUTO DA NÃO-CUMULATIVIDADE EM FACE DA NORMA TRI- BUTÁRIA.}

Quando da análise da regra-matriz do ICM, BARROS CARVALHO situou a nãocumulatividade fora da norma de tributação. Em que pesem opiniões contrárias ${ }^{205}$, para o

\footnotetext{
${ }^{204}$ Eis os fundamentos de SACHA CALMON para inserção do aspecto pessoal na hipótese endonormativa: “(...) O fato jurígeno (um 'ser', 'ter', 'estar' ou 'fazer’) está sempre ligado a uma pessoa e, às vezes, os atributos ou qualificações dessa pessoa são importantes para a delimitação da hipótese de incidência. Exemplo marcante da importância do aspecto pessoal constante das hipóteses de incidência nos oferta o 'fato gerador' do ICM. Com efeito, não basta haver circulação. É mister que a pessoa promotora da circulação seja industrial, comerciante, produtor agropecuário ou equiparado." (COÊLHO, Sacha Calmon Navarro. Teoria Geral do Tributo e da Exoneração Tributária. São Paulo: Revista dos Tribunais, 1982, p. 91).
}

${ }^{205}$ Interplures, vale citar R. G. DE SOUSA, que visualiza a não-cumulatividade integrando o conseqüente endonormativo por considerá-la parte da própria base de cálculo do tributo. Averba o autor: 
jurista o critério quantitativo não comportaria os mecanismos de dedução (tax credit) do valor a pagar. A base de cálculo seria, no caso do ICM, o valor da operação, sobre a qual a alíquota deveria ser aplicada. Posteriormente, no momento de apuração do quantum debeatur o mecanismo da não-cumulatividade atuaria, reduzindo a dívida do contribuinte. Assim, o instituto em comento seria fator exógeno à regra-matriz de incidência tributária ${ }^{206}$.

Por outro lado, se adotarmos a teoria da norma tributária de SACHA CALMON, chegaremos à conclusão de que a não-cumulatividade integra o conseqüente endonormativo. Isso porque, ao lado da base de cálculo e da alíquota, SACHA CALMON inclui as deduções - estas, típicas dos impostos não-cumulativos. Dessa forma, é possível também sustentar que a não-cumulatividade se faz presente na regra-matriz de incidência ${ }^{207}$.

Em qualquer teoria, contudo, resta claro que a base de cálculo não comporta o mecanismo da não-cumulatividade. A consideração importa porque, apesar da nomenclatura, a incidência do IVA (em sua sistemática mais usual, que é a da subtração indireta) não se dá sobre o valor agregado, mas sim sobre a operação cheia ${ }^{208}$. A posteriori é que se tem a dedução, operada pela não-cumulatividade, do tributo pago na etapa anterior. Em sendo assim, como a base de cálculo é o valor da operação, não podemos concordar com a tese

“(...) A base de cálculo define-se expressamente como sendo, em cada operação, a parcela de valor que, agregando-se às parcelas correspondentes às operações precedentes e subseqüientes, contribuirá para compor o valor total da operação tributada." (SOUSA, Rubens Gomes de. Revista de Direito Público, v. 11, p. 18, Apud CARVALHO, Paulo de Barros. A Regra-Matriz do ICM. Tese de Livre Docência. São Paulo: PUC, 1981, pp. 364-5).

${ }^{206}$ BARROS CARVALHO asserta que a não-cumulatividade "se aloja na planície dos meios de apuração da dívida, não tendo significado algum no que diz como elemento estrutural (...) da figura impositiva”. E, prosseguindo, pontifica:

"O comando constitucional da não-cumulatividade, no arcabouço do plexo normativo do ICM, está jungido tão-somente ao método de consideração do valor periódico de cada recolhimento. Nada tem que ver com a base de cálculo, que se congrega à alíquota para determinar o signo patrimonial correlativo à incidência tributária, em cada operação." (CARVALHO, Paulo de Barros. A Regra-Matriz do ICM. Tese de Livre Docência. São Paulo: PUC, 1981, pp. 366-70).

207 O próprio SACHA CALMON invoca a não-cumulatividade tributária para justificar a inclusão das "deduções" no conseqüente da norma:

"Enquanto o devedor for obrigado a fazer operações para conhecer o seu débito, e o credor, para apurar o seu crédito (lançá-lo), necessitar também de fazê-las, já praticada a aplicação da alíquota sobre a base de cálculo, não se terá esgotado o elemento quantitativo da norma de tributação. (...).

Veja-se o caso do ICMS brevitatis causa. Não basta aplicar a alíquota (...) sobre o valor das 'operações tributáveis' ocorridas em lapso de tempo determinado. É necessário ainda que se deduza do montante achado pelo modo atrás descrito o valor dos 'créditos' pelas 'entradas' ocorridas no período, assim como o valor dos 'créditos presumidos' porventura previstos na legislação. Sem essa dedução não se chega ao quantum debeatur. (...). O princípio da não-cumulatividade integra a norma de tributação do ICMS." (COÊLHO, Sacha Calmon Navarro. Curso de Direito Tributário Brasileiro, $9^{\mathrm{a}}$ ed. Rio de Janeiro: Forense, 2007, p. 429).

${ }^{208}$ BERLIRI, Antonio. L'Imposta sul Valore Aggiunto. Milano: Giuffrè, 1971, p. 61. 
dos que sustentam que a não-cumulatividade integra a base de cálculo ${ }^{209}$ do ICM (ou de qualquer imposto sobre valor agregado).

Dessarte, pode-se concluir que:

(a) a não-cumulatividade tributária não integra a base de cálculo de nenhum tributo. Nos IVAs em geral, a alíquota é aplicada sobre o valor da operação ou prestação. Calculado o imposto, passa-se, em um segundo momento, às deduções - que, por serem realizadas a posteriori, não dilapidam a base tributável;

(b) em face disso, se considerarmos que o conseqüente da norma tributária abriga, em seu aspecto quantitativo, tão-somente a base de cálculo e a alíquota, a conclusão inexorável é de que a não-cumulatividade constitui elemento exógeno à norma de tributação; por outro lado, se visualizarmos na conseqüência outros elementos como adições, deduções e demais informações relativas ao pagamento da exação, a não-cumulatividade estará inserida na norma tributária.

\subsection{PRESSUPOSTOS DA NÃO-CUMULATIVIDADE: PLURIFASIA E DIREITO AO ABATIMENTO.}

Como foi visto, a não-cumulatividade é forma de apuração do quantum devido, que se situa dentro (conforme SACHA CALMON ${ }^{210}$ ) ou fora (sob a ótica de BARROS CAR$\mathrm{VALHO}^{211}$ ) do conseqüente da norma tributária. Nota típica dos impostos sobre valor agregado, o instituto em questão é aplicado em mais de 120 países - acompanhando o que a doutrina intitula de "fenômeno IVA", dada a larga aceitação desta espécie exacional.

A não-cumulatividade se perfaz por quaisquer dos métodos de cálculo do IVA, cujas formas de apuração, como visto anteriormente ${ }^{212}$, são:

\footnotetext{
${ }^{209}$ Esta é a tese defendida por R. B. NOGUEIRA, para quem “(...) se a própria configuração do imposto estabelece que ele é sobre o valor acrescido, a lei há de ser a primeira a impedir que possa entrar na base de cálculo o quantum pago na operação anterior". (NOGUEIRA, Ruy Barbosa. Direito Tributário Comparado. São Paulo: Saraiva, 1971, pp. 126-7).

${ }^{210}$ COÊLHO, Sacha Calmon Navarro. Curso de Direito Tributário Brasileiro, $9^{\mathrm{a}}$ ed. Rio de Janeiro: Forense, 2007, p. 429.

${ }^{211}$ CARVALHO, Paulo de Barros. A Regra-Matriz do ICM. Tese de Livre Docência. São Paulo: PUC, 1981, p. 370.

${ }^{212}$ Item 3.3.1, supra.
} 
(a) método da adição (muito pouco utilizado, dadas as dificuldades operacionais), no qual se somam os custos de produção e salários para obtenção do valor acrescido, sobre o qual se aplica a alíquota;

(b) métodos de subtração, que admitem duas variantes:

(b.1) base-contra-base (basis on basis), ou seja, deduz-se do preço de venda o custo de aquisição da mercadoria (ou serviço), obtendo-se com isso a base tributável; e

(b.2) imposto-contra-imposto (tax on tax), no qual o valor do tributo devido na saída é descontado daquele incidente nas etapas anteriores do processo produtivo.

O sistema mais comumente adotado é o imposto-contra-imposto. Nessa hipótese não se tem uma incidência sobre o valor acrescido propriamente dito. Tributa-se o valor integral da operação e, em momento subseqüente, compensa-se o valor do IVA suportado na aquisição de mercadorias para revenda, insumos e bens do ativo imobilizado (desde que estes não sejam alheios à atividade do contribuinte-empresário ${ }^{213}$ ).

A compensação se dá, em regra, por período de tempo (débitos de um mês contra créditos do mesmo mês ou do anterior), não havendo vinculação produto a produto. $\mathrm{Ou}$ trossim, para controle tanto dos contribuintes como do Fisco, a legislação exige o destaque $^{214}$ do imposto em nota fiscal (razão pela qual o método de apuração em comento é também nominado invoice credit).

Dentre as vantagens da não-cumulatividade, destaca-se a de permitir a neutralidade fiscal. Noutro giro verbal, o ônus tributário é transferido ao longo da cadeia de produção até chegar ao consumidor final, que arcará de fato com o tributo ${ }^{215}$.

São essas, em síntese, as características básicas do instituto sub examine, que vimos de ver nos itens precedentes. Isto posto, cumpre-nos indagar: em qual espécie de tributo poderá a não-cumulatividade atuar? Ou melhor: quais são os pressupostos para que determinada exação seja considerada não-cumulativa?

\footnotetext{
${ }^{213}$ É certo que a autorização para crédito relativamente a determinadas aquisições pode variar, haja vista que alguns países adotam o IVA tipo produto (que não reconhece direito ao abatimento do imposto que grava as aquisições para o ativo fixo), o IVA tipo renda (que permite a dedução do ativo de forma fracionada, caso do ICMS no Brasil) ou o IVA tipo consumo (que confere integral direito à compensação do tributo suportado na aquisição do imobilizado).

${ }^{214}$ Na Europa o IVA é calculado "por fora”: em uma operação de R \$ 100,00, o imposto (alíquota de 12\%, v.g.) será cobrado no montante de R \$ 12,00, totalizando um valor devido de R\$ 112,00. No Brasil, o IPI segue a mesma sistemática, ao passo que o ICMS é calculado "por dentro" (uma venda interestadual de R\$ 100,00 importará no pagamento, v.g., de R \$12,00 a título de ICMS, porém o preço final do produto continuará sendo de $\mathrm{R} \$ 100,00)$.

${ }^{215}$ Como já dito e repisado, tal consideração deve ser lida do ponto de vista jurídico, pois economicamente não é possível sustentar-se que a não-cumulatividade transfere o peso fiscal ao consumidor final. Tal constatação depende de variáveis de mercado, alheias ao direito tributário.
} 
A não-cumulatividade foi criada para atuar nos impostos plurifásicos. Dessarte, pode-se afirmar que a plurifasia é imprescindível para a existência da não-cumulatividade (ao menos dentro dos moldes para os quais esta foi erigida). Deve haver um número míni$\mathrm{mo}^{216}$ de operações encadeadas que permita a incidência do gravame e a atuação do mecanismo de abatimento e transferência jurídica do ônus fiscal. Outrossim, o tributo deve efetivamente incidir sobre mais de um estádio do processo produtivo. Dessarte, a plurifasia se concretiza pela existência de várias operações passíveis de tributação e também pela efetiva incidência do IVA sobre elas ${ }^{217}$. Presentes ambas as premissas, têm-se assentadas as bases para que a incumulatividade opere em sua forma tradicional.

A antítese da plurifasia é a monofasia. Nesta, o tributo é cobrado em uma só etapa do processo produtivo. É o caso da retail sales tax: ao incidir tão-somente na venda a varejo, caracteriza-se como tributo monofásico por excelência. Os vetustos impostos únicos federais sobre energia elétrica, combustíveis, lubrificantes e minerais são, também, exemplos de exações monofásicas. A Constituição permitia a escolha, dentre os vários estádios da produção e comercialização desses produtos e serviços, de uma única etapa a ser gravada. Daí a nomenclatura de impostos "únicos"218 - logo, monofásicos.

É imperioso gizar que a monofasia não se confunde com a intitulada substituição tributária para frente ou progressiva, típica do ICMS. Esta pressupõe a existência de tributação plurifásica, é dizer, incidência do gravame sobre mais de uma etapa de circulação da mercadoria. O substituto concentra em si o dever tributário correspondente a duas ou mais fases - porém, o fato de ser recolhido em um só momento não significa que o tributo seja monofásico.

Monofasia corresponde à incidência única; plurifasia, em todas as etapas; substituição tributária progressiva é a concentração do dever fiscal em um único sujeito passivo, que fará as vezes, para o Fisco, dos demais contribuintes ${ }^{219}$ (os quais, se houvesse regular incidência do gravame plurifásico, teriam que fazer a recolha da exação às burras estatais).

\footnotetext{
216 Para haver plurifasia, entendemos serem necessárias, pelo menos, duas operações sucessivas sobre as quais o IVA possa, em tese, recair.

${ }^{217}$ Essa a lição de SACHA CALMON, para quem o princípio da não-cumulatividade pressupõe a incidência "sobre um ciclo completo de negócios (plurifasia impositiva)". (COÊLHO, Sacha Calmon Navarro. Comentários à Constituição de 1988 - Sistema Tributário, 6ª ed. Rio de Janeiro: Forense, 1996, p. 224).

218 Outrossim, apenas o imposto único podia incidir sobre a energia elétrica, combustíveis, lubrificantes e minerais, sendo vedada qualquer outra forma de tributação.

${ }^{219}$ A diferença entre os institutos foi apontada por EDUARDO MANEIRA, em trecho que merece transcrição:
} 
Sendo plurifásica (ainda que haja substituição tributária a ensejar o pagamento do tributo em um só momento), a exação poderá ser cumulativa ou não-cumulativa, conforme a lei de instituição preveja ou não o abatimento do tributo suportado nas aquisições de insumos, bens intermediários, de uso e consumo e ativo imobilizado.

Contudo, que tipo de tributo pode ser considerado plurifásico? Para nós, são plurifásicos por excelência aqueles gravames que incidem sobre operações de circulação de bens e serviços, desde a extração das matérias-primas até a venda ou prestação ao consumidor final.

Dizemos isso pois são apenas nesses casos que se pode, com precisão, visualizar todo o processo de produção ou prestação, impossível de ser aferido noutras modalidades impositivas. Tome-se o exemplo da extinta CPMF, que incidia sempre que havia lançamento a débito, por instituição financeira, em conta-corrente de pessoa natural ou jurídi$\mathrm{ca}^{220}$. O fato de o mesmo valor ser gravado várias vezes pela contribuição a tornava plurifásica (e, portanto, cumulativa, haja vista que inexistia sistema de compensação da CPMF)? Temos que não. Em verdade, as assertivas de que a exação onerava a mesma riqueza por diversas vezes ${ }^{221}$ partiam sempre de modelos baseados em operações com bens ou serviços. Um desses exemplos, citados à exaustão quando das discussões acerca da extinção da CPMF, era o seguinte: um veículo é comprado da fábrica pelo concessionário. Ao fazer o pagamento, o concessionário tem um lançamento a débito de CPMF em sua conta bancária. Quando o automóvel é revendido, nova CPMF incide, desta vez na contacorrente do consumidor que este sacou os valores para quitar o bem. Como não havia abatimento, a alíquota de 0,38\% era aplicada duas vezes. Diante de tal realidade, alguns sustentavam que a CPMF era cumulativa (o que pressuporia, dessarte, que ela fosse plurifási-

“Em primeiro lugar, vamos distinguir monofasia da 'substituição tributária para a frente plena', cuja
aplicação somente é possível nos casos de tributos plurifásicos submetidos à não-cumulatividade.
Na substituição tributária para a frente haverá, como ocorre com a monofasia e daí a possibilidade
de serem confundidas, um único recolhimento. É o caso da refinaria substituir a distribuidora e o
posto de gasolina no ICMS, nas operações com combustível. O recolhimento é único na base, na re-
finaria, mas o cálculo deste imposto levou em consideração a ocorrência de todas as operações. A
refinaria recolhe na condição de contribuinte pela primeira operação, da sua venda para a distribui-
dora e depois recolhe na condição de substituta sobre as outras operações. Na monofasia, ao contrá-
rio, tributa-se apenas uma operação. Monofasia significa incidência única. A tributação monofásica
é antagônica à plurifasia e por via de conseqüência à substituição tributária." (MANEIRA, Eduardo.
Considerações sobre o art. 166 do CTN e a Não-cumulatividade das Contribuições ao PIS e à CO-
FINS. Revista Dialética de Direito Tributário, no 124. São Paulo: Dialética, jan./2006, pp. 43-4).

${ }^{220}$ Hipótese de incidência plasmada no art. $2^{\circ}$, I da Lei n ${ }^{\circ} 9.311$, de 24 de outubro de 1996.

${ }^{221} \mathrm{O}$ que resultava em uma alíquota real (efetiva) superior à nominal (prevista em lei). 
ca, pois, assim como a não-cumulatividade, a sua antípoda tampouco pode existir em tributos monofásicos ${ }^{222}$ ).

Não nos parece que, no exemplo referido, seja correto falar-se em plurifasia e, por conseguinte, em cumulatividade stricto sensu. A hipótese de incidência da exação era um ato isolado, autônomo, que não podia ser vislumbrado como um estádio de um processo de produção ou prestação de serviço. A CPMF gravava lançamentos a débito em contas bancárias - e só. Não havia qualquer vinculação entre a razão do saque (ex.: para adquirir uma mercadoria; para fazer uma doação; para quitar um financiamento de imóvel) e a aplicação da norma tributária. Esta incidia pelo simples ato de se debitar um montante da contacorrente. Sendo assim, para sustentar que a contribuição era perversa por ser "cumulativa", recorria-se a exemplos que, inexoravelmente, estavam ligados a um processo de circulação de riqueza por meio de negócios jurídicos. Entretanto, tal recurso já denota, per se, a insuficiência dos elementos constantes da própria norma de incidência da CPMF para permitir a sua qualificação como exação cumulativa - que pressuporia, como dito, a plurifasia dessa contribuição.

Para nós, plurifasia - e, portanto, cumulatividade e não-cumulatividade - exige, além da incidência plúrima, que os fatos alcançados pela norma sejam de alguma forma encadeados entre si. Tal ocorre nos tributos que gravam a circulação de riquezas, ou seja, nos impostos sobre o consumo de bens e serviços. Nestes, ambas as partes estão ligadas por um negócio jurídico que, a seu turno, é pressuposto para a ocorrência, em momento subseqüente, de outro negócio em torno da mesma mercadoria ou serviço. Vista de fora, a operação é uma só, com seus vários estádios concatenados, possibilitando a circulação do bem desde a extração da matéria-prima (quando tal se fizer necessário) até a entrega do produto ou serviço ao consumidor final. Somente se atendidos esses pressupostos é possível falar-se em plurifasia. Do contrário, ter-se-á gravames incidindo sobre realidades autônomas, que se esgotam em si mesmas, inexistindo o encadeamento lógico e factual necessário para a tributação plurifásica. É o caso das contribuições que incidem sobre a receita ou faturamento das empresas, assim como sobre a folha de salários. Auferida a receita ou pago o salário, realiza-se a hipótese de incidência abstratamente prevista no critério material da norma.

\footnotetext{
${ }^{222}$ EDUARDO MANEIRA partilha deste entendimento, ao averbar que "a não-cumulatividade e cumulatividade são conceitos jurídicos que só têm espaço nos impostos plurifásicos que devem ser não-cumulativos, mas que por alguma deformação do sistema tornam-se cumulativos". (MANEIRA, Eduardo. Considerações sobre o art. 166 do CTN e a Não-cumulatividade das Contribuições ao PIS e à COFINS. Revista Dialética de Direito Tributário, no 124. São Paulo: Dialética, jan./2006, p. 43).
} 
Dir-se-á, em contraponto, que também nos impostos sobre circulação de riquezas a incidência se esgota na venda do bem ou serviço. Sim, é correto. Mas é possível traçar um liame lógico-operacional entre a venda (ou prestação) e as operações anteriores que possibilitam a sua efetivação. Com isso, se pode visualizar o todo da operação e fazer sobre ela incidir, fracionadamente, a exação plurifásica não-cumulativa, de modo que o peso total do gravame não exceda aquele que se teria com a aplicação da alíquota sobre o preço praticado para o consumidor final. Esse tipo de constatação é impossível de ser feito nos tributos sobre realidades não-diretamente relacionadas ao consumo de bens e serviços. Tome-se outro exemplo, o do imposto sobre a renda. Seu fato imponível se esgota na percepção do rendimento. É impróprio, neste caso, falar-se em operação anterior para fins de abatimento.

Um julgado do Supremo Tribunal da década de 1980, que tratou do direito ao crédito do ICM em produtos adquiridos pelo comerciante porém não vendidos porque destruídos em incêndio ${ }^{223}$, abordou, com propriedade, o conceito de plurifasia como requisito essencial da não-cumulatividade. Os excertos do voto do Relator, Ministro OCTAVIO GALLOTTI, lançam luzes sobre o tema:

“(...) O direito, constitucionalmente garantido, da não-cumulatividade, para repartição ideal da carga tributária, só existe ao se considerar presente o trato sucessivo das operações realizadas pelo contribuinte com a mesma mercadoria. (...).

Daí concluir-se que a não-cumulatividade só tem razão de ser se ocorrente a multiplicidade de operações tributáveis, realizadas por comerciantes, industriais ou produtores. É essa a presunção constitucional, que não surte efeitos quando o processo econômico se exaure numa só operação." 224

E prossegue o Min. OCTAVIO GALLOTTI, arrimando-se na doutrina pátria:

"A rigor, como explica o Prof. SOUTO MAIOR BORGES, 'o que a Constituição preserva é simplesmente o dever ser abatido o ICM cobrado nas operações anteriores, se e enquanto plurifásica a sua incidência. Ao contrário, se

\footnotetext{
${ }^{223}$ Saliente-se que, no mérito, a decisão do STF foi errônea, pois negou o direito ao crédito. Ousamos divergir do posicionamento do Excelso Pretório porque a apuração do imposto é feita não por produto, mas sim por período de tempo. Sendo assim, uma vez que a mercadoria ingressa no estabelecimento, o comerciante já pode compensar o crédito de ICMS destacado na nota fiscal de aquisição (inclusive com possibilidade de transporte do saldo credor para períodos subseqüentes, caso os débitos não fossem suficientes para eliminálos por completo). $\mathrm{O}$ fato de o bem ter sido destruído em incêndio não poderia, portanto, obstar o lançamento do crédito do imposto na escrita fiscal do contribuinte. A decisão, sobre ser injurídica, é injusta.

224 STF, Primeira Turma, RE n ${ }^{\circ}$ 105.666/SP, Relator Min. OCTAVIO GALLOTTI, DJ 06.12.1985, p. 22.585 .
} 
monofásico, nada há que abater, nenhum crédito a ser resguardado, exceto se a lei o prevê'(...)."

Tributos plurifásicos exigem, portanto, incidência sobre negócios jurídicos que viabilizem a circulação de riquezas, desde o produtor até o consumidor final. Assim, estão fora dessa classificação não apenas as exações caracteristicamente monofásicas (imposto sobre a renda, contribuições sobre receitas e salários, et caterva), como também aquelas que, apesar de gravarem um negócio jurídico translativo do patrimônio (impostos sobre heranças, doações e transmissão de propriedade imóvel), têm por premissa incidir sobre um fato não enquadrado no processo de produção, circulação e consumo de riquezas. Afinal, o recebimento de uma herança, a aquisição de um terreno, são atos alheios ao processo circulatório de mercadorias e serviços.

Dessarte, podemos afirmar que a plurifasia é nota típica dos impostos sobre o consumo de bens e serviços, caracterizando-se pela incidência do gravame sobre dois ou mais estádios da cadeia produtiva. Sendo plurifásico, o tributo poderá ser cumulativo ou nãocumulativo. No primeiro caso (exação cumulativa), a incidência se dá sobre o valor de cada operação, sem permitir-se qualquer abatimento. É o caso da tributação à cascade - que na França precedeu à atual TVA - e do vetusto Imposto sobre Vendas e Consignações (IVC), que mereceu pungentes críticas da doutrina exatamente por ser cumulativo. No segundo caso (gravame não-cumulativo) também há tributação do valor integral da operação, porém se admite o abatimento do imposto que tenha onerado os insumos, bens intermediários, de uso e consumo e do ativo adquiridos pelo empresário-contribuinte. Esta a lógica do IVA, cujo pilar fundante é exatamente a não-cumulatividade tributária.

Em síntese, para ser qualificado como não-cumulativo, o tributo deve:

(a) ser plurifásico, o que implica a incidência sobre negócios jurídicos que objetivem a circulação de riquezas, desde a fonte produtora até o adquirente final;

(b) conferir ao contribuinte direito de crédito sobre o mesmo imposto recolhido em fases anteriores do processo de produção.

O destaque em nota fiscal do tributo é nota típica da não-cumulatividade, mas por se tratar de mera formalidade não pode ser invocado como um dos elementos caracterizadores do instituto em comento. Tanto é que o STF, em diversas ocasiões, já assegurou o 
direito ao crédito do antigo ICM mesmo na ausência de destaque do imposto na nota, quando o adquirente não tivesse contribuído para tal fato ${ }^{225}$.

${ }^{225}$ Em oportunidades distintas garantiu o Supremo o crédito ao adquirente de mercadorias cujas notas fiscais não continham o destaque do ICM. Uma delas foi no julgamento da aquisição de mercadorias cuja venda se fazia ao abrigo de liminar obtida pelo vendedor para não submetê-las à tributação pelo ICM, mas sim pelo imposto único sobre minerais (que vigorava anteriormente à $\mathrm{CR} / 88$ ). Sustentando que tais liminares seriam posteriormente cassadas, haja vista a consolidação da jurisprudência em sentido contrário à pretensão dos alienantes, assegurou a Suprema Corte o direito de crédito do ICM para o adquirente, mesmo à míngua de destaque na nota fiscal (STF, Primeira Turma, RE no 78.589/SP, Relator Min. ALIOMAR BALEEIRO, DJ 04.11.1974). Outra decisão no mesmo sentido refere-se à aquisição de café do IBC (autarquia imune a impostos), tendo inclusive ensejado a edição da Súmula $\mathrm{n}^{\circ}$ 571:

"O comprador de café ao IBC, ainda que sem expedição de nota fiscal, habilita-se, quando da comercialização do produto, ao crédito do ICM que incidiu sobre a operação anterior."

Nota-se que, no caso do IBC, sequer havia nota fiscal de aquisição, vez que a autarquia era dispensada da sua emissão. 


\section{RELAÇÕES ENTRE TRIBUTAÇÃO INDIRETA E NÃO- CUMULATIVIDADE.}

A tributação indireta tem por pressuposto a transferência jurídica do ônus tributário para o adquirente final. $\mathrm{O}$ tributo indireto pode ser monofásico ou plurifásico; sendo plurifásico, poderá ser cumulativo ou não-cumulativo.

São exemplos de tributos monofásicos indiretos a retail sales tax e, em nosso país, o ISSQN, quando apurado por meio de porcentual sobre o valor do serviço prestado ${ }^{226}$. Em ambas as hipóteses a alíquota é aplicada sobre o valor da transação e destacada em documento fiscal, demonstrando que o contribuinte de facto é o adquirente da mercadoria (na retail sales tax) ou o tomador do serviço (no ISSQN).

A seu turno, a tributação de mercadorias e serviços à cascade (representada no Brasil pelo vetusto Imposto sobre Vendas e Consignações ${ }^{227}$ ) consubstancia típico tributo indi-

${ }^{226}$ Fazemos tal distinção haja vista que há duas formas de cobrança do ISSQN:

(a) per capita, ou seja, mediante pagamento de um valor fixo mensal pela sociedade conforme o número de profissionais que a integram (benefício exclusivo para as sociedades de profissões regulamentadas, como as de arquitetos, engenheiros e advogados); ou

(b) mediante aplicação da alíquota da valorem, cujo teto é de $5 \%$ (cinco por cento), sobre o efetivo valor da prestação.

Na primeira hipótese, o ISSQN não pode ser considerado tributo indireto. Sua incidência em valores fixos impede a translação jurídica do ônus fiscal para o tomador do serviço. O tributo assemelha-se, neste caso, a uma taxa de fiscalização de funcionamento, pois é pago pelo simples fato de o profissional estar em atividade, independendo do valor cobrado. Ao contrário, quando se trata de incidência em porcentual, tem-se grande semelhança com a retail sales tax (cobrança em etapa única, sobre o valor da prestação, com destaque em nota para que o consumidor tenha ciência do ônus que está suportando a título de imposto).

De se notar que, quando do advento da Lei Complementar $n^{\circ} 116$, de 31 de julho de 2003, parte da doutrina passou a entender que a cobrança do ISSQN per capita (que é um benefício para as sociedades de profissionais liberais) teria sido revogada. Isso porque seu fundamento era o art. $9^{\circ}, \S 3^{\circ}$ do Decreto-Lei $n^{\circ} 406$, de 31 de dezembro de 1968, que não mais rege o imposto municipal sobre serviços. Entretanto, o Superior Tribunal de Justiça, arrimado no fundamento de que o dispositivo em questão sobreviveu à edição da $\operatorname{LC}^{\circ}{ }^{\circ} 116 / 03$ que não o teria revogado expressa ou tacitamente - assentou pela prevalência da tributação diferenciada para as sociedades prestadoras de serviços profissionais (STJ, Segunda Turma, REsp nº 713.752/PB, Relator Min. JOÃO OTÁVIO DE NORONHA, DJ 18.08.2006, p. 371). Para maiores detalhes sobre o tema, vide COÊLHO, Sacha Calmon Navarro. A Lei Complementar $n^{\circ} 116 / 03$, os Profissionais Liberais e as suas Sociedades. Revista Dialética de Direito Tributário, n 99. São Paulo: Dialética, dez./2003, pp. 102-11.

${ }^{227}$ O histórico da tributação cumulativa sobre o consumo no Brasil foi resenhado por COELHO:

"O Brasil adotou o imposto de circulação em 1924. Naquele ano o imposto era arrecadado pelo governo federal e as alíquotas variavam entre $2 \%$ e $3 \%$, usando-se selos colados às faturas. Inicialmente, o objetivo principal não era arrecadar receitas tributárias, mas promover o uso de faturas como título comercial no mercado monetário. Somente em 1934 o imposto foi transferido para os governos estaduais como parte do novo sistema incorporado à Constituição de 1934, eliminando-se simultaneamente a tributação sobre o comércio interestadual e este imposto, denominado Imposto sobre Vendas e Consignações (IVC), foi a principal fonte de receita estadual. Com o tempo, tornou-se o principal imposto do país.

(...)

Com o tempo e à medida em que os orçamentos estaduais se tornavam mais dependentes do IVC, a alíquota subiu rapidamente. De 0,3\% a 0,5\% durante a década de 30, em 1940 a alíquota passou para $1,25 \%$ em quase todos os Estados. 
reto cumulativo ${ }^{228}$. Sendo uma exação multifásica cumulativa, substancial parcela do ônus tributário recairá sobre o próprio contribuinte de jure. Afinal, somente o valor do imposto incidente na última etapa da cadeia de circulação será juridicamente trasladado ao contribuinte de facto. Todo o tributo pago sobre os insumos utilizados na produção (ou mesmo sobre a própria mercadoria em etapa anterior, caso se trate de revenda) não será passível de repercussão jurídica.

Já as exações não-cumulativas stricto $\operatorname{sensu}^{229}$ serão, sempre, indiretas. Consoante assentado alhures, é característica da não-cumulatividade fazer com que, do ponto de vista jurídico, o tributo repercuta. A neutralidade, enquanto efeito da não-cumulatividade, faz com que o contribuinte de direito não seja onerado, criando mecanismos para que este traslade o imposto para o consumidor final. Por esta razão o IVA é considerado um típico imposto sobre o consumo, assim como o ICMS e o IPI.

Dessarte, para um tributo ser qualificado como não-cumulativo ele deve preencher requisitos que, reunidos, também o tornarão um tributo indireto. Isso porque as notas necessárias à caracterização da não-cumulatividade stricto $s e n s u^{230}$ coincidem com aquelas que denotam a natureza indireta de determinada exação (em que pese a recíproca não ser verdadeira, já que o tributo indireto pode ser monofásico ou mesmo plurifásico e cumulativo).

Em suma: tributos indiretos (também nominados sobre o consumo) são aqueles nos quais a lei permite a transferência do ônus fiscal. A incidência indireta pode ser monofásica ou plurifásica. Sendo plurifásica, poderá ser cumulativa ou não. Fazendo o caminho inverso, podemos afirmar que a não-cumulatividade, enquanto atributo de impostos pluri-

Em 1950 a alíquota normal girava em torno de 2,5\% e em 1966 a alíquota média do IVC aumentara para 5,8\% (...)." (COELHO, Carlos Nayro de Azevedo. Uma Análise Econômica do Imposto sobre o Valor Adicionado no Brasil. Brasília: Comissão de Financiamento da Produção, 1980, p. 60).

${ }^{228}$ Vale repisar que tanto a cumulatividade como a sua antípoda somente são possíveis em tributos plurifásicos. Estes, consoante visto no item precedente, incidem sobre negócios jurídicos que permitem a circulação de riquezas na sociedade - noutras palavras, sobre as operações com bens e serviços.

${ }^{229}$ A qualificação aqui proposta para a não-cumulatividade clássica se deve ao fato de que, a partir da EC $\mathrm{n}^{\circ}$ 42/03, a Constituição passou a predicar a aplicação desse instituto às contribuições sobre a receita bruta. Como estas não são exações plurifásicas, porém ao mesmo tempo passaram a ser não-cumulativas por imposição da CR/88 e de suas leis de regência, criou-se uma nova modalidade de não-cumulatividade no País, aplicada a exações que não gravam o consumo de bens e serviços. Sendo assim, propomos a distinção entre não-cumulatividade stricto sensu, que é o instituto clássico e aplicado a tributos plurifásicos, e a nãocumulatividade lato sensu, que consiste em mera técnica de apuração do quantum debeatur, sem o condão de alcançar a neutralidade tributária ou mesmo de permitir a translação jurídica do ônus do gravame ao adquirente final. Para maiores detalhes, confira-se o próximo capítulo.

${ }^{230}$ Vide nota de rodapé anterior. 
fásicos sobre o consumo de bens e serviços, é nota típica dos tributos indiretos. Assim, toda exação não-cumulativa é indireta (rectius: criada para, juridicamente, ter o seu ônus transportado para o contribuinte de fato), desde que incida sobre operações de circulação de riquezas. Ao revés, se a não-cumulatividade for aplicada a gravames que incidem sobre outras materialidades (como a receita ou faturamento, caso da contribuição para o PIS/ COFINS) não se poderá concluir da mesma forma (é dizer: nesse caso, a nãocumulatividade não terá sido utilizada em sua função original e, conseqüentemente, não terá o condão de tornar indireta, per se, a exação). 


\section{TRIBUTOS NÃO-CUMULATIVOS NO ORDENAMENTO JURÍDI- CO BRASILEIRO.}

\subsection{Advertência.}

Ab initio, é imperioso alertar que o simples fato de um tributo ser intitulado "nãocumulativo" não o torna, por si só, integrante desta categoria, ao menos com todas as notas características que vimos de ver. O nomen juris não influi na natureza da exação, como, aliás, predica em norma expressa o próprio CTN:

"Art. $4^{\circ}$. A natureza jurídica específica do tributo é determinada pelo fato gerador da respectiva obrigação, sendo irrelevantes para qualificá-la: I - a denominação e demais características formais adotadas pela lei;"

De fato, para ser qualificada como tal, uma exação deverá atender aos requisitos materiais ínsitos à não-cumulatividade tributária, que é instituto jurídico autônomo. Será não-cumulativo, dessarte, aquele tributo que for ao mesmo tempo plurifásico (gravando, portanto, operações de circulação de bens e serviços) e conceder ao contribuinte o direito ao abatimento da exação paga nas etapas anteriores.

Todavia, acedendo ao fato de que a Constituição de um País é soberana (o constituinte originário tudo pode, desde que não fira os direitos humanos fundamentais; e o derivado idem, exceto pela característica de ser limitado pelas cláusulas pétreas postas na Lei Maior), entendemos que, desde o ano de 2003 (quando foi editada a Emenda Constitucional $n^{\circ} 42$ ), existem duas espécies de não-cumulatividade no direito tributário brasileiro.

A primeira, que intitulamos "em sentido estrito", corresponde à concretização de todo o arcabouço teórico que vimos de ver. Ou seja, trata-se da não-cumulatividade propriamente dita, stricto sensu, como forma de obtenção da neutralidade fiscal, aplicável aos tributos plurifásicos que, portanto, gravam o consumo de mercadorias e serviços.

Já a outra é a não-cumulatividade em sentido amplo, que corresponde a uma forma de cálculo do quantum debeatur aplicada aos tributos que não atingem o consumo de bens e serviços (não sendo, por tal razão, plurifásicos). Nesses casos, houve o transporte da noção geral de não-cumulatividade (sistema de compensação de créditos e débitos) para tributos que não se prestam à consecução dos objetivos da tributação sobre o valor acrescido. Tal derivação da corrente tradicional não pode deixar de ser considerada em um estudo sobre a não-cumulatividade no direito brasileiro (em que pesem as características de tais exações passarem ao largo de tudo o que foi analisado até o momento em relação à tributação sobre o valor acrescido). 
Portanto, com o advento da EC $n^{\circ} 42 / 03$, passaram a existir duas espécies de nãocumulatividade no sistema tributário pátrio:

(a) a incumulatividade stricto sensu, aplicável a tributos similares ao IVA;

(b) a não-cumulatividade lato sensu, aplicável a exações que gravam o faturamento ou a receita das empresas.

Feita esta advertência, passemos ao detalhamento dos tributos que possuem a nota da não-cumulatividade no direito pátrio, visando a identificar se o instituto em tela se revela sob a forma ampla ou estrita.

\subsection{Não-cumulatividade em sentido amplo e estrito.}

A Constituição da República de 1988 refere-se à não-cumulatividade ao tratar dos seguintes tributos:

(a) Imposto sobre Produtos Industrializados, que incide sobre operações realizadas por importador, industrial ou a este equiparado (art. 153, IV e $\S 3^{\circ}$ );

(b) Impostos residuais, que somente podem ser criados pela União sobre fatos geradores que não estejam previstos na Constituição (art. 154, I);

(c) Imposto sobre Operações de Circulação Jurídica de Mercadorias e Prestação de Serviços de Transporte Interestadual e Intermunicipal e de Comunicação, no qual, apesar da competência estadual, o imposto cobrado anteriormente em qualquer estado ou no Distrito Federal é obrigatoriamente deduzido do quantum debeatur (art. 155, II e $\S \S 2^{\circ}$ a $\left.5^{\circ}\right)$;

(d) Contribuições para a seguridade social de competência residual da União Federal, que seguem os mesmos ditames dos impostos residuais (art. 195, §4 c/c art. 154, I).

(e) Contribuições para a seguridade social incidentes sobre a receita ou faturamento das empresas, assim como sobre a importação de bens e serviços (art. 195, I, $b$, IV e $\S \S 9^{\circ}, 11$ e 12$)$.

Apesar de nominados não-cumulativos pela própria Carta Magna, não nos parece que o termo não-cumulatividade possua o mesmo sentido em todos os casos. Em que pese parecer uma subversão das regras hermenêuticas, neste particular as interpretações sistemática e teleológica do texto constitucional autorizam dita conclusão. Afinal, como é cediço, o sistema de abatimento de créditos e débitos criado pela TVA francesa e difundido no mundo por meio do IVA somente se opera em impostos plurifásicos sobre o consumo. Sendo assim, dos tributos previstos na Constituição, apenas o IPI e o ICMS podem ser qua- 
lificados como não-cumulativos em sentido estrito. Nessas exações, o instituto em questão permite a obtenção da neutralidade fiscal e a translação (jurídica) do ônus tributário para o adquirente final dos bens ou serviços.

Contudo, nas contribuições sociais incidentes sobre a receita ou faturamento, assim como naquela devida quando da importação de mercadorias e serviços, é impróprio falarse em não-cumulatividade stricto sensu. Afinal, no primeiro caso, o fato eleito pelo critério material da norma tributária (auferimento de receita) é desvinculado de qualquer operação que vise à circulação de riquezas, o que impossibilita a translação jurídica do seu peso fiscal para o consumidor final. Assim, resta prejudicada a obtenção de neutralidade, que é o diferencial obtido pela aplicação da não-cumulatividade em sentido estrito.

Já na segunda hipótese (importação de bens e serviços), um ponto essencial impede a concretização da não-cumulatividade clássica: apesar de o tributo gravar uma operação de circulação de riqueza, a incidência na importação é monofásica. Como a plurifasia é elemento intrínseco dos tributos não-cumulativos, não é possível que, em uma exação monofásica, a não-cumulatividade produza quaisquer efeitos (seja sob a ótica clássica, seja sob a ampliativa). Exatamente por essa razão o legislador nominou as contribuições devidas na importação como PIS/ COFINS - permitindo o abatimento dos valores pagos no desembaraço aduaneiro com o PIS/COFINS devido pelo auferimento de receita quando da venda no mercado interno. De todo modo, sendo tributos com bases de cálculo completamente distintas, essa "compensação" permitida pela legislação (com esforço na Lei Maior) não se equipara ao abatimento realizado nos impostos plurifásicos, consistindo apenas em uma forma de se mitigar o ônus tributário do importador (e tão-somente quando este for sujeitado ao pagamento do PIS/COFINS, em suas vendas internas, na sistemática incumulativa $^{231}$ ).

Portanto, podemos classificar os tributos, à luz da Constituição, como:

(a) não-cumulativos stricto sensu: ICMS e IPI;

(b) não-cumulativos lato sensu: PIS/COFINS, sejam incidentes sobre receita ou faturamento, sejam os devidos na importação de bens e serviços.

Já os impostos e contribuições sociais residuais merecem consideração apartada. Apesar de a Constituição dispor que os mesmos serão obrigatoriamente não-cumulativos, se e quando instituídos pelo legislador complementar federal, temos que tal determinação deve ser compreendida cum grano salis. Isso porque a não-cumulatividade somente faz

${ }_{231}$ Quando o importador for contribuinte do PIS/COFINS cumulativos, inexistirá direito ao abatimento das contribuições incidentes na importação. 
sentido - para fins de exercício da competência residual - quando compreendida em seu sentido clássico. É dizer: caso não se trate de um mecanismo proporcionador de neutralidade na tributação, a não-cumulatividade se torna uma mera fórmula de cálculo do tributo devido, sem maior relevância do ponto de vista jurídico.

Nessa toada, temos que os tributos residuais (impostos e contribuições) somente deverão ser não-cumulativos quando incidirem sobre o consumo. Assim, é apenas para os impostos residuais plurifásicos que se dirige o comando do art. 154, I da Constituição. Se criado, verbi gratia, um imposto residual sobre a propriedade de embarcações e aeronaves (que refogem ao espectro de incidência do IPVA), seria possível fazê-lo não-cumulativo? Decerto que não. Impostos sobre o patrimônio são monofásicos por natureza, impedindo, por tal razão, sua coexistência com a não-cumulatividade clássica. Nesta hipótese, por impossibilidade lógica, a exação não poderia ser considerada inválida por ter ausente a nota da não-cumulatividade.

Portanto, a não-cumulatividade enquanto requisito de validade do imposto ou contribuição residual é aquela stricto sensu, incidente sobre impostos plurifásicos indiretos. Se o critério material da exação não abarcar a incidência sobre operações de circulação de bens e serviços, então resta dispensada a observação do comando normativo.

Sobre o tema, vale apontar decisão do Supremo Tribunal Federal que, ao analisar a constitucionalidade da contribuição social residual instituída pela Lei Complementar $\mathrm{n}^{\circ} 84$, de 18 de janeiro de 1996, afastou a necessidade de observância da não-cumulatividade na espécie. Tal contribuição incide sobre as remunerações pagas, por empresas ou cooperativas, a trabalhadores autônomos, avulsos e demais pessoas físicas sem vínculo empregatício $^{232}$. Segundo o Plenário do STF, somente é possível exigir-se que a competência residual seja pautada pela incumulatividade quando o novel tributo for plurifásico, permitindo, por conseguinte, a compensação de débitos e créditos necessária à própria existência do instituto. A ementa é esclarecedora, pelo que a ofertamos à transcrição:

\section{"CONTRIBUIÇÃO SOCIAL. CONSTITUCIONALIDADE DO ARTIGO $1^{\circ}$, I, DA LEI COMPLEMENTAR N 84/96.}

\footnotetext{
${ }^{232}$ Eis os termos da $\mathrm{LC} \mathrm{n}^{\circ}$ 84/96, na parte analisada pelo STF:

"Art. $1^{\circ}$. Para a manutenção da Seguridade Social, ficam instituídas as seguintes contribuições sociais:

I - a cargo das empresas e pessoas jurídicas, inclusive cooperativas, no valor de quinze por cento do total das remunerações ou retribuições por elas pagas ou creditadas no decorrer do mês, pelos serviços que lhes prestem, sem vínculo empregatício, os segurados empresários, trabalhadores autônomos, avulsos e demais pessoas físicas;"
} 
- O Plenário desta Corte, ao julgar o RE 228.321, deu, por maioria de votos, pela constitucionalidade da contribuição social, a cargo das empresas e pessoas jurídicas, inclusive cooperativas, incidente sobre a remuneração ou retribuição pagas ou creditadas aos segurados empresários, trabalhadores autônomos, avulsos e demais pessoas físicas, objeto do artigo $1^{\circ}$, I, da Lei Complementar $n^{\circ} 84 / 96$, por entender que não se aplica às contribuições sociais novas a segunda parte do inciso I do artigo 154 da Carta Magna, ou seja, que elas não devam ter fato gerador ou base de cálculos próprios dos impostos discriminados na Constituição.

- Nessa decisão está ínsita a inexistência de violação, pela contribuição social em causa, da exigência da não-cumulatividade, porquanto essa exigência - e é este, aliás, o sentido constitucional da cumulatividade tributária só pode dizer respeito à técnica de tributação que afasta a cumulatividade em impostos como o ICMS e o IPI - e cumulatividade que, evidentemente, não ocorre em contribuição dessa natureza cujo ciclo de incidência é monofásico -, uma vez que a não-cumulatividade no sentido de sobreposição de incidências tributárias já está prevista, em caráter exaustivo, na parte final do mesmo dispositivo da Carta Magna, que proíbe nova incidência sobre fato gerador ou base de cálculo próprios dos impostos discriminados nesta Constituição.

- Dessa orientação não divergiu o acórdão recorrido. Recurso extraordinário não conhecido." 233

Portanto, os tributos (impostos e contribuições) residuais somente serão nãocumulativos quando a plurifasia consistir em elemento ínsito aos mesmos - do contrário, torna-se inócua a regra que obriga à observância da não-cumulatividade em tais espécies exacionais $^{234}$.

Do exposto relativamente às espécies lato e stricto sensu do instituto sub examine, pode-se inferir que o conceito amplo de não-cumulatividade consiste em mera fórmula de cálculo do tributo a pagar, pela qual são deduzidos créditos dos débitos eventualmente apurados. O ônus da exação não é, nessa hipótese, juridicamente trasladado para o contribuinte

\footnotetext{
${ }^{233}$ STF, Primeira Turma, RE no 258.470/RS, Relator Min. MOREIRA ALVES, DJ 12.05.2000, p. 32, grifos nossos.

${ }^{234} \mathrm{O}$ relatório do voto do Relator no $\mathrm{RE} \mathrm{n}^{\mathrm{o}}$ 258.470/RS adota o relato da Corte a quo, cujo seguinte trecho merece destaque:

“A referência contida no art. 154, I da CF refere-se à não-cumulatividade interna, que constitui simples técnica de arrecadação, consistente no abatimento ou compensação do que for devido em cada operação com o montante do tributo cobrado nas operações anteriores, tal como se observa no recolhimento do ICMS e no IPI, consoante dispõem os artigos 153, II, $\S 3^{\circ}$ e 155 , II, $\S 1^{\circ}$ da Constituição. Se o contribuinte tivesse querido tratar da não-cumulatividade externa, ou seja, sobreposição de tributos, não teria referido expressamente a proibição constante na parte final do artigo 154, I, da CF: criação de novos tributos sobre fatos que possuam o mesmo fato gerador ou base de cálculo dos impostos já previstos na Constituição. E não se podendo equiparar a contribuição tratada pela Lei Complementar no 84/96 ao ICMS e ao IPI, a isso segue-se que, pelo prisma da não-cumulatividade, não há qualquer inconstitucionalidade na sua cobrança."
} 
de facto pela ausência da plurifasia, necessária a todo e qualquer tributo sobre valor acrescido. O que se tem é apenas um modus operandi diferenciado e mais complexo de apuração do quantum debeatur. E, na prática, uma neutralidade mitigada, pela impossibilidade efetiva de se obtê-la naquela modalidade exacional.

Assim é que o cerne da análise da não-cumulatividade gravita em torno do seu estudo enquanto aplicada aos tributos plurifásicos. É neste tipo de exação que se poderá construir uma teoria da não-cumulatividade satisfatória, aplicando-se os conceitos que vigoram em todo o mundo na tributação sobre o valor acrescido (respeitando, por óbvio, as peculiaridades do direito positivo pátrio).

Entrementes, a não-cumulatividade lato sensu, é dizer, aquela aplicada a exações não incidentes sobre o consumo de bens e serviços, merece atenção nos pontos em que há convergência entre os seus institutos próprios e aqueles da não-cumulatividade clássica. Um exemplo é o alcance do conceito de insumo - bem que não se agrega ao produto final, porém gera crédito para o adquirente. Com o advento da contribuição ao PIS e da COFINS não-cumulativas (lato sensu), tal discussão adquiriu novas matizes e elementos - permitindo uma evolução do tema em matéria de ICMS e IPI, haja vista que também nessas exações a aludida definição assume papel de relevo.

Assentado o conceito de tributo não-cumulativo, bem como as suas duas variantes no ordenamento jurídico pátrio, pode-se passar adiante ao estudo das peculiaridades do tema em face do direito positivo brasileiro. 


\section{TÍTULO II -}

A NÃO-CUMULATIVIDADE NO ALTIPLANO CONSTITUCIONAL 


\section{A NÃO-CUMULATIVIDADE DO ICMS E DO IPI.}

\subsection{INTRÓITO.}

A não-cumulatividade tributária foi trazida à balha no Brasil pelo vetusto imposto sobre o consumo (IC) antecessor do hodierno IPI, por meio da Lei $\mathrm{n}^{\circ} 2.974$, de 26 de novembro de $1956^{235}$, e da Lei $n^{\text {o } 3.520, ~ d e ~} 30$ de dezembro de $1958^{236}$. A primeira norma, restrita aos importadores, permitia-lhes abater, do imposto de consumo devido pela venda dos bens importados no mercado interno, o valor relativo ao IC recolhido quando da importação. Já a Lei no 3.520/58, mais abrangente, permitiu ao industrial-contribuinte a dedução do tributo incidente sobre as matérias-primas utilizadas na produção de mercadorias tributáveis. A subseqüente consolidação da legislação sobre o consumo, operada pela Lei $\mathrm{n}^{\mathrm{o}}$ 4.502, de 30 de novembro de 1964, manteve essas regras, porém detalhando-as com maior vagar ${ }^{237}$. A Emenda Constitucional $n^{\circ} 18$, de $1^{\circ}$ de dezembro de $1965^{238}$, constitu-

${ }^{235}$ Rezava a Lei n ${ }^{\circ} 2.974 / 56$ :

“Art. $1^{\circ}$. O Decreto-lei no 7.404, de 22 de março de 1945 , consolidado pelo Decreto $\mathrm{n}^{\circ} 26.149$, de 5 de janeiro de 1949, passa a vigorar com as seguintes alterações:

(...)

DÉCIMA NONA

Art. $3^{\circ}$. Os produtos importados pagarão o impôsto, inicialmente, com a base no preço de importação, acrescido das despesas de frete, seguro e mais direitos aduaneiros, taxas e adicionais, necessários à entrada do produto no país (...).

(...)

$\S 2^{\circ}$ Posteriormente, os importadores pagarão o impôsto com base nas vendas de produtos tributados, realizadas em cada quinzena, deduzido o impôsto pago na forma dêste artigo (VETADO)."

${ }^{236}$ Eis os termos da não-cumulatividade plasmada na Lei no $3.520 / 58$ :

"Art. 5'. Quando num mesmo estabelecimento produtor se fabricarem artigos sujeitos ao imposto de consumo que, sem saírem deste estabelecimento, forem utilizados na fabricação ou no acondicionamento de outros tributados, o imposto incide somente no produto final, facultada ao fabricante a dedução dos impostos pagos sobre as matérias primas que concorrerem para a sua produção."

${ }^{237}$ É ver a redação da Lei no $4.502 / 64$ :

"Art. 27. A importância a recolher será:

(...)

III - (...) a resultante do cálculo do imposto relativo aos produtos saídos do estabelecimento produtor na quinzena anterior, deduzida:

a) do valor do imposto relativo às matérias primas, produtos intermediários e embalagens, adquiridos no mesmo período, quando se tratar de estabelecimento industrial;

b) do valor do imposto pago por ocasião do despacho ou da remessa, quando se tratar de estabelecimento importador, arrematante ou revendedor, considerados, para efeito da apuração, os capítulos de classificação dos produtos.

$\S 1^{\circ}$. Será excluído do crédito o imposto relativo às matérias primas, produtos intermediários e embalagens que forem objeto de revenda ou que forem empregados na industrialização ou no acondicionamento de produtos isentos e não-tributados."

${ }^{238}$ A Emenda foi fruto da primeira grande reforma tributária no Brasil, que racionalizou e sistematizou a tributação nacional. Vale conferir a seção dos "Impostos sobre a Produção e a Circulação":

"Art. 11. Compete à União o imposto sobre produtos industrializados.

Parágrafo único. $O$ imposto é seletivo em função da essencialidade dos produtos, e não-cumulativo, abatendo-se, em cada operação, o montante cobrado nas anteriores. 
cionalizou a não-cumulatividade para o $\mathrm{ICM}^{239}$ e para o IPI. Segundo ela, o quantum debeatur desses impostos seria obtido "abatendo-se, em cada operação, o montante cobrado nas anteriores". No caso do ICM, ao contrário do IPI, tal abatimento se daria "nos termos do disposto em lei complementar".

A Carta de $1967^{240}$ manteve a não-cumulatividade tanto para o IPI (art. 22, $4^{\circ}$ ) como para o ICM (art. 24, $\S 5^{\circ}$ ), nos exatos termos da EC $n^{\circ} 18 / 65$.

A sistemática permaneceu a mesma sob o pálio da Emenda Constitucional $n^{\circ} 1$, de 17 de outubro de 1969, que predicava:

“Art. 21. Compete à União instituir imposto sobre:

$(\ldots)$

$\mathrm{V}$ - produtos industrializados (...);

(...)

$\S 3^{\circ}$. O imposto sobre produtos industrializados será seletivo em função da essencialidade dos produtos, e não-cumulativo, abatendo-se, em cada operação, o montante cobrado nas anteriores." (destaques nossos)

"Art. 23. Compete aos Estados e ao Distrito Federal instituir impostos sobre: (...)

II - operações relativas à circulação de mercadorias, realizadas por produtores, industriais e comerciantes, impostos que não serão cumulativos e dos quais se abaterá, nos termos do disposto em lei complementar, o montante cobrado nas anteriores pelo mesmo ou por outro Estado." (destaques nossos)

Analisando-se o tratamento conferido à não-cumulatividade do ICM e do IPI, vê-se que tanto a EC no 18/65 como a Constituição de 1967 e a EC nº 01/69 determinavam que, em matéria de ICM, o abatimento se daria "nos termos do disposto em lei complementar" previsão inexistente para o IPI. Partindo dessa diferenciação, alguns doutrinadores passaram a sustentar que o legislador complementar teria o poder de limitar o alcance da não-

Art. 12. Compete aos Estados o imposto sobre operações relativas à circulação de mercadorias, realizadas por comerciantes, industriais e produtores.

(...)

$\S 2^{\circ}$. O imposto é não-cumulativo, abatendo-se, em cada operação, nos termos do disposto em lei complementar, o montante cobrado nas anteriores, pelo mesmo ou por outro Estado, e não incidirá sobre a venda a varejo, diretamente ao consumidor, de gêneros de primeira necessidade, definidos como tais por ato do Poder Executivo Estadual." (destaques nossos)

239 À época da edição da EC n ${ }^{\circ}$ 18/65, o ICM também podia ser cobrado pelos Municípios, em alíquota não superior a $30 \%$ daquela posta pelos Estados.

${ }^{240}$ Vale notar que, com a Constituição de 1967, os Municípios deixaram de ter competência para instituir o adicional do ICM, passando apenas a participar no produto da arrecadação do imposto cobrado pelos Estados $\left(\right.$ art. $\left.24, \S 7^{\circ}\right)$. 
cumulatividade do $\mathrm{ICM}^{241}$. Já no caso do IPI, tal medida seria inadmissível. Assim, para esta corrente a norma constitucional da não-cumulatividade do IPI seria de eficácia plena, ao passo que a do ICM possuiria eficácia contida - havendo liberdade, nesta última, para restrições impostas pela lei complementar.

Com a devida vênia, não nos parece que seja assim. Da leitura dos textos constitucionais extrai-se que, tanto para o IPI como para o ICM, a não-cumulatividade é mandatória. Todavia, como o ICM exige lei complementar de normas gerais para manter a unicidade da legislação estadual em todo o País (haja vista a competência dos 26 Estadosmembros e do Distrito Federal para instituição do tributo), a Constituição remete ao legislador nacional (rectius, complementar) a tarefa de disciplinar a não-cumulatividade. Não se trata de faculdade, mas sim de comando peremptório. Noutro giro verbal, a competência outorgada ao legislador complementar em matéria de ICM nunca consistiu em uma autorização para que ele regulasse, de forma livre, a não-cumulatividade do imposto. Tanto é que a jurisprudência do Supremo Tribunal Federal, desde sempre, equiparou a nãocumulatividade do IPI à do ICM, prescrevendo que as garantias ínsitas ao primeiro, nessa seara, também se estendem ao segundo imposto. Na assentada Plenária de 16 de dezembro de 1977, interplures, os Ministros do STF foram unânimes ao afirmar que "o inciso II, do artigo 23 da Constituição [de 1967-69] estabelece, sem qualquer restrição, o princípio de que o ICM é não-cumulativo" ${ }^{, 242}$. Outrossim, nunca houve sequer um acórdão da Corte Suprema autorizando o legislador complementar a ditar as regras da não-cumulatividade do ICM sem a observância dos ditames constitucionais regentes da matéria.

Dessarte, é lícito afirmar que nunca existiu qualquer possibilidade de amesquinhamento da não-cumulatividade por parte do legislador complementar do ICM. A sua atuação sempre foi pautada pelo alcance que a Suprema Corte conferiu à não-cumulatividade plasmada na Lei Maior.

Com o advento da hodierna Lei Maior, a não-cumulatividade foi positivada para o IPI e o ICMS nos arts. $153, \S 3^{\circ}$, II e $155, \S 2^{\circ}$, I, litteratim:

"Art. 153. (...)

$\S 3^{\circ}$. O imposto previsto no inciso IV [IPI]:

(...) ${ }^{241}$ BALEEIRO sustentava que, para o ICM, "o Congresso é livre de estabelecer o modo e os casos de não-
cumulatividade, desde que não o anule", diferentemente do IPI, "que não sofre restrições à não-
cumulatividade". (BALEEIRO, Aliomar. Direito Tributário Brasileiro, $11^{\text {a }}$ ed. Atualizado por MISABEL
ABREU MACHADO DERZI. Rio de Janeiro: Forense, 2001, p. 418).

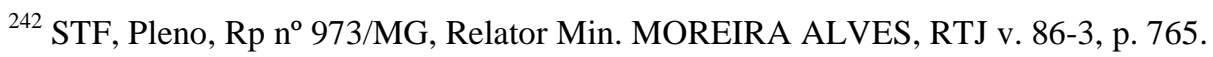


II - será não-cumulativo, compensando-se o que for devido em cada operação com o montante cobrado nas anteriores;"

“Art. 155. (...).

$\S 2 .^{\circ} \mathrm{O}$ imposto previsto no inciso II [ICMS] atenderá ao seguinte:

I - será não-cumulativo, compensando-se o que for devido em cada operação relativa à circulação de mercadorias ou prestação de serviços com o montante cobrado nas anteriores pelo mesmo ou outro Estado ou pelo Distrito Federal;"

Diferentemente do que previam as Constituições pretéritas, a regulamentação da não-cumulatividade do ICMS não foi delegada à lei complementar. A CR/88 dispôs apenas que o legislador complementar deveria "disciplinar o regime de compensação do imposto" (art. 155, §2, XII, c) e "prever casos de manutenção de crédito, relativamente à remessa para outro Estado e exportação para o exterior, de serviços e de mercadorias" (art. 155, §2 XII, $f)$.

De todo modo, seja nas Cartas pretéritas, seja na atual, a não-cumulatividade do IPI e do ICMS sempre foi entendida pela doutrina e pelo STF como norma de eficácia plena, não restringível por nenhum tipo de lei.

Confira-se.

\subsection{A NÃO-CUMULATIVIDADE COMO NORMA DE EFICÁCIA PLENA.}

São normas de eficácia plena aquelas que, desde a promulgação da Constituição, produzem imediatamente seus efeitos, devendo ser obrigatoriamente observadas pelo Estado (lato sensu) e seus cidadãos. Dentre essas, são comumente citadas as que atribuem competências (arts. 21 e 23 da CR/88), inclusive para legislar (arts. 22 e 24) e para instituir tributos (arts. 153, 155 e 156 da Constituição) ${ }^{243}$.

No caso do IPI e também do ICMS, pode-se afirmar que a não-cumulatividade integra a norma de competência ${ }^{244}$, pois se trata de característica que determina a forma de instituição do tributo. Noutras palavras, a previsão de abatimento dos valores cobrados na etapa anterior é condição sine qua non para a validade das leis tributárias. Afinal, os entes

\footnotetext{
${ }^{243}$ Sobre a eficácia das normas constitucionais, vide Capítulo VII, Item 7.2.1, infra.

${ }^{244}$ GAMA oferta-nos o conceito de norma de competência:

“A locução 'norma de competência tributária' pode ser entendida como o signo, formado com base nos textos de direito positivo, a partir do qual se constrói um juízo condicional que contempla em sua hipótese as condições formais de criação de uma norma e, no seu consequiente, os limites materiais da competência tributária." (GAMA, Tácio Lacerda. Competência Tributária - Fundamentos para uma Teoria da Nulidade. São Paulo: Noeses, 2009, p. 218).
} 
federados não podem se afastar dos moldes constitucionais dentro dos quais a competência lhes foi atribuída, sob pena de invalidade de suas leis.

Dessarte, ao receberem a delegação constitucional, a União e os Estados têm o dever de, se instituírem o IPI e o ICMS, fazerem-no sob a forma não-cumulativa. Apenas por razões atinentes à unicidade do sistema tributário a lei complementar se faz necessária para balizar as leis estaduais sobre o ICMS. Todavia, como já averbado e reiteradamente decidido pelo $\mathrm{STF}^{245}$, não pode o legislador mitigar a não-cumulatividade plasmada na Lei Maior. Aquela predica que o contribuinte faz jus à compensação do imposto cobrado nas operações pretéritas. E esse direito é inatacável.

\subsection{CRÉDITO SOBRE IMPOSTO “COBRADO" NA OPERAÇÃO ANTERIOR: SENTIDO DO VOCÁBULO CONSTITUCIONAL.}

Dando forma à não-cumulatividade tributária, as Cartas Constitucionais prescrevem o abatimento do imposto cobrado nas operações anteriores. O emprego do verbo "cobrar" ensejou divergências interpretativas, posto que alude à necessidade de efetivo pagamento do tributo na operação pretérita, não bastando o mero destaque do imposto em nota fiscal para assegurar o creditamento na etapa subseqüente.

A questão foi enfrentada pela Corte Suprema, que aclarou o sentido do termo empregado pelo Constituinte. O leading case envolvia uma contenda entre o Fisco paulista e um contribuinte cujos créditos de ICM não haviam sido reconhecidos pela Secretaria de

\footnotetext{
245 Na sessão Plenária de 16 de abril de 2008, o STF analisou a eficácia da norma que prescreve a nãocumulatividade do ICMS. O caso julgado envolvia uma complexa questão relativa à tributação de derivados de petróleo no Estado do Rio de Janeiro.

Em que pese a $\mathrm{CR} / 88$ remeter à lei complementar a disciplina do regime de compensação do imposto (art. $\left.155, \S 2^{\circ}, X I I, c\right)$, o Supremo Tribunal manteve seu posicionamento de decênios quanto ao tema: considerou que a norma do art. $155, \S 2^{\circ}$, I - que determina que o ICMS será não-cumulativo - é de eficácia plena e aplicabilidade imediata, não sendo passível de restrição por parte do legislador complementar ou ordinário.

Assim, foram refutados os argumentos do Fisco Fluminense que apregoava ser a não-cumulatividade do ICMS restringível pela legislação infraconstitucional, haja vista a delegação feita pelo Constituinte à lei complementar no que toca ao delineamento da forma de compensação do imposto. Confira-se, nas palavras no Min. NELSON JOBIM:

"Não tem razão o Estado quando sustenta que ‘... a Constituição de 1988 não disciplinou o sistema de compensação do imposto, pelo que se conclui que o direito ao crédito decorreria de norma infraconstitucional...'.

O inciso I, do $\S 2^{\circ}$ do art. 155 é auto-aplicável.

Assegura, desde logo, a compensação do '... que for devido em cada operação ... com o montante cobrado nas anteriores...'.

O direito ao abatimento independe de norma infraconstitucional.

Nasce do próprio texto." (STF, Pleno, RE n 199.147/RJ, Relator p/ acórdão Min. MARCO AURÉLIO, DJe-216, pub. 14.11.2008).
}

O Min. NELSON JOBIM, apesar de vencido no mérito, não foi contestado em suas assertivas acima transcritas por nenhum dos demais integrantes da Corte. O contribuinte perdeu a causa pois não produziu provas entendidas pelo STF como essenciais para o desate da lide. 
Fazenda. O Estado resistia à pretensão da empresa pois esta não havia apresentado provas de que o vendedor das mercadorias tivesse efetivamente recolhido o imposto destacado nas notas fiscais cujos créditos pretendia utilizar. O Relator do acórdão, Min. CÉLIO BOR$\mathrm{JA}^{246}$, rejeitou a pretensão fiscal, legitimando o creditamento pretendido pela empresa mesmo à míngua da comprovação de quitação do tributo incidente na etapa pretérita.

O entendimento do STF é correto e predomina até os dias atuais. Se assim não fosse o Estado estaria autorizado a transferir ao particular o dever - indelegável por parte da Administração - de fiscalizar o cumprimento das obrigações tributárias por parte do vendedor das mercadorias. Ora, não cabe ao adquirente assegurar que o ICM devido pelo alienante seja pago. A função do particular se completa com a exigência e recebimento, no ato da aquisição, de nota fiscal idônea, preenchida consoante os predicados legais. A efetiva recolha do tributo pelo alienante, dessarte, não pode ser erigida como conditio sine qua non para o exercício do direito ao crédito pelo adquirente ${ }^{247}$.

Como leciona SACHA CALMON ${ }^{248}$, o não-pagamento do tributo pelo alienante "é problema de fiscalização, ônus da Fazenda Pública, e não pode ser atribuído ao contribuinte-adquirente". Todavia, se houver conluio doloso entre vendedor e comprador é possível descaracterizar-se o crédito - o que dependerá, todavia, de provas da conduta fraudulenta.

\footnotetext{
${ }^{246}$ Confira-se o trecho a seguir, extraído do voto do Min. CÉLIO BORJA:

"Embora não se conteste aos Estados o poder de disciplinar a instituição do ICM e suas relações com os contribuintes, não podem eles fazê-lo em oposição ao que a respeito disponha o direito emanado da Constituição Federal.

A não-cumulatividade do imposto em causa é da sua natureza, tal como deflui da definição adotada no art. 23, II, da CF, verbis:

'...imposto que não será cumulativo e do qual se abaterá, nos termos do disposto em lei complementar, o montante cobrado nas anteriores (operações) pelo mesmo ou outro Estado.' (grifei)

Não disse o constituinte que se abateria o montante pago, mas, imperativamente, o valor cobrado ou exigível nas operações anteriores. Não se trata de mera preferência gratuita por uma expressão ou outra, mas consequiência necessária do antecedente - 'não será cumulativo'.

Os sucessivos contribuintes devem, para efeito de calcular o imposto devido pela operação de saída da mercadoria do seu estabelecimento, abater o que antes e, a título idêntico, dever-se-ia ter pago, a fim de evitar a oneração em cascata, ou cumulativa, da coisa tributada." (STF, Segunda Turma, RE $\mathrm{n}^{\circ}$ 111.757/SP, Relator Min. CÉLIO BORJA, DJ 26.02.1988, p. 3.195. No mesmo sendeiro, confirase: STF, Segunda Turma, RE no 114.878/SP, Relator Min. CÉLIO BORJA, DJ 29.04.1988, p. 9.851).
}

${ }^{247}$ No mesmo sentido é a opinião de BOTTALLO, para quem a compensação independe da efetiva cobrança do tributo nas operações pretéritas (BOTTALLO, Eduardo. IPI - Princípios e Estrutura. São Paulo: Dialética, 2009, p. 47).

${ }^{248}$ COÊLHO, Sacha Calmon Navarro. Curso de Direito Tributário Brasileiro, $9^{\mathrm{a}}$ ed. Rio de Janeiro: Forense, 2007, p. 361. 


\subsection{A “COMPENSAÇÃO” DO ICMS E DO IPI PRESCRITA PELA CR/88 (SUBS- TITUINDO O TERMO “ABATIMENTO”, UTILIZADO PELAS CARTAS ANTE- RIORES).}

Diferentemente das Cartas Pretéritas, determina a atual Lei Maior que tanto o ICMS como o IPI devidos serão compensados com o montante cobrado desses impostos nas operações anteriores. O termo utilizado até então pelas Constituições era abatendo-se, o que leva à indagação se houve algum impacto na estrutura da não-cumulatividade em decorrência dessa modificação terminológica.

A resposta é negativa. Os termos empregados são sinônimos, haja vista que o abatimento pressupõe a compensação de créditos e débitos na conta gráfica do contribuinte.

Todavia, a compensação aqui referida em nada se assemelha à do indébito tributário prescrita nos arts. 170 e 170-A do Código Tributário Nacional ${ }^{249}$ (e regulada pelas leis ordinárias de cada ente federado). A compensação do tributo pago a maior é forma de extinção do crédito tributário (CTN, art. 156, II). Já a compensação dos créditos de exações não-cumulativas consiste em operação contábil, realizada pelo próprio contribuinte, exclusivamente para se alcançar o quantum a pagar de imposto ${ }^{250}$.

A distinção é importante principalmente quando do ajuizamento de ações judiciais que pleiteiem a declaração do direito à escrituração de determinados créditos quando o Poder Público se nega a reconhecê-los. Em tais hipóteses, como não se trata de pedido de repetição do indébito, não se aplica ao caso o art. 166 do $\mathrm{CTN}^{251}$, que exigiria a prova do

${ }^{249}$ Reza o CTN:

"Art. 170. A lei pode, nas condições e sob as garantias que estipular, ou cuja estipulação em cada caso atribuir à autoridade administrativa, autorizar a compensação de créditos tributários com créditos líquidos e certos, vencidos ou vincendos, do sujeito passivo contra a Fazenda pública.

Parágrafo único. Sendo vincendo o crédito do sujeito passivo, a lei determinará, para os efeitos deste artigo, a apuração do seu montante, não podendo, porém, cominar redução maior que a correspondente ao juro de $1 \%$ (um por cento) ao mês pelo tempo a decorrer entre a data da compensação e a do vencimento.

Art. 170-A. É vedada a compensação mediante o aproveitamento de tributo, objeto de contestação judicial pelo sujeito passivo, antes do trânsito em julgado da respectiva decisão judicial."

${ }^{250}$ A lição de SACHA CALMON, estremando a compensação do indébito tributário daquela dos créditos escriturais de ICMS e IPI, é aclaradora:

“(...) Ao abaterem do débito do ICMS ou do IPI devido pelas saídas tributáveis os créditos advindos das entradas tributadas, os contribuintes não estão pagando dívida de imposto com créditos tributários diversos, nascidos de outra relação jurídica. Estão, em verdade, operando abatimentos absolutamente necessários ao cálculo normal do quantum debeatur do imposto." (COÊLHO, Sacha Calmon Navarro. Curso de Direito Tributário Brasileiro, 9ª ed. Rio de Janeiro: Forense, 2007, p. 826).

${ }^{251}$ Reza o CTN:

"Art. 166. A restituição de tributos que comportem, por sua natureza, transferência do respectivo encargo financeiro somente será feita a quem prove haver assumido o referido encargo, ou, no caso de tê-lo transferido a terceiro, estar por este expressamente autorizado a recebê-la. 
não-repasse do imposto ao contribuinte de facto. O creditamento escritural do ICMS e IPI, efetuado pela compensação de créditos e débitos na conta gráfica do pagante, é absolutamente distinto de quaisquer pleitos de compensação de tributos indevidamente pagos ou pagos a maior ${ }^{252}$. Nesse sendeiro, é inapropriado invocar-se o art. 166 do Código Tributário no intuito de obstaculizar a declaração do direito do contribuinte, como de resto já pacificado pelo Superior Tribunal de Justiça, in verbis:

"1. Quanto ao art. 166 do CTN, é firme a orientação da 1 ${ }^{a}$ Seção do STJ no sentido da desnecessidade de comprovação da não-transferência do ônus financeiro correspondente ao tributo, nas hipóteses de aproveitamento de créditos de IPI, como decorrência do mecanismo da não-cumulatividade. Esse o entendimento manifestado, entre outros, nos julgados (...) REsp 440.207/PR, $2^{\text {a }}$ Turma, Min. Castro Meira, DJ de 25.02.2004; (...) REsp 640.773/SC, $1^{\text {a }}$ Turma, Min. Luiz Fux, DJ. de 30.05.2005 e REsp

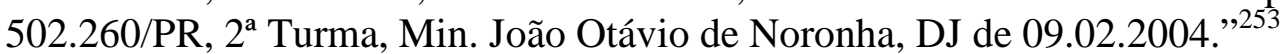

O posicionamento do Supremo Tribunal Federal quanto à natureza dos créditos escriturais corrobora as conclusões do STJ:

"Essas operações de creditamento têm natureza meramente contábil: são os chamados créditos escriturais. Aplica-se a eles técnica de contabilização para viabilizar a equação entre débitos e créditos, para fazer valer o princípio da não-cumulatividade." 254

Em outro aresto, assentou o STF que eventual saldo credor na conta gráfica do contribuinte revela tão-somente "ausência de débito fiscal" 255 , o que coaduna com a distinção ora apregoada entre o crédito escritural - que não gera direito subjetivo do contribuinte contra o Estado - e o crédito decorrente do pagamento indevido do tributo ${ }^{256}$ (que pode

${ }^{252}$ Sobre o tema, averba MISABEL DERZI:

"O art. 166 do CTN abarca apenas as hipóteses de pagamento indevido.

(...) É inaplicável o art. 166 para limitar ou reduzir o princípio da não-cumulatividade constitucionalmente posto. Seria intolerável alteração de norma superior por lei infraconstitucional. Jamais se sujeitará o exercício do direito de compensação de créditos correspondentes a impostos incidentes nas operações anteriores ao regime do art. 166." (BALEEIRO, Aliomar. Direito Tributário Brasileiro, $11^{\mathrm{a}}$ ed. Atualizado por MISABEL ABREU MACHADO DERZI. Rio de Janeiro: Forense, 2001, p. 892).

${ }^{253}$ STJ, Primeira Turma, REsp n ${ }^{\circ}$ 665.252/SC, Relator Min. TEORI ZAVASCKI, DJ 05.10.2006, p. 241.

${ }^{254}$ STF, Pleno, RE nº 386.475/RS, Relatora p/ acórdão Min. CÁRMEN LÚCIA, DJ 22.06.2007, p. 17.

${ }^{255}$ STF, Primeira Turma, RE nº 195.102/SP, Relator Min. ILMAR GALVÃO, DJ 20.11.1998, p. 13.

${ }^{256} \mathrm{O}$ entendimento do STF, do qual comungamos, é também refletido por A. J. COSTA:

“Na verdade, o vocábulo 'crédito' é usado em sentido impróprio porque a entrada de mercadoria no estabelecimento não cria, para o contribuinte, nenhum direito de crédito contra o fisco. $\mathrm{O}$ chamado ‘crédito' de ICM é (...) apenas um elemento a considerar no cálculo do montante de ICM a pagar." 
ocasionar uma condenação do Estado a restituir, financeiramente, o montante recebido a maior).

Outrossim, a ementa do acórdão abaixo - prolatado ainda em 1986 - referenda, em definitivo, a adoção do citado entendimento por parte da Suprema Corte:

"O industrial (...) tem direito a se creditar do valor do imposto (...), não sendo necessária a demonstração de que o imposto foi ou não transferido ao consumidor, no preço do produto, uma vez que a sua dedução é da técnica da tributação." 257

Superada a possível confusão entre os institutos da compensação de créditos escriturais e do indébito tributário - que desde as Cartas pretéritas já gerava celeumas -, podese asseverar que a Constituição de 1988 em nada modificou o tratamento do instituto sub examine pelo fato de ter substituído o termo abatimento por compensação do imposto pago nas etapas anteriores.

\subsection{A APURAÇÃO IMPOSTO-CONTRA-IMPOSTO VERSUS A BASE-CONTRA-} BASE.

A CR/88 (assim como as Constituições que lhe antecederam) optou pelo método imposto-contra-imposto (subtração indireta) de apuração dos tributos não-cumulativos. Assim, o cálculo do IPI e do ICMS a pagar é feito por meio da compensação do imposto incidente nas operações anteriores, tal como ocorre com o IVA europeu ${ }^{258}$.

Todavia, em relação à contribuição para o PIS e à COFINS não-cumulativas, a Carta não definiu a sistemática de apuração (base-contra-base, imposto-contra-imposto ou adição), deixando-a a critério do legislador ordinário.

Poder-se-ia objetar a esta assertiva que as regras da não-cumulatividade plasmadas para o IPI e para o ICMS deveriam ser observadas para o PIS/COFINS, aplicando-se a estes por analogia - e mandatoriamente - o método imposto-contra-imposto. De fato, $a$ priori, a interpretação sistemática do texto constitucional conduziria a tal conclusão. No entanto, as diferenças nas regras-matrizes de incidência dos aludidos tributos conduzem a ilação diversa. Tanto a contribuição para o PIS como a COFINS possuem hipóteses de

(COSTA, Alcides Jorge. ICM na Constituição e na Lei Complementar. São Paulo: Resenha Tributária, 1978, p. 154).

${ }^{257}$ STF, Segunda Turma, RE n ${ }^{\circ}$ 106.033/SP, Relator Min. CARLOS MADEIRA, DJ 13.06.1986, p. 10.451.

${ }^{258}$ O método imposto-contra-imposto é expressamente prescrito no art. 178 da Diretiva 2006/112/CE do Conselho, de observância obrigatória por todos os países integrantes da União Européia. 
incidência absolutamente estranhas para um tributo que pretenda assemelhar-se ao IVA ao contrário do IPI e do ICMS. Tal diferença ontológica, per se, impede a extensão das regras atinentes à não-cumulatividade do IPI e do ICMS àquela prescrita para o PIS/COFINS. Afinal, dentre os pressupostos para utilização da analogia, como leciona $\mathrm{BOBBIO}^{259}$, reside a necessária identidade entre as situações além da inexistência de elemento diferenciador relevante. Ora, a incidência sobre receita bruta, típica do PIS/COFINS, é um severo item de distinção entre essas contribuições e o IPI/ICMS, que gravam operações com mercadorias e serviços (estes, apenas no ICMS). Portanto, estender-se ao PIS e à COFINS as conclusões acerca da não-cumulatividade de tributos com bases de cálculo absolutamente distintas - sendo certo que a base de cálculo é um dos principais elementos caracterizadores da exação, como há muito predicava $\mathrm{BECKER}^{260}$ - é pretender amalgamar o inconciliável.

Por tais razões, pode-se afirmar que a não-cumulatividade do PIS/COFINS é própria dessas contribuições, não havendo necessidade de observância da totalidade dos comandos constitucionais atinentes à não-cumulatividade do IPI e do ICMS. Há, portanto, liberdade para que o legislador ordinário defina a melhor técnica de apuração do quantum debeatur: subtração direta (base-contra-base), subtração indireta (imposto-contra-imposto) ou adição (soma dos custos e cálculo do lucro para obtenção do valor a ser tributado).

Portanto, pode-se afirmar que a Constituição de 1988 predica as seguintes regras em relação à forma de apuração dos tributos não-cumulativos:

(a) para o IPI e o ICMS, o método imposto-contra-imposto (subtração indireta);

(b) para o PIS/COFINS, nenhum método específico, havendo liberdade para a escolha do legislador (base-contra-base, imposto-contra-imposto ou adição).

\subsection{A APURAÇÃO POR PERÍODO DE TEMPO, COM TRANSPORTE DE CRÉ- DITOS NÃO UTILIZADOS PARA COMPETÊNCIAS SUBSEQÜENTES.}

A utilização de contas gráficas viabiliza, na prática, o preceito da nãocumulatividade. Lançam-se naquelas os créditos e débitos para, ao final, apurar-se o quantum devido, que é recolhido ao erário. Todavia, é possível que em determinado período de apuração o valor dos créditos supere o dos débitos. Nessa hipótese, o saldo credor deverá

\footnotetext{
${ }^{259}$ BOBBIO, Norberto. Teoria do Ordenamento Jurídico, $10^{\text {a }}$ ed. Brasília: UNB, 1999, p. 153.

${ }^{260} \mathrm{O}$ autor considerava a base de cálculo como o núcleo da hipótese de incidência do tributo (BECKER, Alfredo Augusto. Teoria Geral do Direito Tributário, $4^{\text {a }}$ ed. São Paulo: Noeses, 2007, p. 348).
} 
transportado para as competências seguintes, podendo haver acúmulo de créditos ao longo de meses ou até anos, até que surjam débitos compensáveis.

Contudo, no passado alguns Estados-membros baixaram leis e decretos determinando o estorno dos créditos não aproveitados quando do encerramento de cada período de apuração. O STF ${ }^{261}$, corretamente, declarou inconstitucionais essas normas. Com isso, o direito ao transporte de créditos escriturais não-utilizados para as competências seguintes passou a integrar o núcleo da não-cumulatividade garantido pela Suprema Corte.

Em outro aresto, o STF reiterou a importância da utilização das contas gráficas para fins de apuração do ICMS (o que se aplica, também, ao IPI). Averbou a Corte que a concretização do princípio da não-cumulatividade é viabilizada pela "existência de uma conta de créditos e débitos, a ensejar acerto em épocas próprias" ${ }^{\text {"262 }}$.

A opção da Corte Suprema merece loas pois, como lembra MISABEL DERZI ${ }^{263}$, o cálculo por período com imputação indiscriminada (dos créditos e débitos) é a forma mundialmente adotada para os IVAs em geral, devido aos seus melhores resultados práticos ${ }^{264}$.

${ }^{261}$ A decisão foi ementada nos seguintes termos:

"ICM. PRINCÍPIO DA NÃO-CUMULATIVIDADE. IMPOSTO MULTIFÁSICO. ESTORNO DE CRÉDITO FISCAL. CF., ART. 23, II. DL. 406, ART. $3^{\circ}$, PAR. $1^{\circ}$.

Descabimento do estorno de saldo a favor do contribuinte, verificado em determinado período, que se há de fazer valer na apuração do débito fiscal do período subseqüente, nos estritos termos da norma complementar do art. $3^{\circ}, \S 1^{\circ}$, do DL 406, 'in fine'.

Resultância do princípio da não-cumulatividade do ICM (art. 23, II da CF).

(...)

Recurso extraordinário conhecido e provido." (STF, Primeira Turma, RE n 96.801/RJ, Relator Min. RAFAEL MAYER, DJ 18.06.1982, p. 5.989).

${ }^{262}$ Confira-se o seguinte excerto do voto do Min. MARCO AURÉLIO, relator da decisão citada:

"Consigne-se, inicialmente, que o princípio da não-cumulatividade, a consubstanciar garantia constitucional do contribuinte, é observado de forma global, ou seja, não diz respeito, em si, à mesma mercadoria. A razão é muito simples: a não ser assim, dificilmente ter-se-iam parâmetros objetivos para chegar-se à viabilização efetiva do tributo porquanto na maioria das vezes dá-se a modificação do produto, já que uma certa mercadoria ingressa no estabelecimento para, mediante industrialização, dar ensejo ao surgimento de outra diversa, processo no qual se consome aquela inicialmente adquirida. Por isso mesmo, o modo de observância do importante princípio mencionado está na existência de uma conta de créditos e débitos, a ensejar acerto em épocas próprias.” (STF, Segunda Turma, RE no 161.257/SP, Relator Min. MARCO AURÉLIO, DJ 17.04.1998, p. 16).

${ }^{263}$ Leciona a jurista:

"O sistema de compensação mercadoria a mercadoria não é prático, trazendo dificuldades contábeis e burocráticas indesejáveis. (...). Aliás, não é praticado em parte alguma, inclusive nos países europeus, que se utilizam da apuração por período com imputação indiscriminada." (BALEEIRO, Aliomar. Direito Tributário Brasileiro, $11^{\mathrm{a}} \mathrm{ed}$. Atualizado por MISABEL ABREU MACHADO DERZI. Rio de Janeiro: Forense, 2001, p. 436).

${ }^{264} \mathrm{Na}$ União Européia a apuração por período de tempo é expressamente determinada pelo art. 179 da Diretiva 2006/112/CE do Conselho. Confira-se:

"Artigo $179^{\circ}$ 
Todavia, vale ressaltar que nenhuma Constituição jamais adentrou na sistemática de apuração dos tributos não-cumulativos, havendo, portanto, liberdade para o legislador nessa seara (que pode optar pelo cálculo por período de tempo ou por produto ${ }^{265}$ ). De todo modo, caso se opte pela apuração por competência - que é a regra aplicável ao IPI, ICMS e PIS/COFINS - não se poderá vedar o transporte de eventual saldo credor para as competências seguintes.

\subsection{AS TENTATIVAS DE RESTRIÇÃO DA NÃO-CUMULATIVIDADE POR LEIS ESTADUAIS E A JURISPRUDÊNCIA DO STF: O CRÉDITO É SEMPRE INTE- GRAL, INDEPENDENTEMENTE DO VALOR DA SAÍDA.}

As lides em torno da não-cumulatividade sempre foram mais freqüentes em matéria de ICMS. Os problemas de caixa dos Estados resultaram (e ainda resultam) na edição de incontáveis normas com o intuito de restringir o direito ao crédito dos contribuintes ${ }^{266}$.

Caso paradigmático foi o de Santa Catarina, analisado pelo Plenário do STF em 1971, no qual a Corte declarou inválido dispositivo de lei estadual que limitava o crédito do então ICM a $80 \%$ do valor que seria devido. Sob a pena do Min. ALIOMAR BALEEIRO, cujo relatório segue abaixo - adotando o voto vencido no Tribunal a quo e o parecer juntado aos autos pela Procuradoria-Geral da República - a questão foi assim solucionada:

“A Lei no 3.985, de 2 de junho de 1967, reza, 'in verbis':

'O total dos créditos do imposto sobre operações relativas à circulação de mercadorias utilizadas em cada decêndio, não será superior a $80 \%$ do imposto devido pela saída de mercadorias procedida no mesmo período'.

A questão é esta: fere esse dispositivo, que estabelece limitação não prevista na Constituição e no Código Tributário, o cânone constitucional da nãocumulatividade? (...). Tenho, 'data venia', que sim. Permite, sem dúvida, ao Estado que cobre, num determinado período, tributo já pago, restringe, ferindo direito estribado em lei federal, a utilização do crédito, e o fato de ser o saldo transferido para o decêndio seguinte, ou para o terceiro, quarto ou quinto decêndio, não contorna, ao que se me afigura, o problema constitucional. Hoje a utilização do crédito está fixada em $80 \%$. Nada impedirá que,

O sujeito passivo efetua a dedução subtraindo do montante total do imposto devido relativamente ao período de tributação o montante do IVA em relação ao qual, durante o mesmo período, surgiu e é exercido o direito à dedução (....).”

${ }^{265}$ Vide Título I, Capítulo III, Item 3.3.5.

${ }^{266}$ Já se viu no item precedente, por exemplo, que os Fiscos estaduais pretenderam estornar os créditos não utilizados pelo contribuinte ao final do mês, impedindo o transporte do saldo credor para as competências subseqüentes. 
amanhã, por quaisquer razões, seja ela reduzida para 70,60, 50, 40 ou até $10 \%$.

(...)

$\mathrm{O}$ art. 25 da lei estadual inquinado de inconstitucional deve ser confrontado, de logo, com o art. $24, \S 5^{\circ}$ da Constituição Federal, assim versado:

'O imposto sobre circulação de mercadorias é não-cumulativo, abatendo-se, em cada operação, nos termos do disposto em lei, o montante cobrado nas anteriores, pelo mesmo ou outro Estado'.

Se, por motivo constitucional, há de ser abatido, em cada operação, o montante cobrado nas anteriores, a lei estadual que limita o abatimento a ser feito é, 'data venia', às declaradas inconstitucional, inexistindo para convalescê-la qualquer justificativa.

De forma alguma a lei autoriza o Estado a reter o crédito do contribuinte, para, quando lhe aprouver, em outra operação, vir a fazer a compensação. Ao contrário: a Lei Maior determina, peremptoriamente, categoricamente, que, em cada operação, abata-se o montante cobrado nas anteriores."267

Noutro aresto, o STF afastou a pretensão do Estado de São Paulo de glosar créditos aproveitados pelas empreiteiras relativamente às sobras de materiais de construção civil (adquiridos no mercado) que, não empregados na obra, foram remetidos ao depósito da empreiteira para posterior revenda. O Relator, Min. OSWALDO TRIGUEIRO, assim delimitou a quaestio facti:

"No caso, o contribuinte adquiriu materiais de construção, sobre os quais os vendedores pagaram o ICM devido. Esses materiais foram remetidos diretamente ao canteiro da obra, não dando entrada no estabelecimento do empreiteiro. Concluída a empreitada, foram recolhidas as sobras de materiais aos depósitos do contribuinte que, então, se creditou pelo ICM já pago pelo vendedor." 268

E, em seguida, manteve o império da não-cumulatividade aos seguintes fundamentos:

"Sobre esses materiais não empregados na construção, o Fisco quer cobrar novo imposto, de vez que impugna o crédito correspondente. Essa pretensão, a meu ver, colide com a norma constitucional da não-cumulatividade do tributo. Se determinada parcela dos materiais adquiridos não foi aplicada na obra, não há como recusar-se ao contribuinte o correspondente crédito do ICM, pela importância já paga pelo vendedor. Parece-me de toda a evidência que o contribuinte tem direito a esse crédito, do mesmo modo que o teria na hipótese de haver a mercadoria entrado em seu estabelecimento, quando adquirida, e dali remetida ao local da obra."

\footnotetext{
${ }^{267}$ STF, Pleno, RE no 70.204, Relator Min. ALIOMAR BALEEIRO, DJ 30.04.1971.

${ }^{268}$ STF, Segunda Turma, RE $n^{\circ}$ 74.902/SP, Relator Min. OSWALDO TRIGUEIRO, DJ 10.11.1972.

${ }^{269}$ STF, Segunda Turma, RE n ${ }^{\circ}$ 74.902/SP, Relator Min. OSWALDO TRIGUEIRO, DJ 10.11.1972.
} 
Também o Estado do Maranhão, importante produtor de arroz, pretendeu limitar o direito ao crédito das empresas beneficiadoras do grão sitas em seu território. Arvorandose em decreto estadual ${ }^{270}$, a fiscalização maranhense determinava o estorno de 4,67\% dos créditos oriundos da aquisição de grãos in natura. O fundamento para a glosa consistia na perda de umidade dos grãos após o beneficiamento, que resultava na redução do peso nesse exato percentual. Sendo assim, não poderia o beneficiador se creditar do valor equivalente ao da "quebra" do arroz. Com acerto, o STF repeliu o posicionamento do Estado, tendo o Min. Relator DÉCIO MIRANDA asseverado:

"Aceite-se que o cereal, depois de descascado e pronto para entrega ao consumo, sofra realmente essa diminuição de peso, por efeito de perda de umidade.

Isso não é razão para fazer o beneficiador perder 4,67\% do imposto que pagou, e que nessa proporção fica impedido de se creditar nas vendas do produto.

(...)

Admita-se que a legislação estadual possa determinar o estorno do imposto pago sobre as mercadorias que hajam perecido ou se tenham deteriorado. Aí, a providência visa a evitar o desvio de mercadorias sem pagamento do imposto ulterior, sob pretexto de fatos aleatórios como o perecimento ou a deterioração.

No caso da perda de umidade do arroz, todavia, o fenômeno é natural, conhecido, quantificado por antecedência. Não se trata de perecimento ou deterioração, que possam servir de capa ao desvio ou à evasão.

Nada, pois, justifica o estorno dos 4,67\%, que apenas encobre uma perda do pagamento anterior, com gravame do pagamento final, que, nessa proporção, passa a ser cumulativo com o que se pagou antes e não se pode descontar."

E, ao cabo, concluído:

"Trata-se, em verdade, de uma parcela do imposto anterior que deixa de ser levado em conta na operação ulterior.

Assim, a imposição fere o princípio da não-cumulatividade do imposto."

A Corte Suprema também julgou caso no qual a legislação de Minas Gerais vedava o crédito do extinto ICM quando:

(a) o crédito excedesse o débito gerado pela saída da mercadoria; ou

\footnotetext{
${ }^{270}$ Assim predicava o Decreto Maranhense $n^{\circ} 5.891 / 75$ :

"Art. $4^{\circ}$. No final de cada mês, os estabelecimentos beneficiadores procederão no Registro de Apuração do ICM ao estorno do imposto no percentual fixado pelo Secretário da Fazenda, sobre o total do imposto creditado no mês relativo à aquisição do arroz 'in natura', a título de quebra."

${ }^{271}$ STF, Pleno, RE nº 87.078/MA, Relator Min. DÉCIO MIRANDA, DJ 24.08.1979.
} 
(b) a alíquota interna mineira fosse inferior ao crédito oriundo da alíquota interestadual aplicada no Estado de origem.

Em outras palavras, sempre que houvesse, em determinada operação isoladamente considerada, acúmulo de crédito oponível contra o Estado de Minas Gerais (seja porque a venda fora realizada a preço inferior ao de custo, seja porque a aquisição interestadual se dera em alíquota superior àquela internamente aplicada no Estado de Minas Gerais), tal excesso deveria ser glosado ${ }^{272}$. No aresto, conduzido pelo Min. MOREIRA ALVES, a nãocumulatividade foi mais uma vez reafirmada, declarando-se inconstitucionais as referidas restrições ao crédito. Eis a ementa do decisum:

"O inciso II do artigo 23 da Constituição estabelece, sem qualquer restrição, o princípio de que o ICM é não-cumulativo.

Inconstitucionalidade do artigo 52 do Decreto 17.759, de 13 de fevereiro de 1976, do Estado de Minas Gerais, por violação do mencionado dispositivo constitucional.

Representação procedente.",273

A decisão, sobre ser acertada, coaduna-se com uma característica tanto do ICMS como do IPI, que é a apuração por período de tempo (competência mensal) e não por produto $^{274}$. Assim, o fato de uma eventual mercadoria ser revendida abaixo do seu preço de aquisição não faz com que haja obrigação de estorno do crédito excessivo supostamente relacionado a esta mercadoria ${ }^{275}$. Os débitos e créditos não são vinculados a produtos espe-

${ }^{272}$ O dispositivo objurgado era o art. 52 do Decreto Mineiro $\mathrm{n}^{\circ}$ 17.759/76, que ostentava a seguinte redação: “Art. 52. O montante do crédito relativo à mercadoria entrada será limitado pelo valor do débito pela saída da mesma quando:

I - o valor da saída for inferior ao valor do custo da mercadoria;

II - em razão da diferença de alíquotas a saída de mercadoria ocasionar débito de imposto inferior ao crédito."

${ }^{273}$ STF, Pleno, Rp no 973/MG, Relator Min. MOREIRA ALVES, DJ 07.04.1978.

Em caso análogo, tendo resultado na declaração de inconstitucionalidade de lei goiana, confira-se também: STF, Pleno, Rp nº 1.157/GO, Relator Min. RAFAEL MAYER, DJ 27.10.1983, p. 16.695.

${ }^{274}$ A legislação federal em matéria de IPI e dos Estados em relação ao ICMS determina a apuração desses impostos por período de tempo.

275 Acerca da legislação mineira - como visto, declarada inconstitucional pelo STF - que determinava o estorno do crédito quando o valor de saída do produto fosse inferior ao da entrada, averbou DIAMANTE:

"É evidente que a intenção de combater a sonegação do ICM, via subfaturamento, por meio das disposições acima transcritas [art. 52 do Decreto mineiro $n^{\circ} 17.759 / 76$ ], se choca com as disposições estruturais e constitucionais do imposto, que determinam que ele seja não-cumulativo e que dele se abata o montante do imposto cobrado nas operações anteriores, pelo mesmo ou por outro Estado.

Mas é evidente também que, além de os meios utilizados serem inconstitucionais, não são racionais, porquanto, no caso de sonegação via subfaturamento, se evitaria uma pequena parcela desta e assim mesmo se o subfaturamento fosse exagerado.

O instrumento planejado para o sonegador e que só o atingiria parcialmente, pode atingir por inteiro o contribuinte correto que eventualmente realize uma transação com prejuízo.” (DIAMANTE, Flá- 
cíficos, mas sim registrados na contabilidade da empresa que, ao final, apura o quantum debeatur e faz a recolha do montante devido - se houver - aos cofres federais ou estaduais $^{276}$.

\subsection{OS EFEITOS DA ISENÇÃO OU NÃO-INCIDÊNCIA INTERCALAR NO ICMS.}

A não-cumulatividade do ICMS - desde a sua criação, como ICM - não possuía originariamente nenhuma limitação no texto constitucional. Foi somente em 1983, com o advento da Emenda Constitucional no 23 (intitulada Passos Porto) que houve a vedação do transporte de créditos para as etapas subseqüentes quando houvesse isenção ou nãoincidência do imposto estadual. Confira-se o texto da Constituição de 1967-69, já modificado pela aludida Emenda:

"Art. 23. Compete aos Estados e ao Distrito Federal instituir impostos sobre: (...)

II - operações relativas à circulação de mercadorias, realizadas por produtores, industriais e comerciantes, imposto que não será cumulativo e do qual se abaterá, nos termos do disposto em lei complementar, o montante cobrado nas anteriores pelo mesmo ou por outro Estado. A isenção ou nãoincidência, salvo determinação em contrário da legislação, não implicará crédito de imposto para abatimento daquele incidente nas operações seguintes." (destaques nossos)

Com essa medida, restou vedado ao adquirente de mercadorias isentas ou nãotributadas o aproveitamento de créditos do então ICM.

Todavia, por força da interpretação conferida pelo STF à EC no 23/83, aquele que procedesse à venda (rectius: o beneficiado pela isenção ou não-incidência), teria ainda que estornar, em sua conta gráfica, os créditos relativos ao ICM por ele suportado na aquisição de matérias-primas, bens para o ativo e para revenda.

Com a Constituição de 1988, houve - nas palavras do STF - um aclaramento do sentido da Emenda Passos Porto. Foi mantida a regra de proibição do transporte de créditos para as etapas de circulação da mercadoria subseqüentes à isenta/não-tributada, porém com a inclusão de um novo comando expresso (que, de acordo com o Supremo, era implícito

vio. ICM - Introdução à Análise da Sistemática - Uma Abordagem Estruturalista, $2^{\mathrm{a}}$ ed. Belo Horizonte: MAI, 1974, p. 43).

${ }^{276}$ Vide Item 6.6, supra. 
até então): a determinação de estorno do crédito relativo às operações anteriores à nãotributada. Veja-se a redação do texto magno:

“Art. 155. (...).

$\S 2^{\circ}$. O [ICMS] atenderá ao seguinte:

(...)

II - a isenção ou não-incidência, salvo determinação em contrário da legislação:

a) não implicará crédito para compensação com o montante devido nas operações ou prestações seguintes;

b) acarretará a anulação do crédito relativo às operações anteriores;"

As duas hipóteses nas quais a não-cumulatividade do ICMS é mitigada pelo próprio texto constitucional merecem análise apartada, haja vista que, no primeiro caso, a Lei Maior impede o transporte de créditos para as operações e prestações seguintes, ao passo que, na segunda proposição, a anulação do crédito pretérito se aplica apenas às operações anteriores (impedindo, a nosso sentir, a anulação do crédito das prestações antecedentes da etapa isenta ou não-tributada).

Vejamos, detalhadamente, a evolução acima narrada.

\subsubsection{A VEDAÇÃO AO TRANSPORTE DE CRÉDITOS PARA AS OPERAÇÕES E PRESTAÇÕES POSTERIORES À ISENTA OU NÃO-TRIBUTADA.}

Em $1^{\circ}$ de dezembro de 1983 , a norma constitucional da não-cumulatividade sofreu sua última modificação antes do advento da atual Lei Maior. A Emenda Constitucional $n^{\circ}$ 23 acresceu uma parte final ao art. 23, II da Constituição de 1967-69, dispondo que a isenção ou não-incidência no ICM impediria o transporte de créditos para a etapa subseqüente, salvo se a legislação do Estado-membro dispusesse em sentido contrário.

A Emenda Passos Porto, como lecionam SACHA CALMON ${ }^{277}$ e MISABEL DER$\mathrm{ZI}^{278}$, veio contrariar jurisprudência do Supremo Tribunal Federal que concedia crédito presumido de ICM ao contribuinte-adquirente de mercadoria isenta ou não-tributada. Permitia a Corte o abatimento dos créditos como se o tributo houvesse incidido na etapa anterior.

\footnotetext{
${ }^{277}$ COÊLHO, Sacha Calmon Navarro. Curso de Direito Tributário Brasileiro, $7^{\mathrm{a}}$ ed. Rio de Janeiro: Forense, 2004, p. 390.

278 BALEEIRO, Aliomar. Direito Tributário Brasileiro, $11^{\mathrm{a}}$ ed. Atualizado por MISABEL ABREU MACHADO DERZI. Rio de Janeiro: Forense, 2001, p. 354.
} 
Uma das primeiras decisões nesse sendeiro foi relatada pelo Min. ALIOMAR BALEEIRO, assegurando o crédito presumido de ICM ao comprador, quando o vendedor de cal virgem, situado noutro Estado, estivesse amparado por decisão judicial que impedisse a exigência do ICM sobre a mercadoria vendida (não havendo, nesse caso, sequer destaque do imposto na nota fiscal) ${ }^{279}$. Um dos fundamentos da decisão residia na possibilidade de locupletamento ilícito do Estado de destino caso o crédito presumido não fosse concedido. Consoante o parecer do Procurador-Geral da República naqueles autos (adotado pelo Min. BALEEIRO em seu voto), "se o imposto é recolhido sem crédito no Estado de destino e o Estado de origem vem a exigi-lo posteriormente sobre a primeira saída - como é o caso, em que a incidência do ICM sobre a cal virgem, repelida pelos Tribunais Estaduais, foi proclamada pelo Pretório Excelso - ocorrerá bitributação. E não poderá o vendedor reclamar a diferença do comprador".

Quando havia isenção do ICM o STF também assegurava o crédito do adquirente. Fundava-se a Corte no argumento de que a negativa do crédito feria a não-cumulatividade tributária e a própria isenção concedida, eis que, à míngua do crédito presumido, o adquirente findaria pagando imposto sobre o produto isento ${ }^{280}$.

De se notar que um dos fundamentos do decisum foi o de que, na isenção, tem-se a efetiva incidência da norma de tributação, gerando imposto a pagar. Todavia, por força de uma norma superveniente - exatamente a isencional - extingue-se crédito tributário, dispensando-se o pagamento da exação ${ }^{281}$. Com base nessa interpretação, a isenção acaba por

\footnotetext{
${ }^{279}$ Vale conferir a ementa do julgado:

"ICM. Crédito nas operações interestaduais. O fato de o estado de origem não ter cobrado dos fornecedores de matérias-primas o ICM e, por isso, não ter havido o destaque do valor desse tributo nas notas fiscais, não autoriza o Estado do destino a exigir o mesmo ICM sobre todo o valor das saídas do revendedor, sem lhe garantir os créditos por suas compras, a fim de que se realize a nãocumulatividade do art. 23, II, da Constituição Federal.” (STF, Primeira Turma, RE nº 78.589/SP, Relator Min. ALIOMAR BALEEIRO, DJ 04.11.1974).
}

${ }^{280} \mathrm{O}$ acórdão foi assim ementado:

"Havendo isenção do imposto de circulação de mercadoria importada, não se pode, na operação subseqüente, cobrar o valor do imposto, que seria devido, não fora a isenção tributária. Tem, assim, o revendedor direito ao acto de destaque do valor isento, nas notas fiscais. Recurso extraordinário a que se dá provimento." (STF, Primeira Turma, RE n 94.177/SP, Relator Min. FIRMINO PAZ, DJ 28.08.1981, p. 8.266).

$\mathrm{O}$ aresto foi posteriormente levado ao Pleno do Tribunal por meio de Embargos de Divergência os quais, em que pese não conhecidos, reafirmaram, em obter dictum, o entendimento pelo direito ao crédito presumido, de modo a preservar-se a não-cumulatividade.

${ }^{281}$ Analisando o posicionamento do STF, SACHA CALMON averba:

"Sob a Carta de 1967, a jurisprudência da Suprema Corte passou a admitir que, nos casos de isenção, o crédito na operação seguinte era devido como se o tributo houvesse sido pago na anterior. Notável a intuição dos ministros da Corte, logo percebendo o sacrifício do contribuinte adquirente pelo 
equivaler ao pagamento do imposto, eis que é forma extintiva do débito originariamente devido. Sendo assim, não se poderia, em atenção à não-cumulatividade, negar-se o crédito na etapa seguinte ${ }^{282}$.

Da mesma forma, o STF assegurava o direito ao crédito integral na etapa subseqüente quando a isenção fosse parcial ${ }^{283}$.

Outrossim, quando a não-incidência decorria de imunidade o Supremo assegurava o direito ao crédito do ICM sobre as etapas anteriores à imune. Entretanto, não concedia crédito presumido ao adquirente. A este só era permitido o abatimento do imposto que efetivamente incidira na compra do bem pelo ente imune. Não era possível, sob a ótica do STF, o cálculo do crédito sobre o preço de venda da mercadoria praticado pelo vendedor imune.

$\mathrm{O}$ caso em que se firmou tal entendimento foi o do Instituto Brasileiro do Café (IBC), autarquia que comprava dos produtores a matéria-prima (café verde) e a revendia aos torrefadores. Estes últimos garantiram no Judiciário o direito ao crédito do imposto que incidira na venda produtor > IBC (não havendo, portanto, qualquer concessão de crédito presumido nessa hipótese, mas apenas manutenção da não-cumulatividade pelo abatimento do imposto cobrado nas etapas anteriores). Somente poder-se-ia falar em crédito presumido

deslocamento do ônus fiscal do contribuinte beneficiário da isenção para o elo seguinte da cadeia de circulação.

Alguns ministros chegaram a motivar os votos com a tese da isenção enquanto dispensa de pagamento devido, só imputável ao próprio ente tributante que dava a isenção. Daí a equiparação de 'imposto isento' (expressão incorreta) a 'imposto pago'.

No entanto, o veraz fundamento dessas atribuições de 'créditos presumidos' pelo Poder Judiciário estaria bem posto se se ativesse à imperiosa necessidade de manter íntegro o princípio da nãocumulatividade do ICM, vulnerada por isenções impeditivas da retransmissão do crédito fiscal." (COÊLHO, Sacha Calmon Navarro. Curso de Direito Tributário Brasileiro, $9^{\mathrm{a}}$ ed. Rio de Janeiro: Forense, 2007, p. 362).

${ }^{282}$ Alinhando-nos com SACHA CALMON (COÊLHO, Sacha Calmon Navarro. Curso de Direito Tributário Brasileiro, $9^{\text {a }}$ ed. Rio de Janeiro: Forense, p. 849), guardamos ressalva em relação a este entendimento do STF quanto à natureza da norma isencional.

Afinal, a isenção, em verdade, impede o nascimento da própria obrigação tributária (em que pese o CTN classificar a isenção como causa de "exclusão" do crédito tributário, em seu art. 175). Entrementes, como o STF a qualifica como dispensa legal de tributo devido (entendimento que permanece até os dias atuais), o raciocínio da Corte, neste particular, solidifica as bases da não-cumulatividade tributária, pois equipara a operação isenta à tributada para fins de concessão de crédito presumido a ser aproveitado na etapa subseqüente.

${ }^{283}$ Confira-se a ementa de um dos acórdãos nesse sentido:

"ICM. ISENÇÃO. ISENÇÃO PARCIAL. CREDITAMENTO. SÚMULA 286.

Cabe o creditamento do ICM, na operação subseqüente, quanto às isenções da mercadoria ingressa no estabelecimento, ainda que a isenção seja parcial. Agravo regimental improvido." (STF, Primeira Turma, AI-AgR nº 107.334/SP, Relator Min. RAFAEL MAYER, DJ 28.02.1986, p. 2.355). 
se o valor do imposto a ser abatido pelo adquirente fosse calculado sobre o valor de venda da mercadoria pelo IBC, estádio no qual não havia incidência do tributo ${ }^{284}$.

Como se pode inferir, a jurisprudência anterior à Emenda Passos Porto era pródiga em assegurar a neutralidade tributária, nota típica do imposto sobre valor agregado estadual criado pela $E C \mathrm{n}^{\circ}$ 18/65. A isenção, quando concedida antes da última operação da cadeia, efetivamente majora o valor devido a título de ICM (e também de IPI, em que pese a Passos Porto ter versado apenas sobre o imposto estadual). Por tal razão a Suprema Corte assegurava os créditos presumidos, tanto quando a operação anterior não fosse tributada, como quando a mesma fosse isenta, no todo ou em parte.

Contudo, tal entendimento benéfico aos contribuintes passou a gerar prejuízo financeiro aos Estados-membros, razão pela qual a Passos Porto foi editada visando à recomposição dos caixas estaduais - o que, por via oblíqua, afetou o regramento constitucional da não-cumulatividade do ICM. O quadro esquemático a seguir retrata a modificação operada pela EC no 23/83:

1. Isenção de ICM concedida em etapa intermediária - antes da $\mathrm{EC}^{\circ}$ 23/83:

\begin{tabular}{|c|c|c|c|}
\hline & FABRICANTE & ATACADISTA & VAREJISTA \\
\hline $\begin{array}{l}\text { Valor de venda da } \\
\text { mercadoria }\end{array}$ & 200 & 400 & 600 \\
\hline $\begin{array}{l}\text { ICM incidente na } \\
\text { operação }(18 \%)\end{array}$ & 36 & Isento & 108 \\
\hline Débito de ICM & 36 & 0 & 108 \\
\hline Crédito de $\mathrm{ICM}^{286}$ & 0 & 0 & $\begin{array}{l}72 \text { (crédito presumi- } \\
\text { do, calculado pela } \\
\text { aplicação da alíquo- } \\
\text { ta sobre o valor da }\end{array}$ \\
\hline
\end{tabular}

${ }^{284}$ Após a edição da Súmula n $n^{\circ} 571$, que assegurou ao comprador de café do IBC o crédito do ICM "que incidiu sobre a operação anterior", outra discussão instalou-se no âmbito do STF: a "operação anterior" referida pela Súmula era a venda IBC > torrefador ou a compra, pelo IBC, do café cru do produtor (venda produtor > IBC)?

Apesar de em alguns arestos ter-se sustentado a necessidade de cálculo de um crédito ficto de ICM sobre o preço pago pelo torrefador ao IBC, o Plenário do STF (nos Embargos de Divergência no RE nº 92.766/RJ, Relator Min. RAFAEL MAYER, DJ 12.03.1982, p. 1.867) solucionou a questão indicando que somente o ICM que incidira na operação produtor > IBC poderia ser creditado pelo torrefador. Na interpretação do Supremo Tribunal, a garantia da não-cumulatividade na espécie não exigia qualquer concessão de crédito presumido, mas apenas a observância da regra que assegura o abatimento do imposto cobrado nas operações antecedentes. E, não tendo havido incidência na operação IBC > torrefador, esta não poderia ser tomada como base de cálculo para o creditamento do imposto.

285 O ICM é calculado "por dentro”, diferentemente do IPI que, à semelhança dos IVAs em geral, é calculado "por fora", agregando-se ao preço da mercadoria. Assim, no ICM o valor de venda do produto equivale ao valor total da operação.

286 Visando a simplificar a demonstração, parte-se do pressuposto de que o fabricante não possui créditos compensáveis do ICM (que seriam oriundos, v.g., das matérias-primas por ele adquiridas). 


\begin{tabular}{|l|l|l|l|}
\hline & & & operação anterior) \\
\hline ICM total $=72$ & 36 & 0 & 36 \\
\hline
\end{tabular}

2. Isenção de ICM concedida em etapa intermediária - após a EC nº 23/83:

\begin{tabular}{|l|l|l|l|}
\hline & FABRICANTE & ATACADISTA & VAREJISTA \\
\hline $\begin{array}{l}\text { Valor de venda da } \\
\text { mercadoria }\end{array}$ & 200 & 400 & 600 \\
\hline $\begin{array}{l}\text { ICM incidente na } \\
\text { operação (18\%) }\end{array}$ & 36 & Isento & 108 \\
\hline Débito de ICM & 36 & 0 & 108 \\
\hline Crédito de ICM & 0 & 0 & 0 \\
\hline ICM total =144 & 36 & 0 & 108 \\
\hline
\end{tabular}

A majoração do imposto pela quebra da não-cumulatividade operada pela Emenda Passos Porto é patente. Todavia, como a Constituição não incluiu a não-cumulatividade entre as cláusulas pétreas, nenhum questionamento quanto à sua validade ocorreu no âmbito do STF, que em diversas ocasiões reconheceu a existência de dois regramentos distintos para o instituto: antes e depois da $\mathrm{EC}^{\circ}$ 23/83. As ementas abaixo aclaram a posição do Pretório Excelso:

"1. ICM. Isenção na importação de matéria-prima. Crédito. Antes da edição da EC 23/83, há direito ao crédito do valor do ICM que seria devido pela importação de matéria-prima industrializada, na saída do produto, no qual utilizada. Precedente: RE 112.554, 3.10.1988, 2ª T., Francisco Rezek, DJ 25.10.1991.

2. Agravo regimental que trata de matéria diversa da dos autos: desprovimento." 287

“CONSTITUCIONAL. TRIBUTÁRIO. ICMS. PRINCÍPIO DA NÃOCUMULATIVIDADE. DIREITO DE CRÉDITO. CF, 1967, ART. 23, II, COM A REDAÇÃO DA EC n 23, de 1983. OPERAÇÃO REALIZADA NA VIGÊNCIA DA EC no $23 / 83$.

I - ICM recolhido na entrada de matéria-prima empregada na fabricação de produto cuja saída é isenta do referido imposto, operação realizada já na vigência da EC 23/83, que introduziu alteração no art. 23, II, da CF/67: inocorrência do direito ao crédito. Precedentes do STF. II - RE não conhecido." 288

${ }^{287}$ STF, Primeira Turma, AI-AgR no 546.669/ES, Relator Min. SEPÚLVEDA PERTENCE, DJ 03.02.2006, p. 19, destaques nossos.

${ }^{288}$ STF, Segunda Turma, RE no 207.354/SP, Relator Min. CARLOS VELLOSO, DJ 01.03.2002, p. 52, destaques nossos. 
Assim é que a mutação constitucional atribuiu nova conformação à nãocumulatividade em matéria de ICM, impedindo o transporte de créditos presumidos para as operações subseqüentes quando as anteriores forem isentas ou não-tributadas.

No âmbito da Constituição de 1988, com a agregação ao ICMS dos serviços de comunicação e de transporte interestadual e intermunicipal, a manutenção da regra criada pela Passos Porto exigiu ampliação para que também as prestações de serviço gravadas pelo imposto estadual fossem sujeitadas à regra do não-transporte de créditos para as prestações subseqüentes. Com isso, o texto magno assumiu a seguinte forma:

“Art. 155. (...).

$\S 2^{\circ}$. O [ICMS] atenderá ao seguinte:

(...)

II - a isenção ou não-incidência, salvo determinação em contrário da legislação:

a) não implicará crédito para compensação com o montante devido nas operações ou prestações seguintes;" (destaques nossos)

Assim, não somente nas operações de circulação jurídica de mercadorias mas também nas prestações de serviço de transporte interestadual e intermunicipal e de comunicação, as isenções ou não-incidências intercalares passaram a mitigar a não-cumulatividade tributária (salvo, vale repisar, disposição legal em contrário).

Já para o IPI nunca houve, seja nas Cartas pretéritas seja na atual, qualquer disposição que mitigue a sua não-cumulatividade.

\subsubsection{O DEVER DE ESTORNO DOS CRÉDITOS DAS OPERAÇÕES ANTERIO- RES À ETAPA ISENTA OU NÃO-TRIBUTADA.}

Como visto, a EC n ${ }^{\circ}$ 23/83 vedou - ressalvando a possibilidade de a lei dispor em sentido contrário - o transporte de créditos do ICM para as operações subseqüentes quando houvesse isenção ou não-incidência intercalar ${ }^{289}$.

Entretanto, a situação inversa não foi tratada pela Passos Porto, a saber: a compra de bens tributados seguida da saída de mercadorias abrigadas pela isenção ou nãoincidência. Neste ponto, surgiu a indagação: o contribuinte que compra bens gravados pelo ICM, para realizar operações isentas ou não-tributadas, pode se apropriar dos créditos relativos às suas aquisições?

\footnotetext{
${ }^{289}$ A discussão só faz sentido quando há ausência de tributação em etapa intermediária do processo de circulação de mercadorias, eis que, se a isenção for concedida na última etapa, inexistirá aumento da carga do ICM (e tampouco haverá interesse em se transportar, para a etapa subseqüente, os créditos presumidos calculados sobre a operação isenta - pois não haverá etapa posterior).
} 
Ao analisar o tema, em 1988, o STF entendeu que, a partir da EC n 23/83, tornouse também devido o estorno dos créditos de ICM referentes às operações anteriores à isenta ou não-tributada ${ }^{290}$, em que pese a Emenda Passos Porto não possuir regra expressa nesse sentido.

Seis anos depois, em 1994, o STF novamente decidiu que desde a Emenda Passos Porto é inequívoca a necessidade de estorno dos créditos relativos às operações anteriores. Veja-se o voto do Relator, Min. ILMAR GALVÃO, que inicialmente busca esclarecer os objetivos da não-cumulatividade tributária:

"O princípio da não-cumulatividade do $\operatorname{ICM}(\ldots)$ opera (...) por meio de compensação do tributo pago na entrada da mercadoria com o valor devido por ocasião da saída, significando, na prática, que a operação de venda é tributada tão-somente pelo valor adicionado ao preço.

Evita-se, desse modo, a cumulação do tributo."291

Para, em seguida, sustentar seu ponto de vista:

"Se uma das duas operações (...) não foi tributada, não haverá, obviamente, possibilidade de cumulação, inexistindo espaço para compensação. Conseqüentemente, perde o seu objeto o crédito fiscal, que se destinava exclusivamente a essa operação."292

Prosseguindo, intenta o Ministro coadunar o seu pensamento com a sistemática de apuração por período de tempo (tarefa, a nosso sentir, impossível, salvo se todas as saídas do adquirente forem não tributadas):

"É certo que, entre nós, o sistema adotado é o de contabilização do tributo numa única conta, que engloba as operações passivas e ativas relativas a todas as entradas e saídas de mercadoria, indistintamente. Tal, entretanto, não invalida a análise acima feita, podendo-se facilmente perceber que, na hipótese de mercadoria com saída isenta, se mantido o crédito alusivo ao tributo

${ }^{290}$ Confira-se o seguinte trecho do voto do Relator, Min. MOREIRA ALVES:

“(...) A recorrente invocou, em favor de sua tese, acórdão prolatado por esta Primeira Turma no RE $\mathrm{n}^{\circ}$ 103.102, e em cuja ementa se lê:

'ICM. Legitimidade do crédito de ICM correspondente às entradas da matéria-prima integradas nos produtos cujas saídas estão isentas do imposto, por força da LC 4/69 (art. $1^{\circ}$, inciso XIV). Não-cumulativo o imposto, vedado o estorno pretendido.

Recurso extraordinário conhecido e provido.'

Com a devida vênia, não me parece que essa decisão deva ser seguida, máxime depois da Emenda Constitucional $n^{\circ} 23$ (que já estava em vigor quando foi importada a matéria-prima em causa)." (STF, Primeira Turma, RE n ${ }^{\circ}$ 115.966/RS, Relator Min. MOREIRA ALVES, DJ 19.08.1988, p. 20.268).

${ }^{291}$ STF, Primeira Turma, RE nº 125.106/SP, Relator Min. ILMAR GALVÃO, DJ 03.02.1995, p. 1.023.

${ }^{292}$ STF, Primeira Turma, RE nº 125.106/SP, Relator Min. ILMAR GALVÃO, DJ 03.02.1995, p. 1.023. 
pago pela entrada (...), constituirá estímulo fiscal por via oblíqua, isto é, sem lei que o preveja." 293

É certo que os fundamentos até o momento indicados se prestariam a sustentar a necessidade de estorno de débitos também para o IPI. Assim, as premissas postas indicariam, a priori, que o STF concluíra que a não-cumulatividade pressupõe saídas tributadas. Não existindo estas, o crédito das operações pretéritas deveria ser estornado.

Entretanto, ao prosseguir em sua fundamentação, o Min. GALVÃO buscou na Emenda Passos Porto o fundamento jurídico decisivo para sedimentar sua posição. É ver:

"Não é outro o entendimento que prevalece nesta Corte, pelo menos a partir da EC $n^{\circ}$ 23/83 que, conforme observado no parecer da Douta Procuradoria Geral da República, 'dando nova redação ao art. 23, II, da Constituição Federal, restringiu, de forma clara e definitiva, os efeitos da isenção à própria operação contemplada com esse benefício, sem qualquer repercussão ou interferência em operações anteriores ou posteriores com a mercadoria'., ${ }^{294}$

Ao cabo, fundando-se na Constituição de 1988 - que não regrava o período analisado no caso, mas foi por GALVÃO utilizada como ferramenta interpretativa da EC $\mathrm{n}^{\circ}$ 23/83 - dispôs:

"Anote-se, por derradeiro, que a nova Carta de 1988, tornando explícito o que se achava subentendido no período em foco, dispôs, pedagogicamente, que:

'Art. 155 , parágrafo $2^{\circ}(\ldots)$

II - a isenção ou não-incidência, salvo determinação em contrário da legislação:

a) não implicará crédito para compensação com o montante devido nas operações ou prestações seguintes;

b) acarretará a anulação do crédito relativo às operações anteriores;",295

Segundo GALVÃO, a Emenda Passos Porto trouxera uma regra explícita (a vedação do transporte de créditos para as etapas subseqüentes à isenta ou não-tributada) e outra implícita (a determinação do estorno de crédito pelo alienante de mercadorias sem tributação). E a Constituição de 1988 aclarou essa segunda regra, que estava latente no Texto Maior (porém devidamente trazida a lume pela jurisprudência do STF).

\footnotetext{
${ }^{293}$ STF, Primeira Turma, RE n ${ }^{\circ}$ 125.106/SP, Relator Min. ILMAR GALVÃO, DJ 03.02.1995, p. 1.023.

${ }^{294}$ STF, Primeira Turma, RE no 125.106/SP, Relator Min. ILMAR GALVÃO, DJ 03.02.1995, p. 1.023, destaques nossos.

${ }^{295}$ STF, Primeira Turma, RE no 125.106/SP, Relator Min. ILMAR GALVÃO, DJ 03.02.1995, p. 1.023.
} 
Tal entendimento - de que a Passos Porto exigia, também, o estorno dos créditos das operações pretéritas à isenta ou não-tributada - restou definitivamente assentado no âmbito do STF, tendo sido confirmado por decisões ulteriores (inter alii, RE-AgR $\mathbf{n}^{\circ}$ $\left.270.827 / \mathrm{SP}^{296}\right)$.

Com a Constituição de 1988, consoante consta no aresto referido, a norma implicitamente contida na $\mathrm{EC} \mathrm{n}^{\mathrm{o}} 23 / 83$ foi explicitada no art. $155, \S 2^{\circ}$, II, $b$, que assim dispõe:

“Art. 155. (...).

$\S 2^{\circ}$. O [ICMS] atenderá ao seguinte:

(...)

II - a isenção ou não-incidência, salvo determinação em contrário da legislação:

(...)

b) acarretará a anulação do crédito relativo às operações anteriores;" (destaques nossos)

Todavia, a CR/88 não dispõe que a isenção ou não-incidência anulará o crédito relativo às prestações anteriores, limitando-se a referir-se, no art. $155, \S 2^{\circ}$, II, $b$, às operações antecedentes à isenta ou não-tributada. Confira-se este ponto a seguir.

\subsubsection{O DIREITO À MANUTENÇÃO DO CRÉDITO DAS PRESTAÇÕES ANTE- RIORES À ETAPA ISENTA OU NÃO-TRIBUTADA.}

A CR/88, diferentemente de quando proíbe o transporte de créditos para as operações e prestações subseqüentes à isenta/não-tributada, determina a anulação dos créditos tão-somente das operações anteriores.

Tal distinção, como alerta MISABEL DERZI ${ }^{297}$, é de suma relevância. Afinal, se o constituinte quisesse ter determinado o estorno dos créditos das prestações de serviço de transporte e de comunicação gravados pelo ICMS, teria expressamente se referido também às prestações - e não apenas às operações, como fez o art. $155, \S 2^{\circ}$, II, $b$ (diferentemente da própria alínea $a$ do mesmo inciso, que veda o creditamento nas operações e prestações

\footnotetext{
${ }^{296}$ Veja-se a ementa:

"ICM. Estorno de crédito. Entrada de matéria-prima com isenção na saída, após a Emenda Constitucional. Não aproveitamento de crédito. EC 23 de 1983. Precedentes do Tribunal. Agravo a que se nega provimento. Min. MARCO AURÉLIO Vencido." (STF, Segunda Turma, RE-AgR n ${ }^{\circ}$ 270.827/SP, Relator Min. NELSON JOBIM, DJ 09.03.2001, p. 108).

${ }^{297}$ Preleciona a Catedrática da UFMG:

"Em caso de ser isenta a operação subseqüente, a anulação dos créditos somente será possível em relação a operações anteriores de circulação de mercadorias, não em relação a prestação de serviços de transporte e de comunicação." (BALEEIRO, Aliomar. Direito Tributário Brasileiro, $11^{\mathrm{a}}$ ed. Atualizado por MISABEL ABREU MACHADO DERZI. Rio de Janeiro: Forense, 2001, p. 422).
} 
subseqüentes). MISABEL DERZI ${ }^{298}$ seleciona, inter alii, os seguintes dispositivos da Constituição para demonstrar que, em todos, há sempre distinção entre operação e prestação para fins de incidência do ICMS, jamais havendo equiparação de prestação de serviço a operação de circulação de mercadoria:

"Art. 155. Compete aos Estados e ao Distrito Federal instituir impostos sobre:

(...)

II - operações relativas à circulação de mercadorias e sobre prestações de serviços de transporte interestadual e intermunicipal e de comunicação, ainda que as operações e as prestações se iniciem no exterior;" (destaques nossos)

“Art. 155. (...).

$\S 2^{\circ}$. O [ICMS] atenderá ao seguinte:

(...)

I - será não-cumulativo, compensando-se o que for devido em cada operação relativa à circulação de mercadorias ou prestação de serviços com o montante cobrado nas anteriores pelo mesmo ou outro Estado ou pelo Distrito Federal;

(...)

IV - resolução do Senado Federal, de iniciativa do Presidente da República ou de um terço dos Senadores, aprovada pela maioria absoluta de seus membros, estabelecerá as alíquotas aplicáveis às operações e prestações, interestaduais e de exportação;

(...)

VII - em relação às operações e prestações que destinem bens e serviços a consumidor final localizado em outro Estado, adotar-se-á:

a) a alíquota interestadual, quando o destinatário for contribuinte do imposto;

b) a alíquota interna, quando o destinatário não for contribuinte dele;" (destaques nossos)

Dos artigos transcritos denota-se que, onde a Constituição pretendeu tratar tanto do ICMS-mercadoria como do ICMS-serviços, ela o fez expressamente. É lícito, portanto, concluir que o silêncio da Constituição Federal em relação à prestação de serviços é eloqüente, pois a omissão é deliberada ${ }^{299}$. Assim, o intérprete não poderia alterar o sentido da Constituição.

298 BALEEIRO, Aliomar. Direito Tributário Brasileiro, $11^{\mathrm{a}}$ ed. Atualizado por MISABEL ABREU MACHADO DERZI. Rio de Janeiro: Forense, 2001, pp. 425-7.

${ }^{299}$ Nesse sentido é também a opinião de LUNARDELLI:

"Notem que a vedação é para o crédito relativo às operações anteriores; logo (...) não implicam o estorno do crédito relativo à contratação de serviços de comunicação ou de transporte. Isso por conta de uma divisão bastante evidente nas regras constitucionais do ICMS. Operações sempre referem-se às mercadorias sujeitas a este imposto, enquanto as prestações indicam apenas os serviços de comunicação e de transporte intermunicipal e interestadual." (LUNARDELLI, Pedro Guilherme Accorsi. Operações com Energia Elétrica e Serviços de Comunicação - Retorno ao Tema dos Créditos Físi- 
Todavia a questão é controversa, haja vista que tanto o Convênio ICM n ${ }^{\circ}$ 66/88 300 como a Lei Complementar $\mathrm{n}^{\text {o }} 87 / 96^{301}$ determinaram o estorno dos créditos também em relação às prestações anteriores à isenta ou não-tributada - não se atendo à literalidade da $\mathrm{CR} / 88$.

A matéria ainda não foi apreciada pelo Supremo Tribunal Federal. Contudo, uma decisão da Segunda Turma indica que, se eventualmente levada à apreciação do Plenário, a tese do direito à manutenção dos créditos de ICMS oriundos das prestações de serviço de transporte e comunicação anteriores à prestação isenta ou não-tributada pode lograr êxito. No precedente referido, ao assentar que uma indústria de papel não possuía direito de se creditar do ICMS incidente sobre insumos adquiridos porque suas saídas eram imunes (papel destinado à impressão de jornais, livros e periódicos ${ }^{302}$ ), o Min. GILMAR MENDES acompanhado pela unanimidade da Segunda Turma - fez questão de ressaltar a literalidade do art. $155, \S 2^{\circ}$, II, $b$ da CR/88:

"Segundo o artigo $155, \S 2^{\circ}$, II, $b$ da Constituição Federal, a isenção ou nãoincidência do ICMS, salvo determinação em contrário da legislação, 'acarretará a anulação do crédito relativo às operações anteriores'.

(...)

Logo, ante a literalidade do dispositivo constitucional, não merece prosperar a pretensão da agravante de aproveitar os créditos de ICMS das operações anteriores àquela considerada imune."303

Ora, se o argumento da literalidade do dispositivo foi utilizado para fazê-lo valer, pode e deve ser reiterado para não deixá-lo desbordar dos estritos limites em que foi posto pela Constituição.

Não obstante, labora em desfavor da tese referida a interpretação ampliativa que o STF conferiu à Emenda Passos Porto, ao dispor que a EC nº 23/83 também determinava -

cos e Financeiros. ROCHA, Valdir de Oliveira (coord.). O ICMS e a LC 102. São Paulo: Dialética, 2000, p. 191).

${ }^{300}$ Convênio ICM n ${ }^{\circ} 66 / 88$ :

"Art. 32. Salvo determinação em contrário da legislação, acarretará a anulação do crédito:

I - a operação ou prestação subseqüente, quando beneficiada por isenção ou não-incidência;"

${ }^{301}$ Lei Complementar no 87/96:

"Art. 21. O sujeito passivo deverá efetuar o estorno do imposto de que se tiver creditado sempre que o serviço tomado ou a mercadoria entrada no estabelecimento:

I - for objeto de saída ou prestação de serviço não-tributada ou isenta, sendo esta circunstância imprevisível na data da entrada da mercadoria ou da utilização do serviço;”

${ }^{302}$ Trata-se da imunidade prevista no art. 150, VI, $d$ da CR/88.

${ }^{303}$ STF, Segunda Turma, AI-ED no 468.900/RS, Relator Min. GILMAR MENDES, DJ 21.11.2008, p. 1.224. 
implicitamente - o estorno dos créditos de todas as operações anteriores (em que pese seu texto fazer referência tão-somente às operações subseqüentes). Se o Supremo Tribunal extraiu da Constituição anterior restrição não escrita à não-cumulatividade, poderia - em tese - também sustentar que, apesar de não expresso, o Constituinte implicitamente determinou o estorno dos créditos das prestações anteriores às isentas ou não-tributadas (o que abriria ampla margem para o arbítrio, já que seria extraído de uma norma restritiva de direitos um sentido contrário à sua interpretação literal).

Como já predicava MAXIMILIANO ${ }^{304}$, "a lei é a vontade transformada em palavras", cabendo ao intérprete buscar "o sentido imanente do texto e não o que o elaborador teve em mira”. Sendo assim, não nos parece razoável pretender extrair-se da CR/88 uma restrição à não-cumulatividade não escrita na Lei Maior. Com a palavra, o Supremo Tribunal Federal.

\subsection{NÃO-INCIDÊNCIA, ISENÇÃO, ALÍQUOTA ZERO E DIREITO AO CRÉDI- TO DO IPI.}

Sob a atual Carta, algumas discussões que se iniciaram de forma tímida há algumas décadas foram retomadas em matéria de IPI. Dentre os principais temas estão os referentes à manutenção do crédito do imposto na hipótese de saídas isentas, não-tributadas ou com alíquota zero, assim como a concessão de créditos presumidos nas saídas tributadas precedidas de aquisições isentas, não-tributadas ou com alíquota zero.

Tratam-se dos mesmos questionamentos que, à luz da Constituição de 1967-69, levaram à edição da Emenda Passos Porto, restringindo o alcance da não-cumulatividade em matéria de ICM.

Para apreender-se adequadamente o tratamento conferido pelo STF à questão, fazse mister definir o sentido e alcance de cada um dos institutos em exame, para somente então proceder-se à análise do mérito da existência ou não do direito ao crédito (real, na

${ }^{304}$ MAXIMILIANO, Carlos. Hermenêutica e Aplicação do Direito, 19ª ed. Rio de Janeiro: Forense, 2002, p. 23.

De mais a mais, o autor assim predica sobre a suposta "vontade" do legislador - in casu, do Constituinte que eventualmente se pretenda perquirir no curso do processo interpretativo:

"A vontade do legislador não será a da maioria dos que tomam parte na votação da norma positiva; porque bem poucos se informam, com antecedência, dos termos do projeto em debate; portanto, não podem querer o que não conhecem." (MAXIMILIANO, Carlos. Hermenêutica e Aplicação do Direito, $19^{\mathrm{a}}$ ed. Rio de Janeiro: Forense, 2002, pp. 19-20). 
hipótese de ingressos gravados e saídas não-tributados; e presumido, quando as entradas forem não-tributadas e as saídas com incidência do IPI).

\subsubsection{DEFINIÇÃO DOS INSTITUTOS.}

Os institutos da isenção, não-incidência e alíquota zero serão aqui analisados sob a ótica do Supremo Tribunal Federal, de modo a se permitir uma análise coerente da jurisprudência da Corte quanto ao creditamento do IPI em face dessas situações, como se fará a seguir.

Pois bem. Considera o STF que a isenção é dispensa legal de tributo devido. Ou seja: há incidência da norma tributária sobre o fato gerador que efetivamente ocorre no mundo fenomênico. Todavia, por força de uma norma secundária - isencional - que atua sobre a norma de tributação, tem-se a remissão do montante devido. Assim, a concessão de isenção equipara-se, sob a ótica do STF, ao próprio pagamento do tributo devido. Afinal, tendo havido incidência e, a posteriori, remissão do tributo e de todos os seus consectários, houve a extinção do crédito tributário com os mesmos efeitos que o pagamento ou qualquer outra causa extintiva predicada no art. 156 do CTN operaria. Essa interpretação não é recente, tendo sido construída ao longo de décadas perante a Suprema Corte, como alerta SACHA CALMON ${ }^{305}$.

Já a não-incidência consiste em situações fáticas não contempladas pela norma de tributação, decorrendo da abrangência limitada da própria norma tributária ${ }^{306}$. É o caso, por exemplo, das vendas de ativo imobilizado das indústrias, que refogem à tributação pelo ICMS por não serem mercadorias ${ }^{307}$ (Súmula 541/STF). Ou, então, das situações ao abrigo de imunidades, logo constitucionalmente impedidas de serem consideradas fatos geradores de obrigações tributárias (v.g., a não-incidência de impostos sobre livros, jornais, periódicos e o papel destinado à sua impressão, posta no art. 150, VI, $d$ da CR/88). A TIPI - Tabela de Incidência do Imposto sobre Produtos Industrializados, atualmente veiculada pelo

\footnotetext{
${ }^{305} \mathrm{O}$ jurista se opõe a esse entendimento acerca da isenção tributária, predicando que norma isencional impede o próprio nascimento da obrigação tributária - pelo que seria errônea a assertiva pretoriana de que isenção equivale à dispensa de tributo devido. (COÊLHO, Sacha Calmon Navarro. Curso de Direito Tributário Brasileiro, $9^{\mathrm{a}}$ ed. Rio de Janeiro: Forense, 2007, p. 362).

${ }^{306}$ STF, Pleno, ADI nº 286/RO, Relator Min. MAURÍCIO CORRÊA, DJ 30.08.2002, p. 60.

${ }^{307}$ Como leciona A. J. COSTA, "mercadoria é toda cousa móvel corpórea produzida para ser colocada em circulação, ou recebida para ter curso no processo de circulação". (COSTA, Alcides Jorge. ICM na Constituição e na Lei Complementar. São Paulo: Resenha Tributária, 1978, p. 99).
} 
Decreto $\mathrm{n}^{\circ}$ 6.006, de 28 de dezembro de 2006 - traz, em seu bojo, a indicação de cada um dos produtos sujeitos ao IPI com as respectivas alíquotas. Em muitos casos, indica-se que o produto é não-tributado (NT), por não ser considerado industrializado (sendo excluído, nesta hipótese, do alcance da norma de tributação do imposto federal).

A alíquota zero, a seu turno, é uma sistemática de tributação encontrada com freqüência na TIPI. Diferentemente dos produtos não-tributados, na alíquota zero tem-se a incidência da norma, estando presentes todos os elementos do antecedente da regra-matriz de incidência tributária. Entretanto, o dever tributário é inexistente, pois no conseqüente da norma o valor atribuído à alíquota é nenhum. Ou seja: a operação é gravada pelo imposto, mas não há tributo a pagar em decorrência da alíquota adotada ${ }^{308}$.

Assim, à luz da jurisprudência do STF, os institutos sub examine podem ser sumariados da seguinte forma:

\begin{tabular}{|c|c|c|c|}
\hline ISENÇÃO & $\begin{array}{c}\text { NÃO- } \\
\text { INCIDÊNCIA }\end{array}$ & $\begin{array}{c}\text { ALÍQUOTA } \\
\text { ZERO }\end{array}$ \\
\hline Conceito & $\begin{array}{c}\text { Dispensa legal de } \\
\text { tributo devido. }\end{array}$ & $\begin{array}{c}\text { Hipótese que não se } \\
\text { enquadra no antece- } \\
\text { dente da regra- } \\
\text { matriz de incidência. }\end{array}$ & $\begin{array}{c}\text { Atribuição de valor } \\
\text { nominal igual a zero } \\
\text { à alíquota (elemento } \\
\text { do critério quantita- } \\
\text { tivo do conseqüente } \\
\text { da regra-matriz de } \\
\text { incidência). }\end{array}$ \\
\hline $\begin{array}{c}\text { Incidência da } \\
\text { norma de } \\
\text { tributação }\end{array}$ & $\begin{array}{c}\text { Sim (a isenção é } \\
\text { norma externa e es- } \\
\text { tranha àquela que faz } \\
\text { surgir o dever tribu- } \\
\text { tário). }\end{array}$ & Não. & $\begin{array}{c}\text { Sim (a alíquota zero } \\
\text { atua no consequiente } \\
\text { e não no antecedente } \\
\text { da regra-matriz). }\end{array}$ \\
\hline $\begin{array}{c}\text { Dever tributário } \\
\text { remiste. Todavia, há } \\
\text { dência posterior da } \\
\text { norma isencional. }\end{array}$ & $\begin{array}{c}\text { Inexistente, pois a } \\
\text { norma tributária não } \\
\text { alcança a situação } \\
\text { abrigada pela não- } \\
\text { incidência. }\end{array}$ & $\begin{array}{c}\text { Inexistente, dado que } \\
\text { o critério quantitati- } \\
\text { vo é equiparado a } \\
\text { zero pela alíquota } \\
\text { aplicada. }\end{array}$ \\
\hline
\end{tabular}

Isto posto, passemos adiante.

6.9.2. O DIREITO À MANUTENÇÃO DOS CRÉDITOS DE IPI NAS SAÍDAS ISENTAS, NÃO-TRIBUTADAS E SUJEITAS À ALÍQUOTA ZERO. O ART. 11 DA LEI No 9.779/99.

\subsubsection{A QUAESTIO JURIS.}

\footnotetext{
${ }^{308}$ STF, Pleno, RE no 353.657/PR, Relator Min. MARCO AURÉLIO, DJe 06.03.2008, pub. 07.03.2008.
} 
A questão que inicialmente se pretende analisar é: a aquisição de insumos tributados pelo IPI, utilizados na fabricação de produtos isentos, não-tributados ou tributados à alíquota zero, exige o estorno dos créditos por parte do fabricante?

O tema não foi enfrentado com vagar pelo STF antes da Constituição de 1988. Conforme leciona MISABEL DERZI ${ }^{309}$, àquela época não havia grandes controvérsias em torno do direito ao crédito do IPI, eis que para tal imposto "as leis costumavam garantir os créditos - oferecendo até mesmo prêmios à exportação - em caso de não-incidência ou de isenção outorgada a uma das fases de industrialização". Nesse período, todavia, ao analisar a possibilidade de manutenção dos créditos do imposto federal quando a operação subseqüente fosse tributada com alíquota zero, a Corte, em dois casos, julgou contrariamente ao pleito dos contribuintes. Alegou o Tribunal que, inexistindo operação subseqüente tributada, não haveria que se falar em garantia ao crédito do imposto suportado pelo industrialadquirente $^{310}$. Tal decorre da diferenciação que o STF sempre efetuou entre isenção e alíquota zero, institutos que, apesar de produzirem idêntico resultado, diferenciam-se na teoria $^{311}$.

Apenas em matéria de ICM, após a edição da EC nº 23/83 a compra de produtos tributados para revenda com isenção ou não-incidência passou a demandar o estorno dos créditos do imposto estadual (em que pese a Passos Porto não ser explícita neste ponto,

309 BALEEIRO, Aliomar. Direito Tributário Brasileiro, $11^{\mathrm{a}}$ ed. Atualizado por MISABEL ABREU MACHADO DERZI. Rio de Janeiro: Forense, 2001, p. 354.

${ }^{310}$ No primeiro precedente, datado de março de 1985, a Corte manteve aresto do Tribunal Federal de Recursos que afirmara:

"No caso dos autos, trata-se de pretensão de crédito do IPI, que seria compensado na saída de produto com alíquota zero. Ora, em face desta situação, não é razoável reconhecer-se à Impetrante o direito de creditar-se da importância de um imposto a cujo pagamento não está sujeita (alíquota zero), pois a compensação do imposto recolhido com o imposto a recolher torna-se inviável.” (STF, Primeira Turma, RE n 99.825/SP, Relator Min. NÉRI DA SILVEIRA, DJ 05.09.1986, p. 15.834).

Pouco mais de um ano depois, em agosto de 1986, novamente a Primeira Turma rejeitou o pleito de manutenção dos créditos de contribuinte que adquirira insumos tributados (naquele caso, material de embalagem) para produção (acondicionamento) de produtos não sujeitos à tributação por força da alíquota zero:

“IMPOSTO SOBRE PRODUTOS INDUSTRIALIZADOS. ALÍQUOTA ZERO. CREDITAMENTO.

Ao negar o direito ao crédito do IPI, incidente sobre embalagens destinadas ao acondicionamento de produto sujeito a alíquota zero, no momento de saída do estabelecimento industrial, o acórdão recorrido não contrariou a regra constitucional da não-cumulatividade (art. $21, \S 3^{\circ}$ ), nem tampouco negou a vigência do art. 49 do Código Tributário Nacional. Dissídio jurisprudencial não configurado. Recurso extraordinário de que não se conhece." (STF, Primeira Turma, RE n 109.047/SP, Relator Min. OCTAVIO GALLOTTI, DJ 26.09.1986, p. 17.721).

${ }^{311}$ Este tema será tratado nos itens subseqüentes, quando da análise do posicionamento da Corte Suprema à luz da Constituição de 1988 sobre o direito ao crédito do IPI nas entradas e saídas com isenção, nãoincidência e alíquota zero. 
pois literalmente ela apenas vedava a concessão de crédito presumido de ICM quando houvesse aquisição de produtos isentos para revenda com tributação). Com a Constituição de 1988, ainda segundo o STF, teria havido um aclaramento da regra contida na EC $\mathrm{n}^{\mathrm{o}}$ 23/83, dispondo-se expressamente que a isenção ou não-incidência no ICMS "acarreta a anulação dos créditos relativos às operações anteriores" (art. 155, §2 ${ }^{\circ}$ II, $b$ da CR/88) ${ }^{312}$.

Nesse sendeiro, é lícito afirmar que as razões invocadas para negar-se o direito à manutenção dos créditos do ICM/ICMS quando as saídas são beneficiadas por isenção ou não-incidência não se aplicam ao imposto federal. Afinal, para o IPI nunca houve qualquer restrição constitucional ao aproveitamento dos créditos.

Assentadas essas premissas, impende agora analisar se o direito à manutenção dos créditos de IPI pelo contribuinte cujas saídas são isentas, não-tributadas ou gravadas com alíquota zero decorre diretamente da Constituição.

Para as saídas de produtos industrializados sem tributação ocorridas a partir de 1999, já vigorava a Lei $\mathrm{n}^{\circ}$ 9.779, de 19 de janeiro daquele ano. O diploma assegurou aos contribuintes do IPI que tivessem créditos do imposto acumulados ao longo de um trimestre, inclusive decorrentes de saída de produtos isentos ou não-tributados, a compensação com quaisquer outros tributos federais, na forma prescrita em $l \mathrm{ei}^{313}$.

Assim, o que se busca responder é: no período anterior à edição da Lei nº 9.779/99, fazem jus os contribuintes do IPI à manutenção, em sua escrita fiscal, dos créditos relativos às aquisições de insumos tributados utilizados no fabrico de produtos não gravados pelo imposto?

\subsubsection{A DECISÃO DA SUPREMA CORTE: INEXISTÊNCIA DE DIREITO AO APROVEITAMENTO DOS CRÉDITOS DE IPI SOBRE INSUMOS QUANDO O PRODUTO FINAL FOR ISENTO, NÃO-TRIBUTADO OU SUJEITO À ALÍQUO- TA ZERO DO IMPOSTO.}

\footnotetext{
${ }^{312}$ STF, Primeira Turma, RE no 125.106/SP, Relator Min. ILMAR GALVÃO, DJ 03.02.1995, p. 1.023.

${ }^{313}$ Lei no 9.779/99:

"Art. 11. O saldo credor do Imposto sobre Produtos Industrializados - IPI, acumulado em cada trimestre-calendário, decorrente de aquisição de matéria-prima, produto intermediário e material de embalagem, aplicados na industrialização, inclusive de produto isento ou tributado à alíquota zero, que o contribuinte não puder compensar com o IPI devido na saída de outros produtos, poderá ser utilizado de conformidade com o disposto nos arts. 73 e 74 da Lei $\mathrm{n}^{\mathrm{o}}$ 9.430, de 27 de dezembro de 1996, observadas normas expedidas pela Secretaria da Receita Federal do Ministério da Fazenda." (destaques nossos).
} 
Em maio de 2009 o Plenário do STF julgou conjuntamente os Recursos Extraordinários $n^{\circ} \mathrm{s} 460.785 / \mathrm{RS}^{314}, 475.551 / \mathrm{PR}^{315}$ e $562.980 / \mathrm{SC}^{316}$. Os três casos envolviam contribuintes cujas saídas eram isentas ou sujeitas à alíquota zero do IPI e que, por essa razão, estavam sendo compelidos a estornar os créditos do imposto acumulados em decorrência da aquisição de insumos tributados.

Por maioria, entendeu a Suprema Corte que, em razão da inexistência de duas operações subseqüentes tributadas, não haveria direito constitucional à manutenção dos créditos de IPI suportados pela indústria na aquisição dos insumos. Isso porque inexistiria cumulatividade, o que afastaria a necessidade de invocação da garantia constitucional. Nessa linha, o art. 11 da Lei $n^{\circ}$ 9.779/99, que permitiu não só a manutenção de tais créditos como também a sua compensação com outros tributos federais (nos termos do art. 74 da Lei $\mathrm{n}^{\circ}$ 9.430/96), teria inovado no ordenamento jurídico, não externando direito decorrente do princípio da não-cumulatividade.

Restaram vencidos os Ministros CEZAR PELUSO e RICARDO LEWANDOWSKI e, em parte, o Min. EROS GRAU. Sustentaram os dois primeiros que negar-se a manutenção do crédito pelo simples fato de a operação subseqüente ser isenta ou sujeita à alíquota zero viola a não-cumulatividade, constitucionalmente plasmada sem qualquer restrição para o IPI. Já o Min. EROS GRAU sustentou que apenas nos casos de saídas isentas haveria direito à manutenção dos créditos, em observância à jurisprudência da Suprema Corte que predica ser a isenção uma dispensa legal do tributo devido (o que pressupõe a incidência da norma de tributação gravando a operação que será isentada a posteriori logo, havendo incidência, ter-se-iam duas operações subsequientes tributadas, cumprindo com o requisito erigido pela maioria da Corte para a aplicação do princípio da nãocumulatividade).

Contudo, como já averbado, baseando-se na premissa de que a não-cumulatividade somente é aplicável quando existentes duas operações seguidamente gravadas pelo imposto, o STF entendeu pela inexistência de direito constitucional à manutenção dos créditos de IPI na hipótese em tela.

\footnotetext{
${ }^{314}$ STF, Pleno, RE no 460.785/RS, Relator Min. MARCO AURÉLIO, j. em 06.05.2009.

${ }^{315}$ STF, Pleno, RE n ${ }^{\circ}$ 475.551/PR, Relator p/ acórdão Min. MENEZES DIREITO, j. em 06.05.2009.

${ }^{316}$ STF, Pleno, RE n 562.980/SC, Relator p/ acórdão Min. MARCO AURÉLIO, j. em 06.05.2009.
} 


\subsubsection{O NOSSO ENTENDIMENTO.}

Data venia do posicionamento externado pela Corte, parece-nos que o art. 11 da Lei ${ }^{\circ}$ 9.779/99 apenas esclareceu um direito preexistente dos contribuintes, que se assentava tanto na jurisprudência pretérita do Supremo Tribunal Federal (em matéria de ICM, porém neste ponto aplicável ao IPI) como na redação da Constituição de 1988. A Lei Maior foi expressa ao determinar, para o ICMS, o estorno dos créditos relativos às operações anteriores às isentas ou não-tributadas. Contudo, a CR/88 não fez tal restrição ao IPI.

Houve apenas dois arestos nos quais, previamente à edição da Carta atual, o STF refutou o direito do contribuinte em manter na sua escrita os créditos de insumos e materiais de embalagem utilizados na produção ou acondicionamento de produtos tributados com alíquota zero. Tratam-se dos acórdãos prolatados no $\mathrm{RE} \mathrm{n}^{\mathrm{o}} 109.047 / \mathrm{SP}^{317}$ e no RE $\mathrm{n}^{\mathrm{o}}$ 99.825/SP ${ }^{318}$. Contudo, as decisões são respectivamente de 1985 e 1986, período anterior à consolidação da jurisprudência do Supremo sobre o alcance da Emenda Passos Porto em matéria de ICM. Concluiu o STF, ao cabo, que o direito de estorno dos créditos nas operações anteriores às isentas ou não-tributadas decorre da restrição imposta à nãocumulatividade do ICM na própria Constituição. Antes dessa vedação, averbou o Supremo, não haveria que se falar em estorno, sob pena de ferimento à não-cumulatividade. Dentre vários, citamos os seguintes acórdãos que corroboram tais assertivas: RE $n^{\circ}$ 125.106/SP (Primeira Turma, Relator Min. ILMAR GALVÃO, DJ 03.02.1995, p. 1.023); RE-AgR n ${ }^{\circ}$ 270.827/SP (Segunda Turma, Relator Min. NELSON JOBIM, DJ 09.03.2001, p. 108).

Assim, foi superada, no próprio âmbito do STF, a posição isolada adotada em dois arestos da Primeira Turma que, no caso do IPI, predicavam o estorno dos créditos de operações anteriores àquelas tributadas com alíquota zero. Pode-se afirmar, com plena convicção, que a atual jurisprudência do STF - firmada há mais de duas décadas - assegura o pleno direito ao crédito do IPI, independentemente de a saída ser ou não-tributada, eis que o imposto é, ademais, apurado por período de tempo e não produto a produto.

No caso do ICMS, repise-se, o estorno é devido posto que determinado pela Constituição de 1988 e, antes desta, implicitamente pela Emenda Passos Porto, como predica o aresto abaixo, prolatado em 2008:

"Segundo o art. $155, \S 2^{\circ}$, II, $b$ da Constituição Federal, a isenção ou nãoincidência do ICMS, salvo determinação em contrário da legislação, 'acarretará a anulação do crédito relativo às operações anteriores'.

\footnotetext{
${ }^{317}$ Primeira Turma, Relator Min. OCTAVIO GALLOTTI, DJ 26.09.1986, p. 17.721.

${ }^{318}$ Primeira Turma, Relator Min. NÉRI DA SILVEIRA, DJ 05.09.1986, p. 15.834.
} 
Neste sentido a Corte tem admitido o estorno de créditos de ICMS nos casos de imunidade ou isenção na saída das mercadorias, desde a Constituição anterior. (...).

Logo, ante a literalidade do dispositivo constitucional, não merece prosperar a pretensão da Agravante de aproveitar os créditos de ICMS das operações anteriores àquela considerada imune."319

Entendimento diverso, a nosso ver, diverge da jurisprudência há decênios firmada pelo STF no sentido de que, inexistindo limitação constitucional expressa, a nãocumulatividade deve ser mantida até mesmo pela concessão de créditos fictícios (do que não cuida a questão ora em comento, que versa apenas sobre a mantença de créditos reais na conta gráfica do contribuinte quando a mercadoria industrializada tiver saída sem tributação).

Ademais, estar-se-ia adotando, para fins de tal raciocínio, a sistemática de apuração produto-a-produto, olvidando-se que o quantum debeatur de IPI é obtido pelo somatório das entradas e saídas, tributadas ou não, em determinado período de tempo. Se houve aquisição de bem gravado pelo imposto, é direito do contribuinte escriturar o crédito em sua contabilidade. Se houve saída isenta ou não-tributada, inexistirá débito a compor o saldo do mês (que poderá ser credor ou devedor, havendo, na primeira hipótese, o transporte dos créditos acumulados para os períodos subseqüentes).

Retomando a temática da precitada Lei $\mathrm{n}^{\circ}$ 9.779/99, entendemos que ela não teve como objetivo apenas assegurar ao contribuinte do IPI a manutenção em sua escrita dos créditos do imposto quando suas saídas fossem não-tributadas (direito que, em nossa opinião, decorria da própria Constituição). A lei pretendia muito mais. $\mathrm{O}$ art. 11 do aludido texto normativo trouxe um importante e novo benefício aos pagantes do imposto: a permissão de compensação, com quaisquer outros tributos federais, dos créditos escriturais de IPI acumulados por mais de um trimestre.

Tal compensação não é aquela efetuada em conta gráfica para alcance do quantum debeatur do tributo devido em determinada competência, comum ao IPI e ao ICMS. Tratase da compensação extintiva do crédito tributário, plasmada no art. 156, II e nos arts. 170 e 170-A, todos do CTN, e regulamentada, no âmbito federal, pelo art. 74 da Lei $\mathrm{n}^{\circ}$ 9.430, de 27 de dezembro de $1996^{320}$.

\footnotetext{
${ }^{319}$ STF, Segunda Turma, AI-ED no 468.900/RS, Relator Min. GILMAR MENDES, DJ 21.11.2008, p. 1.224. ${ }^{320}$ Lei no ${ }^{\circ} 9.430 / 96$ :

"Art. 74. O sujeito passivo que apurar crédito, inclusive os judiciais com trânsito em julgado, relativo a tributo ou contribuição administrado pela Secretaria da Receita Federal, passível de restituição
} 
O direito à mantença dos créditos na conta escritural do contribuinte do IPI, mesmo nas hipóteses de saídas com isenção, alíquota zero ou não-incidência é, em nossa opinião, constitucionalmente irrestrito (ao contrário do que ocorre com o ICMS). Por tal razão, a parte do art. 11 da Lei no 9.779/99 que "permite" a manutenção do crédito referente aos insumos empregados na produção de bens isentos ou não-tributados vem sendo, há muito, tida como norma meramente interpretativa - cujos efeitos são, nos termos do art. 106, I do CTN, retroativos - pelo Superior Tribunal de Justiça ${ }^{321}$ (o que coaduna com o raciocínio que se está a expor).

Entrementes, a jurisprudência do STF que equipara isenção a pagamento do tributo fornece um argumento adicional para a manutenção dos créditos de IPI: como a saída foi devidamente tributada (tendo havido, em momento ulterior à tributação, a dispensa legal do imposto devido), não teria havido interrupção na cadeia de imposição do IPI apta a ensejar o estorno dos créditos até então acumulados. Entretanto, é de suma importância repisar que este é apenas um fundamento adicional. A regra da não-cumulatividade do IPI, que predica o abatimento do imposto pago nas operações anteriores, veda qualquer tentativa de mitigação do direito ao crédito na hipótese de existirem saídas não gravadas pelo imposto. Não se trata de compensação de imposto ficto, de concessão de crédito presumido. Tratase, isto sim, de aplicação pura e simples da não-cumulatividade, tal como plasmada pela Constituição de 1988 e interpretada pelo Supremo Tribunal Federal. Causou surpresa, dessarte, o entendimento da Corte relatado no item precedente, pugnando pela impossibilidade de manutenção dos créditos de IPI quando as saídas subseqüentes são isentas ou sujeitas à alíquota zero.

ou de ressarcimento, poderá utilizá-lo na compensação de débitos próprios relativos a quaisquer tributos e contribuições administrados por aquele Órgão.

$\S 1^{\circ}$. A compensação de que trata o caput será efetuada mediante a entrega, pelo sujeito passivo, de declaração na qual constarão informações relativas aos créditos utilizados e aos respectivos débitos compensados.

$\S 2^{\circ}$. A compensação declarada à Secretaria da Receita Federal extingue o crédito tributário, sob condição resolutória de sua ulterior homologação."

${ }^{321}$ Assim tem decidido o STJ:

"A primeira parte do artigo 11 da Lei no 9.779/99, que dispõe sobre a viabilidade do aproveitamento do crédito referente ao pagamento do IPI na aquisição do insumo empregado na industrialização de produto isento ou tributado a alíquota zero, tem caráter interpretativo, podendo operar efeitos retroativos para atingir operações anteriores ao seu advento, em conformidade com o que preceitua o artigo 106, inciso I, do CTN. Precedentes: EDcl no AgRg no AgRg no REsp nº 1.034.409/SP, Rel. Min. FRANCISCO FALCÃO, DJe de 20/10/08; REsp no 1.004.964/PR, Rel. Min. HUMBERTO MARTINS, DJ de 28/05/08 e REsp no 1.034.398/SP, Rel. Min. CASTRO MEIRA, DJ de 22/04/08." (STJ, Primeira Turma, ED-REsp $\mathrm{n}^{\circ} 1.010 .428 / \mathrm{SP}$, Relator Min. FRANCISCO FALCÃO, DJe 01.12.2008). 


\subsection{A CONCESSÃO DE CRÉDITOS PRESUMIDOS DE IPI AOS ADQUIREN- TES DE INSUMOS ISENTOS, NÃO-TRIBUTADOS E SUJEITOS À ALÍQUOTA ZERO.}

No primeiro precedente sobre o tema em epígrafe analisado pelo Plenário do STF sob a égide da Constituição de 1988, assegurou a Suprema Corte a concessão de créditos presumidos de IPI para o industrial que adquirira insumos isentos, utilizados na fabricação de produtos gravados pelo imposto federal.

Em que pese o voto contrário do Relator, Min. ILMAR GALVÃO, pugnando pelo não-reconhecimento do direito ao crédito, o Min. NELSON JOBIM instaurou divergência ao fundamento de que a isenção seria equiparada a um simples diferimento caso não conferido o crédito presumido na hipótese. Laborou com acerto o Min. JOBIM, eis que a isenção intercalar nos tributos não-cumulativos, como já visto alhures, importa em aumento do tributo a pagar - salvo se reconhecido o direito à apropriação de crédito presumido pelo adquirente das mercadorias isentas. E aumentando-se o imposto a pagar, eleva-se a carga suportada pelo consumidor final, que é o contribuinte de facto da exação. Em consonância com o voto de JOBIM, o Min. MARCO AURÉLIO lembrou que, durante dezoito anos (de 1965 a 1983) o IPI e o ICM gozaram de tratamento igualitário, tendo a multicitada Emenda Passos Porto acabado com a equiparação dos dois tributos. Sendo assim, a jurisprudência pretoriana em matéria de créditos presumidos do ICM - que levou à edição da EC nº 23/83 - é plenamente aplicável ao IPI, que subsiste na Constituição de 1988 com as mesmas garantias da não-cumulatividade que possuía - juntamente com o extinto ICM - quando da edição da EC nº 18/65. Por tal razão, MARCO AURÉLIO anuiu com a conclusão de JOBIM de que a concessão do crédito presumido é imprescindível para evitar que a isenção se torne inócua através da sua transformação em mero diferimento -. As palavras do Min. MARCO AURÉLIO merecem transcrição:

“(...) Não podemos confundir isenção com diferimento, nem agasalhar uma óptica que importe em reconhecer-se a possibilidade de o Estado dar com uma das mãos e retirar com a outra.

Dessa forma, sem que haja norma de estatura maior em tal sentido, porquanto o princípio da não-cumulatividade é constitucional, impossível é concluir-se pelo alijamento, em si, do crédito." 322

${ }^{322}$ STF, Pleno, RE nº 212.484/RS, Relator p/ acórdão Min. NELSON JOBIM, DJ 27.11.1998, p. 22. 
A ementa do acórdão, retratando o julgamento ocorrido no ano de 1998, assim dispôs:

"Não ocorre ofensa à CF (art. 153, $\S 3^{\circ}$, II) quando o contribuinte do IPI credita-se do valor do tributo incidente sobre insumos adquiridos sob o regime de isenção."323

Quatro anos depois, em 2002, o Plenário do Tribunal - agora sob a condução originária de JOBIM - retomou a discussão sobre os créditos presumidos de IPI. Todavia, a lide recaía, nessa oportunidade, sobre o direito ao crédito de materiais sujeitos à alíquota zero do imposto (é fato que, nos votos, há menção ao creditamento sobre insumos nãotributados; todavia, como posteriormente esclarecido em sede de embargos declaratórios, o caso concreto curava exclusivamente de tributação pela alíquota zero).

Relembrando o posicionamento da Corte em matéria de isenção, e equiparando-a à tributação pela alíquota zero e à não-incidência - afinal, o efeito, nos três casos, é a ausência de imposto a pagar - pugnou o Relator pela concessão dos créditos presumidos, no que foi acompanhado pela maioria dos componentes do Plenário, vencido o Ministro ILMAR GALVÃO. Todos os demais membros da Corte, embora reconhecendo a ontológica distinção entre isenção e alíquota zero, entenderam que, para não se transformar a ausência de tributação (que ocorre quando a União determina a alíquota zero para um produto) em um simples diferimento, é imperiosa a concessão do crédito presumido. Os excertos de votos a seguir valem ser lidos:

(a) Ministro NELSON JOBIM (Relator):

"Na verdade, entre a isenção e a alíquota zero, a distinção é meramente teórica. Na prática, os efeitos são semelhantes. Tributação à alíquota zero e isenção, como não-tributação, são hipóteses desonerativas. Em todas elas, o que afinal ocorre é o não recolhimento do tributo."

(b) Ministra ELLEN GRACIE:

“(...) A proibição constitucional introduzida pela Emenda Passos Porto (...) endereça-se claramente ao tributo estadual, ao ICMS. Relativamente ao IPI (...) existe jurisprudência firme desta Casa. O precedente que foi invocado pelas empresas [RE n ${ }^{\circ} 212.484 / \mathrm{SC}$ ] diz respeito à isenção, e os recursos extraordinários que agora discutimos cuidam de alíquota zero. Ambos, no entanto, são casos de desoneração fiscal.,"324

(c) Ministro SEPÚLVEDA PERTENCE:

\footnotetext{
${ }^{323}$ STF, Pleno, RE nº 212.484/RS, Relator p/ acórdão Min. NELSON JOBIM, DJ 27.11.1998, p. 22.

${ }^{324}$ STF, Pleno, RE n 350.446/PR, Relator Min. NELSON JOBIM, DJ 06.06.2003, p. 32.
} 
"A opção pela isenção ou pela alíquota zero e, conseqüentemente, a possibilidade de concessão da alíquota zero, é um mero problema de política fiscal legislativa: uma, para benefícios permanentes, e, outra, para adaptações à conjuntura econômica, que, a meu ver, não têm relevo nenhum na questão discutida com relação à posição do contribuinte."325

(d) Ministro SYDNEY SANCHES:

“(...) Enquanto o Supremo Tribunal Federal mantiver o entendimento adotado no RE $n^{\circ} 212.484$ (...), admitindo o creditamento de IPI em operação isenta, não poderá deixar de fazê-lo quando se tratar de operação nãotributada ou sujeita à alíquota zero. Para as mesmas conclusões, figuram as mesmas razões.",326

$\mathrm{O}$ aresto recebeu ementa nos seguintes termos:

"Se o contribuinte do IPI pode creditar o valor dos insumos adquiridos sob o regime de isenção, inexiste razão para deixar de reconhecer-lhe o mesmo direito na aquisição de insumos favorecidos pela alíquota zero, pois nada estrema, na prática, as referidas figuras desonerativas, notadamente quando se trata de aplicar o princípio da não-cumulatividade. A isenção e a alíquota zero em um dos elos da cadeia produtiva desapareceriam quando da operação subseqüente, se não admitido o crédito."327

Após esse acórdão, a questão passou a ser decidida monocraticamente no STF, às dezenas, sendo confirmada pelas Turmas em sede de agravos regimentais. Garantia-se aos contribuintes do IPI o direito ao crédito presumido na aquisição de insumos sujeitos à alíquota zero, ao argumento - verossímil, diga-se de plano - de que a não-concessão dos créditos importaria em majoração do imposto, decerto não objetivada pela norma que zerou a alíquota de um produto ${ }^{328}$.

Todavia, em todos esses casos a Procuradoria da Fazenda Nacional opunha embargos declaratórios, pedindo a atribuição de efeitos infringentes, na tentativa de reverter o

\footnotetext{
${ }^{325}$ STF, Pleno, RE n ${ }^{\text {o } 350.446 / P R, ~ R e l a t o r ~ M i n . ~ N E L S O N ~ J O B I M, ~ D J ~ 06.06 .2003, ~ p . ~} 32$.

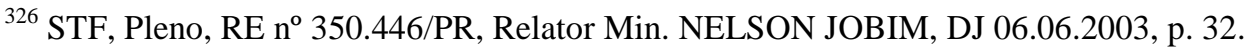

${ }^{327}$ STF, Pleno, RE n ${ }^{\text {o } 350.446 / P R, ~ R e l a t o r ~ M i n . ~ N E L S O N ~ J O B I M, ~ D J ~ 06.06 .2003, ~ p . ~} 32$.

${ }^{328}$ Inter alii, confira-se a seguinte decisão, prolatada pela Segunda Turma:

"O Plenário do Supremo Tribunal Federal reconheceu, em favor da empresa contribuinte, a existência do direito ao creditamento do IPI, na hipótese em que a aquisição de matérias-primas, insumos e produtos intermediários tenha sido beneficiada por regime jurídico de exoneração tributária (regime de isenção ou regime de alíquota zero), inocorrendo, em qualquer desses casos, situação de ofensa ao postulado constitucional da não-cumulatividade. Precedentes.” (STF, Segunda Turma, RE-AgR $\mathrm{n}^{\mathrm{o}}$ 293.511/RS, Relator Min. CELSO DE MELLO, DJ 21.03.2003, p. 63).
} 
posicionamento da Corte - e evitando, com isso, o trânsito em julgado de qualquer processo sobre o tema. Graças aos esforços da União Federal, em 2007 o Plenário voltou a analisar dois recursos extraordinários que curavam dos créditos presumidos de IPI concedidos para insumos sujeitos à alíquota zero ou não-tributados ${ }^{329}$ (em relação à isenção, não mais se voltou a discutir após a decisão prolatada em 1998 no $\mathrm{RE} \mathrm{n} \mathrm{n}^{\circ} 212.484 / \mathrm{SC}$ ).

Pois bem. Iniciadas as discussões ${ }^{330}$, o Ministro MARCO AURÉLIO (Relator), retomou seu entendimento anterior (que era pelo creditamento). Após argumentações de ordem econômica, em que se referia a um "esqueleto de bilhões de reais", o Ministro sustentou que a não-cumulatividade tributária exige, para que haja direito à compensação, a incidência de imposto na etapa anterior. Tal incidência se dá quando há isenção tributária, mas inexiste em se tratando de alíquota zero ou produtos não-tributados. Também modificando seu posicionamento, a Min. ELLEN GRACIE acompanhou MARCO AURÉLIO, diferençando isenção de alíquota zero, in verbis:

"Isenção (...) é, a rigor de técnica, exclusão de um imposto incidente. Já com a alíquota zero não surge obrigação de recolhimento (...). O montante devido (...) é igual a zero.,"331

Salientou ainda a Ministra que a isenção decorre necessariamente de lei (art. 150, $\S 6^{\circ}$ da $\mathrm{CR} / 88$ ), ao passo que a alíquota zero pode ser fixada por decreto. Com essas premissas, concluiu pela não concessão do direito ao crédito para insumos gravados com alíquota zero ou não-tributados, ainda que tal importe em majoração do imposto devido ao longo de toda a cadeia. Segundo o entendimento de GRACIE, o objetivo da aplicação da alíquota zero não seria desonerar o preço do produto final, mas sim estimular a produção do bem. No que tange aos produtos não-tributados, sustentou a Ministra que o fato de o seu fabricante não ser contribuinte do IPI - posto que o bem refoge à incidência do imposto implica a inexistência de qualquer obrigação de se conceder o crédito presumido (se a operação não é tributada, está fora da cadeia de circulação jurídica para fins de incidência do IPI, devendo, portanto, ser desconsiderada). Somados aos votos dos Ministros EROS GRAU, JOAQUIM BARBOSA, CARLOS BRITTO e CÁRMEN LÚCIA, formou-se a maioria de seis votos, que se sobrepôs aos argumentos dos cinco Ministros que ficaram

\footnotetext{
${ }^{329}$ Dessa vez, efetivamente compunha os processos a discussão sobre os insumos não tributados (NTs), que constou indevidamente no $\mathrm{RE} \mathrm{n}^{\mathrm{o}} 350.446 / \mathrm{PR}$, em que pese não ter sido ventilada pelas partes.

${ }^{330}$ Gize-se que o Tribunal possuía composição diferente daquela de 2002, quando o Plenário reconhecera o crédito presumido sobre insumos sujeitos à alíquota zero.

${ }^{331}$ STF, Pleno, RE no 353.657/PR, Relator Min. MARCO AURÉLIO, DJ 07.03.2008, p. 502.
} 
vencidos (NELSON JOBIM, CÉZAR PELUSO, SEPÚLVEDA PERTENCE, RICARDO LEWANDOWSKI e CELSO DE MELLO).

Assim, fixou-se no âmbito do STF a posição de que a diferença ontológica entre isenção (dispensa de tributo devido), não-incidência (hipótese que refoge à norma de tributação) e alíquota zero (incidência com resultado nulo) deve ser considerada para fins de aplicação do princípio da não-cumulatividade tributária em matéria de IPI, concedendo-se crédito presumido apenas nas aquisições de produtos isentos.

Ora, é inegável a diferença ontológica entre os institutos. Todavia, como o próprio STF apontara anteriormente, a aplicação prática dos três institutos no bojo de um tributo não-cumulativo importa resultados idênticos. Em sendo assim, dever-se-ia aplicar a regra ubi ratio, ibi dispositio, mantendo-se o aresto prolatado em 2002 - então infenso aos argumentos econômicos ventilados pela União Federal quando do rejulgamento da lide em 2007. Por todos, esposando nosso posicionamento quanto à questão, valemo-nos de excertos do voto do Min. CELSO DE MELLO que, apesar de vencido, alcançou a questão com percuciência e clareza:

"Qualquer que seja a definição conceitual que se dê à alíquota zero - quer para assimilá-la à isenção (como entendem os eminentes Professores MISABEL DERZI e PAULO DE BARROS CARVALHO), quer para distingui-la, enquanto noção ontologicamente diversa, do fenômeno isentivo (como sustenta o eminente Professor SACHA CALMON) - o que se revela inquestionável é que as conseqüências que derivam da alíquota zero são idênticas, em termos econômicos, aos efeitos peculiares à isenção, o que permite dispensar-lhes o mesmo tratamento, em ordem a considerar presente, quanto a ambas, a existência do direito ao crédito.

(...)

Também partilho do entendimento de que a categoria exonerativa pertinente à não-tributação expõe-se ao mesmo regime jurídico-tributário concernente à isenção, daí derivando, quanto aos produtos não-tributados, as conseqüências comuns e peculiares ao benefício isencional."332

Na hipótese de produtos não-tributados (NTs) pelo IPI, o Min. CELSO DE MELLO adotou o raciocínio expendido pelo também vencido Min. CÉZAR PELUSO. Este dividiu os produtos NTs em três categorias:

(a) não-tributados por ausência de competência tributária (como ocorre com os produtos imunes ao IPI ou que não se enquadram no conceito de "industrializados");

(b) não-tributados por não estarem incluídos na lei que determina a incidência do IPI (em que pese ter a União competência para tanto);

${ }^{332}$ STF, Pleno, RE nº 353.657/PR, Relator Min. MARCO AURÉLIO, DJ 07.03.2008, p. 502. 
(c) não-tributados por expressa disposição legal.

Para MELLO e PELUSO, a primeira situação não geraria, de fato, crédito presumido do IPI, posto que seria alheia "ao ciclo econômico tomado como pressuposto de fato do imposto". Todavia, as hipóteses "b" e "c" seriam equiparáveis à isenção, pois decorreriam de uma clara opção do legislador pela não-tributação de produtos que poderiam ser, a prio$r i$, gravados pelo IPI.

Tal posicionamento parece-nos acertado a mais não poder: independentemente dos conceitos jurídicos de isenção, alíquota zero ou os produtos NTs, no âmbito da nãocumulatividade tributária a manutenção dos créditos é medida que se impõe, sob pena de majoração do imposto a pagar ao longo da cadeia e de quebra da neutralidade tributária, ferindo-se, com tal, o art. $153, \S 3^{\circ}$, II da CR/88.

Contudo, por apertada maioria, o entendimento que prevaleceu foi o abaixo ementado:

“IPI. INSUMO. ALÍQUOTA ZERO. AUSÊNCIA DE DIREITO AO CREDITAMENTO.

Conforme disposto no inciso II do $\S 3^{\circ}$ do artigo 153 da Constituição Federal, observa-se o princípio da não-cumulatividade compensando-se o que for devido em cada operação com o montante cobrado nas anteriores, ante o que não se pode cogitar de direito a crédito quando o insumo entra na indústria considerada a alíquota zero."333

Sendo assim, os argumentos econômicos - claramente expostos no voto do Min. MARCO AURÉLIO - fizeram com que uma decisão Plenária do STF prolatada há menos de cinco anos fosse revista, em detrimento do princípio da não-cumulatividade. Com isso, a informação na TIPI de que um insumo se sujeita à alíquota zero ou é não-tributado passou a representar um mero diferimento do IPI devido pelos seus fabricantes, que não terão créditos a compensar porém pagarão o imposto sobre o valor integral de suas saídas, elevando o montante total de IPI pago no ciclo econômico.

Permanece, entretanto, a indagação acerca da mantença do posicionamento do STF quanto ao crédito presumido na aquisição de insumos isentos do IPI. Apesar de os votos diferençarem tal instituto da alíquota zero e da não-tributação, no final do ano de 2008 o STF reconheceu a existência de repercussão geral em um recurso extraordinário que cura do tema ${ }^{334}$, ainda não submetido à apreciação, no mérito, pelo Plenário.

\footnotetext{
${ }^{333}$ STF, Pleno, RE no 353.657/PR, Relator Min. MARCO AURÉLIO, DJ 07.03.2008, p. 502.

${ }^{334}$ STF, Plenário Virtual, RE no 590.809/RS, Relator Min. MARCO AURÉLIO, repercussão geral reconhecida em 14.11.2008.
} 
Como o STF - contrariando sua jurisprudência de décadas - entendeu que a isenção não pressupõe tributação no caso em que negou o direito à escrituração dos créditos de IPI quando as saídas do estabelecimento forem isentas, há o risco de a Suprema Corte reformar seu entendimento também no que tange à concessão de créditos presumidos sobre insumos isentos utilizados no fabrico de materiais tributados.

Espera-se que tal não ocorra. Do contrário, será necessário rever o conceito jurisprudencial de isenção (sempre classificada pelo STF como dispensa de tributo devido) para assimilá-lo à alíquota zero. Ademais, será definitivamente institucionalizado que, mesmo sendo a apuração por período de tempo, inexistirá direito à compensação do imposto pago nas etapas anteriores quando determinada saída não for sujeita à tributação. Ambas as conseqüências são graves e representariam um incremento na instabilidade jurisprudencial das Cortes Superiores.

\subsection{O DIFERIMENTO E A NÃO-CUMULATIVIDADE.}

\subsubsection{A AUSÊNCIA DE DIREITO A CRÉDITOS PRESUMIDOS PELO ADQUI- RENTE DOS PRODUTOS COM TRIBUTAÇÃO POSTERGADA.}

Os créditos presumidos concedidos anteriormente à EC no 23/83 para os contribuintes adquirentes de materiais isentos ou não-tributados geraram outro pleito reflexo: o da concessão de créditos presumidos quando a mercadoria ingressar no estabelecimento do comprador sob o abrigo do diferimento do então ICM, ocasionalmente concedido ao produtor-vendedor.

Ocorre que o diferimento não exclui o crédito tributário nem retrata uma operação que refoge ao espectro da norma tributária. Assim, não se confunde com a isenção (visualizada pelo STF como dispensa legal de tributo devido e equiparável ao pagamento por ser causa extintiva do crédito tributário) ${ }^{335}$ ou com a não-incidência (hipótese na qual não se configuram os pressupostos do fato gerador da exação). Em verdade, o diferimento apenas

\footnotetext{
${ }^{335}$ O CTN utiliza o verbo "excluir". Veja-se:

"Art. 175. Excluem o crédito tributário:

I - a isenção;"
}

Ao comentar o dispositivo, IVES GANDRA averba que "na isenção, como na anistia e na remissão, nasce a obrigação tributária, apenas o crédito (art. 139 do CTN) sendo excluído, a teor do art. 175 do CTN (...)." (MARTINS, Ives Gandra da Silva. O Princípio da Não-Cumulatividade e os Princípios da Subvenção Pública e da Neutralidade. MACHADO, Hugo de Brito (coord.). Não-Cumulatividade Tributária. São Paulo: Dialética; Fortaleza: ICET, 2009, p. 243). 
retarda a incidência da exação, que grava a etapa subseqüente de circulação da mercadoria, por inteiro.

Em matéria de ICMS, é usual que haja diferimento na venda de produtos rurais in natura para a indústria. Com isso, o produtor fica desobrigado do pagamento do imposto, que será recolhido pelo industrial quando da venda da mercadoria manufaturada. Trata-se, portanto, de uma típica substituição tributária para trás, em que o imposto devido pelo agricultor fica diferido para a etapa subseqüente (saída do produto do estabelecimento industrial).

Como o diferimento não foi criado para beneficiar o contribuinte-substituto, assentou-se no âmbito do STF o entendimento de que não é devida a concessão de crédito presumido nessa hipótese ${ }^{336}$. De fato, no diferimento há apenas a substituição do sujeito passivo (rectius, responsável) pelo pagamento da obrigação tributária, como também pugnou o STF em outros arestos sobre o tema ${ }^{337}$.

O que ocorre no diferimento é a instituição de um terceiro (o adquirente) como responsável pela recolha do imposto devido pelo vendedor. Se o que há é pura e simples modificação do pólo passivo da relação jurídico-tributária, não é lícito pleitear-se créditos

${ }^{336}$ É o que se dessume dos arestos abaixo transcritos, da Primeira e Segunda Turmas do STF: "ICM. LEITE 'IN NATURA'. DIFERIMENTO DO TRIBUTO. CONVÊNIO ICM 07/77.

- O diferimento da incidência do ICM não ofende o princípio constitucional da não-cumulatividade do tributo. Inadequação do crédito presumido na mecânica do diferimento. Precedentes do STF. Recurso extraordinário conhecido e provido." (STF, Primeira Turma, RE nº 97.283/BA, Relator Min. RAFAEL MAYER, DJ 22.10.1982, p. 10.742). "TRIBUTÁRIO. ICM. DIFERIMENTO. CREDITAMENTO.

Se apenas houve o diferimento do ICM, cabendo o pagamento total do imposto, em consequiência, para a oportunidade da saída do produto do estabelecimento que o industrializou - e não havendo autorização legal expressa para que haja o creditamento do valor do tributo quando da entrada da mercadoria - não há razão para tal creditamento. É que com o diferimento não ocorreu o pagamento do ICM naquela ocasião da entrada da mercadoria e, portanto, inexiste razão para o pretendido creditamento. Precedentes. Agravo regimental improvido." (STF, Segunda Turma, AI-AgR n 93.907/SP, Relator Min. ALDIR PASSARINHO, DJ 18.04.1986, p. 5.990).

${ }^{337}$ Confira-se o seguinte trecho do voto do Min. CUNHA PEIXOTO no RE $n^{\circ}$ 91.848/SP:

"Realmente, o diferimento não se confunde com a isenção ou imunidade, já que nele a obrigação tributária surge desde logo, ao realizar-se a operação de circulação da mercadoria; o que não se perfaz, desde logo, é a sua exigibilidade, transferida para outra ocasião.

Pela própria natureza do instituto do diferimento, o fornecedor da matéria-prima não recolhe o ICM, à sua saída; o adquirente é que passa a ser responsável pelo tributo, mas não o paga neste momento, fazendo-o posteriormente, por ocasião da saída do produto final." (STF, Primeira Turma, RE no 91.848/SP, Relator Min. CUNHA PEIXOTO, DJ 21.03.1980, p. 1.554).

No mesmo sendeiro, o Min. ALDIR PASSARINHO assim fundamentou seu posicionamento no RE $\mathrm{n}^{\circ}$ 102.354/SC:

"O diferimento (...) não implica em isenção do ICM na operação anterior, mas simples transferência do momento do recolhimento, e não há cumulatividade do produto porque não há pagamento duplo do tributo referente àquela primeira operação, exatamente pela razão de que não houve qualquer recolhimento do tributo sobre ela." (STF, Segunda Turma, RE n ${ }^{\circ}$ 102.354/SC, Relator Min. ALDIR PASSARINHO, DJ 23.11.1984, p. 19.927). 
presumidos para utilização pelo adquirente. Assim, concordamos com a solução dada pelo STF ao tema, haja vista que o pressuposto do diferimento é transferir a tributação para a etapa subseqüente, o que não seria alcançado se um crédito fictício fosse outorgado ao responsável pela recolha do imposto.

Entretanto, os julgados até aqui referidos não arrostam o problema relativo ao direito do alienante-substituído manter, em sua escrita fiscal, os créditos do imposto relativos aos ingressos tributados (compra de maquinário agrícola, insumos utilizados nas plantações, et caterva). Tal questão somente foi enfrentada pelo Supremo Tribunal à luz da Constituição de 1988, tendo o STF assegurado aos produtores rurais a mantença dos créditos em sua escrita físcal. Apenas não autorizou a Suprema Corte, à míngua de lei estadual, a transferência desses créditos a terceiros ${ }^{338}$.

Confira-se.

\subsubsection{O DIREITO À MANUTENÇÃO DOS CRÉDITOS PELOS ALIENANTES DOS PRODUTOS COM TRIBUTAÇÃO DIFERIDA. IMPOSSIBILIDADE, TODA- VIA, DE TRANSFERÊNCIA DOS CRÉDITOS A TERCEIROS SEM LEI AUTO- RIZATIVA.}

Como visto, o diferimento pressupõe tributação. A exação devida em determinado estádio do processo produtivo é recolhida noutro momento subseqüente ${ }^{339}$.

Sendo assim, inexiste óbice para que, na operação diferida, o alienante (beneficiado pelo diferimento) mantenha os créditos resultantes dos ingressos tributados em seu estabelecimento. Em tal hipótese, o adquirente dos produtos (que recolherá o imposto às burras

\footnotetext{
${ }^{338} \mathrm{O}$ pleito de transferência foi formulado pelos contribuintes sujeitos ao diferimento porque a sua maioria (formada por produtores rurais) não possui débitos do imposto estadual. Como praticamente todas as saídas têm tributação diferida, ocorre um acúmulo constante de créditos (oriundos das aquisições tributadas para o ativo permanente, para utilização como insumos nas lavouras, etc) que remanescem sem utilização.

339 BARROS CARVALHO vislumbra três possibilidades de diferimento nos impostos plurifásicos nãocumulativos: como isenção, quando houver mutilação no critério temporal da hipótese impedindo a norma de alcançar determinada situação; como simples postergação da data de pagamento; e como substituição tributária para trás. Esta última é a configuração dada pelo STF à norma que institui o diferimento em matéria de ICMS. Confira-se, nas palavras de BARROS CARVALHO, a definição do diferimento enquanto modalidade de substituição tributária:

“(...) Será verdadeira substituição tributária a hipótese de diferimento onde houver postergação do instante para pagamento do tributo, transferindo-se a obrigação fiscal para o sujeito que realiza a etapa subseqüente da cadeia de positivação. Aí, a regra-matriz permanece intacta em todos os seus aspectos, podendo incidir e dar nascimento a outras obrigações tributárias. Apenas a exigibilidade do cumprimento dessa relação jurídica é que será adiada, verificando-se em momento posterior, por sujeito passivo diverso daquele que praticou o fato jurídico tributário." (CARVALHO, Paulo de Barros. Direito Tributário, Linguagem e Método. São Paulo: Noeses, 2008, p. 656).
} 
estatais) não terá o direito de se creditar do montante cobrado nas operações anteriores, sob pena de se transformar o diferimento em um benefício fiscal - afinal, como tais créditos já serão aproveitados pelo vendedor, caso o adquirente também pudesse fazê-lo haveria redução - e não mera postergação - da carga tributária.

Sob as luzes da Constituição de 1988, o STF preservou o seu posicionamento pretérito de não conceder créditos presumidos de ICMS ao adquirente de produtos com tributação diferida. O aresto abaixo foi prolatado sob a condução da Min. ELLEN GRACIE:

"O regime de diferimento, ao substituir o sujeito passivo da obrigação tributária, com o adiamento do recolhimento do imposto, em nada ofende o princípio da não-cumulatividade. (...). Na hipótese dos autos, a saída da produção dos agravantes não é tributada pelo ICMS, pois sua incidência é diferida para a próxima etapa do ciclo econômico. Se nada é recolhido na venda da mercadoria, não há que se falar em efeito cumulativo. (...). Se a entrada da mercadoria não é tributada, não há créditos a compensar na saída."340

Neste mesmo acórdão, apreciou-se também a questão da manutenção do crédito por parte do alienante sujeito ao diferimento. Assentou a Corte que o produtor rural faz jus à escrituração dos créditos do imposto decorrentes da aquisição de insumos e bens do ativo tributados. Todavia, não há direito à transferência de tais créditos ao adquirente dos produtos caso o agricultor sujeito ao diferimento não consiga utilizá-los (pelo fato de a totalidade das suas saídas ser diferida). Confira-se trecho da ementa que esclarece o raciocínio da Corte:

“4. O atacadista ou industrial, ao comprar a produção dos agravantes, não recolhe o ICMS, portanto não escritura qualquer crédito desse imposto. Se a entrada da mercadoria não é tributada, não há créditos a compensar na saída. 5. Impertinente a invocação do princípio da não-cumulatividade para permitir a transferência dos créditos de ICMS, referente à compra de insumos e maquinário, para os compradores da produção agrícola, sob o regime de diferimento." 341

Os seguintes excertos do voto da Min. GRACIE são ainda mais aclaradores. Inicialmente, o pleito dos produtores agrícolas é delineado:

"Alegam os agravantes [plantadores de soja] que (...) o ICMS arrecadado na aquisição de insumos e maquinário agrícolas essenciais para sua cultura deixa de ser creditado, pois, na saída de seus produtos, não recolhem o imposto, tendo em vista que a responsabilidade pertence ao comprador. Esses créditos, então, ficam perdidos, o que onera a produção e gera efeito cumulati-

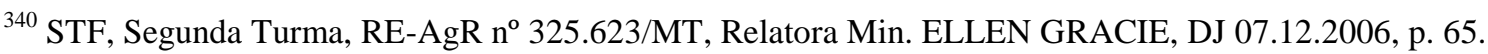

${ }^{341}$ STF, Segunda Turma, RE-AgR no 325.623/MT, Relatora Min. ELLEN GRACIE, DJ 07.12.2006, p. 65.
} 
vo do ICMS, em afronta ao disposto no art. $155, \S 2^{\circ}$, I da Constituição Federal.

O Tribunal a quo, acolhendo os argumentos dos agravantes e para evitar a perda desses créditos, concedeu a segurança para 'assegurar aos adquirentes o direito (...) de transferirem seus créditos tributários relativos e originários de insumos agrícolas aos adquirentes dos produtos da atividade rural $(\ldots), ., 342$

E, na seqüência, é rechaçado:

"Na hipótese dos autos, a saída da produção dos agravantes não é tributada pelo ICMS, pois, como explicado acima, sua incidência é diferida, postergada, para a próxima etapa do ciclo econômico.

(...)

Da mesma forma, o atacadista ou industrial, ao comprar a produção dos agravantes, não recolhe o ICMS, portanto não escritura qualquer crédito deste imposto em seus livros. Em resumo, se a entrada da mercadoria não é tributada, não há créditos a compensar na saída.

(...)

Os agravantes, ao venderem a soja por eles plantada, não recolheram ICMS, por isso seus compradores - atacadistas e exportadores - nada têm a compensar. É, assim, impertinente a invocação do princípio da nãocumulatividade para permitir a transferência dos créditos de ICMS, referentes à compra de insumos e maquinário, para os compradores da produção agrícola, sob o regime de diferimento." 343

A decisão do Tribunal foi acertada ao reconhecer, ainda que por via oblíqua, o direito de preservação dos créditos de ICMS (oriundos da aquisição de insumos e bens do ativo gravados pelo imposto) pelo alienante de mercadorias com tributação diferida. De fato, a saída com diferimento não significa não-incidência (que exigiria o estorno dos créditos do alienante). Tal diferenciação foi assentada pelos Ministros NELSON JOBIM, CARLOS VELLOSO e JOAQUIM BARBOSA no julgamento do RE n 199.147/RJ, tendo este último averbado:

"[No diferimento] não há propriamente desoneração por isenção ou mera não-incidência do tributo. O que há é o deslocamento da responsabilidade pelo pagamento do tributo para outro sujeito passivo, posicionado em outra etapa do ciclo produtivo." 344

\footnotetext{
${ }^{342}$ STF, Segunda Turma, RE-AgR n 325.623/MT, Relatora Min. ELLEN GRACIE, DJ 07.12.2006, p. 65.

${ }^{343}$ STF, Segunda Turma, RE-AgR n ${ }^{\circ}$ 325.623/MT, Relatora Min. ELLEN GRACIE, DJ 07.12.2006, p. 65.

${ }^{344}$ STF, Pleno, RE no 199.147/RJ, Relator p/ acórdão Min. MARCO AURÉLIO, DJ 14.11.2008, p. 564.
} 
Segundo os Ministros citados, o diferimento pressupõe a ocorrência da hipótese de incidência do tributo - exatamente porque posterga, e não impede, a sua exigência.

A definição é acertada, justificando a manutenção dos créditos relativos às aquisições tributadas feitas pelo alienante beneficiado pelo diferimento do imposto.

Outrossim, parece-nos também correta a vedação de transferência dos créditos acumulados a terceiros $^{345}$. Tal somente seria possível se existisse lei estadual autorizativa da medida. Não parece dessumível do princípio da não-cumulatividade um direito de cessão do saldo credor quando este não puder ser integralmente utilizado pelo contribuinte. Afinal, a não-utilização decorre de uma opção negocial, feita livremente pelo empresário, de atuar exclusivamente em um ramo no qual a tributação é diferida (como o agronegócio, v.g.). Se ele exercesse outras atividades (tais como a compra-e-venda de insumos agrícolas), seria possível dar vazão aos créditos acumulados na atividade com tributação diferida. Do contrário, a solução será recorrer a planejamentos societários, como cisões e incorporações, para fins de aproveitamento de créditos escriturais acumulados ${ }^{346}$.

\subsection{A VEDAÇÃo AO CRÉDITO EM CASO DE PERECIMENTO DA MERCA- DORIA.}

Problema interessante é o do direito ao aproveitamento do crédito de ICM referente à entrada de mercadoria que, por furto, roubo, incêndio ou qualquer eventualidade, perece, não havendo posterior saída do estabelecimento comercial (e não gerando, via de conseqüência, débito de imposto a pagar). Em tais hipóteses, o STF não reconhece o direito ao aproveitamento do crédito escriturado pela entrada do bem que, a posteriori, pereceu. Segundo a Corte, o comerciante torna-se consumidor final com a perda da mercadoria, tendo, por conseguinte, o dever de suportar o ônus do imposto ${ }^{347}$.

${ }_{345}$ Posição externada pelo STF no multicitado RE-AgR nº 325.623/MT.

${ }^{346}$ Na Europa, a Diretiva 2006/112/CE do Conselho autoriza os Países a restituírem em dinheiro o IVA acumulado em determinada competência:

"Artigo $183^{\circ}$

Quando o montante das deduções exceder o montante do IVA devido relativamente a um período de tributação, os Estados-Membros podem efectuar o reporte do excedente para o período seguinte, ou proceder ao respectivo reembolso nas condições por eles fixadas.

Todavia, os Estados-Membros podem não autorizar o reporte ou o reembolso quando o excedente for insignificante." (destaques nossos)

${ }^{347}$ Eis a ementa de um dos acórdãos sobre a questão:

"ICM. PRODUTOS ADQUIRIDOS PELA EXECUTADA E ULTERIORMENTE DESTRUIDOS POR INCÊNDIO.

A obrigatoriedade do estorno correspondente à entrada não infringe o princípio constitucional da não-cumulatividade (art. 23, II), uma vez que o perecimento das mercadorias, no próprio estabele- 
A justificativa da decisão é singela: a não-cumulatividade pressupõe uma série de etapas encadeadas que irão resultar no consumo final da mercadoria. Se a plurifasia é interrompida em determinado momento pela perda ou destruição do produto, então a última operação (de entrada no estabelecimento em que o mesmo pereceu) não pode gerar crédito. Sob essa ótica, como não se completou o ciclo predicado pela Constituição para fazer valer a cadeia débito-crédito, o comerciante transmuda-se em consumidor final ${ }^{348}$.

Nada mais errôneo e contrário aos próprios precedentes do Supremo Tribunal acerca da matéria. Afinal, já se havia assentado que o imposto é apurado por período de tempo e não mercadoria a mercadoria. Também se decidira que, por tal característica, os créditos e débitos deveriam ser controlados em uma conta gráfica, de natureza e fins contábeis. Ao se legitimar o estorno dos créditos de mercadorias que pereceram no estabelecimento do contribuinte (como na hipótese analisada, em que houve um incêndio), mitiga-se a nãocumulatividade sem justificativa plausível para tanto (o crédito estava escriturado e a saída não ocorreu por caso fortuito, logo inimputável ao contribuinte). Trata-se, sobremais, de uma determinação injusta, penalizando duplamente o comerciante que, além de ver perecer as suas mercadorias, perderá os créditos sobre o ICMS cobrado na etapa anterior.

Perquirindo com vagar os motivos que levaram o STF a adotar tal posicionamento, pode-se dizer que o Tribunal agiu no intuito de mitigar as fraudes contra o erário. Afinal, a se conferir aos contribuintes o direito de manutenção dos créditos do imposto nas hipóteses de perda das mercadorias, bastaria a alegação de que o produto perecera para o comerciante desobrigar-se do pagamento do ICMS. E, nesse caso, não bastasse a sonegação na saída, o infrator ainda manteria o crédito referente à exação suportada quando do ingresso da mercadoria em seu estabelecimento. Com a determinação de estorno do crédito, a fraude passa a ser menos lucrativa ${ }^{349}$.

cimento do comerciante, importa a ruptura das etapas de circulação que compõem o ciclo da tributação.” (STF, Primeira Turma, RE n 105.666/SP, Relator Min. OCTAVIO GALLOTTI, DJ 06.12.1985, p. 22.585).

No mesmo sentido, vale mencionar: STF, Primeira Turma, RE nº 113.395/SP, Relator Min. OCTAVIO GALLOTTI, DJ 07.08.1987, p. 15.441.

${ }^{348}$ No precedente citado na nota de rodapé anterior, o seguinte trecho do voto do Relator demonstra claramente que o perecimento da mercadoria transforma o comerciante em consumidor final:

"A deterioração, o perecimento, a destruição da mercadoria são circunstâncias excepcionais que acarretam a quebra do encadeamento natural de etapas, na tributação do ICM, equiparando-se ao consumo de mercadoria, pela sua precoce retirada de circulação." (STF, Primeira Turma, RE n 105.666/SP, Relator Min. OCTAVIO GALLOTTI, DJ 06.12.1985, p. 22.585).

${ }^{349}$ É o que se dessume da seguinte passagem do RE nº 87.078/MA: 
Ora, adotar-se como premissa para a negativa do direito ao crédito que a maior parte dos contribuintes é formada por sonegadores equivale a sustentar que todo o sistema fiscalizatório instituído para assegurar a arrecadação tributária é insuficiente - além de incorrer-se no grave equívoco de tomar a exceção pela regra. Podemos afirmar, com MISABEL DERZI ${ }^{350}$, que a boa-fé e a confiança presidem a relação entre EstadoAdministração e contribuinte. Nessa linha, quando o Judiciário legitima norma estatal editada em prejuízo de todos mas dirigida apenas aos sonegadores, tem-se flagrante descompasso com os princípios condutores da relação entre os Poderes constituídos e o cidadão.

Ademais, a se coadunar com o raciocínio expendido pelo STF no caso em tela, até mesmo quando o estabelecimento do contribuinte fosse furtado ou roubado haveria vedação ao aproveitamento dos créditos referentes aos bens subtraídos pelos meliantes. Afinal, as etapas de circulação jurídica da mercadoria efetivamente se encerram com o furto ou roubo, inexistindo operação posterior a legitimar o creditamento ${ }^{351}$. A conclusão é injurídica, sobre ser injusta como referido alhures. Todavia, decorre do entendimento manifestado pelo Supremo Tribunal em relação à matéria.

\subsection{A EXPORTAÇÃO E O DIREITO À MANUTENÇÃo DOS CRÉDITOS ES- CRITURAIS DE IPI E ICMS.}

A Constituição assegura a não-incidência do IPI e do ICMS na exportação de mercadorias e serviços. Para o IPI a regra foi desde sempre ampla, imunizando toda e qualquer venda para o estrangeiro de produtos industrializados:

“Art. 153. (...).

$\S 3^{\circ}$. O [IPI]:

III - não incidirá sobre produtos industrializados destinados ao exterior.”

"Admita-se que a legislação estadual possa determinar o estorno do imposto pago sobre mercadorias que hajam perecido ou se deteriorado. Aí, a providência visa a evitar o desvio de mercadorias sem pagamento do imposto ulterior, sob pretexto de fatos aleatórios como o perecimento ou a deterioração.” (STF , Pleno, RE nº 87.078/MA, Relator Min. DÉCIO MIRANDA, DJ 24.08.1979).

\footnotetext{
${ }^{350}$ Leciona MISABEL DERZI que a boa-fé objetiva é "fonte de deveres da Administração Tributária e dos contribuintes”. (DERZI, Misabel Abreu Machado. Modificações da Jurisprudência no Direito Tributário. São Paulo: Noeses, 2009, p. 601).

No mesmo sendeiro, confira-se: GUIMARÃES, Vasco Branco. A Responsabilidade Civil da Administração Fiscal Emergente da Obrigação de Pagar Imposto. Belo Horizonte: Fórum, 2007, p. 287-9.

${ }^{351}$ Consoante visto anteriormente, a ausência de operação posterior exigiria, no entender da Suprema Corte, o estorno dos créditos relativos à mercadoria perecida.
} 
Os contribuintes do IPI nunca enfrentaram óbices para a manutenção, em sua escrita contábil, dos créditos relativos às aquisições tributadas de insumos utilizados em produtos posteriormente exportados. Ademais, com o intuito de estimular a indústria nacional, foram criados por lei créditos-prêmio e presumidos de IPI para os exportadores, compensáveis inclusive com outros tributos federais, o que denota o esforço da União em prol do export drive $e^{352}$.

Já em matéria de ICMS nem todas as exportações foram imunizadas pelo Constituinte de 1988, que inicialmente restringiu a benesse às vendas de produtos industrializados para o estrangeiro ${ }^{353}$. Os intitulados "produtos semi-elaborados" - que se situavam entre as matérias-primas e as mercadorias industrializadas - foram excluídos da regra imunizante. Confira-se o texto original da CR/88:

“Art. 155. (...).

$\S 2^{\circ}$. O [ICMS]:

$\mathrm{X}$ - não incidirá:

a) sobre operações que destinem ao exterior produtos industrializados, excluídos os semi-elaborados definidos em lei complementar."

Outrossim, foi atribuído ao legislador complementar do ICMS o poder de "excluir da incidência do imposto, nas exportações para o exterior, serviços e outros produtos além dos mencionados no inciso X, 'a'” (art. 155, §2 $, \mathrm{XII}, e)$.

Nesta fase inicial, competia também à lei complementar definir as hipóteses nas quais haveria a manutenção dos créditos de ICMS quando os produtos e serviços fossem exportados para o exterior:

“Art. 155. (...).

$\S 2^{\circ} .(\ldots)$.

\footnotetext{
${ }^{352}$ O intitulado crédito-prêmio do IPI foi instituído pelo art. $1^{\circ}$ do Decreto-lei no $491 / 69$. Tratava-se (há divergências sobre a sua vigência até os dias de hoje) da concessão de créditos sobre o valor das vendas para o mercado externo, que podiam ser compensados com o IPI eventualmente devido em razão de operações internas praticadas pela empresa. Se o IPI interno não fosse suficiente para absorção integral do crédito-prêmio, o exportador poderia compensá-lo com débitos de outros tributos federais. $O$ valor do benefício era calculado mediante multiplicação do preço dos produtos exportados pela alíquota que seria aplicável em caso de venda no mercado interno, com teto de $15 \%$ (art. $2^{\circ}$ do Decreto-lei $n^{\circ} 491 / 69$ ).

Já o crédito presumido de IPI, em verdade, é uma forma de se compensar o exportador pela incidência da contribuição para o PIS e da COFINS sobre os insumos adquiridos no mercado interno e utilizados no processo produtivo das mercadorias vendidas para o estrangeiro. Foi instituído pela Lei ${ }^{\circ}$ 9.363/96, sendo calculado mediante a multiplicação do porcentual de 5,37\% sobre o valor total das aquisições de matériasprimas, produtos intermediários e material de embalagem utilizados na produção destinada à exportação (para chegar-se à base de cálculo do incentivo, aplica-se o porcentual de exportações da empresa sobre o valor de todas as aquisições de insumos no mercado interno - art. $2^{\circ}$, caput e $\S 1^{\circ}$ da Lei $\left.n^{\circ} 9.363 / 96\right)$. Para maiores detalhes, vide o Título III, Capítulo XI, Itens 11.4.7.2 e 11.5.
}

${ }^{353}$ Vale relembrar que a Constituição de 1988 foi editada sob o pálio de forte lobby para incremento das receitas dos Estados-membros. 
XII - cabe à lei complementar:

f) prever casos de manutenção de crédito, relativamente à remessa para outro Estado e exportação para o exterior, de serviços e de mercadorias;"

A norma possuía razão de ser, uma vez que o art. $155, \S 2^{\circ}$, II, $b$ determina a anulação dos créditos de ICMS das operações anteriores àquela isenta ou não-tributada. Como a imunidade é um caso típico de não-incidência, a regra era o estorno dos créditos acumulados pelo exportador, salvo disposição de lei em contrário - exatamente a função atribuída à lei complementar pelo art. 155, §2 $2^{\circ}$ XII, $f$ (o Convênio ICM nº 66/88 e as Leis Complementares $n^{\circ}$ s $65 / 91$ e 87/96 cumpriram tais papéis ${ }^{354}$ ).

Posteriormente, com a Emenda Constitucional n ${ }^{\circ}$ 42, de 19 de dezembro de 2003, o dispositivo teve sua redação modificada, assegurando expressamente a manutenção dos créditos de ICMS cobrados nas operações e prestações anteriores à exportação:

“Art. 155. (...).

$\S 2^{\circ}$. O [ICMS]:

$\mathrm{X}$ - não incidirá:

a) sobre operações que destinem mercadorias para o exterior, nem sobre serviços prestados a destinatários no exterior, assegurada a manutenção e o aproveitamento do montante do imposto cobrado nas operações e prestações anteriores;"

${ }^{354}$ Durante o período em que vigorou, o Convênio ICM n ${ }^{\circ}$ 66/88 isentava do imposto estadual a exportação de produtos industrializados (art. $3^{\circ}$, I). Contudo, autorizava a manutenção dos créditos de ICMS relativos a insumos adquiridos para o fabrico de tais produtos, desde que fossem listados em convênio:

“Art. 34 Não se exigirá a anulação do crédito por ocasião das saídas para o exterior dos produtos industrializados constantes de lista que será definida em convênio específico, na forma da Lei Complementar $n^{\circ} 24$, de 7 de janeiro de 1975, relativamente à entrada de mercadorias para utilização como matéria-prima ou material intermediário ou secundário na fabricação e embalagem dos produtos exportados."

Já a Lei Complementar $n^{\circ}$ 65/91 (que, em seu art. $1^{\circ}$, definiu o conceito de produto semi-elaborado, que estaria fora da regra isencional dos produtos destinados ao exterior) assim dispunha:

“Art. $3^{\circ}$. Não se exigirá a anulação do crédito relativo às entradas de mercadorias para utilização como matéria-prima, material secundário e material de embalagem, bem como o relativo ao fornecimento de energia e aos serviços prestados por terceiros na fabricação e transporte de produtos industrializados destinados ao exterior."

A seu turno, a Lei Complementar $n^{\circ}$ 87/96 foi além, isentando do ICMS todo e qualquer serviço ou produto destinado ao exterior, inclusive os semi-elaborados (art. $3^{\circ}$, II). Quanto à manutenção dos créditos relativos a insumos adquiridos para a prestação do serviço ou fabricação do produto exportado, também atuou em benefício dos exportadores:

"Art. 32. A partir da data de publicação desta Lei Complementar:

II - darão direito de crédito, que não será objeto de estorno, as mercadorias entradas no estabelecimento para integração ou consumo em processo de produção de mercadorias industrializadas, inclusive semi-elaboradas, destinadas ao exterior;" 
O hodierno texto constitucional é condizente com o princípio da nãocumulatividade e com a regra mundial de desoneração das exportações ${ }^{355}$. O desenvolvimento de um país depende da inserção dos seus produtos e serviços no mercado global. Por essa razão a EC n 42/03 assegurou, de forma ampla, a manutenção dos créditos de ICMS pelos exportadores. A Carta faz menção também ao aproveitamento de tais créditos pelos contribuintes. Assim, na hipótese de empresas predominantemente exportadoras (ou seja, que acumulem constantemente créditos do imposto), deverá haver um mecanismo que permita a utilização dos créditos (a transferência a terceiros foi a saída encontrada pelo legislador pátrio ${ }^{356}$ ).

Vale lembrar, entretanto, que no IVA-europeu a regra aplicável em situações como tais é a devolução, em dinheiro, do valor suportado a título de imposto pelo exportador.

${ }^{355}$ O ponto de vista de XAVIER merece ser transcrito. Para o jurista, a manutenção dos créditos de ICMS na exportação "deriva de um princípio autônomo do da não-cumulatividade, que é o de assegurar à imunidade eficácia integral". Continua o autor:

“As regras em causa nada têm que ver com o princípio da não-cumulatividade (...). Antes, são corolário lógico de outro princípio distinto e autônomo - o princípio da tributação exclusiva pelo país de destino, o qual, ao invés, exige a manutenção de tais créditos como forma de assegurar a total exoneração de imposições fiscais no país de origem. (...). O princípio do país do destino (...) exige que as exportações saiam do país exportador com um conteúdo fiscal nulo." (XAVIER, Alberto Pinheiro. Regime Constitucional das Isenções e Incentivos Fiscais às Exportações: o Caso do ICMS. Do Direito à Utilização Integral de Saldo Acumulado de Créditos de ICMS como corolário da Imunidade das Exportações. TORRES, Heleno Taveira (coord.). Tratado de Direito Constitucional Tributário: estudos em homenagem a Paulo de Barros Carvalho. São Paulo: Saraiva, 2005, pp. 611-3).

Discordamos apenas da parte em que o autor sustenta inexistir identidade entre o princípio da nãocumulatividade e o direito à manutenção dos créditos escriturais na exportação. Ora, não fosse a exceção à não-cumulatividade do ICMS plasmada na CR/88 (de resto inexistente para o IPI), a manutenção de tais créditos poderia decorrer, sim, da não-cumulatividade. Apenas a sua utilização efetiva - via transferência a terceiros, que foi a opção do legislador pátrio - é decorrente, de forma exclusiva, do princípio do país de destino. Não obstante, tal regra contribui para a realização, em sua plenitude, dos fins objetivados pela nãocumulatividade tributária.

${ }^{356}$ Assim dispôs a Lei Complementar no 87/96 em relação ao saldo credor de ICMS acumulado pelos exportadores:

“Art. 25. (...).

$\S 1^{\circ}$. Saldos credores acumulados a partir da data de publicação desta Lei Complementar por estabelecimentos que realizem operações e prestações de que tratam o inciso II do art. $3^{\circ}$ e seu parágrafo único podem ser, na proporção que estas saídas representem do total das saídas realizadas pelo estabelecimento:

I - imputados pelo sujeito passivo a qualquer estabelecimento seu no Estado;

II - havendo saldo remanescente, transferidos pelo sujeito passivo a outros contribuintes do mesmo Estado, mediante a emissão pela autoridade competente de documento que reconheça o crédito."

Ou seja: garantiu o legislador complementar o aproveitamento do saldo credor de ICMS eventualmente não utilizado pelo exportador em face da ausência de débitos compensáveis. Por outro lado, no que tange aos créditos acumulados em decorrência de outros fatores - que não a exportação - a Lei Kandir apenas delegou aos Estados a faculdade de viabilizar ou não seu aproveitamento, via transferência a terceiros:

"Art. 25. (...).

$\S 2^{\circ}$. Lei estadual poderá, nos demais casos de saldos credores acumulados a partir da vigência desta

Lei Complementar, permitir que:

I - sejam imputados pelo sujeito passivo a qualquer estabelecimento seu no Estado;

II - sejam transferidos, nas condições que definir, a outros contribuintes do mesmo Estado.” 
Com isso, obtém-se verdadeira neutralidade fiscal e desoneração da cadeia produtiva, permitindo ao produto nacional ter maior competitividade em face dos estrangeiros.

Entrementes, mesmo não determinando a restituição em espécie, a EC no 42/03 trouxe importante norma para o desenvolvimento do País, assegurando de forma geral e irrestrita a efetivação do princípio da não-cumulatividade nas exportações de serviços (de comunicação e transporte interestadual e intermunicipal) e de quaisquer categorias de produtos (sejam primários, semi-elaborados ou industrializados). Afinal, a vedação de manutenção dos créditos acumulados pelo exportador ou, ainda, a inexistência de formas práticas para efetivamente utilizar-se o saldo credor gera cumulatividade residual, mitigando a plena aplicação do princípio constitucional regente do IPI e do ICMS.

\subsection{O ICMS E A PROBLEMÁTICA DA EQUIPARAÇÃO, À ISENÇÃO, DA RE- DUÇÃO DE BASE DE CÁLCULO.}

Diversas leis estaduais - e tal fato não é recente - intentam restringir o valor do crédito a ser aproveitado pelo contribuinte, condicionando-o à existência de um débito (gerado pela saída da mercadoria) de, no mínimo, valor idêntico ao da entrada. Ocorre que a não-cumulatividade se opera de forma plena, por período de tempo, não sendo lícita a redução do valor a creditar em razão da saída de um produto específico ocorrer por preço inferior ao de aquisição. Tal prática - venda abaixo do preço de custo - é comum principalmente em empresas que lidam com grandes volumes de vendas ao varejo. É até usual que determinados produtos sejam comercializados em valor inferior ao de custo no intuito de atrair o público para as lojas de determinada empresa. Sendo assim, nessas vendas específicas o empresário terá direito de crédito superior ao valor do débito gerado na operação de venda. Nenhum problema há quanto a isso, sendo inconstitucionais as leis estaduais que pretendam mitigar a não-cumulatividade neste ponto ${ }^{357}$.

Já nas hipóteses em que a mercadoria é vendida ao abrigo de isenção ou nãoincidência, deverá o contribuinte anular os créditos das operações anteriores, salvo disposição de lei em contrário, como de resto predica o art. 155, §2 , II, $b$ da atual Carta. Contudo, tal lógica (estorno dos créditos) também se aplica quando a saída ocorre com redução de base de cálculo?

A Suprema Corte, operando a distinção entre redução de base de cálculo, isenção e não-incidência, sempre entendeu - até uma decisão Plenária de 2005, como visto supra -

\footnotetext{
${ }^{357}$ Para maiores detalhes sobre o tema, vide o item subseqüente, 6.14.2.
} 
que seria legítima a manutenção integral dos créditos de ICMS nas saídas com base de cálculo reduzida, posto que esta não se confunde com isenção ou não-incidência (hipóteses nas quais o dever de estorno do imposto estadual é previsto na própria Constituição).

A redução da base de cálculo é correntemente utilizada para fazer valer a seletividade do ICMS, como ocorre com os produtos da cesta básica, que gozam de tal benefício. Com isso, reduz-se o quantum debeatur. O efeito é o mesmo obtido quando da redução de alíquotas - apenas a forma eleita para tanto é diversa ${ }^{358}$.

A redução de base de cálculo não se confunde, em nenhuma hipótese, com a isenção. Tal assertiva é confirmada pela análise do art. $150, \S 6^{\circ}$ da CR/88, que estipula:

“Art. 150. (...).

$\S 6^{\circ}$. Qualquer subsídio ou isenção, redução de base de cálculo, concessão de crédito presumido, anistia ou remissão, relativos a impostos, taxas ou contribuições, só poderá ser concedido mediante lei específica, federal, estadual ou municipal, que regule exclusivamente as matérias acima enumeradas ou o correspondente tributo ou contribuição, sem prejuízo do disposto no art. $155, \S 2 .^{\circ}, \mathrm{XII}, \mathrm{g} . ”$

Os objetivos da norma são dois:

(a) determinar que subsídios, isenções, reduções de base de cálculo, concessões de crédito presumido, anistia ou remissão de tributos sejam sempre concedidos por lei específica;

(b) reforçar que, em matéria de ICMS, para além da lei estadual é imperiosa a celebração prévia de Convênio, nos moldes da Lei Complementar no 24/75 (à qual remete $\mathrm{o}$ art. $\left.155, \S 2^{\circ}, \mathrm{XII}, g\right)$.

A forma pela qual o dispositivo constitucional foi redigido denota com clareza que a isenção (dispensa legal de tributo devido, sob a ótica da Suprema Corte) difere da redução da base de cálculo (na qual a obrigação tributária já nasce reduzida, eis que há uma mutilação no critério quantitativo do conseqüente da norma tributária). Tanto é que foi necessária a referência a ambos os institutos no $\S 6^{\circ}$ do art. 150 da Constituição (e, como predica a boa técnica hermenêutica, a Lei Maior não abriga palavras desnecessárias, do que se dessume que os institutos em lume são, de fato, distintos).

Desde o advento da EC no 23/83, o Supremo Tribunal Federal tem sido claro ao decidir que apenas a isenção - e nunca a redução da base de cálculo - determina o estorno dos créditos de ICMS das operações anteriores.

\footnotetext{
${ }^{358} \mathrm{Na}$ venda de mercadorias usadas a redução da base de cálculo do ICMS é também bastante utilizada, chegando a reduzir até $95 \%$ da base tributável quando comparada com a do mesmo bem ainda novo.
} 
Coerente com tal raciocínio, em 1997 o Plenário do STF assentou que "conflita com o princípio da não-cumulatividade norma vedadora da compensação do valor recolhido na operação anterior”. Segundo entendimento da Corte, “os preceitos das alíneas 'a' e 'b' do inciso II, do $\S 2^{\circ}$ do art. 155 da Constituição Federal somente têm pertinência em caso de isenção ou não-incidência, institutos inconfundíveis com o benefício fiscal em questão"359.

De fato, sendo a não-cumulatividade em matéria de ICMS mitigada tão-somente nas hipóteses de operações isentas ou não-tributadas, não se pode impor ao contribuinte que goze do benefício da redução de base de cálculo o estorno dos créditos acumulados.

A redução da base imponível equivale, em seus efeitos tributários, à venda de mercadoria abaixo do preço de aquisição. Com a diferença de que, neste último caso, o contribuinte opta livremente por alienar as mercadorias abaixo do preço de custo, ao passo que no primeiro é o Estado quem determina a utilização de base inferior à efetivamente praticada pelo alienante. Com base nessa analogia, pode-se asseverar que a jurisprudência já consolidada pela Corte Suprema - que impede a exigência do estorno proporcional de créditos quando da venda de bens por valor inferior ao de aquisição - é aplicável, em tudo, aos casos em que há redução da base de cálculo do ICMS.

Posteriormente à assentada Plenária de 1997, diversos outros arestos da Suprema Corte corroboraram tal entendimento sob o pálio da CR/88. Confira-se a seguinte ementa da Primeira Turma:

"TRIBUTÁRIO. REDUÇÃO DA BASE DE CÁLCULO. BENEFÍCIO FISCAL. CRÉDITO. COMPENSAÇÃO. POSSIBILIDADE. PRINCÍPIO DA NÃO-CUMULATIVIDADE. OBSERVÂNCIA.

Benefício fiscal outorgado a contribuinte. Crédito decorrente da redução da base de cálculo do tributo. Vedação. Impossibilidade. A Constituição Federal somente não admite o lançamento do crédito nas hipóteses de isenção ou não-incidência. Precedente do Tribunal Pleno. Agravo regimental não provido." 360

Entretanto, em março de 2005, a Corte máxima mudou inopinadamente seu entendimento ao único argumento de que a redução da base de cálculo equivaleria a uma isenção parcial. Sendo assim, a saída com redução da base se submeteria à restrição imposta à não-cumulatividade do ICMS pelo art. $155, \S 2^{\circ}, b$ da CR/88. É ver a ementa que, a despei-

\footnotetext{
${ }^{359}$ STF, Pleno, RE no 161.031/MG, Relator Min. MARCO AURÉLIO, DJ 06.06.1997, p. 24.881.

${ }^{360}$ STF, Primeira Turma, AI-AgR no 418.412/RS, Relator Min. EROS GRAU, DJ 15.10.2004, p. 5. No mesmo sentido decidiu também a Segunda Turma no RE-AgR n $240.395 / R S$, Relator Min. MAURÍCIO CORRÊA, DJ 02.08.2002, p. 101.
} 
to da necessária previsibilidade das decisões das Cortes Superiores ${ }^{361}$, rompeu com o entendimento pretérito e consolidado do STF:

"Imposto sobre Circulação de Mercadorias. ICMS. Créditos relativos à entrada de insumos usados em industrialização de produtos cujas saídas foram realizadas com redução da base de cálculo. Caso de isenção fiscal parcial. Previsão de estorno proporcional. (...). Aplicação do art. $155, \S 2^{\circ}$, inc. II, letra 'b', da CF.",362

Após o aviamento de embargos declaratórios, a Corte Suprema reafirmou seu novo posicionamento, ementando que:

"O Supremo Tribunal Federal entrou a aproximar as figuras da redução da base de cálculo do ICMS e da isenção parcial, a ponto de as equiparar, na interpretação do art. 155, § 2º II, 'b', da Constituição da República.”363

No aresto que julgou os aclaratórios, o Relator, Min. CEZAR PELUSO, reconheceu e sustentou a radical inflexão no entendimento da Suprema Corte:

"A atual posição da Corte parece-me, portanto, bastante clara: a redução da base de cálculo do ICMS corresponde a isenção parcial e, não, como outrora se considerava, categoria autônoma em relação assim à da isenção, como à da não-incidência. Observe-se que a interpretação dada pela Corte ao art. $155, \S 2^{\circ}$, II, $b$, não representa ampliação do rol de restrições ao aproveitamento integral do crédito de ICMS, que permanece circunscrito às hipóteses de não-incidência e isenção; entendeu-se, simplesmente, que a isenção entra nesta última classe, como isenção parcial, que é em substância." 364

De fato, equiparar-se a redução de base de cálculo à isenção parcial leva à inexorável conclusão pela obrigatoriedade de estorno dos créditos proporcionais à diminuição da base tributável. Portanto, somente nas hipóteses em que a lei estadual autorizar a manutenção do crédito pelo alienante de mercadorias com base de cálculo reduzida é que ele estará autorizado a não realizar o estorno proporcional. Tal conclusão foi reafirmada pelo STF quando do julgamento da $\mathrm{ADI} \mathrm{n}^{\mathrm{o}} 2.320 / \mathrm{SC}^{365}$, na qual foi declarada a constitucionalidade

${ }^{361}$ Sobre a segurança jurídica na seara jurisprudencial, averba MISABEL DERZI:

“(...) A mesma técnica, os mesmos critérios de segura aplicação do princípio da irretroatividade das leis devem reger a irretroatividade das modificações jurisprudenciais. É evidente que a confiança está pressuposta, como confiança sistêmica, difusa. Todos devem acreditar, crer, confiar honestamente nos comandos do legislador e dos tribunais superiores." (DERZI, Misabel Abreu Machado. Modificações da Jurisprudência no Direito Tributário. São Paulo: Noeses, 2009, pp. 567-8).

${ }^{362}$ STF, Pleno RE no 174.478/SP, Relator p/ acórdão Min. CEZAR PELUSO, DJ 30.09.2005, p. 5.

${ }^{363}$ STF, Pleno, RE-ED n ${ }^{\circ}$ 174.478/SP, Relator Min. CEZAR PELUSO, DJe 29.05.2008, pub. 30.05.2008.

${ }^{364}$ STF, Pleno, RE-ED no 174.478/SP, Relator Min. CEZAR PELUSO, DJe 29.05.2008, pub. 30.05.2008.

${ }^{365}$ STF, Pleno, ADI nº 2.320/SC, Relator Min. EROS GRAU, DJ 16.03.2007, p. 19. 
de dispositivo de lei catarinense que dispensava o vendedor de estornar os créditos relativos à diferença entre o valor da entrada da mercadoria e a saída com redução da base de cálculo ou isenção. Assim, a regra, para ambas as hipóteses, é o estorno, sendo o creditamento em sua integralidade a exceção.

De notar que o Min. MARCO AURÉLIO restou vencido no RE no 174.478/SP, em que a jurisprudência do Supremo foi modificada em desfavor dos contribuintes. Salientou o Ministro que “o preceito das alíneas ' $a$ ' e ' $b$ ' do inciso II do $§ 2^{\circ}$ do artigo 155 da Carta da República encerra restrição ao princípio da não-cumulatividade", pelo que "a ele somente cabe emprestar interpretação restritiva". Mesmo sendo voto vencido, sua posição era - a nosso sentir - a correta por duas razões:

(a) as restrições à não-cumulatividade devem ser interpretadas de forma nãoampliativa, como predica a boa técnica hermenêutica em se tratando de mitigações a direitos assegurados pela Constituição;

(b) existe diferença ontológica essencial entre isenção e redução de base de cálculo.

Analisemos com maior vagar ambas as assertivas, que denotarão de forma hialina o desacerto da inflexão jurisprudencial perpetrada pelo STF em 2005 e mantida até a data presente $^{366}$.

\subsubsection{A CONSTITUIÇÃO E A INTERPRETAÇÃO DAS REGRAS RESTRITIVAS DE DIREITOS.}

Em acórdão datado de 1966, o Pleno do STF averbou que "as leis concessivas de isenções tributárias devem ser restritivamente interpretadas"367. A causa foi julgada antes do advento do Código Tributário Nacional, que trouxe regra expressa nesse sentido ${ }^{368}$. E por qual razão a Suprema Corte decidiu dessa forma? Porque a isenção limita o poder tributante do Estado. De fato, não há sentido em conferir-se interpretação ampliativa a um

\footnotetext{
${ }^{366}$ Diversos arestos posteriores ao RE $\mathrm{n}^{\circ}$ 174.478/SP têm seguido o posicionamento do Plenário sobre o tema. Da Primeira Turma, aponte-se o RE $n^{\circ}$ 205.262/SP, Relator Min. MENEZES DIREITO, DJe $\mathrm{n}^{\circ} 157$, pub. 22.08.2008; da Segunda Turma, tem-se o RE-AgR no 478.605/RS, Relator Min. EROS GRAU, DJe no 112, pub. 20.06.2008.

${ }^{367}$ STF, Pleno, RMS n 10.004/GB, Relator Min. ADALÍCIO NOGUEIRA, RTJ v. 36-3, p. 328.

${ }^{368}$ Reza o CTN, que adveio posteriormente à citada decisão:

"Art. 111. Interpreta-se literalmente a legislação tributária que disponha sobre:

I - suspensão ou exclusão do crédito tributário;

II - outorga de isenção;

III - dispensa do cumprimento de obrigações tributárias acessórias."
} 
favor fiscal, em detrimento daquele que o concedeu (posto que a isenção é sempre veiculada por lei do próprio ente federado ${ }^{369}$ ).

Visando a transplantar o raciocínio para a hipótese sub examine, vale lembrar que, em matéria de ICMS, apenas nos casos de isenção ou não-incidência a Carta determina o estorno dos créditos ( $\operatorname{art} .155, \S 2^{\circ}$, II, $b$ ). Ou seja: há a outorga de um direito - abatimento do imposto cobrado nas operações anteriores - e a imediata restrição. A diferença em relação ao precedente prolatado há mais de quarenta anos pelo STF é que, no caso do ICMS, a restrição - constitucionalmente posta - é ao direito do contribuinte, e não do EstadoAdministração. Fora esse ponto, a identidade entre os casos - para os fins ora propostos - é plena.

Sendo assim, é lícito concluir que as regras restritivas da não-cumulatividade plasmadas no texto constitucional devem ser restritivamente interpretadas. Laborou, dessarte, com acerto o Min. MARCO AURÉLIO ao averbar no RE $n^{\circ}$ 174.478/SP que a interpretação estrita é a única aceitável "em toda e qualquer hipótese na qual o intérprete se defronte com norma que encerre verdadeira exceção, ${ }^{370}$.

Entretanto, este não é o único fundamento pelo qual se sustenta a necessidade de nova revisão de jurisprudência do STF em relação à matéria objurgada. É que, causando verdadeira confusão entre os institutos da isenção e da redução da base de cálculo, a Suprema Corte equiparou-os, contrariando a doutrina e dezenas de precedentes da própria Casa, que sempre operaram a distinção entre tais hipóteses.

\subsubsection{A INEXISTÊNCIA DA INTITULADA "ISENÇÃO PARCIAL". DEFINI- ÇÕES ONTOLÓGICO-JURÍDICAS DE ISENÇÃO E REDUÇÃO DE BASE DE CÁLCULO.}

\footnotetext{
${ }^{369}$ A única isenção heterônoma hoje admitida pela Constituição é a da exportação de serviços gravados pelo ISSQN. Mediante autorização do art. 156, $\S 3^{\circ}$, II da CR/88 ("em relação ao [ISSQN] cabe à lei complementar excluir da sua incidência exportações de serviços para o exterior"), o art. $2^{\circ}$, I da Lei Complementar ${ }^{\circ}$ $116 / 03$ isentou do imposto municipal os serviços prestados a tomadores situados no exterior.

${ }^{370}$ Esta é a regra predicada não só pela jurisprudência como também pela doutrina. Sobre o tema, MAXIMILIANO já averbou que:

“As leis especiais limitadoras da liberdade, e do domínio sobre as coisas, isto é, as de impostos, higiene, polícia e segurança, e as punitivas bem como as disposições de Direito Privado, porém de ordem pública e imperativas ou proibitivas, interpretam-se estritivamente." (MAXIMILIANO, Carlos. Hermenêutica e Aplicação do Direito, 19 a ed. Rio de Janeiro: Forense, p. 182, destaques nossos).

O mesmo autor conceitua interpretação restritiva:

"Rigorosamente, portanto, a exegese restritiva corresponde, na atualidade, à que outrora se denominava declarativa estrita; apenas declara o sentido verdadeiro e o alcance exato; evita a dilatação, porém não suprime coisa alguma." (MAXIMILIANO, Carlos. Hermenêutica e Aplicação do Direito, $19^{\text {a }}$ ed. Rio de Janeiro: Forense, p. 164, destaques nossos).
} 
Isenção, sob a ótica do STF, é a dispensa legal de tributo devido. Noutras palavras: o fato gerador ocorre e a norma tributária incide sobre ele, juridicizando-o; em momento subseqüente, a regra isencional atua, extinguindo o crédito (e, conseqüentemente, a obrigação), em benefício do contribuinte.

Já redução da base de cálculo é uma mutilação no critério quantitativo do conseqüente da regra-matriz de incidência tributária. É dizer: a obrigação já nasce reduzida, posto que a alíquota é aplicada sobre quantum inferior àquele efetivamente praticado na operação. Ou seja: não há o surgimento da obrigação tributária e a posterior extinção de seu objeto (o crédito tributário). Este já surge reduzido, amesquinhado, haja vista atuar o instituto (da redução de base) no interior da própria norma de tributação (aspecto quantitativo do conseqüiente).

Assentadas tais premissas, a conclusão lógica a que se chega é pela inexistência do instituto da “isenção parcial”. A isenção é ou não é. Ou se exclui in totum o dever tributário ou ele permanece (e não é possível, nessa última hipótese, falar-se em isenção). Nesse sendeiro já averbaram SACHA CALMON ${ }^{371}$ e BARROS CARVALHO ${ }^{372}$.

Entretanto, tornou-se moeda corrente na doutrina nominar como isenções parciais as reduções de base de cálculo que resultem em menos tributo a pagar. Um dos primeiros a utilizar tal nomen juris (isenções parciais) foi S. M. BORGES ${ }^{373}$. Todavia, o próprio autor

${ }^{371}$ Preleciona o Catedrático da UFRJ:

“(...) À luz da teoria da norma jurídica tributária, a denominação de isenção parcial para o fenômeno da redução parcial do imposto a pagar, através das minorações diretas de bases de cálculo e de alíquotas, se afigura absolutamente incorreta e inaceitável. A isenção ou é total ou não é (...). As reduções são diminuições monetárias no quantum da obrigação, via base de cálculo rebaixada ou alíquota reduzida." (COÊLHO, Sacha Calmon Navarro. Teoria Geral do Tributo e da Exoneração Tributária. São Paulo: Revista dos Tribunais, 1982, pp. 159-60, destaques no original).

${ }^{372}$ Averba o Titular da USP:

"Não confundamos subtração do campo de abrangência do critério da hipótese de incidência ou da consequiência com mera redução da base de cálculo ou da alíquota, sem anulá-las. A diminuição que se processa no critério quantitativo, mas que não conduz ao desaparecimento do objeto, não é isenção, traduzindo singela providência modificativa que reduz o quantum de tributo que deve ser pago." (CARVALHO, Paulo de Barros. Curso de Direito Tributário, 17ª ed. São Paulo: Saraiva, 2005, p. 496).

${ }^{373}$ Confira-se a lição de S. M. BORGES, em livro de doutrina escrito há quatro décadas:

"A isenção parcial consiste, mais propriamente, numa redução ou bonificação do débito tributário.

Nas hipóteses da chamada isenção parcial, seria lícito falar-se, com maior rigor terminológico e conceitual, em bonificação de débito tributário, porque o fato gerador de obrigação se produz.

Apenas, como acentua Sainz de Bujanda, o efeito liberatório consiste, em tais casos, na exigência de pagamento menor ao que, sem a isenção, esse fato geraria.

As isenções parciais podem revestir-se de diversas modalidades técnicas, segundo o elemento de quantificação da relação tributária que se utiliza para provocar o efeito liberatório desejado, podendo, assim, falar-se em bonificações na base de cálculo, nos tipos de gravame ou na alíquota.

Como se vê, a isenção geral de tributos, isenção propriamente dita e não mera redução do débito, consoante anterior conceituação (supra, $\$ 7^{\circ}$ ), implica necessariamente em isenção total de impos- 
salientou a atecnia da nomenclatura, pois do ponto de vista jurídico é impossível ter-se isenção em parte. A isenção deve necessariamente excluir o dever de pagar tributo, sob pena de se transmutar em outra espécie de benesse tributária.

O jurista pernambucano bem esclarece que a isenção propriamente dita é aquela que exclui integralmente o dever de pagar tributo. Já a expressão "isenção parcial" andaria melhor se fosse tratada como "bonificação de débito tributário". Ou seja: um dos pioneiros a tratar do conceito de isenção parcial reconhece, de modo expresso, que dita definição é inadequada para qualificação dos institutos que reduzem o valor devido a título de tributo sem a sua exclusão integral.

Tais premissas dogmáticas - que tornam incompatíveis as figuras da redução da base de cálculo (em que o crédito já nasce reduzido pela exoneração endógena amesquinhadora de seu aspecto quantitativo) e da isenção (na qual, segundo a jurisprudência do STF, o crédito nasce em sua integralidade e é in totum dispensado por norma posterior) demonstram o desacerto da equiparação de ambos os institutos.

Em conclusão, temos que as premissas utilizadas pela própria Suprema Corte até a mutação jurisprudencial ocorrida em $2005^{374}$, eram as corretas, devendo ser resgatadas em futuros julgamentos do Supremo Tribunal Federal.

\subsection{CRÉDITO FÍSICO VERSUS CRÉDITO FINANCEIRO.}

O direito ao crédito nos impostos plurifásicos não-cumulativos pode ser:

(a) físico, quando são aproveitáveis apenas os créditos oriundos da aquisição de mercadorias para revenda e, no caso das indústrias, os produtos diretamente aplicados na produção, que se incorporem ao produto final ou sejam integralmente consumidos no processo industrial; ou

(b) financeiro, quando, além da garantia mínima do creditamento físico, assegura-se também ao comerciante, industrial ou produtor o direito ao abatimento do imposto incidente sobre bens do ativo permanente e material de uso e consumo da empresa (material este que não se enquadra no conceito de produto intermediário, o qual e-

tos, taxas e contribuições de melhoria, mas a recíproca não é verdadeira; nem sempre a isenção total consiste numa isenção geral: pode, p. ex., haver isenção total do imposto, porém mantida a obrigação do pagamento de taxas e contribuição de melhoria." (BORGES, José Souto Maior. Isenções Tributárias. São Paulo: Sugestões Literárias, 1969, pp. 281-2, destaques nossos).

${ }^{374}$ STF, Pleno RE nº 174.478/SP, Relator p/ acórdão Min. CEZAR PELUSO, DJ 30.09.2005, p. 5. 
xige a aplicação diretamente no processo produtivo, entrando em contato físico com o produto final e sendo consumido integralmente).

Em razão das diferenças pontuais quanto ao regramento dos tributos, propõe-se a análise da questão, em separado, relativamente ao IPI e ao ICMS.

\subsubsection{AS REGRAS APLICÁVEIS AO IPI.}

Os artigos 163 e seguintes do Regulamento ${ }^{375}$ do IPI (Decreto ${ }^{\circ} 4.544$, de 26 de dezembro de 2002) asseguram ao contribuinte do imposto, em linhas gerais, o direito de abater créditos calculados sobre ${ }^{376}$ :

(a) matéria-prima (MP), produtos intermediários (PI) e material de embalagem (ME);

(b) bens importados, cujo IPI tenha sido pago no desembaraço aduaneiro;

(c) bens de produção, quando adquiridos por comerciantes equiparados a industriais.

Pode-se dessumir dessa breve relação que não geram créditos de IPI os bens integrantes do ativo permanente da empresa (o que é confirmado inclusive pela redação do art. 164, I do RIPI, que garante o crédito aos bens intermediários, salvo se estiverem compreendidos entre os bens do ativo permanente).

375 As leis que dão suporte ao RIPI são variadas, destacando-se o Código Tributário Nacional e a Lei $\mathrm{n}^{\circ}$ 4.502/64 (que regia o vetusto imposto de consumo).

${ }^{376}$ Veja-se a relação completa dos intitulados "créditos básicos" do RIPI:

"Art. 164. Os estabelecimentos industriais, e os que lhes são equiparados, poderão creditar-se (Lei n⿳4.502, de 1964, art. 25):

I - do imposto relativo a MP, PI e ME, adquiridos para emprego na industrialização de produtos tributados, incluindo-se, entre as matérias-primas e produtos intermediários, aqueles que, embora não se integrando ao novo produto, forem consumidos no processo de industrialização, salvo se compreendidos entre os bens do ativo permanente;

II - do imposto relativo a MP, PI e ME, quando remetidos a terceiros para industrialização sob encomenda, sem transitar pelo estabelecimento adquirente;

III - do imposto relativo a MP, PI e ME, recebidos de terceiros para industrialização de produtos por encomenda, quando estiver destacado ou indicado na nota fiscal;

IV - do imposto destacado em nota fiscal relativa a produtos industrializados por encomenda, recebidos do estabelecimento que os industrializou, em operação que dê direito ao crédito;

$\mathrm{V}$ - do imposto pago no desembaraço aduaneiro;

VI - do imposto mencionado na nota fiscal que acompanhar produtos de procedência estrangeira, diretamente da repartição que os liberou, para estabelecimento, mesmo exclusivamente varejista, do próprio importador;

VII - do imposto relativo a bens de produção recebidos por comerciantes equiparados a industrial;

VIII - do imposto relativo aos produtos recebidos pelos estabelecimentos equiparados a industrial que, na saída destes, estejam sujeitos ao imposto, nos demais casos não compreendidos nos incisos V a VII;

IX - do imposto pago sobre produtos adquiridos com imunidade, isenção ou suspensão quando descumprida a condição, em operação que dê direito ao crédito; e

$\mathrm{X}$ - do imposto destacado nas notas fiscais relativas a entregas ou transferências simbólicas do produto, permitidas neste Regulamento.

Parágrafo único. Nas remessas de produtos para armazém-geral e depósito fechado, o direito ao crédito do imposto, quando admitido, é do estabelecimento depositante." 
Nesse sendeiro é lícito afirmar que, em matéria de IPI, o legislador adotou o creditamento físico, não extensivo aos bens de capital e tampouco aos produtos consumidos na indústria que não sejam diretamente aplicados na produção.

É interessante notar que não houve posicionamento do Supremo acerca da matéria sob o pálio da atual Constituição. Assim, os precedentes existentes que levam à conclusão pela inadmissibilidade dos créditos de IPI sobre bens de uso e consumo (rectius, não caracterizáveis como matéria-prima, produtos intermediários ou material de embalagem) e do ativo permanente são todos pretéritos à CR/88. O aresto abaixo, que em 1981 negou ao importador de maquinário (bem do ativo) tributado pelo IPI o direito ao aproveitamento do crédito do tributo que incidira na importação denota que o STF:

(a) considera inexistir, pela não-cumulatividade, o direito de crédito na aquisição de bens importados para o ativo imobilizado;

(b) entende que, quando concedida, caracteriza um incentivo fiscal, eis que vai além dos estritos limites da não-cumulatividade do IPI.

Veja-se a ementa:

"IPI. CRÉDITO DO IMPOSTO PAGO NA IMPORTAÇÃO DE PAÍS MEMBRO DO GATT, RELATIVO A BEM PARA O ATIVO FIXO. Sua inaplicação à hipótese, pois tal creditamento constitui incentivo à indústria nacional e, por isso, somente favorece os produtos nacionais (Lei $\mathrm{n}^{\circ}$ 4.502/64, Decreto $n^{\circ} 70.182 / 72$, art. 36). AgRg improvido."377

À época, vigorava norma que autorizava o Ministro da Fazenda a listar, em Portaria, os equipamentos que gerariam crédito de IPI para as indústrias-adquirentes. Todavia, somente bens nacionais gozavam de tal benefício, pelo que o STF negou aos adquirentes de bens de capital importados a possibilidade de se creditar do IPI suportado em suas aquisições.

Dessarte, pode-se sustentar que, para a não-cumulatividade do IPI, o mínimo constitucional assegurado pelo STF corresponde ao crédito físico. O Tribunal não estende o direito de crédito para bens do ativo permanente e de uso e consumo, relegando o tema à normatização infraconstitucional ${ }^{378}$.

\footnotetext{
377 STF, Segunda Turma, AI-AgR no 81.199/SP, Relator Min. CORDEIRO GUERRA, DJ 05.06.1981, p. 5.396 .

${ }^{378}$ Para maiores detalhes, vide Item 6.15.3.
} 


\subsubsection{AS NORMAS DO ICMS.}

\subsubsection{O CRÉDITO FÍSICO DO CONVÊNIO ICM Nº 66/88.}

A Constituição de 1988 determinou a edição de lei complementar para delinear as normas gerais de incidência do ICMS. Todavia, enquanto não advinda tal lei, um Convênio entre os Estados-membros (firmado na forma prescrita pela Lei Complementar $n^{\circ} 24$, de 7 de janeiro de 1975) faria as vezes, em caráter excepcional, de tal normatização ${ }^{379}$.

Cumprindo essa determinação, foi publicado o Convênio ICM nº 66/88, que vedava o creditamento do ICMS:

(a) na entrada de bens destinados ao uso e consumo do estabelecimento;

(b) na aquisição de bens para o ativo imobilizado;

(c) no ingresso de bens não-classificáveis como matérias-primas ou produtos intermediários;

(d) na utilização de serviços de transporte e de comunicação (exceto se empregados: na execução de serviços da mesma natureza; para fins de revenda de mercadorias; ou no bojo de processo extrativo ou industrial).

O Convênio ICM n ${ }^{\circ}$ 66/88 optou claramente pelo crédito físico. Outrossim, também restringiu o aproveitamento dos créditos de ICMS quando da contratação dos serviços que passaram a ser gravados pelo imposto. Mesmo diante dessas mitigações ao direito de crédito, o STF entendeu pela constitucionalidade do Convênio nesta parte. Para a Corte Suprema, todos os bens e serviços acima listados (cujo crédito foi vedado) são adquiridos pelas empresas na qualidade de consumidoras finais. Nessa linha, não seria possível falar em ofensa à não-cumulatividade, haja vista que o ônus jurídico do tributo deve ser efetivamente suportado pelo contribuinte de facto, ainda quando este se confunda com um contribuinte de jure que, ao vender suas mercadorias ou prestar serviços, também fará a recolha do ICMS às burras estatais.

Outro argumento utilizado pelo STF, especificamente para justificar a restrição ao crédito dos bens adquiridos para o ativo imobilizado, consistiu na ausência de tributação quando alienados pelas empresas-contribuintes (entendimento sumulado desde a época do

\footnotetext{
${ }^{379}$ É o que consta do Ato das Disposições Constitucionais Transitórias:

"Art. 34. (...).

$\S 8^{\circ}$. Se, no prazo de sessenta dias contados da promulgação da Constituição, não for editada a lei complementar necessária à instituição do imposto de que trata o art. 155, I, 'b', os Estados e o Distrito Federal, mediante convênio celebrado nos termos da Lei Complementar $n^{\mathbf{0}} 24$, de 7 de janeiro de 1975, fixarão normas para regular provisoriamente a matéria."
} 
vetusto imposto sobre vendas e consignações ${ }^{380}$ ), haja vista não se enquadrarem no conceito de mercadoria. Sendo assim, não haveria operação de circulação jurídica subseqüente, passível de incidência do ICMS, o que desautorizaria o crédito por parte do adquirente.

Tais fundamentos foram ventilados pela Primeira Turma no RE-AgR $n^{\circ}$ 349.543/SP, assim ementado:

"IMPOSTO SOBRE CIRCULAÇÃO DE MERCADORIAS E SERVIÇOS. ICMS. PRINCÍPIO DA NÃO-CUMULATIVIDADE. CRÉDITO. BENS INTEGRADOS AO ATIVO FIXO. INEXISTÊNCIA DE ELO CONSIDERADA MERCADORIA PRODUZIDA. PERÍODO ANTERIOR À LEI COMPLEMENTAR N $87 / 96$.

A aquisição de equipamentos que irão integrar o ativo fixo da empresa ou produtos destinados ao uso e consumo não gera o direito ao crédito, tendo em conta que a adquirente mostra-se, na realidade, como destinatária final." 381

A seu turno, a Segunda Turma assentou no AI-AgR n 602.998/MG que "se não há saída do bem, ainda que na qualidade de componente de produto industrializado, não há falar-se em cumulatividade tributária" ${ }^{382}$, razão pela qual denegou o pleito de empresa mineradora que pretendia o crédito de bens destinados ao seu uso e consumo e ativo permanente.

Em outros arestos, foram confirmadas as restrições ao crédito de serviço de comunicação e de transportes, assim como - com posicionamento vencido do Min. MARCO AURÉLIO - a negativa de crédito sobre a energia elétrica consumida, ao argumento de que ela somente se enquadraria na categoria de bem intermediário quando utilizada em processo industrial. Portanto, a energia objeto de consumo nas áreas não-operacionais das indústrias (como o setor administrativo), assim como a consumida por estabelecimentos comerciais, não geraria direito ao crédito. Confira-se:

\footnotetext{
${ }^{380}$ Súmula 541 do STF:

"Imposto sobre vendas e consignações não incide sobre a venda ocasional de veículos e equipamentos usados, que não se insere na atividade profissional do vendedor, e não é realizada com o fim de lucro, sem caráter, pois, de comercialidade."

$O$ entendimento tem sido reiterado à luz da atual Carta. Confira-se:

"ICMS. VENDA DE BENS NO ATIVO FIXO DA EMPRESA. NÃO-INCIDÊNCIA DO TRIBUTO. A venda de bens do ativo fixo da empresa não se enquadra na hipótese de incidência determinada pelo art. 155, I, $b$, da Carta Federal, tendo em vista que, em tal situação, inexiste circulação no sentido jurídico-tributário: os bens não se ajustam ao conceito de mercadorias e as operações não são efetuadas com habitualidade. Recurso extraordinário não conhecido." (STF, Primeira Turma, RE n ${ }^{\circ}$ 194.300/SP, Relator Min. ILMAR GALVÃO, DJ 12.09.1997, p. 43.737).

${ }^{381}$ STF, Primeira Turma, RE-AgR nº 349.543/SP, Relator Min. MARCO AURÉLIO, DJ 21.11.2008, p. 730.

${ }^{382}$ STF, Segunda Turma, AI-AgR nº 602.998/MG, Relator Min. EROS GRAU, DJ 01.06.2007, p. 74.
} 
"Firme o entendimento do Supremo Tribunal de não reconhecer o direito de creditamento do valor do ICMS, quando pago em razão de operações de consumo de energia elétrica, ou de utilização de serviço de comunicação."383

A ementa acima se refere a processo julgado pela Primeira Turma em 2006, no qual uma empresa produtora de celulose disputava o crédito sobre energia, transporte e comunicação, tendo sido denegado o pleito.

Apesar de não estar claro no aresto, a menção ao consumo de energia elétrica refere-se àquela não-enquadrável como produto intermediário, posto que não utilizada no processo de produção (na hipótese, de celulose). Entendimento diverso violaria o próprio conceito de bem intermediário, assentado há décadas no Supremo Tribunal.

A Segunda Turma não destoou, tendo igualmente indeferido o pleito - no caso, de uma usina de açúcar e álcool - de escrituração dos créditos referentes à energia elétrica e serviços de comunicação utilizados. O acórdão é do ano de 2006:

"2. Compensação de créditos de ICMS resultante da aquisição de bens que integram o ativo fixo, energia elétrica e serviços de comunicações. Impossibilidade. Precedentes.

3. Período anterior à LC nº 87, de 1996. Compensação. Impossibilidade. Precedentes." 384

A mesma ressalva feita anteriormente vale aqui ser repisada: a negativa de crédito da energia elétrica para uma indústria só pode ser compreendida para as suas áreas nãooperacionais. Afinal, no leading case em que a Suprema Corte reconheceu a validade da vedação do crédito de ICMS sobre a energia elétrica (RE no 200.168/RJ), a recorrente era uma empresa revendedora de vestuário. Diferençando a atividade comercial da industrial, assentou o Relator, Min. ILMAR GALVÃO:

“O parecer da Douta Procuradoria Geral da República assim apreciou a controvérsia em seu cerne:

'A recorrente, em síntese, é indiscutivelmente a consumidora final da mercadoria energia elétrica, que não se integra como insumo nos produtos que revende, por tratar-se de uma empresa dedicada ao comércio varejista de vestuário (...). Somente no processo industrial, em que a energia elétrica é indispensável na combinação dos fatores de produção, na condição de insumo, concorrendo para a formação de um determinado produto é que se pode aplicar o princípio constitucional da não-cumulatividade.'

\footnotetext{
${ }^{383}$ STF, Primeira Turma, AI-AgR n ${ }^{\circ}$ 355.683/SP, Relator Min. SEPÚLVEDA PERTENCE, DJ 20.04.2006, p. 6.

${ }^{384}$ STF, Segunda Turma, AI-AgR no 491.743/SP, Relator Min. GILMAR MENDES, DJ 03.02.2006, p. 45.
} 
(...)

Com efeito, não há falar-se em ofensa ao princípio da não-cumulatividade, se o bem tributado é consumido no próprio estabelecimento, não se destinando à comercialização ou à utilização em processo de produção de novos bens, como elemento indispensável à composição destes." 385

O STF, assim decidindo, equiparou a energia elétrica consumida por estabelecimento comercial a bem de uso e consumo, cujo creditamento era - na esteira do Convênio ICM $n^{\circ}$ 66/88 e da sua jurisprudência remansosa - vedado. Todavia, houve no decisum menção expressa ao direito de crédito por parte de estabelecimentos industriais, haja vista que neles a energia é consumida no processo de produção, caracterizando-se como verdadeiro bem intermediário (consumido de forma imediata e integral no processo produtivo). Tanto é que esse detalhe, de fundamental importância, foi ressaltado na ementa:

“TRIBUTÁRIO. PRETENDIDO CRÉDITO RELATIVO AO ICMS INCIDENTE SOBRE A ENERGIA ELÉTRICA CONSUMIDA EM ESTABELECIMENTO COMERCIAL. Descabimento. 'Não implicará crédito para compensação com o montante do imposto devido nas operações ou prestações seguintes, a entrada de bens destinados a consumo ou à integração no ativo fixo do estabelecimento' (art. 31, II, do Convênio ICMS 66/88). Se não há saída do bem, ainda que na qualidade de componente de produto industrializado, não há falar-se em cumulatividade tributária. Recurso não conhecido." 386

A ementa (espelhando com exatidão o inteiro teor do aresto) afirma com clareza que a negativa do crédito se aplica tão-somente aos estabelecimentos comerciais. E ainda aduz que, se industrialização houvesse, o ICMS incidente sobre a energia utilizada em tal processo poderia ser objeto de creditamento.

Dessarte, os acórdãos que se seguiram a este, invocando-o quase sempre, em que pese não terem descido ao detalhe da questão, devem ser interpretados como proibitivos do creditamento apenas da energia não utilizada na produção.

Outrossim, a vedação constante do Convênio ICM nº 66/88 quanto ao crédito do imposto incidente nos serviços de comunicação e transporte foi também integralmente legitimada pelo STF.

\subsubsection{O CRÉDITO FINANCEIRO DA LC No 87/96 E O REGRESSO AO CRÉ- DITO FÍSICO OPERADO PELA LC N 102/00.}

\footnotetext{
${ }^{385}$ STF, Primeira Turma, RE nº 200.168/RJ, Relator Min. ILMAR GALVÃO, DJ 22.11.1996, p. 45.717.

${ }^{386}$ STF, Primeira Turma, RE nº 200.168/RJ, Relator Min. ILMAR GALVÃO, DJ 22.11.1996, p. 45.717.
} 
Sob a égide da Lei Complementar nº 87, de 13 de outubro de 1996 - que veio substituir o Convênio ICM n ${ }^{\circ}$ 66/88 - o direito ao crédito foi ampliado, autorizando-se o aproveitamento do ICMS incidente sobre a energia elétrica consumida, sobre os bens de uso e consumo, do ativo permanente e sobre os serviços de comunicação e transporte utilizados pela empresa.

Na primeira (energia elétrica) e nas duas últimas hipóteses (serviços de comunicação e transportes), o crédito era irrestrito e incondicionado; no segundo caso (bens de uso e consumo), seria autorizado a partir de uma data futura (que vem sendo sucessivamente prorrogada por diversas outras leis complementares desde então). Na terceira situação (bens do ativo permanente), caso o contribuinte alienasse o bem antes de decorridos sessenta meses de sua aquisição, deveria estornar proporcionalmente os créditos do ICMS aproveitados (estorno de $20 \%$ por ano não completo antes de transcorrido o qüinqüênio).

Tendo ampliado os direitos dos contribuintes ao adotar a sistemática do creditamento financeiro - embora mitigada pela postergação do direito ao crédito sobre bens de uso e consumo (não implementada até hoje, estando atualmente diferida para $1^{\circ}$ de janeiro de 2011 pela Lei Complementar $n^{\circ}$ 122, de 12 de dezembro de 2006) - a LC n 87/96, em sua redação originária, foi alvo de poucos questionamentos no que tange à regulação da nãocumulatividade.

Afinal, o STF já havia assentado que inexistia direito ao crédito sobre bens do ativo (todavia autorizado pela $\mathrm{LC} \mathrm{n}^{\circ}$ 87/96), sobre bens de uso e consumo (reconhecido, porém diferido pela Lei Kandir), sobre energia elétrica que não fosse consumida na produção industrial (amplamente autorizada pela multicitada lei complementar) e sobre serviços de comunicação e transporte não utilizados na prestação de serviços da mesma natureza ou não diretamente afetados à produção (também permitidos pela LC no 87/96). Ou seja: a Lei Kandir trouxe apenas benesses aos contribuintes no âmbito da não-cumulatividade do ICMS, comparativamente com seu antecessor, o Convênio ICM nº 66/88.

As lides acerca da não-cumulatividade sob o pálio da LC nº 87/96 advieram, precipuamente, em razão das modificações que lhe foram impingidas pela Lei Complementar $\mathrm{n}^{\circ}$ 102, de 11 de julho de 2000. Dita lei, segundo a própria União, foi editada para recompor os caixas dos Estados-membros, de modo a trazer maior equilíbrio federativo ${ }^{387}$.

Pelas novas regras implantadas, pode-se afirmar que a $\mathrm{LC} \mathrm{n}^{\circ} 102 / 00$ :

\footnotetext{
${ }^{387}$ Note-se a semelhança com a justificativa para a edição da Emenda Passos Porto, quase vinte anos antes. A história se repete!
} 
(a) modificou a sistemática de crédito de bens do ativo imobilizado: em vez de permitir o creditamento integral e à vista no momento do ingresso do bem no estabelecimento do contribuinte, com estorno proporcional em caso de alienação antes de decorridos cinco anos da entrada, passou-se a permitir o crédito de forma fracionada, à razão de 1/48 por mês (sem direito à correção monetária);

(b) restringiu o direito ao crédito de energia elétrica e serviços de comunicação, autorizando-o apenas quando o consumo de energia e serviços destinar-se a produzir mercadorias ou bens para exportação, na proporção do volume exportado, ou em hipóteses tópicas, a saber:

(b.1) no caso da energia elétrica, quando utilizada na produção de energia ou, então, quando consumida em processo industrial;

(b.2) nos serviços de comunicação, quando utilizados para viabilizar a prestação desses mesmos serviços.

No julgamento da medida cautelar em Ação Direta de Inconstitucionalidade $\mathrm{n}^{\circ}$ 2.325/DF, ocorrido em 2004, o Plenário do Supremo Tribunal Federal reconheceu que as medidas predicadas pela $\mathrm{LC} \mathrm{n}^{\circ} 102 / 00$, restritivas da não-cumulatividade, implicavam majoração do ICMS devido. Essa parte do decisum superou o argumento aduzido nos autos pela União Federal de que se estava diante de "simples alteração da forma de apurar-se o ICMS", sem efetivo aumento do tributo devido. Por tal razão, afastou-se a aplicação da lei no exercício em que publicada, em atenção ao princípio da anterioridade plasmado no art. 150 , III, $b$ da CR/88 ${ }^{388}$. Todavia, reconheceu-se - vencido o Relator, Min. MARCO AURÉLIO - a eficácia dos dispositivos que restringiam o crédito sobre a energia elétrica e os serviços de comunicação, assim como daqueles que modificavam a sistemática da nãocumulatividade para os bens do ativo permanente.

O voto-vista do Min. CARLOS VELLOSO foi decisivo para que a Corte não seguisse a proposição do Relator, Min. MARCO AURÉLIO, e legitimasse - exceção feita ao termo inicial de sua eficácia - a Lei Complementar no 102/00. O Min. VELLOSO assentou que a garantia mínima constitucionalmente prevista para o ICMS (e via, de conseqüência, para o IPI) é a do crédito físico. Sendo assim, somente a aquisição de mercadorias para revenda, assim como de bens que se integrem ao produto final no processo de industrialização, têm, pela letra da Constituição, direito ao abatimento assegurado. Qualquer outro

${ }^{388}$ Com isso, o STF invalidou o art. $7^{\circ}$ da $\mathrm{LC} \mathrm{n}^{\circ} 102$, publicada em julho de 2000 , que assim predicava: "Art. $7^{\circ}$. Esta lei complementar entra em vigor no primeiro dia do mês subseqüente ao da sua publicação." 
crédito eventualmente concedido pelo legislador - e a Carta Magna não veda tal ampliação - será válido, mas poderá ser retirado pela lei a qualquer tempo, desde que observadas as garantias constitucionais contra o poder tributante, como a anterioridade anual.

Abaixo transcrevemos a manifestação de VELLOSO, que vale ler sida por aclaradora do pensamento do STF:

"Durante muito tempo discutiu-se se o crédito, oriundo do princípio da nãocumulatividade, seria crédito financeiro ou crédito físico.

Pelo regime do crédito financeiro, assegura-se (...) 'o crédito do imposto pago em todas as operações (...) e prestações (...) que constituam custo do estabelecimento'.

(...)

Pelo regime do crédito físico, (...) 'só o imposto relativo à entrada de bens que são vendidos pelo estabelecimento ou que, no caso de indústria, integram fisicamente o produto industrializado a ser vendido, enseja crédito para compensação com o imposto devido na saída'.

(...)

A cláusula constitucional (...) não adota o crédito financeiro, mas o crédito físico. Compensa-se (...) 'o que for devido em cada operação de circulação de mercadoria ou prestação de serviços com o montante cobrado nas anteriores'. Ora, falando a Constituição em 'operação relativa à circulação de mercadorias', tem-se a idéia de (...) mercadorias ou bens que são comprados e vendidos, bens e mercadorias que circulam.,"389

Tendo assentado seu entendimento de que o art. $155, \S 2^{\circ}$, I da Constituição veicula o preceito da não-cumulatividade com a garantia mínima do crédito físico, VELLOSO analisa a evolução operada pelas Leis Complementares nº 87/96 e 102/00:

"Na forma do estabelecido no art. 155, §2 , XII, $c$, da Constituição Federal, cabe à lei complementar disciplinar o regime de compensação do imposto. A Lei Complementar no 87, de 1996 (Lei Kandir), estatuiu que o crédito do ICMS referente à aquisição do ativo permanente poderia ser aproveitado, e aproveitado de uma só vez, integralmente; estatuiu, também, que o crédito do ICMS referente à energia elétrica poderia ser aproveitado sem restrições; e estatuiu, mais, que o crédito do ICMS referente a telecomunicações poderia ser utilizado também sem restrições.

A lei complementar assim dispôs, porque a norma constitucional, art. 155, $\S 2^{\circ}$, I, não impede que o legislador ordinário conceda mais. O que não pode fazer é conceder menos, na interpretação do texto constitucional. Noutras palavras, competindo ao legislador ordinário, mediante lei complementar, disciplinar o regime de compensação do imposto - $\mathrm{CF}$, art. $155, \S 2^{\circ}, \mathrm{XII}, c$ - pode ela adotar interpretação mais benéfica ao contribuinte.

E foi o que aconteceu com a Lei Complementar 87/96.

Sobreveio, então, a Lei Complementar $n^{\circ} 102$, de 11.07.2000, que alterou dispositivos da Lei Complementar 87/96, estabelecendo: a) o crédito de

\footnotetext{
${ }^{389}$ STF, Pleno, ADI-MC nº 2.325/DF, Relator Min. MARCO AURÉLIO, DJ 06.10.2006, p. 32.
} 
ICMS referente à aquisição de ativo permanente deverá ser aproveitado em 48 parcelas; b) o crédito de ICMS referente à energia elétrica passível de aproveitamento é somente aquele decorrente do consumo no processo de industrialização ou em operações que resultarem em exportação, na proporção do volume exportado; c) o crédito de ICMS referente a telecomunicações poderá ser aproveitado somente naquelas empresas que prestarem serviços da mesma natureza ou quando o consumo resultar em exportação, na proporção do volume exportado." 390

E, ao final, conclui:

"Assim posta a questão, força é convir que foi a Lei Complementar n 87/96 que permitiu o crédito relativo à entrada de bens destinados ao consumo ou ao ativo permanente, permitindo a adoção do crédito financeiro. Em suma: à lei complementar cumpre disciplinar o sistema de compensação do imposto (CF, art. 155, §2, XII, c). Fê-lo, então, a Lei Complementar 87/96, permitindo o crédito financeiro. Ora, se é na lei complementar que estava o crédito financeiro e não na Constituição, lei complementar subseqüente poderia alterar a antecedente. E foi o que aconteceu: a Lei Complementar 87/96 simplesmente foi alterada pela Lei Complementar 102/00."391

Apesar de ter sido julgado tão-somente o pedido cautelar na ADI, restando ainda pendente a apreciação do mérito pelo Plenário, o fato é que decisões liminares como esta, que antecipam em boa parte as discussões do processo, tendem a ser um prenúncio do que será efetivamente decidido pelo Supremo ao final (o que pode tardar anos).

Tamanha é a força cogente de decisões liminares em Ações Diretas de Inconstitucionalidade que elas se tornam jurisprudência, sendo observadas em julgados subseqüentes - mesmo sem a conclusão em definitivo do julgamento da ADI. As ementas abaixo, que retratam decisões da Primeira e Segunda Turmas do STF - ambas posteriores ao julgamento da cautelar na $\mathrm{ADI} \mathrm{n}^{\circ} 2.325 / \mathrm{DF}$ - denotam o que se está a dizer:

"AGRAVO REGIMENTAL NO RECURSO EXTRAORDINÁRIO. LEI COMPLEMENTAR No 87/96. SUPERVENIÊNCIA DA LEI COMPLEMENTAR N ${ }^{\circ}$ 102/00. CRÉDITO DE ICMS. LIMITAÇÃO TEMPORAL À SUA EFETIVAÇÃO. VULNERAÇÃO DO PRINCÍPIO DA NÃOCUMULATIVIDADE. INOCORRÊNCIA. PRECEDENTES.

1. O Plenário desta Corte, no julgamento da ADI-MC $\mathrm{n}^{\circ} 2.325$, DJ de 4.10.04, fixou entendimento no sentido de não ser possível a compensação de créditos de ICMS em razão de operações de consumo de energia elétrica ou utilização de serviços de comunicação ou, ainda, de aquisição de bens destinados ao uso e/ou à integração no ativo fixo do próprio estabelecimento.

\footnotetext{
${ }^{390}$ STF, Pleno, ADI-MC n ${ }^{\circ}$ 2.325/DF, Relator Min. MARCO AURÉLIO, DJ 06.10.2006, p. 32.

${ }^{391}$ STF, Pleno, ADI-MC no 2.325/DF, Relator Min. MARCO AURÉLIO, DJ 06.10.2006, p. 32.
} 
2. As modificações nos artigos $20, \S 5^{\circ}$, e 33 , da Lei Complementar $n^{\circ}$ 87/96, não violam o princípio da não-cumulatividade. Agravo regimental a que se nega provimento." 392

“AGRAVO REGIMENTAL NO RECURSO EXTRAORDINÁRIO. LEI COMPLEMENTAR No 87/96. SUPERVENIÊNCIA DA LC No 102/2000. CRÉDITO DE ICMS. LIMITAÇÃO TEMPORAL À SUA EFETIVAÇÃO. VULNERAÇÃO DO PRINCÍPIO DA NÃO-CUMULATIVIDADE.

Imposto sobre Circulação de Mercadorias e Serviços. Crédito. Compensação. Aproveitamento integral do crédito decorrente das aquisições para o ativo permanente. Superveniência da Lei Complementar $n^{\circ}$ 102/2000. Limitação temporal para o aproveitamento ao longo do período de 48 meses. Restrição à possibilidade de o contribuinte recuperar o imposto pago, como contribuinte de fato, na aquisição de bens para o ativo fixo dentro do período de vida útil. Vulneração ao princípio da não-cumulatividade. Inexistência. Precedente: ADI n ${ }^{\circ}$ 2.325, Relator o Ministro Marco Aurélio, Sessão Plenária do dia 23.9.2004. Agravo regimental não provido., 393

Sendo assim, resta insofismável, à luz da jurisprudência do Supremo Tribunal Federal, que o crédito físico continuou a pautar a não-cumulatividade dos tributos sujeitos a tal sistemática, mesmo após a Constituição de 1988.

\subsubsection{COMENTÁRIOS SOBRE O CRÉDITO FÍSICO COMO O MINIMUM MI- NIMORUM DA NÃO-CUMULATIVIDADE PLASMADO NA CONSTITUIÇÃO.}

Exercendo seu poder interpretativo das Constituições, o STF garantiu, desde os primórdios da implantação da não-cumulatividade, tão-somente o direito ao crédito dos insumos utilizados na atividade industrial. Por insumos compreendem-se as matériasprimas e os intitulados produtos intermediários, que não se agregam ao produto acabado porém se consomem integralmente no processo produtivo ${ }^{394}$.

\footnotetext{
${ }^{392}$ STF, Segunda Turma, RE-AgR n ${ }^{\circ}$ 461.878/MG, Relator Min. EROS GRAU, DJ 01.08.2008, p. 1.247.

${ }^{393}$ STF, Primeira Turma, RE-AgR n ${ }^{\circ}$ 392.991/MG, Relator Min. EROS GRAU, DJ 29.04.2005, p. 27.

${ }^{394}$ O vocábulo "insumos" foi utilizado no ordenamento jurídico pátrio, por primeira vez, no Ato Complementar no 34, de 30 de janeiro de 1967 (baixado pelo Presidente da República com base no Ato Institucional $\left.n^{\circ} 02\right)$. O AC no 34/67 assegurava o crédito de ICM sobre os "insumos necessários à produção" de determinadas mercadorias que gozavam de isenção. Não aclarava, todavia, o sentido do termo, que foi, ademais, alvo de críticas por parte de BALEEIRO:

“'Insumos' (...) é uma algaravia de origem espanhola, inexistente em português, empregada por alguns economistas para traduzir a expressão inglesa input, isto é, o conjunto dos fatores produtivos, como matérias-primas, energia, trabalho, amortização do capital etc., empregados pelo empresário para produzir o output, ou produto final." (BALEEIRO, Aliomar. Curso de Direito Tributário Brasileiro, $11^{a}$ ed. Atualizado por MISABEL ABREU MACHADO DERZI. Rio de Janeiro: Forense, 2001, pp. 405-6).

Segundo o autor, não haveria unanimidade quanto ao sentido da locução:

“'Insumos' são os ingredientes da produção, mas há quem limite a palavra aos 'produtos intermediários' que, não sendo matérias-primas, são empregados ou se consomem no processo de produção."
} 
A jurisprudência firmada no âmbito do STF referia-se, inicialmente, ao imposto sobre consumo, posteriormente renomeado para IPI, pago eminentemente pelos industriais.

Com a criação do ICM em 1965, a jurisprudência que se construíra para o imposto de consumo (e para seu sucessor, o IPI) foi simplesmente aplicada ao novel imposto estadual.

Ao fazê-lo, a Suprema Corte não atentou para as peculiaridades que o ICM - cuja base de contribuintes era muito mais ampla que o IPI - possuía. Afinal, o crédito sobre os insumos utilizados nas indústrias já consistia em importante garantia da nãocumulatividade, que, ademais, gozavam à época de uma importante benesse: a importação de bens de capital sem pagamento do IPI ou do ICM (por força de um posicionamento do STF, a nosso sentir errôneo, que pugnava serem os bens do ativo intributáveis pelo IPI e pelo ICM haja vista não consistirem em mercadorias e sim em produtos adquiridos para consumo final. O equívoco do entendimento reside no fato de a análise ter sido feita sob a ótica do comprador e não do alienante, como seria devido).

Todavia, de que serve ao comerciante, que nada industrializa, o direito de crédito sobre insumos (compreendidos estes apenas como as matérias-primas e bens intermediários?). É certo que sobre as mercadorias adquiridas para revenda existe a premissa - assegurada pelo STF - do direito ao crédito, sob pena de negativa da própria nãocumulatividade.

Mas e os bens adquiridos pelos lojistas para utilização em seus estabelecimentos, como as placas em que os produtos e seus respectivos preços são anunciados? E a compra de brindes para distribuição aos clientes? Todas essas aquisições são tributadas pelo imposto estadual, que acaba sendo suportado pelo adquirente-comerciante, não sendo repassado juridicamente ao consumidor final na medida em que a garantia dos créditos (para além daqueles calculados sobre as mercadorias para revenda) se restringe aos insumos, compreendidos estes sob a ótica industrial, e nada mais.

Essa primeira constatação leva-nos à seguinte reflexão: a jurisprudência construída para os contribuintes industriais (por força do IPI) foi transplantada para o ICM sem maiores indagações ou discussões por parte da Corte Suprema. O núcleo da não-cumulatividade

(BALEEIRO, Aliomar. Curso de Direito Tributário Brasileiro, $11^{\mathrm{a}}$ ed. Atualizado por MISABEL ABREU MACHADO DERZI. Rio de Janeiro: Forense, 2001, p. 406).

Apesar das críticas, pode-se asseverar que hodiernamente tanto as matérias-primas como os bens intermediários enquadram-se em tal conceito, consoante interpretação predominante no Judiciário. 
para ambos os tributos (IPI e ICM) foi considerado o mesmo, gerando, obviamente, distorções no instituto em questão.

De todo modo, como o STF possui a palavra final, restou assente que a garantia mínima da não-cumulatividade no plano constitucional é a do crédito físico - sem que haja qualquer vedação para a ampliação do direito pelas normas infraconstitucionais, como o próprio Supremo ressaltou.

A crítica que fazemos, é importante gizar, refere-se mais à forma pela qual o STF chegou a tal conclusão para o ICM do que ao mérito da questão em si.

Explicamo-nos: o Supremo é o guardião da Constituição. Cremos que o espaço para divergências quanto ao núcleo mínimo do direito de crédito, passados mais de cinqüenta anos do advento da não-cumulatividade no País, é reduzido (em que pese, do ponto de vista acadêmico, não concordarmos com o posicionamento da Corte Suprema). Entretanto, é aterrador (a palavra é propositadamente forte) que não tenha havido um único acórdão no qual tenha sido feita a diferenciação entre IPI e ICM para concluir-se que o crédito físico já decidido para o primeiro - seria também aplicável ao segundo imposto. O transplante puro e simples das regras de um imposto a outro, deixando os comerciantes (que não são contribuintes do IPI) tão-somente com a garantia dos créditos pela aquisição de mercadorias para revenda fere até mesmo o direito à ampla defesa e ao devido processo legal. Afinal, incumbe ao Judiciário analisar cada caso levado a seu conhecimento, atendo-se às suas especificidades. Tal não ocorreu, como visto, no que tange à não-cumulatividade tributária.

Note-se que a observação não é meramente de cunho histórico. É atual e se aproposita pois, em 1988, dois serviços foram incluídos dentre aqueles alcançados pelo ICMS: transporte interestadual e intermunicipal ${ }^{395}$ e comunicação. E no âmbito da Constituição de 1988 a Suprema Corte ainda não apreciou, com vagar, o núcleo mínimo do direito ao crédito do ICMS em tais prestações. A se manter como está, tem-se o grave risco de o STF aplicar uma regra construída à luz do imposto de consumo, cobrado dos industriais no século passado, para a tributação de dois serviços que - por força das pressões políticas exercidas quando da Assembléia Nacional Constituinte de 1987, como relata SACHA CAL$\mathrm{MON}^{396}$ - foram incluídos na competência dos Estados-membros, agregando o "S" final ao

\footnotetext{
${ }^{395}$ Exceto o transporte aéreo de passageiros, como decidido pelo STF na ADI $n^{\circ}$ 1.600/DF (Pleno, Relator p/ acórdão Min. NELSON JOBIM, DJ 20.06.2003, p. 56).

${ }^{396}$ COÊLHO, Sacha Calmon Navarro. Curso de Direito Tributário Brasileiro, $7^{\mathrm{a}}$ ed. Rio de Janeiro: Forense, 2004, p. 387.
} 
ICM. Ora, de que vale o direito ao crédito físico se o serviço é, por natureza, uma prestação cujo resultado é algo imaterial? Assegurar-se aos transportadores e às operadoras de telecomunicação o crédito físico é o mesmo que negar a não-cumulatividade em tais atividades.

\subsection{A IMPORTAÇÃO DE MERCADORIAS POR NÃO-CONTRIBUINTES: SIS- TEMÁTICAS DISTINTAS PARA O IPI E O ICMS. \\ 6.16.1. A EVOLUÇÃO JURISPRUDENCIAL.}

A regra mundialmente aplicada para exportações e importações predica que as saídas do País são desoneradas de tributos, ao passo que os ingressos são gravados tal e qual os produtos e serviços nacionais. Gravar-se a importação é, portanto, uma questão de isonomia, além de ser estratégica para a viabilização do crescimento do País.

Sendo assim, é normal que haja incidência tanto de ICMS como de IPI quando do ingresso de bens estrangeiros em território nacional. Entretanto, dado que tais exações gozam do predicado da não-cumulatividade, alguns importadores pessoas físicas, que traziam do exterior mercadorias para utilização pessoal, passaram a questionar a incidência desses impostos (exigidos no momento do desembaraço aduaneiro das mercadorias ${ }^{397}$ ). O fundamento era o de que a exigência tanto do IPI como do ICMS de importadores nãocontribuintes feria a não-cumulatividade, pois seria impossível a recuperação (via creditamento em conta gráfica) do imposto pago na entrada do bem.

O tema foi apreciado pelo Pleno do STF em 1999, que assim decidiu por maioria de votos:

"RECURSO EXTRAORDINÁRIO. CONSTITUCIONAL. TRIBUTÁRIO. PESSOA FÍSICA. IMPORTAÇÃO DE BEM. EXIGÊNCIA DE PAGAMENTO DO ICMS POR OCẢSIÃO DO DESEMBARAÇO ADUANEIRO. IMPOSSIBILIDADE.

1. A incidência do ICMS na importação de mercadoria tem como fato gerador operação de natureza mercantil ou assemelhada, sendo inexigível o imposto quando se tratar de bem importado por pessoa física.

2. Princípio da não-cumulatividade do ICMS. Pessoa física. Importação de bem. Impossibilidade de se compensar o que devido em cada operação com o montante cobrado nas anteriores pelo mesmo ou outro Estado ou pelo Distrito Federal. Não sendo comerciante e como tal não estabelecida, a pessoa

\footnotetext{
${ }^{397}$ Súmula 661 do STF (aplicável também ao IPI):

"Na entrada de mercadoria importada do exterior, é legítima a cobrança do ICMS por ocasião do desembaraço aduaneiro."
} 
física não pratica atos que envolvam circulação de mercadoria. Recurso extraordinário não conhecido." ${ }^{398}$

Pela leitura do aresto nota-se que, além do fundamento da não-cumulatividade, outro ponto foi considerado pelo STF para decidir-se pela não-incidência do ICMS na importação por pessoa física: o fato desta não praticar a mercancia, pelo que o imposto não seria exigível. Gize-se que, à época do julgado, vigorava a redação originária do art. $155, \S 2^{\circ}$, IX, o qual predizia que o imposto somente incidiria sobre mercadorias trazidas do exterior: “Art. 155. (...). $\S 2 .^{\circ} \mathrm{O}$ imposto previsto no inciso II [ICMS] atenderá ao seguinte: IX - incidirá também:

a) sobre a entrada de mercadoria importada do exterior, ainda quando se tratar de bem destinado a consumo ou ativo fixo do estabelecimento, assim como sobre serviço prestado no exterior, cabendo o imposto ao Estado onde estiver situado o estabelecimento destinatário da mercadoria ou do serviço;" (destaque nosso)

Como o conceito de mercadoria é o de coisa móvel destinada à mercancia, consoante leciona BARROS CARVALHO ${ }^{399}$, pugnaram os Ministros do STF - em divergência iniciada por MAURÍCIO CORRÊA contra os votos de ILMAR GALVÃO e NELSON JOBIM, que denegavam o pleito $^{400}$ - que não se poderia qualificar um produto importado para uso particular como tal.

Neste ponto, remetemo-nos a excertos do voto de CORRÊA (Relator designado), para melhor apreensão do raciocínio pretoriano:

“(...) O imposto não é devido pela pessoa física que importou o bem, visto que não exerce atos de comércio de forma constante nem possui 'estabelecimento destinatário da mercadoria', hipótese em que, a teor do disposto no art. 155, IX, alínea $a$, da Constituição Federal, o tributo seria devido ao Estado da sua localização (...).

${ }^{398}$ STF, Pleno, RE nº 203.075/DF, Relator p/ acórdão Min. MAURÍCIO CORRÊA, DJ 29.10.1999, p. 18.

${ }^{399}$ Assim predica o jurista sobre o tema:

"A natureza mercantil do produto não está, absolutamente, entre os requisitos que lhe são intrínsecos, mas na destinação que se lhe dê. É mercadoria a caneta exposta à venda entre outras adquiridas para esse fim. Não o será aquela que mantenho em meu bolso e se destina a meu uso pessoal. Não se operou a menor modificação na índole do objeto referido. Apenas sua destinação veio a conferir-lhe atributos de mercadorias." (CARVALHO, Paulo de Barros. Regra Matriz do ICM (tese). São Paulo: PUC, 1981, p. 207).

${ }^{400}$ Os votos vencidos de GALVÃO (Relator originário) e JOBIM não versaram sobre a não-cumulatividade na importação, o que é importante ressaltar. Ativeram-se apenas à matéria que fora discutida na Corte $a$ quo: a possibilidade de se aplicar o art. $155, \S 2^{\circ}$, IX, $a$ à pessoa física importadora de um veículo automotor estrangeiro. 
Observo, ainda, a impossibilidade de se exigir o pagamento do ICMS na importação de bem por pessoa física, dado que, não havendo circulação de mercadoria, não há como se lhe aplicar o princípio constitucional da nãocumulatividade do imposto, pois somente ao comerciante é assegurada a compensação do que for devido em cada operação com o montante cobrado nas anteriores pelo mesmo ou outro Estado ou pelo Distrito Federal.",401

Em seu voto, o Min. MARCO AURÉLIO adotou a argumentação de CORRÊA e repisou o fato de que, havendo referência à palavra estabelecimento por duas vezes no art. $155, \S 2^{\circ}, \mathrm{IX}, a$, não se poderia sustentar a aplicação do dispositivo às pessoas naturais, que possuem domicílio ou residência - mas não estabelecimento para ingresso de mercadorias importadas e definição do Estado responsável pela cobrança do imposto.

Os Ministros SEPÚLVEDA PERTENCE e NÉRI DA SILVEIRA acompanharam a divergência, porém em suas razões não versaram sobre a não-cumulatividade, mas apenas sobre a definição de mercadoria e a inexistência de um estabelecimento para a pessoa física. A mesma linha foi seguida por MOREIRA ALVES. Todavia, o Min. CARLOS VELLOSO, último a votar, retomou o argumento da não-cumulatividade (que, é interessante notar, jamais fora levantado em todo o processo até o voto-divergente do Min. MAURÍCIO CORRÊA), in verbis:

"Ao estabelecer a incidência (...) o constituinte (...) optou pelo comerciante, ou pelo industrial, é dizer, por aquele que tem um estabelecimento, certo que o particular, que não comerciante ou industrial, tem simplesmente domicílio ou residência. E por que procedeu assim o constituinte? Porque o importador (...) que é comerciante ou industrial, pode, na operação seguinte, utilizar o crédito do tributo que pagou no ato do desembaraço aduaneiro. $\mathrm{O}$ particular, que não é comerciante ou industrial, jamais poderia fazer isso. É dizer, caberia a ele o ônus total do tributo." ${ }^{, 402}$

Em face de tal decisão, passaram a ser importadas, por pessoas físicas, as mais diversas mercadorias sem o pagamento do ICMS. Tal fato levou o constituinte derivado a promover uma alteração na redação do art. $155, \S 2^{\circ}$, IX, $a$, de modo a tributar pelo ICMS todas as importações, feitas por pessoas naturais ou jurídicas, contribuintes ou não do imposto. Eis a redação do dispositivo (que é a atual) após a EC nº 33/01:

“Art. 155. (...).

$\S 2 .^{\circ} \mathrm{O}$ imposto previsto no inciso II [ICMS] atenderá ao seguinte:

IX - incidirá também:

${ }^{401}$ STF, Pleno, RE nº 203.075/DF, Relator p/ acórdão Min. MAURÍCIO CORRÊA, DJ 29.10.1999, p. 18.

${ }^{402}$ STF, Pleno, RE n 203.075/DF, Relator p/ acórdão Min. MAURíCIO CORRÊA, DJ 29.10.1999, p. 18. 
a) sobre a entrada de bem ou mercadoria importados do exterior por pessoa física ou jurídica, ainda que não seja contribuinte habitual do imposto, qualquer que seja a sua finalidade, assim como sobre o serviço prestado no exterior, cabendo o imposto ao Estado onde estiver situado o domicílio ou o estabelecimento do destinatário da mercadoria, bem ou serviço;"

Após a EC n 33/01, todas as importações passaram a sujeitar-se ao ICMS, sem exceção - como, aliás, é o correto, inclusive por razões de isonomia com os produtos nacionais.

Entretanto, haja vista que um dos fundamentos do precedente foi o princípio da não-cumulatividade, dois questionamentos ainda permaneceram: as pessoas jurídicas nãocontribuintes do imposto (porém possuidoras de estabelecimento e importadoras de mercadorias) também fariam jus à não-incidência, no período anterior à $\mathrm{EC} \mathrm{n}$ 33/01? E no caso do IPI, tributo para o qual inexiste norma constitucional determinando sua incidência nas importações, sendo tal referência feita apenas pelo $\mathrm{CTN}^{403}$ ?

Pois bem. No primeiro caso (importação de bem por pessoa jurídica nãocontribuinte do ICMS), o STF houve por bem afastar toda e qualquer tributação pelo ICMS, baseando-se no princípio da não-cumulatividade. Após a prolação de diversas decisões $^{404}$, o seguinte entendimento (válido, ressalte-se, apenas para os fatos geradores anteriores à $E C n^{\circ} 33 / 01$ ) foi sumulado:

"Súmula 660. Não incide ICMS na importação de bens por pessoa física ou jurídica que não seja contribuinte do imposto."

No que tange ao IPI, contudo, como não houve emenda constitucional para sujeitar todo produto importado à sua incidência, a conclusão da Suprema Corte foi pela impossibilidade de cobrança das pessoas físicas importadoras de mercadorias para uso próprio. Confira-se:

"CONSTITUCIONAL. TRIBUTÁRIO. IPI. IMPORTAÇÃO: PESSSOA FÍSICA NÃO COMERCIANTE OU EMPRESÁRIO: PRINCÍPIO DA NÃO-CUMULATIVIDADE: CF, art. 153, § $3^{\circ}$, II. NÃO-INCIDÊNCIA DO IPI.

I - Veículo importado por pessoa física que não é comerciante nem empresário, destinado ao uso próprio: não-incidência do IPI: aplicabilidade do

\footnotetext{
${ }^{403}$ Dispõe o Código Tributário:

"Art. 46. O imposto, de competência da União, sobre produtos industrializados tem como fato gerador:

I - o seu desembaraço aduaneiro, quando de procedência estrangeira;”

${ }^{404}$ Inter alii, diversos hospitais conseguiram, em juízo, afastar a incidência do ICMS na importação de equipamentos médicos destinados ao seu uso e consumo ou ativo permanente, dado que são sociedades simples, não-contribuintes do imposto estadual.
} 
princípio da não-cumulatividade: $\mathrm{CF}$, art. $153, \S 3^{\circ}$, II. Precedentes do STF relativamente ao ICMS, anteriormente à EC 33/2001 (...).",405

Invocando-se o precedente em que se pugnou pela não-incidência do ICMS nas importações por pessoa física com base no princípio da não-cumulatividade (apesar de não ter sido somente este o fundamento, como visto), a regra foi aplicada ao IPI ao argumento de que "onde existe a mesma razão, prevalece a mesma regra de direito: ubi eadem ratio, ibi eadem legis dispositio" $"$.

As conclusões, por dedução lógica, também se aplicam à importação de bens por pessoas jurídicas não-contribuintes do IPI, haja vista que seu fundamento é a impossibilidade de concretização da não-cumulatividade pela inexistência de etapa posterior de circulação que gere débitos a compensar com o IPI-importação.

\subsubsection{NOSSA OPINIÃO: NECESSÁRIA INCIDÊNCIA DE ICMS E IPI NAS IM- PORTAÇÕES POR NÃO-CONTRIBUINTES. INEXISTÊNCIA DE FERIMENTO À NÃO-CUMULATIVIDADE.}

Temos que as decisões do STF acerca do não-recolhimento de ICMS ou IPI na importação por não-contribuintes (sejam pessoas físicas ou jurídicas) são, data venia, equivocadas. Vejamos, por partes, os fundamentos da Suprema Corte e nossas objeções.

O primeiro argumento invocado pela maioria do Tribunal é de que o bem importado para utilização própria (seja por pessoa natural ou jurídica) não é mercadoria, posto que não destinado à mercancia. Ora, a qualificação de mercadoria dá-se sob o ponto de vista do alienante, nunca do adquirente do bem. A ser assim, as aquisições de bens para uso pessoal no mercado interno brasileiro também passariam ao largo da incidência de ICMS e IPI.

Vale lembrar que, sob a égide das Constituições pretéritas, o STF desonerou do ICM a importação de bens para o ativo imobilizado das empresas (inclusive das que eram contribuintes do imposto). $\mathrm{O}$ fundamento invocado foi o de que o ativo não se destinava à circulação jurídica e sim à utilização própria pelos importadores. Logo, refugiria ao alcance do imposto estadual ${ }^{407}$.

\footnotetext{
${ }^{405}$ STF, Segunda Turma, RE-AgR n ${ }^{\circ}$ 255.682/RS, Relator Min. CARLOS VELLOSO, DJ 10.02.2006, p. 14. ${ }^{406}$ STF, Segunda Turma, RE-AgR no 255.682/RS, Relator Min. CARLOS VELLOSO, DJ 10.02.2006, p. 14. No mesmo sentido: STF, Segunda Turma, RE-AgR n ${ }^{\circ}$ 272.230/SP, Relator Min. CARLOS VELLOSO, DJ 10.02.2006, p. 14 .

${ }^{407}$ O seguinte aresto denota o posicionamento pretérito da Suprema Corte:

"ICM.TUBOS DE AÇO IMPORTADOS PARA USO PRÓPRIO.
} 
Foi somente a partir da EC $\mathrm{n}^{\mathrm{o}} 23 / 83^{408}$ que o STF passou a sustentar que, caso os Estados assim dispusessem em lei própria, a importação de bens de capital poderia ser gravada pelo $\mathrm{ICM}^{409}$.

Ora, não nos parece que tais inferências, antes ou após a Emenda Passos Porto, sejam corretas. $\mathrm{O}$ alienante das mercadorias (situado no exterior) as considera como bens sujeitos à mercancia. E, no IPI e ICMS incidentes na importação, o contribuinte no Brasil é, de certa forma, "substituto tributário" daquele situado no exterior, que não pode ser alcançado pelas leis brasileiras. Sendo assim, tanto o IPI como o ICMS recolhidos na importação são devidos sob o prisma do vendedor, em que pese serem - por impossível de outro modo - pagos pelo importador nacional. Portanto, tal argumento não possui sustentação jurídica, como de resto já averbou MISABEL DERZI ${ }^{410}$ em candentes críticas ao posicionamento do Supremo Tribunal Federal.

O segundo fundamento, este válido apenas para as pessoas físicas, é o de que a Constituição de 1988 - na redação anterior à EC nº 33/01 - estipulava que o ICMS seria devido ao Estado em que situado o estabelecimento do importador. Temos que, neste caso,

Tratando-se de bens que se destinam a uso próprio da importadora, e que, portanto, integrarão seu ativo fixo, não há incidência do ICM, pois sua importação não configura circulação de mercadoria para o efeito dessa incidência. Recurso extraordinário conhecido e provido.” (STF, Segunda Turma, RE $\mathrm{n}^{\circ}$ 88.176/SP, Relator Min. MOREIRA ALVES, DJ 29.12.1977).

${ }^{408}$ A Emenda Passos Porto, tendo em vista a jurisprudência que se firmara no âmbito do STF impedindo a incidência do ICM na importação de bens de capital ou para uso próprio das empresas, acrescentou o $\$ 11$ ao art. 23 da CR/67-69:

“Art. 23. (...).

$\S 11$. O [ICM] incidirá, também, sobre a entrada, em estabelecimento comercial, industrial ou produtor, de mercadoria importada do exterior por seu titular, inclusive quando se tratar de bens destinados a consumo ou ativo fixo do estabelecimento."

${ }^{409}$ Confira-se:

"REPETIÇÃO DE INDÉBITO TRIBUTÁRIO. ICM RECOLHIDO EM IMPORTAÇÃO DE BENS DE CAPITAL, DESTINADOS AO ATIVO FIXO, EM PERÍODOS ANTERIORES À E.C. N 23 , DE $1 / 12 / 1983$.

Caráter inovativo do parágrafo 11 do art. 23 da C.F., acrescentado por essa emenda constitucional e que, embora outorgando competência aos Estados para legislarem sobre sua incidência em tal hipótese, não a impôs automaticamente." (STF, Primeira Turma, RE nº 107.984/RJ, Relator Min. SYDNEY SANCHES, DJ 06.05.1988, p. 10.632).

${ }^{410}$ Preleciona a jurista:

"O conceito de mercadoria deve ser sempre apreendido do ponto de vista de quem promove a operação de circulação, não do ponto de vista do adquirente. Se assim não fosse, inexistiria a incidência nas operações de circulação no varejo em que se dá a aquisição para o consumo. A única peculiaridade da incidência do ICMS nas importações está no fato de que o sujeito passivo, em lugar de ser a pessoa que promove a exportação (sediada no exterior), é o adquirente-importador. Achamos equivocada a jurisprudência anterior à Constituição de 1988 que entendia não incidir o imposto nas importações de bens do ativo fixo." (BALEEIRO, Aliomar. Direito Tributário Brasileiro, $11^{\mathrm{a}}$ ed. Atualizado por MISABEL ABREU MACHADO DERZI. Rio de Janeiro: Forense, 2001, p. 381). 
foi olvidada a interpretação sistemática da Constituição que apregoa, tanto de forma genérica no art. $5^{\circ}$, caput, como especificamente para o direito tributário no art. 150, II, o princípio da isonomia. A concessão de benefícios fiscais ao fabricante estrangeiro - por meio da exoneração do ICMS e do IPI nas importações realizadas por pessoas físicas - fere frontalmente a igualdade, além de ser danosa à indústria nacional. Por que razão os empresários de outras plagas, quando na venda direta a cidadãos brasileiros, gozam da nãoincidência de ICMS e IPI sobre seus produtos, contrariamente ao que deve ser observado sob pena de pesadas autuações - pelas empresas aqui estabelecidas? A mera ausência de menção a domicílio ou residência no texto constitucional quando da determinação de incidência do ICMS sobre bens importados (que, a nosso sentir, sequer precisaria estar expressa, pois decorreria da aplicação do princípio da isonomia) autoriza a conclusão de que pessoas físicas estariam desobrigadas da recolha desse imposto na importação? Não poderia a lei de normas gerais do ICMS e do próprio IPI suprir tal lacuna na Constituição? A resposta a essa última pergunta foi positiva nos votos dos Ministros JOBIM e GALVÃO quando do julgamento do leading case sobre o tema (RE $n^{\circ}$ 203.075/DF), os quais, entretanto, restaram vencidos no Plenário.

Por tais razões, filiamo-nos aos votos vencidos no $\mathrm{RE} \mathrm{n}^{\mathrm{o}}$ 203.075/DF, para entender que, seja na importação por pessoa física ou jurídica, contribuinte ou não do IPI ou do ICMS, o direito da União e dos Estados de tributar decorre diretamente da Constituição. Basta, por óbvio, apenas que a legislação infraconstitucional assim o predique. E adicionamos: o ferimento à isonomia é patente no entendimento que prevaleceu, desprestigiando a indústria nacional e incentivando os produtores estrangeiros, na contramão das regras mundiais de tributação.

O terceiro e último argumento invocado pelo STF para não gravar as importações realizadas por pessoas físicas ou não-contribuintes é o que toca de forma mais direta o tema sub examine: de acordo com a Corte, haveria ofensa à não-cumulatividade tributária caso exigido o ICMS e o IPI em tais importações, na medida em que os não-contribuintes restariam impossibilitados de se creditar dessas exações, pagas quando do desembaraço aduaneiro.

Nada mais errôneo. A importação de mercadorias é uma situação na qual há a concentração, em uma só pessoa (natural ou jurídica), das figuras do contribuinte de jure e de facto. Afinal, sendo inviável exigir-se que o exportador situado em território estrangeiro recolha ICMS e IPI aos cofres brasileiros, tal cobrança é feita do importador (que paga o tributo que seria devido pelo exportador). Caso o importador não seja contribuinte, ele reu- 
nirá as características de contribuinte de jure - por "substituição" do exportador situado além-mar - e de facto, que é a sua regular natureza em qualquer aquisição dentro do País, suportando juridicamente o ônus econômico dos impostos não-cumulativos.

Em face de tais razões temos por equivocado o posicionamento do STF que, até os dias atuais, declara não incidir IPI nas importações feitas por não-contribuintes (assim como é errôneo, data maxima venia, o entendimento sumulado no período anterior à $\mathrm{EC} \mathrm{n}^{\mathrm{o}}$ 33/01, pela não-incidência do ICMS na mesma situação).

\subsection{A SUBSTITUIÇÃO TRIBUTÁRIA PARA FRENTE E O DIREITO À RESTI- TUIÇÃO DO TRIBUTO PAGO A MAIOR.}

\subsubsection{ORIGENS.}

Quando da criação do ICM, ainda na década de 1960, alguns Estados pretenderam amesquinhar o princípio da não-cumulatividade e, conseqüentemente, incrementar sua arrecadação tributária, mediante a criação de pautas de valores que presumiam o preço final de venda dos produtos, sempre em montantes superiores aos efetivamente praticados. Com tal medida, aumentava-se o débito a pagar do imposto, em detrimento do valor da operação real.

Ora, o arbitramento da base de cálculo do ICM somente é admissível em caráter excepcional e na forma prescrita pelo art. 148 do $\mathrm{CTN}^{411}$. Assim é que a discussão sobre tais "ficções jurídicas" criadas pelos Estados-membros não tardou a chegar ao Supremo Tribunal Federal.

Um caso pitoresco - e pioneiro - foi o mandado de segurança impetrado no Estado do Rio Grande do Norte por um vendedor ambulante de fumo, que comprava sua matériaprima em Alagoas e a revendia na cidade de Caicó, no Rio Grande do Norte. Atingido por uma portaria estadual que fixava em Cr\$ 6,00 a base de cálculo do ICM sobre o quilo de fumo, o ambulante recorreu ao Judiciário argumentando que comprava seu produto a Cr\$ 2,00 o quilo em Arapiraca/AL, revendendo-o a Cr\$ 2,60 (e não Cr\$ 6,00) em Caicó/RN.

\footnotetext{
${ }^{411}$ De fato, o arbitramento não é modalidade de lançamento, mas sim autorização excepcionalmente conferida aos agentes fiscais para, mediante processo regular - no qual deverá ser provado que os documentos do contribuinte não merecem fé - arbitrar a base de cálculo de quaisquer tributos eventualmente devidos e não pagos. É conferir o CTN:

"Art. 148. Quando o cálculo do tributo tenha por base, ou tome em consideração, o valor ou o preço de bens, direitos, serviços ou atos jurídicos, a autoridade lançadora, mediante processo regular, arbitrará aquele valor ou preço, sempre que sejam omissos ou não mereçam fé as declarações ou os esclarecimentos prestados, ou os documentos expedidos pelo sujeito passivo ou pelo terceiro legalmente obrigado, ressalvada, em caso de contestação, avaliação contraditória, administrativa ou judicial."
} 
Sob tal fundamento pediu o afastamento da portaria, com a conseqüente exigência do tributo sobre o efetivo valor de venda. Tendo ganhado em primeira instância e perdido no TJRN, o pequeno comerciante não se resignou e levou a questão ao STF. A Primeira Turma da Corte asseverou que o Estado não pode pautar de forma genérica os valores das mercadorias para fins de incidência do ICM. O arbitramento somente é admissível em casos pontuais, individualizados e mediante observância do procedimento regular exigido pelo Código Tributário Nacional ${ }^{412}$. Com isso, foi declarada a inconstitucionalidade da norma estatal fixadora do preço fictício para o fumo revendido pelo ambulante, retomandose a sistemática regular de cobrança do ICM sobre o valor de saída da mercadoria.

Posteriormente, a Segunda Turma do STF - invocando o precedente do ambulante de Caicó - uniformizou o entendimento de ambas as Turmas do Supremo Tribunal com a seguinte ementa:

"ICM. Pauta fiscal. A base de cálculo do ICM é o valor da operação de que decorrer a saída da mercadoria (art. $2^{\circ}$, I, do DL. 406, de 1968). Não é lícito ao legislador estadual inovar quanto a esse aspecto (art. 18, par. $1^{\circ}$, da E.C. 1, de 1969). A predeterminação de valor para as operações pode contrariar essa disposição, implicando, por outro lado, em majoração do imposto (art. 97, par. $1^{\circ}$, do CTN). Aplicação do art. 148 do CTN. A pauta fiscal só se legitima quando, em processo regular, não ficar demonstrado o valor real da operação de que decorrer a saída da mercadoria. RE conhecido e provido." $" 413$

Desde então, as Cortes pátrias passaram a repelir os intentos estatais de majoração da arrecadação do ICM pela aplicação de pautas de valores irreais, obrigando os entes federados a respeitar o efetivo valor de venda das mercadorias ${ }^{414}$. Tal medida foi importante para que a não-cumulatividade pudesse se firmar. Afinal, se a fixação unilateral pelos Estados-membros da base de cálculo do ICM não tivesse sido combatida e afastada quando destoante da realidade, submergiria toda a teoria da tributação sobre o valor acrescido, cujo

\footnotetext{
${ }^{412}$ Confira-se a ementa:

"IMPOSTO DE CIRCULAÇÃO DE MERCADORIAS, CÁLCULO DE TRIBUTO COM BASE EM VALOR OU PREÇO DE BENS, DIREITOS, SERVIÇOS OU ATOS JURÍDICOS.

$\mathrm{O}$ arbitramento feito pela autoridade lançadora só poderá ser feito mediante 'processo regular' (art. 148 do Código Tributário Nacional) e não por portaria de efeito normativo, sem exame de cada caso em particular.

Recurso extraordinário conhecido e provido." (STF, Primeira Turma, RE no 72.400/RN, Relator Min. BARROS MONTEIRO, DJ 26.11.1971).

${ }^{413}$ STF, Segunda Turma, RE no 78.577/SP, Relator Min. CORDEIRO GUERRA, DJ 04.04.1975.

414 Interplures, cite-se: STF, Primeira Turma, RE $\mathrm{n}^{\circ}$ 77.544/SP, Relator Min. ALIOMAR BALEEIRO, DJ 27.09.1974.
} 
objetivo primordial é assegurar a neutralidade na tributação - arrimando-se, para tanto, no pilar da não-cumulatividade ${ }^{415}$.

Entretanto, desde essa época passou-se a admitir, em certos casos, a antecipação do momento da recolha do imposto aos cofres públicos, atribuindo-se aos atacadistas a responsabilidade pelo pagamento do ICM devido nas operações dos varejistas. Apesar de ainda não denominada como tal, tratava-se do embrião da intitulada substituição tributária para frente, que atribuía a terceiro (o responsável, referido no art. 121 do $\mathrm{CTN}^{416}$ ) o dever de pagar o tributo devido por outrem. O STF admitiu a legitimidade dessa antecipação em mais de um caso, argumentando que a prática evitava a sonegação por parte dos pequenos comerciantes $^{417}$.

\subsubsection{CONCEITO.}

A substituição tributária (ST) admite duas modalidades:

(a) para trás, na qual há o diferimento do pagamento do imposto devido para a etapa subseqüente da cadeia de circulação da mercadoria. É o caso dos laticínios, que recolhem na venda do leite industrializado o valor do ICMS que seria devido pelos

\footnotetext{
${ }^{415}$ Vale notar que a decisão do STF não condena a utilização da pauta fiscal, mas sim impede a sua prevalência quando demonstrado que, no caso concreto, a aplicação do valor arbitrado destoa da realidade em prejuízo do contribuinte. A. J. COSTA, apontando essa sutileza no posicionamento da Suprema Corte, pugna pela legitimidade do uso em larga escala das pautas fiscais, desde que se assegure ao contribuinte inconformado uma avaliação contraditória do valor arbitrado, em cumprimento à exigência do art. 148 do CTN (COSTA, Alcides Jorge. ICM na Constituição e na Lei Complementar. São Paulo: Resenha Tributária, 1978, p. 159).

${ }^{416}$ Em seu art. 121 o CTN conceitua (e diferencia) contribuinte e responsável tributário:

"Art. 121. (...).

Parágrafo único. O sujeito passivo da obrigação principal diz-se:

I - contribuinte, quando tenha relação pessoal e direta com a situação que constitua o respectivo fato gerador;

II - responsável, quando, sem revestir a condição de contribuinte, sua obrigação decorra de disposição expressa de lei."

Para, adiante, definir as premissas que devem ser observadas pelas leis de cada ente federado quando da instituição do responsável por substituição:

"Art. 128. Sem prejuízo do disposto neste capítulo, a lei pode atribuir de modo expresso a responsabilidade pelo crédito tributário a terceira pessoa, vinculada ao fato gerador da respectiva obrigação, excluindo a responsabilidade do contribuinte ou atribuindo-a a este em caráter supletivo do cumprimento total ou parcial da referida obrigação."

${ }^{417}$ Interplures, confira-se: STF, Pleno, RE no 60.284/PB, Relator Min. LINS E SILVA, DJ 27.06.1967. A hipótese tratava do antigo imposto sobre vendas e consignações, cujo recolhimento antecipado pelo atacadista foi legitimado, à unanimidade, pelo Plenário.

Já sob a égide do ICM, o Tribunal admitiu a antecipação do recolhimento do imposto quando se tratasse de venda de mercadoria para outro Estado (STF, Segunda Turma, RE n ${ }^{\circ}$ 108.104/RS, Relator Min. CÉLIO BORJA, DJ 14.08.1987, p. 16.089).
} 
fazendeiros dos quais adquirem a matéria-prima (sendo que estes nada pagam, posto que beneficiados pelo diferimento);

(b) para frente, quando se atribui a agente situado nas fases iniciais do processo de circulação da mercadoria a responsabilidade pelo pagamento do imposto que será devido nas etapas posteriores. Como exemplo, o industrial recolhe antecipadamente ao erário público os valores que seriam pagos pelos atacadistas e varejistas. Nessa hipótese, a indústria pagará o ICMS incidente em sua própria operação (fabricante $>$ atacadista) e também o imposto devido por substituição tributária progressiva, relativo às operações subseqüentes até a venda ao consumidor final. $\mathrm{O}$ cálculo do ICMS-ST é feito com base nos preços médios praticados no varejo, utilizando-se das tabelas de preços para o consumidor final editadas pelos fabricantes ou de publicações feitas pelos Estados-membros.

A prática do diferimento - que equivale à substituição tributária para trás ou regressiva - em nada ofende a não-cumulatividade. Isso porque se assegura ao contribuinte nãopagante do imposto a manutenção dos créditos relativos às aquisições tributadas ${ }^{418}$.

Já a substituição tributária para frente ou progressiva pode ferir a nãocumulatividade, caso os preços de venda ao consumidor final sejam erroneamente presumidos (para mais) pelo Estado-Administração e não exista garantia de devolução ao substituto do tributo eventualmente pago a maior.

De todo modo, sob a égide das Cartas pretéritas a intitulada substituição tributária para frente - então tratada como "antecipação do imposto devido" - foi, como já referido, legitimada pela Suprema Corte. Entenderam os Ministros que não havia semelhança entre tal hipótese e aquela das "pautas fiscais", nas quais, por mero comodismo, o Estado fixa um preço presumido de venda do produto não sujeito à substituição tributária.

É dizer: na pauta fiscal, o que se tem é um arbitramento feito pelo Fisco do valor de venda do produto. Desconsidera-se a realidade para cobrar-se imposto sobre um valor ditado pelo Estado e desconforme com a realidade. Ao contrário, na substituição tributária para frente é necessária a presunção do preço de venda ao consumidor final - ou então não será possível operacionalizá-la.

Noutras palavras, a substituição tributária progressiva exige que se presuma o valor de venda das mercadorias - pois se trata de uma operação que ocorrerá futuramente. Essa a distinção básica entre a pauta fiscal e a substituição tributária para frente: a primeira repele

\footnotetext{
${ }^{418}$ Vide Capítulo VI, Item 6.11, supra, e Capítulo IX, Item 9.3, infra.
} 
os dados concretos e existentes para instituir tributação sobre valores fictícios, unilateralmente arbitrados pelo Estado; a segunda exige uma presunção, ou seja, uma tabela de valores na qual constarão os preços presumidos de venda ao consumidor final, de modo a permitir que, antes da ocorrência dessa venda, opere-se a tributação para toda a cadeia (que recairá sobre o substituto tributário).

\subsubsection{A JURISPRUDÊNCIA DO STF À LUZ DA CONSTITUIÇÃO DE 1988.}

Como já apontado, anteriormente à atual Constituição a ST era tratada pelo STF como mera "antecipação de imposto devido", sem maiores digressões quanto à sua natureza - mesmo porque o número de lides em relação ao tema era restrito.

Após a promulgação da atual Lei Maior, os Estados-membros pretenderam, arrimados no Convênio ICM n ${ }^{\circ}$ 66/88 e em Convênios específicos (como o de nº 107/89, referente ao setor automotivo), ampliar a utilização do instituto da substituição tributária para frente, até então presente de forma tímida e pontual.

Contrárias à utilização do instituto, as concessionárias de automóveis (as mais atingidas, nessa fase inicial, pela ST progressiva ${ }^{419}$ ), recorreram ao Judiciário, argumentando, em suma, que a exigência antecipada do imposto configurava cobrança de tributo sem a ocorrência do respectivo fato gerador.

Tal argumento foi rechaçado pelo STF. A Corte afirmou que a própria CR/88 (no art. $34, \S 9^{\circ}$ do $\mathrm{ADCT}^{420}$ ) previra a substituição tributária para frente e para trás no setor de geração e distribuição de energia. Assim, a ST para frente poderia inclusive ser regulada por convênio enquanto não editada a lei complementar que, nos termos do art. $155, \S 2^{\circ}$, XII, $b$ da Constituição, deveria "dispor sobre substituição tributária" no ICMS. Sendo assim, e conforme autorizado também pelo art. 128 do CTN (que permite a atribuição do

\footnotetext{
${ }^{419}$ Afinal, o valor pago pelas concessionárias à montadora foi majorado, pois o ICMS-ST (relativo à operação concessionária > consumidor final) passou a ser antecipadamente recolhido pelo fabricante, que se ressarcia financeiramente mediante repasse do custo no preço do veículo vendido às concessionárias.

${ }^{420}$ ADCT da CR/88:

“Art. 34. (...).

$\S 9^{\circ}$. Até que lei complementar disponha sobre a matéria, as empresas distribuidoras de energia elétrica, na condição de contribuintes ou de substitutos tributários, serão as responsáveis, por ocasião da saída do produto de seus estabelecimentos, ainda que destinado a outra unidade da Federação, pelo pagamento do imposto sobre operações relativas à circulação de mercadorias incidente sobre energia elétrica, desde a produção ou importação até a última operação, calculado o imposto sobre o preço então praticado na operação final e assegurado seu recolhimento ao Estado ou ao Distrito Federal, conforme o local onde deva ocorrer essa operação."
} 
dever tributário a terceiro, excluindo a responsabilidade do contribuinte originário), a substituição para frente seria legítima sob as luzes da Carta de 1988.

A alegada ofensa à não-cumulatividade, também pontuada pelos contribuintes, foi afastada pelo STF. Para o Tribunal, desde que a base de cálculo presumida para a substituição tributária equivalesse ao preço cobrado do consumidor final, não haveria que se falar em ferimento à não-cumulatividade ${ }^{421}$. E, de mais a mais, eventuais diferenças relativas a recolhimentos feitos a maior poderiam ser diretamente compensadas pelos contribuintessubstituídos, ainda que a lei assim não dispusesse. O direito decorreria do próprio princípio da não-cumulatividade ${ }^{422}$.

Mesmo diante das decisões plenárias do STF (RE no 213.396/SP e RE $n^{\circ}$ 194.382/SP) que assentaram pela legitimidade do instituto da substituição tributária progressiva, o constituinte derivado - em face da elevada litigiosidade em torno da matéria houve por bem plasmar na Lei Maior norma expressamente autorizativa da ST para frente (EC nº 03/93), aplicável a qualquer espécie de imposto ou contribuição:

"Art. 150. (...).

$\S 7^{\circ}$ A lei poderá atribuir a sujeito passivo de obrigação tributária a condição de responsável pelo pagamento de imposto ou contribuição, cujo fato gerador deva ocorrer posteriormente, assegurada a imediata e preferencial restituição da quantia paga, caso não se realize o fato gerador presumido."

Após a emenda, tornou-se assente - em que pesem algumas vozes em sentido contrário $^{423}$ - que o instituto era, efetivamente, legítimo. Assim, desde que respeitados os de-

${ }^{421}$ Confira-se o trecho do voto do Relator do RE $n^{\mathbf{o}}$ 213.396/SP:

"Por igual se mostra descabida a alegação de ofensa ao princípio da não-cumulatividade, se no preço do produto passado do industrial para o varejista não se embute mais do que se embutiria na hipótese de tratar-se de operações regulares, ou seja, o tributo devido pela saída do bem do estabelecimento industrial, mais a parcela incidente sobre o valor acrescido até sua entrega ao consumidor final." (STF, Pleno, RE no 213.396/SP, Relator Min. ILMAR GALVÃO, DJ 01.12.2000, p. 97).

${ }^{422}$ A assertiva constou do voto do Relator de outro acórdão Plenário do STF, no qual foi legitimada a ST para frente no setor automotivo:

"Vê-se, portanto, inexistir a alegada ofensa ao princípio da não-cumulatividade, dado que a concessionária antecipou o pagamento do ICMS à montadora quando recebeu os veículos para revenda, sendo que à montadora, na qualidade de substituto tributário, competia o recolhimento da exação afastando a substituída (concessionária) da relação jurídico-tributária. Assim, se eventualmente houver crédito na apuração do saldo devedor ou credor o substituído poderá compensá-lo, ainda que a respeito não haja previsão na lei ordinária, porque a fonte primeira desse direito encontra-se na Constituição Federal (art. 155, §2º, I).” (STF, Pleno, RE nº 194.382/SP, Relator Min. MAURÍCIO CORRÊA, DJ 25.04.2003, p. 35).

423 O Min. MARCO AURÉLIO nunca admitiu, mesmo após a EC nº 03/93, que se pudesse cobrar tributo "por ficção", considerando ocorrido fato gerador ainda não realizado. Segundo o magistrado, legitimando-se o instituto, chegaríamos rapidamente "ao dia em que essa substituição tributária para a frente tornar-se-á regra, deixando de ser, portanto, (...) uma exceção”. (STF, Pleno, RE n 194.382/SP, Relator Min. MAURÍCIO CORRÊA, DJ 25.04.2003, p. 35). 
mais comandos constitucionais - em especial o da legalidade - a substituição tributária progressiva tornou-se válida à luz da Constituição de 1988.

Todavia, como sói ocorrer quando se confere amplos poderes aos entes federados em matéria tributária, alguns exageros na aplicação da regra fizeram com que as premissas adotadas pelo STF para legitimá-la deixassem de existir.

A mais importante delas, para o tema que nos toca, refere-se à garantia da nãocumulatividade. A princípio, é correto afirmar - como se fez no $\mathrm{RE}^{\circ}{ }^{\circ} 194.382 / \mathrm{SP}$ - que a mera mudança na forma de cobrança do tributo não implica em violação da nãocumulatividade. Desde que assegurado ao substituído o direito à restituição ${ }^{424}$ do ICMS relativo às vendas a consumidor final realizadas por preço superior ao presumido (e que fora por aquele suportado, ao pagar o montante da operação mais o ICMS-ST ao substituto), a garantia insculpida no art. $155, \S 2^{\circ}$, I da $\mathrm{CR} / 88$ restaria assegurada.

Entretanto, quando do julgamento da Ação Direta de Inconstitucionalidade $\mathrm{n}^{\circ}$ 1.851/AL ${ }^{425}$, pugnou o Plenário do STF pela constitucionalidade de legislação estadual que vedava a devolução, ao contribuinte-substituído, do ICMS-ST eventualmente recolhido a maior pelo substituto tributário. Na assentada, fundou-se o Supremo nas seguintes premissas:

(a) a substituição tributária modifica o momento de ocorrência do fato gerador, que se dá na saída do estabelecimento substituto - e não na venda, pelo substituído, ao consumidor final;

(b) como o ICMS é devido na saída da mercadoria, não há que se falar em restituição do imposto caso a venda substituído > consumidor final ocorra em valor inferior ao presumido;

(c) a se admitir tal devolução, macular-se-á de vício insanável a sistemática de cobrança antecipada do tributo, em prejuízo da praticidade que pautou a sua criação;

BARROS CARVALHO segue o mesmo sendeiro, sustentando ser a substituição tributária progressiva "maculada por vícios de inconstitucionalidade, tendo em vista a pretensão de se tributar 'fato futuro', atropelando uma série de princípios constitucionais". (CARVALHO, Paulo de Barros. Direito Tributário, Linguagem e Método. São Paulo: Noeses, 2008, p. 581).

${ }^{424}$ Para produzir efeitos, a restituição deve ser preferencialmente em espécie. Na hipótese de a lei autorizar apenas a escrituração de créditos no valor do imposto pago a maior, deve-se garantir ao substituído o direito de transferir tais créditos ao substituto.

${ }^{425}$ STF, Pleno, ADI n ${ }^{\circ}$ 1.851/AL, Relator Min. ILMAR GALVÃO, DJ 22.11.2002, p. 55. 
(d) o $\S 7^{\circ}$ do art. 150 da $C R / 88$, nesta acrescido pela $E C n^{\circ} 03 / 93$, dispõe que somente em caso de não-realização do fato gerador presumido será autorizada a restituição do tributo indevidamente pago;

(e) a não-ocorrência do fato gerador presumido somente ocorre quando se tem perecimento da mercadoria (em decorrência, $v \cdot g$., de incêndio ou roubo), impedindo que a operação subseqüente ocorra. Se houver a venda, por qualquer valor, inexiste direito à restituição do tributo pago a maior quando a base de cálculo presumida for superior à real.

Em outras palavras, arrimando-se no princípio da praticidade e em uma duvidosa tese de que o fato gerador do ICMS-ST ocorreria no momento da saída da mercadoria do estabelecimento do contribuinte-substituto, tornou o Supremo Tribunal Federal definitiva a base de cálculo presumida do ICMS na substituição tributária progressiva.

Os riscos da interpretação carreada na $\mathrm{ADI} \mathrm{n}^{\circ}$ 1.851/AL foram claramente vislumbrados pela doutrina. SACHA CALMON e MISABEL DERZI, em parecer sobre o tema, averbaram ser "pedestre a interpretação que reconhece aplicabilidade ao dispositivo constitucional somente nas hipóteses em que não ocorresse o fato gerador" ${ }^{\text {"426. }}$. MANEIRA ${ }^{427}$ igualmente sustentou que "a definitividade de uma base de cálculo irreal representa total submissão dos princípios da capacidade contributiva, não-confisco, razoabilidade e proporcionalidade à praticidade tributária”, subvertendo-se os valores consagrados pela Constituição.

Como previsto, os Estados-membros - arvorando-se na autorização da Suprema Corte - se puseram a editar regimes de substituição tributária presumindo preços acima da média de mercado. Com isso, os contribuintes passaram a ser compelidos a recolher o im-

\footnotetext{
${ }^{426}$ E prosseguem, com absoluta propriedade:

"Em tema de impostos, todo fato gerador tem uma dimensão que lhe é ínsita. Tanto faz o fato gerador se não realizar quanto realizar-se em valor menor que o 'presumido' ou 'pautado' pela autoridade fiscal, caso contrário estariam irremediavelmente lesados o bom senso, a boa-fé, a isonomia, a proibição de excesso, a legalidade da tributação e a vedação do confisco por meio de tributos ilegítimos. [Legitimar a interpretação da ADI $\left.n^{\circ} 1.851 / A L\right]$ seria fazer pouco da prudência e da inteligência dos juízes, conspurcar a justiça e escancarar as portas do sistema legal aos abusos e excessos do Executivo, que passaria a tributar os sujeitos passivos do ICMS com esforço em pautas fiscais $j u$ re et de jure, verdadeiro contra-senso, repelido pelo STF em diversas ocasiões." (COÊLHO, Sacha Calmon Navarro e DERZI, Misabel Abreu Machado. O Direito do Sujeito Passivo do ICMS de Compensar o Imposto Pago a Maior, em Razão da Técnica da Substituição Tributária Progressiva. Revista Dialética de Direito Tributário, no 101. São Paulo: Dialética, fev./2004, p. 120).
}

${ }^{427}$ MANEIRA, Eduardo. Da Substituição Tributária Para a Frente no ICMS. Revista Dialética de Direito Tributário, nº 95. São Paulo: Dialética, ago./2003, p. 64. 
posto estadual sobre base de cálculo fictícia, arbitrariamente posta pelos Estados - com o aval do $\mathrm{STF}^{428}$.

Contudo, transcorridos alguns anos da decisão na ADI n ${ }^{\circ}$ 1.851/AL (prolatada em 2001), seus nefastos efeitos passaram a sensibilizar alguns Ministros do STF, que retomaram a discussão da matéria em outra Ação Direta de Inconstitucionalidade (ADI n ${ }^{\circ}$ $2.777 / \mathrm{SP})$.

A ADI n ${ }^{\circ}$ 2.777/SP - ajuizada pelo Governador do Estado de São Paulo após ter ciência da decisão na ADI $n^{\circ} 1.851 / \mathrm{AL}^{429}$ - volta-se contra legislação paulista instituidora da substituição tributária que resguardou o direito:

(a) do contribuinte pleitear a devolução do ICMS pago a maior quando o fato gerador ocorrer em valor inferior ao presumido;

(b) do Estado de São Paulo pleitear o pagamento aos cofres públicos do imposto pago a menor, quando a venda da mercadoria ocorrer em valor superior à base de cálculo presumida.

O Governador, após ter ciência da decisão prolatada na ADI n ${ }^{\circ}$ 1.851/AL, insurgiuse contra o dispositivo da lei paulista que prevê a possibilidade de restituição do ICMS pago na modalidade de substituição tributária, quando o fato gerador ocorrer em valor inferior ao presumido (art. 66-B, II, da Lei $\mathrm{n}^{\circ}$ 6.374/89, acrescido pela Lei $\mathrm{n}^{\circ}$ 9.176/95, ambas do Estado de SP).

Não questionou, todavia, o dispositivo da mesma lei que permite ao Estado cobrar a diferença do substituto tributário quando o valor final da venda for superior ao montante presumido para fins de recolhimento do ICMS-ST (art. 66-C da Lei $\mathrm{n}^{\circ}$ 6.374/89, regulamentado pelo art. 265 do Decreto estadual $n^{\circ}$ 45.490/00).

Dessarte, se acatada a declaração de inconstitucionalidade pleiteada, o Estado de São Paulo terá o direito de cobrar do contribuinte o ICMS recolhido a menor quando a operação futura ocorrer em valor superior ao presumido; todavia, não poderá o contribuinte

\footnotetext{
${ }^{428}$ O precedente na ADI $\mathrm{n}^{\circ}$ 1.851/AL passou a ser observado tanto por decisões posteriores do STF como pelas demais Cortes (o STJ inclusive reviu seu posicionamento, que até então assegurava a restituição, ao contribuinte-substituído, do ICMS-ST pago a maior). Inter alii, no âmbito da Corte Suprema, cite-se: STF, Segunda Turma, RE-AgR n 357.365/MG, Relator Min. GILMAR MENDES, DJ 24.02.2006, p. 45.

${ }^{429}$ O Estado de São Paulo, assim como o de Pernambuco, possui lei autorizando a restituição do ICMS pago a maior pelo contribuinte-substituto. Isso porque a interpretação de SP e PE acerca do $\$ 7^{\circ}$ do art. 150 da $\mathrm{CR} / 88$ era a mais consentânea com os princípios informadores da tributação: se houvesse excesso na exigência fiscal por meio da substituição tributária, o Estado deveria devolvê-lo ao contribuinte. Contudo, em face da decisão prolatada na ADI n ${ }^{\circ}$ 1.851/AL, o Governador de São Paulo (assim como o de Pernambuco) ajuizou Ação Direta de Inconstitucionalidade para ver declarada a invalidade do regime de devolução do ICMSST recolhido a maior instituído antes do posicionamento do STF sobre o tema.
} 
pleitear a restituição do valor pago a maior se a venda final se der em montante inferior ao previamente estipulado como base de cálculo.

O STF, nos autos da ADI $n^{\circ} 2.777 / \mathrm{SP}$ - que possui cinco votos favoráveis e cinco contrários ao seu provimento, pendente, na data atual, o voto de minerva do Min. CARLOS BRITO - possui a oportunidade única de esclarecer definitivamente o sentido e o alcance do $\S 7^{\circ}$ do art. 150 da Constituição de 1988. Ademais, algumas observações importantes quanto ao primeiro precedente que julgou constitucional a não-devolução do ICMSST pago a maior ao Estado de Alagoas merecem destaque:

(a) havia um benefício fiscal concedido pelo Estado de Alagoas (redução da base de cálculo do ICMS na venda de veículos), ao qual poderiam (ou não) aderir os revendedores de automóveis;

(b) o revendedor que não aderisse permaneceria submetido ao recolhimento do ICMS na sistemática normal de débito e crédito;

(c) o que fizesse a opção pelo benefício ganharia a redução da base de cálculo porém ficaria obrigado a suportar o imposto pago por ST de forma definitiva. É dizer, se feita a opção pelo regime especial, não haveria restituição do ICMS para o contribuinte quando a venda final do veículo fosse realizada em valor inferior ao presumido. Tampouco haveria possibilidade de cobrança, pelo Estado de Alagoas, do ICMS eventualmente recolhido a menor caso a venda final se desse por preço superior àquele presumido.

Já na legislação paulista atualmente sob o crivo do STF, a substituição tributária é obrigatória, inexistindo opção para o contribuinte. Sendo assim, há elemento diferenciador relevante para se modificar a jurisprudência da Corte com alguma coerência em relação ao julgado na ADI $n^{\circ}$ 1.851/AL. Afinal, quando se trata de regime especial, ao qual o contribuinte tem a opção de aderir ou não, é razoável tornar-se definitiva a base de cálculo para a substituição tributária. Contudo, sendo mandatória a adesão ao regime da ST, e havendo cláusula predicando a possibilidade de cobrança ulterior, pelo Estado, de valores pagos a menor, seria injurídico não garantir ao contribuinte o direito de restituição do ICMS eventualmente recolhido a maior no regime de substituição.

Tal oportunidade de evolução jurisprudencial não pode ser desperdiçada com uma interpretação que adota a exceção (a saber, a não realização do fato gerador) como regra única pela qual a restituição do ICMS seria cabível. Ora, na maior parte das operações tributadas pelo regime de substituição o fato gerador sempre ocorre. Todavia, pode não ocorrer da forma como presumida, o que legitimará Estados e contribuintes a pleitearem a dife- 
rença uns dos outros. Nada mais justo. Nada mais consentâneo com o princípio da nãocumulatividade e a busca da neutralidade fiscal. Nada mais razoável, sem descurar da praticidade (vez que o regime de ICMS-ST continuará sendo validamente aplicado, assegurando a arrecadação).

Portanto, caso o STF pugne pela validade - e, pelo teor dos votos já prolatados, obrigatoriedade - da restituição ao contribuinte do ICMS-ST indevidamente pago quando tal regime for obrigatório para determinado segmento econômico, restaurar-se-á a normalidade da cadeia de débitos e créditos que pauta a não-cumulatividade, retomando-se a realidade assinalada pelo próprio Supremo quando do julgamento da constitucionalidade da substituição tributária progressiva ( $\operatorname{RE~n}^{\circ}$ 213.396/SP e RE nº 194.382/SP): desde que assegurado ao substituído o direito de crédito do valor eventualmente cobrado a maior, inexistirá ofensa ao princípio magno da não-cumulatividade ${ }^{430}$.

\subsection{A MONOFASIA DO ICMS INCIDENTE SOBRE COMBUSTÍVEIS EM FACE DA NÃO-CUMULATIVIDADE: ANÁLISE DA EMENDA CONSTITUCIONAL No} 33/01.

Aos 11 de dezembro de 2001 adveio a Emenda Constitucional $n^{\circ}$ 33, cuja função foi a de preparar o País para a abertura do mercado de distribuição de combustíveis, até então monopolizado pela Petrobras e outras poucas empresas que gozavam de autorização governamental.

No bojo desse processo, foi necessária uma adequação na tributação dos combustíveis, visando, principalmente, a evitar a sonegação fiscal (problema bastante grave no setor), que poderia colocar por terra o projeto de se ter um mercado livre e auto-regulador (sob o pálio da Agência Nacional de Petróleo) no segmento de distribuição de derivados de petróleo.

\footnotetext{
${ }^{430}$ MANEIRA novamente lança luzes sobre a definitividade da base de cálculo presumida do ICMS, predicando que "nos casos de substituição tributária 'para a frente' no ICMS, a base de cálculo presumida deverá espelhar o valor da operação futura e preservar a capacidade contributiva do contribuinte-substituído". E prossegue, em conclusões que endossamos in totum:

“(...) A base de cálculo presumida somente poderá ser definitiva, nos casos em que for comprovadamente inferior à base de cálculo real. Isto é, a base de cálculo definitiva como forma de presunção absoluta no direito tributário só é aceitável se deliberadamente for favorável ao contribuinte." (MANEIRA, Eduardo. Da Substituição Tributária Para a Frente no ICMS. Revista Dialética de Direito Tributário, nº 95. São Paulo: Dialética, ago./2003, pp. 61-2).
} 
Dentre as mudanças operadas pela $\mathrm{EC} \mathrm{n}^{\circ}$ 33/01 houve a inclusão de dispositivo que autoriza a cobrança do ICMS em uma única fase sobre os combustíveis e lubrificantes, nos termos a serem estabelecidos por lei complementar ${ }^{431}$, in verbis:

“Art. 155. (...).

$\S 2^{\circ}$. (...).

XII - cabe à lei complementar:

h) definir os combustíveis e lubrificantes sobre os quais o imposto incidirá uma única vez, qualquer que seja a sua finalidade, hipótese em que não se aplicará o disposto no inciso $\mathrm{X}, b$;"’

A alínea $b$ do inciso $\mathrm{X}$ do $\S 2^{\circ}$ do art. 155 da CR/88 predica que o ICMS não incidirá nas operações interestaduais com lubrificantes, combustíveis e energia elétrica ${ }^{432}$. Dessarte, no novel método da EC $n^{\circ} 33 / 01$, a monofasia se aplicaria a toda e qualquer saída, sejam as internas, sejam as destinadas a outros Estados.

A edição da norma partiu do pressuposto de que os distribuidores de combustíveis e lubrificantes - cujo número aumentaria exponencialmente com a abertura do mercado -

431 Os limites da atuação do legislador complementar para fins de instituição do ICMS monofásico sobre combustíveis e lubrificantes foram bosquejados pela própria $\mathrm{EC} \mathrm{n}^{\mathrm{o}} 33 / 01$ :

"Art. 155. (...).

$\S 4^{\circ}$. Na hipótese do inciso XII, $h$, observar-se-á o seguinte:

I - nas operações com os lubrificantes e combustíveis derivados de petróleo, o imposto caberá ao Estado onde ocorrer o consumo;

(...)

IV - as alíquotas do imposto serão definidas mediante deliberação dos Estados e Distrito Federal, nos termos do $\S 2^{\circ}$, XII, $g$; (...).”

Vale notar que, mesmo no sistema monofásico, continuou a vigorar a regra de pertença da receita do ICMS ao Estado em que consumidos os combustíveis e lubrificantes (vide nota de rodapé seguinte).

${ }^{432}$ Ao interpretar a imunidade, restringiu-a o STF às hipóteses de vendas interestaduais entre contribuintes. Argumentou o Supremo Tribunal que, a se imunizar a venda para consumidores finais, estar-se-ia criando diferenciação tributária entre os vendedores de energia elétrica, combustíveis e lubrificantes sitos em um Estado e aqueles estabelecidos em outras unidades da federação (sendo que estes últimos gozariam de vantagens tributárias na venda para adquirentes finais situados naqueloutro Estado, desequilibrando a concorrência). Sustentou-se ainda que a imunidade em tela assemelha-se a um diferimento, de modo a assegurar que o ICMS relativo aos combustíveis e lubrificantes seja arrecadado pelo Estado no qual se der o consumo dos mesmos. Não se trata, portanto, de uma imunidade destinada a reduzir o preço para o consumidor final, mas sim a assegurar a adequada distribuição das receitas tributárias, aplicando-se o princípio do destino (beneficiando-se, com isso, os Estados menos desenvolvidos). Vale conferir a ementa:

"TRIBUTÁRIO. ICMS. LUBRIFICANTES E COMBUSTÍVEIS LÍQUIDOS E GASOSOS, DERIVADOS DO PETRÓLEO. OPERAÇÕES INTERESTADUAIS. IMUNIDADE DO ART. 155, § $2^{\circ}, \mathrm{X}, B$, DA CONSTITUIÇÃO FEDERAL.

Benefício fiscal que não foi instituído em prol do consumidor, mas do Estado de destino dos produtos em causa, ao qual caberá, em sua totalidade, o ICMS sobre eles incidente, desde a remessa até o consumo. Conseqüente descabimento das teses da imunidade e da inconstitucionalidade dos textos legais, com que a empresa consumidora dos produtos em causa pretendeu obviar, no caso, a exigência tributária do Estado de São Paulo. Recurso conhecido, mas desprovido." (STF, Pleno, RE $\mathrm{n}^{\circ}$ 198.088/SP, Relator Min. ILMAR GALVÃO, DJ 05.09.2003, p. 32). 
poderiam se valer de técnicas para fraudar o Fisco, dificultando a atuação das Receitas Estaduais na arrecadação do ICMS sobre tais derivados.

Nesse sendeiro, a tributação monofásica autorizada pela EC n $33 / 01$ autorizaria a cobrança do imposto na refinaria, liberando os demais agentes econômicos do controle do ICMS a pagar - que não mais seria por eles devido.

A situação, a priori, assemelha-se à substituição tributária para frente, mas com esta não se confunde.

$\mathrm{Na}$ substituição tributária progressiva, o ICMS efetivamente incide em todas as etapas da cadeia produtiva. Tanto é que os substituídos possuem legitimidade para ingressar em juízo pleiteando a restituição de valores que "pagaram" a maior (rectius, suportaram no preço de aquisição da mercadoria sujeita à ST) em decorrência da utilização de base de cálculo presumida superior à efetivamente praticada ${ }^{433}$.

No caso da monofasia, contribuinte do imposto é aquele que efetivamente faz a recolha dos valores aos cofres públicos. Não há incidência do tributo nas operações subseqüentes a ser "concentrada" no contribuinte monofásico (ao contrário do que ocorre na substituição tributária progressiva). Em verdade, as demais operações serão não-tributadas (não que sejam imunes ou isentas, mas sim porque estarão fora do âmbito de incidência do imposto).

Obviamente, a monofasia, se instituída no início da cadeia produtiva (como é a intenção, a depender apenas da lei complementar mencionada pela EC $n^{\circ} 33 / 01$, que ainda não foi editada) exigirá a aplicação de uma alíquota mais elevada do ICMS. Afinal, a base de cálculo do imposto será, obrigatoriamente, o valor da venda dos combustíveis e lubrificantes feita pela refinaria (contribuinte monofásico do ICMS). Não é possível, no sistema monofásico de tributação, que haja majoração da base de cálculo, adotando-se aquela praticada na venda ao consumidor final. Essa sistemática somente é admissível na substituição tributária progressiva. Em se tratando de monofasia, o preço de venda da mercadoria nas etapas subseqüentes é irrelevante para cálculo do imposto devido. Aplicar-se-á a alíquota (que, de acordo com a EC n 33/01, será estabelecida pelo CONFAZ) sobre o preço de venda praticado pelo contribuinte eleito pela lei complementar.

\footnotetext{
${ }^{433}$ Importante notar que a assertiva aqui feita refere-se à legitimidade ativa ad causam do substituído, que é o contribuinte do imposto (o substituto é tão-somente o responsável pela recolha do numerário às burras estatais). Quanto à efetiva existência do direito à devolução do tributo recolhido a maior na substituição tributária progressiva, vide Capítulo VI, Item 6.17, supra.
} 
Pois bem. E como fica a não-cumulatividade nessa novel forma de incidência tributária? Ora, já foi visto à saciedade que a plurifasia é elemento intrínseco à nãocumulatividade. Sem aquela, esta não se realiza. Dessa forma, a monofasia é incompatível com a não-cumulatividade. A conclusão é lógica. Portanto, após a saída dos combustíveis e lubrificantes do estabelecimento do contribuinte não há que se falar em débitos e, tampouco, em créditos do ICMS para os agentes econômicos localizados na seqüência da cadeia produtiva. A distribuidora que fizer a aquisição da refinaria terá, a priori, créditos pela entrada do combustível. Contudo, não possuindo débitos pela saída, impor-se-á a aplicação do art. $155, \S 2^{\circ}$, II, $b$, que - excepcionando a não-cumulatividade - determina a glosa dos créditos de ICMS relativos às operações anteriores à não-tributada.

Entrementes, temos que a não-cumulatividade impõe a garantia, ao contribuinte do ICMS monofásico, do crédito pela aquisição de insumos utilizados no processo de fabricação dos combustíveis e lubrificantes. Afinal, sua saída será tributada (monofasicamente). Logo, não será aplicável a regra do estorno predicada pelo art. $155, \S 2^{\circ}$, II, $b$. E, como ele suportará o ICMS em suas compras de insumos, fará jus, por óbvio, ao creditamento, reduzindo o quantum debeatur a título de ICMS.

Já nas etapas posteriores, simplesmente não haverá que se falar em tributação pelo imposto estadual - refugindo tais operações ao âmbito de incidência da novel norma de tributação.

Não nos parece que a $E C n^{\circ} 33 / 01$ tenha conflitado com a não-cumulatividade ao instituir uma forma diferenciada de arrecadação do ICMS sobre combustíveis e lubrificantes. Defendemos a não-cumulatividade como método eficaz e mundialmente testado para cobrança e arrecadação de tributos sobre o consumo. Todavia, não é factível sustentar-se que ela consiste em cláusula pétrea da Constituição. Afinal, o Constituinte é livre para dispor sobre os tributos e suas nuanças, pelo que nos parece consentâneo com a Carta de 1988 a modificação na forma de incidência do ICMS operada pela EC no 33/01.

A monofasia consiste em técnica de arrecadação alternativa e incompatível com a não-cumulatividade no que tange às operações posteriores à monofásica ${ }^{434}$. Por ser constitucionalmente autorizada, inexistem óbices para a sua implementação (ainda não efetivada, como referido alhures).

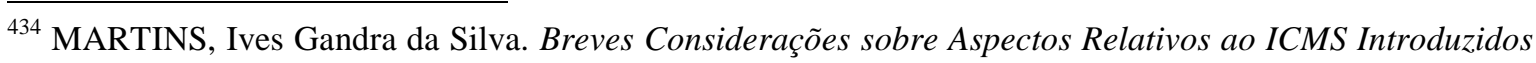
pela EC 33/01. ROCHA, Valdir de Oliveira (coord.). O ICMS e a EC 33. São Paulo: Dialética, 2002, p. 114.
} 


\subsection{O CÁlCULO “POR DENTRO” DO ICMS: FERIMENTO À NÃO- CUMULATIVIDADE?}

\subsubsection{CÁLCULO “POR FORA" VERSUS CÁLCULO “POR DENTRO”.}

Tema também constitucionalizado pela EC n n $^{3} 3 / 01$ foi o cálculo "por dentro" do ICMS. Até então, referida previsão existia apenas nas normas infraconstitucionais ${ }^{435}$.

Diferentemente do IPI, que é acrescido ao valor da operação - tal e qual os IVAs europeu e latino-americano - no caso do ICMS o valor de saída da mercadoria ou serviço já deve englobar o imposto. Expliquemos.

Em uma venda de mercadoria industrializada por $\mathrm{R} \$ 100,00$, sujeita ao IPI, o imposto é acrescido ao preço no momento de emissão da nota fiscal. Supondo uma alíquota simbólica de 15\%, o valor total a ser pago pelo bem seria de $\mathrm{R} \$ 115,00$ ( $\mathrm{R} \$ 100,00$ mais o IPI calculado "por fora" - noutras palavras, somado a posteriori ao valor da operação).

Nesta mesma hipótese, contudo, o valor de $\mathrm{R} \$ 100,00$ (preço de venda da mercadoria) já deve conter o ICMS, que é calculado "por dentro". Ou seja: o imposto estadual está sempre incluso no preço de saída do bem ou serviço, não sendo lícito estipular-se um valor e a este adicionar-se o ICMS quando da efetivação da venda. Esse o sentido da assertiva de que o ICMS integra a sua própria base.

Via de consequiência, o ICMS também integrará a base de cálculo do IPI, pois o imposto federal incide sobre o valor da mercadoria (que já inclui o quantum devido a título de imposto $)^{436}$. Como consectário lógico dessa regra, o IPI não deveria integrar a base de cálculo do ICMS, pois incide em momento posterior à formação do preço, ao qual ab initio o ICMS já se agrega. Todavia, a legislação complementar ${ }^{437}$ - tida como válida pelos Tri-

\footnotetext{
${ }^{435}$ O Decreto-lei no 406/68 possuía o seguinte dispositivo:

"Art. $2^{\circ}$. (...).

$\S 7^{\circ}$. O montante do imposto de circulação de mercadorias integra a base de cálculo a que se refere este artigo, constituindo o respectivo destaque mera indicação para fins de controle."
}

O Convênio ICM n 66/88, que sucedeu o DL n 406/68 no regramento infraconstitucional do imposto, possuía dispositivo idêntico (art. 14), que foi também reproduzido pela atual Lei Complementar nº 87/96 (art. 13, $\left.\S 1^{\mathrm{o}}\right)$.

\footnotetext{
${ }^{436}$ As Súmulas nº 258/TFR e 68/STJ sedimentaram o entendimento de acordo com o qual o ICMS está incluso na base de cálculo do IPI.

${ }^{437}$ Confira-se a Lei Complementar no 87/96:

"Art. 13. A base de cálculo do imposto é:

(...)

V - na hipótese do inciso IX do art. 12 [importação de mercadorias], a soma das seguintes parcelas:

(...)

c) imposto sobre produtos industrializados;

(...)
} 
bunais - dispôs que o IPI deverá, em regra, ser incluído na base de cálculo do ICMS (a exceção é apenas para as vendas, entre contribuintes, de produtos destinados à industrialização ou comercialização). Assim, em todas as vendas de contribuinte para nãocontribuinte, assim como nas importações de mercadorias, o IPI deverá compor a base de tributação do imposto estadual.

O cálculo "por dentro" do ICMS faz com que sua alíquota real seja maior do que a nominalmente prevista em lei. Vejamos, exemplificando ab initio com o IVA. Como seu cálculo é "por fora", considerando-se uma alíquota de $25 \%$ e uma mercadoria vendida a $\mathrm{R} \$$ 100,00, ter-se-á:

(a) valor do bem: R \$ 100,00 (não inclui o IVA);

(b) valor do IVA: $\mathrm{R} \$ 25,00$;

(c) valor total da operação: $\mathrm{R}$ \$ 125,00 ;

(d) porcentual efetivo do IVA em relação ao preço praticado: $25 \%$

(preço real $=100$; tributo $=\mathrm{R} \$ 25$. Cálculo: $25 / 100=25 \%$ ).

Todavia, calculando-se "por dentro" o ICMS na mesma operação, o resultado é distinto no que tange ao porcentual de imposto cobrado em face do valor total da venda:

(a) valor total da operação: R\$ 125,00 (já inclui o ICMS);

(b) valor do ICMS: R\$ 31,25;

(c) porcentual efetivo do ICMS em relação ao preço real do produto: 33,33\%

(preço real $=93,75 ;$ tributo $=31,25$. Cálculo: $31,25 / 93,75=33,33 \%$ ).

Ou seja: trata-se de uma forma de apuração do quantum devido que leva à majoração da alíquota prevista em lei, o que gerou candentes críticas doutrinárias quanto à sua constitucionalidade, como as tecidas por CARRAZZA ${ }^{438}$, para quem "tivesse a Constituição desejado fossem instituídos 'impostos sobre impostos', teria atribuído tal competência às pessoas políticas".

Como que acatando as críticas de CARRAZZA, a EC no 33/01 - que ampliou o espectro de incidência do ICMS nas importações, para abarcar as realizadas por não-

VII - no caso do inciso XI do art. 12 [aquisição em hasta pública de mercadorias], o valor da operação acrescido do valor dos impostos de importação e sobre produtos industrializados e de todas as despesas cobradas ou debitadas ao adquirente;

(...)

$\S 2^{\circ}$. Não integra a base de cálculo do imposto o montante do Imposto sobre Produtos Industrializados, quando a operação, realizada entre contribuintes e relativa a produto destinado à industrialização ou à comercialização, configurar fato gerador de ambos os impostos."

${ }^{438}$ CARRAZZA, Roque Antonio. ICMS, 10ª ed. São Paulo: Malheiros, 2005, p. 252. 
contribuintes $^{439}$-, determinou também que o ICMS passaria a integrar a sua própria base de cálculo:

“Art. 155. (...).

$\S 2^{\circ} .(\ldots)$.

XII - cabe à lei complementar:

i) fixar a base de cálculo, de modo que o montante do imposto a integre, também na importação do exterior de bem, mercadoria ou serviço;"

É dizer: apesar de voltada apenas à tributação da importação de bens e serviços, a norma constitucionalizou o cálculo "por dentro" do ICMS também nas operações e prestações internas, legitimando a prática que já era comezinha entre os entes Federados, posto que baseada na lei de normas gerais do ICMS.

\subsubsection{A FORMA DE CÁLCULO ("POR DENTRO" OU "POR FORA") DO TRI- BUTO NÃO POSSUI RELAÇÃO COM A OPERACIONALIZAÇÃO DA NÃO- CUMULATIVIDADE TRIBUTÁRIA.}

Um possível ferimento à não-cumulatividade pela forma de cálculo adotada para o ICMS foi analisado pelo STF antes mesmo da EC n ${ }^{\text {o } 33 / 01 . ~ O ~ P l e n a ́ r i o, ~ e m ~ j u n h o ~ d e ~ 1999, ~}$ chegou à conclusão de que o cálculo "por dentro" não viola a não-cumulatividade, em que pese não terem restado claros os fundamentos do decisum nesta parte.

O Min. MARCO AURÉLIO, vencido por declarar inconstitucional o "cálculo por dentro", sustentou uma suposta afronta à não-cumulatividade, porém não a esclareceu:

“(...) Noto o menosprezo à norma configuradora de garantia constitucional que é a do inciso I do $\S 2^{\circ}$ do artigo 155 . Como preservar-se a nãocumulatividade se se chega ao cálculo englobado?"440

NELSON JOBIM, iniciando divergência posteriormente seguida pelos demais Ministros, assentou pela validade do cálculo, refutando os argumentos iniciais de MARCO AURÉLIO $^{441}$. Para JOBIM, o ICMS não incidiria sobre o valor auferido pelo comerciante (no qual, por óbvio, não se inclui o imposto), mas sim sobre a operação de circulação jurí-

\footnotetext{
${ }^{439}$ Para maiores detalhes sobre cobrança de ICMS e IPI na importação, vide Item 6.16, supra.

${ }^{440}$ STF, Pleno, RE nº 212.209/RS, Relator p/ acórdão Min. NELSON JOBIM, DJ 14.02.2003, p. 60.

${ }^{441}$ O Min. MARCO AURÉLIO sustentara ser inconstitucional a ampliação, pelo legislador complementar, da base de cálculo do ICMS. Na sua ótica - com a qual concordamos - o imposto somente pode incidir sobre o valor da operação, é dizer, o montante que o comerciante aufere com a venda do produto ou prestação do serviço.
} 
dica de mercadoria - cujos contornos poderiam, como de fato o foram, ser delineados minudenciadamente pelo legislador complementar.

Todavia, os argumentos dos Ministros MOREIRA ALVES, ILMAR GALVÃO e SEPÚLVEDA PERTENCE - também pugnando pela validade da forma de cobro "por dentro" - são os que interessam à presente espécie. Vejamo-los:

(a) Min. MOREIRA ALVES:

"Se o ICMS não for um imposto 'por dentro', jamais chegaremos ao que se deve chegar com a observância do princípio da não-cumulatividade, com o seu jogo de compensações. Ademais, o fato gerador é que decorre da Constituição, mas é a lei complementar que impõe a base de cálculo, e ela só seria inconstitucional, nesse ponto, se estabelecer base de cálculo que não se coadune com o fato gerador, o que não ocorre aqui, em que a base de cálculo é a única que se compatibiliza com o próprio imposto, inclusive para a observância do princípio da não-cumulatividade."

(b) Min. ILMAR GALVÃO:

“(...) O princípio da não-cumulatividade aplicável ao ICMS não tem outro sentido senão e justamente impedir a tributação em cascata, é um meio de compensar o que se pagou pelo mesmo tributo anteriormente. Por meio da compensação, anula-se praticamente a incidência do ICMS sobre o tributo que integra o preço da mercadoria relativamente a operações anteriores."

(c) Min. SEPÚLVEDA PERTENCE:

“(...) Ao invés de contrariá-lo, a inclusão do ICMS da própria operação na sua base de cálculo é contingência do princípio da não-cumulatividade, é essencial à sua mecânica." 444

No que tange ao mérito da discussão - constitucionalidade do cálculo "por dentro" do ICMS - o fato é que desde 1966 o imposto estadual é calculado "por dentro", sendo certo que a partir de 2001 (EC n⿳3 33) passou a existir autorização constitucional expressa para tanto. Dessarte, a questão está há muito superada, inclusive por modificação operada na própria Lei Maior ${ }^{445}$.

Entretanto, os argumentos tecidos em relação ao cálculo por dentro do imposto e sua relação com a não-cumulatividade tributária exigem exame acurado. Afinal, dois Mi-

\footnotetext{
${ }^{442}$ STF, Pleno, RE n 212.209/RS, Relator p/ acórdão Min. NELSON JOBIM, DJ 14.02.2003, p. 60.

${ }^{443}$ STF, Pleno, RE no 212.209/RS, Relator p/ acórdão Min. NELSON JOBIM, DJ 14.02.2003, p. 60.

${ }^{444}$ STF, Pleno, RE no 212.209/RS, Relator p/ acórdão Min. NELSON JOBIM, DJ 14.02.2003, p. 60.

${ }^{445}$ Ressalvamos, apenas, nosso entendimento pessoal quanto à impropriedade técnica do cálculo por dentro, no qual se mascara a alíquota real - efetivamente incidente sobre o produto - não condizendo com a transparência que deve pautar os atos estatais.
} 
nistros (MOREIRA ALVES e PERTENCE) sustentaram que o cálculo "por dentro" é imprescindível para a operacionalização da não-cumulatividade. GALVÃO não chegou a tanto, apenas tendo pugnado que a sistemática de apuração não-cumulativa legitima o cálculo "por dentro", pois autoriza o abatimento de todo o imposto pago na etapa anterior. Outrossim, MARCO AURÉLIO, vencido, sustenta que a inclusão na própria base do ICMS fere a não-cumulatividade.

Afinal, qual a relação entre cálculo por dentro do ICMS e não-cumulatividade? Um é necessário à existência do outro?

Temos que não, do contrário o IPI e o próprio IVA seriam cumulativos, já que ambos são calculados "por fora". Ademais, a não-cumulatividade no método imposto-contraimposto, adotado para o ICMS, não é afetada pela forma de cálculo do tributo (por dentro ou por fora). Se para uma alíquota nominal de $25 \%$ a alíquota real do ICMS corresponde a $33,33 \%$ do preço do produto, o adquirente do bem terá crédito equivalente aos 33,33\%. Sendo assim, nenhum prejuízo advirá para a não-cumulatividade. O que não significa que tal forma de apuração do quantum devido seja imprescindível para que a nãocumulatividade opere. Ora, a conta gráfica do contribuinte suporta o lançamento de créditos e débitos do imposto. Seu funcionamento independe da forma de obtenção dos valores a creditar e a debitar. Sendo assim, parece-nos correto afirmar que não há qualquer relação entre a não-cumulatividade tributária e o cálculo "por dentro" do ICMS.

\subsection{O DIFERENCIAL DE ALÍQUOTAS DO ICMS E O DIREITO À SUA COM- PENSAÇÃO.}

Vigora no Brasil o princípio da origem para fins de cobrança do ICMS. Isso significa que o aludido imposto é devido, em regra, ao Estado em que situado o estabelecimento que realizar a operação ou prestação tributada pelo ICMS.

Em alguns casos o princípio da origem é excepcionado, cedendo espaço ao princípio do destino. Este predica que o ICMS caberá ao Estado onde estiver o destinatário da mercadoria ou serviço. A exportação é um caso típico de aplicação do princípio do destino. A imunidade na saída do País impede o recolhimento do imposto estadual na origem. Todavia, quando a mercadoria adentra em território estrangeiro há a incidência de tributo equivalente ao ICMS (no caso da Europa, o IVA).

Outra exceção ao princípio da origem ocorre por meio do intitulado "diferencial de alíquotas". 
Dispõe a $\mathrm{CR} / 88^{446}$ que, nas operações interestaduais entre contribuintes do $I C M S^{447}$, a alíquota aplicável pelo remetente (rectius, recolhida ao Estado de origem) não será a interna, mas sim a interestadual. Esta última foi fixada pelo Senado Federal por meio da Resolução no $22 / 89^{448}$, que estipula:

(a) alíquota de $7 \%$ para as operações ou prestações interestaduais que destinarem mercadorias ou serviços para contribuintes situados nas Regiões Norte, Nordeste, Centro-Oeste e no Estado do Espírito Santo;

(b) alíquota de $12 \%$ para as operações ou prestações interestaduais que destinarem mercadorias ou serviços a contribuintes situados nas Regiões Sul e Sudeste.

O esquema abaixo clarifica a situação em comento:

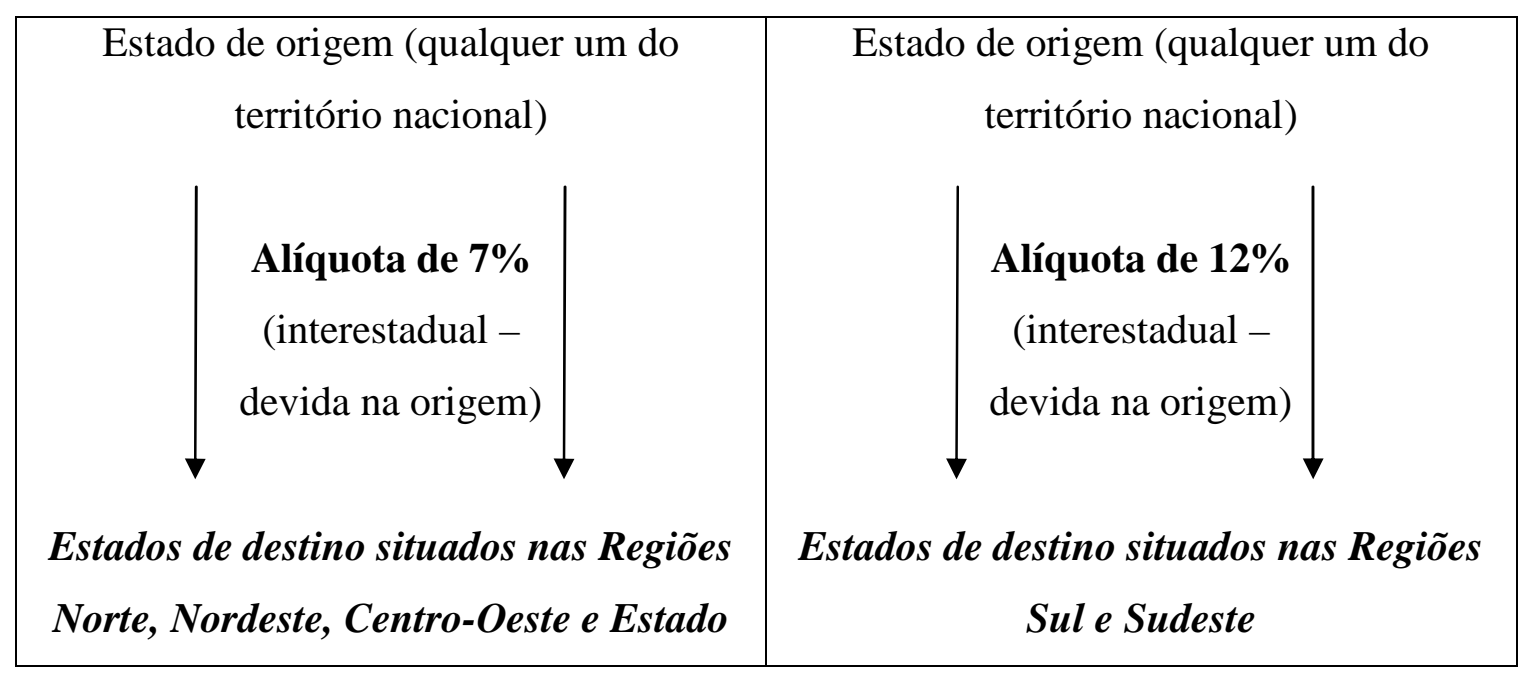

$\overline{{ }^{446} \text { Confira-se o texto constitucional: }}$

"Art. 155. (...).

$\S 2^{\circ}$. O [ICMS] atenderá ao seguinte:

(...)

VII - em relação às operações e prestações que destinem bens e serviços a consumidor final localizado em outro Estado, adotar-se-á:

a) a alíquota interestadual, quando o destinatário for contribuinte do imposto;

b) a alíquota interna, quando o destinatário não for contribuinte dele;"' (destaques nossos)

${ }^{447}$ Impende repisar que, se a remessa interestadual for para não-contribuinte do ICMS, o princípio da origem será normalmente aplicado. O remetente recolherá, ao Estado em que estiver estabelecido, a alíquota aplicável às operações internas com o produto, nada sendo devido ao Estado de destino - e não havendo, nessa hipótese, que se falar em diferencial de alíquotas.

${ }^{448}$ Resolução do Senado Federal no 22 , de 19 de maio de 1989:

“Art. $1^{\circ}$ A alíquota do Imposto sobre Operações Relativas à Circulação de Mercadorias e sobre Prestação de Serviços de Transporte Interestadual e Intermunicipal e de Comunicação, nas operações e prestações interestaduais, será de doze por cento.

Parágrafo único. Nas operações e prestações realizadas nas Regiões Sul e Sudeste, destinadas às Regiões Norte, Nordeste e Centro-Oeste e ao Estado do Espírito Santo, as alíquotas serão:

I - em 1989, oito por cento;

II - a partir de 1990, sete por cento.

Art. $2^{\circ}$. A alíquota do imposto de que trata o art. $1^{\circ}$, nas operações de exportação para o exterior, será de treze por cento.

Art. $3^{\circ}$. Esta Resolução entra em vigor em $1^{\circ}$ de junho de 1989." 


\section{do Espírito Santo}

Considerando-se que a alíquota interna do ICMS gira em torno de $17 \%$, pode-se afirmar que a interestadual é, em regra, inferior à interna. Outrossim, de acordo com a Constituição $^{449}$, o contribuinte-adquirente tem o dever de recolher ao seu Estado a diferença entre as alíquotas interestadual e interna - exatamente o montante que se intitula "diferencial de alíquotas" (alíquota interna do Estado de destino menos a interestadual devida ao Estado de origem). Assim, o quadro acima pode ser novamente visualizado, agora com a alíquota do destino e o diferencial:

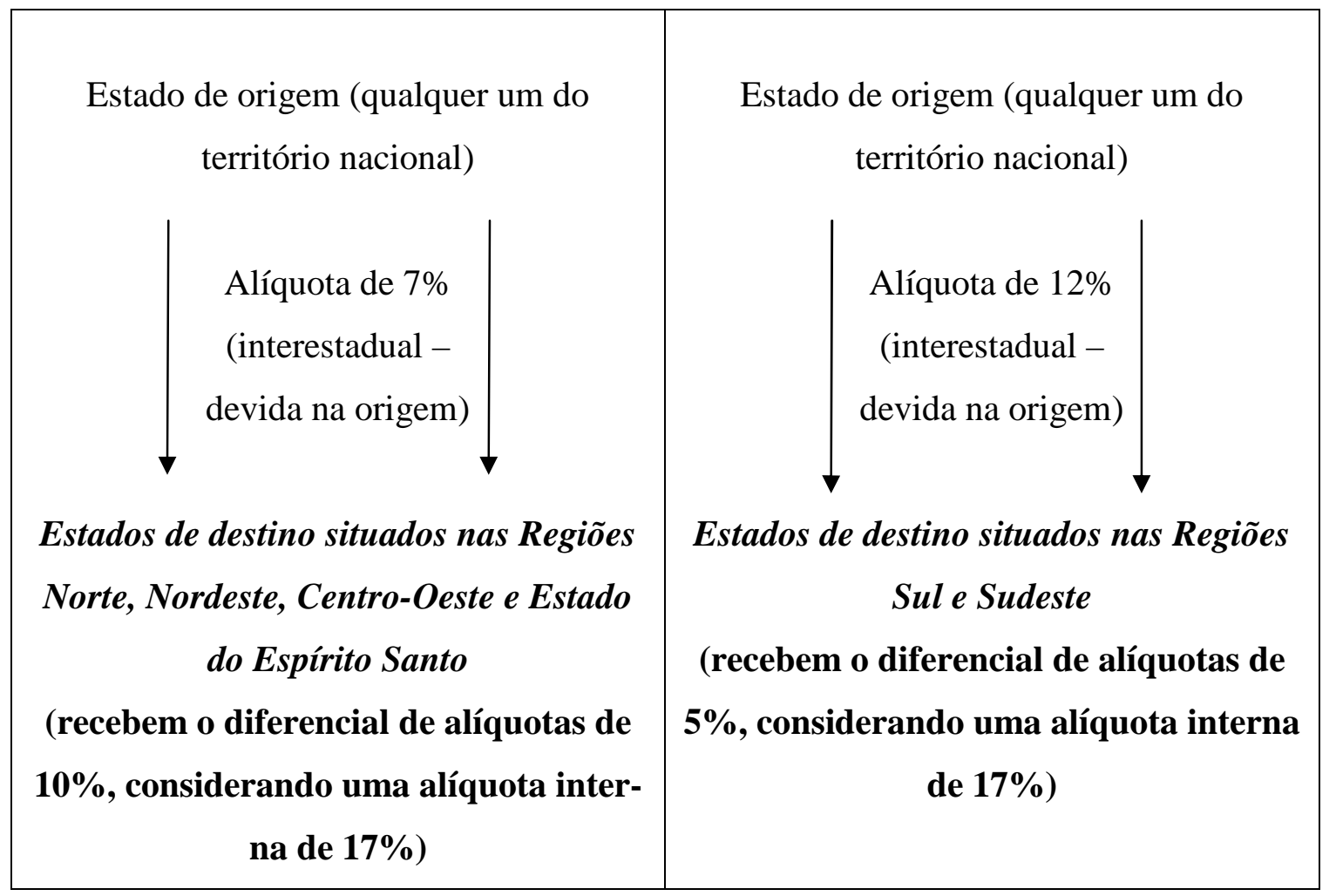

A exceção parcial ao princípio da origem em prol da tributação no destino, por meio do diferencial de alíquotas, visa à melhor distribuição da riqueza entre os entes federados. Afinal, sendo o ICMS devido ao Estado de situação do remetente das mercadorias, a maior parte do imposto arrecadado permanecerá com os Estados-produtores (mais desen-

${ }^{449} \mathrm{CR} / 88$ :

"Art. 155. (...).

$\S 2^{\circ}$. O [ICMS] atenderá ao seguinte:

(...)

VIII - na hipótese da alínea 'a' do inciso anterior [cobrança de alíquota interestadual nas operações entre contribuintes do imposto sitos em Estados distintos], caberá ao Estado da localização do destinatário o imposto correspondente à diferença entre a alíquota interna e a interestadual;" 
volvidos e industrializados) caso não se confira tratamento distinto às operações interestaduais.

A diferença de alíquotas, portanto, se presta a elevar a participação do Estado de destino no ICMS incidente na operação interestadual. Trata-se de mera técnica de divisão da arrecadação tributária entre os Estados, mantendo-se incólumes as demais características do imposto em tela.

Isto posto, pode-se concluir que o pagamento do diferencial de alíquotas pelo destinatário da mercadoria em nada altera o princípio constitucional da não-cumulatividade, permitindo ao contribuinte-adquirente a compensação integral do referido valor em sua conta gráfica. Afinal, o ICMS-diferencial de alíquotas é parte integrante do ICMS incidente na aquisição de bens e serviços, sobre o qual o adquirente possui direito ao crédito. A única especificidade do caso reside no fato de o pagante do diferencial de alíquotas ser, ao mesmo tempo, o titular do crédito do imposto por ele pago. A situação é análoga à do ICMS-importação. Neste, o importador faz a recolha do imposto no desembaraço aduaneiro da mercadoria. Posteriormente, registra o ICMS-importação como crédito e compensa-o com os débitos do ICMS do período. A questão, como se vê, é simples e possui precedente na legislação.

Entretanto, alguns Estados ${ }^{450}$ têm vedado o crédito do ICMS incidente sobre o diferencial de alíquotas. A medida é inconstitucional, pois erige restrição ao creditamento não plasmada na Constituição.

Como dito, a situação do contribuinte-destinatário pagante do diferencial de alíquotas é análoga à do contribuinte-importador. O crédito de ICMS sobre débitos pagos pelo próprio contribuinte nunca foi vedado pela Constituição. O diferencial, aliado à alíquota interestadual, consiste em uma forma de cobrança fracionada do ICMS incidente sobre mercadorias e serviços. A soma total desses valores (alíquota interestadual + diferencial) equivale ao crédito a ser aproveitado pelo adquirente, pois representa o valor global do ICMS incidente na operação. Assim, desde que o bem, pela sua natureza, gere créditos do ICMS (consistindo em mercadoria para revenda, produto intermediário ou bem do ativo imobilizado ${ }^{451}$ ), a negativa do crédito é injurídica, merecendo a repreensão dos Tribunais.

\footnotetext{
${ }^{450}$ O Estado do Mato Grosso proíbe o contribuinte de se creditar do diferencial de alíquotas pago na entrada de mercadorias em seu estabelecimento por meio do art. $15, \S 1^{\circ} \mathrm{c} / \mathrm{c}$ art. $25, \S 6^{\circ}$ da Lei estadual $\mathrm{n}^{\mathrm{o}} 7.098$, de 30 de dezembro de 1998. Da mesma forma procede o Estado do Espírito Santo, com espeque no art. 101, inciso VIII do Decreto n ${ }^{\circ}$ 1.090-R, de 25.10.2002 (RICMS/ES).

${ }^{451}$ A LC n ${ }^{\circ}$ 87/96, modificada pela LC no 102/00, assegura o crédito do ICMS incidente sobre bens destinados ao ativo imobilizado das empresas, à razão de 1/48 por mês (efetuando-se o creditamento completo,
} 


\section{A NÃO-CUMULATIVIDADE DO PIS/COFINS.}

\subsection{A PREVISÃO CONSTITUCIONAL.}

A partir da Emenda Constitucional no 42, de 19 de dezembro de 2003, a CR/88 passou a prever a não-cumulatividade da contribuição para o PIS e da COFINS para determinados setores ou atividades econômicas a serem definidos por lei. Vale ainda notar que a EC $n^{\circ}$ 42/03 instituiu nova modalidade de contribuição - a incidente sobre a importação de bens ou serviços do exterior - que também gozaria do atributo da não-cumulatividade caso o legislador ordinário assim optasse. Por fim, a EC ñ 42/03 indicou a intenção de se substituir, no tempo, a contribuição sobre folha-de-salários pelo PIS/COFINS não-cumulativos. É ver:

"Art. 195. (...).

$\S 12$. A lei definirá os setores de atividade econômica para os quais as contribuições incidentes na forma dos incisos I, $b$ [incidentes sobre receita ou faturamento]; e IV [incidente sobre importação de bens e serviços] do caput, serão não-cumulativas.

$\S 13$. Aplica-se o disposto no $§ 12$ inclusive na hipótese de substituição gradual, total ou parcial, da contribuição incidente na forma do inciso I, $a$ [folha-de-salários e demais rendimentos pagos a pessoa física], pela incidente sobre a receita ou o faturamento."

Vejamos, a seguir, o regramento em tela com maior vagar, assim como as identidades e distinções da não-cumulatividade do PIS/COFINS com a do IPI e ICMS.

\subsection{A NÃO-CUMULATIVIDAdE DA CONTRIBUIÇÃO AO PIS E DA COFINS, INCLUSIVE QUANDO DEVIDAS NA IMPORTAÇÃO DE MERCADORIAS E SERVIÇOS.}

Antes de procedermos à análise das nuanças da não-cumulatividade da contribuição para o PIS e da COFINS, faz-se mister uma breve digressão sobre o conceito de eficácia das normas constitucionais. Tal marco teórico é fundamental para o que se pretende em seguida, que é o enquadramento dos dispositivos constitucionais atinentes à nãocumulatividade do PIS/COFINS como normas de eficácia limitada de princípio institutivo impositivo, extraindo-se, em sequiência, as conseqüências jurídicas de tal ilação.

\subsubsection{A EFICÁCIA DAS NORMAS CONSTITUCIONAIS: CONCEITO E MODA-}

\section{LIDADES.}

portanto, no período de 4 anos). O fracionamento em questão é aplicável também ao diferencial de alíquotas. Afinal, este nada mais é do que o próprio ICMS suportado pelo adquirente na aquisição do bem. 
Para KELSEN ${ }^{452}$, o termo eficácia remete à observância, na prática, da norma posta pela ordem jurídica. Trata-se de uma visão do instituto como fenômeno social. Entretanto, a eficácia ora tratada é a jurídica, que se traduz na "qualidade de produzir, em maior ou em menor grau, efeitos jurídicos ao regular, desde logo, as situações, relações e comportamentos de que cogita" ${ }^{453}$.

As normas constitucionais - na classificação de J. A. DA SILVA ${ }^{454}$ - podem ser de eficácia plena, contida ou limitada ${ }^{455}$.

As normas de eficácia plena (cuja aplicabilidade é direta, imediata e integral) têm o condão de produzir todos os seus efeitos quando da promulgação da Constituição, dispensando qualquer lei para tanto. Um exemplo é a norma do art. $2^{\circ}$ da Constituição de 1988, a qual prescreve o princípio da separação e independência dos Poderes da União. Outrossim, os preceitos atributivos de competência tributária dos arts. 153, 154 e 155 - que conferem à União, Estados e Distrito Federal ${ }^{456}$ o poder de instituir impostos sobre os fatos geradores designados pela Constituição - também possuem o atributo da plena eficácia.

Como de eficácia contida compreendem-se as normas que produzem plenos efeitos quando da edição da Constituição, mas que podem ter sua abrangência reduzida por lei (a aplicabilidade de tais normas, dessarte, é direta e imediata, mas possivelmente - a depender do legislador complementar ou ordinário - não integral). O comando do parágrafo único do art. 170 da atual Lei Maior, que assegura o livre exercício de qualquer atividade eco-

\footnotetext{
${ }^{452}$ KELSEN, Hans. Teoria Pura do Direito. Trad. por MACHADO, João Baptista. São Paulo: Martins Fontes, 2006, pp. 235-7.

453 TEIXEIRA, José Horácio Meirelles. Curso de Direito Constitucional. Atualizado por MARIA GARCIA. Rio de Janeiro: Forense Universitária, 1991, p. 289, Apud SILVA, José Afonso da. Aplicabilidade das Normas Constitucionais, $7^{\text {a }}$ ed. São Paulo: Malheiros, 2007, p. 66.

${ }^{454}$ SILVA, José Afonso da. Aplicabilidade das Normas Constitucionais, 7 a ed. São Paulo: Malheiros, 2007 , pp. 88-164.

455 Outros autores, como J. MIRANDA e FERREIRA FILHO, adotam classificações que, nominalmente, distinguem-se da de J. A. DA SILVA, porém, em seu conteúdo, aproximam-se da tricotomia proposta pelo citado jurista. (MIRANDA, Jorge. Teoria do Estado e da Constituição. Rio de Janeiro: Forense, 2007, pp. 445-6).

${ }^{456}$ Alguns autores também incluem o art. 156 (atributivo de competência aos Municípios para instituição de impostos) dentre as normas de eficácia plena. Contudo, não nos parece que tal assertiva seja correta. Para nós trata-se de norma de eficácia limitada. Isso porque a existência de lei complementar prévia definindo fato gerador, base de cálculo e contribuintes é condição sine qua non para exercício da competência tributária em matéria de impostos. À míngua de lei complementar, os Estados podem, por força do art. $24, \S 3^{\circ}$ da CR/88, editar leis próprias que irão permitir o regular exercício de sua competência tributária até a superveniência da lei complementar de normas gerais. Os Municípios, contudo, não têm alternativa para exercício de seu poder tributante em matéria de impostos à míngua de lei complementar sobre o tema. Portanto, sua competência advém da CR/88, mas somente pode ser exercida uma vez editada a lei exigida pelo art. 146, III, $a$ da Constituição.
} 
nômica independentemente de autorização de órgãos públicos, salvo nos casos previstos em lei, constitui lapidar exemplo de norma de eficácia contida (afinal, é integral e imediatamente aplicável com base na Constituição, podendo, contudo, ter sua eficácia restringida por lei ulterior).

Por derradeiro, as normas de eficácia limitada possuem aplicabilidade diferida, pois dependem de lei (complementar ou ordinária) para produzirem efeitos.

Dentro desta última categoria, existem duas subdivisões: as normas de princípio institutivo e as de princípio programático. As de princípio institutivo cuidam dos esquemas gerais de estruturação de órgãos, entidades ou institutos, que deverão ser posteriormente regulados pelo legislador infraconstitucional. $\mathrm{O}$ art. 146 da Carta atual, que delineia as funções da lei complementar em matéria tributária, consiste em clássico exemplo de norma de eficácia limitada de princípio institutivo. Já as programáticas apenas direcionam a atuação do Estado, assegurando direitos como saúde, educação, et caterva, que deverão ser implementados com o decorrer do tempo.

A seu turno, as citadas normas de eficácia limitada de princípio institutivo podem ser impositivas ou facultativas. São normas de princípio institutivo impositivas "as que determinam ao legislador, em termos peremptórios, a emissão de uma legislação integrativa", ao passo que as facultativas "limitam-se a dar ao legislador ordinário a possibilidade de instituir ou regular a situação nelas delineada"457. Ou seja: na primeira modalidade (normas impositivas), não há discricionariedade para o legislador (complementar ou ordinário), que deve seguir o comando insculpido na Lei Maior. Na segunda espécie (normas facultativas), a lei pode ou não optar pelo caminho ditado pela Constituição. Entretanto, se exercida a opção, não poderá haver restrição (ao contrário do que ocorre com as normas de eficácia contida) ou ampliação do disposto pela Carta Magna.

Para facilitar a visualização da classificação aqui mencionada, veja-se o seguinte resumo:

${ }^{457}$ SILVA, José Afonso da. Aplicabilidade das Normas Constitucionais, $7^{\mathrm{a}}$ ed. São Paulo: Malheiros, 2007, pp. 126-7. 


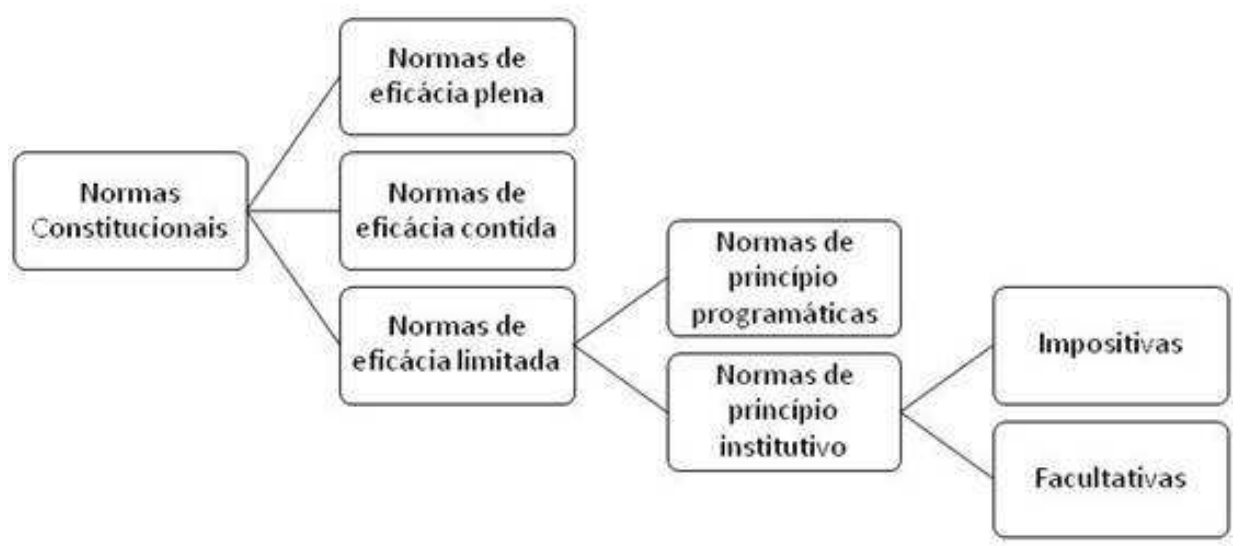

A análise seguinte - em face do caso concreto sub examine - irá aclarar os pontos ora versados.

\subsubsection{A NÃO-CUMULATIVIDADE DO PIS/COFINS: NORMA DE EFICÁCIA LIMITADA DE PRINCÍPIO INSTITUTIVO FACULTATIVO.}

A EC $n^{\circ} 42 / 03$ outorgou ao legislador ordinário o poder de instituir, em setores da atividade econômica a serem definidos pela própria lei, a contribuição para o PIS e a COFINS na sistemática não-cumulativa ${ }^{458}$ :

“Art. 195. (...).

$\S 12$. A lei definirá os setores de atividade econômica para os quais as contribuições incidentes na forma dos incisos I, $b$ [sobre receita ou faturamento]; e IV [sobre importação de bens e serviços] do caput, serão nãocumulativas.

$\S 13$. Aplica-se o disposto no $\S 12$ inclusive na hipótese de substituição gradual, total ou parcial, da contribuição incidente na forma do inciso I, $a$ [folha-de-salários e demais rendimentos pagos a pessoa física], pela incidente sobre a receita ou o faturamento."

Note-se que a contribuição autorizada pela EC n ${ }^{\circ} 42 / 03$ sobre a importação de bens e serviços (prescrita no inciso IV do art. 195 da CR/88) também admite a forma nãocumulativa de cobrança - o que somente é possível, mesmo no sentido lato da nãocumulatividade, se considerarmos que o tributo que grava a importação é o mesmo que gravará a receita auferida pelo importador quando da revenda para o mercado interno. Afinal, apesar de incidir sobre uma operação de circulação de riqueza (importação de bem ou serviço), tem-se no caso uma única etapa tributável, impedindo-se com isso a dedução do

\footnotetext{
${ }^{458}$ É fato, contudo, que as contribuições sociais sobre a receita (PIS e COFINS) não-cumulativas já haviam sido criadas antes edição da $\mathrm{EC} \mathrm{n}^{\circ}$ 42/03, pela Lei ${ }^{\circ}$ 10.637/02 (fruto da conversão da MP $\mathrm{n}^{\circ}$ 66/02) e pela $\mathrm{MP} \mathrm{n}^{\circ}$ 135/03 (convertida, dez dias após o advento da $\mathrm{EC} \mathrm{n}^{\circ}$ 42/03, na Lei $\mathrm{n}^{\circ} 10.833 / 03$ ).
} 
tributo pago nos estádios anteriores (que não existirão ${ }^{459}$ ). Ciente disso - e em que pese a diferença das bases de cálculo ${ }^{460}$ - o legislador nominou tais exações de contribuições para o PIS e a COFINS devidas na importação (Lei n ${ }^{\circ} 10.865$, de 30 de abril de 2004), permitindo-se a compensação do PIS/COFINS não-cumulativos que gravam a receita bruta com as contribuições recolhidas pelo importador.

O $\S 13$ do art. 195, a seu turno, traz uma norma programática, que prescreve, ad futuram, a substituição da contribuição sobre folha-de-salários pelo PIS/COFINS, cumulativos ou não.

Essas são as regras, plasmadas na $\mathrm{CR} / 88$, que versam sobre a não-cumulatividade do PIS/COFINS. Analisando-se o texto constitucional, é possível extrair as seguintes conclusões:

(a) a contribuição para o PIS e a COFINS, tanto internos como devidos na importação, poderão continuar sendo cobradas na forma cumulativa, ficando ao alvedrio do legislador optar (ou não) pela não-cumulatividade;

(b) caso o legislador faça a opção, poderá, para determinados setores da economia, instituir uma forma de apuração não-cumulativa do PIS/COFINS.

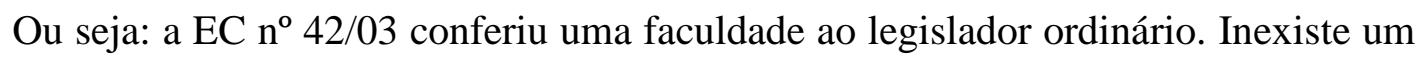
comando imperativo, tratando-se de mera autorização.

Com tais constatações, é possível afirmar-se que a não-cumulatividade do PIS e da COFINS não consiste, ao contrário daquela do IPI e do ICMS, em norma de eficácia plena. Afinal, o simples fato de depender da lei para produção de seus efeitos já retira o caráter pleno de sua eficácia. Por essa mesma razão, não poderia tampouco ser qualificada como norma de eficácia contida, pois esta também opera plenos efeitos quando da publicação da Lei Maior (podendo, todavia, ter sua eficácia restringida por norma infraconstitucional).

\footnotetext{
${ }^{459}$ Fazendo-se um paralelo, se amanhã for inserida na Constituição a não-cumulatividade para o imposto de importação, será impossível permitir ao importador o abatimento do imposto pago no desembaraço aduaneiro com esse mesmo tributo devido nas operações seguintes, justamente porque o II é monofásico.

${ }^{460}$ A contribuição para o PIS e a COFINS instituídas pelas Leis $n^{\circ}$ s 10.637/02 e 10.833/03 gravam a receita bruta das empresas, realidade distinta da contribuição para o PIS e da COFINS instituídas pela Lei ${ }^{\circ}$ 10.865/04, que tributa a importação de bens ou serviços estrangeiros. Apesar de o nomen juris não definir a espécie exacional (CTN, art. $4^{\circ}$ ), a identificação das contribuições foi propositalmente feita para se autorizar a dedução, do PIS/COFINS a pagar no mercado interno (na sistemática não-cumulativa), das contribuições incidentes na importação de bens e serviços. Tal e qual o ICMS e o IPI, o importador deverá pagar as contribuições (da Lei $\mathrm{n}^{\circ} 10.865 / 04$ ) no desembaraço aduaneiro, mas poderá compensar esses valores quando do cálculo do PIS/COFINS devido com base nas Leis nº 10.637/02 e 10.833/03.
} 
A qualificação da regra insculpida no art. 195, §12 da Constituição como de eficácia limitada é comprovada inclusive pela sua aplicabilidade diferida. Somente por meio da opção do legislador ordinário - que pode não exercê-la - será possível implantar-se a nãocumulatividade do PIS/COFINS.

Sendo norma de eficácia limitada, a não-cumulatividade do PIS/COFINS pode se apresentar de duas formas: de princípio institutivo e programática. O $§ 12$ do art. 195 pode ser qualificado como regra de eficácia limitada de princípio institutivo, como já averbado, posto que remete ao legislador ordinário a função de regular a aplicação da nãocumulatividade ao PIS/COFINS. Já o $§ 13$ do art. 195 emana uma insofismável norma programática, propugnando uma futura substituição - sine die - da contribuição sobre a folhade-salários pelas contribuições sobre a receita bruta, cumulativas ou não.

Outrossim, sendo certo que o legislador é livre para seguir ou não os caminhos ditados pela EC no 42/03 em matéria de não-cumulatividade do PIS/COFINS, a regra de eficácia limitada de princípio institutivo é facultativa e não obrigatória. Isso porque, não estando o legislador adstrito a seguir o comando constitucional, mas podendo fazê-lo, estamos diante de uma faculdade: a possibilidade de eleger ou não o caminho que lhe foi aberto pela Constituição.

Possuindo eficácia limitada - e restando claro, por tal razão, que o legislador será livre para seguir ou não o predicado constitucional - resta ainda uma indagação: a nãocumulatividade poderia ser adotada por metade para a apuração do quantum debeatur do PIS/COFINS? Por exemplo: poder-se-ia inadmitir o crédito sobre insumos para determinado segmento da economia, sendo certo que a jurisprudência do STF desde sempre assegurou esse direito nos tributos não-cumulativos? Poderia, ainda, o legislador federal determinar que o valor dos créditos escriturais de PIS/COFINS que excedesse os débitos em determinada competência deveria ser estornado, como pretenderam no passado algumas leis estaduais, estas invalidadas pelo STF? Ou, ainda, poderia a lei estipular que o contribuinte somente teria o direito de aproveitamento de $80 \%$ dos créditos calculados, como pretendeu o Estado de Santa Catarina para o extinto ICM na década de 1970, no que foi repelido pela Suprema Corte?

Parece-nos que a resposta a todos esses questionamentos é negativa.

Sendo o $\$ 12$ do art. 195 norma de eficácia limitada de princípio institutivo facultativo, o legislador tem o poder de escolher se adotará a não-cumulatividade. Poderá não fazê-lo, mantendo a forma cumulativa de exigência do PIS/COFINS, inclusive nas importações. Poderá adotar as contribuições não-cumulativas para apenas um, dois ou dez seg- 
mentos da economia, a seu alvedrio, desde que tal escolha não fira a isonomia e tampouco provoque desequilíbrios concorrenciais. Todavia, no que tange ao núcleo da nãocumulatividade, ou seja, à observância dos princípios postos pelo STF ao longo de décadas de litígios envolvendo o antigo imposto de consumo, o IPI, o ICM e o ICMS, não possui o legislador ordinário federal opção: deverá observá-los, caso opte por adotar a não- cumulatividade, naquilo em que for compatível com as contribuições sobre receita bruta e importação de bens e serviços.

Em suma: no que tange ao PIS e à COFINS, há faculdade de seleção do método de cálculo do quantum debeatur pelo Congresso Nacional no momento prévio à edição da lei. Entretanto, optando pela não-cumulatividade, o núcleo mínimo essencial desse instituto deverá ser mandatoriamente observado. Existe liberdade no momento de escolha; feita a opção, não há outra saída para a lei que não a adoção das regras constitucionais atinentes ao instituto que, livremente, decidiu-se por implantar em dados segmentos da economia. Assim, um sistema não-cumulativo de PIS/COFINS que não permita o transporte de créditos (saldo credor) para os períodos subsequientes ou que vede os créditos sobre insumos, verbi gratia, será inválido por violação à Constituição.

\subsection{A NÃO-CUMULATIVIDADE DO PIS/COFINS QUE GRAVA AS RECEITAS BRUTAS SE AMOLDA APENAS EM PARTE À DO ICMS E IPI.}

As conclusões acima identificam a não-cumulatividade do PIS/COFINS com aquela do ICMS e IPI. Afinal, quando a Constituição utiliza um termo específico e este é burilado durante décadas pelo STF, transformando-se em verdadeiro instituto jurídico, a sua utilização pela Lei Maior para regência de qualquer outro tributo obriga o legislador a observar os parâmetros já ditados pelo Supremo Tribunal Federal acerca da matéria, na medida em que compatíveis com a nova exação.

Sendo certo que sobre este ponto não pairam no momento maiores dúvidas, tem-se, todavia, que alertar para um fato relevante.

Os tributos sobre valor agregado, em torno dos quais se criou a figura da nãocumulatividade, se prestam à tributação de operações que gravam a produção ou circulação de riquezas. O objetivo de sua incidência nesse tipo de exação é fazer com que o tributo perpasse toda a cadeia produtiva e seja, ao fim, suportado pelo contribuinte de facto, o consumidor final. Por tal razão surgiu a TVA francesa, na década de 1950, expandida para o resto do mundo, inclusive o Brasil (por meio, hodiernamente, do IPI e do ICMS). As contribuições não-cumulativas que incidem sobre a importação de bens e serviços amoldam-se 
em parte a essa premissa, haja vista que gravarão a entrada em território nacional de uma mercadoria estrangeira ou de um serviço prestado em terras forâneas, mas cujos resultados se verifiquem no País. Contudo, por serem monofásicas não têm como introjetar o comando da não-cumulatividade, tendo sido necessário para tanto a sua equiparação (ainda que apenas nominalmente) às contribuições sobre receita devidas pelo importador quando da venda no mercado interno. Com isso, criou-se (ficticiamente) uma segunda etapa de incidência das contribuições devidas na importação, permitindo-se a dedução dos créditos oriundos do pagamento do PIS/COFINS no desembaraço aduaneiro com os débitos de PIS/COFINS devidos pelo auferimento de receitas na venda interna dos bens ou serviços estrangeiros. Todavia, vale repisar: trata-se de uma ficção jurídica, pois ontologicamente as contribuições devidas na importação são monofásicas e, por tal razão, inconciliáveis com a não-cumulatividade.

Tampouco as contribuições incidentes sobre a receita bruta das empresas admitem a não-cumulatividade em sua forma clássica. Afinal, é impossível gravar-se a receita "agregada" em cada fase do processo produtivo. A receita possui várias origens. Pode decorrer de uma aplicação financeira; pode decorrer da venda de um ativo; pode decorrer da consecução do objeto social da empresa, produzindo ou vendendo mercadorias e/ou prestando serviços. Enfim, a receita é uma realidade incompatível com a repercussão jurídica do tributo, já que é inviável repassar os custos fiscais para o contribuinte de facto (consumidor final) e alcançar-se, com isso, a neutralidade tributária ${ }^{461}$.

É certo que, no limite, todos os tributos gravam receitas. Porém, estas são sempre vinculadas - naqueles não-cumulativos stricto sensu - a uma operação de produção ou circulação de riquezas (bens ou serviços). Desfeito o vínculo, o que se tem no caso do PIS/COFINS incidente sobre receitas é uma amplíssima base de tributação, à qual serão aplicadas algumas deduções previstas em lei, mas nem por isso se tornarão tributos assemelhados ao IVA, ao ICMS ou ao IPI.

\footnotetext{
${ }^{461}$ A Diretiva 2006/112/CE do Conselho da União Européia, em seus consideranda, esclarece os princípios retores do IVA:

"7. O sistema comum do IVA deverá (...) conduzir a uma neutralidade concorrencial, no sentido de que, no território de cada Estado-Membro, os bens e os serviços do mesmo tipo estejam sujeitos à mesma carga fiscal, independentemente da extensão do circuito de produção e de distribuição.

(...)

30. A fim de preservar a neutralidade do IVA, as taxas aplicadas pelos Estados-Membros deverão permitir a dedução normal do imposto aplicado no estádio anterior."

É patente a incompatibilidade dos fins clássicos do tributo com as contribuições incidentes sobre a receita, que não possuem uma vinculação necessária com as operações com bens ou serviços, tornando impossível aferir-se a consecução da desejada neutralidade tributária e do repasse jurídico do ônus fiscal ao consumidor final.
} 
Em conclusão, é correto sustentar que a não-cumulatividade é mandatória e de eficácia plena para o IPI e ICMS, irradiando seus efeitos desde a publicação da Constituição. Outrossim, é facultativa para o PIS e a COFINS (norma de eficácia limitada instituidora de princípio impositivo facultativo). Porém, uma vez eleita pelo legislador como o caminho para apuração do quantum debeatur dessas contribuições, não terá ele plena liberdade para fixar uma não-cumulatividade em tudo diversa daquela do IPI e ICMS. Afinal, as amarras postas pelo STF na interpretação do vocábulo constitucional hoje aplicável às contribuições sobre a importação e a receita bruta não podem ser ignoradas. A discricionariedade conferida ao legislador pela EC no $42 / 03$ refere-se ao momento pré-legislativo, de escolha do sistema a ser adotado. Se eleita a não-cumulatividade, as normas constitucionais que asseguram eficácia mínima ao instituto devem ser observadas ${ }^{462}$.

Entretanto, a não-cumulatividade do PIS/COFINS que gravam receitas brutas não será idêntica à do IPI e do ICMS. Afinal, não conseguimos vislumbrar a possibilidade de transferência jurídica para o consumidor final do ônus de tributos que não incidam sobre atos ou negócios jurídicos. As receitas, como já averbado, provêem de variadas fontes. Logo, os créditos concedidos sobre as despesas com insumos (que entendemos como o minimum minimorum a ser observado pelo legislador ordinário federal), reduzirão em parte o quantum debeatur a título das multicitadas contribuições, porém nunca serão aptos a assegurar a neutralidade tributária, dada a ausência de controle sobre a origem das receitas gravadas pelo PIS/COFINS.

\subsection{O PIS E A COFINS DEVIDOS NA IMPORTAÇÃO DE BENS E SERVIÇOS.}

$A \mathrm{EC}^{\circ}$ 42/03, como visto, instituiu uma nova contribuição que grava a importação de bens e serviços. A medida foi salutar, posto que equiparou os bens importados (que não

\footnotetext{
${ }^{462}$ Não podemos concordar, data venia, com MARIZ DE OLIVEIRA que sustenta existir plena liberdade de atuação do legislador ordinário em matéria de PIS/COFINS não-cumulativos, in verbis:

"É muito difícil argumentar contra a liberdade de definição do legislador ordinário (...) quando se tem em mente que a não-cumulatividade da Cofins e da contribuição ao PIS não é mandamento constitucional, mas possibilidade aberta à lei ordinária.

Assim sendo, se a lei comum pode até instituir a tributação economicamente em cascata, também a pode evitar apenas em parte (...)." (OLIVEIRA, Ricardo Mariz de. Visão Geral sobre a Cumulatividade e a Não-cumulatividade (Tributos com Incidência Única ou Múltipla), e a "Nãocumulatividade" da Cofins e da Contribuição ao PIS. MACHADO, Hugo de Brito (coord.). São Paulo: Dialética; Fortaleza: ICET, 2009, pp. 442-3).

Para nós, essa ampla liberdade existia quando não havia, na $\mathrm{CR} / 88$, um comando obrigando o legislador ordinário a - se feita a opção - respeitar os ditames da não-cumulatividade. Portanto, a fase de liberdade absoluta não mais existe desde a $\mathrm{EC} \mathrm{n}^{\circ} 42 / 03$. O pressuposto da norma de eficácia limitada de princípio institutivo facultativo é permitir a discricionariedade na escolha, mas não na execução. Noutras palavras, não é dado ao legislador ordinário modificar o conceito de não-cumulatividade que o STF tem lapidado há décadas.
} 
pagavam PIS e COFINS ao adentrarem em território nacional) aos aqui produzidos (que sofriam a incidência dessas contribuições em cascata, durante todas as etapas de seu processo produtivo). A dúvida que se instaurou, todavia, foi: como se operacionalizará a nãocumulatividade se tais contribuições incidem apenas no desembaraço aduaneiro?

A indagação se justifica, haja vista que a premissa da não-cumulatividade é a existência de duas etapas tributadas pela mesma exação, compensando-se aquela devida no estádio subseqüente com a paga no negócio jurídico anterior. Sendo assim, parece-nos, em interpretação conforme o texto constitucional, que as contribuições incidentes na importação de bens e serviços devem ser compensadas com o PIS e a COFINS internos. Afinal, o PIS e a COFINS devidos na importação foram criados exatamente para equiparar os bens estrangeiros aos nacionais em relação ao PIS/COFINS cobrados internamente. Como previsto, essa foi a solução adotada pela Lei $n^{\circ} 10.865 / 04$, instituidora das exações em comento, que predica a compensação do PIS/COFINS-importação com o PIS/COFINS-receita.

Contudo, para que seja possível referida compensação, o importador deverá ser contribuinte do PIS/COFINS não-cumulativo em suas vendas internas, possuindo contabilidade apropriada e conta gráfica para apuração dos créditos e débitos. Do contrário, do ponto de vista pragmático-operacional, será impossível o aproveitamento dos créditos gerados pela aquisição de bens e serviços no estrangeiro. Afinal, o sistema cumulativo não se coaduna com a apuração débito-crédito em conta gráfica. São realidades inconciliáveis. Assim, é inegável que haverá aumento de carga fiscal para o importador que não estiver sujeito ao pagamento do PIS/COFINS-receita na forma não-cumulativa.

A solução para evitar tal afronta à isonomia seria a redução de alíquotas do PIS/COFINS-importação devidos pelo importador sujeito à apuração cumulativa do PIS/COFINS-receita.

Contudo, à míngua de lei nesse sentido, restaria apenas o recurso ao Poder Judiciário para que fosse declarada a inconstitucionalidade ${ }^{463}$ do PIS/COFINS-importação quando devido por importador sujeito à apuração cumulativa do PIS/COFINS-receita, em razão do ferimento ao princípio da isonomia.

Afinal, é premissa do PIS/COFINS sobre receitas que a cobrança na forma cumulativa, no plano interno, deve equivaler - em termos de ônus fiscal - à da modalidade não-

\footnotetext{
${ }^{463}$ O Poder Judiciário não poderia arbitrar uma nova alíquota de PIS/COFINS-importação para restabelecer a isonomia no caso, sob pena de se tornar legislador positivo. O Judiciário deve se limitar a dizer se a lei é ou não é válida. Alterar as disposições legais - in casu, as alíquotas do PIS/COFINS-importação - é tarefa exclusiva do Poder Legislativo.
} 
cumulativa. Assim, não pode haver efeito cumulativo na importação para um (importador sujeito à cumulatividade das contribuições nas vendas internas) e possibilidade de abatimento de créditos para outro (importador que paga PIS/COFINS não-cumulativos nas operações no País). Tal medida quebranta a igualdade, diferençando contribuintes em idêntica situação tributária ${ }^{464}$.

Em suma, pode-se asseverar que as contribuições incidentes na importação de bens e serviços:

(a) poderão ser não-cumulativas;

(b) em o sendo, serão compensáveis com o PIS/COFINS devido sobre as receitas internas do importador, desde que este se sujeite à apuração das contribuições na sistemática não-cumulativa;

(c) se exigidas de contribuinte sujeito ao pagamento do PIS/COFINS sobre receitas na forma cumulativa, serão inconstitucionais, salvo se a lei contiver previsão de alíquotas reduzidas do PIS/COFINS-importação.

${ }^{464}$ A doutrina tem apontado dita impropriedade do PIS/COFINS-importação, recomendando o recurso ao Judiciário:

“(...) A exigência de recolhimento de PIS e COFINS na importação, quanto à sua essência legal e constitucional, é duvidosa (...); os importadores (...) não poderão compensar os créditos pagos de PIS e COFINS na importação (...) porque prevalece o recolhimento das contribuições de forma cumulativa prevista nas Leis 9.715/98 e 9.718/98, desvirtuando-se, assim, o princípio da nãocumulatividade, não restando outra alternativa aos contribuintes a não ser submeterem as questões ao crivo do Poder Judiciário, que certamente corrigirá malsinadas exigências." (BENÍCIO, Sérgio Gonini e BENÍCIO JR., Benedicto Celso. As Principais Questões do PIS e COFINS NãoCumulativos e sua Incidência sobre as Importações. PEIXOTO, Marcelo Magalhães e FISCHER, Octavio Campos (coord.). PIS-COFINS - Questões Atuais e Polêmicas. São Paulo: Quartier Latin, 2005, p. 766). 


\section{NÃO-CUMULATIVIDADE DOS IMPOSTOS E CONTRIBUI- ÇÕES RESIDUAIS.}

\subsection{AS NORMAS DA LEI MAIOR.}

Reza a Constituição de 1988:

“Art. 154. A União poderá instituir:

I - mediante lei complementar, impostos não previstos no artigo anterior, desde que sejam não-cumulativos e não tenham fato gerador ou base de cálculo próprios dos discriminados nesta Constituição;"

Posteriormente, a Carta volta a referir-se ao dispositivo acima, da seguinte forma:

“Art. 195. A seguridade social será financiada por toda a sociedade, de forma direta e indireta, nos termos da lei, mediante recursos provenientes dos orçamentos da União, dos Estados, do Distrito Federal e dos Municípios, e das seguintes contribuições sociais:

(...)

$\S 4^{\circ}$. A lei poderá instituir outras fontes destinadas a garantir a manutenção ou expansão da seguridade social, obedecido o disposto no art. 154, I."

As normas em comento autorizam a União Federal a instituir, por lei complementar, impostos e contribuições (estas, para a seguridade social) no exercício de sua competência residual. Todavia, além do limite formal (refugindo à regra de que tributo se cria por lei ordinária), outras duas condições são impostas pela Lei Maior:

(a) tanto a base de cálculo como o fato gerador devem ser distintos daqueles já previstos pela Constituição para impostos e contribuições sociais ${ }^{465}$;

(b) os impostos e contribuições residuais deverão ser não-cumulativos.

Ambas as regras são claras e previnem excessos. Contudo, a obrigatoriedade de a contribuição ou imposto residual ser não-cumulativo deve ser compreendida cum grano salis. Expliquemos.

Se criado um imposto residual sobre a propriedade de embarcações e aeronaves (não tributáveis pelo IPVA), seria impossível dotá-lo do atributo da não-cumulatividade. Impostos sobre o patrimônio são monofásicos por natureza, ao passo que a nãocumulatividade exige duas operações concatenadas e sucessivas para que, na segunda, abata-se o montante cobrado na primeira.

\footnotetext{
${ }^{465}$ O STF entende que tal restrição somente se aplica entre impostos e entre contribuições, ou seja, seria legítima uma contribuição residual que tivesse base de cálculo de imposto (STF, Pleno, RE n ${ }^{\circ}$ 177.137/RS, Relator Min. CARLOS VELLOSO, DJ 18.04.1997, p. 13.788), o que, todavia, não nos parece correto. A vontade do Constituinte, a nosso sentir, foi evitar a bitributação e o bis in idem. Para que ambos existam, é irrelevante a espécie tributária utilizada, bastando que a mesma realidade seja gravada por dois tributos (seja do mesmo ente, no caso do bis in idem, seja de entes diversos, na bitributação).
} 


\subsection{A JURISPRUDÊNCIA.}

Na sessão Plenária de $1^{\text {o }}$ de outubro de $1998^{466}$ estava em discussão no Supremo Tribunal Federal a constitucionalidade da Lei Complementar $n^{\circ} 84 / 96$, pela qual a União instituíra - arvorando-se na competência residual - contribuição sobre remunerações pagas a trabalhadores avulsos, autônomos e outras pessoas físicas sem vínculo empregatício ${ }^{467}$. Tendo sido observado o requisito formal (edição de lei complementar) e restando atestada a não-incidência sobre bases de cálculo de outras contribuições, o STF validou o tributo criado por meio da LC no 84/96 sem que fosse examinado o seu caráter não-cumulativo (que também é pressuposto de validade dos gravames residuais).

Um ano e meio depois, em março de 2000, a Primeira Turma, sob a relatoria do Min. MOREIRA ALVES, reafirmou a constitucionalidade da contribuição previdenciária da LC $n^{\circ}$ 84/96. Nesta assentada, porém, foi analisada a observância do requisito da nãocumulatividade predicado no art. 154, I da CR/88. Conforme excertos do relatório de MOREIRA ALVES, a Corte a quo assim enfrentara a questão:

"A referência contida no art. 154, I da CF refere-se à não-cumulatividade interna, que constitui simples técnica de arrecadação, consistente no abatimento ou compensação do que for devido em cada operação com o montante do tributo cobrado nas operações anteriores, tal como se observa no recolhimento do ICMS e no IPI, consoante dispõem os artigos 153 , II, $\S 3^{\circ}$ e 155 , II, $\S 1^{\circ}$ da Constituição.

Se o contribuinte tivesse querido tratar da não-cumulatividade externa, ou seja, sobreposição de tributos, não teria referido expressamente a proibição constante na parte final do artigo 154, I, da CF: criação de novos tributos sobre fatos que possuam o mesmo fato gerador ou base de cálculo dos impostos já previstos na Constituição. E não se podendo equiparar a contribuição tratada pela Lei Complementar $n^{\circ}$ 84/96 ao ICMS e ao IPI, a isso seguese que, pelo prisma da não-cumulatividade, não há qualquer inconstitucionalidade na sua cobrança." 468

É interessante a menção, no aresto, à diferença entre não-cumulatividade interna ínsita ao ICMS e IPI como técnica de arrecadação consistente no abatimento dos valores de imposto pagos nas operações ou prestações anteriores - e a não-cumulatividade externa,

\footnotetext{
${ }^{466}$ STF, Pleno, RE no 228.321/RS, Relator Min. CARLOS VELLOSO, DJ 30.05.2003, p. 30.

${ }^{467}$ A LC n ${ }^{\text {o } 84 / 96 ~ f o i ~ e d i t a d a ~ a p o ́ s ~ a ~ d e c l a r a c ̧ a ̃ o ~ d e ~ i n c o n s t i t u c i o n a l i d a d e ~ d o ~ a r t . ~} 3^{\circ}$, I e do art. 22, I, respectivamente, das Leis $n^{\circ}$ s 7.787/89 e 8.212/91, que foram invalidadas pelo STF por vício formal, eis que as contribuições residuais devem ser instituídas por lei complementar (no RE n 177.296/RS foi declarada a inconstitucionalidade da contribuição sobre remunerações pagas a "avulsos, autônomos e administradores", prevista no art. $3^{\circ}$, I da Lei $n^{\circ} 7.787 / 89$; e na ADI $n^{\circ}$ 1.102/DF declarou-se a invalidade da cobrança de contribuições sobre remunerações pagas a "empresários e autônomos", insculpida no art. 22, I da Lei no 8.212/91).
}

${ }^{468}$ STF, Primeira Turma, RE no 258.470/RS, Relator Min. MOREIRA ALVES, DJ 12.05.2000, p. 32, grifos nossos. 
que o acórdão define como a "sobreposição de tributos". A distinção é feita apenas para se afirmar que o Constituinte pretendeu imprimir aos impostos e contribuições residuais a intitulada "não-cumulatividade interna", característica do IPI e ICMS (à época do julgamento inexistia a forma não-cumulativa de cobrança do PIS e da COFINS).

Ao votar, o Ministro MOREIRA ALVES assim discorreu sobre o tema:

"Nessa decisão [Plenária do STF que declarou a constitucionalidade da contribuição instituída pela LC $n^{\circ}$ 84/96] está ínsita a inexistência de violação, pela contribuição social em causa, da exigência da não-cumulatividade, porquanto essa exigência - e é este, aliás, o sentido constitucional da cumulatividade tributária - só pode dizer respeito à técnica de tributação que afasta a cumulatividade em impostos como o ICMS e o IPI - e cumulatividade que, evidentemente, não ocorre em contribuição dessa natureza cujo ciclo de incidência é monofásico -, uma vez que a não-cumulatividade no sentido de sobreposição de incidências tributárias já está prevista, em caráter exaustivo, na parte final do mesmo dispositivo da Carta Magna, que proíbe nova incidência sobre fato gerador ou base de cálculo próprios dos impostos discriminados nesta Constituição."

Portanto, os tributos (impostos e contribuições) residuais somente serão nãocumulativos quando também forem plurifásicos. É o que se dessume da assertiva do Min. MOREIRA ALVES, ao sustentar que a não-cumulatividade se aplica a "impostos como o ICMS e o IPI", e não "em contribuição (...) cujo ciclo de incidência é monofásico"470.

Vale apenas gizar, uma vez mais, que a aplicação da não-cumulatividade sobre tributos que não gravam operações com bens e serviços consiste em mera fórmula de cálculo do tributo a pagar, na qual são deduzidos créditos dos débitos eventualmente apurados. $\mathrm{O}$ ônus dessas exações não será, portanto, juridicamente trasladado para o contribuinte de facto em tais espécies exacionais, por impossibilidade lógica decorrente do próprio critério material da regra-matriz de incidência tributária, alheio a operações e prestações destinadas a compor o produto ou serviço adquirido pelo usuário final.

\subsection{CONCLUSÕES.}

Ante o exposto, pode-se concluir que os impostos e contribuições residuais somente deverão ter o atributo da não-cumulatividade quando gravarem a circulação de riquezas. Noutro giro verbal, a exigência constante do art. 154, I c/c 195, §4º da CR/88 - caráter não-cumulativo dos tributos residuais - refere-se à não-cumulatividade em sentido estrito,

\footnotetext{
${ }^{469}$ STF, Primeira Turma, RE n ${ }^{\circ}$ 258.470/RS, Relator Min. MOREIRA ALVES, DJ 12.05.2000, p. 32.

${ }^{470}$ STF, Primeira Turma, RE no 258.470/RS, Relator Min. MOREIRA ALVES, DJ 12.05.2000, p. 32.
} 
e não à forma de apuração do quantum debeatur aplicável a tributos como o PIS e a COFINS por força da $\mathrm{EC} \mathrm{n}^{\circ} 42 / 03$. 


\section{O NÚCLEO CONSTITUCIONAL MÍNIMO DA NÃO- CUMULATIVIDADE À LUZ DA JURISPRUDÊNCIA DO SUPREMO TRIBUNAL FEDERAL.}

\subsection{A EXIGÊNCIA DE DUAS ETAPAS GRAVADAS PELO TRIBUTO.}

Analisando-se as normas constitucionais e a evolução da jurisprudência do Supremo Tribunal Federal, pode-se afirmar que a não-cumulatividade tributária no direito pátrio possui um núcleo mínimo, que deverá, por conseguinte, ser obrigatoriamente observado pelos legisladores.

A não-cumulatividade pressupõe, como deixa assente o STF, pelo menos duas etapas tributadas. Nas hipóteses em que inexista tributação em um dos estádios, a Suprema Corte tem se inclinado pela obrigatoriedade de estorno dos créditos e vedação de transporte dos mesmos para a operação subseqüente à não-tributada - salvo se houver disposição de lei em sentido contrário ${ }^{471}$.

Em que pese a existência de alguns arestos em sentido contrário, a tendência atual da jurisprudência do Pretório Excelso é de se exigir, para o creditamento, que tanto a entrada como a saída da mercadoria tenham sido tributadas. Prova do aludido posicionamento foi a revisão da jurisprudência da Corte que, até então, concedia créditos presumidos de IPI na aquisição de insumos não-tributados ou sujeitos à alíquota zero do imposto; outrossim, o STF, em nova reviravolta, passou a negar ao contribuinte do IPI o direito de manter créditos escriturais decorrentes de ingressos tributados quando suas saídas forem isentas, não-tributadas ou gravadas à alíquota zero, no período anterior à Lei nº 9.779/99 (que, a partir de sua edição, concedeu tal benesse). Apenas nas hipóteses de concessão de isenções tem a Suprema Corte admitido, para o IPI (eis que em matéria de ICMS existe vedação constitucional), a concessão de créditos presumidos quando as aquisições são isentas do imposto federal. Contraditoriamente, no entanto, não assegurou o STF a mantença dos créditos escriturais de IPI na hipótese de aquisições tributadas seguidas de saídas isentas (o que colide com o conceito de isenção que desde sempre vigorou na Corte Máxima ${ }^{472}$ ).

\footnotetext{
${ }^{471}$ A assertiva funda-se na exegese literal da CR/88 em matéria de ICMS e na interpretação teleológica carreada pela Suprema Corte para estender, ao IPI, a restrição ao crédito do ICMS plasmada no art. $155, \S 2^{\circ}, \mathrm{II}, a$ e $b$.

${ }^{472}$ Para o STF a isenção exige incidência da norma de tributação, posto que se constitui em uma dispensa legal de tributo devido. Logo, se há tributação (ainda que a posteriori anulada pela norma isencional), atende-se ao pressuposto para a manutenção do crédito, que é a existência de duas operações gravadas, em seqüência.
} 
A mutação da jurisprudência que grassou na Corte Máxima durante decênios ${ }^{473}$ funda-se nas seguintes premissas:

(a) a aplicação da não-cumulatividade exige pelo menos duas fases gravadas pelo imposto. Logo, se a etapa anterior não for tributada, inexiste direito a créditos presumidos; da mesma forma, caso a saída seja não-tributada, os créditos registrados na escrita fiscal deverão ser estornados;

(b) se houver isenção, como esta corresponde (sob a ótica do STF) à dispensa de tributo devido e, ademais, retrata a intenção do legislador de reduzir a tributação na cadeia produtiva, a operação isenta deve ser considerada regularmente tributada, gerando direito à concessão de créditos presumidos ou à manutenção dos créditos escriturais.

Contudo, vale aqui repisar: em contradição ao seu próprio conceito de isenção, o STF tem sustentado que, na aquisição de insumos tributados para produtos cujas saídas são isentas, deve haver estorno dos créditos escriturados na conta gráfica. A contrario sensu, o Supremo Tribunal tem reconhecido o direito aos créditos presumidos de IPI na aquisição de insumos isentos com saídas tributadas. Verdadeira contradição, que deve ser sanada, sob pena de rompimento da lógica do sistema jurídico erigido pela própria Corte Maior.

Já em matéria de ICMS, a isenção implica anulação do crédito das etapas anteriores e impossibilidade de transporte de créditos para os estádios subseqüentes, em face das regras plasmadas no art. $155, \S 2^{\circ}$, II, $a$ e $b$.

Nas exportações de mercadorias e serviços, em que a saída é não-tributada por imunidade constitucional do IPI e do ICMS, tem-se também uma exceção - expressa na Constituição para o ICMS ${ }^{474}$ e implícita para o IPI - à regra que determina o estorno dos créditos das operações anteriores. Afinal, não se concedendo ao exportador o direito ao crédito dos impostos não-cumulativos que suportou em suas aquisições, seu custo e, via de conseqüência, seus preços, serão impactados, resultando em menor competitividade dos produtos brasileiros no mercado mundial e em anulação da própria imunidade concedida.

\footnotetext{
${ }^{473}$ Vale lembrar que, no passado, o alcance conferido à não-cumulatividade era tão amplo que foi editada uma emenda constitucional, a Passos Porto, para restringir o direito ao crédito do então ICM e recompor os caixas dos Estados. Vide Capítulo VI, itens 6.8.1 e 6.8.2, supra.

${ }^{474} \mathrm{CR} / 88$ :

“Art. 155. (...).

$\S 2^{\circ}$. O [ICMS]:

$\mathrm{X}$ - não incidirá:

a) sobre operações que destinem mercadorias para o exterior, nem sobre serviços prestados a destinatários no exterior, assegurada a manutenção e o aproveitamento do montante do imposto cobrado nas operações e prestações anteriores;" (destaques nossos)
} 


\subsection{O CRÉDITO ESCRITURAL.}

A não-cumulatividade normalmente se operacionaliza por meio da conta gráfica onde são lançados os débitos e créditos do tributo, calculados segundo a forma prescrita em lei. Por tal razão, o crédito é intitulado escritural. Sua natureza é contábil, pois é utilizado para apurar-se o quantum de tributo devido. Portanto, não possui a natureza de um título contra o Estado ou mesmo de um indébito recolhido às burras públicas. Ao contrário, se uma empresa encerra suas atividades com créditos acumulados, não possuirá direito à restituição de tais valores.

Os créditos, no caso do IPI e do ICMS, são comprovados pelo destaque em nota fiscal do tributo. Possuindo o documento os requisitos de validade erigidos pela lei, o contribuinte-adquirente fará jus à escrituração do crédito relativo ao imposto destacado, ainda que o alienante não proceda à recolha efetiva do gravame. No caso da contribuição para o PIS e da COFINS, como inexiste destaque em nota, os créditos são calculados sobre as despesas incorridas pelos próprios contribuintes. Nesta hipótese, inexiste o problema de saber se houve ou não efetiva recolha dos tributos pelo alienante ${ }^{475}$.

Sendo apurado saldo credor em determinada competência, é autorizado o transporte dos créditos para os períodos de apuração subseqüentes. Portanto, serão inconstitucionais leis federais (no caso do IPI e do PIS/COFINS) ou estaduais (ICMS) que impeçam o carregamento de tais créditos. Inobstante, o STF entende inexistir, na Constituição, a garantia da correção monetária dos créditos escriturais, mesmo em períodos inflacionários.

Outrossim, se o contribuinte compra bens e os revende por preço inferior ao de custo $^{476}$, inexiste qualquer óbice para que mantenha os créditos oriundos de ingressos tributados em seu estabelecimento. Portanto, leis que limitem o valor do crédito ao do débito gerado pela saída do produto são inválidas em face da não-cumulatividade, consoante a jurisprudência do STF. Tais normas contrariam, ainda, a apuração por competência, que não coaduna com esse tipo de restrição, somente admissível se houvesse apuração por produto, que nunca foi a opção dos legisladores pátrios.

\footnotetext{
${ }^{475}$ De todo modo e consoante averbado, a questão do efetivo pagamento do tributo na etapa pretérita como condição para exercício do direito ao crédito foi superada há muito pela Corte Suprema. Decidiu o STF que o direito à escrituração do crédito dos impostos não-cumulativos independe do efetivo pagamento do imposto pelo alienante, bastando o destaque em documento fiscal idôneo para amparar a aludida escrituração.

${ }^{476}$ Em épocas inflacionárias essa prática era muito comum. O comerciante adquiria mercadorias diretamente do fabricante, com prazo de 30 dias para pagar. Com o "overnight" girando em torno de $100 \%$ ao mês, era melhor negócio vender o bem no dia seguinte - ainda que, para isso, fosse necessário aliená-lo em valor inferior ao de custo - e aplicar o dinheiro até a data de vencimento da fatura junto ao industrial.
} 


\subsection{A SUBSTITUIÇÃO TRIBUTÁRIA PARA FRENTE E PARA TRÁS.}

O regime de diferimento (substituição tributária para trás) e a substituição para frente coexistem com a não-cumulatividade.

No primeiro caso, a saída é tributada, porém de forma diferida. A constatação é importante, pois o alienante não poderá ser obrigado a estornar seus créditos, seja em matéria de ICMS (em que há ordem expressa na Constituição para tanto quando a saída for isenta ou não-tributada), seja para o IPI, em que apesar da ausência de determinação constitucional o STF vem entendendo que, à míngua de duas etapas tributadas em sequiência, o direito ao crédito resta afastado. Saída diferida é, dessarte, saída tributada, para todos os efeitos legais.

Todavia, o direito de transferência para terceiros dos créditos acumulados pelo contribuinte não integra a não-cumulatividade (exceto se o acúmulo se der em decorrência de exportação ${ }^{477}$ ). Assim, é possível que o vendedor sob abrigo do diferimento acumule créditos que, com o tempo, se demonstrem irrealizáveis. Contudo, esse saldo credor de IPI ou ICMS somente será aproveitável se o contribuinte passar a realizar operações ou prestações gravadas pelos referidos impostos. Do contrário, acumulará um sem-fim de créditos, com nenhuma perspectiva de realização. Isso não fere, na visão da Corte Suprema, a nãocumulatividade. A natureza meramente contábil do crédito, já assentada de forma pacífica pelo STF, conduz igualmente a tal conclusão. Se o modelo negocial do contribuinte faz com que a totalidade das suas saídas se dê com tributação diferida, inexistindo débitos a compensar com os créditos acumulados em razão de suas aquisições tributadas, trata-se de uma opção empresarial, cujos efeitos tributários eventualmente indesejados devem ser suportados.

Na substituição tributária para frente, alçada ao plano constitucional pela Emenda $n^{\circ}$ 03/93, ainda existe margem para discussão no que toca à proteção da nãocumulatividade. Isso porque há dúvida quanto à interpretação do $\S 7^{\circ}$ do art. 150 quando assegura a "imediata e preferencial restituição do imposto pago" caso o fato gerador presumido não se realize. Conforme demonstrado no item 6.17 supra, na ADI n ${ }^{\circ}$ 1.851/AL, julgada em 08 de maio de 2002 pelo Plenário, definiu-se que se a venda ao consumidor final ocorrer em valor inferior ao presumido não haverá obrigação do ente estatal de resti-

${ }^{477}$ Como na exportação tem-se imunidade de ICMS e IPI, para que a própria regra imunizante seja eficaz é fundamental a previsão de realização dos créditos acumulados pelo exportador. 
tuir o substituído (em espécie ou sob a forma de créditos transferíveis para o substituto). Essa obrigação do Estado somente existiria - nos termos da decisão na ADI no 1.851/AL na hipótese de a venda futura (cujo imposto fora antecipadamente recolhido) efetivamente não se realizar, o que ocorre apenas quando há perecimento do objeto (roubo, incêndio, etc). Todavia, na ADI n ${ }^{\circ}$ 2.777/SP, atualmente em julgamento na Corte Suprema, o Plenário está dividido quanto à matéria, tendo sido prolatados cinco votos pela manutenção do entendimento esposado na ADI $n^{\circ} 1.851 / A L$ e outros cinco pela sua revisão. Alegam os Ministros que pretendem a reforma da jurisprudência o ferimento à não-cumulatividade caso não se assegure a devolução, ao substituído, do valor cobrado a maior na hipótese de venda abaixo do preço presumido. A definitividade da base de cálculo - em inexistindo o ajuste posterior - seria, sob a ótica dos que pugnam pela modificação da jurisprudência, um retorno às pautas fiscais criadas por alguns Estados no início da implantação da incumulatividade no País, que foram declaradas inconstitucionais, ad nauseam, pelo STF.

\subsection{O NÚCLEO INATACÁVEL DO DIREITO AO CRÉDITO.}

A implantação da não-cumulatividade no Brasil ocorreu, como visto, sob a égide do imposto de consumo, antiga nomenclatura do hodierno IPI. Foi a partir da jurisprudência firmada na Corte Suprema acerca do direito ao crédito desse extinto tributo que se assentaram as bases mínimas, inatacáveis por qualquer lei, do rol de aquisições geradoras de créditos escriturais.

Como o imposto de consumo era pago pelas indústrias, as matérias-primas permitiam o crédito, que foi posteriormente - com um impulso das normas infraconstitucionais, então já sob a égide do IPI - estendido para os materiais utilizados em embalagens e produtos intermediários. A partir de então, cristalizou-se o entendimento jurisprudencial segundo o qual os insumos que se agregam fisicamente ao produto final (ou são consumidos de forma imediata e integral no processo produtivo) geram crédito compensável com o IPI. Essa definição foi posteriormente estendida para o ICM, por analogia. De acordo com o STF, como a não-cumulatividade é um só instituto, a sua aplicação a ambos impostos (IPI e ICM), da mesma forma, era uma conseqüência natural.

Vale aqui repisar as restrições que possuímos com relação à forma pela qual o Supremo Tribunal curou do regramento da não-cumulatividade do ICM, simplesmente aplicando a teoria do crédito físico construída em torno do imposto de consumo e do IPI. Ao proceder dessa forma, a Corte Maior olvidou-se das peculiaridades do então novel imposto estadual sobre circulação de mercadorias, que, ao contrário do IPI, não é pago somente 
pelos industriais e importadores, sendo largamente aplicável em todo o setor comercial, cujos insumos são absolutamente distintos daqueles utilizados nas indústrias.

Inobstante o errôneo processo decisório, a teoria do crédito físico avançou, ao longo das décadas, de forma intacta. Com o julgamento da medida cautelar na ADI nº 2.325/DF, já sob a égide da Carta de 1988, a Suprema Corte reafirmou expressamente seu entendimento pela aplicação do crédito físico como garantia mínima da não-cumulatividade, pugnando pela validade das restrições ao crédito de ICMS operadas pela LC n ${ }^{\circ} 102 / 00$.

Portanto, pode-se assentar que, salvo disposição de lei em contrário, inexiste direito ao crédito nos tributos não-cumulativos para além dos insumos fisicamente incorporados ao produto final ou daqueles consumidos integralmente (e imediatamente) na produção industrial.

Permanece ainda a dúvida acerca do alcance que o STF conferirá à nãocumulatividade aplicada à prestação de serviços, trazida à balha pela Carta de 1988 com o ICMS e ampliada pela inserção da não-cumulatividade no âmbito do PIS/COFINS. Afinal, o crédito físico foi criado para reger a atividade das indústrias, não se amalgamando com a atividade dos prestadores de serviços, cujo resultado final não é um produto e sim algo imaterial e intangível. 


\section{NÃO-CUMULATIVIDADE: PRINCÍPIO OU REGRA?}

Em face do exposto, cumpre indagar em que consiste a não-cumulatividade plasmada na Constituição de 1988. Trata-se, afinal:

(a) de instituto universal e abstrato, caracterizável como princípio, que se exterioriza por meio das normas constitucionais; ou

(b) mera regra que predica a compensação do tributo incidente nas operações anteriores, sem que com isso se pretenda um alcance maior, como a obtenção da neutralidade fiscal.

A resposta pressupõe uma digressão prévia sobre os conceitos jurídicos de princípios e regras.

\subsection{PRINCÍPIOS E REGRAS: DISTINÇÕES FUNDAMENTAIS.}

Sob o prisma objetivo ${ }^{478}$, o direito é formado por um conjunto de normas destinadas a regular as situações sociais ${ }^{479}$. Das normas extraem-se princípios e regras jurídicas ${ }^{480}$.

Os primeiros são gerais, abstratos, podem estar implícitos ou explícitos, sendo extraídos do contexto normativo. Prestam-se a orientar não só o exegeta mas também o legislador, pois sua validade efunde efeitos que se irradiam para além do mero texto positivo. Noutro giro verbal, os princípios são pilares fundantes do ordenamento jurídico, orientando sua elaboração, interpretação e aplicação. Por tal razão há menção ao seu caráter abstrato e geral. Um princípio tem o condão, dessarte, de invalidar normas que com ele conflitem, posto que paira acima do ordenamento, perpassando-o.

\footnotetext{
${ }^{478}$ A distinção aqui referida é a clássica diferenciação entre direito objetivo e subjetivo. Este último é considerado do ponto de vista do titular do direito, daquele possui as condições para exercê-lo. Já o direito objetivo trata do instituto em si, objeto de análise neste tópico. FERRAZ JR. assim opera a distinção:

"A dicotomia [direito objetivo versus subjetivo] pretende realçar que o direito é um fenômeno objetivo, que não pertence a ninguém socialmente, que é um dado cultural, composto de normas, instituições, mas que, de outro lado, é também um fenômeno subjetivo, visto que faz, dos sujeitos, titulares de poderes, obrigações, faculdades, estabelecendo entre eles relações." (FERRAZ JR., Tércio Sampaio. Introdução ao Estudo do Direito - técnica, decisão, dominação, $5^{\text {a }}$ ed. São Paulo: Atlas, 2007, p. 145).

${ }^{479}$ MOREIRA ALVES predica, na esteira da teoria normativa jurídica, que "o direito é um conjunto de normas gerais e abstratas, impostas coativamente pelo Estado, para disciplinar a conduta dos homens na sociedade". (ALVES, José Carlos Moreira. Direito Romano, 14ª ed. Rio de Janeiro: Forense, 2007, p. 79).

RÁO não destoa, averbando que direito é "o conjunto sistemático de normas destinadas a disciplinar a conduta dos homens na convivência social". (RÁO, Vicente. O Direito e a Vida dos Direitos, $6^{\mathrm{a}}$ ed. São Paulo: Revista dos Tribunais, 2004, p. 215).
}

${ }^{480}$ CANOTILHO, J. J. Gomes. Direito Constitucional e Teoria da Constituição, $2^{\mathrm{a}}$ ed. Coimbra: Almedina, 1998, p. 1034-49. 
Já as regras consistem em normas com menor grau de abstração, mais próximas dos casos concretos por ela regulados. Dessarte, não são pilares fundantes do sistema, tampouco pairam acima das demais normas. Regras regulam situações específicas e determinadas, devendo pura e simplesmente ser observadas pelo intérprete. Para a hermenêutica das regras, os princípios terão importante valia. Afinal, as regras têm o escopo de concretizar as diretrizes traçadas pelos princípios.

Entretanto, o critério generalidade, como bem aponta $\mathrm{ALEXY}^{481}$, não é suficiente para a distinção entre princípios e regras, podendo gerar disfunções quando de sua aplicação prática. Por tal razão, o citado autor adiciona outro atributo às regras, que é a imperatividade de sua observância. Uma regra somente pode ser cumprida ou descumprida. Não há espaço para balanceamentos ou ponderações. Na hipótese de colisão entre regras, apenas uma será observada, aplicando-se, para tanto, os critérios existentes no ordenamento para solução de antinomias (tais como lex specialis derogat generalis, lex posterior derogat priori e lex superior derogat inferiori ${ }^{482}$ ). Esta característica foi nominada por DWOR$\mathrm{KIN}^{483}$ como o "tudo ou nada" que rege a aplicabilidade das regras. Os princípios, por sua vez, podem ser sopesados em caso de colisão, sem que isso signifique a invalidação daquele de menor envergadura, como registra CANARIS ${ }^{484}$. Assim, os princípios não são determinações objetivas. São "mandados de otimização" 485 que podem ser cumpridos em diferentes graus. A medida do cumprimento dos princípios é determinada não só pelas possibilidades fáticas, mas também pelas jurídicas. Assim é que preceitos constitucionais oriundos de normas que dependam de regulamentação, ainda que embasados por princípios, podem não ser cumpridos de plano (dada a ausência de regras viabilizadoras da efetivação principiológica).

\footnotetext{
${ }^{481}$ ALEXY, Robert. Teoria da Argumentação Jurídica: a Teoria do Discurso Racional como Teoria da Justificação Jurídica, $2^{\mathrm{a}}$ ed. Trad. por SILVA, Zilda Hutchinson Schild. São Paulo: Landy, 2001, p. 270.

${ }^{482}$ DINIZ, Maria Helena. Conflito de Normas, $7^{\mathrm{a}}$ ed. São Paulo: Saraiva, 2007, pp. 34-41.

${ }^{483}$ DWORKIN, Ronald. Levando os Direitos a Sério. Trad. por BOEIRA, Nelson. São Paulo: Martins Fontes, 2002, pp. 39-40.

${ }^{484}$ CANARIS, Claus-Wilhelm. Pensamento Sistemático e Conceito de Sistema na Ciência do Direito, $2^{\mathrm{a}}$ ed. Trad. por CORDEIRO, Antonio Menezes. Lisboa: Fundação Calouste Gulbenkian, 1996, p. 88.

${ }^{485}$ ALEXY, Robert. Teoria de los Derechos Fundamentales. Madrid: Centro de Estudios Constitucionales, 1993, pp. 86-7.
} 
Sendo o princípio derivado de normas constitucionais, sua sobreposição às regras é patente, dada a hierarquia superior da Lei Maior em relação aos demais estamentos da ordem jurídica.

Os princípios, podemos concluir, são axiológicos. Fundam-se em valores maiores, orientando a elaboração e interpretação das regras. Estas são normas prescritoras de condutas (obrigatórias, permitidas ou proibidas) e impositivas de sanção em caso de seu descumprimento. As regras orientam o agir do homem; os princípios são invocados para evitar que, em casos concretos, a aplicação da regra seja desarrazoada, desproporcional ou injusta.

\subsection{A NÃO-CUMULATIVIDADE ENQUANTO PRINCÍPIO CONSTITUCIO- NAL.}

Quando o comando "abatendo-se o montante cobrado nas operações anteriores" foi constitucionalizado para o ICM e para o IPI, a Lei Maior passou a efundir mais do que uma simples regra de apuração do quantum devido. Plasmou-se na Carta um verdadeiro princípio. Isso porque a não-cumulatividade possui diversas funções, perseguindo, com sua implantação no sistema jurídico:

(a) a neutralidade fiscal, de modo que os tributos sejam repassados (sob o prisma jurídico) ao contribuinte de facto, não onerando os agentes produtivos;

(b) o desenvolvimento da sociedade, pois a experiência mundial denota que a tributação cumulativa sobre o consumo gera pobreza ao dificultar a circulação das mercadorias e serviços;

(c) a conquista de mercados internacionais, permitindo-se a efetiva desoneração tributária dos bens e serviços exportados (impraticável no regime à cascade de tributação);

(d) a isonomia entre produtos estrangeiros e nacionais, haja vista que torna possível a cobrança, na importação, de tributo idêntico àquele suportado pelo produtor nacio$\mathrm{nal}^{486}$.

Portanto, quando introduzida na ordem jurídica pátria, a não-cumulatividade adveio como pilar fundante de dois importantes tributos, almejando-se com isso o progresso da nação, à luz da experiência noutras plagas. Trata-se, dessarte, de um princípio que se exte-

\footnotetext{
${ }^{486}$ Em se tratando de gravames cumulativos, os produtos acabados trazidos do estrangeiro não teriam condições de ser equiparados aos brasileiros, que aqui sofrem diversas incidências ao longo dos seus estádios de produção e distribuição até se chegar ao consumidor final.
} 
rioriza por meio da regra de abatimento do imposto pago nas operações anteriores - mas que, nem por isso (ou seja, por se externar por meio de uma regra), deixa de ser princípio.

Trata-se de entendimento que partilhamos com SACHA CALMON ${ }^{487}$, MISABEL DERZI $^{488}$ e BARROS CARVALHO ${ }^{489}$, os quais sustentam o cariz principiológico da nãocumulatividade no sistema tributário brasileiro. Os citados juristas nunca lhe negaram o caráter de técnica arrecadatória. Entretanto, sempre reconheceram que essa regra de apuração do quantum não era um fim em si mesmo, possuindo um valor superior, tal como acima explicitado, do que exsurgiria o seu matiz principiológico.

De fato, pode-se afirmar que a não-cumulatividade é o princípio constitucional tributário que mais se aproxima de uma regra técnica ${ }^{490}$. Trata-se de um princípio-técnica: parte-se de valores superiores (neutralidade tributária, v.g.) para, então, prescrever-se uma conduta (abatimento do montante cobrado nas operações anteriores) que permitirá o alcance dos fins propostos ${ }^{491}$.

Também pugnam pela natureza de princípio: A. J. COSTA ${ }^{492}$, CARRAZZA $^{493}$, MELO e LIPO ${ }^{494}$, G. DE MATTOS ${ }^{495}$, inter alii.

${ }^{487}$ COÊLHO, Sacha Calmon Navarro. Curso de Direito Tributário Brasileiro, $7^{\mathrm{a}}$ ed. Rio de Janeiro: Forense, 2004, pp. 384-97.

${ }^{488}$ BALEEIRO, Aliomar. Direito Tributário Brasileiro, $11^{\mathrm{a}}$ ed. Rio de Janeiro: Forense, 2001, pp. 419-27.

${ }^{489}$ CARVALHO, Paulo de Barros. A Regra-matriz do ICM. Tese de Livre-Docência. São Paulo: PUC, 1981, p. 377.

${ }^{490}$ SILVA, Paulo Roberto Coimbra. A Substituição Tributária Progressiva nos Impostos Plurifásicos e Nãocumulativos. Belo Horizonte: Del Rey, 2001, p. 112.

${ }^{491}$ Sobre a natureza de princípio-técnica da não-cumulatividade, veja-se o escólio de BRITO:

“Há, porém, normas às quais se quer emprestar a natureza de 'princípio', mas que não o têm. Há outras que em certos sistemas jurídicos são meras técnicas de tributação, enquanto em outros tomam o prestígio de 'princípio'. Por conseguinte, deve-se identificar, por exemplo, no campo tributário, aquilo que constitui 'princípio', juridicamente considerado, e o que é, simplesmente, uma técnica de tributação. (...) Consequentemente, importa identificar a natureza de cada critério constitutivo do núcleo, até porque, ora podem aparentas 'princípios' e serem meras 'técnicas' e vice-versa. (...) É possível, então, nestes termos, que técnicas tributárias como a progressividade e nãocumulatividade assumam no contexto a natureza de princípio. E já se pode avançar afirmando que a idéia de 'não-cumulatividade' é, entre nós, um 'princípio' tributário uma vez que garante a observância da capacidade econômica do contribuinte." (BRITO, Edvaldo. ICMS: Restrições à Compensação do ICMS - Bens do Ativo e Bens Destinados a Consumo do Estabelecimento. ROCHA, Valdir de Oliveira (coord.). O ICMS e a LC 102. São Paulo: Dialética, 2000, pp. 52-4, destaques no original).

${ }^{492}$ A. J. COSTA, tratando do então ICM, lembra que a técnica de dedução do imposto pago nas etapas anteriores é uma decorrência do princípio maior da não-cumulatividade:

"O dispositivo constitucional inscreve o princípio da não-cumulatividade do ICM. Deste princípio decorre, em um imposto plurifásico, a dedução, em cada operação, do imposto cobrado nas anteriores, nos termos do disposto em lei complementar." (COSTA, Alcides Jorge. ICM na Constituição e na Lei Complementar. São Paulo: Resenha Tributária, 1978, p. 149). 
Não obstante, impende notar que parte considerável da doutrina sustenta ser a nãocumulatividade uma simples regra enunciadora de técnica arrecadatória, que passaria ao largo de ser princípio ${ }^{496}$. Os adeptos dessa linha de pensamento buscam estremar os valores perseguidos com a aplicação da não-cumulatividade (neutralidade, desenvolvimento, et caterva) da regra de abatimento propriamente dita. Para essa corrente, podem existir princípios constitucionais que se realizam por intermédio da não-cumulatividade, o que não significa que ela seja um princípio ${ }^{497}$.

S. M. BORGES ${ }^{498}$ é uma das principais vozes que ecoam em favor da tese, sustentando que a não-cumulatividade não permeia as demais normas constitucionais que lhe são afeitas, do que exsurge seu caráter de simples regra técnica.

${ }^{493}$ CARRAZZA, Roque Antonio. ICMS, $10^{\mathrm{a}}$ ed. São Paulo: Malheiros, 2005, pp. 289-90.

${ }^{494}$ Os argumentos invocados por MELO e LIPO para caracterizar a não-cumulatividade como princípio seguem abaixo, em síntese:

“(...) A não cumulatividade é um princípio constitucional, posto que a sua supressão causaria sensível abalo nas relações de consumo, na produção de bens e na prestação de serviços, com evidentes reflexos até mesmo nas relações de emprego, em função do aumento artificial de custos." (MELO, José Eduardo Soares de; LIPPO, Luiz Francisco. A Não-Cumulatividade Tributária (ICMS, IPI, ISS, PIS e COFINS), $2^{\text {a }}$ ed. São Paulo: Dialética, 2004, p. 101).

Para os citados autores, o elemento distintivo entre regra e princípio é a potencialidade de abalo na estrutura estatal - se o abalo é mínimo, trata-se de regra; se é grave, está-se diante de princípio.

${ }^{495}$ G. DE MATTOS lembra que a técnica imposto-contra-imposto é apenas uma dentre as várias que poderiam ter sido eleitas pelo Constituinte para a operacionalização da incumulatividade (MATTOS, Aroldo Gomes de. ICMS - Comentários à Legislação Nacional. São Paulo: Dialética, 2006, pp. 272-3).

${ }^{496}$ Essa a posição de MENDONÇA, para quem "o direito tratou a não-cumulatividade (...) como um enunciado prescritivo que permite a compensação do que foi cobrado anteriormente com o cobrado na operação atual". (MENDONÇA, Christine. A Não-Cumulatividade do ICMS. São Paulo: Quartier Latin, 2005, p. 98).

${ }^{497}$ LUNARDELLI bem explicita esse ponto de vista:

“(...) Não se confundem valor e a regra técnica da não-cumulatividade.

Isto não quer dizer que não se completem na tarefa de atingir aquela finalidade constitucionalmente fixada. Completam-se, sem dúvida alguma. Aliás, foram construídos juridicamente para isso.

O valor direciona o sentido a ser dado a estes tributos, impregnados que estão pelo viés nãocumulativo. A regra implanta este direcionamento, dando ao valor concretude e objetividade no seio do ambiente jurídico-tributário." (LUNARDELLI, Pedro Guilherme Accorsi. A NãoCumulatividade do ICMS - uma Aplicação da Teoria sobre as Regras do Direito e as Regras dos Jogos. São Paulo: Quartier Latin, 2009, pp. 166-7).

${ }^{498}$ Confira-se, nas palavras do Catedrático da UFPE:

"Posto estudada como um princípio, a incumulatividade não o é. Trata-se de simples regra. Se princípio constitucional tributário fora, ela permearia todo o subconjunto das normas constitucionais sobre matéria tributária, condicionando-lhes a exegese. Precisamente porque não o é, tais regras sobre a incumulatividade sequer são aplicáveis indistintamente ao IPI e ao ICMS. Cada um desses impostos tem, relativamente ao crédito fiscal, regras próprias; regras que são aplicáveis exclusivamente ao IPI ou ao ICMS (alternativa de excludência, entenda-se). Regras restritivas que são aplicáveis ao ICMS não se aplicam ao IPI." (BORGES, José Souto Maior. Crédito do IPI Relativo a Insumo Isento. Revista Dialética de Direito Tributário, no 48. São Paulo: Dialética, set./1999, p. 160). 
ÁVILA ${ }^{499}$, arrimado na característica dos princípios que permite a sua realização em variados graus (em atenção à relativização ínsita a esse instituto), propaga ser a nãocumulatividade uma regra, justamente por não admitir balanceamento.

GRECO $^{500}$ tampouco vislumbra matriz principiológica na não-cumulatividade, assim como BOTTALLO ${ }^{501}$, que apenas adota a nomenclatura "princípio" por ser expressão de uso consagrado, mas ressalva que a não-cumulatividade constitui "mera técnica de apuração do quantum da obrigação tributária a cargo do sujeito passivo".

A nosso sentir, reduzir a não-cumulatividade a uma regra técnica de apuração do quantum debeatur é olvidar-se das premissas que levaram o Constituinte, ainda nos idos de 1965, a plasmar na Lei Maior a norma em questão. Ora, as técnicas que permitem a operacionalização desse princípio são as do imposto-contra-imposto e base-contra-base (na sistemática de deduções) ou a da adição (em que se soma o valor acrescido à mercadoria ou serviço para, então, sujeitar-se essa parcela à tributação). Técnica não se confunde com o princípio. Ao enunciá-lo, para o ICMS e para o IPI, o Constituinte de 1988 fez opção pela técnica imposto-contra-imposto. É óbvio que são realidades (princípio e técnica) imbricadas, como aliás reconhecem adeptos de ambas as correntes expostas. Contudo, negar os valores perseguidos pela não-cumulatividade, dispondo que a forma de cálculo é tudo o que o Constituinte pretendeu enunciar quando a plasmou na $\mathrm{CR} / 88$, não nos parece, data maxima venia, adequado ${ }^{502}$.

${ }^{499}$ Os seguintes excertos clarificam as premissas de ÁVILA:

“(...) Se princípio é definido como uma norma realizável em vários graus, dependendo dos princípios com os quais ela entra em conflito concreto, e que, por isso, exige uma aplicação que lhe atribua dimensão de peso, indaga-se: a norma da não-cumulatividade, enquanto norma que permite deduzir, do imposto a pagar, o montante do imposto incidente na operação anterior do ciclo econômico pode ser qualificada como um princípio e ser objeto de flexibilização em decorrência de outros princípios? (...). Evidentemente que não. Onde estão as referidas propriedades de ausência de estrutura hipotética, de possibilidade de realização em vários graus segundo as restrições advindas de outros princípios? Elas não estão presentes." (ÁVILA, Humberto. Teoria dos Princípios - da Definição à Aplicação dos Princípios Jurídicos, $8^{a}$ ed. São Paulo: Malheiros, 2008, pp. 89-90).

${ }^{500}$ Leciona o autor:

"Não-cumulatividade é (...) técnica para determinação do valor a recolher por um determinado contribuinte. Princípio supõe a incorporação de algum valor constitucionalmente protegido, ou a disciplina e a regulação de um determinado fim a ser obtido. (...). O princípio diz respeito a valores e fins e não a modos de cálculo e apuração do montante a ser recolhido." (GRECO, Marco Aurélio. A Não-Cumulatividade das Contribuições COFINS/PIS. Revista de Estudos Tributários, $\mathrm{n}^{\circ} 41$. Porto Alegre: Síntese, jan.-fev./2005, pp. 126-7).

${ }^{501}$ BOTTALLO, Eduardo Domingos. IPI - Princípios e Estrutura. São Paulo: Dialética, 2009, p. 34.

${ }^{502}$ MACHADO aclara essa natureza dúplice (princípio e técnica) da não-cumulatividade:

"A não-cumulatividade pode ser vista como princípio e também como técnica. 
Ao mesmo tempo, não pretendemos aqui sustentar ser a não-cumulatividade uma cláusula pétrea da Constituição. Os valores que orientam a inserção do princípio no texto constitucional são inquestionáveis. Todavia, sua exclusão da Lei Maior não feriria nenhuma norma intocável. A não-cumulatividade vincula-se a uma opção do EstadoAdministração para o auferimento de receitas derivadas por meio de tributos. É uma escolha consentânea com diversos valores perseguidos pelas democracias hodiernas. Sua ausência, entretanto, não colidiria frontalmente com nenhum direito ou garantia individual. Seria, por óbvio, um retrocesso indesejável, mas não inconstitucional.

\subsection{O PRINCÍPIO DA NÃO-CUMULATIVIDADE SOMENTE ENCONTRA CONDIÇÕES DE ATINGIR SEUS FINS QUANDO APLICADO A EXAÇÕES PLURIFÁSICAS (QUE GRAVEM A CIRCULAÇÃO DE RIQUEZAS).}

Sendo certo que a não-cumulatividade é princípio, para que produza seus efeitos neutralidade tributária, transferência do ônus ao consumidor final, entre outros - é imperioso que existam as condições fáticas e jurídicas necessárias para tanto. Um princípio somente é eficaz quando, no mundo fenomênico e jurídico, encontra elementos que permitem sua implantação ${ }^{503}$.

Isto posto, indagamos: quais são as condições necessárias para a produção plena dos efeitos da não-cumulatividade tributária? Parece-nos indubitável que é a existência de tributos plurifásicos, sobre os quais a técnica-princípio incide, trasladando o ônus da exação para a última etapa da cadeia produtiva. Ou seja: somente em meio a exações que gravem a circulação de riquezas em mais de um estádio se faz possível o alcance dos fins pretendidos com a não-cumulatividade. Quando estendida para contribuições cujas hipóteses de incidência são realidades estanques e não vinculadas a um negócio jurídico mercantil (caso da receita, ampla base de tributação que advém das mais diversas fontes), a não-

É um princípio, quando enunciada de forma genérica, como está na Constituição no dispositivo que se reporta ao IPI dizendo que esse imposto 'será não-cumulativo, compensando-se o que for devido em cada operação com o montante cobrado nas anteriores'. (...) Embora já esteja de certa forma definido o que se deva entender por não-cumulatividade, não se estabelece exaustivamente o modo pelo qual esta será efetivada. Não se estabelece a técnica. Tem-se simplesmente o princípio.

A técnica da não-cumulatividade, a seu turno, é o modo pelo qual se realiza o princípio. Técnica é 'maneira ou habilidade especial de executar algo'. Assim, a técnica da não-cumulatividade é o modo pelo qual se executa ou se efetiva o princípio." (MACHADO, Hugo de Brito. Virtudes e Defeitos da Não-Cumulatividade no Sistema Tributário Brasileiro. MARTINS, Ives Gandra da Silva (coord.). Caderno de Pesquisas Tributárias no 10 (nova série) - O Princípio da Não-Cumulatividade. São Paulo: Revista dos Tribunais/Centro de Extensão Universitária, 2004, p. 72).

${ }^{503}$ Disso decorre a possibilidade de realização, em graus distintos, de um princípio. Havendo todas as condições necessárias à sua observância, o grau será máximo, ao passo que, na inexistência delas, será mínimo. 
cumulatividade resta impedida de operar a contento seu principal efeito, que é a translação ao contribuinte de facto do ônus fiscal. Nesse ambiente adverso, contudo, a nãocumulatividade mantém suas características básicas, que deverão ser observadas pelos legisladores sempre que possível. Entretanto, seus fins não serão atingidos por completo, pois ela terá sido aplicada fora do arcabouço jurídico para o qual foi concebida - que é a atuação sobre as exações plurifásicas de modo a torná-las neutras e indiretas.

Portanto, a não-cumulatividade clássica existe, no ordenamento jurídico brasileiro, para o ICMS, o IPI e as contribuições e impostos residuais (estes últimos, quando gravarem operações com bens e serviços em mais de um estádio da cadeia produtiva). Por tal razão a nominamos não-cumulatividade stricto sensu.

Já no caso da contribuição para o PIS e da COFINS incidentes sobre a receita bruta, a não-cumulatividade consiste em mera forma de apuração do quantum debeatur, pois não encontra as condições necessárias à produção de seus efeitos. O núcleo mínimo do princípio deverá ser observado desde que não seja incompatível com as citadas contribuições. Mas os efeitos de translação jurídica do ônus e demais consectários, como neutralidade na tributação, não serão alcançados. Afinal, a matriz das contribuições é incompatível com os fins perseguidos pelo princípio eleito para guiá-las ${ }^{504}$.

Vale ainda lembrar que ambas as exações (PIS e COFINS) foram tornadas nãocumulativas por leis ordinárias (Lei $n^{\circ} 10.637 / 02$, precedida pela MP $n^{\circ}$ 66/02 e Lei $n^{\circ}$ 10.833/03, precedida pela MP no 135/03). A Emenda Constitucional $n^{\circ}$ 42/03 é, dessarte, posterior à criação, no sistema jurídico pátrio, do regime não-cumulativo das contribuições $^{505}$. Contudo, uma vez editada, a Constituição passou a determinar expressamente que a não-cumulatividade - instituto que somente tem um único significado, como predica a boa técnica hermenêutica - deve ser aplicada às contribuições sobre a receita bruta. Ora, em face dessa mutação constitucional, a não-cumulatividade ganhou foros de princípio também para o PIS/COFINS. Contudo, como ocorre sempre que um princípio é utilizado em situações nas quais não encontra as condições necessárias à sua efetivação, o grau de eficácia da não-cumulatividade nesses casos é restrito, gerando ampla liberdade para o

\footnotetext{
${ }^{504}$ No mesmo sentido é a lição de R. L. TORRES:

“(...) Não se pode extrapolar a técnica da não-cumulatividade do ICMS e do IPI para o PIS e a COFINS, já que estes últimos não incidem sobre fatos e negócios jurídicos relativos à circulação de bens, mas sobre o faturamento e as receitas das empresas." (TORRES, Ricardo Lobo. A NãoCumulatividade no PIS/COFINS. PEIXOTO, Marcelo Magalhães e FISCHER, Octavio Campos (coord.). PIS-COFINS - Questões Atuais e Polêmicas. São Paulo: Quartier Latin, 2005, p. 72).
}

505 A EC no 42/03 apenas antecedeu, em dez dias, a Lei n ${ }^{\circ}$ 10.833/03. Todavia, as regras da nãocumulatividade veiculadas pela lei já se encontravam em vigor por força da MP nº 135/03. 
legislador, exceto sobre o núcleo mínimo do direito ao crédito físico (calculado sobre as despesas com insumos), que acaba sendo o único liame entre a não-cumulatividade das contribuições sociais sobre a receita bruta (extensível ao PIS/COFINS-importação) e a não-cumulatividade stricto sensu aplicável ao IPI e ao ICMS. 
TÍTULO III - A NÃO-CUMULATIVIDADE E AS NORMAS INFRACONSTITUCIONAIS 


\section{IMPOSTO SOBRE PRODUTOS INDUSTRIALIZADOS.}

\subsection{A REGRA-MATRIZ DO IPI.}

Quando da edição da $E C$ n $^{\circ} 18 / 65$, foi outorgada à União competência para instituição do Imposto sobre Produtos Industrializados (IPI), em substituição ao vetusto Imposto de Consumo (IC). Com pouco tempo o IPI se tornou o mais importante tributo federal, status que manteve até 1975, quando sua arrecadação foi superada pela do Imposto de Renda $^{506}$.

A CR/88, tal como suas antecessoras, limitou-se a permitir a cobrança de imposto sobre "produtos industrializados" "507. Devido ao laconismo constitucional, a legislação complementar e ordinária tem exercido papel fundamental na definição da regra-matriz em comento.

O Código Tributário Nacional delineou os contornos do IPI em seus arts. 46 a 51, que vigoram até hoje.

Consoante o CTN, as hipóteses de incidência do IPI são três:

(a) saída ${ }^{508}$ de produto industrializado do estabelecimento industrial ou a este equiparado;

(b) importação ${ }^{509}$, com incidência no momento do desembaraço aduaneiro ${ }^{510}$;

${ }^{506}$ BALEEIRO, Aliomar. Direito Tributário Brasileiro, $11^{\mathrm{a}}$ ed. Atualizado por MISABEL ABREU MACHADO DERZI. Rio de Janeiro: Forense, 2001, p. 335.

${ }^{507} \mathrm{CR} / 88$ :

“Art. 153. Compete à União instituir impostos sobre:

(...)

IV - produtos industrializados;"

${ }^{508}$ Não se trata de saída pura e simples, mas sim daquela amparada em um negócio jurídico que modifica a posse ou propriedade do produto industrializado, como leciona ATALIBA:

"É (...) hipótese de incidência do IPI o fato de um produto, sendo industrializado, sair de estabelecimento do produtor, em razão de um negócio jurídico translativo da posse ou da propriedade do mesmo." (ATALIBA, Geraldo. Estudos e Pareceres de Direito Tributário, v. I. São Paulo: Revista dos Tribunais, 1978, p. 3, destaques no original).

De todo modo, a mera transferência da posse do produto, desde que suportada em negócio jurídico válido, gera o dever de pagar IPI, diferentemente do ICMS, que exige a concretização de uma operação de circulação jurídica da mercadoria, com transmissão da propriedade do bem.

509 Para alguns autores, a exigência de IPI na importação de mercadorias é inconstitucional, posto que a $\mathrm{CR} / 88$ apenas autoriza a cobrança do imposto sobre produtos industrializados, sendo certo que sobre o ingresso de mercadorias estrangeiras já existe o Imposto de Importação. Nessa toada, cobrar o IPI-importação consistiria em bis in idem, repelido pela ordem jurídica (nesse sentido: MELO, José Eduardo Soares de; LIPPO, Luiz Francisco. A Não-Cumulatividade Tributária (ICMS, IPI, ISS, PIS e COFINS), $2^{\text {a }}$ ed. São Paulo: Dialética, 2004, p. 77).

Data venia, não concordamos com tal assertiva. A Constituição de 1988 outorgou competência à União para tributar produtos industrializados, pura e simplesmente. Exercendo a liberdade de escolha proporcionada pela Lei Maior, o legislador federal elegeu três condutas distintas relacionadas com o objeto produtos industrializados: industrializar produtos e dar-lhes saída; importar produtos industrializados e arrematar, em lei- 
(c) arrematação, em leilão, de produto industrializado que tenha sido apreendido ou abandonado $^{511}$.

Após delinear os três critérios materiais de incidência do IPI, o CTN define "produto industrializado" como o "que tenha sido submetido a qualquer operação que lhe modifique a natureza ou a finalidade, ou o aperfeiçoe para o consumo" ${ }^{, 512}$. Note-se que o conceito é $l a t o^{513}$, razão pela qual a jurisprudência do STF já assentou, v.g., pela incidência do IPI sobre mármores e granitos revendidos por comerciantes que cortam as placas dessas pedras, preparando-as para assentamento em edificações ${ }^{514}$. A seu turno, o Regulamento do IPI prescreve haver industrialização, dentre outras hipóteses, quando da transformação,

lões, produtos industrializados apreendidos ou abandonados. Trata-se de exercício legítimo da competência, sem restrições, diretamente derivada da Carta Constitucional. Nessa toada são as lições de BARROS CARVALHO, ao sustentar que "o constituinte se refere, no art. 153, IV, a instituir imposto sobre produtos industrializados, não adscrevendo o verbo a ser agregado a esse complemento, o que possibilitou ao legislador ordinário fazê-lo" (CARVALHO, Paulo de Barros. Direito Tributário, Linguagem e Método. São Paulo: Noeses, 2008, p. 610).

A jurisprudência corrobora a incidência do IPI sobre a importação de produtos industrializados. As discussões judiciais acerca do IPI-importação, em sua maior parte, restringem-se ao alcance de isenções concedidas em relação ao imposto. Parte-se sempre, portanto, do pressuposto da legitimidade da exação (interplures, cite-se: STJ, Primeira Turma, REsp nº 643.076/CE, Relator Min. LUIZ FUX, DJ 09.05.2005, p. 306).

${ }^{510}$ Note-se que, diferentemente do imposto de importação, cujo fato gerador ocorre no momento do ingresso da mercadoria estrangeira em território nacional, o IPI-importação somente se torna exigível quando do desembaraço alfandegário.

511 Saliente-se que a legislação ordinária não instituiu tal modalidade do IPI, podendo, todavia, fazê-lo a qualquer tempo.

${ }^{512}$ CTN, art. 46, parágrafo único.

${ }^{513}$ Em muitos casos há dúvidas acerca da incidência de IPI ou ISSQN sobre determinados produtos. Por exemplo, um alfaiate produz um terno da mesma forma que a indústria o faz. Contudo, paga-se ISSQN no primeiro caso e IPI no segundo. Nesta hipótese, o que distingue o critério material de ambos os impostos é a natureza da obrigação: de fazer, para o ISSQN, e de dar, para o IPI. Sobre o tema, leia-se: ATALIBA, Geraldo. Conflitos entre ICMS, ISS e IPI. Revista de Direito Tributário, nº 7/8, jan.-jun./1979, pp. 105-31.

${ }^{514}$ STF, Segunda Turma, RE no 69.825/RS, Relator Min. THOMPSON FLORES, DJ 10.03.1972.

Registre-se que, na hipótese, discutia-se ainda a possibilidade de incidência do imposto único sobre minerais (então vigente) na fase de venda das pedras preparadas para consumo final. O STF rechaçou a tributação pelo IU-M, pugnando pela incidência tanto do IPI como do então ICM (no mesmo sendeiro foi o acórdão, também da Segunda Turma, no RE no 70.028/ES, Relator Min. ANTONIO NEDER, DJ 01.09.1972).

Lado outro, quando do julgamento de caso envolvendo óleos lubrificantes e seus aditivos, o Supremo Tribunal distinguiu as situações: na primeira, determinou a incidência do imposto único, ao passo que no segundo caso sustentou a tributação pelo IPI, haja vista tratar-se de um produto industrializado e não de um típico óleo sujeito ao imposto único sobre combustíveis e lubrificantes (STF, Pleno, AR n ${ }^{\circ}$ 1.164/DF, Relator Min. ALFREDO BUZAID, DJ 08.06.1984, p. 9.256). 
beneficiamento, montagem, acondicionamento, renovação ou recondicionamento ${ }^{515}$ de produto $^{516}$.

Prescreve ainda o $\mathrm{CTN}^{517}$ que a base de cálculo do IPI corresponderá ao valor de saída do produto do estabelecimento industrial; ao preço pago na arrematação de bens apreendidos ou abandonados; ou ao valor constante da Declaração de Importação ${ }^{518}$.

Ao cabo, o Código Tributário Nacional elenca os contribuintes do IPI $^{519}$ :

(a) o importador ou quem a lei a ele equiparar;

(b) o industrial ou a quem a lei a ele equiparar;

(c) o arrematante de produtos apreendidos ou abandonados, levados a leilão ${ }^{520}$;

(d) os comerciantes que vendem produtos sujeitos ao IPI para indústrias ${ }^{521}$.

A seletividade, atributo mandatório constitucionalmente infundido ao IPI, é também objeto de menção expressa no $\mathrm{CTN}^{522}$. Ela consiste no dever de tributar os produtos

${ }^{515}$ Arts. $3^{\circ}$ e $4^{\circ}$ do RIPI (Decreto ${ }^{\circ}$ 4.544, de 26 de dezembro de 2002).

${ }^{516}$ Contudo, em alguns casos a Lei no 4.502, de 30 de novembro de 1964 (que, ainda hoje, é a norma básica do IPI na legislação ordinária), excepciona o conceito de industrialização, vedando a incidência do imposto federal sobre: conserto de máquinas, aparelhos e objetos pertencentes a terceiros; acondicionamento destinado ao mero transporte do produto; manipulação de medicamentos em farmácias especializadas para venda direta ao consumidor; montagem de óculos, sob prescrição médica; mistura de tintas feita pelo estabelecimento varejista para venda ao consumidor final, desde que a indústria fabricante das tintas não pertença ao mesmo grupo econômico do estabelecimento que as vende no varejo (art. $3^{\circ}$, parágrafo único e incisos da Lei $\left.n^{\circ} 4.502 / 64\right)$.

${ }^{517}$ CTN, art. 47.

518 O valor constante da Declaração de Importação será, ainda acrescido do Imposto de Importação e dos demais encargos (inclusive cambiais) e taxas exigidos para o ingresso do produto no País.

${ }^{519}$ CTN, art. 51.

${ }^{520}$ Como já dito, essa hipótese de incidência, apesar de autorizada pela CR/88 e pelo CTN, não está prevista na legislação do IPI.

${ }^{521}$ Desde a época do imposto sobre consumo, muito se discutiu nos Tribunais acerca do alcance da imunidade tributária: ela beneficiaria apenas o contribuinte de direito ou também o contribuinte de fato? Prevaleceu, ao fim, a tese restritiva, pela qual o contribuinte de facto não faz jus à imunidade dos tributos indiretos (in casu, do IPI). A Súmula n 591 do STF expressa tal posicionamento:

"A imunidade ou a isenção tributária do comprador não se estende ao produtor, contribuinte do imposto sobre produtos industrializados."

Contudo, se o beneficiado pela imunidade é próprio contribuinte de jure, resta afastada a incidência do tributo indireto, como também já decidido pelo STF:

"IMUNIDADE TRIBUTÁRIA. IMPOSTO SOBRE PRODUTOS INDUSTRIALIZADOS E IMPOSTO DE IMPORTAÇÃO. ENTIDADE DE ASSISTÊNCIA SOCIAL. IMPORTAÇÃO DE 'BOLSAS PARA COLETA DE SANGUE'.

A imunidade prevista no art. 150, VI, $c$, da Constituição Federal, em favor das instituições de assistência social, abrange o Imposto de Importação e o Imposto sobre Produtos Industrializados, que incidem sobre bens a serem utilizados na prestação de seus serviços específicos. (...)." (STF, Primeira Turma, RE nº 243.807/SP, Relator Min. ILMAR GALVÃO, DJ 28.04.2000, p. 98).

${ }^{522}$ Predica o art. 48 do CTN que o IPI "é seletivo em função da essencialidade dos produtos.” 
supérfluos com alíquotas gravosas e os bens essenciais com alíquotas reduzidas. Tal variação visa a atingir, com maior precisão, a capacidade econômica do contribuinte de facto ${ }^{523}$ (eis que o IPI é um típico tributo indireto, juridicamente repercutível nos preços das mercadorias).

Dessa exposição, podem-se extrair elementos para o bosquejo do antecedente e do conseqüente da regra-matriz de incidência do IPI:

\begin{tabular}{|c|c|}
\hline Hipótese de incidência & Conseqüência jurídica \\
\hline $\begin{array}{l}\text { Aspecto material: saída, importação ou } \\
\text { arrematação de produto industrializado; } \\
\text { Aspecto temporal: momento da saída, do } \\
\text { desembaraço aduaneiro ou da arrematação } \\
\text { da mercadoria; } \\
\text { Aspecto espacial: em qualquer lugar do } \\
\text { território nacional; } \\
\text { Aspecto pessoal: industrial, importador } \\
\text { ou arrematante. }\end{array}$ & $\begin{array}{l}\text { Sujeito ativo: União Federal; } \\
\text { Sujeito passivo: industrial, importador ou } \\
\text { arrematante; } \\
\text { Base de cálculo: valor da venda do produ- } \\
\text { to industrializado; valor da importação } \\
\text { acrescido do Imposto de Importação e } \\
\text { encargos/taxas aduaneiros; valor da arre- } \\
\text { matação; } \\
\text { Alíquota: fixada na TIPI }{ }^{524} \text {, observando- } \\
\text { se os limites máximo e mínimo fixados na } \\
\text { legislação ordinária; } \\
\text { Quanto pagar: o valor resultante da de- } \\
\text { dução, dos débitos calculados sobre as } \\
\text { operações e prestações tributáveis, dos } \\
\text { créditos do imposto aos quais o contribu- } \\
\text { inte fizer jus; } \\
\text { Como e onde pagar: previsto no RIPI }{ }^{525} \text {. }\end{array}$ \\
\hline
\end{tabular}

${ }^{523}$ Sobre este tema, confira-se: ESTURILIO, Regiane Binhara. A Seletividade no IPI e no ICMS. São Paulo: Quartier Latin, 2008.

${ }^{524}$ Tendo em vista que no IPI as alíquotas podem ser fixadas por ato do Poder Executivo, obedecendo aos limites mínimos e máximos preestabelecidos em lei $(\mathrm{CR} / 88$, art. 153, §1º), o Presidente da República edita periodicamente a Tabela de Incidência do Imposto sobre Produtos Industrializados (TIPI). Atualmente, a TIPI é veiculada pelo Decreto ${ }^{\circ}$ 6.006, de 28 de dezembro de 2006, estabelecendo as alíquotas dos produtos gravados pelo IPI.

${ }^{525}$ Regulamento do Imposto sobre Produtos Industrializados (Decreto $\mathrm{n}^{\mathrm{o}} 4.544$, de 26 de dezembro de 2002). 
A esparsa legislação em matéria de IPI é regida em boa parte pela Lei $n^{\circ} 4.502 / 64$, que regulava, ab initio, o extinto Imposto sobre o Consumo. O Regulamento do IPI, a seu turno, é atualmente veiculado pelo Decreto $n^{\circ} 4.544$, de 26 de dezembro de 2002.

O IPI é, todavia, um imposto "vetusto e antieconômico", como enfatiza SACHA $\mathrm{CALMON}^{526}$, com carradas de razão. Afinal, a sua finalidade é apenas repartir entre a União e os Estados (que têm competência para cobrança do ICMS) a tributação sobre o consumo de mercadorias. Em verdade, ele consiste numa hipótese de bitributação constitucionalmente autorizada, pois grava as mesmas realidades que o ICMS (apesar deste último ser mais amplo).

Seja lá como for, o IPI ainda existe e não se tem notícia de reforma tributária que tencione aboli-lo, tornando-se necessário o estudo de sua não-cumulatividade, agora em sede infraconstitucional.

É o que se fará a seguir.

\subsection{A NÃO-CUMULATIVIDADE DO IPI NO CÓdIGO TRIBUTÁRIO NACIO-} NAL.

Desde sua criação o IPI é não-cumulativo por força da Constituição. Espelhando o comando da Lei Maior, prescreve o CTN:

"Art. 49. O imposto é não-cumulativo, dispondo a lei de forma que o montante devido resulte da diferença a maior, em determinado período, entre o imposto referente aos produtos saídos do estabelecimento e o pago relativamente aos produtos nele entrados.

Parágrafo único. O saldo verificado, em determinado período, em favor do contribuinte transfere-se para o período ou períodos seguintes."

Tal e qual a Constituição, o CTN prescreve a apuração do IPI pelo método impostocontra-imposto (tax on tax). Assim, o IPI devido pelas saídas tributadas é abatido do IPI suportado pelo contribuinte em suas aquisições. Noutro giro verbal, abate-se do imposto a pagar o imposto incidente nas etapas anteriores do processo produtivo.

Para além do que a CR/88 dispõe, o Código Tributário Nacional determina a apuração do IPI por período de tempo, com transporte de eventual saldo credor para as competências (períodos) seguintes.

${ }^{526}$ COÊLHO, Sacha Calmon Navarro. Curso de Direito Tributário Brasileiro, $9^{\mathrm{a}}$ ed. Rio de Janeiro: Forense, 2007, p. 510. 
O Código não detalha os produtos passíveis de creditamento, sendo impossível, a partir de sua leitura, definir se o IPI será regido pelo crédito físico ou financeiro ${ }^{527}$.

Para logo, pode-se concluir que, se a CR/88 é concisa ao estatuir a nãocumulatividade do IPI - predicando tão-somente a apuração imposto-contra-imposto ${ }^{528}$ - o CTN não vai muito além. Como visto, o Código Tributário inova apenas ao estipular a apuração por período de tempo e o transporte de créditos não-utilizados para as competências subseqüentes (sendo que ambas as regras seriam, de qualquer forma, dessumíveis da não-cumulatividade constitucional).

Portanto, o estudo da legislação ordinária e do regulamento do IPI é fundamental para a adequada apreensão da não-cumulatividade do referido imposto.

Confira-se.

\subsection{A NÃO-CUMULATIVIDADE NA LEGISLAÇÃO ORDINÁRIA.}

\subsubsection{O ART. 25 DA LEI No 4.502/64 E SUAS DEMAIS DISPOSIÇÕES SOBRE O} TEMA.

A Lei $n^{\circ}$ 4.502/64 é o diploma normativo basilar do IPI. Apesar de editada quando ainda vigorava o Imposto de Consumo, suas normas - adaptadas por leis supervenientes são aplicáveis ao atual Imposto sobre Produtos Industrializados.

O dispositivo mais importante acerca da não-cumulatividade na Lei $n^{\circ}$ 4.502/64 é o art. 25, que assim predica em seu caput:

“Art. 25. A importância a recolher será o montante do imposto relativo aos produtos saídos do estabelecimento, em cada mês, diminuído do montante do imposto relativo aos produtos nele entrados, no mesmo período, obedecidas as especificações e normas que o regulamento estabelecer."

Algumas ilações podem ser extraídas do artigo em questão.

A primeira delas é que o período de apuração será mensal, pois o cálculo do imposto far-se-á pelo cotejo entre os valores das saídas e das entradas "em cada mês". De todo modo, é possível que leis ulteriores modifiquem (como de fato foi feito) o período de apuração, desde que isso não implique restrição à não-cumulatividade ${ }^{529}$. Nos dias atuais a

\footnotetext{
${ }^{527}$ A omissão do CTN, neste ponto, permite ao legislador ordinário federal optar pelo crédito físico ou financeiro. Como se verá adiante, a escolha recaiu sobre a primeira opção.

${ }^{528} \mathrm{O}$ art. $153, \S 3^{\circ}, \mathrm{I}$ da $\mathrm{CR} / 88$ determina que o IPI será "não-cumulativo, compensando-se o que for devido em cada operação com o montante cobrado nas anteriores".

${ }^{529}$ Certa feita o Estado de Rondônia editou decreto determinando que o pagamento do ICMS sobre a prestação de serviços de comunicação e operações com energia elétrica seria diário. A norma exigia que as empre-
} 
regra geral continua sendo a apuração por competência mensal, em que pese haver exceções, como a apuração decendial do IPI sobre cigarros.

Outrossim, o caput do art. 25 da Lei no 4.502/64 delega ao Poder Executivo a competência para estabelecer as "especificações e normas" referentes ao cálculo e pagamento do IPI, o que atualmente é feito por meio do Decreto $\mathrm{n}^{\circ} 4.544 / 02\left(\operatorname{RIPI}^{530}\right)$.

Prosseguindo, o $\$ 1^{\circ}$ do supracitado art. 25 dispõe especificamente sobre os créditos compensáveis do imposto:

"§ $1^{\circ}$. O direito de dedução só é aplicável aos casos em que os produtos entrados se destinem à comercialização, industrialização ou acondicionamento e desde que os mesmos produtos ou os que resultarem do processo industrial sejam tributados na saída do estabelecimento."

Consoante tal norma, o crédito restringir-se-á aos produtos destinados à comercialização, industrialização ou acondicionamento. Não há crédito, portanto, sobre bens adquiridos para o ativo imobilizado das empresas. Portanto, a Lei $n^{\circ} 4.502 / 64$ optou pelo regime do crédito físico (IVA tipo produto).

Ademais, para que haja direito ao crédito, exige-se que a saída do produto industrializado seja tributada. É certo, contudo, que essa disposição foi parcialmente revogada por relativa incompatibilidade com o art. 11 da Lei $n^{\circ} 9.779 / 99$. Este passou a permitir o crédito sobre insumos mesmo quando as saídas forem isentas ou sujeitas à alíquota zero, mantendo a regra do estorno apenas para as saídas não-tributadas ${ }^{531}$.

sas recolhessem aos bancos os valores de ICMS referentes às prestações e operações do dia. Essa medida impossibilitou a apuração dos tributos na forma não-cumulativa. Afinal, é necessário que haja um período mínimo de tempo para que os créditos sejam abatidos dos débitos, chegando-se ao quantum efetivamente devido. Por essa razão, entendeu o Superior Tribunal de Justiça que a modificação do período de apuração do ICMS, nesta hipótese, era ilegítima. Confira-se o seguinte trecho da ementa:

"1. A sistemática do recolhimento imediato do ICMS, estabelecida pelo Decreto Estadual $\mathrm{n}^{\circ}$ $8.615 / 99$, impossibilita o contribuinte de proceder ao encontro de contas entre o montante do tributo pago na aquisição de insumos ou materiais necessários à prestação dos serviços de telecomunicações com o valor da exação incidente sobre a conta paga pelo usuário, tornando impossível a compensação.” (STJ, Segunda Turma, RMS nº 11.438/RO, Relator Min. FRANCIULLI NETTO, DJ 01.07.2002, p. 269).

As conclusões também se aplicam ao IPI. O período de apuração prescrito no caput do art. 25 da Lei $\mathrm{n}^{\circ}$ 4.502/64 é mensal, podendo ser reduzido ou ampliado por leis ulteriores. Entrementes, a redução nunca poderá chegar ao ponto de retirar do contribuinte o tempo mínimo necessário para o cotejo entre débitos e créditos do imposto, como fez o Estado de Rondônia no precedente citado.

${ }^{530} \mathrm{O}$ decreto possui importante papel na apuração do Imposto sobre Produtos Industrializados. Mas o Poder Executivo deve ter em mente que sua função, conforme aclarada pelo art. 99 do CTN, é apenas a de operacionalizar o recolhimento do imposto. É defeso às normas infralegais a modificação do sentido e alcance das leis. Assim, em nenhum momento o regulamento poderá restringir direitos do contribuinte, sobremais o da não-cumulatividade, cujo suporte, em última instância, é constitucional.

${ }^{531}$ Para maiores detalhes sobre o art. 11 da Lei n ${ }^{\circ}$ 9.779/99, vide próximo tópico. 


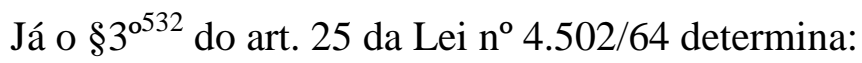

“§ 3․ O Regulamento disporá sobre a anulação do crédito ou o restabelecimento do débito correspondente ao imposto deduzido, nos casos em que os produtos adquiridos saiam do estabelecimento com isenção do tributo ou os resultantes da industrialização estejam sujeitos à alíquota zero, não estejam tributados ou gozem de isenção, ainda que esta seja decorrente de uma operação no mercado interno equiparada a exportação, ressalvados os casos expressamente contemplados em lei."

Trata-se de uma reafirmação da regra prescrita no $\S 1^{\circ}$ do art. 25 , pela qual a saída tributada é condição sine qua non para a manutenção dos créditos. Na hipótese do $\S 3^{\circ}$, considera-se a possibilidade de o contribuinte, ab initio, ter registrado os créditos de insumos em sua escrita fiscal, ao pressuposto de que suas saídas seriam tributadas. Porém, ao cabo, os bens produzidos saem sem tributação (seja por mudança na lei, seja por modificação do produto que implique reenquadramento legal). Nesse caso, deverá o regulamento predicar a forma de anulação do crédito, que será obrigatoriamente glosado. O estorno não será devido, contudo, nas saídas de produtos isentos ou sujeitos à alíquota zero a partir de 1999, por força do art. 11 da citada Lei ${ }^{\circ} 9.779 / 99^{533}$.

Prosseguindo, a Lei $n^{\circ} 4.502 / 64$ predica $^{534}$ ainda o transporte de eventual saldo credor para o mês subseqüente, na esteira do art. 49 do CTN.

Por fim, estipula a Lei $n^{\circ} 4.502 / 64$ que, nas hipóteses de devolução do produto ao estabelecimento de origem, permitir-se-á o estorno do débito de IPI anteriormente lançado, por meio da concessão de crédito do imposto no exato montante do débito escriturado ${ }^{535}$. Trata-se de regra que se relaciona apenas de forma indireta com o princípio da não-

${ }^{532} \mathrm{O} \S 2^{\circ}$ do art. 25 foi revogado pelo Decreto-lei $\mathrm{n}^{\mathrm{o}} 2.433$, de 19 de maio de 1988 . Suas disposições autorizavam o Ministro da Fazenda a conceder créditos de IPI para os bens do ativo imobilizado adquiridos por empresas industriais, ainda que o vendedor não fosse contribuinte do IPI. Tratava-se, portanto, de um benefício fiscal (eis que o crédito da Lei $\mathrm{n}^{\circ}$ 4.502/64 é físico), que era concedido "de acordo com as diretrizes gerais de política de desenvolvimento econômico do país" (art. 25, §2 da Lei $\mathrm{n}^{\circ} 4.502 / 64$, texto revogado em 1988).

${ }^{533}$ A regra, entrementes, não é válida para as saídas não-tributadas (NT).

${ }^{534}$ Lei no ${ }^{\circ} 4.502 / 64$ :

“Art. 27. Quando ocorrer saldo credor de imposto num mês, será ele transportado para o mês seguinte, sem prejuízo da obrigação de o contribuinte apresentar ao órgão arrecadador, dentro do prazo legal previsto para o recolhimento, a guia demonstrativa desse saldo.”

${ }^{535}$ Lei $^{\circ}$ 4.502/64:

"Art. 30. Ocorrendo devolução do produto ao estabelecimento produtor, devidamente comprovada, nos termos que estabelecer o regulamento, o contribuinte poderá creditar-se pelo valor do imposto que sobre ele incidiu quando da sua saída.” 
cumulatividade. Afinal, se houve saída tributada o imposto é devido. Contudo, se essa operação é cancelada, o débito há de ser glosado em razão da perda do substrato jurídico para a sua cobrança.

\subsubsection{AS BENESSES DO ART. 11 DA LEI N 9.779/99.}

Em 20 de janeiro de 1999 foi publicada a Lei $n^{\circ}$ 9.779, que trouxe dispositivo da mais alta relevância para a não-cumulatividade do IPI. Ei-lo:

"Art. 11. O saldo credor do Imposto sobre Produtos Industrializados - IPI, acumulado em cada trimestre-calendário, decorrente de aquisição de matéria-prima, produto intermediário e material de embalagem, aplicados na industrialização, inclusive de produto isento ou tributado à alíquota zero, que o contribuinte não puder compensar com o IPI devido na saída de outros produtos, poderá ser utilizado de conformidade com o disposto nos arts. 73 e 74 da Lei no 9.430, de 27 de dezembro de 1996, observadas normas expedidas pela Secretaria da Receita Federal do Ministério da Fazenda."

O artigo veicula duas importantes normas para o regramento do imposto:

(a) a possibilidade de manutenção dos créditos de insumos utilizados na produção de bens isentos ou tributados à alíquota zero;

(b) o direito de compensação do saldo credor do IPI, acumulado durante um trimestre, com outros tributos federais.

É o que se verá a seguir.

\subsubsection{DIREITO AOS CRÉDITOS DO IPI QUANDO OS PRODUTOS FINAIS FOREM ISENTOS OU TRIBUTADOS À ALÍQUOTA ZERO.}

De acordo com o $\S 1^{\circ}$ do art. 25 da Lei $\mathrm{n}^{\circ} 4.502 / 64$, o contribuinte é proibido de utilizar créditos do IPI relativos aos insumos utilizados no fabrico de produtos não tributados. A vedação baseia-se na exigência de duas etapas tributadas em sequiência para que se operem os efeitos da não-cumulatividade.

A ausência de tributação dos produtos industrializados pode decorrer de:

(a) isenção;

(b) alíquota zero; ou

(c) não-tributação propriamente dita ${ }^{536}$.

$\mathrm{O}$ art. 11 da Lei $\mathrm{n}^{\circ}$ 9.779/99 permite ao contribuinte do IPI descontar créditos relativos à aquisição de matérias-primas, de produtos intermediários e de materiais de embala-

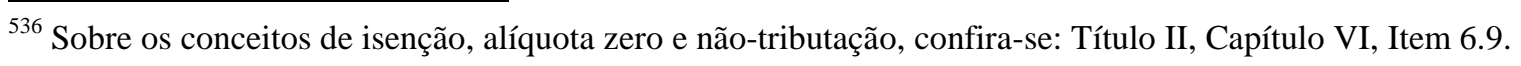


gem, quando utilizados na industrialização de produtos isentos ou tributados à alíquota zero. Como o dispositivo refere-se apenas a "produto isento ou tributado à alíquota zero", e sendo certo que os benefícios fiscais devem ser restritivamente interpretados, pode-se concluir que a norma exclui o direito ao crédito sobre os insumos utilizados em produtos nãotributados (NT).

Nesse sentido, desde o advento do supracitado art. 11, os insumos utilizados no fabrico de produtos isentos ou sujeitos à alíquota zero passaram a gerar, para o seu adquirente, direito a créditos do IPI. Já para os produtos não-tributados (NT) continuou a vigorar a regra que predica a glosa dos créditos ${ }^{537}$. Esse foi também o entendimento consolidado no âmbito do STJ. A Corte rechaçou as pretensões de contribuintes que tencionavam manter os créditos de insumos empregados em bens não-tributados. Argumentou o STJ, com acerto, que o benefício em comento não se aplicava a tal situação ${ }^{538}$.

Outro ponto atinente ao art. 11 da Lei $n^{\circ}$ 9.779/99 refere-se à suposta eficácia retroativa que lhe foi atribuída por alguns julgados ${ }^{539}$. De acordo com esses, o dispositivo em

${ }^{537}$ Art. $25, \S 1^{\circ}$ da Lei $n^{\circ} 4.502 / 64$.

${ }^{538}$ Interplures, a ementa a seguir demonstra o entendimento prevalente no STJ:

"IPI. AQUISIÇÃO DE INSUMOS E MATÉRIAS-PRIMAS TRIBUTADOS UTILIZADOS NA FABRICAÇÃO DE PRODUTOS NÃO-TRIBUTADOS. ART. 11 DA LEI No 9.779/99. CREDITAMENTO. IMPOSSIBILIDADE. (...).

I - O art. 11 da Lei 9.779/99 prevê duas hipóteses para o creditamento do IPI pago na aquisição de insumos e matérias-primas, na saída de produtos industrializados: a) quando os insumos são utilizados na elaboração de produtos isentos; e b) quando são usados na industrialização de produtos tributados à alíquota zero.

II - Na análise da lei tributária é vedada sua interpretação extensiva, in casu, não tendo a norma legal incluído como hipótese de creditamento de IPI a saída do produto industrializado nãotributado, tem-se indevido o pleito de creditamento da exação.

(...)” (STJ, Primeira Turma, REsp n ${ }^{\circ}$ 1.109.232/RS, Relator Min. FRANCISCO FALCÃO, DJe 22.04.2009, destaques nossos).

No mesmo sendeiro: STJ, Primeira Turma, REsp n 917.236/RN, Relator Min. JOSÉ DELGADO, DJ 02.08.2007, p. 414.

${ }^{539}$ Confira-se a ementa de uma das decisões nesse sentido:

“AQUISIÇÃO DE INSUMOS COM PAGAMENTO DE IPI PARA UTILIZAÇÃO NA INDUSTRIALIZAÇÃO DE PRODUTOS TRIBUTADOS À ALÍQUOTA ZERO. APROVEITAMENTO. ART. 11 DA LEI No 9.779/99. REGRA DE CARÁTER INTERPRETATIVO. APLICAÇÃO RETROATIVA. POSSIBILIDADE. (...).

I - O direito ao creditamento do IPI é consectário do princípio da não-cumulatividade previsto no artigo 153 da Constituição Federal. Tal creditamento foi reconhecido pelo artigo 11 da Lei $\mathrm{n}^{\circ}$ 9.779/99, que afirmou de forma expressa a possibilidade do aproveitamento do crédito de IPI acumulado pela aquisição de insumos empregados na industrialização de produto isento ou tributado a alíquota zero, na saída de outros produtos igualmente tributados pelo IPI.

(...)

III - A primeira parte do artigo 11 da Lei $n^{\circ}$ 9.779/99, que dispõe sobre a viabilidade do aproveitamento do crédito referente ao pagamento do IPI na aquisição do insumo empregado na industrialização de produto isento ou tributado a alíquota zero, tem caráter interpretativo, podendo operar efeitos retroativos para atingir operações anteriores ao seu advento, em conformidade com o que preceitua o artigo 106, inciso I, do CTN. Precedentes: REsp nº 1.034.398/SP, Rel. Min. CASTRO 
questão era expressamente interpretativo da não-cumulatividade do IPI. Por esse motivo, sua aplicação deveria atingir os casos pretéritos, com espeque no art. 106, I do $\mathrm{CTN}^{540}$.

Entretanto, o STF colocou uma pá de cal sobre essa tentativa de aplicação retrospectiva dos efeitos do benefício estatuído pelo art. 11 da Lei $n^{\circ}$ 9.779/99. Entendeu o Supremo Tribunal Federal que o direito ao crédito sobre insumos utilizados na produção de bens isentos e tributados à alíquota zero não deriva diretamente da Constituição, que exige duas operações tributadas em seqüência para a operacionalização da não-cumulatividade. À míngua de dois estádios tributados, não haveria que se falar em cumulatividade. Por conseguinte, inexistiria direito ao crédito. Afinal, o art. 11 da Lei no 9.779/99 teria instituído uma benesse para o IPI. Não haveria fundamento, dessarte, para a sustentação da tese da retroatividade da norma baseada em seu suposto cariz interpretativo ${ }^{541}$.

A nosso sentir, ao decidir desta forma o STF incorreu parcialmente em contradição. Referimo-nos à negativa de manutenção dos créditos dos insumos empregados em produtos isentos. Ora, a função da norma isencional é exatamente reduzir o tributo a pagar. Nas exações não-cumulativas, a isenção intercalar ${ }^{542}$ majora o tributo devido, como já restou demonstrado anteriormente ${ }^{543}$. Portanto, a negativa de manutenção do crédito dos insumos em questão nega vigência à própria isenção. Noutro giro verbal, para evitar a majoração do ônus tributário decorrente da isenção intercalar o reconhecimento do direito ao crédito é fundamental. Do contrário, ter-se-á a produção do efeito contrário ao pretendido pela regra isentiva.

De mais a mais, a jurisprudência do STF equipara isenção a tributo pago. Para a Suprema Corte, a norma isencional atua de forma secundária, após o surgimento da obrigação tributária, excluindo o dever de pagar o tributo. Com isso, a operação isenta equipole, para fins da não-cumulatividade, a uma operação tributada. Assim é que o contribuinte

MEIRA, DJ de 22/04/08, REsp no 1.004.964/PR, Rel. Min. HUMBERTO MARTINS, DJ de 28/05/08 e EDcl no REsp no $1.010 .428 / \mathrm{SP}$, Rel. Min. FRANCISCO FALCÃO, julgado em 05/06/08." (STJ, Primeira Turma, AgRg no REsp n 1.058.032/SP, Relator Min. FRANCISCO FALCÃO, DJe 20.10.2008, destaques nossos).

${ }^{540}$ Assim reza o Código Tributário:

"Art. 106. A lei aplica-se a ato ou fato pretérito:

I - em qualquer caso, quando seja expressamente interpretativa, excluída a aplicação de penalidade à infração dos dispositivos interpretados;"

${ }^{541}$ Vide Título II, Capítulo VI, Item 6.9.2.

${ }^{542} \mathrm{Ou}$ seja, a isenção que não é concedida na última operação tributada pelo imposto, mas sim em etapa intermediária do processo produtivo.

${ }^{543}$ Vide Título I, Capítulo III, Item 3.4. 
faz jus aos créditos sobre os insumos empregados em produtos isentos, à luz do entendimento consolidado há decênios pelo próprio Supremo Tribunal Federal ${ }^{544}$. Portanto, temos que o acórdão do STF que negou eficácia retroativa ao art. 11 da Lei n ${ }^{\circ}$ 9.779/99 incorreu em parcial erronia. Lado outro, laborou o STF com acerto quando reconheceu não derivar da Constituição a manutenção do crédito de IPI quando a operação seguinte fosse sujeita à alíquota zero.

\subsubsection{DIREITO À COMPENSAÇÃO DOS CRÉDITOS DE IPI ACUMULADOS AO LONGO DE UM TRIMESTRE COM OUTROS TRIBUTOS FEDERAIS.}

$\mathrm{O}$ art. 11 da Lei $\mathrm{n}^{\circ}$ 9.779/99 também autorizou que o saldo credor de IPI acumulado no trimestre, por qualquer razão, seja compensado com outros tributos federais, na forma do art. 74 da Lei $n^{\circ} 9.430 / 96^{545}$. Com essa medida, criou-se um benefício em prol dos contribuintes que não possuem débitos de IPI suficientes para a utilização integral de seus cré$\operatorname{ditos}^{546}$. A permissão para compensação dos referidos créditos permite o abatimento do IRPJ, da CSLL e do PIS/COFINS a pagar, à míngua da existência de débitos do próprio IPI.

\subsection{A NÃO-CUMULATIVIDADE NO REGULAMENTO DO IPI. 11.4.1. DISPOSIÇÕES PRELIMINARES.}

\footnotetext{
544 A questão não passou despercebida aos Ministros RICARDO LEWANDOWSKI, CEZAR PELUSO e EROS GRAU, especialmente para este último. Ora, se o STF reconhece direito a créditos presumidos na aquisição de insumos isentos (utilizados no fabrico de produtos tributados) por que motivo não haveria de reconhecer o direito à escrituração de créditos reais, oriundos da aquisição de insumos tributados? O contrasenso é evidente.

${ }^{545}$ Reza a Lei no 9.430/96:

"Art. 74. O sujeito passivo que apurar crédito, inclusive os judiciais com trânsito em julgado, relativo a tributo ou contribuição administrado pela Secretaria da Receita Federal, passível de restituição ou de ressarcimento, poderá utilizá-lo na compensação de débito próprios relativos a quaisquer tributos e contribuições administrados por aquele Órgão.”

Sobre a evolução das normas referentes à compensação de tributos federais, confira-se nosso estudo: MOREIRA, André Mendes. Da Compensação de Tributos Administrados pela Receita Federal - Evolução Legislativa e Modalidades. Revista Dialética de Direito Tributário, no 95. São Paulo: Dialética, ago./2003, pp. 7-17.

546 Essa situação ocorre, por exemplo, com fabricantes de produtos sujeitos à alíquota zero que adquiram insumos tributados pelo IPI.
} 
A não-cumulatividade é prescrita no Capítulo X ("Dos Créditos") do Título VII (“Da Obrigação Principal”) do RIPI, em seus arts. 163 a $198^{547}$.

O dispositivo inaugural ${ }^{548}$ reitera o disposto no CTN, prescrevendo a apuração pelo sistema imposto-contra-imposto, por período de tempo.

Outrossim, predica o RIPI (tal como o art. $25, \S 3^{\circ}$ da Lei $n^{\circ} 4.502 / 64$ ) o estorno dos débitos relativos a bens devolvidos ou retornados ao estabelecimento do contribuinte ${ }^{549}$ Assim, evita-se a tributação de materiais que, por razões não previstas inicialmente pelas partes, são devolvidos ao estabelecimento de origem ${ }^{550}$. A alíquota aplicável para o creditamento, quando da devolução da mercadoria, é aquela em vigor no momento de sua saída do estabelecimento originário (ainda que a posteriori a alíquota tenha sido majorada ou reduzida). Afinal, a intenção da regra é anular o débito anteriormente lançado, o que somente é possível com a utilização da mesma alíquota que gerou o débito original.

A norma em comento também esclarece que os créditos de IPI "de outra nature$\mathrm{za}{ }^{551}$ ou concedidos a título de incentivo ${ }^{552}$ devem ser tratados de forma escritural ${ }^{553}$. Con-

${ }^{547}$ Para melhor visualização do tratamento da não-cumulatividade do RIPI, segue abaixo o índice sistemático de temas e artigos correlatos:

TÍTULO VII - DA OBRIGAÇÃO PRINCIPAL

CAPÍTULO X - DOS CRÉDITOS

Seção I - Disposições Preliminares.

Art. 163

Seção II - Das Espécies dos Créditos

Subseção I - Dos Créditos Básicos

Arts. 164 a 166

Subseção II - Dos Créditos por Devolução ou Retorno de Produtos

Arts. 167 a 173

Subseção III - Dos Créditos como Incentivo.

Arts. 174 a 177

Subseção IV - Dos Créditos de Outra Natureza.

Art. 178

Subseção V - Do Crédito Presumido.

Arts. 179 a 189

Seção III - Da Escrituração dos Créditos

Arts. 190 a 194

Seção IV - Da Utilização dos Créditos Arts. 195 a 198

${ }^{548}$ RIPI, art. 163.

${ }^{549}$ RIPI, art. $163, \S 1^{\circ}$.

${ }^{550}$ Importante ressaltar que a devolução aqui referida é aquela não prevista $a b$ initio pelas partes. Quando o produto é remetido para outra empresa já com a intenção de ser devolvido ao estabelecimento de origem (v.g., como ocorre na industrialização por encomenda), a legislação considera que não houve saída do estabelecimento produtor (art. $5^{\circ}$, II da Lei $4.502 / 64 \mathrm{c} / \mathrm{c}$ art. $163, \S 1^{\circ}$ do RIPI).

${ }^{551}$ Os créditos de "outra natureza" são previstos no art. 178 do RIPI e permitem ao contribuinte creditar-se:

(a) do valor lançado como débito do IPI, quando a nota fiscal for cancelada antes da saída efetiva da mercadoria; e

(b) da diferença paga a maior do imposto, quando o lançamento do IPI tenha sido feito de forma antecipada.

O detalhamento dessa modalidade de crédito será feito no Item 11.4.5, infra.

${ }^{552}$ Regidos pelos arts. 174 a 177 do RIPI e relacionados a operações nas áreas da Superintendência de Desenvolvimento da Amazônia (SUDAM), Superintendência de Desenvolvimento do Nordeste (SUDENE) e Amazônia Ocidental. Seu estudo será realizado no Item 11.4.7, infra. 
tudo, tal previsão afigura-se desnecessária, pois o cálculo do quantum debeatur por meio do confronto entre débitos e créditos na conta gráfica é da própria natureza do imposto em tela.

\subsubsection{ESPÉCIES DE CRÉDITOS.}

Os arts. 164 e seguintes do Regulamento dispõem sobre as espécies de créditos cujo aproveitamento é autorizado. São elas:

(a) créditos básicos;

(b) créditos por devolução ou retorno de produtos;

(c) créditos de outra natureza;

(d) créditos como incentivo; e

(e) créditos presumidos.

A primeira hipótese corresponde aos créditos decorrentes da aplicação do princípio da não-cumulatividade propriamente dito ${ }^{554}$. Dentre estes, se incluem os créditos decorrentes de quebras no estoque e da saída de resíduos, sucatas e aparas, assim como os créditos de IPI derivados dos insumos utilizados em bens exportados.

Já os créditos por devolução ou retorno de $\operatorname{produtos}^{555}$ são apenas uma conseqüência indireta da não-cumulatividade. Afinal, cancelado o negócio que originou a saída tributada, a exigência do imposto perde sustentação jurídica. O estorno do débito (via lançamento a crédito) restaura o status quo ante.

Da mesma forma, os créditos de "outra natureza" também se relacionam de forma indireta com a não-cumulatividade, pois consistem em ajustes feitos na conta gráfica do contribuinte para que o débito do IPI corresponda ao valor efetivamente devido (como o cancelamento do débito quando a nota físcal tiver sido emitida antes da saída do bem e esta, por algum motivo, for cancelada).

\footnotetext{
${ }^{553}$ RIPI, art. $163, \S 2^{\circ}$.

${ }^{554}$ Como lecionam REIS e BORGES, “créditos básicos (...) são aqueles diretamente associados ao princípio da não-cumulatividade e ao processo de industrialização, cuja titularidade pertence ao estabelecimento industrial ou equiparado". (REIS, Maria Lúcia Américo e BORGES, José Cassiano. O IPI ao Alcance de Todos. Rio de Janeiro: Revista Forense, 1999, p. 167).

555 Os crédito por devolução ou retorno de produtos foram referidos brevemente no item anterior, por serem mencionados pelo RIPI em seu art. 163. Serão tratados com maior vagar no Item 11.4.4, infra.
} 
Por fim, os créditos presumidos e incentivados consistem numa opção feita pelo legislador para desonerar os contribuintes do imposto ${ }^{556}$. Tais espécies de créditos não se relacionam com a não-cumulatividade, pelo que serão tratados na parte final deste capítulo.

\subsubsection{OS CRÉDITOS BÁSICOS DO IPI.}

O fundamento dos créditos básicos do IPI previstos no Regulamento é a nãocumulatividade plasmada no art. $25, \S 1^{\circ}$ da Lei ${ }^{\circ} 4.502 / 64$. Assim, reconhece-se o direito ao crédito quando há:

(a) entrada de produtos destinados à comercialização, industrialização ou acondicionamento; e, igualmente,

(b) tributação, quando da saída do estabelecimento, dos produtos revendidos ou resultantes do processo industrial.

De se notar que a premissa para a utilização do "crédito básico" é a existência de tributação na operação seguinte. Contudo, como já visto, desde $1999^{557}$ os contribuintes fazem jus à manutenção dos créditos de IPI quando suas saídas forem isentas ou sujeitas à alíquota zero. Tal benefício, consoante também referido alhures ${ }^{558}$, não se estende aos insumos utilizados no fabrico de produtos não-tributados (NT), que seguem a regra geral do art. 164 do RIPI.

Já o art. 165 do Regulamento do IPI traz outra benesse para os contribuintes: o industrial que adquirir matérias-primas, produtos intermediários e materiais de embalagem de comerciante atacadista não-contribuinte do imposto poderá se creditar de 50\% (cinqüenta por cento) dos créditos aos quais faria jus caso as aquisições fossem tributadas ${ }^{559}$.

\footnotetext{
${ }^{556}$ REIS, Maria Lúcia Américo e BORGES, José Cassiano. O IPI ao Alcance de Todos. Rio de Janeiro: Revista Forense, 1999, pp. 169-74.

${ }^{557}$ Por força do art. 11 da Lei n ${ }^{\circ} 9.779$, de 20 de janeiro de 1999.

${ }^{558}$ Vide Item 11.3.2.1, supra.

${ }^{559}$ A Solução de Consulta $n^{\circ}$ 9/05, da $8^{\text {a }}$ Região Fiscal (DOU de 22.02.2005), dá o tom ao benefício insculpido no art. 165 do RIPI:

"BENS DE PRODUÇÃO. MATERIAL DE EMBALAGEM. AQUISIÇÃO DE COMERCIAL VAREJISTA. CRÉDITOS. Industrial que adquire bens de produção (aí incluído o material de embalagem) de estabelecimento comercial varejista só terá direito ao crédito de IPI de que trata o art. 165 do RIPI/02 se o varejista for caracterizado como comerciante atacadista e, ainda, não for contribuinte do IPI. Não basta o comerciante varejista vender bens de produção a estabelecimento industrial para ser caracterizado como atacadista. (Decisão no 9, da SRRF 8 a RF - DOU de 22/02/05)." (OLIVEIRA, Waldemar de. Regulamento do Imposto sobre Produtos Industrializados. São Paulo: FISCOSoft, 2008, pp. 240-1).
} 
Prosseguindo na análise do RIPI, as espécies de créditos básicos são assim delineadas, em rol numerus clausus:

“Art. 164. Os estabelecimentos industriais, e os que lhes são equiparados, poderão creditar-se:

I - do imposto relativo a $\mathrm{MP}^{560}, \mathrm{PI}^{561}$ e $\mathrm{ME}^{562}$, adquiridos para emprego na industrialização de produtos tributados, incluindo-se, entre as matériasprimas e produtos intermediários, aqueles que, embora não se integrando ao novo produto, forem consumidos no processo de industrialização, salvo se compreendidos entre os bens do ativo permanente;

II - do imposto relativo a MP, PI e ME, quando remetidos a terceiros para industrialização sob encomenda, sem transitar pelo estabelecimento adquirente;

III - do imposto relativo a MP, PI e ME, recebidos de terceiros para industrialização de produtos por encomenda, quando estiver destacado ou indicado na nota fiscal;

IV - do imposto destacado em nota fiscal relativa a produtos industrializados por encomenda, recebidos do estabelecimento que os industrializou, em operação que dê direito ao crédito;

$\mathrm{V}$ - do imposto pago no desembaraço aduaneiro;

VI - do imposto mencionado na nota fiscal que acompanhar produtos de procedência estrangeira, diretamente da repartição que os liberou, para estabelecimento, mesmo exclusivamente varejista, do próprio importador;

VII - do imposto relativo a bens de produção recebidos por comerciantes equiparados a industrial;

VIII - do imposto relativo aos produtos recebidos pelos estabelecimentos equiparados a industrial que, na saída destes, estejam sujeitos ao imposto, nos demais casos não compreendidos nos incisos V a VII;

IX - do imposto pago sobre produtos adquiridos com imunidade, isenção ou suspensão quando descumprida a condição, em operação que dê direito ao crédito; e

$\mathrm{X}$ - do imposto destacado nas notas fiscais relativas a entregas ou transferências simbólicas do produto, permitidas neste Regulamento.

Parágrafo único. Nas remessas de produtos para armazém-geral e depósito fechado, o direito ao crédito do imposto, quando admitido, é do estabelecimento depositante."

Vejamos, a seguir, os principais questionamentos em torno dos pontos acima listados.

\subsubsection{A VEDAÇÃO AO CRÉDITO SOBRE BENS DO ATIVO IMOBILIZADO.}

\footnotetext{
${ }^{560}$ Matérias-primas.

${ }^{561}$ Produtos intermediários.

${ }^{562}$ Materiais de embalagem.
} 
Uma das primeiras ilações extraídas da leitura do art. 164, I do RIPI é a vedação do crédito sobre bens destinados ao ativo permanente ${ }^{563}$ das empresas, constante de forma expressa em sua parte final.

O dispositivo é consentâneo com o art. 25 da Lei no 4.502/64, que apenas permite o crédito sobre produtos destinados à comercialização, industrialização ou acondicionamento. Como os bens do ativo não se enquadram nessas características (afinal, são adquiridos para integrar o patrimônio do contribuinte, desgastando-se naturalmente com o tempo), inexiste, em relação a eles, direito ao creditamento.

Trata-se de clara opção pela sistemática do crédito físico, que vigorou para o ICM e, durante alguns anos, também para o ICMS (sob a égide do Convênio ICM nº 66/88). A restrição tem sido validada pelo $\mathrm{STJ}^{564}$, como não poderia deixar de ser, haja vista o posicionamento do STF sobre o tema ${ }^{565}$.

Ao negar a dedução dos créditos calculados sobre o ativo imobilizado, o legislador do IPI assemelhou o imposto a um IVA tipo produto ${ }^{566}$, modalidade em franco desuso nos países que adotam a tributação sobre o valor acrescido.

${ }^{563} \mathrm{O}$ conceito de ativo permanente equivale, para fins do creditamento do IPI, ao de ativo imobilizado, que é assim definido pela ciência contábil:

“Ativo imobilizado são bens corpóreos (palpáveis) destinados à manutenção da atividade principal da empresa ou exercidos com essa finalidade, inclusive os decorrentes de operações que transfiram à empresa os benefícios, riscos e controle desses bens. Os bens que auxiliam a empresa na consecução de sua atividade pertencem ao imobilizado: máquinas, equipamentos, prédios (em uso), ferramentas, móveis e utensílios, instalações, veículos, etc.” (MARION, José Carlos. Contabilidade Básica. 9. ed. São Paulo: Atlas, 2008, pp. 65-6).

${ }^{564}$ É ver:

"1. Discute-se nos autos o creditamento de Imposto sobre Produtos Industrializados - IPI, na hipótese de incorporação de bens a ativo permanente da empresa, com base no princípio constitucional da não-cumulatividade (art. 153, $\S 3^{\circ}$, inciso II, da Constituição da República).

(...)

3. A jurisprudência do STJ, ao contrário dos bem lançados argumentos recursais, assevera que o Regulamento do IPI desautoriza expressamente o creditamento do imposto a ser pago, na hipótese de aquisição de bens para o ativo permanente da empresa (art. 147 do Decreto n. 2.637/98)." (STJ, Segunda Turma, REsp nº 1.028.459/SC, Relator Min. HUMBERTO MARTINS, DJe 26.06.2008).

No mesmo sentido: STJ, Primeira Turma, AgRg no REsp n ${ }^{\circ}$ 1.063.630/RJ, Relator Min. FRANCISCO FALCÃO, DJe 29.09.2008; STJ, Segunda Turma, AgRg no REsp no 414.922/SC, Relator Min. HUMBERTO MARTINS, DJ 17.08.2007, p. 406; STJ, Primeira Turma, REsp nº 640.175/SC, Relator Min. LUIZ FUX, DJ 29.11.2004, p. 255; STJ, Segunda Turma, AgRg no REsp nº 462.560/PR, Relatora Min. DENISE ARRUDA, DJ 15.03.2004, p. 156.

${ }^{565}$ O STF já assentou, em inúmeras oportunidades, que a garantia mínima da não-cumulatividade corresponde ao crédito físico.

${ }^{566}$ Vide Título I, Capítulo III, Item 3.3.2. 
Vale lembrar que, em 1970, a legislação ${ }^{567}$ autorizou o cálculo de crédito do IPI sobre bens destinados ao ativo imobilizado das empresas (máquinas, aparelhos e equipamentos $)^{568}$, desde que produzidos no País ${ }^{569}$ e listados em Portaria do Ministério da Fazen$\mathrm{da}^{570}$. Assim, o IPI tornou-se, apenas para algumas indústrias, um IVA tipo Consumo (pois o crédito era aproveitável à vista) ${ }^{571}$. Entretanto, esse dispositivo vigorou apenas até 1988 , quando foi revogado pelo Decreto-lei $\mathrm{n}^{\circ} 2.433$, de 19 de maio daquele ano.

Assim, respaldado pelo STF e com o beneplácito do STJ, o RIPI interpreta a Lei $n^{\circ}$ $4.502 / 64$ e veda expressamente ${ }^{572}$ o crédito sobre bens incorporados ao ativo imobilizado das empresas.

\subsubsection{MATÉRIAS-PRIMAS, PRODUTOS INTERMEDIÁRIOS E MATERIAIS DE EMBALAGEM.}

\footnotetext{
${ }^{567}$ O Decreto-lei $n^{\circ} 1.136$, de 7 de dezembro de 1970, incluiu um $\S 2^{\circ}$ ao art. 25 da Lei $n^{\circ} 4.502 / 64$, que passou a ostentar a seguinte redação:

"Art. 25. (...).

$\S 2^{\circ}$. O Ministro da Fazenda poderá atribuir aos estabelecimentos industriais o direito de crédito do imposto sobre produtos industrializados relativo a máquinas, aparelhos e equipamentos, de produção nacional, inclusive quando adquiridos de comerciantes não contribuintes do referido imposto destinados à sua instalação, ampliação ou modernização e que integrarem o seu ativo fixo, de acordo com as diretrizes gerais de política de desenvolvimento econômico do país."
}

${ }^{568}$ Também foi autorizado o crédito sobre o IPI suportado na aquisição de máquinas e equipamentos destinados à produção, pelo estabelecimento, de bens a serem incorporados ao seu próprio ativo imobilizado.

${ }^{569}$ Alguns contribuintes intentaram creditar-se do IPI incidente sobre bens importados de países signatários do GATT (Acordo Geral de Tarifas e Comércio). A pretensão foi rechaçada pela jurisprudência, com base na interpretação restritiva que deve ser dispensada aos dispositivos de lei que veiculam benefícios fiscais (TFR, Primeira Turma, AMS nº 79.289/SP, Relator Min. CORREA PINA, DJ 23.10.1980).

${ }^{570}$ A jurisprudência convalidou a delegação ao Poder Executivo da função de listar os bens do ativo passíveis

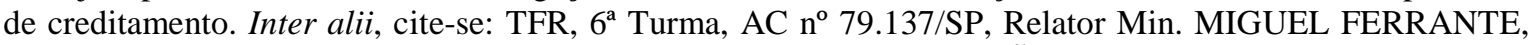

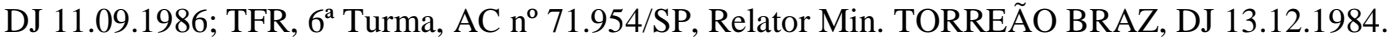

${ }^{571} \mathrm{O}$ aresto a seguir, do extinto Tribunal Federal de Recursos, retrata essa mudança normativa: “TRIBUTÁRIO. IPI. CRÉDITO. AQUISIÇÃO MAQUINÁRIO DE FABRICAÇÃO NACIONAL. DECRETO-LEI 1136/70. PORTARIA MINISTERIAL 96/81. COMPENSAÇÃ̃O DE CRÉDITO FISCAL.

(...)

II - Comprovado que o crédito em debate decorreu da compra de material destinado à aquisição de maquinário nacional para ampliação do parque industrial, habilita-se a parte ao credito do IPI, eis que incidentes os comandos do Decreto-lei 1136/70 e Portaria Ministerial 96/81." (TFR, 5 Turma, AC no 134.575/RN, Relator Min. GERALDO SOBRAL, DJ 14.04.1988).

Em outros julgados, o TFR esclareceu ainda que o pressuposto para o aproveitamento do crédito, mesmo quando o bem do ativo estivesse listado na portaria do Ministro da Fazenda, era a produção de bens tributados pelo IPI. Assim, a empresa que industrializasse produtos não-tributados era impedida de escriturar créditos sobre bens do ativo, mesmo quando inseridos em portaria ministerial (TFR, $6^{\mathrm{a}}$ Turma, AC $\mathrm{n}^{\circ}$ 99.581/RS, Relator Min. CARLOS MÁRIO VELLOSO, DJ 07.04.1988, p. 7.337).

${ }^{572}$ Art. 164, I, in fine do RIPI. 
Como se viu, o art. 164 do Regulamento do IPI assegura o cálculo de créditos básicos sobre matérias-primas (MP), produtos intermediários (PI) e materiais de embalagem (ME). Imperiosa, dessarte, a conceituação desses institutos. Confira-se.

\subsection{MATÉRIAS-PRIMAS.}

Segundo o Dicionário Aurélio da Língua Portuguesa ${ }^{573}$, matéria-prima consiste na "substância bruta principal e essencial com que é fabricada alguma coisa". Esse conceito passou a interessar à não-cumulatividade ainda sob a égide do Imposto de Consumo (IC). A vetusta Lei ${ }^{\circ}$ 3.520/58, uma das pioneiras da não-cumulatividade no Brasil, autorizou a dedução do IC suportado na aquisição de matérias-primas que concorressem para a fabricação do produto final ${ }^{574}$. Desde então, o crédito sobre matérias-primas passou a integrar o núcleo essencial da não-cumulatividade tributária, que foi transplantado para o IPI, para o ICM/ICMS e, atualmente, também para o PIS/COFINS ${ }^{575}$.

Dessa forma, nota-se que não há maiores divergências quanto ao conceito de matéria-prima: trata-se de todo e qualquer bem que se consome ou se modifica no processo de industrialização, integrando fisicamente o produto final. Assim, as chapas de aço são matérias-primas para a fabricação de automóveis; a madeira, para a indústria de móveis; o plástico, para a indústria de brinquedos, dentre infindáveis exemplos cuja enumeração se faz despicienda.

\subsection{PRODUTOS INTERMEDIÁRIOS.}

\subsection{ORIGEM NORMATIVA.}

${ }^{573}$ Dicionário Aurélio da Língua Portuguesa, versão eletrônica.

${ }^{574}$ Trata-se do art. $5^{\circ}$ do Decreto-lei $\mathrm{n}^{\mathrm{o}}$ 7.404, de 22 de março de 1945, com a redação que lhe foi impingida pela Lei $n^{\circ} 3.520$, de 30 de dezembro de 1958:

"Art. 5". Quando num mesmo estabelecimento produtor se fabricarem artigos sujeitos ao imposto de consumo que, sem saírem deste estabelecimento, forem utilizados na fabricação ou no acondicionamento de outros tributados, o imposto incide somente no produto final, facultada ao fabricante a dedução dos impostos pagos sobre as matérias primas que concorrerem para a sua produção."

${ }^{575}$ Como já ressaltado anteriormente, o regime aplicável às contribuições não é o da não-cumulatividade em sua inteireza, sendo-o apenas nos pontos em que compatível com a tributação sobre a receita bruta. A nosso sentir, entretanto, a garantia mínima do crédito físico - sobre matérias-primas, bens intermediários e materiais de embalagem - pode e deve ser aplicada às contribuições não-cumulativas, exigindo que o legislador ordinário, ao optar por esse regime, permita o cálculo do crédito, no mínimo, sobre as despesas com aquisição desse tipo de produto. 
Como já referido, a Lei no 3.520/58 autorizou a dedução do Imposto de Consumo suportado na aquisição de matérias-primas utilizadas na fabricação do produto final.

Entretanto, ao regulamentar a referida lei o Executivo federal ampliou o direito ao crédito, assegurando que outros produtos (além das matérias-primas) utilizados na fabricação ou acondicionamento de mercadorias permitissem a dedução do Imposto de Consumo $\operatorname{a~pagar~}^{576}$.

Posteriormente, a Lei $n^{\circ}$ 4.153/62, em verdadeira interpretação autêntica, conferiu o seguinte sentido aos outros produtos mencionados no decreto regulamentador do Imposto de Consumo:

"Art. 34. O artigo 148 do atual Regulamento do Imposto de Consumo aprovado pelo Decreto $n^{\circ} 45.422$, passa a vigorar com as seguintes alterações: (...)

b) Para os fins do art. 148, entendem-se como adquiridos para emprego na fabricação e acondicionamento de artigos ou produtos tributados:

1 - na fabricação: as matérias primas ou artigos e produtos secundários ou intermediários que, integrando o produto final ou sendo consumidos total ou parcialmente no processo de sua fabricação, sejam utilizados na sua composição, elaboração, preparo, obtenção e confecção, inclusive na fase de apresto e acabamento." (destaques nossos)

Dessarte, além de ganhar respaldo legal, o direito ao crédito sobre "outros produtos" - para além das matérias-primas - passou a ser delineado com maior precisão. Esses "outros", como visto, foram intitulados produtos secundários ou intermediários. Segundo a lei, tais bens deveriam:

(a) ser consumidos total ou parcialmente no processo de fabricação; ou

(b) ser utilizados na composição, elaboração, preparo, obtenção e confecção dos produtos finais, ainda que na fase final (apresto e acabamento).

A Lei $n^{\circ} 4.502 / 64$, que derradeiramente regulou o Imposto de Consumo no País (antes de sua extinção pela $\mathrm{EC} \mathrm{n}^{\circ} 18 / 65$ ), também se referiu aos produtos intermediários de forma expressa (assegurando o cálculo de créditos sobre aqueles, ao lado das matériasprimas e embalagens ${ }^{577}$ ). A seu turno, o regulamento dessa derradeira legislação do Imposto de Consumo conceituou os intermediários como os bens que, "embora não se integrando no novo produto, são consumidos no processo de industrialização" 578 .

\footnotetext{
${ }^{576}$ Art. 148 do Decreto n ${ }^{\circ} 45.422$, de 12 de fevereiro de 1959.

${ }^{577}$ Art. $25, \S^{\circ}$ da Lei $n^{\circ} 4.502 / 64$.

${ }^{578}$ Decreto $n^{\circ} 56.791$, de 26 de agosto de 1965 :
} 
Com a EC nº 18/65 e a edição do Código Tributário Nacional, as regras antes aplicáveis ao Imposto de Consumo passaram a reger o IPI $^{579}$, que era legalmente definido como a "nova denominação" do $\mathrm{IC}^{580}$.

O primeiro Regulamento do IPI, editado em 1967, simplesmente repetiu a qualificação de produto intermediário constante do anterior. Assim, o contribuinte faria jus ao crédito se houvesse consumo do bem no processo de industrialização ${ }^{581}$.

A novidade adveio no RIPI/72, que passou a conceituar como produto intermediário o consumível de forma imediata e integral no processo de industrialização ${ }^{582}$. A celeuma se instalou entre o Fisco federal e os contribuintes, que passaram a discutir em que consistiria o novel requisito do RIPI.

Com o intuito de aclarar a interpretação da norma, o Coordenador do Sistema de Tributação (CST) editou o Parecer Normativo ${ }^{\circ}$ 181/74. Segundo ele, as matérias-primas e produtos intermediários teriam participação intrínseca no processo produtivo, ao passo que as máquinas, equipamentos e instalações, bem como suas partes, peças e acessórios agiriam sobre o processo de industrialização, de modo extrínseco. Logo, a exigência de

"Art. 27. Para efeito do recolhimento, será deduzido do valor resultante do cálculo, na forma do art. 29:

I - o imposto relativo às matérias-primas, produtos intermediários e embalagens, adquiridos ou recebidos para emprego na industrialização e no acondicionamento de produtos tributados, compreendidos, entre os primeiros, aqueles que, embora não se integrando no novo produto, são consumidos no processo de industrialização;"

${ }^{579}$ Interplures, a Lei $\mathrm{n}^{\mathrm{o}} 4.502 / 64$, que tratava da não-cumulatividade do imposto de consumo e passou a reger a do IPI, foi modificada pelos Decretos-leis n's 34/66, 400/68 e 1.136/70.

${ }^{580}$ Art. $1^{\circ}$ do $\mathrm{DL} \mathrm{n}$ o $34 / 66$.

${ }^{581}$ RIPI/67 (Decreto n ${ }^{\circ}$ 61.514, de 12 de outubro de 1967):

"Art. 30. Os estabelecimentos industriais e os que lhe são equiparados poderão creditar-se pelo imposto:

I - relativo a matérias-primas, produtos intermediários e material de embalagem, importados ou de fabricação nacional, recebidos para emprego na industrialização de produtos tributados, por estabelecimento industrial ou pelo estabelecimento a que se refere o inciso III, do $\S 1^{\circ}$ do art. $3^{\circ}$, compreendidos, entre as matérias-primas e produtos intermediários, aqueles que, embora não se integrando no novo produto, forem consumidos no processo de industrialização."

${ }^{582}$ RIPI/72 (Decreto no 70.162 , de 18 de fevereiro de 1972):

"Art. 32. Os estabelecimentos industriais e os que lhes são equiparados poderão creditar-se do imposto:

I - Relativo a matérias-primas, produtos intermediários e material de embalagem, importados ou de fabricação nacional, recebidos para emprego na industrialização de produtos tributados, por estabelecimento industrial ou pelo estabelecimento a que se refere o inciso III do $\S 1^{\circ}$ do artigo $3^{\circ}$, compreendidos, entre as matérias-primas e produtos intermediários, aqueles que, embora não se integrando no novo produto, forem consumidos, imediata e integralmente, no processo de industrialização;" 
consumo imediato consistia apenas em se aclarar a necessária participação intrínseca do produto intermediário no processo industrial.

Outrossim, o parecer sustenta ainda a necessidade de desgaste integral após uma única utilização para que o bem seja considerado intermediário. Trata-se do sentido da expressão consumo integral empregada pelo RIPI/72.

Dessarte, para o Parecer Normativo CST n 181/74, o Regulamento do IPI de 1972 teria apenas explicitado o entendimento já consolidado da Receita Federal de que bens intermediários são os que:

(a) participam direta e intrinsecamente da industrialização;

(b) se consomem integralmente no processo industrial, "de tal forma que, após o término de cada etapa do processo" ${ }^{, 583}$ não mais se prestem à finalidade que lhes é própria.

Ao cabo, o parecer exemplifica (em rol numerus apertus) os bens que não gerariam crédito do imposto. Para melhor compreensão, dividiremos tais produtos em duas categorias:

(a) produtos incorporados às instalações industriais, partes, peças e acessórios de máquinas, equipamentos e ferramentas;

(b) produtos empregados na manutenção das instalações, máquinas e equipamentos, inclusive lubrificantes e combustíveis necessários ao seu funcionamento, tais como: limas, rebolos, lâminas de serras, brocas, tijolos refratários utilizados em fornos de produção de metais, tintas e lubrificantes empregados na manutenção de máquinas e equipamentos.

A primeira categoria de bens acima listada compreende, a nosso sentir, mercadorias que integram o ativo imobilizado da empresa. Portanto, de fato não se tratam de bens intermediários, salvo se consumíveis em menos de um ano (o período temporal é aqui referido pois a legislação do Imposto de Renda determina que os bens incorporados ao patrimônio da empresa por doze meses ou mais passam a integrar o seu ativo imobilizado).

Já a segunda relação contém produtos verdadeiramente intermediários, que o Parecer Normativo CST $n^{\circ} 181 / 74$ se recusa a reconhecer, arrimado na necessidade de consumido imediato (que exige contato direto e intrínseco com o bem produzido) e integral (instantâneo) do insumo.

${ }^{583}$ Parecer Normativo do Coordenador do Sistema de Tributação - CST n ${ }^{\circ}$ 181/74, DOU 23.10.1974. 
Como se vê, a exigência de consumo imediato e integral do bem intermediário, constante do RIPI/72, foi interpretada de forma bastante restritiva pela fiscalização. Todavia, já no Regulamento seguinte (RIPI/79) a referida exigência deixou de existir.

De fato, o RIPI/79 restabeleceu o tradicional conceito de produto intermediário: aquele que, embora não se integrando no novo produto, seja consumido no processo de industrialização ${ }^{584}$. Por primeira vez, também no RIPI/79, vedou-se expressamente o crédito sobre bens do ativo imobilizado ${ }^{585}$.

Baseado no Regulamento de 1979, o Coordenador do Sistema de Tributação (CST) elaborou novo parecer normativo ${ }^{586}$, em que:

(a) se explicitou a impossibilidade de retroação do conceito de produto intermediário constante do RIPI/79 para as situações abrigadas pelo RIPI/72 (que exigia a já referida consumição imediata e integral); e

(b) se adicionou um novo requisito para a caracterização do bem intermediário: o contato físico direto entre a mercadoria consumida e o produto final.

Os trechos a seguir demonstram a preocupação do Parecer Normativo CST n ${ }^{\circ}$ 65/79 em estremar a então novel definição dos bens intermediários - mais benéfica aos contribuintes - da anterior, regida pelo RIPI/72:

“10.2. A expressão 'consumidos', sobretudo levando-se em conta que as restrições 'imediata e integralmente', constantes dos dispositivos correspondentes do Regulamento anterior, foram omitidas, há de ser entendida em sentido amplo, abrangendo, exemplificativamente, o desgaste, o desbaste, o dano e a perda de propriedades físicas ou químicas (...)."

Contudo, nesse mesmo trecho, arremata-se, ao final, que o desgaste, o desbaste, o dano e a perda de propriedades físicas devem ser "decorrentes de ação direta do insumo

${ }^{584}$ RIPI/79 (Decreto no 53.263, de 9 de março de 1979):

"Art. 66. Os estabelecimentos industriais e os que lhe são equiparados poderão creditar-se:

I - do imposto relativo a matérias-primas, produtos intermediários e material de embalagem, adquiridos para emprego na industrialização de produtos tributados, incluindo-se entre as matérias-primas e os produtos intermediários aqueles que, embora não se integrando ao novo produto, forem consumidos no processo de industrialização, salvo se compreendidos entre os bens do Ativo Permanente."

${ }^{585} \mathrm{O}$ art. $25, \S 1^{\circ}$ da Lei $\mathrm{n}^{\mathrm{o}} 4.502 / 64$ proibia - mediante interpretação a contrario sensu - o crédito sobre bens do ativo imobilizado. Entretanto, tal vedação ainda não havia sido retratada com clareza pelos regulamentos do IPI.

\footnotetext{
${ }^{586}$ Parecer Normativo do Coordenador do Sistema de Tributação - CST nº 65, DOU 06.11.1979.

${ }^{587}$ Parecer Normativo do Coordenador do Sistema de Tributação - CST nº 65, DOU 06.11.1979.
} 
sobre o produto em fabricação, ou deste sobre o insumo",588. Não satisfeito, o parecer insiste no ponto:

"10.3. Passam, portanto, a fazer jus ao crédito, distintamente do que ocorria em face da norma anterior, as ferramentas manuais e as intermutáveis, bem como quaisquer outros bens que, não sendo partes nem peças de máquinas (...), se consumirem em decorrência de um contato físico, ou melhor dizendo, de uma ação diretamente exercida sobre o produto em fabricação, ou por este diretamente sofrida." 589

E, ao final, conclui que bens geradores de crédito são:

(a) aqueles que se incorporam fisicamente ao produto final (matérias-primas ou bens intermediários stricto sensu);

(b) quaisquer outros que sofram alterações (tais como desgaste, dano, perda de propriedades físicas ou químicas) em função de ação diretamente exercida sobre o bem em industrialização, ou vice-versa, salvo se tais produtos integrarem o ativo imobilizado da empresa.

Tal parecer, em vigor até os dias de hoje (eis que os Regulamentos do IPI de $1982^{590}, 1998^{591}$ e $2002^{592}$ apenas repetiram o conceito de produto intermediário plasmado no RIPI/79), restringe, ilegalmente, o direito ao crédito de IPI.

\footnotetext{
${ }^{588}$ Parecer Normativo do Coordenador do Sistema de Tributação - CST nº 65, DOU 06.11.1979.

${ }^{589}$ Parecer Normativo do Coordenador do Sistema de Tributação - CST nº 65, DOU 06.11.1979.

${ }^{590}$ RIPI/82 (Decreto n ${ }^{\circ} 87.981$, de 23 de dezembro de 1982):
}

“Art. 82. Os estabelecimentos industriais, e os que lhes são equiparados, poderão creditar-se: I - do imposto relativo a matérias-primas, produtos intermediários e matéria. de embalagem, adquiridos para emprego na industrialização de produtos tributados, exceto as de alíquota 0 (zero) e os isentos, incluindo-se, entre as matérias-primas e produtos intermediários, aqueles que, embora não se integrando ao novo produto, forem consumidos no processo de industrialização, salvo se compreendidos entre os bens do ativo permanente;"

${ }^{591}$ RIPI/98 (Decreto no 2.637 , de 25 de junho de 1998):

"Art. 147. Os estabelecimentos industriais, e os que lhes são equiparados, poderão creditar-se: I - do imposto relativo a matérias-primas, produtos intermediários e material de embalagem, adquiridos para emprego na industrialização de produtos tributados, incluindo-se, entre as matériasprimas e produtos intermediários, aqueles que, embora não se integrando ao novo produto, forem consumidos no processo de industrialização, salvo se compreendidos entre os bens do ativo permanente;"

${ }^{592}$ RIPI/02 (Decreto no 4.544, de 26 de dezembro de 2002):

"Art. 164. Os estabelecimentos industriais, e os que lhes são equiparados, poderão creditar-se: I - do imposto relativo a MP, PI e ME, adquiridos para emprego na industrialização de produtos tributados, incluindo-se, entre as matérias-primas e produtos intermediários, aqueles que, embora não se integrando ao novo produto, forem consumidos no processo de industrialização, salvo se compreendidos entre os bens do ativo permanente;" 
Afinal, a Lei n ${ }^{\circ} 4.153 / 62$, que por primeira e única vez dispôs, no plano legal, sobre o conceito de produtos intermediários, exige apenas o seu consumo, total ou parcial, no processo de industrialização. A Lei $n^{\circ}$ 4.502/64 refere-se a bem intermediário mas não o define. Todavia, pela interpretação histórica, o conceito somente pode ter o sentido que lhe foi conferido pela Lei $n^{\circ} 4.153 / 62$. Erigir requisitos como consumição "imediata e integral", como pretendeu o RIPI/72, ou "contato direto com o produto final", consoante predicado pelo Parecer Normativo CST no 65/79, é extrair da legislação sentido que ela não possui. Como predica a boa técnica hermenêutica, se a lei não distingue, não cabe ao intérprete distinguir.

A partir dessas normas, instaurou-se a discussão sobre quais bens poderiam ser considerados intermediários. As lides sobre o tema eram e ainda são (pois subsistem até hoje) delongadas, haja vista a necessidade de complexas perícias técnicas que detalham a utilização dos bens no processo produtivo.

Vejamos, a seguir, como se comportou a jurisprudência de nossas Cortes Superiores em relação ao tema em comento. Como se verá, as lides recaíram, principalmente, sobre a definição de consumo imediato e integral do produto intermediário. Apesar de terem sido expressamente previstos apenas no RIPI de 1972, tais requisitos - no sentido que os Tribunais lhes conferiu - passaram a integrar o conceito de produto intermediário que perdura até os dias de hoje.

\subsection{A JURISPRUDÊNCIA DAS CORTES SUPERIORES.}

O Supremo Tribunal Federal definiu o conceito de produto intermediário no final da década de 1970, conferindo a solução esperada: desde que o bem fosse consumido diretamente na produção e não integrasse o ativo permanente ${ }^{593}$ do contribuinte, seria caracterizado como intermediário, gerando direito ao crédito.

As indústrias siderúrgicas tiveram importante papel nessas discussões, haja vista o elevado número de componentes utilizados para fabricação do aço. Um tema recorrentemente analisado pelo STF foi o da natureza dos materiais refratários que revestem os for-

\footnotetext{
${ }^{593}$ A conclusão foi extraída do estudo das decisões sobre o tema. Todas as vezes em que os fatos narrados no processo conferiam ao produto uma natureza próxima à de ativo imobilizado, negava-se o cariz de bem intermediário; por outro lado, quando demonstrado que havia desgaste, rápido ou lento, mas em velocidade que não indicava a incorporação ao imobilizado, o Supremo Tribunal Federal assegurava o creditamento, classificando o produto como intermediário.
} 
nos onde o aço é fabricado (cujo crédito, vale lembrar, era expressamente negado pelo Parecer Normativo CST no 181/74, à luz do RIPI/72).

A Primeira Turma do Tribunal, em 1979, concluiu pela natureza de produtos intermediários dos refratários, haja vista se desgastarem no processo de produção, "de nada mais servindo o resíduo" ${ }^{, 594}$. Com tal assentada, afastou-se a restrição ao crédito do RIPI/72, pois os refratários não se consomem de forma imediata (no sentido de serem intrinsecamente ligados ao produto) ou integral (na acepção de se tornarem imprestáveis após cada utilização). Ao contrário: atuam sobre o produto, de modo extrínseco, e se tornam impróprios para consumo apenas depois de várias utilizações ${ }^{595}$.

Já a Segunda Turma, ao analisar o tema em 1981, arrimou-se na questão formal (vencido o relator) para não julgar o mérito da lide. Segundo o acórdão, não poderia o STF declarar a ilegalidade do RIPI/72 eis que, nesse caso, haveria violação indireta à Constituição da República. O decreto que veiculou o RIPI estava em desacordo com a Lei $\mathrm{n}^{\circ}$ 4.502/64, que era constitucional. Assim, apenas de forma indireta havia violação à Constituição, o que desautorizava o conhecimento do extraordinário. Não obstante, todos os Ministros concordaram que, se o mérito fosse apreciado, a solução seria o afastamento da ilegal restrição do RIPI/72 ao creditamento do imposto federal ${ }^{596}$.

\footnotetext{
${ }^{594}$ STF, Primeira Turma, RE nº 90.205/RS, Relator Min. SOARES MUÑOZ, DJ 23.03.1979, p. 2.103.

595 Apesar de o tema não envolver questão constitucional (tratava-se de decreto - RIPI/72 - editado em contrariedade à Lei $n^{\circ} 4.502 / 64$ ), a não-cumulatividade plasmada pela EC $n^{\circ} 18 / 65$ foi invocada para a solução da lide. A Suprema Corte, então, interpretou o RIPI/02 conforme a Constituição. Veja-se, no voto do Min. SOARES MUÑOZ:

"Estou em que, tendo o acórdão recorrido admitido o fato de que os refratários são consumidos na fabricação do aço, a circunstância de não se fazer esse consumo em cada fornada, mas em algumas sucessivas, não constitui causa impeditiva à regra constitucional e legal que proíbe a cumulatividade do IPI.

(...)

Aceito a interpretação que concilia o (...) Regulamento (...) com a Lei $n^{\circ}$ 4.502/64." (STF, Primeira Turma, RE no 90.205/RS, Relator Min. SOARES MUÑOZ, DJ 23.03.1979, p. 2.103, destaques nossos).
}

\footnotetext{
${ }^{596}$ Tratava-se do RE no 93.545/SP em que se discutia a classificação, como bens intermediários, de panos filtrantes utilizados na fabricação de papel transparente. O Relator originário, Min. LEITÃO DE ABREU, entendeu que o RIPI/1972 extrapolara a Lei $n^{\circ}$ 4.502/64 ao determinar que bens intermediários seriam apenas aqueles consumidos de forma imediata e integral na produção - o que impediria, no caso, o crédito dos panos filtrantes, que admitiam mais de uma utilização antes de seu efetivo descarte. Da fundamentação do Min. LEITÃO DE ABREU nenhum outro integrante da Segunda Turma divergiu. Todavia, somente o Min. CORDEIRO GUERRA acompanhou o relator originário. Os outros três julgadores (Ministros DÉCIO MIRANDA, MOREIRA ALVES e DJACI FALCÃO) não conheceram do extraordinário por questão formal: como o relator apontara que a contrariedade era do RIPI à lei, e apenas por via oblíqua à Constituição (eis que a lei era consentânea com esta), não poderia o STF julgar a causa. (STF, Segunda Turma, RE nº 93.545/SP, Relator Min. LEITÃO DE ABREU, DJ 11.09.1981, p. 8.791).
} 
Assim, no início da década de 1980 o STF já havia superado o óbice criado pelo RIPI/72 à caracterização dos produtos intermediários.

Entretanto, em 1982 a Segunda Turma negou o crédito de IPI ao revestimento refratário utilizado na fabricação de cimento, haja vista que aquele se desgastava lentamente, sendo substituído de três em três anos ${ }^{597}$. De todo modo, isso não significou uma mudança de posicionamento da Suprema Corte. Afinal, os materiais com duração superior a 12 (doze) meses não podem ser classificados como produtos intermediários, pois passam a pertencer ao ativo permanente da empresa. Nesse sendeiro, correta a decisão que nega o cariz de produto intermediário ao revestimento do forno que possui duração superior a um ano.

A conclusão pelo afastamento da restrição pretendida pelo RIPI/72 pode ainda ser confirmada pela jurisprudência do extinto Tribunal Federal de Recursos. Entendeu o TFR que a usina siderúrgica fazia jus ao crédito dos materiais refratários utilizados na fabricação do aço. O fundamento invocado pelo TFR, tal como nos casos analisados pelo Supremo Tribunal Federal, foi o princípio da não-cumulatividade tributária ${ }^{598}$. Em oportunidade distinta, confirmando o que se está a sustentar, o TFR textualmente predicou existir direito de crédito do IPI sobre o material refratário consumido, "embora lentamente", no processo de fabricação de ladrilhos ${ }^{599}$. Esse mesmo entendimento, anos depois, foi reiterado pelo

${ }^{597}$ O Min. Relator DÉCIO MIRANDA assentou:

"Aos revestimentos (de fornos de calcinação de cal) que se desgastam lentamente, obrigando à sua renovação em cerca de três a três anos, negou o acórdão a condição de 'produto intermediário', qualificação que o art. 32, I do Decreto $\mathrm{n}^{\circ} 70.162$, de 1972, reserva para 'aqueles que, embora não se integrando no novo produto, forem consumidos, imediata e integralmente, no processo de industrialização'.

Conquanto a palavra 'imediata' do texto regulamentar não se refira somente ao requisito temporal, mas também ao requisito de proximidade operacional (imediato é o que está diretamente ligado àquela específica operação produtiva), é bem de ver que a palavra 'consumidos' indica a absorção do produto em termos relativos consideráveis, e não o mero desgaste paulatino. Deste último sofre toda a instalação, com maior ou menor rapidez, sem que se possa equiparar a consumo imediato e integral aquele consumo lento e espaçado, identificado como desgaste." (STF, Segunda Turma, RE ${ }^{\circ}$ 96.934/MG, Relator Min. DÉCIO MIRANDA, DJ 22.10.1982, p. 10.742).

${ }^{598}$ É ver a ementa:

“TRIBUTÁRIO. AÇÃO ANULATÓRIA DE DÉBITO FISCAL. IPI. MATERIAIS REFRATÁRIOS CONSUMIDOS NO PROCESSO DE INDUSTRIALIZAÇÃO DO AÇO. (...).

Não há como deixar de reconhecer ao industrial o direito de creditar-se ao IPI pago na aquisição dos materiais em questão, em atenção ao princípio constitucional da não-cumulatividade, desde que, são eles inteiramente consumidos durante o processo de fabricação, não integrando, destarte, o novo produto." (TFR, Quarta Turma, AC n 87.471/MG, Relator Min. ARMANDO ROLEMBERG, DJ 24.10.1985).

No mesmo sendeiro: TFR, Quinta Turma, REO $\mathrm{n}^{\circ}$ 48.932/PR, Relator Min. MOACIR CATUNDA, DJ 16.09.1982.

${ }^{599}$ TFR, Sexta Turma, REO nº 64.953/SP, Relator Min. JOSÉ DANTAS, DJ 26.09.1980. 
STJ. A Corte Superior de Justiça deixou claro que os materiais refratários, embora consumidos "de maneira lenta" dão" referida nos acórdãos deve ser obtemperada: se o bem se incorpora ao patrimônio da empresa por um ano, passa a integrar o ativo imobilizado, descaracterizando-se como produto intermediário.

O Tribunal Federal de Recursos somente negou o crédito de IPI a produtos que, agregados a máquinas ou equipamentos, destes fizessem parte. Em outros termos: valendose do critério legal para caracterização de bens do ativo imobilizado ${ }^{601}$ e do princípio da preponderância - utilizado para perquirir se o bem se amoldava com maior propensão ao conceito de ativo ou de produto intermediário - o TFR, por exemplo, denegou o pleito de indústrias produtoras de papel que pretendiam creditar-se do IPI suportado na compra de telas e feltros utilizados em suas máquinas. Como tais produtos se incorporavam ao maquinário, entendeu o TFR que se tratavam de bens destinados ao ativo imobilizado ${ }^{602}$.

Todavia, em arestos nos quais o feltro foi caracterizado como um produto nãointegrante do ativo imobilizado, consumindo-se na produção do papel, o TFR conferiu o direito ao crédito, qualificando como produto intermediário ${ }^{603}$.

Pode-se dizer que o TFR entrou em contradição ao decidir de formas diferentes quanto ao crédito dos feltros e telas utilizados pela indústria de papel e celulose (ora caracterizando-os como produtos intermediários, ora como partes e peças integrantes do ativo imobilizado)? Temos que não. As Cortes Superiores se limitam a aplicar o direito à moldura fática apresentada pelo acórdão recorrido. Assim, é possível que em certos processos uma perícia cuidadosa tenha demonstrado que o consumo de feltros para a indústria de papel se dá em intervalo inferior a um ano, não havendo incorporação do bem ao ativo da empresa. Nessa hipótese, baseando-se nos conceitos já assentados pela Corte, a única solução é o reconhecimento do crédito. Já, noutras ações em que as conclusões periciais foram pela incorporação do feltro ao bem do ativo, o Tribunal deve se adstringir ao descrito nos autos, negando, à luz da verdade formal que pauta o processo judicial, o crédito de IPI.

\footnotetext{
${ }^{600}$ STJ, Segunda Turma, REsp no 18.361/SP, Relator Min. HÉLIO MOSIMANN, DJ 07.08.1995, p. 23.026.

${ }^{601}$ A legislação do Imposto sobre a Renda determina a ativação de todo bem que se integrar ao patrimônio da empresa por período igual ou superior a 1 (um) ano.

${ }^{602}$ Dentre vários, cite-se: TFR, Sexta Turma, AC no 62.840/SP, Relator Min. TORREÃO BRAZ, DJ 21.10.1982; TFR, Segunda Seção, EIAC nº 64.688/PR, Relator Min. HUGO MACHADO, DJ 13.02.1989.

${ }^{603}$ TFR, Quinta Turma, REO n 59.442/SP, Relator Min. PEDRO ACIOLI, DJ 01.07.1981.
} 
Dessa forma, em feitos nos quais se discute a natureza dos bens intermediários, a descrição dos fatos é condição fundamental para o êxito do pleito de creditamento. Do contrário, ter-se-ão decisões divergentes, como as apontadas acima. Estas, contudo, não decorrem da oscilação do entendimento do Tribunal, mas sim da forma pela qual a causa lhe foi apresentada.

O Superior Tribunal de Justiça também apreciou - em um de seus mais importantes precedentes sobre a matéria, que é sistematicamente invocado pelos Ministros quando do julgamento de lides acerca de produtos intermediários do IPI - a questão do crédito sobre telas e feltros empregados nas máquinas produtoras de papel. A Corte Superior de Justiça negou nesse leading case o caráter de produto intermediário às telas e feltros referidos. Entretanto, o STJ não teceu maiores digressões sobre os bens em si, limitando-se a aplicar a lei sobre os fatos narrados pelo acórdão recorrido. Merece leitura o seguinte trecho do voto do Relator, Min. HUMBERTO GOMES DE BARROS:

"A recorrente insiste em afirmar que os feltros de pano e metal utilizados em seus maquinários, na fabricação de papel, se desgastam e uma vez retirados dos equipamentos não apresentam características senão de sucata.

Sob esse enfoque, o apelo não comporta conhecimento, posto que, assentado na instância ordinária que as telas e feltros não são produtos intermediários, mas integram bens de capital, não se consomem, mas desgastam-se com o uso, inviável o reexame da questão, por incidente o Verbete $\mathrm{n}^{\circ} 07$ do STJ." ${ }^{\circ 04}$

Nesse sentido, como a descrição fática indicava que os feltros e telas equivaliam a "bens de produção, bens de capital, equipamentos, que se depreciam, que se acabam, pela inexorável lei do desgaste", do que decorria a sua não-caracterização como bens intermediários, o STJ decidiu da única forma que lhe competia: mantendo o aresto recorrido e negando o crédito de IPI.

As decisões posteriores do STJ sobre a questão não discrepam: consideram a descrição fática do acórdão recorrido. Se esse prega haver consumo imediato e integral ${ }^{605}$ do bem no processo de produção, reconhecem o crédito ${ }^{606}$; caso contrário, denegam ${ }^{607}$.

${ }^{604}$ STJ, Primeira Turma, REsp no $30.938 /$ PR, Relator Min. HUMBERTO GOMES DE BARROS, DJ 07.03.1994, destaques nossos.

${ }^{605}$ O STJ utiliza a expressão consumo imediato e integral, tal como fazia o RIPI/72, porém, obviamente, com a interpretação que lhe foi conferida pelo STF, TFR e pelo próprio STJ.

${ }^{606}$ Confira-se a ementa a seguir, que clarifica o exposto:

"I - Considerando que somente há o direito de creditamento do IPI pago anteriormente quando se tratar de insumos que se incorporam ao produto final ou que são consumidos no curso do processo de industrialização, de forma imediata e integral, há que se falar em crédito no caso em exame, quando a sentença e o acórdão recorrido afirmam que ocorreu o aludido consumo." (STJ, Primeira 
Quanto à necessidade de contato físico direto entre o bem intermediário e o produto final, requisito ilegalmente erigido pelo Parecer Normativo CST n ${ }^{\circ}$ 65/79, a jurisprudência nunca debateu o tema a contento. Ressaltamos apenas o absurdo da exigência, erigida por parecer normativo, sem amparo em qualquer lei ou mesmo em decreto.

\subsection{CONCEITO DE BEM INTERMEDIÁRIO.}

Do exposto, é possível concluir que o requisito de consumo imediato e integral do produto intermediário, trazido à balha pelo RIPI/ $72^{608}$, foi incorporado pela jurisprudência sem as restrições que o fisco lhe tentou impingir por meio do Parecer Normativo CST $\mathrm{n}^{\circ}$ 181/74. Consumo imediato foi definido como o realizado de forma intrínseca ou extrínseca em relação ao produto. Já consumo integral implica o desgaste completo do produto, após uma ou várias utilizações.

De todo modo, a exigência da consumição imediata e integral do bem intermediário foi revogada pelo RIPI/79 e nunca mais positivada. Entretanto, apesar de não mais existente nas normas do IPI, tal requisito continuou sendo utilizado pela jurisprudência para perquirição da natureza do bem empregado no processo de produção.

Turma, AgRg no AgRg no REsp no 386.774/MG, Relator Min. FRANCISCO FALCÃO, DJ 29.11.2004, p. 226).

Em seu voto, o Min. Relator averba:

“(...) De acordo com o que delineou a sentença e o acórdão recorrido, os materiais utilizados na fabricação do cimento foram consumidos durante o processo industrial, o que, no teor da jurisprudência desta Corte, possibilita a dedução do IPI." (STJ, Primeira Turma, AgRg no AgRg no REsp n 386.774/MG, Relator Min. FRANCISCO FALCÃO, DJ 29.11.2004, p. 226).

E rechaça o pleito da Fazenda de caracterização dos bens objurgados como integrantes do ativo imobilizado aos seguintes fundamentos:

“(...) Não há como se chegar à conclusão de que os produtos utilizados no processo industrial façam parte do ativo permanente da agravada, eis que nem a sentença, nem o acórdão atacado explicitam tal afirmação." (STJ, Primeira Turma, AgRg no AgRg no REsp no 386.774/MG, Relator Min. FRANCISCO FALCÃO, DJ 29.11.2004, p. 226).

${ }^{607}$ É ver:

“TRIBUTÁRIO. IPI. CREDITAMENTO. PRODUTO ADQUIRIDO E UTILIZADO DE FORMA IMEDIATA E INTEGRALMENTE.

1. É pacífica a jurisprudência do Superior Tribunal de Justiça no sentido de que a dedução do IPI somente se aplica aos casos em que os produtos intermediários, matérias-primas e embalagens adquiridos pela empresa destinem-se à fabricação do produto final.

2. No caso em análise, merece reparo a decisão do Tribunal de origem que deferiu a apropriação de créditos de IPI decorrentes da aquisição de bens que não se consomem imediata e integralmente no processo produtivo." (STJ, Segunda Turma, AgRg no REsp no 1.082.522/SP, Relator Min. HUMBERTO MARTINS, DJe 04.02.2009).

${ }^{608}$ Impende lembrar que o RIPI/72 foi revogado, nesta parte, pelo RIPI/79, cuja redação foi reproduzida nos demais regulamentos do imposto, inclusive no presente, no qual não se tem a exigência de consumo "imediato e integral" do bem intermediário. 
Portanto, pode-se conceituar como produto intermediário aquele consumido de forma integral, ainda que de forma lenta, no bojo do processo produtivo. Obviamente o consumo lento não pode resultar na incorporação do bem por mais de um ano ao patrimônio da empresa, eis que, nesse caso, ele se torna integrante do ativo imobilizado da pessoa jurídica.

É importante ressaltar, entretanto, que existe uma zona de incerteza em relação aos bens intitulados "de uso e consumo" da empresa, tais como óleos lubrificantes, materiais de limpeza, et caterva. Adotando-se o requisito da essencialidade ao processo produtivo, conclui-se pela sua caracterização como produtos intermediários e conseqüente existência do direito ao crédito. Entrementes, o STJ já pugnou ${ }^{609}$ que óleos lubrificantes são apenas indiretamente utilizados na produção, pelo que não seriam produtos intermediários e sim bens de consumo, não gerando crédito aproveitável.

A nosso sentir, a restrição do conceito de bem intermediário, caracterizando-se como tal apenas os bens diretamente ligados ao produto é injurídica. As leis do Imposto de Consumo, que edificaram o conceito, sempre foram taxativas ao mencionar o consumo no processo de produção. Os sucessivos Regulamentos do IPI, inclusive o presente, também classificam - com fincas na vetusta definição legal - os intermediários como bens que, não se integrando ao produto final, são consumidos no processo industrial.

Ora, é impossível o funcionamento de uma indústria sem a utilização de óleos para lubrificação de suas máquinas. Os lubrificantes não se relacionam diretamente com o produto, isso é fato; mas as normas do IPI sempre exigiram a relação direta com o processo industrial. E, para a indústria, os lubrificantes são imprescindíveis.

Portanto, desde que haja consumo diretamente no processo industrial, existirá para o contribuinte o direito ao crédito sobre o bem, descabendo considerações quanto à relação direta ou indireta do bem intermediário em relação ao produto industrializado.

\subsection{A ENERGIA ELÉTRICA UTILIZADA NA PRODUÇÃO.}

\footnotetext{
${ }^{609}$ Eis a ementa:

“TRIBUTÁRIO. IPI. CREDITAMENTO DE VALORES PAGOS NA AQUISIÇÃO DE BENS DE USO E CONSUMO UTILIZADOS NO PROCESSO PRODUTIVO. DESGASTE INDIRETO. INEXISTÊNCIA DO DIREITO AO CRÉDITO.

(...)

2. No caso dos autos, ficou assentado que os bens de uso e consumo sofreram desgaste indireto no processo produtivo, não sendo cabível o creditamento do IPI pago na sua aquisição.” (STJ, Primeira Turma, REsp nº 608.181/SC, Relator Min. TEORI ZAVASCKI, DJ 27.03.2006, p. 161).
} 
Como visto, são produtos intermediários aqueles que, embora não se integrem ao produto final, se consomem no processo de industrialização. Já as matérias-primas agregam-se fisicamente ao bem produzido. Tanto estas como aqueles são qualificados pela doutrina e jurisprudência como insumos utilizados no processo produtivo. A chave abaixo representa o que se está a dizer:

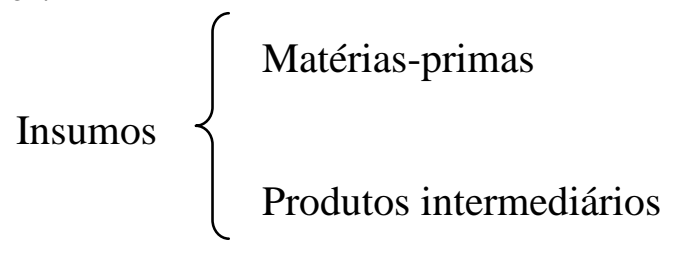

Com base nessas premissas, pode-se sustentar que a energia elétrica consiste em insumo (da espécie bem intermediário) quando utilizada na área operacional das indústrias? A resposta é afirmativa.

Atualmente todo processo produtivo depende da energia elétrica. Trata-se do mais básico insumo de produção deste século. É impensável uma indústria que funcione sem energia. Essa, ademais, é considerada mercadoria para todos os fins, sendo tributável pelo ICMS e podendo, inclusive, ser objeto do crime de furto ${ }^{610}$.

Considerando-se tais fatores, conclui-se que a energia elétrica utilizada no setor operacional das indústrias é insumo, na modalidade bem intermediário, pois é consumida diretamente no processo de industrialização, viabilizando-o.

Contrariando a realidade dos fatos, entretanto, o Superior Tribunal de Justiça tem sistematicamente negado o cariz de insumo da energia utilizada pelo setor industrial ${ }^{611}$. Ao fazê-lo, o STJ parece exigir o desgaste do bem intermediário "em função de ação exercida diretamente sobre o produto em fabricação" ${ }^{\prime 612}$. Essa seria, de fato, a única justificava para se negar o caráter de insumo à energia elétrica - apesar de não ter sido explicitamente ventilada em nenhum aresto do STJ sobre o tema.

\footnotetext{
${ }^{610} \mathrm{O}$ furto tipifica-se com a subtração, para si ou para outrem, de coisa alheia móvel, à qual a energia elétrica é expressamente equiparada pelo art. $155, \S 3^{\circ}$ do Código Penal.

${ }^{611}$ Interplures, confira-se o seguinte trecho de ementa:

"1. A energia elétrica não pode ser considerada insumo, para fins de aproveitamento de crédito gerado pela sua aquisição, a ser descontado do valor apurado na operação de saída do produto industrializado. (...)." (STJ, Segunda Turma, REsp n 710.997/RS, Relator Min. CASTRO MEIRA, DJ 20.04.2006, p. 142).

No mesmo sentido: STJ, Primeira Turma, REsp n ${ }^{\circ}$ 638.745/SC, Relator Min. LUIZ FUX, DJ 26.09.2005, p. 191.

${ }^{612}$ Parecer Normativo do Coordenador do Sistema de Tributação - CST nº 65, DOU 06.11.1979.
} 
Entretanto, podemos afirmar, com algum conforto, que a jurisprudência do Superior Tribunal de Justiça nunca erigiu como requisito do produto intermediário o contato direto entre o bem consumido na produção e o produto final. A orientação jurisprudencial é firme no sentido de exigir que os insumos sejam tão-somente consumidos de forma imediata e integral no processo produtivo.

Portanto, a qualificação da energia elétrica como insumo é inquestionável, sendo incompreensíveis, a mais não poder, os arestos do STJ que lhe negam essa feição.

Entretanto, em recentes decisões, o STJ tem pugnado pela natureza de insumo da energia utilizada na produção industrial. Apesar de a conclusão ser correta, seus fundamentos são equivocados. Para melhor compreensão das razões que levaram o STJ a mudar de posicionamento, valemo-nos da transcrição de um dos acórdãos que retratam a mutação jurisprudencial:

"3. A energia elétrica pode ser considerada como insumo, para fins de aproveitamento de crédito gerado pela sua aquisição, a ser descontado do montante devido na operação de saída do produto industrializado, desde que comprovada sua utilização 'no processo de industrialização'. Precedente: EREsp 899.485/RS, Rel. Ministro HUMBERTO MARTINS, PRIMEIRA SEÇÃ̃, julgado em 13/08/2008, DJ 15/09/2008.",613

A assertiva constante da ementa é irretocável. Afinal, se consumida em processo de industrialização a energia se enquadra como insumo, como já averbamos acima. O equívoco radica no precedente invocado para a mudança de entendimento acerca o tema. Vejamse alguns excertos do voto do Min. Relator, LUIZ FUX:

"No tocante ao (...) direito ao creditamento do IPI, por ocasião da aquisição de energia elétrica para industrialização de seus produtos, merece prosperar a pretensão do contribuinte.

Com efeito, a matéria restou pacificada pela Primeira Seção deste Tribunal Superior, por ocasião do julgamento do ERESP 899.485/RS, de relatoria do e. Ministro Humberto Martins, publicado no DJ de 15/09/2008, no sentido de que tem direito ao creditamento de ICMS o contribuinte que comprovar ter utilizado a energia elétrica 'no processo de industrialização' ou ter utilizado serviços de comunicação na 'execução de serviços da mesma natureza'. O aresto restou assim ementado:

TRIBUTÁRIO - ICMS - CREDITAMENTO RELATIVO A ENERGIA ELÉTRICA E SERVIÇOS DE TELECOMUNICAÇÕES - ART. 33, INCISO II, 'B' , E, INCISO IV, 'A' N. 87/96 - POSSIBILIDADE.

O contribuinte tem direito ao creditamento de ICMS se comprovar ter utilizado a energia elétrica 'no processo de industrialização' ou ter utili-

${ }^{613}$ STJ, Primeira Turma, REsp n ${ }^{\circ}$ 904.082/SC, Relator Min. LUIZ FUX, DJe 25.03.2009. 
zado serviços de comunicação na 'execução de serviços da mesma natureza'.

Embargos de divergência providos.

O ICMS e o IPI são exações informadas pelo princípio da nãocumulatividade, sendo-lhes aplicável regramento semelhante, nesse particular (ubi eadem ratio ibi eadem dispositio), por isso que idêntica a incidência jurisprudencial." 614

O precedente invocado na decisão (EREsp no 899.485/RS) havia reconhecido o direito ao crédito de ICMS sobre a energia elétrica consumida no processo de industrialização. Todavia, esse direito é expressamente autorizado pela $\mathrm{LC}^{\circ}$ 87/96, modificada pela LC $n^{\circ} 102 / 00^{615}$. Assim, não houve qualquer digressão, no precedente, quanto à natureza da energia elétrica.

Repise-se, para que não haja equívocos na compreensão do que se está a expor: o aresto invocado pelo STJ para modificar sua jurisprudência que negava o caráter de insumo à energia elétrica para fins de crédito do IPI trata, em verdade, do crédito de ICMS sobre energia elétrica, que se sujeita a regras próprias plasmadas na Lei Kandir. Nesse sentido, é de todo impróprio afirmar, como fez o acórdão em tela, que se a energia é insumo e gera crédito para o ICMS, também será insumo e gerará crédito para o IPI, em face da identidade jurídica entre esses impostos.

Ora, a não-cumulatividade do IPI é distinta do ICMS desde a Constituição. É certo que em vários pontos existe uma convergência de regimes jurídicos. Contudo, a generalização leva a equívocos. Se a lei de normas gerais do ICMS prescreve que a energia elétrica consumida em processo industrial gera crédito do imposto não se pode automaticamente concluir - como fez o STJ - que o precedente se aplica ao IPI, com as mesmas conseqüências jurídicas ${ }^{616}$.

\footnotetext{
${ }^{614}$ STJ, Primeira Turma, REsp no 904.082/SC, Relator Min. LUIZ FUX, DJe 25.03.2009.

${ }^{615} \mathrm{~A} \mathrm{LC} \mathrm{n}^{\circ}$ 102/00 restringiu o crédito de ICMS sobre a energia elétrica consumida (que era amplo sob a égide da redação originária da $\mathrm{LC} \mathrm{n}^{\circ}$ 87/96), mas resguardou esse direito quando se tratasse de energia consumida em processo industrial.

${ }^{616}$ Vejam-se, para maior aclaramento do tema, trechos do voto do Min. HUMBERTO MARTINS, Relator dos Embargos de Divergência no REsp no 899.485/RS (invocado como precedente para a mutação jurisprudencial em relação à qualificação da energia elétrica como insumo para fins de creditamento do IPI):

"O acórdão embargado declarada que 'é inviável o creditamento do ICMS relativo à energia elétrica e aos serviços de telecomunicações utilizados, tanto por estabelecimento comercial, como por estabelecimento industrial, visto que não se caracterizam como insumo'.

$\mathrm{O}$ acórdão divergente declara expressamente que:

'A LC 102/2000 não alterou substancialmente a restrição, explicitando apenas que o creditamento somente se daria quando a energia elétrica fosse consumida no processo de industrialização ou quando fosse o objeto da operação.'

Nesse sentido, o julgado da Segunda Turma aplica - textualmente - o disposto no art. 33 da Lei Complementar n. 87/96, ao autorizar o creditamento do ICMS referente ao consumo de energia elé-
} 
Não bastasse o fato de ter utilizado um paradigma inaplicável ao caso, o STJ, ao reconhecer o cariz de insumo da energia elétrica, permitiu também o creditamento do IPI sobre os dispêndios com o referido insumo.

Todavia, a imunidade da energia elétrica em relação ao IPI impede que o seu consumo gere créditos do imposto, por se tratar de entrada não-tributável.

Prossigamos, no item seguinte, com este último raciocínio.

\subsection{1. A IMPOSSIBILIDADE DE CÁlCULO DE CRÉDITOS DO IPI SO- BRE AS DESPESAS COM ENERGIA ELÉTRICA: EFEITO DA IMUNIDADE DO ART. 155, $\S^{\circ}$ DA CR/88.}

Com a $\mathrm{CR} / 88$, os antigos impostos federais que gravavam os combustíveis, os minerais e a energia elétrica foram extintos. Aos Estados foi atribuída a competência tributária para gravar tais produtos, por meio do ICMS.

Considerando a elevada relevância desses insumos para o desenvolvimento da nação e, com o intuito de evitar que outras exações fossem instituídas sobre os combustíveis, minerais e energia elétrica, plasmou-se na Lei Maior a seguinte imunidade:

"Art. 155. (...).

$\S 3^{\circ}$. À exceção dos impostos de que tratam o inciso II do caput deste artigo

[ICMS] e o art. 153, I e II [II e IE], nenhum outro imposto poderá incidir sobre operações relativas a energia elétrica, serviços de telecomunicações, derivados de petróleo, combustíveis e minerais do País." (redação da EC n ${ }^{\circ}$ $33 / 01)$

Originariamente, o $\$ 3^{\circ}$ do art. 155 da $\mathrm{CR} / 88$ vedava a instituição de qualquer outro tributo sobre a energia elétrica (e demais produtos nele mencionados). Com a $\mathrm{EC} \mathrm{n}^{\mathrm{o}} 33 / 01$, o espectro da imunidade foi restringido, proibindo-se apenas a instituição de outros impostos além do ICMS, II e IE. De todo modo, nunca foi possível - seja antes, seja após a EC n ${ }^{\circ}$ 33/01 - a cobrança de IPI sobre a energia elétrica por força do art. 155, $\$ 3^{\circ}$ da Constituição.

Portanto, considerando-se que:

(a) a energia constitui produto não-tributado pelo IPI;

trica, desde que consumida no processo de industrialização; e o creditamento dos serviços de comunicação, uma vez prestados na execução de serviços da mesma natureza.

(...)

Entendo que deve prevalecer a posição adotada no acórdão embargado - da Segunda Turma -, em razão do disposto no art. 33, inciso II, 'b', e, inciso IV, 'a' [da LC n' 87/96, modificado pela LC $\mathrm{n}^{\circ}$ 102/00].” (STJ, Primeira Seção, ERESP n’ 899.485/RS, Relator Min. HUMBERTO MARTINS, DJe 15.09.2008). 
(b) tanto a Lei $\mathrm{n}^{\circ}$ 4.502/64 como o RIPI impedem o cálculo de créditos sobre a aquisição de produtos não-tributados ${ }^{617}$,

é lícito concluir que a energia elétrica não gera créditos de IPI, mesmo que consista em insumo indispensável ao processo industrial ${ }^{618}$.

\subsection{MATERIAL DE EMBALAGEM.}

Insere-se no conceito legal de industrialização ${ }^{619}$ a mera mudança na apresentação do produto por meio da colocação de embalagem - mesmo que apenas em substituição à original $^{620}$. Por essa razão, tanto o RIPI ${ }^{621}$ como a Lei $n^{\circ} 4.502 / 64^{622}$ asseguram o direito de crédito sobre materiais utilizados na embalagem de produtos industrializados.

A embalagem prepara o produto para sua comercialização, rotulando-o e agregando-lhe valor. Portanto, não é todo e qualquer invólucro que pode ser considerado embalagem, mas apenas aquele que valoriza a mercadoria, tornando-a comerciável ${ }^{623}$. Desde que

617 A lei e o RIPI estão em consonância com a atual interpretação do STF acerca da não-cumulatividade, que exige duas operações tributadas em seqüência para legitimar o aproveitamento do crédito.

${ }^{618}$ A não-incidência do imposto federal em decorrência da imunidade é causa autônoma e suficiente para impedir o aproveitamento de créditos sobre a energia elétrica.

${ }^{619}$ Previsto no art. 46, parágrafo único do CTN.

${ }^{620}$ Não se terá industrialização, contudo, se a embalagem destinar-se tão-somente ao transporte da mercadoria. Tratar-se-á, nesse caso, de mero acondicionamento ou reacondicionamento de produto, não tributável pelo IPI (art. $4^{\circ}$, IV do RIPI/02).

${ }^{621}$ Art. 164 do RIPI/02.

${ }^{622}$ Art. $25, \S 1^{\circ}$ da Lei $n^{\circ} 4.502 / 64$.

${ }^{623}$ As seguintes respostas a Consultas de Contribuintes diferenciam o acondicionamento da mera embalagem, estipulando ainda os requisitos para caracterização desta:

"INDUSTRIALIZAÇÃ̃O. ACONDICIONAMENTO. Não constitui industrialização por acondicionamento a operação de 'peliculagem', feita por estabelecimento não contribuinte do IPI, consistindo em agrupar várias unidades de produtos acabados e embalados pelo fabricante, envolvendo-os em película plástica soldada a quente, sem a aposição de rótulos ou valorização do produto, mas com o intuito de facilitar o transporte. Dispositivos legais: RIPI/82, art. 3º IV (Decisão nº 6, de 07/04/97, da Disit da $7^{\mathrm{a}} \mathrm{RF}$ - DO de 27/08/97).

INDUSTRIALIZAÇÃO. ACONDICIONAMENTO. Não constitui industrialização por acondicionamento a colocação de mercadorias para revenda em embalagens conhecidas como display boxes, feita por estabelecimento não contribuinte do IPI, consistindo tais embalagens em expositores descartáveis de papelão, sem rótulos promocionais e que não acarretam valorização das mercadorias, tendo como finalidade facilitar o transporte, o manuseio e a exposição do produto acabado aos consumidores. Dispositivos legais: RIPI/82, art. $3^{\circ}$, IV (Decisão n ${ }^{\circ} 27$, de 10/04/97, da DISI da $7^{\mathrm{a}}$ RF DO de 27/08/97)." (OLIVEIRA, Waldemar de. Regulamento do Imposto sobre Produtos Industrializados. São Paulo: FISCOSoft, 2008, p. 36). 
atendendo a esses requisitos, o material de embalagem adquirido pelo contribuinte irá gerar créditos aproveitáveis do IPI.

\subsubsection{A MANUTENÇÃO DO CRÉDITO EM CASO DE QUEBRAS.}

As quebras são diferenças verificadas entre as entradas e as saídas de uma fábrica. Para a produção de 100 mil pães, por exemplo, é necessária uma tonelada de farinha. Contudo, pode ocorrer que a aquisição de uma tonelada de farinha resulte na produção de apenas 95 mil pães. A diferença entre o que seria, em tese, possível de se obter com a tonelada de farinha adquirida (100 mil pães) e o produto final (95 mil pães) é intitulada quebra (no caso, de 5 mil pães). Trata-se de realidade comum às indústrias. Afinal, por mais automatizados que sejam os processos, sempre há margens de erro, ínsitas a qualquer atividade humana.

Essas quebras já renderam diversas liças entre Fiscos e contribuintes. Caso notório, já citado neste trabalho, se deu no Maranhão, em matéria de ICMS (à época, ainda ICM). O governo maranhense editou decreto que predicava a glosa de $4,67 \%$ dos créditos oriundos da aquisição in natura de matéria-prima pelas indústrias de arroz. Fundava-se a norma no argumento de que o beneficiamento gerava perda de umidade do grão e conseqüiente redução de peso nesse exato porcentual. Com acerto, o Judiciário repeliu essa e outras tentativas dos Fiscos, arvorando-se no fato de que o ICMS (assim como o IPI) é apurado por período de tempo e não por produto. Sendo assim, as quebras naturais ocorridas no processo industrial não geram dever de estorno dos créditos ${ }^{624}$.

Com o intuito de evitar tais conflitos, as normas do IPI asseguram, de modo expresso, o direito de crédito quando houver quebras de estoque. Apenas nos casos de diferenças excessivas poderá o contribuinte ser instado a se justificar por meio de laudos técnicos específicos.

\subsubsection{MANUTENÇÃO DO CRÉDITO NAS SAÍDAS DE SUCATA, RESÍDUOS E ASSEMELHADOS.}

O processo industrial pode gerar sucatas, aparas, fragmentos e assemelhados, que são comercializados pelas indústrias. Mesmo nesses casos, em que não se tem saída de um produto industrializado stricto sensu, mas sim de resíduos, o direito de crédito sobre os

\footnotetext{
${ }^{624}$ Vide Título II, Capítulo VI, Item 6.7.
} 
insumos deve ser mantido, por expressa disposição do RIPI ${ }^{625}$. A norma é salutar apesar de, a nosso sentir, desnecessária. Afinal, ainda que o produto final consista em sucata, se houver saída tributada pelo IPI o contribuinte terá crédito sobre os insumos utilizados na produção. A ilação decorre da não-cumulatividade tal como interpretada pelo STF.

\subsubsection{MANUTENÇÃO DOS CRÉDITOS RELATIVOS AOS INSUMOS TRIBU- TADOS UTILIZADOS NO FABRICO DE PRODUTOS PARA EXPORTAÇÃO.}

A manutenção dos créditos do IPI pelo contribuinte-exportador é implicitamente assegurada pela Constituição. Se assim não fosse, estar-se-ia negando vigência à imunidade plasmada no art. $153, \S 3^{\circ}$, III da CR/ $88^{626}$.

Mesmo com a garantia conferida pela Lei Maior, o Decreto-lei no 491/69 assegurou a "manutenção e utilização do crédito do IPI relativo às matérias-primas, produtos intermediários e material de embalagem efetivamente utilizados na industrialização dos produtos exportados" $" 627$. A regra, apesar de nunca ter sido revogada, foi "restabelecida" pela Lei $\mathrm{n}^{\circ} 8.402 / 92^{628}$, reforçando a sua aplicabilidade.

O RIPI também predica o direito aos créditos do IPI relativos às matérias-primas, produtos intermediários e materiais de embalagem "adquiridos para emprego na industrialização de produtos destinados à exportação para o exterior, saídos com imunidade"629.

${ }^{625}$ Confira-se o RIPI:

“Art. 194. É assegurado o direito à manutenção do crédito do imposto em virtude da saída de sucata, aparas, resíduos, fragmentos e semelhantes, que resultem do emprego de MP, PI e ME, bem assim na ocorrência de quebras admitidas neste Regulamento.

(...)

Art. 449. As quebras alegadas pelo contribuinte, nos estoques ou no processo de industrialização, para justificar diferenças apuradas pela fiscalização, serão submetidas ao órgão técnico competente, para que se pronuncie, mediante laudo, sempre que, a juízo de autoridade julgadora, não forem convenientemente comprovadas ou excederem os limites normalmente admissíveis para o caso."

${ }^{626}$ Confira-se a Constituição:

“Art. 153. (...).

$\S 3^{\circ}$. O [IPI]:

III - não incidirá sobre produtos industrializados destinados ao exterior.”

Para maiores detalhes sobre o direito constitucional à preservação dos créditos de IPI na exportação, vide Título II, Capítulo VI, Item 6.13.

${ }^{627}$ Art. $5^{\circ}$ do DL n ${ }^{\circ} 491 / 69$.

${ }^{628}$ O "restabelecimento" deriva do dispositivo da Constituição que predicava a extinção de todos os benefícios fiscais setoriais no prazo de dois anos, contados da promulgação da atual Carta, caso não fossem convalidados pelo Congresso Nacional (art. 41 do ADCT).

${ }^{629}$ RIPI, art. 176. A regra é também aplicável às saídas industriais com suspensão do imposto para posterior exportação (RIPI, art. 177). 
Repise-se, contudo, nosso entendimento - fulcrado na interpretação da regra imunizante do IPI na exportação - pela desnecessidade dos dispositivos em questão, que tãosomente aclaram os desígnios do Constituinte, já trazidos (ainda que implicitamente) na Lei Maior.

\subsubsection{CRÉDITOS POR DEVOLUÇÃO OU RETORNO DE PRODUTOS.}

Nos casos de devolução do produto ao estabelecimento fabricante este poderá creditar-se do valor do imposto que incidira na saída. Todavia, o exercício do direito é condicionado à comprovação da devolução ou retorno do produto, na forma a ser estabelecida pelo regulamento ${ }^{630}$.

Todavia, a devolução de produto cuja saída tenha ocorrido em razão de arrendamento ou locação não ensejará crédito do imposto (exceto na hipótese de o produto arrendado ou locado ter sido submetido, pelo arrendatário ou locatário, a nova industrialização) ${ }^{631}$.

Os procedimentos para comprovação ${ }^{632}$ da devolução/retorno do produto que ensejará a apropriação do crédito pelo contribuinte ${ }^{633}$ são sistematizados pelo RIPI, devendo ser observados sob pena de não-reconhecimento do crédito pelo Fisco federal.

Por derradeiro, cumpre notar que a alíquota aplicável para cálculo do crédito por retorno de produto é a vigente no momento da saída originária do estabelecimento e não quando da devolução da mercadoria ${ }^{634}$.

\subsubsection{CRÉDITOS DE OUTRA NATUREZA.}

Predica ainda o RIPI ${ }^{635}$ a existência de créditos intitulados “de outra natureza". São os decorrentes de:

\footnotetext{
${ }^{630}$ Lei ${ }^{\circ} 4.502 / 64$, art. 30.

${ }^{631}$ RIPI, arts. 167 e 168.

${ }^{632}$ Sem a comprovação inexiste direito ao crédito. Confira-se a jurisprudência administrativa: "CRÉDITO POR DEVOLUÇÕES. As operações de devoluções de mercadorias geram direito ao crédito, desde que devidamente comprovadas, seja pela escrituração no Livro Controle de Estoque e Produção ou mediante controles subsidiários. (...). (Ac. 201-78007, de 9/11/2004, do $2^{\circ}$ CC - DOU de 10/04/06)." (OLIVEIRA, Waldemar de. Regulamento do Imposto sobre Produtos Industrializados. São Paulo: FISCOSoft, 2008, p. 242).

${ }^{633} \mathrm{O}$ procedimento é estabelecido nos arts. 169 a 173 do RIPI.

${ }^{634}$ OLIVEIRA, Waldemar de. Regulamento do Imposto sobre Produtos Industrializados. São Paulo: FISCOSoft, 2008, p. 242.
} 
(a) cancelamento da nota fiscal antes da saída da mercadoria, no caso de o imposto já ter sido escriturado. Faz-se, nesse caso, um estorno do débito, via lançamento a crédito na conta gráfica;

(b) redução posterior da alíquota do imposto quando este tenha sido recolhido antecipadamente pelo contribuinte (antes da diminuição de alíquota e da própria saída da mercadoria). Nessa hipótese, a saída, quando ocorrida, se dará ao abrigo de alíquota do IPI inferior à vigente no momento do pagamento adiantado ${ }^{636}$.

Em ambos os casos, o contribuinte fica obrigado a registrar a origem do crédito na coluna “Observações” do Livro de Apuração do IPI ${ }^{637}$.

\subsubsection{CASOS DE ANULAÇÃO DO CRÉDITO.}

O Regulamento do IPI $^{638}$ traz diversas hipóteses nas quais o crédito escriturado deverá ser anulado, mediante lançamento a débito no mesmo valor.

Seu fundamento legal, nesta parte, é o art. $25, \S 3^{\circ}$ da Lei $n^{\circ} 4.502 / 64$. Esse dispositivo prescreve que "o regulamento disporá sobre a anulação do crédito (...) correspondente ao imposto deduzido", nos casos em que

(a) os produtos adquiridos saiam do estabelecimento com isenção;

(b) os produtos resultantes da industrialização estejam sujeitos à alíquota zero, não sejam tributados ou gozem de isenção.

A sistemática acima foi modificada pelo já referido art. 11 da Lei $n^{\circ}$ 9.779/99, que assegurou o crédito dos insumos quando as saídas forem isentas ou sujeitas à alíquota zero. Assim, somente quando os produtos saírem sem tributação será devida a glosa do crédito.

$\mathrm{O}$ atual RIPI já incorporou as modificações legais referidas. Vejamos os seus principais pontos.

\subsubsection{AS SAÍDAS NÃO-TRIBUTADAS OU COM SUSPENSÃO DO IMPOSTO.}

\footnotetext{
${ }^{635}$ RIPI, art. 178.

${ }^{636}$ O RIPI assim prevê o "Lançamento Antecipado", que é autorizado pelo art. 51 da Lei no 4.502/64:

“Art. 128. Será facultado ao sujeito passivo da obrigação tributária antecipar os atos de sua iniciativa, para o momento:

I - da venda, quando esta for à ordem ou para entrega futura do produto; ou

II - do faturamento, pelo valor integral, no caso de produto cuja unidade não possa ser transportada de uma só vez."

${ }^{637}$ RIPI, art. 178, parágrafo único.

${ }^{638}$ RIPI, art. 193.
} 
O Regulamento predica o estorno dos créditos relativos a matérias-primas, produtos intermediários e materiais de embalagem utilizados na fabricação ou acondicionamento de produtos não-tributados ${ }^{639}$. Também deverão ser glosados os créditos de insumos e materiais de embalagem empregados na produção de bens saídos com suspensão do imposto.

A determinação de estorno no caso de saídas não-tributadas segue o padrão atualmente ditado pela jurisprudência do STF quanto à não-cumulatividade: inexistindo operação subseqüente tributada, não há que se falar em direito ao crédito. Isso porque a nãocumulatividade exige dois estádios gravados em seqüência para operar seus efeitos. À míngua de uma das incidências necessárias, entende o STF que não há cumulatividade e, portanto, inexiste direito ao crédito ${ }^{640}$.

No que tange às saídas com suspensão, a regra é a manutenção dos créditos. Isso ocorre porque a suspensão equipole a um diferimento: a operação é tributada, porém em momento posterior. Por essa razão, inexiste a priori obrigação de estorno dos créditos ${ }^{641}$. Entrementes, em hipóteses nas quais a saída com suspensão não resulta em tributação posterior, determina o RIPI o estorno dos créditos pelo alienante ${ }^{642}$.

\subsubsection{O ESTORNO DOS CRÉDITOS DE INSUMOS NO CASO DE PERECI- MENTO DOS PRODUTOS FINAIS.}

Tal e qual a legislação predica para o ICMS $^{643}$ e para o PIS/COFINS ${ }^{644}$, o RIPI ${ }^{645}$ determina o estorno dos créditos relativos a matérias-primas, produtos intermediários e

\footnotetext{
${ }^{639}$ Dispõe o RIPI:

"Art. 193. Será anulado, mediante estorno na escrita fiscal, o crédito do imposto:

I - relativo a MP, PI e ME, que tenham sido:

a) empregados na industrialização, ainda que para acondicionamento, de produtos não-tributados;" (...)

$\S 2$. O disposto na alínea $a$ do inciso I aplica-se, inclusive, a produtos destinados ao exterior." Ressalte-se que o $\$ 2^{\circ}$, acima transcrito, não produz efeitos em face do direito, constitucional e legal (art. $5^{\circ}$ do DL nº 491/69), de manutenção dos créditos de IPI pelo exportador.

${ }^{640}$ Vide as conclusões sobre o estudo da não-cumulatividade à luz da jurisprudência do STF apresentadas no Título II, Capítulo IX, Item 9.1.

${ }^{641}$ Sobre o diferimento e o direito à manutenção dos créditos, confira-se o Título II, Capítulo VI, Item 6.11.

${ }^{642}$ RIPI, art. 193, I, $b$ e $c$ c/c art. 42, VII, XI, XII e XII e art. 43.

${ }^{643}$ Art. 21, IV da LC no 87/96.

${ }^{644}$ Art. $3^{\circ}, \S 13$ c/c art. 15, II da Lei no $10.833 / 03$.

${ }^{645}$ Art. 193, IV do RIPI.
} 
"quaisquer outros produtos" que tenham sido furtados, roubados, deteriorados, inutilizados ou empregados em produtos que tenham tido a mesma sorte.

\subsubsection{A OBRIGAÇÃO DE ESTORNAR OS CRÉDITOS QUANDO DA DEVO- LUÇÃO DE PRODUTOS.}

Quando determinado produto é devolvido, cancela-se o IPI que incidiu na saída do estabelecimento de origem. Por essa razão, determina-se também o estorno do crédito escriturado pelo estabelecimento que fizer a devolução.

O objetivo é anular a operação, como um todo, do ponto de vista tributário. Afinal, com a devolução ${ }^{646}$, os efeitos fiscais decorrentes do negócio jurídico desfeito não podem ser produzidos. Acertada, portanto, a regra insculpida no art. 193, I c/c 169, I do RIPI ${ }^{647}$.

Da mesma forma, quando o estabelecimento remetente recebe em retorno produtos que, por alguma razão (ex.: defeitos de fábrica) não serão objeto de nova saída tributada, o contribuinte deverá estornar os créditos relativos às matérias-primas, produtos intermediários e materiais de embalagem utilizados na produção do bem devolvido. Sendo assim, terse-á:

(a) anulação da incidência ocorrida na primeira saída do bem do estabelecimento produtor, por força do crédito escriturado em razão da devolução/retorno;

(b) anulação dos créditos relativos a MP, PI e ME utilizados na produção do bem que não será mais comercializado.

A regra em questão é consonante com a exigência de duas etapas tributadas, em seqüência, para a operacionalização da não-cumulatividade tributária. Como o produto final não sairá do estabelecimento produtor, este não poderá se creditar do IPI que suportou na aquisição dos insumos utilizados na fabricação.

\footnotetext{
${ }^{646}$ A devolução sub examine decorre do desfazimento do negócio jurídico anteriormente celebrado entre as partes. O retorno ao estabelecimento de origem não pode, nesses casos, ser inicialmente previsto e desejado pelas partes contratantes (como ocorre, por exemplo, nas remessas de mercadorias para industrialização por encomenda, que são devolvidas ao estabelecimento de origem em cumprimento ao contrato celebrado).

${ }^{647}$ Confiram-se os artigos:

"Art. 193. Será anulado, mediante estorno na escrita fiscal, o crédito do imposto:

VI - relativo a produtos devolvidos, a que se refere o inciso I do art. 169.

Art. 169. O direito ao crédito do imposto ficará condicionado ao cumprimento das seguintes exigências:

I - pelo estabelecimento que fizer a devolução, emissão de nota fiscal para acompanhar o produto, declarando o número, data da emissão e o valor da operação constante do documento originário, bem assim indicando o imposto relativo às quantidades devolvidas e a causa da devolução;"
} 


\subsubsection{ESTORNO, PELO ESTABELECIMENTO IMPORTADOR, DO CRÉDITO DE IPI-IMPORTAÇÃO QUANDO DA REMESSA DO BEM DIRETAMENTE DA REPARTIÇÃO ADUANEIRA PARA OUTRO ESTABELECIMENTO DA MESMA EMPRESA.}

É cediço que, na importação de mercadorias, o estabelecimento importador pode se creditar do IPI pago no desembaraço aduaneiro. Afinal, tendo que recolher o imposto quando da saída do bem de seu próprio estabelecimento, o importador gerará um débito futuro a ser compensado com o crédito pela entrada do produto estrangeiro. Havendo duas etapas tributadas em seqüência, o direito ao crédito decorre da não-cumulatividade tal como interpretada pelo Supremo Tribunal Federal.

Entretanto, a pedido da própria empresa importadora, a mercadoria pode ser remetida diretamente da repartição aduaneira para outro estabelecimento da mesma empresa. Nesse caso, o bem não adentrará no estabelecimento importador para posterior saída. Sendo diretamente remetido a outro estabelecimento, este (e não o importador) fará jus ao crédito do IPI-importação, desde que a posteriori dê saída ao bem, gerando débito do IPI.

Na aludida hipótese, o estabelecimento importador deverá estornar os créditos do IPI-importação, eis que não ocorrerá saída tributada do bem, necessária para legitimar o aproveitamento de créditos nos tributos não-cumulativos ${ }^{648}$.

\subsubsection{CRÉDITOS DECORRENTES DE INCENTIVOS FISCAIS PREVISTOS NO REGULAMENTO DO IPI.}

\subsubsection{CRÉDITOS INCENTIVADOS PARA AS ÁREAS DA SUDAM, SUDENE E AMAZÔNIA OCIDENTAL.}

Visando a atender às políticas de desenvolvimento regional, bem como à necessidade de redução das desigualdades entre os Estados, o RIPI prevê créditos incentivados para abatimento do IPI devido pelas empresas situadas na Amazônia Ocidental ${ }^{649}$ e em áreas abarcadas pelas Superintendências de Desenvolvimento do Nordeste (SUDENE) e da Amazônia (SUDAM) ${ }^{650}$. A nomenclatura “créditos como incentivo" decorre do fato de não

\footnotetext{
${ }^{648}$ A regra aplicável ao importador foi plasmada, de forma expressa, no art. 193, III do Regulamento do IPI.

${ }^{649}$ Estados do Acre, Amazonas, Rondônia e Roraima.

${ }^{650}$ O RIPI fala em ADA - Agência de Desenvolvimento da Amazônia e ADENE - Agência de Desenvolvimento do Nordeste. De fato, à época de sua edição as antigas SUDAM e SUDENE haviam sido extintas pelo governo federal, tendo sido substituídas pelas referidas agências. Contudo, o governo posterior recriou tanto a SUDAM como a SUDENE, extinguindo, via de conseqüência, a ADA e a ADENE. O RIPI não acompa-
} 
derivarem da aquisição de insumos tributados. São benefícios fiscais criados em prol de contribuintes situados em áreas menos desenvolvidas.

É conferir.

\subsection{CRÉDITO FICTO DE IPI PARA EMPRESAS ISENTAS DE IRPJ INS- CRITAS NO PROGRAMA DE ALIMENTAÇÃO DO TRABALHADOR.}

$\mathrm{O}$ primeiro incentivo ${ }^{651}$ destina-se às empresas estabelecidas nas áreas da SUDAM $^{652}$ e da SUDENE ${ }^{653}$. Trata-se da concessão de créditos fictos de IPI para empresas que adotem o Programa de Alimentação do Trabalhador (PAT).

O PAT ${ }^{654}$ faculta às pessoas jurídicas que operam no lucro real a dedução, da base de cálculo do IRPJ, do valor correspondente ao dobro das despesas incorridas na alimentação de seus funcionários ${ }^{655}$ (o benefício é, todavia, limitado a $4 \%$ do IR devido ${ }^{656}$ ).

Entretanto, é comum que as empresas situadas nas áreas da SUDAM e da SUDENE possuam isenção de IRPJ. Nesses casos, não haveria razão para que essas empresas aderissem ao PAT, uma vez que não teriam lucro tributável para dedução dos investimentos feitos no programa.

Para que os trabalhadores não restassem prejudicados, a legislação ${ }^{657}$ previu a concessão de créditos fictos do IPI no exato valor da dedução do IRPJ que a opção pelo PAT proporcionaria à empresa, caso esta não fosse isenta do IR.

nhou essa evolução, o que não invalida os dispositivos que tratam dos créditos incentivados para as regiões abrangidas pelas Superintendências (que são as mesmas até então abarcadas pela ADA e ADENE).

${ }^{651}$ RIPI, art. 174.

${ }^{652}$ Estados do Acre, Amapá, Amazonas, Mato Grosso, Pará, Rondônia, Roraima, Tocantins e parte do Estado do Maranhão.

${ }^{653}$ Estados do Maranhão, Piauí, Ceará, Rio Grande do Norte, Paraíba, Pernambuco, Alagoas, Sergipe, Bahia e parte dos Estados de Minas Gerais e do Espírito Santo.

${ }^{654}$ Instituído pela Lei $\mathrm{n}^{\mathrm{o}}$ 6.321/76 e regulamentado pelo Decreto $\mathrm{n}^{\mathrm{o}}$ 05/91 e pela Portaria $\mathrm{n}^{\mathrm{o}}$ 03/02 do Ministério do Trabalho.

${ }^{655}$ A dedução do lucro tributável é permitida pois o PAT consiste em uma benesse concedida pela empresa ao funcionário. O empregador é obrigado a arcar com no mínimo 80\% (oitenta por cento) dos custos da alimentação que deve, outrossim, seguir padrões mínimos de qualidade ditados pelo Ministério do Trabalho.

O programa se destina aos trabalhadores de baixa renda (que percebem até 05 salários-mínimos mensais), mas não exclui a participação dos que auferem rendimentos mais elevados, desde que assegurado o atendimento à totalidade dos primeiros.

${ }^{656}$ O limite é estabelecido pelo art. $5^{\circ}$ da Lei no 9.532, de 10 de dezembro de 1997.

"Art. $5^{\circ}$. A dedução do Imposto de Renda relativa aos incentivos fiscais previstos no art. $1^{\circ}$ da Lei $\mathrm{n}^{\circ}$ 6.321, de 14 de abril de 1976, no art. 26 da Lei $\mathrm{n}^{\circ}$ 8.313, de 23 de dezembro de 1991, e no inciso I do art. $4^{\circ}$ da Lei $n^{\circ} 8.661$, de 1993 , não poderá exceder, quando considerados isoladamente, a quatro por cento do Imposto de Renda devido, observado o disposto no $\S 4^{\circ}$ do art. $3^{\circ}$ da Lei $n^{\circ} 9.249$, de 1995." 
Na hipótese de o contribuinte não conseguir aproveitar os créditos de IPI - dada a ausência ou o baixo valor dos débitos desse imposto - poderá pleitear o ressarcimento em espécie da importância correspondente. O pagamento será feito com recursos do Ministério do Trabalho, órgão responsável pela gestão do PAT.

Ressalte-se, novamente, que o crédito ficto de IPI em questão é restrito às empresas isentas de IRPJ situadas nas regiões da SUDAM e da SUDENE que adotam o Programa de Alimentação do Trabalhador.

\subsection{ISENÇÃO DE IPI PARA PRODUTOS ELABORADOS A PARTIR DE INSUMOS AGRÍCOLAS E VEGETAIS (EXCETO FUMO E BEBIDAS ALCOÓ- LICAS).}

As empresas situadas na área da Amazônia Ocidental fazem jus a isenção de IPI nas vendas de produtos elaborados a partir de matéria-prima agrícola e extrativa vegetal (exceto fumo e bebidas alcoólicas) ${ }^{658}$.

Outrossim, os adquirentes desses produtos poderão descontar créditos de IPI sobre suas aquisições, desde que utilizem os aludidos materiais na industrialização de bens sujeitos ao imposto.

Essa previsão, contudo, não seria necessária se as autoridades administrativas reconhecessem o posicionamento do Supremo Tribunal Federal que assegura créditospresumidos do IPI para os adquirentes de insumos isentos ${ }^{659}$.

\subsubsection{CRÉDITOS PRESUMIDOS PARA COMPENSAÇÃO DO PIS E DA CO- FINS SUPORTADOS PELO EXPORTADOR (LEIS N'S 9.363/96 E 10.276/01).}

Com o intuito de fomentar a exportação de produtos nacionais, a Lei $\mathrm{n}^{\circ}$ 9.363, de 13 de dezembro de 1996, instituiu um crédito "presumido" do IPI. O benefício visa a ressarcir os exportadores do ônus do PIS/COFINS suportado quando da aquisição de produtos nacionais para venda no exterior ${ }^{660}$.

\footnotetext{
${ }^{657}$ Lei no 6.542 , de 28 de junho de 1978.

${ }^{658}$ RIPI, art. 175 c/c 82, III.

${ }^{659}$ Vide Título II, Capítulo VI, Item 6.9.2.

${ }^{660}$ Confira-se, para tanto, o artigo inaugural da Lei $\mathrm{n}^{\circ}$ 9.363/96:

"Art. $1^{\circ}$. A empresa produtora e exportadora de mercadorias nacionais fará jus a crédito presumido do Imposto sobre Produtos Industrializados, como ressarcimento das contribuições de que tratam as
} 
Posteriormente, a Lei $\mathrm{n}^{\circ} 10.276$, de 10 de setembro de 2001, criou um método alternativo de cálculo do incentivo em questão. Assim, o crédito presumido pode ser obtido de duas formas:

(a) mediante aplicação do percentual de 5,37\% (cinco vírgula trinta e sete por cento) sobre o valor das aquisições de produtos intermediários, matérias-primas e materiais de embalagem pelo exportador, na proporção das suas receitas de exporta$c ̧ \tilde{a} o^{661}$

(b) pela multiplicação do valor das receitas de exportação por 0,0365 e aplicação, desse resultado, sobre o custo de aquisição de insumos (MP, PI, ME, energia, combustíveis, frete, seguro e industrialização por encomenda) adquiridos no mercado interno, somado ao valor pago a título de industrialização por encomenda, na proporção das receitas de exportação do contribuinte ${ }^{662}$.

A principal diferença entre ambos os regimes é a inclusão, na sistemática da Lei $n^{\circ}$ 10.276/01, dos custos com energia elétrica, combustíveis, frete, seguro e industrialização por encomenda na base de cálculo do crédito presumido ${ }^{663}$.

A opção do contribuinte por um dos métodos vincula-o por todo o ano-calendário. Outrossim, a apuração do crédito é feita de forma centralizada pelo estabelecimento-matriz da pessoa jurídica exportadora, facultando-se a possibilidade de transferência a qualquer outro estabelecimento da companhia para fins de compensação com débitos do IPI.

Se o exportador não possuir débitos de IPI - hipótese comum, dado que as vendas para o exterior são imunes do imposto - a Lei n ${ }^{\circ}$ 9.363/96 determina o pagamento do benefício em moeda corrente ao estabelecimento-matriz da empresa.

A venda para empresa comercial exportadora com finalidade específica de exportação autoriza a utilização do crédito presumido de IPI pelo produtor-vendedor. Entretanto, se a comercial exportadora não efetivar a exportação no prazo de 180 dias ou revender a mercadoria no mercado interno, algumas conseqüências lhe serão imputadas. Primeiramen-

Leis Complementares $n^{\text {os }} 7$, de 7 de setembro de 1970,8 , de 3 de dezembro de 1970 , e 70 , de 30 de dezembro de 1991, incidentes sobre as respectivas aquisições, no mercado interno, de matériasprimas, produtos intermediários e material de embalagem, para utilização no processo produtivo.

Parágrafo único. O disposto neste artigo aplica-se, inclusive, nos casos de venda a empresa comercial exportadora com o fim específico de exportação para o exterior."

${ }^{661}$ Lei $\mathrm{n}^{\circ} 9.363 / 96$, art. $2^{\mathrm{o}}$.

${ }^{662}$ Lei n $^{\mathrm{o}} 10.276 / 01$, art. $^{\circ}$ e Anexo.

${ }^{663}$ RACTZ, Juliana. A Inclusão da Energia Elétrica na Base de Cálculo do Crédito Presumido do IPI. BRASIL JR., Vicente (coord.). IPI - Questões Atuais. Curitiba: Juruá, 2008, p. 126. 
te, a comercial exportadora deverá pagar o PIS/COFINS calculados sobre o valor de compra dos produtos não-exportados. Após, recolherá ainda aos cofres públicos o montante equivalente ao crédito presumido concedido ao produtor-vendedor ${ }^{664}$.

As regras acima mencionadas, todas constantes das Leis $\mathrm{n}^{\circ}$ s 9.363/96 e 10.276/01, são detalhadas pelo RIPI em seus arts. 179 a 186. Contudo, a definição dos "requisitos e periodicidade para apuração e para fruição do crédito presumido e respectivo ressarcimento" e dos documentos fiscais comprobatórios da exportação são de competência do Ministro da Fazenda ${ }^{665}$.

Por derradeiro, impende lembrar que a Receita Federal do Brasil intentou, certa feita, restringir o benefício veiculado pela Lei $n^{\circ} 9.363 / 96$. Conforme o art. $2^{\circ}, \S 2^{\circ}$ da Instrução Normativa SRF no 23/97, o cálculo do crédito-presumido relativo a produtos oriundos da atividade rural deveria tomar como base apenas os insumos adquiridos de pessoas jurídicas sujeitas ao pagamento do PIS/COFINS ${ }^{666}$. O fundamento da norma era claro: se o objetivo do crédito de IPI autorizado pela referida lei era o de compensar o exportador pelo custo do PIS/COFINS suportado em suas aquisições, quando essas fossem feitas de nãocontribuintes inexistiria crédito a calcular, pois não haveria PIS/COFINS a ressarcir.

Entretanto, valendo-se da máxima ubi lex non distinguit nec interpres dis, o STJ declarou ilegal essa restrição à aplicabilidade da Lei no $9.363 / 96^{667}$.

${ }^{664}$ O cálculo do crédito presumido a ser ressarcido será feito:

(a) aplicando-se o porcentual de 5,37\% (cinco vírgula trinta e sete por cento) sobre $60 \%$ (sessenta por cento) do preço de aquisição dos produtos adquiridos e não exportados; ou

(b) multiplicando-se $60 \%$ (sessenta por cento) do preço de aquisição dos produtos não-exportados por 0,0365 .

${ }^{665}$ Lei no $9.363 / 96$, art. $6^{\circ}$.

${ }^{666}$ Confira-se a IN/SRF no $23 / 97$ :

“Art. $2^{\circ}$. (...).

$\S 2^{\circ}$. O crédito presumido relativo a produtos oriundos da atividade rural, conforme definida no art. $2^{\circ}$ da Lei $\mathrm{n}^{\circ} 8.023$, de 12 de abril de 1990, utilizados como matéria-prima, produto intermediário ou embalagem, na produção de bens exportados, será calculado, exclusivamente, em relação às aquisições, efetuadas de pessoas jurídicas, sujeitas às contribuições PIS/PASEP e COFINS.”

${ }^{667} \mathrm{O}$ excerto de voto do Min. HUMBERTO MARTINS, relator de um dos casos sobre a espécie, aclara os fundamentos da orientação do STJ:

"Ora, uma norma subalterna, qual seja, instrução normativa, não tem a faculdade de restringir o alcance de um texto de lei. Ofende-se, destarte, o princípio da legalidade, inserto no art. 150, inciso I, da $\mathrm{CF} / 88$.

O princípio da legalidade entrelaça-se à idéia de autotributação, em que o próprio povo, por intermédio de representantes eleitos, define a tributação, que deve incidir sobre o patrimônio." (STJ, Segunda Turma, REsp no 729.433/CE, Relator Min. HUMBERTO MARTINS, DJ 12.09.2007, p. 183). 
Portanto, o crédito-presumido de IPI permanece em pleno vigor na forma da Lei $\mathrm{n}^{\circ}$ 9.363/96 (com a alternativa de cálculo veiculada pela Lei ${ }^{\circ} 10.276 / 01$ ), sem possibilidade de ter sua eficácia restringida por atos normativos inferiores, pretéritos ou futuros.

O benefício, entrementes, não é aplicável às empresas que apuram o PIS/COFINS com base no regime não-cumulativo, por expressa vedação legal ${ }^{668}$.

\subsection{DIREITO AO CÔMPUTO DOS DISPÊNDIOS COM ENERGIA ELÉ- TRICA NO CÁlCULO DO CRÉDITO PRESUMIDO DO IPI PREVISTO NA LEI $\mathbf{N}^{0}$ 9.363/96.}

Sendo certo que a energia elétrica consiste em produto intermediário quando utilizada na industrialização, pode-se concluir que o cálculo do crédito presumido do IPI deve levar em consideração os dispêndios com essa energia.

Afinal, o crédito é obtido pela aplicação do porcentual de 5,37\% sobre os custos de matérias-primas, produtos intermediários e materiais de embalagem, na proporção da receita de exportação do contribuinte.

Assim, se a base de cálculo do benefício compreende as despesas com produtos intermediários (com ou sem incidência do IPI), é natural que dentro desses valores se incluam os custos de aquisição da energia utilizada nos setores operacionais do estabelecimento.

Ressalte-se, todavia, o entendimento contrário do Conselho Administrativo de Recursos Fiscais, plasmado em sua Súmula nº 12, que apregoa:

"Não integram a base de cálculo do crédito presumido da Lei n ${ }^{\circ} 9.363$, de 1996, as aquisições de combustíveis e energia elétrica uma vez que não são consumidos em contato direto com o produto, não se enquadrando nos conceitos de matéria-prima ou produto intermediário." ${ }^{669}$

${ }^{668}$ Lei no $10.833 / 03$ :

“Art. 14. O disposto nas Leis $\mathrm{n}^{\circ} \mathrm{s} 9.363$, de 13 de dezembro de 1996, e 10.276, de 10 de setembro de 2001, não se aplica à pessoa jurídica submetida à apuração do valor devido na forma dos arts. $2^{\circ}$ e $3^{\circ}$ desta Lei [COFINS não-cumulativa] e dos arts. $2^{\circ}$ e $3^{\circ}$ da Lei no 10.637, de 30 de dezembro de 2002 [PIS não-cumulativo]."

${ }^{669}$ Segundo Conselho de Contribuintes Federal, DOU de 26.09.2007. 
A definição adota o ilegal entendimento constante do Parecer Normativo CST $n^{\circ}$ 65/79, que erige requisito não previsto na Lei ${ }^{\circ} 4.502 / 64$ ou no RIPI para caracterização do insumo gerador de crédito do imposto.

Tratando-se de posicionamento que não encontra respaldo nos fatos ou na legislação, a única conclusão a que se chega é pela sua invalidade.

Assim, reafirmamos o entendimento pela possibilidade de cômputo do custo da energia elétrica diretamente empregada na industrialização na base de cálculo do crédito presumido do IPI.

\subsection{O CRÉDITO-PRÊMIO DE IPI PLASMADO NO DECRETO-LEI Nº 491/69.}

Discussão que passa ao largo da não-cumulatividade - porém se refere a créditos compensáveis do IPI, pelo que merece aqui ser tratada - é a da vigência do intitulado "crédito-prêmio" de IPI.

Trata-se de benefício criado em $1969^{670}$ que prevê a outorga de créditos fictícios de IPI ao exportador. O crédito é calculado pela aplicação da alíquota do IPI vigente para as vendas no mercado interno ${ }^{671}$ sobre os produtos exportados. A benesse visa a compensar os exportadores pela carga tributária que suportam nas aquisições internas de bens e serviços. Dessa forma, evita-se a exportação de produtos com tributos embutidos em seus preços e a conseqüente perda de competitividade no mercado externo.

O referido benefício foi intitulado, pela doutrina e jurisprudência, crédito-prêmio do IPI, designação contra a qual A. J. $\operatorname{COSTA}^{672}$ se insurgiu. De todo modo, a questão controvertida refere-se à vigência do crédito-prêmio e não à sua nomenclatura.

\footnotetext{
${ }^{670}$ Confira-se o art. $1^{\circ}, \S \S 1^{\circ}$ e $2^{\circ}$ do Decreto-lei no 491 , de 5 de março de 1969 :

"Art. $1^{\circ}$. As empresas fabricantes e exportadoras de produtos manufaturados gozarão, a título de estímulo fiscal, créditos tributários sobre suas vendas para o exterior, como ressarcimento de tributos pagos internamente.

$\S 1^{\circ}$. Os créditos tributários acima mencionados serão deduzidos do valor do Imposto sobre Produtos Industrializados incidente sobre as operações no mercado interno.

$\S 2^{\circ}$. Feita a dedução e havendo excedente de crédito, poderá o mesmo ser compensado no pagamento de outros impostos federais, ou aproveitado nas formas indicadas por regulamento."

${ }^{671}$ Caso os produtos exportados sejam isentos ou não-tributados no mercado interno, compete ao Poder Executivo fixar as alíquotas do benefício que, em nenhuma hipótese, poderá superar o montante de 15\% (quinze por cento).

672 Argumenta o autor que "prêmio" não é a designação correta para o benefício em questão, que apenas reembolsa o exportador dos tributos que pagou internamente ou suportou no preço dos produtos remetidos ao exterior. (COSTA, Alcides Jorge. O Decreto-lei $n^{o} 491 / 1969$ Não Cria Incentivos, Apenas Remove Obstáculos. Crédito-Prêmio de IPI - Estudos e Pareceres III. Barueri: Manole, 2005, pp. 128-9).
} 
Após mais de uma década prolatando reiterados acórdãos no sentido de que o Decreto-Lei $n^{\circ} 491 / 69$ - instituidor do benefício - estaria em vigor até os dias atuais ${ }^{673}$, o Superior Tribunal de Justiça recentemente mudou de posicionamento.

Inicialmente, sustentou o STJ que o crédito-prêmio teria sido extinto em 30 de junho de 1983, por força do Decreto-lei no 1.658 , de 24 de janeiro de 1979.

Sabe-se que o DL n ${ }^{\circ} 1.658 / 79$, de fato, predicava que o crédito-prêmio seria reduzido gradualmente, a partir de 1979, até sua completa extinção, que se daria em 30 de junho de $1983^{674}$. Contudo, o DL no $1.658 / 79$ havia sido tacitamente revogado (por incompatibilidade de disposições) pelo Decreto-lei $n^{\circ} 1.724$, de 7 de dezembro de $1979^{675}$, que atribuiu ao Ministro de Estado da Fazenda a competência para reduzir, majorar ou extinguir o crédito-prêmio, sem qualquer restrição temporal. Posteriormente, o próprio DL no 1.724/79 foi revogado (também por incompatibilidade) pelo Decreto-lei $\mathrm{n}^{\mathrm{o}} 1.894 / 81^{676}$, que, além de

${ }^{673}$ Confira-se a seguinte ementa de aresto da Primeira Seção, oriunda de julgamento realizado em 11 de novembro de 1998:

"PROCESSUAL CIVIL E TRIBUTÁRIO. EMBARGOS DE DIVERGÊNCIA. IMPOSTO SOBRE PRODUTOS INDUSTRIALIZADOS (IPI). CRÉDITO-PRÊMIO. DECRETO-LEI N ${ }^{\circ} 461 / 69$ E DECRETO No 64.833/69. RESSARCIMENTO EM ESPÉCIE. AUTORIZAÇÃO LEGAL. POSSIBILIDADE.

1. Conforme estabelecido na legislação de regência, o benefício físcal previsto no art. $1^{\circ}$ do DL $n^{\circ}$ 461/69 (crédito prêmio do IPI) tanto pode ser recebido em moeda corrente, como pode ser usado para o pagamento de outros tributos.

2. Embargos de divergência recebidos por unanimidade." (STJ, Primeira Seção, EREsp no 44.727/DF, Relator Min. DEMÓCRITO REINALDO, DJ 14.12.1998, p. 85).

${ }^{674}$ Decreto-lei no $1.658 / 79$ :

“Art. $1^{\circ}$. O estímulo fiscal de que trata o artigo $1^{\circ}$ do Decreto-lei no 491, de 5 de março de 1969, será reduzido gradualmente, até sua definitiva extinção.

$\S 1^{\circ}$. Durante o exercício financeiro de 1979, o estímulo será reduzido:

a) a 24 de janeiro, em $10 \%$ (dez por cento);

b) a 31 de março, em $5 \%$ (cinco por cento);

c) a 30 de junho, em $5 \%$ (cinco por cento);

d) a 30 de setembro, em $5 \%$ (cinco por cento);

e) a 31 de dezembro, em $5 \%$ (cinco por cento).

$\S 2^{\circ}$. A partir de 1980, o estímulo será reduzido em 5\% (cinco por cento), a 31 de março, a 30 de junho, a 30 de setembro e a 31 de dezembro, de cada exercício financeiro, até sua total extinção a 30 de junho de 1983."

${ }^{675}$ Decreto-lei no $1.724 / 79$ :

“Art. $1^{\circ}$. O Ministro de Estado da Fazenda fica autorizado a aumentar ou reduzir, temporária ou definitivamente, ou extinguir os estímulos fiscais de que tratam os artigos $1^{\circ}$ e $5^{\circ}$ do Decreto-lei $n^{\circ} 491$, de 5 de março de 1969."

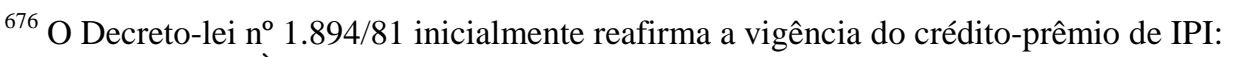

“Art. $1^{\circ}$. Às empresas que exportarem, contra pagamento em moeda estrangeira conversível, produtos de fabricação nacional, adquiridos no mercado interno, fica assegurado:

II - o crédito de que trata o artigo $1^{\circ}$ do Decreto-lei $n^{\circ} 491$, de 5 de março de 1969."

Em seguida, outorga competência plena ao Ministro da Fazenda para extinguir, majorar, reduzir e estipular condições para fruição de benefícios à exportação: 
reiterar a vigência do art. $1^{\circ}$ do DL n 491/69, conferiu ao Ministro da Fazenda competência não apenas para reduzir, majorar ou extinguir quaisquer incentivos fiscais à exportação, como também para estabelecer prazo, forma e condições para sua fruição. Assim, o arcabouço normativo então vigente predicava:

(a) a existência do crédito-prêmio, sem data específica para sua extinção;

(b) a possibilidade de o Ministro da Fazenda, por ato próprio, extinguir, reduzir ou majorar o incentivo, a qualquer tempo.

O que levou o Superior Tribunal de Justiça a defender a extinção do crédito-prêmio na data de 30 de junho de $1983^{677}$ foi a declaração de inconstitucionalidade pelo STF de parte dos Decretos-lei nos 1.724/79 e 1.894/71, revogadores do DL no 1.658/79. Entendeu o STF que era inconstitucional a delegação ao Ministro da Fazenda dos poderes de extinção, redução ou suspensão dos incentivos fiscais à exportação ${ }^{678}$. Competiria ao Ministro apenas majorá-los por ato próprio, se assim desejasse, mas nunca limitá-los. Na esteira

“Art. $3^{\circ}$. O Ministro da Fazenda fica autorizado, com referência aos incentivos fiscais à exportação, a:

I - estabelecer prazo, forma e condições, para sua fruição, bem como reduzi-los, majorá-los, suspendê-los ou extingui-los, em caráter geral ou setorial;"

${ }^{677}$ Confira-se uma das decisões pioneiras nesse sentido:

“TRIBUTÁRIO. IPI. CRÉDITO-PRÊMIO. DECRETO-LEI 491/69 (ART. 1º). INCONSTITUCIONALIDADE DA DELEGAÇÃO DE COMPETÊNCIA AO MINISTRO DA FAZENDA PARA ALTERAR A VIGÊNCIA DO INCENTIVO. EFICÁCIA DECLARATÓRIA E EX TUNC. MANUTENÇÃO DO PRAZO EXTINTIVO FIXADO PELOS DECRETOS-LEIS 1.658/79 E 1.722/79 (30 DE JUNHO DE 1983). (...).

1. $\mathrm{O}$ art. $1^{\circ}$ do Decreto-lei 1.658/79, modificado pelo Decreto-lei 1.722/79, fixou em 30.06.1983 a data da extinção do incentivo fiscal previsto no art. $1^{\circ}$ do Decreto-lei 491/69 (crédito-prêmio de IPI relativo à exportação de produtos manufaturados).

2. Os Decretos-leis 1.724/79 (art. $1^{\circ}$ ) e 1.894/81 (art. $3^{\circ}$ ), conferindo ao Ministro da Fazenda delegação legislativa para alterar as condições de vigência do incentivo, poderiam, se fossem constitucionais, ter operado, implicitamente, a revogação daquele prazo fatal. Todavia, os tribunais, inclusive o STF, reconheceram e declararam a inconstitucionalidade daqueles preceitos normativos de delegação.

3. Em nosso sistema, a inconstitucionalidade acarreta a nulidade ex tunc das normas viciadas, que, em conseqüência, não estão aptas a produzir qualquer efeito jurídico legítimo, muito menos o de revogar legislação anterior. Assim, por serem inconstitucionais, o art. $1^{\circ}$ do Decreto-lei 1.724/79 e o art. $3^{\circ}$ do Decreto-lei 1.894/81 não revogaram os preceitos normativos dos Decretos-leis 1.658/79 e 1.722/79, ficando mantida, portanto, a data de extinção do incentivo fiscal.” (STJ, Primeira Turma, REsp n 790.967/RS, Relator Min. TEORI ZAVASCKI, DJ 03.04.2006, p. 278).

${ }^{678}$ Interplures, confira-se a ementa do RE $\mathrm{n}^{\mathrm{o}}$ 180.828/RS, julgado pelo Pleno do STF em 14 de março de 2002 à luz da Constituição de 1967, porém plenamente aplicável sob a égide da Carta de 1988:

"CONSTITUCIONAL. TRIBUTÁRIO. INCENTIVOS FISCAIS: CRÉDITO-PRÊMIO: SUSPENSÃO MEDIANTE PORTARIA. DELEGAÇÃO INCONSTITUCIONAL. DL 491, de 1969, arts. $1^{\circ}$

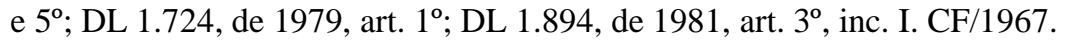

I - Inconstitucionalidade, no art. $1^{\circ}$ do DL 1.724/79, da expressão 'ou reduzir, temporária ou definitivamente, ou extinguir', e, no inciso I do art. $3^{\circ}$ do DL 1.894/81, inconstitucionalidade das expressões 'reduzi-los' e 'suspendê-los ou extingui-los'. Caso em que se tem delegação proibida: CF/67, art. $6^{\circ}$. Ademais, matérias reservadas à lei não podem ser revogadas por ato normativo secundário. II - RE conhecido, porém não provido (letra b)." (STF, Pleno, RE n ${ }^{\circ}$ 180.828/RS, Relator Min. CARLOS VELLOSO, DJ 14.03.2003, p. 28). 
desse entendimento, foi publicada pelo Senado Federal a Resolução $\mathrm{n}^{\circ} 71$, de 26 de dezembro de 2005, com a seguinte redação:

“Art. $1^{\circ}$. É suspensa a execução, no art. $1^{\circ}$ do Decreto-Lei no 1.724 , de 7 de dezembro de 1979, da expressão 'ou reduzir, temporária ou definitivamente, ou extinguir', e, no inciso I do art. $3^{\circ}$ do Decreto-Lei $n^{\circ} 1.894$, de 16 de dezembro de 1981, das expressões 'reduzi-los' e 'suspendê-los ou extinguilos', preservada a vigência do que remanesce do art. $1^{\circ}$ do Decreto-Lei ${ }^{\circ}$ 491, de 5 de março de 1969."

Equivocadamente, compreendeu o STJ que a declaração de inconstitucionalidade dos aludidos Decretos-lei teria o condão de repristinar as normas do DL n ${ }^{\circ} 1.658 / 79$, inclusive no tocante à fixação do prazo de extinção do crédito-prêmio. Entretanto, olvidou-se a Corte Superior de Justiça que a declaração de inconstitucionalidade se ateve à delegação de poderes ao Ministro da Fazenda para extinção, suspensão ou redução do benefício, Dessarte, como lei posterior revoga a anterior, não seria possível sustentar-se a prevalência do DL $\mathrm{n}^{\mathrm{o}} 1.658 / 79$ sobre os atos de mesma hierarquia que lhe sucederam na regulamentação da matéria.

Na tentativa de novamente pacificar a matéria no âmbito daquele Sodalício, a Primeira Seção do Superior Tribunal de Justiça reuniu-se e prolatou, em maio de 2006, o seguinte aresto:

“TRIBUTÁRIO. EMBARGOS DE DIVERGÊNCIA. IPI. CRÉDITOPRÊMIO. DECRETO-LEI 491/69. ART. $1^{\circ}$. VIGÊNCIA. PRAZO.

1. A Segunda Turma, no aresto embargado, concluiu que o crédito-prêmio de IPI vigora por prazo indeterminado, pois a declaração de inconstitucionalidade do art. $1^{\circ}$ do DL $1.724 / 79$ e do art. $3^{\circ}$ do DL n ${ }^{\circ} 1.894 / 81$ tornou sem efeito o cronograma de extinção do benefício previsto no art. $1^{\circ}$ do $\mathrm{DL} \mathrm{n}^{\circ}$ $1.658 / 79$.

2. A Primeira Turma, no acórdão paradigma, entendeu que o crédito-prêmio foi extinto em 30.06 .83 , porquanto o cronograma de extinção do benefício fixado no art. $1^{\circ}$ do $\mathrm{DL} \mathrm{n}^{\circ} 1.658 / 79$ não foi revogado por norma posterior nem atingido pela declaração de inconstitucionalidade do art. $1^{\circ}$ do DL $n^{\circ}$ $1.724 / 79$ e do art. $3^{\circ}$ do DL n ${ }^{\circ} 1.894 / 81$.

3. Para a tese que se sagrou vencedora na Seção no julgamento do REsp n ${ }^{\circ}$ 652.379/RS, o beneficio fiscal foi extinto em 04.10.1990 por força do art. $41, \S 1^{\circ}$, do Ato das Disposições Constitucionais Transitórias - ADCT, segundo o qual se considerarão 'revogados após dois anos, a partir da data da promulgação da Constituição, os incentivos fiscais que não forem confirmados por lei'. Assim, por constituir-se o crédito-prêmio de IPI em benefício de natureza setorial (já que destinado apenas ao setor exportador) e não tendo sido confirmado por lei, fora extinto no prazo a que alude o ADCT.

4. O crédito-prêmio do IPI, embora não se aplique às exportações realizadas após 04.10.90, é aplicável às efetuadas entre 30.06 .83 e 05.10 .90 (voto médio). 
5. Na hipótese, a autora, ora embargada, postulou o reconhecimento do direito ao crédito-prêmio de IPI tão-somente até 05 de outubro de 1990, portanto, dentro do biênio previsto no art. $41, \S 1^{\circ}$, do ADCT.

6. Embargos de divergência improvidos."

Dessarte, unificando o entendimento de ambas as Turmas, o STJ passou a considerar que o crédito-prêmio foi revogado por força do art. 41, caput e $\S 1^{\circ}$ do Ato das Disposições Constitucionais Transitórias, que exigia confirmação por lei dos "incentivos fiscais de natureza setorial" em vigor quando da edição da CR/88, no prazo máximo de 2 (dois) anos contados da promulgação da atual Carta ${ }^{680}$. Como o crédito-prêmio não foi confirmado por lei nesse prazo, teria perdido a validade.

O raciocínio parte de premissa errônea, data maxima venia, pois o ADCT referese a incentivos setoriais. Ora, não é factível sustentar-se que todas as exportações do País constituem um único setor. Ao revés, variados segmentos da economia (siderúrgico, minerário, têxtil, calçadista, et caterva) são importantes exportadores. Nesse sentido, como o crédito-prêmio alcança toda e qualquer exportação, trata-se de benefício concedido em caráter geral.

O objetivo do art. 41 do ADCT, como leciona FERRAZ JR. ${ }^{681}$, foi averiguar, por ocasião da nova Carta, se benesses fiscais concedidas a setores específicos não haviam se tornado anacrônicas com o passar dos anos, merecendo revisão pelo legislador federal, estadual ou municipal. Afinal, é comum que dificuldades temporárias ensejem a criação de

\footnotetext{
${ }^{679}$ STJ, Primeira Seção, EREsp no 396.836/RS, Relator Min. TEORI ZAVASCKI, DJ 05.06.2006, p. 235.

${ }^{680}$ Confira-se o ADCT:
}

“Art. 41. Os Poderes Executivos da União, dos Estados, do Distrito Federal e dos Municípios reavaliarão todos os incentivos fiscais de natureza setorial ora em vigor, propondo aos Poderes Legislativos respectivos as medidas cabíveis.

$\S 1^{\circ}$. Considerar-se-ão revogados após dois anos, a partir da data da promulgação da Constituição, os incentivos que não forem confirmados por lei."

${ }^{681}$ Assim predica o jurista:

“(...) A preocupação do Constituinte, ao prever, no art. 41, caput e $\S 1^{\circ}$ da CF/1988, a necessidade de reavaliação pelos Poderes Executivos da União, Estados, Distrito Federal e Municípios de todos os incentivos fiscais de natureza setorial em vigor, foi com a manutenção das circunstâncias que suscitaram o estabelecimento de tais incentivos, uma vez que as circunstâncias e a conjuntura econômica modificam-se e, como visto, os benefícios setoriais podem favorecer determinado setor antes não tão desenvolvido a ponto de torná-lo privilegiado, criando uma situação de desigualdade." (FERRAZ JR., Tércio Sampaio. Crédito-Prêmio de IPI e Incentivo Fiscal Setorial: da Inaplicabilidade do Art. 41 do ADCT da CF/1988. Crédito-Prêmio de IPI - Estudos e Pareceres III. Barueri: Manole, 2005, p. 47). 
incentivos fiscais para setores importantes da economia. Todavia, cessadas as causas que levaram a tal concessão, essa deve ser extinta, sob pena de se tornar anti-isonômica.

De todo modo, a decisão do Superior Tribunal de Justiça, por assentar-se em fundamento constitucional (interpretação do art. 41, caput e $\S 1^{\circ}$ do ADCT), não tardará a ser examinada pelo STF, que dará a palavra final sobre o tema ${ }^{682}$.

${ }^{682}$ O STF, em Sessão Plenária Virtual finalizada no dia 19.04.2008, reconheceu a repercussão geral da matéria, que é tratada no RE $\mathrm{n}^{\circ}$ 577.302/RS, de relatoria do Min. RICARDO LEWANDOWSKI. 


\section{O IMPOSTO SOBRE OPERAÇÕES DE CIRCULAÇÃO JURÍDI- CA DE MERCADORIAS E PRESTAÇÕES DE SERVIÇO DE TRANS- PORTE INTERESTADUAL E INTERMUNICIPAL E DE COMUNI- CAÇÃo.}

\subsection{A AMPLA REGRA-MATRIZ DE INCIDÊNCIA DO ICMS.}

Criado pela EC n ${ }^{\circ}$ 18/65, o ICM gravava as operações de circulação jurídica de mercadorias, exceto as que envolviam combustíveis, lubrificantes, minerais e energia elétrica (que se submetiam ao vetusto imposto único federal ${ }^{683}$ ). Os serviços passavam ao largo de sua hipótese de incidência, sendo gravados ora pelos Municípios (por meio do ISSQN), ora pela União, que se valia do ISSC (Imposto sobre Serviços de Comunicação) e do ISTR (Imposto sobre Serviços de Transporte) quando se tratassem de serviços de transporte e comunicação interestaduais e intermunicipais (o transporte e a comunicação dentro de um só Município sujeitavam-se ao ISSQN).

Por força da Constituição de 1988, o ICM incorporou os fatos geradores dos impostos federais acima referidos (ISSC, ISTR e impostos únicos) e também do ISSQN, na parte referente à tributação dos serviços de comunicação de natureza estritamente municipal ${ }^{684}$. A par de todas essas incidências, a Constituição determinou ainda que o ICMS gravasse a importação das mercadorias e dos serviços de transporte e comunicação.

Por essas razões, a regra-matriz de incidência do ICMS possui vários matizes. Afinal, são muitos impostos aglutinados em um só núcleo.

As normas gerais do ICMS são veiculadas pela Lei Complementar $n^{\circ} 87$, de 13 de setembro de 1996. Seu art. $2^{\circ}$ delimita o alcance do imposto ${ }^{685}$, determinando sua incidência sobre:

\footnotetext{
${ }^{683}$ Esse era assim nominado pois se tratava da única exação que podia gravar tais insumos. Ademais, sua incidência também era exclusiva, ocorrendo em uma só fase de todo o processo produtivo da energia, minerais, combustíveis e lubrificantes.

${ }^{684}$ Curiosamente, a CR/88 manteve a competência dos Municípios para tributação dos serviços de transporte estritamente municipal.

${ }^{685} \mathrm{LC} \mathrm{n}^{\circ} 87 / 96$ :

"Art. $2^{\circ}$. O imposto incide sobre:

I - operações relativas à circulação de mercadorias, inclusive o fornecimento de alimentação e bebidas em bares, restaurantes e estabelecimentos similares;

II - prestações de serviços de transporte interestadual e intermunicipal, por qualquer via, de pessoas, bens, mercadorias ou valores;

III - prestações onerosas de serviços de comunicação, por qualquer meio, inclusive a geração, a emissão, a recepção, a transmissão, a retransmissão, a repetição e a ampliação de comunicação de qualquer natureza;
} 
(a) operações de circulação ${ }^{686}$ de mercadorias ${ }^{687}$, inclusive:

(a.1) fornecimento de alimentação e bebidas em bares e restaurantes;

(a.2) fornecimento de mercadorias com prestação de serviços tributáveis pelo ISSQN quando a lei do imposto municipal determinar a incidência do ICMS na operação; e

(a.3) fornecimento de mercadorias com prestação de serviços não-tributáveis pelo ISSQN;

(b) prestações de serviços de transporte interestadual e intermunicipal, de pessoas ${ }^{688}$, bens, mercadorias ou valores - por qualquer via;

(c) prestações onerosas de serviços de comunicação;

(d) entrada de mercadoria ou bem importado do exterior, assim como importação de serviços de transporte e comunicação, inclusive aqueles cuja prestação tenha ocorrido fora do país;

IV - fornecimento de mercadorias com prestação de serviços não compreendidos na competência tributária dos Municípios;

$\mathrm{V}$ - fornecimento de mercadorias com prestação de serviços sujeitos ao imposto sobre serviços, de competência dos Municípios, quando a lei complementar aplicável expressamente o sujeitar à incidência do imposto estadual.

$\S 1^{\circ}$. O imposto incide também:

I - sobre a entrada de mercadoria ou bem importados do exterior, por pessoa física ou jurídica, ainda que não seja contribuinte habitual do imposto, qualquer que seja a sua finalidade;

II - sobre o serviço prestado no exterior ou cuja prestação se tenha iniciado no exterior;

III - sobre a entrada, no território do Estado destinatário, de petróleo, inclusive lubrificantes e combustíveis líquidos e gasosos dele derivados, e de energia elétrica, quando não destinados à comercialização ou à industrialização, decorrentes de operações interestaduais, cabendo o imposto ao Estado onde estiver localizado o adquirente."

${ }^{686}$ Apesar de a LC nº 87/96 não fazer referência à circulação jurídica, que pressupõe a translação da propriedade da mercadoria por meio de negócio válido celebrado entre comprador e vendedor, a jurisprudência é remansosa ao dispor que a simples circulação física do bem não implica na ocorrência do fato gerador do ICMS. Inclusive restou sumulado pelo STJ (Súmula $\mathrm{n}^{\circ}$ 166) que a mera transferência de mercadorias entre estabelecimentos do mesmo titular, ainda que situados em unidades da federação distintas, não importa em ocorrência do fato gerador do imposto, haja vista inexistir a necessária transferência de titularidade que o ICMS exige para ser cobrado.

Ademais, a CR/88, ao delimitar a hipótese de incidência do imposto, é expressa ao dispor que a exação exige "operação de circulação jurídica de mercadoria" (art. 155, II).

${ }^{687}$ Mercadoria é a coisa móvel destinada ao consumo. Assim, não se considera como tal, por exemplo, o bem integrado ao ativo imobilizado da empresa que seja eventualmente alienado (o que impede, no caso, a incidência do imposto).

${ }^{688}$ O Supremo Tribunal Federal, por meio da ADI-MC no 1.600/DF (Pleno, Relator Min. SYDNEY SANCHES, DJ 06.02.1998, p. 2), declarou inconstitucional a incidência do ICMS sobre o transporte de passageiros por via aérea. Ele sustentou inexistir, na lei de normas gerais, um mecanismo adequado de controle do imposto pago por essa modalidade de serviço. Apesar de restrita às companhias aéreas, em prol das quais a ADI foi ajuizada, a decisão final menciona que o dispositivo do acórdão somente não abarcou o transporte terrestre de passageiros porque tal não fora requerido na exordial. 
(e) entrada de petróleo, lubrificantes, combustíveis líquidos e gasosos dele derivados e de energia elétrica, quando se tratar de operação interestadual e quando o adquirente for o consumidor final desses produtos (não os destinando à revenda ou industrialização).

A existência de inúmeras especificidades no ICMS é dessumível dessa breve listagem de operações e prestações que são sujeitas ao imposto.

A base de cálculo do imposto é, como os IVAs em geral, o valor integral da operação ou prestação tributada. No caso de importação, ao valor da mercadoria descrito nos documentos aduaneiros deverão ser agregados os custos de importação, o IPI, o II, o IOF, além de outras taxas e contribuições aduaneiras.

Contribuinte é o comerciante, industrial, produtor, importador ou prestador de serviço de comunicação e transporte (interestadual e intermunicipal).

Desse breve escorço legislativo, pode-se delinear a regra-matriz de incidência do ICMS da seguinte forma:

\begin{tabular}{|c|c|}
\hline Hipó & Conseqüência jurídica \\
\hline $\begin{array}{l}\text { Aspecto material: compra-e-venda ou } \\
\text { importação de mercadoria; prestação de } \\
\text { serviço de comunicação ou de transporte } \\
\text { interestadual e intermunicipal; } \\
\text { Aspecto temporal: momento da saída da } \\
\text { mercadoria, do desembaraço aduaneiro ou } \\
\text { da prestação do serviço }{ }^{689} \text {; } \\
\text { Aspecto espacial: em qualquer lugar do } \\
\text { território nacional; } \\
\text { Aspecto pessoal: comerciante, industrial, } \\
\text { produtor, importador, prestador de serviço } \\
\text { de comunicação e de transporte interesta- } \\
\text { dual e intermunicipal. }\end{array}$ & $\begin{array}{l}\text { Sujeito ativo: Estados-membros e Distrito } \\
\text { Federal; } \\
\text { Sujeito passivo: comerciante, industrial, } \\
\text { produtor, importador, prestador de serviço } \\
\text { de comunicação e de transporte interesta- } \\
\text { dual e intermunicipal; } \\
\text { Base de cálculo: valor da operação ou } \\
\text { prestação; valor da importação acrescido } \\
\text { de II, IPI, IOF, despesas aduaneiras, taxas } \\
\text { e contribuições exigidos na importação; } \\
\text { Alíquota: a interna é livremente estabele- } \\
\text { cida pelos Estados }{ }^{690} \text {, sendo em média } \\
17 \% \text { para as operações com mercadorias e }\end{array}$ \\
\hline
\end{tabular}

\footnotetext{
${ }^{689}$ No caso de serviços de comunicação pré-pagos, considera-se, por ficção, ocorrido o fato gerador no momento da entrega ao usuário da ficha, cartão ou assemelhado com que o serviço for pago (art. $12, \S 1^{\circ}$ da $\mathrm{LC}$ $\left.n^{\circ} 87 / 96\right)$.

690 Apesar de a CR/88 facultar ao Senado Federal a edição de resolução, fixando o teto das alíquotas do ICMS nas operações e prestações internas, para solucionar conflitos entre Estados (art. 155, §2 $, \mathrm{V}, b)$, tal competência nunca foi exercida. Tampouco o Senado faz uso do poder de estipular alíquotas mínimas para o ICMS, que lhe é outorgado da mesma forma pela Carta Magna (art. 155, $\left.2^{\circ}, \mathrm{V}, b\right)$.
} 


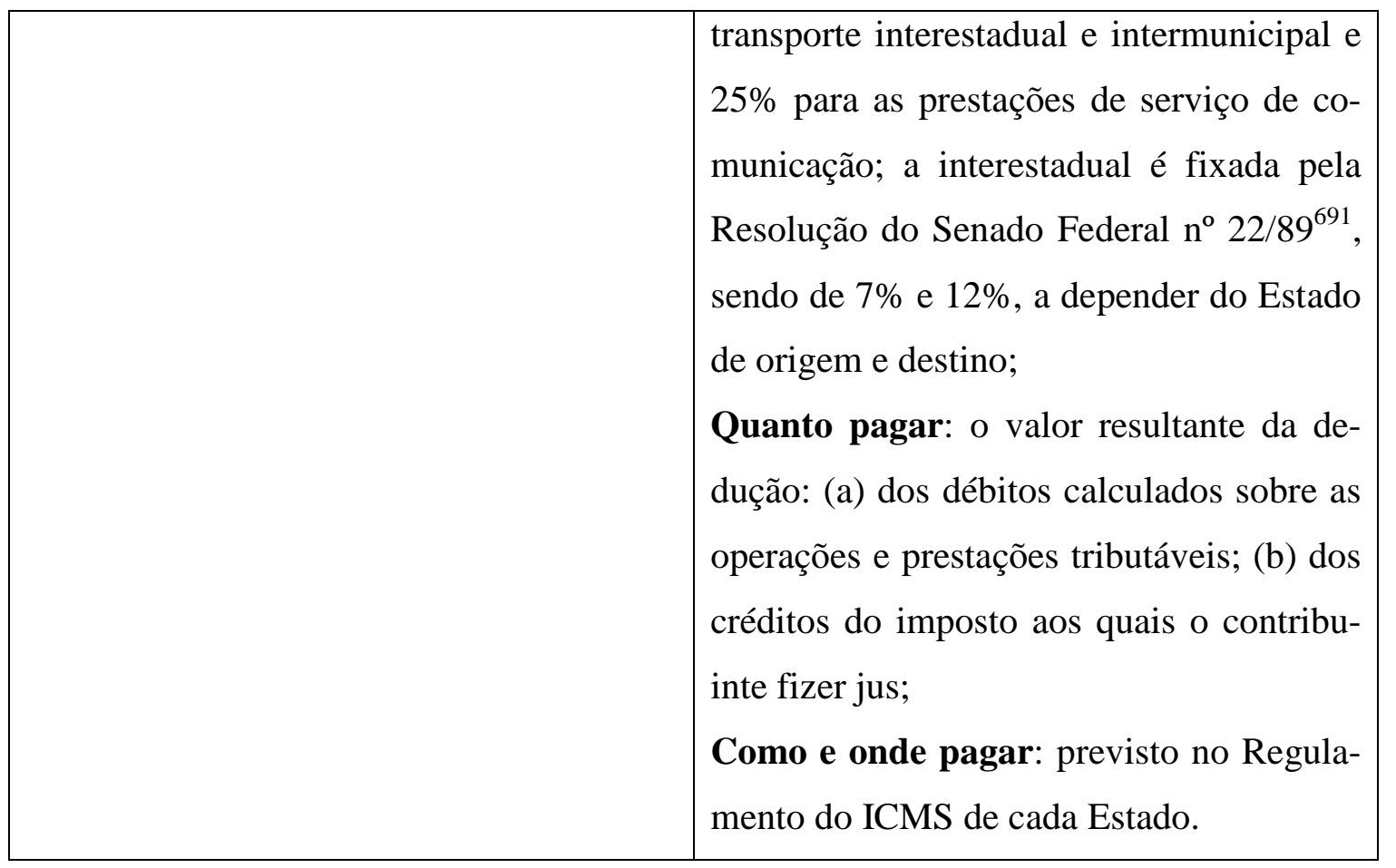

O regramento infraconstitucional do ICMS é feito, como já referido, pela Lei Complementar $n^{\circ} 87 / 96$, com suas posteriores alterações (antes da LC no 87/96, o Convênio ICM $n^{\circ} 66 / 88$ fazia as vezes de lei de normas gerais do ICMS, por força do art. $34, \S 8^{\circ}$ do $\mathrm{ADCT}^{692}$ ). Outrossim, os Convênios celebrados pelo CONFAZ exercem importante papel na autorização de incentivos e benefícios fiscais em matéria de ICMS $^{693}$. Cada Estado pos-

${ }^{691}$ Atendendo ao disposto no art. 155, $§ 2^{\circ}$, IV da CR/88, o Senado Federal editou, em 19 de maio de 1989, a Resolução $\mathrm{n}^{\circ} 22$, que estabelece:

“Art. 1. A alíquota do Imposto sobre Operações Relativas à Circulação de Mercadorias e sobre Prestação de Serviços de Transporte Interestadual e Intermunicipal e de Comunicação, nas operações e prestações interestaduais, será de doze por cento.

Parágrafo único. Nas operações e prestações realizadas nas Regiões Sul e Sudeste, destinadas às Regiões Norte, Nordeste e Centro-Oeste e ao Estado do Espírito Santo, as alíquotas serão:

I - em 1989, oito por cento;

II - a partir de 1990, sete por cento.”

${ }^{692}$ ADCT:

"Art. 34. O sistema tributário nacional entrará em vigor a partir do primeiro dia do quinto mês seguinte ao da promulgação da Constituição, mantido, até então, o da Constituição de 1967, com a redação dada pela Emenda ${ }^{\circ}$ 1, de 1969 , e pelas posteriores.

(...)

$\S 8^{\circ}$. Se, no prazo de sessenta dias contados da promulgação da Constituição, não for editada a lei complementar necessária à instituição do imposto de que trata o art. 155, I, "b", os Estados e o Distrito Federal, mediante convênio celebrado nos termos da Lei Complementar $n^{\mathbf{o}} 24$, de 7 de janeiro de 1975, fixarão normas para regular provisoriamente a matéria."

${ }^{693}$ Vide CR/88 (art, 155, §2 XII, $g$ ) e LC n ${ }^{\circ} 24 / 75$. 
sui, além de suas leis próprias do imposto, extensos regramentos infralegais: os Regulamentos do ICMS, veiculados por decretos ${ }^{694}$.

Trata-se do mais importante tributo estadual e, seguramente, um dos mais complexos impostos, título oriundo precipuamente da não-cumulatividade que lhe rege. Portanto, sem maiores delongas, passemos a esmiuçar a não-cumulatividade do ICMS, agora sob as luzes da legislação complementar.

\subsection{AS NORMAS INFRACONSTITUCIONAIS SOBRE A NÃO- CUMULATIVIDADE DO ICMS.}

Os arts. 19 e seguintes da $\mathrm{LC}^{\circ}$ 87/96, exercendo a função que lhes foi incumbida pelo art. $155, \S 2^{\circ}$, XII, $c$ da Constituição, disciplinam o regime de compensação do imposto, operacionalizando a não-cumulatividade tributária.

A Lei Kandir, quando de sua edição, consistiu em importante garantia da nãocumulatividade, posto que o Convênio ICM nº 66/88 restringia sobremaneira os créditos aproveitáveis, que se reduziam ao minimum minimorum assegurado pela CR/88 695 .

Para melhor compreensão do tema, o estudo da LC no 87/96 - e de seu antecessor, o Convênio ICM nº 66/88 - será dividido em quatro tópicos:

(a) disposições gerais sobre a não-cumulatividade;

(b) o modus operandi do abatimento do imposto devido na etapa anterior (crédito financeiro mitigado);

(c) o tratamento dos créditos de ICMS acumulados em decorrência da exportação de produtos ou serviços;

(d) a idoneidade do documento fiscal como condição sine qua non para o creditamento. Confira-se.

\subsubsection{DISPOSIÇÕES GERAIS SOBRE A NÃO-CUMULATIVIDADE.}

${ }^{694}$ Sobre o papel dos decretos em matéria tributária, alerta SACHA CALMON, com esforço no CTN:

"O art. 99 do CTN põe os decretos no seu devido lugar.

'Art. 99. O conteúdo e o alcance dos decretos restringem-se aos das leis em função das quais sejam expedidos, determinados com observância das regras de interpretação estabelecidas nesta Lei.'

Os decretos são entes normativos servos de lei. Se se apresentarem contra legem ou ultra legem, serão censurados pelo Judiciário como ilegais. E há fenômeno mais corriqueiro que o da Administração, a pretexto de interpretar ou aplicar a lei fiscal, lançar o dardo além da meta?" (COÊLHO, Sacha Calmon Navarro. Curso de Direito Tributário Brasileiro, 9ª ed. Rio de Janeiro: Forense, 2007, p. 624).

${ }^{695}$ Vide Título II, Capítulo VII, Item 7.7. 
Seguindo o determinado pela CR/88 (art. 155, §2º, I), estabelecia o Convênio ICM $n^{\circ}$ 66/88 (art. 28) e dispõe a LC n 87/96 (art. 19) que o ICMS será não-cumulativo, compensando-se o que for devido em cada operação (relativa à circulação de mercadorias) ou prestação (de serviços de comunicação ou de transporte interestadual e intermunicipal) com o montante cobrado nas anteriores, pelo mesmo ou por outro Estado.

Portanto, apesar de ser uma exação estadual, o abatimento do ICMS a recolher independe da origem da mercadoria ou serviço, obrigando, assim, os Estados a reconhecerem como crédito o imposto pago em outras unidades da federação.

\subsubsection{PERÍODO DE APURAÇÃO DO IMPOSTO E TRANSPORTE DO SALDO CREDOR ACUMULADO PARA AS COMPETÊNCIAS SUBSEQUENTES.}

Compete aos Estados ${ }^{696}$ a fixação do período de apuração do imposto ${ }^{697}$. Utilizando-se da faculdade concedida pela legislação complementar, as unidades da federação adotam, em regra, o cálculo mensal do ICMS devido.

Caso o valor dos créditos supere o dos débitos em determinada competência, o saldo credor será transportado para os exercícios subseqüentes ${ }^{698}$. O crédito escritural, portanto, será mantido na conta gráfica até sua efetiva utilização. Não há, todavia, previsão nas normas gerais do ICMS quanto à correção monetária dos créditos acumulados.

Findo o período de apuração, as obrigações consideram-se vencidas, devendo-se quitar os débitos mediante compensação com os créditos auferidos no período e eventual saldo credor trazido da competência anterior. Sendo necessário, a diferença será recolhida em dinheiro pelo contribuinte, no prazo fixado pelo Estado ${ }^{699}$ (art. 24, II da LC no 87/96).

\subsubsection{AUTONOMIA DOS ESTABELECIMENTOS.}

\footnotetext{
${ }^{696}$ Todas as referências aos Estados, em matéria de ICMS, aplicam-se também ao Distrito Federal (art. 155, caput e inciso II da CR/88; arts. 35 da LC nº 87/96 e do Convênio ICM nº 66/88).

${ }^{697}$ Art. 24, caput da LC no 87/96 e art. 29, caput e inciso I do Convênio ICM nº 66/88.

${ }^{698}$ Art. 24, I e III da LC nº 87/96 e art. 29, $3^{\circ}$ do Convênio ICM nº 66/88.

${ }^{699}$ A data de pagamento do tributo não é sujeita à reserva legal, podendo ser estabelecida por decreto, instrução normativa ou outro ato do Poder Executivo, conforme interpretação jurisprudencial do art. 97 do CTN, que trata do conteúdo material do princípio da legalidade (STF, $1^{\text {a }}$ Turma, RE no 195.218/MG, Relator Min. ILMAR GALVÃO, DJ 02.08.2002, p. 84; STJ, $2^{\mathrm{a}}$ Turma, REsp n ${ }^{\mathrm{o}}$ 70.640/SP, Relator Min. ANTÔNIO DE PÁDUA RIBEIRO, DJ 09.12.1996, p. 49.242).
} 
Um dos princípios que regem o ICMS é o da autonomia dos estabelecimentos ${ }^{700}$. Cada qual possui sua própria inscrição estadual e apura, em separado, seus créditos e débitos. Entretanto, o imposto devido pelo contribuinte titular de vários estabelecimentos será calculado por meio da compensação dos saldos credores e devedores apurados em cada um dos estabelecimentos no mesmo período (art. 25, caput da LC n 87/96). Ou seja, apesar de existir a autonomia dos estabelecimentos, a apuração do ICMS é, hoje, centralizada, havendo inter-compensação dos créditos e débitos apurados por todos os estabelecimentos do mesmo contribuinte.

\subsubsection{A TRANSFERÊNCIA DO SALDO CREDOR A OUTROS CONTRIBUIN- TES DENTRO DO MESMO ESTADO.}

À exceção dos créditos de ICMS acumulados em decorrência da exportação de mercadorias ou serviços pelo contribuinte, que possuem tratamento privilegiado por força de comando constitucional específico ${ }^{701}$, os demais saldos credores não garantem nenhum direito contra o Estado, salvo o de compensar em conta gráfica o ICMS devido. O crédito, por ser meramente escritural, não se incorpora ao patrimônio da empresa, consistindo apenas em fórmula financeira para chegar-se ao quantum debeatur do imposto.

Essa realidade é confirmada pela jurisprudência. O STF já afirmou que o evento de extinção da empresa que possua saldo credor do ICMS não gera direito à restituição desses créditos em espécie e tampouco a sua transferência para terceiros ${ }^{702}$.

Entretanto, é possível que os Estados autorizem, por lei própria, a transferência a terceiros dos créditos acumulados do ICMS. Trata-se de faculdade concedida pelo art. 25, $\S 2^{\circ}$, II da LC no 87/96, que não existia à época do Convênio ICM n $66 / 88$. Os entes federados têm, topicamente e em casos especiais, se utilizado dessa opção, beneficiando determinados setores cujas atividades resultem, naturalmente, em acúmulo de créditos do ICMS. Todavia, à míngua de lei estadual, não se pode pretender a aludida transferência, eis

\footnotetext{
${ }^{700}$ Art. $11, \S 3^{\circ}$, II e III da LC no 87/96 e art. 22 do Convênio ICM n ${ }^{\circ}$ 66/88.

${ }^{701}$ Vide Título II, Capítulo VII, Item 7.12.

${ }^{702}$ Confira-se o seguinte trecho do voto do Min. ILMAR GALVÃO no AgR no AI no 230.478/SP: "O denominado crédito no ICMS é puramente escritural (...). Esse crédito (...) existe apenas para fazer valer o princípio da não-cumulatividade, em operações puramente matemáticas, não se incorporando ao patrimônio do contribuinte, tanto que este, ao encerrar suas atividades, não tem o direito de cobrar da Fazenda seus créditos que não puderam ser utilizados para compensar seus débitos na conta mensal de chegada." (STF, Primeira Turma, AgR no AI n ${ }^{\circ}$ 230.478/SP, Relator Min. MOREIRA ALVES, DJ 13.08.1999, p. 10).
} 
que a autorização para tanto consiste em faculdade - e não obrigação - dos Estadosmembros.

\subsubsection{FORMAS DE APURAÇÃO DO IMPOSTO.}

Além do cálculo por competência, universalmente adotado pelos Estados-membros, as normas infraconstitucionais ofertam duas outras alternativas de apuração do $\operatorname{ICMS}^{703}$, a critério do sujeito ativo:

(a) cotejo de créditos e débitos por mercadoria ou serviço, dentro de determinada competência;

(b) confronto de créditos e débitos por mercadoria ou serviço, em cada operação.

A intenção, ao se adotar uma das alternativas acima, é permitir o crédito apenas quando a saída daquele produto ou serviço específico for tributada. Diferente é a hipótese do cálculo por período de tempo, em que as aquisições tributadas geram créditos a ser abatidos dos débitos gerados pelas saídas gravadas pelo imposto.

Sabe-se que no cálculo por período de tempo incide a regra de estorno dos créditos, quando houver operação ou prestação isenta ou não-tributada ${ }^{704}$, salvo previsão em contrário da legislação. Assim, a opção em comento (apuração por produto), se exercida pelos Estados, não importará em prejuízo para a não-cumulatividade do ICMS. Afinal, mesmo na apuração por período de tempo é possível anular o crédito proporcionalmente às saídas não tributadas, com espeque não só na lei complementar como também na própria Constituição (art. 155, $\S 2^{\circ}$, II, $a$ e $b$ ).

Sendo assim, a adoção do cálculo por período de tempo como regra geral é válida. Porém, não consiste em garantia da efetivação da não-cumulatividade tributária, ao menos para o ICMS. As alternativas ofertadas pelo art. 26, I e II da LC nº 87/96 implicam, decerto, em maiores dificuldades operacionais (obrigações acessórias mais complexas). Todavia, não se chocam com o princípio constitucional da não-cumulatividade, que já vem mutilado, para o ICMS, desde a Lei Maior.

\subsubsection{A APURAÇÃO POR ESTIMATIVA.}

\footnotetext{
${ }^{703}$ Art. 26, I e II da LC no 87/96, que corresponde ao art. 29, II e III do revogado Convênio ICM nº 66/88.

${ }^{704}$ Art. $20, \S 1^{\circ}$ da LC nº 87/96 e art. 31, I do Convênio ICM nº 66/88.
} 
Em determinados setores da economia, a apuração e pagamento regular do imposto dentro do prazo de vencimento estipulado pelo Estado se faz impossível, dado o elevado número de operações que devem ser consideradas para cálculo do quantum debeatur.

Atento a essa especificidade (comum a empresas de grande porte), o legislador possibilita aos Estados calcularem o ICMS por estimativa, para pagamento dentro do prazo legal. Posteriormente, em data futura - consentânea com o prazo necessário para apurar-se o montante efetivo de tributo a recolher - será feito o acerto de contas, com pagamento pelo contribuinte de eventual diferença apurada ou, se o recolhimento tiver sido feito a maior, apuração de crédito a ser compensado com o tributo devido por estimativa nas competências subseqüentes $^{705}$.

Como o imposto não deixará, em nenhuma hipótese, de ser regularmente calculado e pago, o contribuinte deverá adimplir com todas as suas obrigações acessórias, consoante previsão - a nosso sentir desnecessária - do art. 26, §2 da LC nº 87/96.

\subsubsection{O CRÉDITO FINANCEIRO MITIGADO AUTORIZADO PELA LC No 87/96.}

O Convênio ICM n n $^{\circ}$ /88 vedava totalmente o aproveitamento de créditos sobre bens destinados ao ativo imobilizado e serviços de transporte. A energia elétrica creditável era somente a consumida em processo de industrialização. Os serviços de comunicação, a seu turno, somente geravam crédito quando utilizados para a prestação de serviço da mesma natureza.

Assim, tirante as referidas exceções pontuais da energia elétrica e dos serviços de comunicação, o Convênio ICM n ${ }^{\circ}$ 66/88 assegurava tão-somente o crédito decorrente da aquisição de mercadorias para revenda, de matérias-primas e bens intermediários. A Lei Kandir, por outro lado, trouxe à balha o crédito financeiro, permitindo o seu cálculo sobre:

(a) entrada de mercadorias para revenda, de matérias-primas, bens intermediários ou de uso e consumo;

(b) bens destinados ao ativo permanente;

(c) serviços de transporte interestadual e intermunicipal;

(d) serviços de comunicação;

(e) energia elétrica.

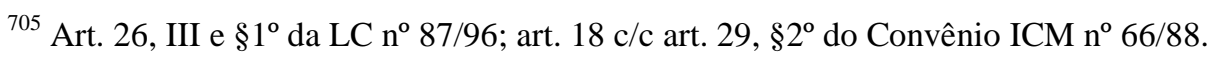


No caso das alíneas $a$ e $b$, vale gizar que a $\mathrm{LC}^{\circ}$ 87/96 não autorizou o crédito sobre bens alheios à atividade do estabelecimento.

Outrossim, o crédito sobre mercadorias destinadas ao uso e consumo do estabelecimento não foi permitido de imediato pela Lei Kandir, que o autorizou somente a partir de $1^{\circ}$ de janeiro de 1998, na redação originária da LC nº 87/96 (que, como se verá, sofreu diversas modificações, estando atualmente diferido para $1^{\circ}$ de janeiro de 2011). Por essa razão qualificamos o crédito financeiro outorgado pela $\mathrm{LC} \mathrm{n}^{\circ}$ 87/96 como mitigado, eis que seus plenos efeitos nunca chegaram a ser produzidos.

Para a exata percepção da diferença no tratamento da não-cumulatividade entre o Convênio ICM no 66/88 e a LC nº 87/96, é fundamental definir-se os conceitos de:

(a) insumos (nos quais se enquadram as matérias-primas e bens intermediários ${ }^{706}$ );

(b) bens de uso e consumo;

(c) bens do ativo permanente;

(d) bens alheios à atividade do estabelecimento ${ }^{707}$.

A partir dessas distinções, que serão feitas sob a luz da jurisprudência do $\mathrm{STJ}^{708}$, será possível avaliar o atual regramento da não-cumulatividade do ICMS no plano infraconstitucional.

\subsubsection{CRÉDITOS DE ICMS SOBRE MATÉRIAS-PRIMAS, PRODUTOS IN- TERMEDIÁRIOS E BENS DE USO E CONSUMO.}

12.2.2.1. ORIGEM NORMATIVA DOS TERMOS EM QUESTÃO. 12.2.2.1.1.1. O PERÍODO DO DECRETO-LEI Nº 406/68.

\footnotetext{
${ }^{706}$ Alguns autores sustentam que o termo insumo somente seria aplicável aos produtos intermediários, não qualificando as matérias-primas, que pertenceriam a uma categoria à parte. A nosso sentir, todavia, como o termo insumo é genérico, sendo qualificado como todo "elemento que entra no processo de produção de mercadorias ou serviços” (Dicionário Aurélio da Língua Portuguesa, versão eletrônica), ele abarcaria, por conseguinte, as matérias-primas e os bens intermediários.

De todo modo, as divergências quanto a essa definição não modificam o aproveitamento dos créditos de ICMS, pois tanto as matérias-primas como os produtos intermediários geram direito ao creditamento do referido tributo.

${ }^{707}$ Os bens alheios, sejam de uso e consumo ou integrantes do ativo imobilizado, não geram direito ao crédito do ICMS.

${ }^{708} \mathrm{O}$ tema foi analisado no Título II, Capítulo VII, Item 7.7.2, do presente, sob a luz da Constituição da República. Entretanto, como o mínimo constitucional da não-cumulatividade compreende apenas o crédito físico, e sendo certo que a LC no 87/96 ampliou o espectro da não-cumulatividade ao adotar o creditamento financeiro, é a jurisprudência do STJ que efetivamente importará para a adequada apreensão dos conceitos de insumos, bens do ativo, bens alheios à atividade da empresa e bens de uso e consumo.
} 
Antes da Constituição de 1988, o Decreto-lei n 406, de 31 de dezembro de 1968, fazia as vezes de lei de normas gerais do então ICM. O diploma, que adotava a linha do crédito físico, assim dispunha sobre as matérias-primas e bens intermediários (então materiais secundários):

"Art. $3^{\circ}$. (...).

$\S 3^{\circ}$. Não se exigirá o estorno do imposto relativo às mercadorias entradas para utilização, como matéria-prima ou material secundário, na fabricação e embalagem dos produtos de que tratam o $\S 3^{\circ}$, inciso I [destinados à exportação] e o $\$ 4^{\circ}$, e o inciso III [vendidos internamente por indústrias nacionais que venceram licitações internacionais e recebem divisas de bancos ou governos estrangeiros para tanto], do artigo $1^{\circ}$. O disposto neste parágrafo não se aplica, salvo disposição da lei estadual em contrário, às matérias-primas de origem animal ou vegetal que representem, individualmente, mais de $50 \%$ do valor do produto resultante de sua industrialização." (destaques nossos)

Como a exportação e a venda interna de bens produzidos no país, mediante financiamento estrangeiro, eram isentas do imposto, o DL n 406/68 houve por bem assegurar expressamente o direito à manutenção do crédito de ICM das matérias-primas e dos produtos secundários, utilizados na fabricação e embalagem desses bens.

Além do mencionado dispositivo, o DL no 406/68 não fazia referências acerca da natureza das mercadorias que gerariam crédito quando adquiridas pelo contribuinte. Sendo assim, o que se interpretou à época foi que os Estados-membros teriam liberdade para legislar acerca dos materiais que, após entrarem no estabelecimento, permitiriam o creditamento. A nosso sentir, deveria ter valido a máxima de que "onde o legislador complementar não distingue, não cabe ao legislador ordinário distinguir", mormente porque o DL $\mathrm{n}^{\circ}$ 406/68 em momento algum delegou a tarefa de definir os bens passíveis de creditamento. De todo modo, não foi esse o entendimento prevalente à época, como já apontou A. J. $\operatorname{COSTA}^{709}$.

Suprindo essa lacuna do DL n 406/68, as Administrações Tributárias de diversos Estados editaram orientações a seus contribuintes no que tange ao creditamento do ICM. A preocupação-mor era definir, no bojo do processo industrial, os bens geradores de crédito, com espeque nos conceitos existentes na legislação do IPI (matérias-primas, produtos in-

\footnotetext{
${ }^{709}$ Leciona o jurista:

“(...) A norma constitucional deixou ao legislador complementar liberdade para escolher entre os diversos tipos de imposto sobre o valor acrescido: tipo renda, tipo produto bruto ou tipo consumo. $\mathrm{O}$ curioso é que o decreto-lei no 406/68, tão minucioso sob outros aspectos, omitiu-se neste. Ficou, pois, ao legislador estadual a tarefa de eleger o tipo do imposto." (COSTA, Alcides Jorge. ICM na Constituição e na Lei Complementar. São Paulo: Resenha Tributária, 1978, p. 156).
} 
termediários e materiais de embalagem). Invocando a semelhança do ICM com o citado imposto federal, a intenção das autoridades estaduais foi a de permitir o crédito sobre os mesmos produtos que autorizavam o creditamento do IPI - e, via de conseqüência, vedá-lo quando as normas federais também o fizessem.

Nessa linha, a Coordenação da Administração Tributária do Estado de São Paulo editou a Decisão CAT n ${ }^{\circ}$ 2, de 4 de junho de 1982. O escopo do ato administrativo era responder a consulta sobre a possibilidade de creditamento do ICM relativo à entrada de feltros utilizados na fabricação de papel transparente. No bojo da resposta, definem-se os conceitos de matérias-primas, produtos intermediários e produtos secundários, sendo que apenas os dois primeiros gerariam créditos do ICM. Confiram-se, ab initio, as definições trazidas pela CAT/SP:

“1) Matéria-prima é, em geral, toda a substância com que se fabrica alguma coisa e da qual é obrigatoriamente parte integrante. Exemplos: o minério de ferro, na siderurgia, integrante do ferro-gusa; o calcário, na industrialização do cimento, parte integrante do novo produto cimento; o bambu ou o eucalipto, na indústria da autora, integrantes do novo produto - papel, etc."

“2) Produto Intermediário (assim denominado porque proveniente de indústria intermediária própria ou não) é aquele que compõe ou integra a estrutura físicoquímica do novo produto, via de regra sem sofrer qualquer alteração em sua estrutura intrínseca. Exemplos: pneumáticos, na indústria automobilística e dobradiças, na marcenaria, compondo ambos os respectivos produtos novos (sem que sofram qualquer alteração em suas estruturas intrínsecas) - o automóvel e o mobiliário; a cola, ainda na marcenaria, que, muito embora alterada em sua estrutura intrínseca, vai integrar o novo produto - mobiliário."

“3) Produto Secundário - é aquele que, consumido no processo de industrialização, não se integra no novo produto. Exemplos: calcáreo - $\mathrm{CaCO}_{3}$ (que na indústria do cimento é matéria-prima), na siderurgia, é 'produto secundário', porquanto somente usado para extração das impurezas do minério de ferro, com as quais se transforma em escória e consome-se no processo industrial sem integrar o novo produto: o ferro-gusa; o óleo de linhaça, usado na cerâmica (para o melhor desprendimento da argila na prensa), depois de consumido na queima, não vai integrar o novo produtotelha; qualquer material líquido, usado na indústria da autora, que consumido na operação de secagem, deixa de integrar o novo produto - papel."

Com esse entendimento, o Estado de São Paulo adotou posicionamento que restringia, mais do que a própria legislação do IPI, o creditamento do ICM. Segundo a referida Decisão CAT, apenas os bens que se integrassem fisicamente ao produto final gerariam créditos do ICM. A distinção entre matérias-primas e bens intermediários - que, à luz do entendimento da CAT, necessariamente se agregam ao bem fabricado - residiria no fato de as matérias-primas perderem suas características ou qualidades (como o minério de ferro 
utilizado na fabricação do ferro-gusa), ao passo que os intermediários as mantêm (pneus utilizados no fabrico do automóvel).

Os produtos secundários, que não autorizariam o creditamento, seriam todos aqueles que, consumidos no processo de fabricação, não se integrassem fisicamente ao produto final. Exemplo: os produtos químicos líquidos utilizados pela indústria de papel que se evaporam no processo de secagem do bem fabricado.

Quatro anos depois do advento da decisão paulista, o Diretor da Superintendência de Legislação e Tributação do Estado de Minas Gerais editou a Instrução Normativa ${ }^{\circ}{ }^{0}$, de 20 fevereiro de 1986. Seus consideranda merecem ser lidos:

"Considerando que nos termos da legislação em vigor, para efeito de apuração do valor do ICM a pagar, será abatido o imposto incidente nas operações realizadas no período, sob a forma de crédito, dentre outros valores, o valor do imposto correspondente à entrada do produto intermediário; considerando que o produto intermediário é aquele que, empregado diretamente no processo de industrialização, integrar-se ao novo produto; considerando que, por extensão, produto intermediário é também o que, embora não se integrando ao novo produto, é consumido, imediata e integralmente, no curso da industrialização;

considerando as controvérsias que têm envolvido a conceituação extensiva de produto intermediário, e que o ponto essencial de divergência se prende às dificuldades verificadas na precisa identificação da efetiva participação do produto no processo de industrialização;

considerando, com efeito, que o centro das controvérsias reside no dúplice circunstanciamento, qual seja o produto ser consumido imediata e integralmente dentro da linha de produção;"

O intróito à IN/SLT $n^{\circ}$ 01/86 trouxe importantes definições. Nesse sentido, produto intermediário seria aquele que:

(a) empregado no processo industrial, se integrasse a novo produto; ou

(b) embora não se integrasse ao novo produto, seria consumido de forma imediata e integral no processo produtivo.

Como se infere, a IN/SLT $n^{\circ}$ 1/86 classificou como bens intermediários as categorias que a Decisão CAT n ${ }^{\circ}$ 2/82 segregou em bens intermediários (que, para SP, gerariam créditos de ICM) e produtos secundários (que não autorizariam o creditamento sob a ótica do fisco paulista). Portanto, o conceito mineiro de bem intermediário se fez mais abrangente.

Entretanto, para ser considerado como tal e, conseguintemente, gerar créditos aproveitáveis do ICM, a IN/SLT n ${ }^{\circ}$ 1/86 dispunha que o produto intermediário deveria, cumulativamente, ser: 
(a) essencial ao processo de produção; e

(b) consumido de forma imediata e integral.

Visando a pontuar com clareza esses requisitos adicionais, a IN/SLT n ${ }^{\circ} 1 / 86$ apregoou:

"I - Por consumo imediato entende-se o consumo direto, de produto individualizado, no processo de industrialização; assim, considera-se consumido diretamente no processo de industrialização o produto individualizado, quando sua participação se der num ponto qualquer da linha de produção, mas nunca marginalmente ou em linhas independentes, e na qual o produto tiver o caráter de indiscutível essencialidade na obtenção do novo produto.

II - Por consumo integral entende-se o exaurimento de um produto individualizado na finalidade que lhe é própria, sem implicar, necessariamente, o seu desaparecimento físico total; neste passo, considera-se consumido integralmente no processo de industrialização o produto individualizado que, desde o início de sua utilização na linha de industrialização, vai-se consumindo ou desgastando, contínua, gradativa e progressivamente, até resultar acabado, esgotado, inutilizado, por força do cumprimento de sua finalidade específica no processo industrial, sem comportar recuperação ou restauração de seu todo ou de seus elementos.

III - Não se consideram consumidas imediata e integralmente os produtos, como ferramentas, instrumentos ou utensílios, que embora se desgastem ou deteriorem no processo de industrialização - como aliás ocorre em qualquer bem ao longo do tempo - não se esgotam de maneira contínua, gradativa e progressiva, até o completo exaurimento, na linha de produção.

IV - Igualmente não são considerados produtos consumidos imediata e integralmente no processo de industrialização as partes e peças de máquina, aparelho ou equipamento, pelo fato de não se constituírem em produto individualizado, com identidade própria, mas apenas componentes de uma estrutura estável e duradoura, cuja manutenção naturalmente pode importar na substituição das mesmas.

$\mathrm{V}$ - Excepcionam-se da conceituação do inciso anterior as partes e peças que, mais que meros componentes de máquina, aparelho ou equipamento, desenvolvem atuação particularizada, essencial e específica, dentro da linha de produção, em contacto físico com o produto que se industrializa, o qual importa na perda de suas dimensões ou características originais, exigindo, por conseguinte, a sua substituição periódica em razão de sua inutilização ou exaurimento, embora preservada a estrutura que as implementa ou as contém."

Em razão da IN/SLT n ${ }^{\circ}$ 1/86, pode-se afirmar que, para o Estado de Minas Gerais, o produto intermediário deve:

(a) ser consumido instantaneamente ou lentamente no processo de produção, desgastando-se gradualmente até se tornar inutilizável (o que corresponde ao consumo integral); 
(b) integrar a linha de produção principal, não compondo linhas marginais ou secundárias.

Bens como ferramentas e utensílios que, apesar de utilizados na produção, não se desgastam naturalmente no processo fabril, não se caracterizam como intermediários. Da mesma forma, partes e peças de máquinas e equipamentos cuja substituição se faz eventualmente necessária não correspondem ao conceito em tela, salvo se estas partes e peças forem específicas, desenvolvendo papel fundamental no processo produtivo e entrando em contato direto com o produto final, acarretando-lhes perda de suas características originais e a conseqüente necessidade de substituição periódica.

Como se infere, à míngua de uma conceituação na lei de normas gerais, os regramentos dos Estados (à época do DL no 406/68) eram bastante discrepantes quanto ao tema.

\subsection{O CONVÊNIO ICM No 66/88 E A LEI COMPLEMENTAR Nº 87/96.}

O Convênio ICM no 66/88, ao autorizar o crédito sobre matérias-primas e bens intermediários, assim dispunha:

“Art. 31. Não implicará crédito para compensação com o montante do imposto devido nas operações ou prestações seguintes:

(...)

III - a entrada de mercadorias ou produtos que, utilizados no processo industrial, não sejam nele consumidos ou não integrem o produto final na condição de elemento indispensável a sua composição;"

A partir da redação convenial, é possível extrair os conceitos jurídicos de:

(a) matérias-primas: mercadorias ou produtos que integrem o produto final na condição de elemento indispensável à sua composição;

(b) produtos intermediários: mercadorias ou produtos que sejam consumidos no processo industrial.

É interessante notar que, ao tratar da matéria-prima, o Convênio remete à tradicional teoria do crédito físico, exigindo a incorporação do produto à mercadoria final. Entretanto, quando se refere a produtos cuja consumição se dá no processo industrial, deixa-se de exigir a incorporação física ao bem produzido. Essa foi uma importante modificação trazida pelo Convênio ICM n ${ }^{\circ}$ 66/88, eis que, antes dele, o DL n ${ }^{\circ}$ 406/68 nada dispunha a esse respeito, como visto no item precedente.

Uma importante consequiência já pode ser extraída do novel regramento infraconstitucional da matéria: os bens intermediários foram, definitivamente, diferençados das matérias-primas, com base no critério de agregação física ao produto final. Isso abriu as portas 
para se discutir, no bojo de casos concretos, as demais qualidades que um bem consumido no processo industrial deveria ter para gerar direito ao creditamento do ICMS.

Quando do advento da Lei Complementar n 87/96, a definição de produto intermediário novamente perdeu seu supedâneo nas normas gerais do ICMS. Todavia, um novo conceito foi agregado ao tema: os bens de uso e consumo. Eles gerariam créditos somente a partir de uma data futura fixada na $\mathrm{LC} \mathrm{n}^{\circ}$ 87/96 (que vem sendo sistematicamente postergada desde então). Por outro lado, todas as demais mercadorias que não fossem destinadas ao uso e consumo gerariam créditos aproveitáveis, fossem matérias-primas, bens intermediários ou produtos para revenda.

Assim, com a edição da LC $n^{\circ}$ 87/96 tornou-se importante segregar:

(a) os bens de uso e consumo, cujo creditamento passou a ser autorizado a partir de $1^{\circ}$ de janeiro de 1998 (prazo já postergado diversas vezes, sendo atualmente $1^{\circ}$ de janeiro de 2011);

(b) as matérias-primas; e

(c) os produtos intermediários.

À míngua de definição na lei, alguns Estados se propuseram a regulamentar a questão. Em Minas Gerais, a vigência da precitada IN/SLT n ${ }^{\circ} 1 / 86$ foi reafirmada pelas autoridades administrativas. Com base nela, o Executivo editou a IN/SLT $n^{\circ} 1 / 01$, definindo os bens intermediários cujos créditos de ICMS seriam aproveitáveis na indústria de mineração. Confiram-se, inicialmente, os trechos que reafirmam a vigência dos conceitos trazidos pela IN/SLT n ${ }^{\circ} 01 / 86$ :

"Considerando que, para efeito de apuração do valor do ICMS a pagar, será abatido o imposto incidente nas operações realizadas no período, sob a forma de crédito, dentre outros valores, o valor do imposto correspondente à entrada do produto intermediário;

considerando que o produto intermediário é aquele que, empregado diretamente no processo de extração e industrialização de minérios, integra-se ao novo produto;

considerando que, por extensão, produto intermediário é também o que, embora não se integrando ao novo produto, é consumido, imediata e integralmente, no processo da extração ou industrialização;"

Em seguida, após salientar as dificuldades de se inferir a "precisa identificação da efetiva participação do produto no processo" de mineração, para fins de definir se o mesmo é ou não intermediário, estabelece a IN/SLT n ${ }^{\circ} 1 / 01$ :

“Art. $1^{\circ}$. Por processo produtivo desempenhado por empresas mineradoras entende-se aquele compreendido entre a fase de desmonte da rocha ou re- 
moção de estéril até a fase de estocagem, inclusive a movimentação do minério do local de extração até o de beneficiamento ou estocagem.

Art. $2^{\circ}$. Para efeitos de crédito no imposto, considera-se produto intermediário, observado o disposto na Instrução Normativa SLT $n^{\circ} 01$, de 20 de fevereiro de 1986, todo o material consumido nas fases do processo desenvolvido pelas empresas mineradoras, tais como: broca, haste, manto (correia transportadora), chapa de desgaste, óleo diesel, tela de peneira, filtro, bola de moinho, amido, amina/soda cáustica, dentre outros, consumidos na lavra, na movimentação do material e no beneficiamento."

Dentre os bens classificados como intermediários, vale destacar o óleo diesel, a correia transportadora do minério, os filtros e a soda cáustica. Esses quatro equivalem, na antiga definição da Decisão CAT n ${ }^{\circ}$ 2/82 de São Paulo, aos produtos secundários, que não geravam (para o fisco paulista) créditos do ICM. Entretanto, com o advento do Convênio $\mathrm{ICM} \mathrm{n}^{\circ} 66 / 88$, as premissas que pautaram a aludida Decisão CAT tornaram-se anacrônicas. Mas foi somente em 2001, já sob a égide da LC n 87/96, que São Paulo reformulou seu entendimento quanto aos conceitos sub examine. Por meio da Decisão CAT $\mathrm{n}^{\mathrm{o}} 1$, de 25 de abril de 2001, assentou-se:

"3. Diante das normas legais e regulamentares atrás citadas, dão direito ao crédito do valor imposto as seguintes mercadorias entradas ou adquiridas ou os serviços tomados pelo contribuinte:

3.1 - insumos

A expressão 'insumo' consoante o insigne doutrinador Aliomar Baleeiro ‘é uma algaravia de origem espanhola, inexistente em português, empregada por alguns economistas para traduzir a expressão inglesa input, isto é, o conjunto dos fatores produtivos, como matérias-primas, energia, trabalho, amortização do capital, etc., empregados pelo empresário para produzir o output ou o produto final. (...). Insumos são os ingredientes da produção, mas há quem limite a palavra aos produtos intermediários que, não sendo matérias-primas, são empregados ou se consomem no processo de produção' (Direito Tributário Brasileiro, Forense, Rio de Janeiro, 1980, 9a edição, pág. 214).

Nessa linha, como tais têm-se a matéria-prima, o material secundário ou intermediário, o material de embalagem, o combustivel e a energia elétrica, consumidos no processo industrial ou empregados para integrar o produto objeto da atividade de industrialização, própria do contribuinte ou para terceiros, ou empregados na atividade de prestação de serviços, observadas as normas insertas no subitem 3.4 deste trabalho.

Entre outros, têm-se ainda, a título de exemplo, os seguintes insumos que se desintegram totalmente no processo produtivo de uma mercadoria ou são utilizados nesse mesmo processo produtivo para limpeza, identificação, desbaste, solda etc: lixas; discos de corte; discos de lixa; eletrodos; oxigênio e acetileno; escovas de aço; estopa; materiais para uso em embalagens em geral - tais como etiquetas, fitas adesivas, fitas crepe, papéis de embrulho, sacolas, materiais de amarrar ou colar (barbantes, fitas, fitilhos, cordões e congêneres), lacres, isopor utilizado no isolamento e proteção dos produtos 
no interior das embalagens, e tinta, giz, pincel atômico e lápis para marcação de embalagens -; óleos de corte; rebolos; modelos/matrizes de isopor utilizados pela indústria; produtos químicos utilizados no tratamento de água afluente e efluente e no controle de qualidade e de teste de insumos e de produtos.

IV - DA MERCADORIA PARA USO OU CONSUMO

5. Assim entendido a mercadoria que não for utilizada na comercialização ou a que não for empregada para integração no produto ou para consumo no respectivo processo de industrialização ou produção rural, ou, ainda, na prestação de serviço sujeita ao imposto (artigo 66, V, do RICMS).

Nota: Essa mercadoria somente gerará direito ao crédito do valor do ICMS que onera sua entrada ou aquisição a partir de 1\%1/2003, nos termos do inciso I do artigo 33 da Lei Complementar n 87/96, na redação da Lei Complementar $n^{\circ}$ 99/99 (artigo $2^{\circ}$ das DDTT do RICMS)." (destaques nossos)

Percebe-se, assim, que a categoria dos produtos secundários foi extinta. Introduziuse uma nova nomenclatura - insumos - para abarcar tanto as matérias-primas como os bens intermediários (que tiverem seu conceito ampliado, passando a abranger os produtos que, mesmo não integrando a mercadoria final, são consumidos no processo produtivo). Ademais, o crédito sobre materiais de embalagem, combustíveis e energia elétrica, também estão compreendidos nessa nova denominação.

Os insumos compreendem, nos termos da norma: as mercadorias consumidas no processo industrial e as que integram o produto objeto da atividade de industrialização ou prestação de serviços. É interessante notar que há menção expressa à existência de insumos na prestação de serviços, o que se coaduna com a atual regra-matriz de incidência do ICMS, que não mais se restringe às operações de circulação jurídica de mercadorias.

Os bens de uso e consumo foram também tratados pela Decisão Normativa CAT $n^{\circ}$ 1/01. Pode-se dizer que, por exclusão, as mercadorias não enquadráveis como insumos (conceito lato) ou como bens para revenda, serão destinadas ao uso e consumo pelo estabelecimento. Portanto, sempre que uma mercadoria:

(a) não for destinada à revenda;

(b) não se integrar ao produto final;

(c) não for consumida no processo de produção ou na prestação de serviço tributável, será considerada bem de uso e consumo pelas autoridades paulistas.

\subsection{A JURISPRUDÊNCIA DO SUPERIOR TRIBUNAL DE JUSTIÇA.}

Como o STF prescreve que o mínimo constitucional da não-cumulatividade resguarda o crédito apenas do que fisicamente se integra ao produto final ou se consome no 
processo produtivo, a definição dos pontos sensíveis da não-cumulatividade ficou a cargo das normas infraconstitucionais. Assim, quando a Lei Complementar $n^{\circ} 87 / 96$ positivou o crédito financeiro, a sua interpretação pelo STJ tornou-se de fundamental importância para a correta apreensão dos conceitos em tela.

Os julgados abaixo, agrupados por tema, demonstram a consolidação e evolução da jurisprudência da Corte Superior de Justiça relativamente à questão.

\subsection{CONSUMO VERSUS DESGASTE: DIFERENCIAÇÃO ENTRE PRO- DUTOS INTERMEDIÁRIOS E PARTES E PEÇAS DE REPOSIÇÃO INTEGRAN- TES DO ATIVO IMOBILIZADO.}

O Convênio ICM nº 66/88 vedava o crédito sobre bens destinados ao consumo ou ao ativo imobilizado das empresas, porém autorizava o aproveitamento do ICMS incidente nas aquisições de produtos consumidos no processo industrial ou integrantes da mercadoria fabricada. À época desse Convênio, as querelas entre Fiscos e contribuintes consistiam:

(a) no interesse fiscal em classificar a maior parte dos produtos adquiridos pelos contribuintes como integrantes do ativo imobilizado ou destinados ao uso e consumo das empresas;

(b) no interesse dos contribuintes em qualificar as suas aquisições sempre como produtos intermediários (que a jurisprudência nominou insumos), sustentando que, apesar de não se integrarem fisicamente no produto final, consumiam-se no processo de produção.

Um dos precedentes mais citados do gênero, exatamente por ser um dos arestos pioneiros sobre o tema no STJ, foi relatado pelo Min. JOSÉ DELGADO, no ano de 1996. O caso tratava de uma usina de cana-de-açúcar que pretendia qualificar como "bens consumidos no processo produtivo" as peças e acessórios que adquiria para suas moendas. Partindo da premissa fática de que as máquinas de moendas integravam o ativo imobilizado da empresa - logo, pela legislação à época, não geravam créditos aproveitáveis de ICMS - o Min. DELGADO pugnou pela negativa do creditamento. Argumentando que as peças e acessórios não se consomem no processo industrial, mas apenas se desgastam com o uso, e utilizando-se da máxima de que "o acessório segue o principal”, pugnou o Relator, seguido pela unanimidade da Primeira Turma do STJ, que peças e acessórios adquiridos para as moendas integram estas últimas, tornando-se bens do ativo permanente. Assim, o desgaste sofrido pelas peças, conforme este julgado, é natural, intrínseco a bens do ativo, 
tais como ferramentas e prédios industriais. Consumir exigiria a transformação do produto em resíduo, o que inocorria na espécie ${ }^{710}$.

Ao final desse mesmo ano de 1996 foi a julgamento, também na Primeira Turma, outro caso paradigmático para o presente estudo. Tratava-se do pleito de uma indústria dedicada ao fabrico de chapas de acrílico. As fôrmas utilizadas para moldagem do acrílico eram chapas de vidro que, com o tempo, sofriam o desgaste natural de qualquer bem e demandavam substituição. Como tais trocas tornaram-se freqüentes, ingressou a empresa em juízo pleiteando a escrituração do crédito de ICMS incidente sobre as chapas de vidro, ao argumento de que as mesmas, apesar de não se integrarem ao produto final, consumiam-se no bojo do processo de industrialização. À luz do art. 31, III do Convênio ICM n ${ }^{\circ}$ 66/88 estaria, portanto, autorizado o creditamento pretendido.

Contra a pretensão do contribuinte invocou o Min. MILTON LUIZ PEREIRA o verbo latino consumere - do qual deriva a palavra consumo - que significa gastar, destruir, extinguir. Para o Relator, as chapas de vidro eram bens integrantes do ativo imobilizado do contribuinte, pois se desgastavam naturalmente, não se deteriorando de forma acelerada no processo fabril. Com tais considerações, negou o pretendido caráter de insumo às fôrmas de vidro e, conseqüentemente, o direito ao creditamento ${ }^{711}$.

Já no ano de 2002, tratando de caso à luz do DL nº 406/68, o STJ novamente reiterou o posicionamento acima esposado - inclusive de forma expressa, invocando o prece-

${ }^{710} \mathrm{O}$ aresto foi assim ementado:

“TRIBUTÁRIO. ICMS. PRINCÍPIO DA NÃO-CUMULATIVIDADE. PEÇAS E ACESSÓRIOS. MOENDA QUE FABRICA ALCOOL E AÇÚCAR. (...).

1. A dedução do ICMS pago anteriormente só poderá ocorrer se se tratar de insumos que se incorporarem ao produto final ou, não se incorporando, são consumidos no curso de processo de industrialização, de forma imediata e integral.

2. Peças e acessórios da máquina moedora de cana-de-açúcar empregados para fabricar açúcar e álcool. Inexistência do direito ao crédito do ICMS." (STJ, Primeira Turma, REsp nº 84.808/SP, Relator Min. JOSÉ DELGADO, DJ 20.05.1996, p. 16.679).

${ }^{711} \mathrm{O}$ acórdão foi unânime:

“TRIBUTÁRIO. ICMS. PRODUTO SECUNDÁRIO DE PRODUÇÃO. DESGASTE NA FABRICAÇÃO DE MERCADORIAS TRIBUTADAS. CREDITAMENTO. CORREÇÃO MONETÁRIA. DEL 406/1968 (ART. 3º). CONVÊNIO 66/1988 (ART. 31, III).

1. A correção monetária, no caso, aconsoantado aos precedentes jurisprudenciais, depende de prévio reconhecimento do creditamento do ICMS, direito não consubstanciado, porque não se confunde o desgaste das chapas de vidro com o consumo no processo industrial. Na espécie, inocorrência de ofensa ao princípio da não-cumulatividade.

2. Recurso improvido." (STJ, Primeira Turma, REsp n 88.161/SP, Relator Min. MILTON LUIZ PEREIRA, DJ 03.02.1997, p. 678). 
dente relatado pelo Min. DELGADO em 1996 - ao negar o crédito de ferramentas utilizadas no processo industrial ${ }^{712}$.

Portanto, em mais de uma oportunidade o STJ diferençou o consumo de bens no processo de produção do seu mero desgaste ao longo do tempo. Nesse sentido, se há a inutilização em prazo inferior a 12 meses, o produto merecerá o adjetivo de "bem intermediário", ensejando para o adquirente o direito ao crédito do ICMS. Do contrário, será bem destinado ao ativo imobilizado da empresa.

A diferenciação entre desgaste natural e consumo, que deve resultar da inutilização do produto em período de tempo inferior a 12 meses tornou-se, portanto, ponto pacífico na jurisprudência da Corte Superior de Justiça ${ }^{713}$.

${ }^{712}$ Confiram-se trechos do relatório e do voto do Min. FRANCISCO FALCÃO, relator na oportunidade:

"Cuida-se de recurso especial interposto pela Fazenda do Estado de São Paulo, com fulcro no artigo 105, III, alínea 'a', do permissivo constitucional, contra acórdão do Tribunal de Justiça daquele Estado, que reconheceu o direito de crédito do ICMS destacado na aquisição de ferramentas, tais como, brocas, facas para alargadores, bitz, dedames, limas, rebolos, vídias, frezas, machos e serras, por entender que, embora não se incorporem ao produto final - 'máquinas ferramentas' (prensas mecânicas hidráulicas de grande porte) -, desgastam-se totalmente no processo produtivo.

(...).

Como visto, cinge-se a questão em saber-se se a compra dos bens acima descritos pela recorrida, por serem partes componentes de equipamentos utilizados na fabricação de bens, geram crédito de ICM para compensar no imposto devido pelas saídas de mercadorias fabricadas.

(...)

Trata-se de bens que, não obstante o natural desgaste advindo do seu uso, não chegam a se consumir ou integrar o produto final. São peças adquiridas para integrarem o ativo fixo da empresa e fazem parte das várias etapas do processo de industrialização, sendo que sua substituição periódica decorre da própria atividade industrial.

Considerando que somente há o direito de creditamento do ICMS pago anteriormente quando se tratar de insumos que se incorporam ao produto final ou que são consumidos no curso do processo de industrialização, de forma imediata e integral, não há que se falar em crédito no caso em exame." (STJ, Primeira Turma, AgRg no REsp no 139.996/SP, Relator Min. FRANCISCO FALCÃO, DJ 12.08.2002, p. 166).

No mesmo sendeiro, no final do ano de 2002 a Turma reiterou seu posicionamento em precedente bastante similar, cuja ementa segue abaixo:

"TRIBUTÁRIO. AGRAVO REGIMENTAL. AGRAVO DE INSTRUMENTO. ICMS. PRODUTOS INTERMEDIÁRIOS. IMPOSSIBILIDADE DE CREDITAMENTO.

I. A aquisição de insumos que, apesar de integrarem o processo de industrialização, não integram o produto final, tampouco são consumidos de forma imediata e integral, não geram direito ao creditamento do ICMS. Precedentes desta Corte.

II. Agravo regimental improvido." (STJ, Primeira Turma, AgRg no Ag no 438.945/SP, Relator Min. FRANCISCO FALCÃO, DJ 03.02.2003, p. 284).

${ }^{713}$ Os excertos de ementas a seguir, de julgados dos anos de 2006 e 2007 de ambas as Turmas de Direito Público do STJ, comprovam a assertiva:

"1. Na vigência do Decreto-lei 406/68 e do Convênio 66/88, a aquisição de produtos ou mercadorias que, apesar de integrarem o processo de industrialização, nele não eram completamente consumidos e nem integravam o produto final, não gerava direito ao creditamento do ICMS, posto que ocorre quanto a estes produtos apenas um desgaste, e a necessidade de sua substituição periódica é inerente à atividade industrial. (...)." (STJ, Segunda Turma, REsp nº 626.181/SC, Relatora Min. ELIANA CALMON, DJ 16.5.2006, p. 202). 
Mais recentemente, em 2008, o mesmo tema foi novamente apreciado pelo STJ, que manteve seu posicionamento tradicional. Nesse caso, determinado contribuinte pretendia qualificar como bens intermediários as partes e peças integrantes de seus tratores e guindastes, que sofriam desgastes com a utilização contínua em condições extremas. Contudo, fiel à qualificação de tais produtos como integrantes do ativo da empresa (seguindo a linha de que "o acessório segue o principal", ditada há muito pelo Min. JOSÉ DELGADO), a Corte negou o crédito (apesar de ter ressaltado que, se a aquisição de tais partes e peças tivesse ocorrido sob a égide da $\mathrm{LC}^{\circ}$ 87/96, seria permitido o creditamento, desde que provado não se tratar de bens alheios à atividade do estabelecimento) ${ }^{714}$.

Sendo assim, pode-se afirmar que para o STJ:

(a) existem duas categorias de insumos que geram direito ao crédito: os bens intermediários e as matérias-primas, que se incorporam fisicamente ao produto final;

"5. In casu, consoante assentado no aresto recorrido, os bens cuja aquisição, segundo a recorrente, ensejariam o direito ao aproveitamento dos créditos de ICMS, não obstante o natural desgaste advindo do seu uso, não consubstanciam matéria-prima ou insumo a ser utilizado no processo de industrialização. Ao revés, integram o ativo fixo da empresa e fazem parte das várias etapas do processo de industrialização, sendo que sua substituição periódica decorre da própria atividade industrial.” (STJ, Primeira Turma, REsp no 799.724/RJ, Relator Min. LUIZ FUX, DJ 09.04.2007, p. 233).

"11. É cediço que somente há o direito de creditamento do ICMS pago anteriormente quando se tratar de insumos que se incorporam ao produto final ou que são consumidos no curso do processo de industrialização, de forma imediata e integral." (STJ, Primeira Turma, REsp n ${ }^{\circ}$ 765.128/SC, Relator Min. LUIZ FUX, DJ 03.05.2007, p. 219).

${ }^{714}$ O seguinte trecho do voto do Relator, Min. LUIZ FUX, lança luzes sobre o caso:

"Noticiam os autos que a ora recorrente ajuizou ação, em 21/08/98, objetivando o reconhecimento do direito ao aproveitamento de créditos extemporâneos de ICMS advindos da entrada ou aquisição de materiais intermediários (a serem apurados e definidos mediante prova pericial a ser realizada), que se integrassem ao produto final ou se desgastassem durante o processo produtivo, em período inferior a um exercício financeiro, com juros e correção monetária.

O laudo da perícia técnica concluiu, em síntese, pela existência de desgaste de bens de uso, como tratores, guindastes, material de laboratório, não só em decorrência da idade dos equipamentos, bem como pela sujeição do aço à corrosão e da alta pressão e temperatura a que submetidos.

(...)

No pertinente ao direito ao creditamento de ICMS relativo à aquisição de (...) partes e peças de bens do ativo permanente, tem-se que o seu reconhecimento somente ocorreu com a vigência da LC 87/96, cujo art. 20, assim dispõe:

'Art. 20. Para a compensação a que se refere o artigo anterior, é assegurado ao sujeito passivo o direito de creditar-se do imposto anteriormente cobrado em operações de que tenha resultado a entrada de mercadoria, real ou simbólica, no estabelecimento, inclusive a destinada ao seu uso e consumo ou ativo permanente, ou o recebimento de serviços de transporte interestadual e intermunicipal ou de comunicação.'

(...)

Destarte, tendo restado caracterizado que os bens alegadamente tidos como intermediários não obedecem a requisito essencial para o exercício do direito ao creditamento, posto não se incorporarem ao produto final nem serem consumidos no curso do processo de industrialização, não pode ser atendido o pleito da recorrente." (STJ, Primeira Turma, REsp n 889.414/RJ, Relator Min. LUIZ FUX, DJe 14.05.2008). 
(b) o bem intermediário exige consumição imediata e integral no processo produtivo. Ainda que o imediato não signifique instantâneo, o fato é que após o uso, o produto intermediário deve se tornar imprestável;

(c) as partes e peças utilizadas na linha industrial cujo desgaste se dá, normalmente, com o decurso do tempo, enquadram-se como bens pertencentes ao ativo imobilizado das empresas, gerando créditos aproveitáveis somente a partir da vigência da LC no $87 / 96$.

\subsection{BENS DE USO E CONSUMO.}

\subsection{1. BREVE HISTÓRICO NORMATIVO.}

O conceito de bem de uso e consumo - mercadoria que, apesar de utilizada nas atividades da empresa, não se consome no setor produtivo - foi delineado principalmente em julgados do Superior Tribunal de Justiça, que trataram do direito ao crédito sobre combustíveis, energia elétrica e serviços de comunicação utilizados pelo estabelecimento.

Neste ponto, vale lembrar que o Convênio ICM n ${ }^{\circ}$ 66/88 vedava o crédito de bens destinados a consumo ou integração ao ativo imobilizado, assim como daqueles que não fossem matérias-primas ou produtos intermediários (rectius, que não se agregassem fisicamente ao produto final ou não fossem consumidos no processo produtivo).

Com o advento da $\mathrm{LC} \mathrm{n}^{\circ}$ 87/96, foi autorizado o crédito sobre bens do ativo, de uso e consumo e também sobre a energia elétrica consumida, essa por meio de norma específica:

“Art. 33. (...).

II - a energia elétrica usada ou consumida no estabelecimento dará direito de crédito a partir da data da entrada desta Lei Complementar em vigor;"

Posteriormente, a LC n ${ }^{\circ}$ 102/00 restringiu o crédito financeiro inicialmente plasmado na $\mathrm{LC} \mathrm{n}^{\circ} 87 / 96$. Dentre as modificações operadas pela primeira, vale destacar as seguintes:

(a) o crédito de energia elétrica, antes autorizado de forma genérica, foi restrito às hipóteses em que a energia:

(a.1) fosse utilizada para viabilizar operações de sua própria saída;

(a.2) fosse consumida em processo de industrialização;

(a.3) fosse utilizada em processo que resultasse na exportação de mercadoria ou serviço para o exterior. 
Sendo assim, a energia passou a gerar créditos de ICMS quando utilizada para viabilizar a exportação (regra cujo fundamento é constitucional); para viabilizar a saída da própria energia (hipótese restrita às empresas geradoras e distribuidoras de eletricidade); ou quando fosse qualificável como bem intermediário, é dizer, quando sua consumição ocorresse no bojo de processo industrial.

Em resumo, o tratamento legal dispensado à não-cumulatividade do ICMS pelo Convênio ICM n ${ }^{\circ} 66 / 88$, pela LC n ${ }^{\circ} 87 / 96$ e pela $\operatorname{LC~}^{\circ} 102 / 00$ predicava:

(a) crédito sobre todas as matérias-primas e produtos intermediários;

(b) vedação (Convênio ICM no 66/88) ou reconhecimento com postergação (LC $n^{\circ}$ 87/96) do crédito sobre bens de uso e consumo;

(c) crédito sobre a energia elétrica quando caracterizada como produto intermediário (Convênio ICM n ${ }^{\circ}$ 66/88, de forma implícita, e LC nº 102/00, expressamente);

(d) crédito sobre a energia elétrica mesmo quando utilizada para uso e consumo do estabelecimento ( $\mathrm{LC} \mathrm{n}^{\circ}$ 87/96, redação original);

Tendo em mente a legislação aplicável ao tema, passemos à análise dos julgados do STJ que permitirão, ao cabo, a formulação do conceito de bens de uso e consumo.

\subsection{2. OS JULGADOS DO STJ.}

Como se viu no item precedente, a energia elétrica somente gerava créditos de ICMS sob a égide do Convênio ICM n 66/88, quando caracterizável como produto intermediário. Noutro giro verbal, somente quando se provasse que a energia tivesse sido diretamente utilizada no processo industrial seria permitido o creditamento. Confira-se:

"RECURSO ESPECIAL. TRIBUTÁRIO. ICMS. CREDITAMENTO. BENS DE CONSUMO. ENERGIA ELÉTRICA. OPERAÇÕES ANTERIORES À LC 87/96. APLICAÇÃO DO CONVÊNIO 66/88. ATIVIDADE COMERCIAL. RECURSO DESPROVIDO.

1. A orientação firmada nesta Corte de Justiça é no sentido de que somente a partir da entrada em vigor da Lei Complementar 87/96 ficou autorizado o creditamento relativo a bens destinados ao ativo fixo e ao uso e consumo. Anteriormente à edição da referida norma, as regras relativas à compensação de créditos referentes ao ICMS estavam dispostas no Convênio ICMS $66 / 88$, que expressamente vedava tal creditamento em relação ao estabelecimento comercial.

2. Nos termos do art. 31 do Convênio 66/88, era vedada a compensação relativa a bens destinados ao ativo fixo e ao uso e consumo do estabelecimento comercial. Desse modo, o ICMS incidente sobre as contas de energia elétrica não poderia ser creditado como espécie de insumo, quando utilizado por empresa com atividade de mero comércio. 
3. Recurso especial desprovido."

A ementa do julgado esclarece com precisão o conteúdo do aresto. Em síntese, considera-se que a energia elétrica, quando consumida por estabelecimento comercial, possui a natureza de mercadoria destinada ao uso e consumo. Não sendo insumo - rectius, não consistindo em produto intermediário - seria vedado o crédito em questão.

“TRIBUTÁRIO. ICMS. COMPENSAÇÃO DO ICMS DAS CONTAS DE ENERGIA ELÉTRICA: PRINCÍPIO DA NÃO COMULATIVIDADE.

1. A utilização de energia elétrica por empresa comercial não pode ser tratada como insumo para efeito de compensação com o montante do imposto devido nas operações ou prestações seguintes.

2. Previsão expressa do não creditamento (art. 31, II, do Convênio 66/88). (...).

3. Recurso especial improvido., ${ }^{, 716}$

Corte:

Os seguintes excertos do voto da Min. ELIANA CALMON aclaram o raciocínio da

"As questões que devem ser respondidas são: a energia elétrica utilizada na atividade exclusivamente comercial pode ser objeto de creditamento do ICMS para compensação com as operações futuras, na comercialização de mercadorias? Em caso negativo, o não creditamento viola o princípio da não-cumulatividade? A resposta é negativa à luz da legislação pertinente.

(...)

O Convênio 66/88 previu, em seu art. 31, especificamente, as hipóteses em que não haveria o creditamento do ICMS para futura compensação, com algumas exceções:

'Art. 31. Não implicará crédito para compensação com o montante do

imposto devido nas operações ou prestações seguintes:

I - a operação ou a prestação beneficiada por isenção ou nãoincidência, salvo determinação em contrário da legislação;

II - a entrada de bens destinados a consumo ou à integração no ativo fixo do estabelecimento;

III - a entrada de mercadorias ou produtos que, utilizados no processo industrial, não sejam nele consumidos ou não integrem o produto final na condição de elemento indispensável a sua composição;

IV - os serviços de transporte e de comunicação, salvo se utilizados pelo estabelecimento ao qual tenham sido prestados na execução de serviços da mesma natureza, na comercialização de mercadorias ou em processo de produção, extração, industrialização ou geração, inclusive de energia.'

A regra, como se vê, era a impossibilidade de creditamento do tributo pago na entrada de bens destinados ao consumo, como, verbi gratia, a energia e-

\footnotetext{
${ }^{715}$ STJ, Primeira Turma, REsp nº 623.583/RJ, Relatora Min. DENISE ARRUDA, DJ 02.08.2007, p. 332.

${ }^{716}$ STJ, Segunda Turma, REsp no 482.435/RS, Relatora Min. ELIANA CALMON, DJ 04.08.2003, p. 277.
} 
létrica, excepcionando-se as hipóteses em que: 1) a operação ou mercadoria fosse beneficiada por legislação específica pela isenção ou pela nãoincidência e 2) as mercadorias que tivessem entrado fossem utilizadas em processo de industrialização da mercadoria, agregando-se, de alguma forma, ao produto final.

Atente-se que a exceção do inciso IV retrata hipótese distinta da dos autos, pois previu a possibilidade de creditamento do ICMS sobre serviços de transporte e de comunicação (operação anterior) quando tivessem sido utilizados no processo de geração, inclusive de energia elétrica (operação posterior).

Por conseqüência, na simples atividade de comercialização de mercadorias em que não houvesse qualquer tipo de processo de industrialização, estava vedado o creditamento."

O raciocínio expendido no aresto denota o posicionamento do STJ acerca do conceito de bem de uso e consumo: seria toda a mercadoria não consumida no processo de industrialização, ainda que diretamente aplicada à atividade da empresa, e que tampouco se incorporasse ao ativo imobilizado do contribuinte.

Em mais um acórdão no mesmo sentido, o STJ nega a qualidade de insumo à energia utilizada pelos estabelecimentos comerciais:

“TRIBUTÁRIO. ICMS. COMPENSAÇÃO. ENERGIA ELÉTRICA. ESTABELECIMENTO COMERCIAL. IMPOSSIBILIDADE. SÚMULAS 07 E 83/STJ. PRECEDENTES.

1. Inviável a compensação do ICMS relativo à energia elétrica utilizada por estabelecimento comercial, visto que não se caracteriza como insumo.

(...)

4. Agravo regimental improvido.,"717

Sob a égide da $\operatorname{LC} n^{\circ} 102 / 00$ a questão foi novamente analisada pelo STJ, em acórdão que tratava tanto do ICMS incidente sobre a energia elétrica como daquele incidente sobre os serviços de comunicação. Confira-se:

"O acórdão embargado declarada que 'é inviável o creditamento do ICMS relativo à energia elétrica e aos serviços de telecomunicações utilizados, tanto por estabelecimento comercial, como por estabelecimento industrial, visto que não se caracterizam como insumo'.

O acórdão divergente declara expressamente que:

'A LC 102/2000 não alterou substancialmente a restrição, explicitando apenas que o creditamento somente se daria quando a energia elétrica fosse consumida no processo de industrialização ou quando fosse o objeto da operação.'

${ }^{717}$ STJ, Segunda Turma, AgRg no Ag no 623.105/RJ, Relator Min. CASTRO MEIRA, DJ 21.03.2005, p. 330. 
Ou seja, o julgado da Segunda Turma aplica - textualmente - o disposto no art. 33 da Lei Complementar $n^{\circ} 87 / 96$, ao autorizar o creditamento do ICMS pago referente ao consumo de energia elétrica, desde que consumida no processo de industrialização; e o creditamento dos serviços de comunicação, desde que prestados na execução de serviços da mesma natureza. Conforme letra da lei que transcrevo:

'Art. 33. Na aplicação do art. 20 observar-se-á o seguinte:

(...)

II - somente dará direito a crédito a entrada de energia elétrica no estabelecimento:

(...)

b) quando consumida no processo de industrialização;

(...)

IV - somente dará direito a crédito o recebimento de serviços de comunicação utilizados pelo estabelecimento:

a) ao qual tenham sido prestados na execução de serviços da mesma natureza; (...)' (grifei)

Entendo que deve prevalecer a posição adotada no acórdão embargado - da Segunda Turma -, em razão do disposto no art. 33, inciso II, 'b', e, inciso IV, 'a', acima transcrito.

Em outro dizer, tem direito ao creditamento de ICMS o contribuinte que comprovar ter utilizado a energia elétrica 'no processo de industrialização' ou ter utilizado serviços de comunicação na 'execução de serviços da mesma natureza'.

Ante o exposto, dou provimento aos embargos de divergência.,"718

O caso, em síntese, resultou na restauração, pelo STJ, do primado da lei. Isso porque a LC no 87/96 (modificada pela LC $n^{\circ} 102 / 00$ ) dispõe que a energia elétrica utilizada em processo de industrialização é passível de creditamento, assim como o serviço de comunicação utilizado na execução de serviço da mesma natureza. Nesse sendeiro, por existirem regras expressas em relação a ambos os créditos pleiteados, seria indevido negá-los como fez, equivocadamente, o aresto que gerou a divergência acima transcrita.

Desse breve escorço quanto ao tratamento da energia elétrica em matéria de creditamento do ICMS, pode-se afirmar que as discussões mais profícuas quanto ao conceito de insumo, distinguindo-o dos bens de uso e consumo, foram as travadas sob a égide do Convênio ICM no 66/88. Analisando os precedentes, dentre os quais estão os transcritos anteriormente, resta claro que o conceito de insumo (ou produto intermediário) é relacionado pelo STJ com a produção industrial, não podendo ser caracterizável como tal a energia utilizada em estabelecimentos comerciais.

Para melhor delineamento da questão, serão analisados arestos que cuidaram do direito ao crédito de ICMS sobre combustíveis. Em relação a fatos ocorridos sob a égide do

${ }^{718}$ STJ, Primeira Seção, ERESP no 899.485/RS, Relator Min. HUMBERTO MARTINS, DJe 15.09.2008. 
Convênio ICM n ${ }^{\circ} 66 / 88$, confira-se a seguinte ementa que, apesar de longa, sumaria todos os fundamentos dos votos integrantes do acórdão:

“TRIBUTÁRIO. ICMS. CREDITAMENTO NA ENTRADA DE BENS DESTINADOS AO USO E CONSUMO E BENS DO ATIVO FIXO. PERÍODO ANTERIOR À LC 87/96. IMPOSSIBILIDADE. (...).

1. O direito ao creditamento do ICMS advindo da aquisição de bens que compõem o ativo imobilizado, bem como daqueles que se destinam ao uso e consumo, foi reconhecido apenas com a vigência da Lei Complementar 87/96, cujo artigo 33 afastou, expressamente, a retroatividade de sua incidência. (...).

2. In casu, restou assente no Tribunal de origem que:

(i) '(...)

Pelo que se infere do contrato de constituição de fls. 42/46, a empresa autora desenvolve a atividade comercial de transporte de produtos próprios e de terceiros (Cláusula $3^{\mathrm{a}}$, inciso X). Pretende a autora, ora apelante, o aproveitamento do crédito

decorrente do ICMS incidente sobre o combustível adquirido e utilizado no transporte das mercadorias por ela comercializadas. O Réu, em nenhum momento, sustenta que o crédito objeto do aproveitamento pretendido, não tenha sido no todo ou em parte utilizado na atividade de transporte de mercadorias, merecendo, pois, crédito a alegação feita pela autora.

Com efeito, referidos bens são necessários ao processo de industrialização e/ou comercialização das mercadorias produzidas pela autora, integrando, portanto, o custo do produto final, com base no qual se calcula o seu preço.

(...)

Dessa forma, entendo perfeitamente possível, o aproveitamento do ICMS pago quando da aquisição de insumos, para fins de compensação de créditos tributários.' (acórdão que julgou o recurso de apelação)

e

(ii) 'O ICMS referente às mercadorias adquiridas para consumo ou incorporação ao ativo permanente não acarreta crédito para a empresa até os dias atuais, pois a vigência da Lei Complementar $n^{\circ} 87 / 96$, que admite o crédito, ainda não se iniciou.

Ao contrário de mercadoria para consumo, o combustível constitui insumo, pois é parte da cadeia de produção da empresa, pelo que não se enquadra na vedação de aproveitamento do ICMS.' (acórdão que julgou os embargos infringentes)

3. Nada obstante, a aquisição de combustível consumido no transporte das mercadorias comercializadas pela empresa foi efetuada durante a vigência do Convênio 66/88, cujo artigo 31, inciso III, vedava expressamente a compensação nesses casos (Entendimento análogo ao REsp 850.362/MG, Rel. Ministra Eliana Calmon, Segunda Turma, julgado em 15.02.2007, DJ 02.03.2007).

(...)

5. Recurso especial parcialmente provido."719

${ }^{719}$ STJ, Primeira Turma REsp n ${ }^{\circ}$ 919.363/DF, Relator Min. LUIZ FUX, DJe 07.08.2008. 
O caso era de uma empresa comercial que possuía uma pequena frota para transporte de produtos próprios. Seu pleito, acolhido pela Corte de origem, residia no direito de abater do ICMS a pagar, os créditos do imposto referentes ao combustível utilizado em sua frota. Entretanto, o STJ, ante a ausência de regra específica quanto ao crédito de combustíveis, valeu-se do seu tradicional entendimento de que, não sendo o óleo diesel ou a gasolina utilizados no processo industrial (hipótese do art. 33, III, do Convênio ICM nº 66/88), inexistiria autorização para o crédito.

Reafirmando esse entendimento, porém sob a égide da LC no 87/96, o STJ qualificou como bem de uso e consumo o óleo diesel utilizado para transporte interno do ferrogusa entre setores da usina siderúrgica. Segundo o STJ, como o consumo do óleo diesel não se dava na produção, mas sim em uma atividade lateral, seria inviável qualificá-lo como insumo para fins de creditamento do ICMS. Equivocadamente, no entanto, o STJ reconheceu o crédito sobre o óleo diesel a partir de 01.01.1998, data originária insculpida na LC n $n^{\circ} 87 / 96$, para que o crédito de ICMS sobre bens de uso e consumo fosse aproveitado pelos contribuintes. Olvidou-se a Corte de que tal prazo foi postergado diversas vezes, nunca tendo advindo o termo inicial para exercício do direito ao crédito (que, atualmente, está diferido para 01.01.2011, por força da $\mathrm{LC}^{\circ}{ }^{\mathrm{1}}$ 122/06). Veja-se a ementa:

“TRIBUTÁRIO. ICMS. APROVEITAMENTO DE CRÉDITO. UTILIZAÇÃO MATERIAL DE CONSUMO NO PROCESSO PRODUTIVO (ÓLEO DIESEL PARA TRANSPORTE INTERNO DO FERRO GUSA). DECRETO-LEI 406/68, CONVÊNIO 66/88 E LEI COMPLEMENTAR 87/96. (...). (...)

2. Na vigência do Decreto-lei 406/68 e do Convênio 66/88, a aquisição de produtos ou mercadorias que, apesar de integrarem o processo de industrialização, nele não eram completamente consumidos e nem integravam o produto final, não gerava direito ao creditamento do ICMS. Previsão expressa do não-creditamento (inciso III do art. 31 do Convênio 66/88).

3. Entretanto, a LC $87 / 96$ (Lei Kandir) veio a reconhecer o direito ao crédito de ICMS relativo à aquisição de bens destinados ao ativo imobilizado, material de uso e consumo, bem como ao recebimento de serviço de transporte. Jurisprudência pacificada nesta Corte.

4. Reconhecimento, no caso concreto, da legalidade do aproveitamento de crédito do ICMS sobre aquisição de óleo diesel consumido no processo produtivo a partir de $1^{\circ}$ de janeiro de 1998 , de acordo com o art. 33 da LC 87/96 (em sua redação original).

5. Recurso especial da Fazenda não conhecido e provido em parte o recurso especial da USIMINAS."

${ }_{720}$ STJ, Segunda Turma, REsp no $850.362 /$ MG, Relatora Ministra ELIANA CALMON, DJ 02/03/2007, p. 285. 
E, agora, os principais trechos do voto da Min. ELIANA CALMON, Relatora do caso:

"A perícia apontou que o material objeto da execução é utilizado nos setores da linha de produção, entre os altos-fornos e aciarias e a finalidade seria a de gerar energia para as locomotivas que levam o ferro gusa entre de um desses setores para o outro (sic). Conclui a perícia, ainda, que o óleo diesel é totalmente consumido no processo industrial e que a legislação a respeito dispõe que somente darão direito de crédito as mercadorias destinadas ao uso ou consumo, que tenham sido empregadas a partir de janeiro de 2.007 , havendo um dispositivo anterior que indicava que tal permissivo remontaria a partir de entradas ocorridas a partir de janeiro de 1.998. Conclui a perícia também, que a embargante classifica o combustível usado no transporte interno como produtos intermediários, porque, na sua visão, tais materiais possuem esta característica. Entende o perito que se faria presente o direito de a embargante querer se aproveitar do crédito na operação em tela. (fls. 321)

(...)

A questão reside exatamente em saber-se se o óleo combustível utilizado para movimentar o carro torpedo no transporte do ferro gusa (produto intermediário) de uma seção para outro do estabelecimento é ou não consumido de forma integral e imediata na produção do aço (produto final) e, portanto, equiparado a produto intermediário, passível de creditamento do ICMS na operação de entrada para compensação com as operações de saída do produto final, na comercialização deste.

(...) O Convênio 66/88 previu, em seu art. 31, especificamente, as hipóteses em que não haveria o creditamento do ICMS para futura compensação:

'Art. 31. Não implicará crédito para compensação com o montante do imposto devido nas operações ou prestações seguintes:

(...)

III - a entrada de mercadorias ou produtos que, utilizados no processo industrial, não sejam nele consumidos ou não integrem o produto final na condição de elemento indispensável a sua composição;'

(...)

Verifico que a exceção do inciso III retratava a hipótese dos autos, pois previu que a entrada de mercadorias ou produtos que, utilizados no processo industrial, não fossem nele consumidos ou não integrassem o produto final na condição de elemento indispensável a sua composição, não implicariam em crédito para compensação. No caso em referência, o óleo diesel utilizado no transporte interno do ferro gusa, apesar de consumido no processo de produção, não se agrega, de nenhuma forma, ao produto final.

(...)

Posteriormente, a Lei Complementar 87/96, regulando o ICMS, assim dispôs sobre as hipóteses de creditamento:

(...)

Mais uma vez, a legislação restringiu, de forma expressa, as hipóteses de creditamento do ICMS, proibindo-o quando ele se referisse a entrada de mercadorias que não fizessem parte da atividade do estabelecimento.

Não obstante, a LC 87/96, nesse ponto, passou a evitar a oneração excessiva do processo industrial com a tributação em cascata da matéria-prima (inclu- 
indo-se o material secundário) e dos serviços relacionados com a atividade específica do estabelecimento.

(...)

Com estas considerações, não conheço do recurso especial da FAZENDA e dou parcial provimento ao recurso especial da USIMINAS, apenas para reconhecer a legalidade do aproveitamento de crédito do ICMS sobre a aquisição de óleo diesel consumido no processo produtivo a partir de $1^{\circ}$ de janeiro de 1998.",721

Como se dessume do trecho transcrito, o STJ afasta o caráter de insumo do óleo diesel ao argumento de que ele não se agrega ao produto final. Apesar da redação ser deficiente, pode-se inferir que o STJ pretendeu também dizer que o óleo diesel em questão não é consumido no processo produtivo, eis que não integra a linha principal, prestando-se apenas para uma atividade acessória (transporte interno do ferro-gusa na siderúrgica). Assim, seria bem de uso e consumo, gerador de crédito a partir da data futura fixada na $\mathrm{LC}^{\circ}$ $87 / 96$.

\subsection{AS DEFINIÇÕES.}

Do escorço normativo e jurisprudencial realizado, pode-se, agora, passar à definição do que sejam matérias-primas, produtos intermediários e bens de uso e consumo para fins de creditamento do ICMS.

\subsection{MATÉRIAS-PRIMAS.}

São matérias-primas - também tratadas como espécie do gênero insumos (com o que concordamos, em face da amplitude deste termo) - todos os bens que se agregam ao produto final. Em outros termos, ela é, necessariamente, um insumo consumido na produção e integrante da mercadoria fabricada.

O conceito calha à fiveleta para as indústrias, cuja atividade precípua é a transformação de materiais em produtos acabados. Entretanto, a definição não é adequada para as atividades comerciais e tampouco para as prestações de serviço tributadas pelo ICMS.

Afinal, como o comerciante adquire produtos para posterior revenda, obviamente, deverá fazer investimentos que permitam ou facilitam a venda para o consumidor. É o caso da aquisição de folders publicitários, de cartazes utilizados em vitrines, enfim, de diversas formas de comunicação com o cliente, fundamentais para o exercício do comércio.

$\overline{721}$ STJ, Segunda Turma, REsp n ${ }^{\circ}$ 850.362/MG, Relatora Ministra ELIANA CALMON, DJ 02/03/2007, p. 285 , destaques nossos. 
No caso dos serviços de comunicação e transporte interestadual e intermunicipal a situação é similar. Afinal, sendo impossível que algo se agregue ao produto final - que é, por exemplo, um serviço ou uma atividade imaterial - não se pode falar na existência de matérias-primas. Entretanto, como deve-se tratar dos créditos de energia elétrica no serviço de comunicação e do combustível no transporte? Seria coerente com a lógica da nãocumulatividade, a determinação do creditamento, pois são produtos essenciais para a consecução dessas atividades, ainda que não se agreguem - por impossibilidade lógica - ao produto final.

A solução para o cumprimento adequado da não-cumulatividade do ICMS (tanto para o setor comercial, como para o de prestação de serviços) estaria na adequada conceituação dos produtos intermediários. Sendo cediço que as matérias-primas devem integrar a mercadoria produzida, outros bens utilizados de forma essencial (no processo industrial, comercial ou de prestação de serviços) deveriam gerar o direito ao creditamento do ICMS. Entretanto, por erronia, o conceito de produtos intermediários também é apenas aplicável aos processos industriais, tendo sido excluidos o comércio e os serviços de comunicação e transporte.

\subsection{PRODUTOS INTERMEDIÁRIOS.}

\subsection{DEFINIÇÃO INICIAL.}

Os bens intermediários são, muitas vezes, nominados insumos, em que pese entendermos que insumo é um gênero ao qual pertencem tanto as matérias-primas como os produtos intermediários.

Pois bem. A partir dos conceitos explicitados nos itens anteriores, pode-se definir produto intermediário como:

(a) mercadoria consumida na linha principal do processo de produção;

(b) item essencial à industrialização.

Portanto, segundo normas estaduais e, ainda, de acordo com julgados, tanto do $\mathrm{STF}^{722}$ como do STJ, para se conceituar produto intermediário não basta que determinada mercadoria seja consumida no processo produtivo. $\mathrm{O}$ consumo deve estar diretamente ligado à linha principal de produção. Ademais, o bem deverá ser essencial para a atividade da indústria, sob pena de ser qualificado como bem de uso e consumo.

A qualificação em linha principal e linha secundária deriva da indústria automotiva. Os automóveis são montados em uma linha de produção, passando por vários estádios até

${ }^{722}$ Vide Título II, Capítulo VI, Item 6.12. 
serem finalizados. Todo o consumo de peças, tintas e outros bens na linha principal será passível de creditamento do ICMS, sendo qualificados (esses produtos) como intermediários ou insumos. Lado outro, o combustível utilizado para que o test-drive final, na saída da fábrica, possa ser feito, não se qualifica como insumo, por estar fora do processo de produção. Nessa toada, trata-se de bem de uso e consumo, passível apenas em tese de creditamento, pois na prática seu dies a quo está, hoje, postergado para 01.01.2011.

Assim, para ser produto intermediário não basta ser consumido pela indústria. Deve haver uma relação de essencialidade entre o bem e o processo produtivo. Do contrário, inexistirá direito ao crédito.

Esse é o conceito de produto intermediário, aplicado pelos Tribunais e por considerável parte das legislações estaduais. Contudo, há um erro de premissa na definição, conforme já alertamos anteriormente: toda a discussão acerca da existência ou não do direito em tela é construída em torno das indústrias. Contudo, o ICMS é recolhido também pelos comerciantes e pelos prestadores de serviço de transporte e comunicação. Dessarte, não sendo o imposto em tela restrito às indústrias, a atual definição de produto intermediário ignora solenemente a amplitude do ICMS, em face de suas distintas regras-matrizes e contribuintes.

Tal fato já seria suficiente para pleitear uma revisão da jurisprudência do STJ sobre o tema. Mas os problemas não se encerram neste ponto. A exigência de utilização da mercadoria na linha principal da produção leva a absurdos como o não-reconhecimento dos créditos de ICMS sobre o combustível utilizado para transportar a matéria-prima (ferrogusa) de um setor a outro da siderúrgica. Da mesma forma, o combustível destinado ao test-drive final dos automóveis que saem da linha de montagem não é considerado insumo. Ora, o processo produtivo é um todo e não se resume ao espaço físico pelo qual a mercadoria passa até adquirir sua conformação final. As indústrias podem ter grandes áreas, cada qual com uma finalidade. Podem dividir o processo em várias etapas, realizadas, inclusive, em estabelecimentos distintos. Assim, é equivocada a delimitação de uma suposta "linha principal" e a negativa do crédito de ICMS a todos os bens consumidos fora dela (ao argumento de que não seriam insumos, mas sim material de uso e consumo). Isto porque tal raciocínio trabalha com premissas irreais, que não coadunam com a atividade industrial do século XXI.

Portanto, a nosso sentir, o conceito de produto intermediário merece uma profunda revisão por parte da doutrina e da jurisprudência, de modo que: 
(a) seja estendido às atividades comerciais e às prestações de serviço tributáveis pelo ICMS;

(b) se permita, na indústria, o creditamento de todos os bens utilizados na produção, e não apenas os aplicados em uma suposta "linha principal" de montagem.

\subsection{CONSUMO VERSUS DESGASTE E A INEXIGÊNCIA DE CONTA- TO DIRETO COM O PRODUTO FINAL.}

Além dos requisitos acima referidos, é cediço que os bens intermediários devem ser consumidos de forma imediata e integral no processo produtivo.

Por integral entende-se a inutilização completa da mercadoria, dela restando apenas resíduos ou, caso contrário, tornando-se imprópria para o uso.

Já o termo imediato gerou inúmeras controvérsias entre Fiscos e contribuintes. Isso porque diversas empresas, consoante se infere das lides que chegaram ao STJ, pretenderam enquadrar como intermediários bens que, em verdade, integram o seu ativo imobilizado, como por exemplo ferramentas, partes e peças de máquinas, dentre outros.

Atento a esse fato, o STJ distinguiu, com propriedade, as seguintes situações:

(a) bens que integram o ativo imobilizado (é dizer, incorporam-se ao patrimônio da empresa por 12 meses ou mais ${ }^{723}$ ): o seu desgaste natural, ínsito a qualquer mercadoria, não é equiparável ao consumo imediato exigido para caracterização dos produtos intermediários;

(b) bens que admitem mais de uma utilização, porém se consomem em período inferior a 12 (doze) meses: podem, a priori, ser enquadrados como intermediários. É o caso dos materiais refratários que revestem fornos de siderúrgicas, os quais têm desgaste lento, porém não se integram ao forno dado que são periodicamente substituídos, resultando na sua qualificação como produto intermediário ${ }^{724}$.

Assim, consumo imediato não significa instantâneo. Da mesma forma, não permite que um bem que demore mais de um ano para ser consumido seja caracterizado como in-

\footnotetext{
${ }^{723}$ Dispõe o Regulamento do Imposto de Renda (Decreto no 3.000/99):

"Aplicações de Capital

Art. 301. (...).

$\S 2^{\circ}$. Salvo disposições especiais, o custo dos bens adquiridos ou das melhorias realizadas, cuja vida útil ultrapasse o período de um ano, deverá ser ativado para ser depreciado ou amortizado (Lei $\mathrm{n}^{\circ}$ 4.506, de 1964, art. $\left.45, \S 1^{\circ}\right)$."

${ }^{724}$ STJ, Segunda Turma, REsp n 18.361/SP, Relator Min. HELIO MOSIMANN, DJ 07.08.1995, p. 23.026.
} 
termediário. Afinal, após um ano a mercadoria passa a integrar o ativo da empresa e, por essa razão, seu desgaste natural não se confundirá com o consumo imediato.

Outro debate relacionado aos bens intermediários referia-se à necessidade de contato físico com o produto final. Para o Fisco, seria essencial que a mercadoria consumida tivesse contato direto com a mercadoria resultante do processo industrial; já os contribuintes predicavam, com base na própria redação do Convênio ICM nº 66/88, que bastava o consumo no processo, ainda que sem contato com o produto, para que exsurgisse o direito ao creditamento. Como se infere dos acórdãos do STJ colacionados anteriormente, o consumo no processo já é suficiente (com a ressalva de que, por erronia, a jurisprudência e os Fiscos exigem que a utilização se dê na linha principal da produção, como visto no item precedente).

Para logo, pode-se concluir que bem intermediário é aquele consumido de forma imediata ${ }^{725}$ e integral, diretamente no processo de produção, ainda que não entre em contato físico com o produto final. Isto é, o consumo imediato não exige a inutilização instantânea dos materiais, desde que esses não se integrem ao ativo imobilizado, entre outros requisitos. Assim, um bem pode ser classificado como intermediário mesmo sendo reutilizado algumas vezes até a sua efetiva consumição.

\subsection{BENS DE USO E CONSUMO.}

Destinam-se ao uso e consumo do estabelecimento as mercadorias que se consomem, porém não sendo diretamente utilizadas no processo produtivo. Enfim, são bens que indiretamente integram o custo final das mercadorias comercializadas e dos serviços prestados. Todavia, não estando diretamente afetados ao processo de produção (caso dos materiais de limpeza), não podem ser qualificados como insumos à luz da jurisprudência dominante.

Novamente manifestamos nossa discordância com o conceito restrito de bens intermediários que os Fiscos estaduais têm apregoado, com o beneplácito da jurisprudência do $\mathrm{STJ}^{726}$. Não se pode admitir, v.g., que uma indústria funcione sem a limpeza regular e contínua de suas instalações fabris, que exige, além do material regular de limpeza, trocas

\footnotetext{
${ }^{725}$ Não se trata de consumo instantâneo, mas deve ocorrer antes de 12 (doze) meses, do contrário o bem deixa de ser caracterizado como insumo para se tornar integrante do ativo imobilizado.

${ }^{726}$ Rejeitando o crédito sobre os citados materiais de limpeza, cite-se: STJ, Primeira Turma, REsp $\mathrm{n}^{\mathbf{0}}$ 197.121/MG, Relator Min. GARCIA VIEIRA, DJ 10.05.1999, p. 119.
} 
de óleos, lubrificantes e assemelhados das máquinas. Entrementes, esses materiais têm sido qualificados como destinados ao uso e consumo. Sendo essencial para o funcionamento regular da indústria e sendo nesta consumido, o produto, a nosso sentir, já possui os requisitos necessários para ser qualificado como intermediário.

De todo modo, é fato que, à luz da doutrina e jurisprudência dominantes, os materiais de uso e consumo diferem dos intermediários pela forma de sua utilização. Ao passo que os bens intermediários são empregados na linha central de produção e os destinados ao uso e consumo são utilizados nas linhas marginais (como no caso do combustível utilizado em frota própria para transporte de insumos de um a outro setor da usina, na esteira do entendimento do STJ).

A importância da adequada distinção entre bens intermediários e material de consumo decorre do fato de que o crédito sobre tais bens nunca pôde ser aproveitado. No bojo do Convênio ICM n $66 / 88$ havia vedação expressa ao creditamento sobre os bens destinados ao consumo (art. 31, II). Apesar de a LC nº 87/96 ter autorizado expressamente o crédito sobre os bens de uso e consumo a partir de $1^{\text {o }}$ de janeiro de 1998 (ou seja, um ano e meio após sua publicação), desde sua edição o referido dies a quo vem sendo sucessivamente postergado por diversas leis complementares. Confira-se:

\begin{tabular}{|l|l|l|}
\hline Diploma normativo & Data de publicação & $\begin{array}{l}\text { Data de início do } \\
\text { aproveitamento do crédito } \\
\text { sobre bens } \\
\text { de uso e consumo }\end{array}$ \\
\hline LC n 87 (texto original) & 13.09 .1996 & 01.01 .1998 \\
\hline LC n ${ }^{\circ} 92$ & 23.12 .1997 & 01.01 .2000 \\
\hline$L C n^{\circ} 99$ & 20.12 .1999 & 01.01 .2003 \\
\hline$L C n^{\circ} 114$ & 16.12 .2002 & 01.01 .2007 \\
\hline$L C n^{\circ} 122$ & 12.12 .2006 & 01.01 .2011 \\
\hline
\end{tabular}

As sucessivas postergações têm sido objeto de candentes críticas doutrinárias. De fato, além de atentar contra a intenção original da lei - que claramente é a de conceder direito ao crédito financeiro, inclusive sobre mercadorias destinadas ao uso e consumo do estabelecimento - as modificações têm sido perpetradas dias antes do advento do termo 
legal. Isso surpreende o contribuinte que, decerto, já considerava os créditos de ICMS aos quais passaria a fazer jus na competência seguinte. Tanto é que diversas empresas têm argüido judicialmente a impossibilidade de aplicação das normas que postergam o direito ao aproveitamento dos créditos antes de decorridos 90 (noventa) dias de sua publicação. Segundo essa corrente, como as leis em comento, ao impedirem o creditamento, majoram o tributo devido, elas devem observância à espera nonagesimal. Essa regra é aplicável ao ICMS desde o advento da $\mathrm{EC} \mathrm{n}^{\circ} 42 / 03^{727}$ que estendeu, para todos os tributos, a regra antes aplicável apenas às contribuições para a seguridade social do art. 195 da Lei Maior ${ }^{728}$.

\subsubsection{CRÉDITO SOBRE BENS DESTINADOS AO ATIVO PERMANENTE. 12.2.2.2.1. HISTÓRICO NORMATIVO.}

O Decreto-lei $n^{\circ}$ 406/68, consoante já visto, não possuía disposições aprofundadas acerca da não-cumulatividade. Como lembra A. J. COSTA ${ }^{729}$, competia aos Estadosmembros a edição de regras para determinar se o crédito seria físico ou financeiro, dentre outras medidas necessárias à regulamentação da não-cumulatividade. Nesse período, as normas aplicáveis ao IPI foram a base para a edição das regras regentes do ICM. Portanto, não se permitia o cálculo de créditos do imposto estadual sobre os bens adquiridos para o ativo imobilizado das empresas, o que fazia com que o ICM fosse, tal como o IPI, um IVA da espécie produto bruto.

Com a edição do Convênio ICM nº 66/88, já sob a égide da atual Constituição, o tema passou a ser tratado - como deveria ter sido desde sempre - no âmbito das normas gerais do ICMS. Todavia, a regra insculpida no art. 31, IV do referido Convênio, proibia o

${ }^{727} \mathrm{CR} / 88$ :

“Art. 150. Sem prejuízo de outras garantias asseguradas ao contribuinte, é vedado à União, aos Estados, ao Distrito Federal e aos Municípios:

III - cobrar tributos:

c) antes de decorridos noventa dias da data em que haja sido publicada a lei que os instituiu ou aumentou, observado o disposto na alínea $b$; (incluído pela Emenda Constitucional $\mathrm{n}^{\circ} 42$, de 19.12.2003)"

\footnotetext{
${ }^{728}$ Até o advento da $\mathrm{EC} \mathrm{n}$ o 42/03, como é sabido, apenas as contribuições para financiamento da seguridade social previstas no art. 195 da CR/88 sujeitavam-se à espera nonagesimal. Os demais tributos eram submetidos ao princípio da anterioridade anual, que permitia manobras como a publicação de leis tributárias em 31 de dezembro para cobrança no dia imediatamente subseqüente. A EC n 42/03 corrigiu o problema, cumulando a noventena à garantia da anterioridade anual.

${ }^{729}$ COSTA, Alcides Jorge. ICM na Constituição e na Lei Complementar. São Paulo: Resenha Tributária, 1978, p. 156.
} 
desconto de créditos do imposto estadual sobre a entrada de bens destinados "à integração no ativo fixo do estabelecimento".

A autorização para creditamento do ICMS suportado na aquisição de bens para o ativo fixo somente adveio por meio da $\mathrm{LC}^{\circ}$ 87/96, que positivou o crédito financeiro do ICMS. No caput do art. 20 o direito à compensação do imposto pago nas operações anteriores era permitido de forma ampla, abarcando também a entrada de mercadorias destinadas ao "ativo permanente" do estabelecimento ${ }^{730}$.

Todavia, caso o bem integrante do ativo fosse alienado antes de decorridos 5 (cinco) anos de sua aquisição, o contribuinte deveria estornar o crédito que, no momento do ingresso do ativo em seu estabelecimento, fora integralmente aproveitado à vista. $\mathrm{O}$ estorno previsto no $\S 1^{\circ}$ do art. 21 da $\operatorname{LC} n^{\circ} 87 / 96$, em sua redação originária, era da ordem de $20 \%$ (vinte por cento) por ano ou fração que faltasse para completar o lustro.

Outrossim, na hipótese de bens do ativo serem utilizados para a produção de mercadorias ou prestação de serviços isentos ou não-tributados, o crédito inicialmente escriturado deveria ser estornado proporcionalmente ${ }^{731}$. O cálculo do estorno era simples: dividiase o valor do crédito aproveitado à vista por 60 (sessenta). Afinal, após 60 meses o contribuinte, se desejasse, poderia até mesmo alienar o bem do ativo sem estornar qualquer valor de ICMS. Sobre a fração de 1/60 aplicava-se a relação entre as saídas isentas e nãotributadas e as saídas totais no período. Assim, v.g., se 50\% das operações do contribuinte tivessem sido realizadas ao abrigo da tributação, ele teria que estornar, no mês, metade do crédito correspondente a 1/60 do valor já aproveitado no momento de ingresso do ativo em seu estabelecimento ${ }^{732}$. As exportações eram equiparadas a operações tributadas, não entrando no cômputo do fator de estorno ${ }^{733}$. Após decorrido o prazo de cinco anos da entrada do bem do ativo no estabelecimento, o valor remanescente do crédito seria cancelado (art. $21, \S 8^{\circ}$ da redação originária da $\left.\operatorname{LC} n^{\circ} 87 / 96\right)$.

\footnotetext{
${ }^{730}$ A autorização foi pro futuro, não operando efeitos retroativos. É ver a $L C \mathrm{n}^{\circ}$ 87/96: "Art. 33. (...).

III - somente darão direito de crédito as mercadorias destinadas ao ativo permanente do estabelecimento, nele entradas a partir da data da entrada desta Lei Complementar em vigor.”

${ }^{731}$ Art. $20, \S 5^{\circ}$, c/c art. $21, \S \S 4^{\circ}, 5^{\circ}, 6^{\circ}$ e $7^{\circ}$ da $\operatorname{LC~n}{ }^{\circ} 87 / 96$, redação originária.

732 Os cálculos aqui referidos seriam todos feitos no Controle de Ingressos do Ativo Permanente (Livro CI$\mathrm{AP}$ ), por força da determinação constante do art. $20, \S 5^{\circ} \mathrm{c} / \mathrm{c}$ art. $21, \S 7^{\circ}$ da LC n ${ }^{\circ}$ 87/96 (redação originária).

${ }^{733}$ Art. $21, \S 5^{\circ}$ da LC nº 87/96, redação originária.
} 
Com a $\mathrm{LC} \mathrm{n}^{\circ} 102 / 00$, a forma de aproveitamento do crédito sobre bens do ativo fixo sofreu modificações. Ao invés de creditamento à vista, no momento da entrada no estabelecimento, com eventuais estornos (em decorrência da alienação do bem antes de transcorrido um qüinqüênio ou na proporção das saídas isentas ou não-tributadas dentro dos primeiros cinco anos), o crédito passou a ser fracionadamente apropriado à razão de 1/48 por mês (art. 20, $\S 5^{\circ}$ da LC no 87/96, redação atual). Essa fração deve ser multiplicada pelo resultado da divisão entre as operações e prestações tributadas e o total de operações e prestações do período. Equiparam-se às tributadas as saídas tanto para exportação, quanto as de papel destinado à impressão de livros, jornais e periódicos (art. 20, §5 , III, cuja redação atual decorre da $\mathrm{LC} \mathrm{n}^{\circ} 120 / 05$, que passou a considerar tributadas, para efeitos do cálculo, as saídas de papel imune ${ }^{734}$ ). Se o bem do ativo permanente for alienado antes de transcorrido o quadriênio dentro do qual se dá o creditamento, cessa o direito do contribuinte de continuar aproveitando os créditos. Outrossim, ao cabo dos quatro anos, eventual saldo remanescente do crédito (em razão dos estornos realizados) será cancelado.

Caso o ativo imobilizado seja previamente destinado a fim alheio à atividade do estabelecimento, o $\$ 1^{\circ}$ do art. 20 da $\mathrm{LC} \mathrm{n}^{\circ} 87 / 96$ impede o creditamento (em regra aplicável a todas as mercadorias e serviços tributados adquiridos pelo contribuinte). Da mesma forma, se após a entrada no estabelecimento o bem do ativo vier a ser destinado a fim diverso à atividade do contribuinte, o crédito deverá ser estornado (art. 21, III da LC no 87/96).

\subsection{O CONCEITO DE ATIVO PERMANENTE.}

O Convênio ICM nº 66/88 vedava os créditos sobre as entradas destinadas ao "ativo fixo”. Já a LC n 87/96, com suas alterações posteriores, autoriza o creditamento sobre as mercadorias que integrem o "ativo permanente".

Esses conceitos utilizados pela legislação do ICMS (e, também, pela do IPI, como já visto, e pela do PIS/COFINS, como se verá) são oriundos da ciência da contabilidade e foram positivados na legislação pátria por meio da Lei de Sociedades por Ações (Lei $\mathrm{n}^{\circ}$ 6.404/76 e com as modificações das Leis $n^{\circ}$ s 11.638/07 e 11.941/09). Confira-se:

"Art. 178. No balanço, as contas serão classificadas segundo os elementos do patrimônio que registrem, e agrupadas de modo a facilitar o conhecimento e a análise da situação financeira da companhia.

734 O papel destinado à impressão de livros, jornais e periódicos é imune de impostos por força do art. 150 , VI, $d$ da CR/88. 
$\S 1^{\circ}$. No ativo, as contas serão dispostas em ordem decrescente de grau de liquidez dos elementos nelas registrados, nos seguintes grupos:

I - ativo circulante; e

II - ativo não circulante, composto por ativo realizável a longo prazo, investimentos, imobilizado e intangível." (destaques nossos)

Dessarte, a conta do ativo abriga diversas rubricas, classificadas pelo grau de liquidez. A primeira delas é a do ativo circulante, que corresponde aos direitos "realizáveis no curso do exercício social subseqüente" e às "aplicações de recursos em despesas do exercício seguinte" (art. 179, I da Lei $n^{\circ}$ 6.404/76 e modificações posteriores). A segunda é a do ativo não-circulante, que admite quatro subespécies:

(a) ativo realizável a longo prazo;

(b) investimentos;

(c) ativo imobilizado;

(d) intangível.

O ativo realizável a longo prazo corresponde, em síntese, a direitos realizáveis após o término do exercício financeiro seguinte (art. 179, II da Lei $n^{\circ} 6.404 / 76$ e alterações posteriores $^{735}$ ).

A conta de investimentos compreende às "participações permanentes em outras sociedades e os direitos de qualquer natureza, não classificáveis no ativo circulante, e que não se destinem à manutenção da atividade da companhia ou da empresa" (art. 179, III da Lei $n^{\circ}$ 6.404/76 e alterações posteriores).

Ao ativo imobilizado pertencem "os direitos que tenham por objeto bens corpóreos destinados à manutenção das atividades da companhia ou da empresa ou exercidos com essa finalidade, inclusive os decorrentes de operações que transfiram à companhia os benefícios, riscos e controle desses bens" (art. 179, IV da Lei n ${ }^{\circ} 6.404 / 76$ e alterações posteriores). Assim, todo bem corpóreo destinado à manutenção das atividades da empresa (inclusive os que estão na posse da companhia por força de leasing) são classificados na conta do ativo imobilizado.

No intangível estão registrados "os direitos que tenham por objeto bens incorpóreos destinados à manutenção da companhia ou exercidos com essa finalidade, inclusive o fundo de comércio adquirido" (art. 179, VI da Lei n ${ }^{\circ}$ 6.404/76 e alterações posteriores).

\footnotetext{
735 O ativo realizável a longo prazo abarca também os direitos "derivados de vendas, adiantamentos ou empréstimos a sociedades coligadas ou controladas, diretores, acionistas ou participantes no lucro da companhia, que não constituírem negócios usuais na exploração do objeto da companhia" (art. 179, II da Lei n $^{\circ}$ $6.404 / 76$ e alterações posteriores).
} 
O Regulamento do Imposto de Renda (Decreto ${ }^{\circ}$ 3.000/99), ao detalhar os requisitos para depreciação de bens do ativo permanente, estipula - com base nas leis de regência do IRPJ - o critério da incorporação ao patrimônio da empresa por 12 (doze) meses ou mais. Veja-se:

"Art. 301. O custo de aquisição de bens do ativo permanente não poderá ser deduzido como despesa operacional, salvo se o bem adquirido tiver valor unitário não superior a trezentos e vinte e seis reais e sessenta e um centavos, ou prazo de vida útil que não ultrapasse um ano (Decreto-Lei $\mathrm{n}^{\circ}$ 1.598, de 1977, art. 15, Lei no 8.218, de 1991, art. 20, Lei no 8.383, de 1991, art. $3^{\circ}$, inciso II, e Lei $\mathrm{n}^{\circ} 9.249$, de 1995 , art. 30).

$\S 1^{\circ}$. Nas aquisições de bens, cujo valor unitário esteja dentro do limite a que se refere este artigo, a exceção contida no mesmo não contempla a hipótese onde a atividade exercida exija utilização de um conjunto desses bens. $\S 2^{\circ}$. Salvo disposições especiais, o custo dos bens adquiridos ou das melhorias realizadas, cuja vida útil ultrapasse o período de um ano, deverá ser ativado para ser depreciado ou amortizado (Lei no 4.506, de 1964, art. 45, $\left.\S 1^{\circ}\right)$." (destaques nossos)

Além de estipular o critério temporal, o RIR determina que tanto os bens adquiridos como as melhorias realizadas (cuja vida útil ultrapasse um ano) deverão ser ativados para fins de depreciação ou amortização.

A Receita Federal do Brasil, em instrução e parecer normativos emitidos sobre o tema, delineia o conceito sub examine. Confira-se, inicialmente, a Instrução Normativa $\mathbf{n}^{\circ}$ 71/78:

"No ativo imobilizado serão classificados os direitos que tenham por objeto bens destinados à manutenção das atividades da pessoa jurídica, ou os exercidos com essa finalidade, inclusive os de propriedade industrial e comercial." 736

O mesmo caminho é trilhado pelo Parecer Normativo $n^{\circ} 2 / 84$, ao tratar das partes e peças de reposição (que os contribuintes intentavam, equivocadamente, classificar como bens intermediários):

"As contas que registrem recursos aplicados na aquisição de partes e peças, máquinas e equipamentos de reposição de bens do ativo imobilizado, quando referidas partes e peças tiverem vida útil superior a um ano, devem ser classificadas no ativo imobilizado."737

\footnotetext{
736 TEBECHRANI, Alberto. Novo Regulamento do Imposto de Renda, v. I. São Paulo: Resenha Gráfica, 1999, p. 690.

737 TEBECHRANI, Alberto. Novo Regulamento do Imposto de Renda, v. I. São Paulo: Resenha Gráfica, 1999, p. 691.
} 
É interessante registrar que o termo "ativo fixo" utilizado pelo Convênio ICM n 66/88 nunca constou da Lei de Sociedades por Ações, mas desde sempre foi interpretado como sinônimo de ativo permanente.

Por outro lado, a nomenclatura "ativo permanente", utilizada na LC n 87/96 e no próprio RIR, não mais subsiste na Lei de S/As por força da última alteração realizada pela Lei $\mathrm{n}^{\mathrm{o}} 11.941 / 09$. Originariamente, as contas do ativo eram divididas em: circulante, realizável a longo prazo e permanente. Esta se dividia em sub-contas de investimentos, ativo imobilizado e ativo diferido. Com o advento da Lei $\mathrm{n}^{\circ}$ 11.638/07, incluiu-se mais uma subconta no ativo permanente, a de intangíveis. Contudo, a Lei $\mathrm{n}^{\mathrm{o}}$ 11.941/09 modificou toda essa formatação, consoante se viu anteriormente. Assim, hoje têm-se duas grandes contas do ativo: circulante e não-circulante. Dentro do circulante encontramos as sub-contas do ativo realizável a longo prazo (que era uma conta apartada do ativo permanente), de investimentos, do imobilizado e do intangível (sendo que estas três compunham o ativo permanente).

Assim, o conceito de ativo permanente, por força das interpretações sistemática e histórica, compreende os bens e direitos classificados como investimentos, imobilizado ou intangíveis. Todavia, sendo certo que o ICMS incide sobre operações com circulação de mercadorias e serviços, que devem necessariamente ser tributadas para gerar créditos aproveitáveis pelo adquirente, é correto afirmar que apenas o ativo imobilizado se prestará para fins de cálculo do ICMS. Não obstante, a norma do art. 301 do RIR continua valendo para essa categoria de bens, sendo de importante valia na definição prática das mercadorias que integram o ativo imobilizado e daquelas que são consumidas antes de completado o período de 12 meses previsto na legislação do imposto de renda.

É com base nessas premissas que se deve interpretar os dispositivos do ICMS relativos ao crédito sobre mercadorias destinadas ao ativo permanente.

\subsection{BENS DO ATIVO PERMANENTE ALHEIOS À ATIVIDADE FIM DO CONTRIBUINTE.}

\subsection{A REGRA GERAL.}

Já se notou que existe vedação expressa ao creditamento do ICMS relativo a mercadorias alheias à atividade do contribuinte, assim prevista na $\mathrm{LC}^{\circ} 87 / 96$ :

“Art. 20. (...).

$\S 1^{\circ}$. Não dão direito a crédito as entradas de mercadorias ou utilização de serviços resultantes de operações ou prestações isentas ou não tributadas, ou 
que se refiram a mercadorias ou serviços alheios à atividade do estabelecimento."

A regra encontra ressonância nos IVAs de todo o mundo. Afinal, a aquisição de mercadorias e serviços não utilizados na atividade do contribuinte não pode, de fato, gerar créditos aproveitáveis do ICMS. A premissa da não-cumulatividade é abater do imposto recolhido em cada etapa o valor desse mesmo imposto pago na etapa anterior. Se o bem adquirido será empregado em outras atividades - que não geram imposto a pagar - não se pode autorizar o creditamento, pois o adquirente terá feito a compra na qualidade de consumidor final.

A discussão ganha importância em se tratando de ativo permanente. Isso porque a jurisprudência do STJ tem sido bastante restritiva em relação ao conceito de bem alheio à atividade do estabelecimento. A interpretação do art. $20, \S 1^{\circ}$ da $\mathrm{LC}^{\circ}{ }^{\circ} 87 / 96$ está sendo feita como se o dispositivo exigisse a utilização do ativo imobilizado na atividade-fim da empresa, ou seja, no processo industrial ou de prestação de serviços propriamente dito. Bens que compõem a parte administrativa da empresa, tais como mesas, cadeiras, divisórias, computadores, seriam alheios à atividade industrial, comercial ou de prestação de serviços, impedindo o aproveitamento dos créditos.

Como exemplo, cite-se o caso de uma empresa fabricante de bebidas que pleiteava o crédito sobre equipamentos de informática utilizados em seu estabelecimento. O STJ negou o pedido do contribuinte ao argumento de que "os equipamentos de informática não se constituem em matéria-prima, insumos ou máquinas que sejam utilizados no processo de industrialização e tampouco integram o produto final, o que afasta o direito ao creditamento do ICMS",738. Com essa decisão, o STJ confirmou o aresto recorrido, cuja ementa e fundamentos (extraídos do relatório do Min. CASTRO MEIRA) eram os seguintes:

“A Lei Complementar no 87/96 fixou normas gerais sobre o ICMS, autorizando os entes políticos titulares de competência tributária a instituí-lo. Assim o fez o Estado do Rio de Janeiro ao editar a Lei ${ }^{\circ} 2.657 / 96$. Cotejandose o dispositivo desta com o art. 20, $\S 1^{\circ}$, da LC 87/96, nenhuma discrepân-

\footnotetext{
${ }^{738}$ Eis a ementa:

“TRIBUTÁRIO. ICMS. EQUIPAMENTOS DE INFORMÁTICA. CRÉDITO. ART. 20, § $1^{\circ}$ DA LC No $87 / 96$.

(...)

2. Os equipamentos de informática não se constituem em matéria-prima, insumos ou máquinas que sejam utilizados no processo de industrialização e tampouco integram o produto final, o que afasta o direito ao creditamento do ICMS.

3. Recurso especial improvido." (STJ, Segunda Turma, REsp n ${ }^{\circ}$ 740.285/RJ, Relator Min. CASTRO MEIRA, DJ 20.02.2006, p. 308).
} 
cia se verifica existir entre eles. Ambas as normas não dão direito a crédito quando a mercadoria que entra no estabelecimento, ainda que destinada ao ativo imobilizado, seja alheia à atividade do contribuinte.

(...)

Embora a aquisição de computadores e equipamentos de informática seja útil ao desempenho das atividades de qualquer sociedade empresarial, nenhuma ligação existe entre tais bens e a atividade-fim da apelante." 739

Apesar do desfecho desfavorável, a nosso sentir a razão assistia ao contribuinte. Computadores são bens fundamentais para o funcionamento de todo e qualquer estabelecimento comercial ou industrial. Ainda que não utilizados na linha de produção, como era o caso, sua utilização na área administrativa e financeira da empresa é fundamental para que a atividade empresarial tenha seu curso regular. Nesse sendeiro, não é lícito restringirse o direito ao crédito, sob pena de ferimento à $L C n^{\circ} 87 / 96$.

Todavia, como já averbado, a jurisprudência tem se inclinado - com erronia, a nosso sentir - a admitir o crédito sobre bens do ativo imobilizado somente quando utilizados diretamente na linha de produção, comercialização ou prestação do serviço. Isto é, o computador da sala do presidente da empresa é bem do ativo permanente alheio à atividade do estabelecimento. O raciocínio chega às raias do absurdo, como se infere deste exemplo. Afinal, se o presidente da empresa não está envolvido com as atividades empresariais, certamente o empreendimento estará fadado ao insucesso em curto espaço de tempo.

É pedestre o raciocínio que restringe indevidamente o crédito sobre bens do ativo permanente. A nosso sentir, a jurisprudência assim se consolidou por força de uma analogia com a definição de produtos intermediários. Esses, como visto, devem ser diretamente vinculados à atividade-fim, à linha de produção - assim como se pretende fazer com as mercadorias integrantes do ativo permanente.

Uma mutação jurisprudencial seria não somente desejável, como absolutamente imprescindível para evitar-se o malferimento a autorização legal de crédito do imposto sobre bens do ativo permanente que, em sua maior parte (à exceção, por óbvio, de objetos decorativos, v.g.), estão afetados à atividade da empresa. Todavia, enquanto a jurisprudência atual se mantém, os Fiscos estaduais restringem - com o beneplácito do Poder Judiciário - créditos que, pela $\mathrm{LC} \mathrm{n}^{\circ}$ 87/96 (em nossa interpretação), deveriam estar sendo reconhecidos aos contribuintes. A título de exemplo, confiram-se as conclusões da Decisão Normativa CAT $\mathrm{n}^{\circ}$ 2, de 7 de novembro de 2000:

${ }^{739}$ STJ, Segunda Turma, REsp n ${ }^{\circ}$ 740.285/RJ, Relator Min. CASTRO MEIRA, DJ 20.02.2006, p. 308. 
“(...) Podemos concluir que os ditos bens ('equipamentos de escritório’), citados na inicial, não obstante possam até ser conceituados contabilmente como Ativo Permanente, na forma atrás exposta, em nada, em termos de ICMS, à vista do princípio da não-cumulatividade, de que trata o artigo 19 da Lei Complementar nº 87/96, colaboram na industrialização e/ou comercialização de mercadorias com saídas tributadas, como condição indispensável para fins de lançamento do imposto a quem tem direito o contribuinte."

A seu turno, a Instrução Normativa n ${ }^{\circ}$ 1, de 6 de maio de 1998, emitida pela Diretoria de Legislação Tributária da Superintendência da Receita Estadual do Estado de Minas Gerais, também classifica como alheios à atividade do estabelecimento as mercadorias e serviços que não são utilizadas "na área de produção industrial, agropecuária, extrativa, de comercialização, ou de prestação de serviços" (art. $1^{\circ}$, II, c).

As orientações fiscais, a nosso sentir, são incorretas. O conceito de mercadorias alheias à atividade empresarial é aquele relativo a bens que passam completamente ao largo de serem úteis, ainda que de forma indireta no processo de produção, comercialização ou prestação do serviço (eis que a lei limita-se a dispor que deverá ser não-alheio à atividade do estabelecimento). Definindo a questão de forma mais clara, a Diretiva 2006/112/CE do IVA-europeu exclui do direito à dedução do imposto as despesas desprovidas de caráter estritamente profissional, tais como as "sumptuárias, recreativas ou de representação" (art. 176). Porém, há um longo e distante caminho entre computadores que integram o ativo da empresa e, v.g., um vídeo-game instalado na área de lazer dos empregados. É contra este que se volta a vedação do crédito inserta no $§ 1^{\circ}$ do art. 20 da $L C n^{\circ} 87 / 96$, e não contra os computadores e móveis que guarnecem o setor administrativo do estabelecimento.

\subsection{CRÉDITO SOBRE MATERIAIS UTILIZADOS NA CONSTRUÇÃO DE IMÓVEIS.}

É comum que empresas adquiram materiais para emprego na construção de imóveis destinados à sua atividade empresarial. Da mesma forma, é também usual que benfeitorias sejam realizadas em imóveis já prontos. Quando tais despesas não se destinarem à mera conservação do imóvel, a regra predicada pela Receita Federal do Brasil (com fulcro no art. 301 do RIR) é a contabilização desses gastos como ativo permanente, como de resto tem pugnado o Conselho Administrativo de Recursos Fiscais ${ }^{740}$.

\footnotetext{
${ }^{740}$ Confiram-se as seguintes ementas do CARF:

"IRPJ. DESPESAS INDEDUTÍVEIS. Os gastos suportados com obras de melhoramentos, construções e instalações para fábrica não se identificam como despesas de conservação de imóvel, deven-
} 
A Receita Federal do Brasil trata a questão sob a ótica do Imposto de Renda das Pessoas Jurídicas, determinando a classificação como ativo permanente dos gastos realizados com obras civis que impliquem em novas construções ou benfeitorias nos imóveis já existentes. Assim, os materiais, a mão-de-obra, os dispêndios com transporte e outras despesas relacionadas com a obra serão ativados, sendo paulatinamente amortizados na apuração do IRPJ.

Para fins do creditamento de ICMS, entretanto, o que importa são apenas as aquisições de materiais utilizados na construção, eis que a mão-de-obra, o transporte intramunicipal e outros gastos não são alcançados pelo imposto estadual. Assim, pode-se afirmar a priori que as aquisições de matéria-prima, quando feitas por contribuinte do ICMS para integração a seus imóveis, passam a integrar o ativo imobilizado da empresa.

As questões que se colocam, todavia, são:

(a) a aquisição de materiais para integração a imóvel da empresa pode, a priori, gerar créditos compensáveis do ICMS;

(b) caso a resposta acima seja positiva, qual o conceito de imóvel alheio à atividade da empresa para fins da vedação constante do art. $20, \S^{\circ}$ da $\operatorname{LC} n^{\circ} 87 / 96$ ?

Quanto ao primeiro questionamento, o Estado de São Paulo, por meio da Decisão Normativa da Coordenação da Administração Tributária $n^{\circ} 2$, de 7 de novembro de $2000^{741}$, sustenta que o imóvel é uma "não-mercadoria". Ademais, sendo certo que suas

do ser ativados quando realizados em imóvel próprio." (Primeiro Conselho de Contribuintes Federal, PTA n ${ }^{\circ}$ 13709.003955/92-76, Acórdão no 108-08333, j. em 19.05.2005).

"IRPJ. BENS DE NATUREZA PERMANENTE. COMPROVAÇÃO. CUSTOS/DESPESAS. Não se identificam como custos ou despesas operacionais a aquisição de bens passíveis de imobilização, bem assim as não comprovadas com documentos hábeis e idôneos. Subsiste, entretanto, o acolhimento dos encargos de depreciação e amortização dos respectivos bens." (Primeiro Conselho de Contribuintes Federal, PTA n ${ }^{\circ}$ 13163.000049/97-66, Acórdão nº 103-19276, j. em 18.03.1998).

${ }^{741}$ Decisão Normativa CAT $n^{\circ}$ 2/00:

“15. (...) O princípio da não-cumulatividade há de ser entendido somente em relação às operações com mercadorias e prestações de serviços, e nunca nas operações com imóveis, uma vez que estas sujeitam-se ao ITBI. O que existe, na verdade, é a venda de um bem, que não se confunde com o conceito de mercadoria, conforme se verá mais adiante. Então, aquele princípio só pode estar inserido no contexto das operações e prestações sujeitas ao ICMS. E as operações com imóveis jamais terão tal tributação, porque, como dito, estão jungidos a outro tributo. A mesma assertiva vale também para os bens imóveis construídos por meio de pré-moldados.Sempre serão bens imóveis qualquer que seja a forma de construí-los (por administração, por empreitada ou subempreitada, por incorporação, por empreitada mista, etc).

16. Ou seja, aquele princípio não deve ser interpretado de forma global envolvendo diversos tributos, mas sim, e tão-somente, no âmbito das operações sujeitas ao Imposto sobre Circulação de Mercadorias e Serviços (ICMS).

(...)

21. (...) Bem Imóvel é uma não-mercadoria, não obstante fazer parte do Ativo Permanente. O direito ao crédito aludido no artigo 20 da LC 87/96, é legítimo quando decorrente de aquisição ou entrada 
operações de compra-e-venda sujeitam-se ao Imposto sobre Transmissão de Bens Imóveis, não se afigurariam - sob a ótica do Fisco paulista - presentes os requisitos erigidos pelo caput do art. 20 da LC no 87/96 para o creditamento.

A nosso sentir, tal entendimento é equivocado. O pressuposto inicial para a incidência do ICMS é a aquisição de mercadorias e serviços tributados na etapa antecedente. Os produtos utilizados no processo de construção (tintas, cimento, aço, inter alii), quando adquiridos pela empresa-contribuinte, vêm acobertados por nota fiscal com destaque do imposto recolhido pelo alienante. Assim, é incorreto falar que tais produtos se tratariam de "não-mercadorias" posto que sua destinação final seria a integração ao imóvel do contribuinte. O que importa para a presente análise é que, no momento de sua aquisição, o material de construção é sim uma mercadoria. Tanto o é que o ICMS é recolhido pelo vendedor. Do contrário, não o seria.

Entrementes, uma observação é importante: somente quando o material for diretamente adquirido pelo contribuinte haverá o direito ao crédito do ICMS. Quando se tratar de obra por empreitada global, em que todas as aquisições são de responsabilidade do empreiteiro (que não é contribuinte do imposto ${ }^{742}$ ), o titular do imóvel não poderá pleitear os créditos de ICMS sobre os materiais, pois não terá realizado aquisições tributadas.

Sendo assim, pode-se concluir que a compra de materiais tributados pelo ICMS para utilização em obra no estabelecimento do contribuinte pode, a princípio, gerar créditos aproveitáveis do imposto, eis que se destina ao ativo imobilizado da empresa.

Cumpre, agora, responder à segunda indagação: o imóvel onde se realizam as atividades industriais, comerciais ou de prestação de serviços do contribuinte do ICMS pode ser considerado bem do ativo destinado à sua atividade, não se enquadrando na vedação do crédito posta pelo $\$ 1^{\circ}$ do art. 20 da LC no $87 / 96$ (que proíbe o creditamento sobre bens $a$ lheios à atividade do estabelecimento)?

de mercadoria 'destinada ... ao Ativo Permanente', observadas, logicamente, as demais regras previstas nesta lei."

${ }^{742}$ Em diversas ocasiões o STJ já esclareceu, com acerto, que a empresa dedicada à construção civil não faz jus aos créditos de ICMS sobre os materiais por ela adquiridos para integração às suas obras, pois não é contribuinte do imposto. Inexistindo saída tributada, é impossível falar-se em crédito sobre as entradas:

“5. (...) A Recorrente não se enquadra como contribuinte do [ICMS], posto tratar-se de empresa ligada ao ramo da construção civil, o que, de plano, conduz à conclusão de ser carecedora do direito ao ressarcimento do ICMS pago pela entrada de bens que adquiriu como consumidor final. Isso porque a compensação prevista no art. $155, \S 2^{\circ}$, I, da Carta Maior, pressupõe não apenas a tributação na entrada da mercadoria, como uma saída igualmente tributada, sendo que, in casu, não ocorreu sequer a saída da mercadoria (...)". (STJ, Primeira Turma, RMS n 20.454/RJ, Rel. Ministro LUIZ FUX, DJ 31/05/2007 p. 320). 
As autoridades administrativas e o próprio STJ consideram que os bens imóveis são sempre alheios à atividade da empresa, independentemente de sua utilização. Mesmo no caso de galpões que abriguem máquinas industriais ${ }^{743}$ ou de prédios onde funcione o estabelecimento comercial $^{744}$, o crédito do ICMS é negado ao contribuinte-adquirente dos materiais empregados na obra.

Não nos parece que tal entendimento seja correto. Afinal, se as mercadorias são adquiridas com incidência do ICMS e passam a integrar o ativo imobilizado; e se o ativo em questão é essencial para a atividade da empresa, a conclusão é pelo direito ao creditamento do ICMS com espeque no art. 20, caput e $\$ 1^{\circ}$ da $\mathrm{LC} \mathrm{n}^{\circ} 87 / 96$ e conforme as regras predicadas no $\S 5^{\circ}$ do art. 20 da mesma lei.

Outra interpretação significa menoscabo à letra da própria $\mathrm{LC} \mathrm{n}^{\circ}$ 87/96, que merece uma releitura por parte do Superior Tribunal de Justiça, nesse ponto.

\subsection{VEÍCULOS DESTINADOS AO TRANSPORTE PESSOAL.}

Por derradeiro, cumpre analisar a LC n $87 / 96$ acerca dos créditos de ICMS calculados sobre veículos automotores:

“Art. 20. (...).

$\S 2^{\circ}$. Salvo prova em contrário, presumem-se alheios à atividade do estabelecimento os veículos de transporte pessoal."

Trata-se de presunção juris tantum criada pela lei, dentro da margem de liberdade que lhe foi conferida pelo STF. Afinal, se o núcleo mínimo da não-cumulatividade é o crédito físico, cabe à lei complementar conceder, de forma plena ou mitigada, ou mesmo negar o crédito sobre ativo permanente e material destinado ao uso e consumo. Assim, o crédito sobre veículos automotores poderia ser negado pela norma em comento, inexistindo qualquer inconstitucionalidade na presunção criada pela lei (que ademais, admite prova em contrário).

A ratio da presunção criada pelo art. $20, \S 2^{\circ}$ da $L C n^{\circ} 87 / 96$ reside no fato de que os automóveis das empresas, destinados a uso pessoal, são concedidos como fringe bene-

\footnotetext{
${ }^{743}$ Secretaria da Fazenda do Estado de Minas Gerais, Resposta à Consulta de Contribuinte no 233/2007.

${ }^{744}$ O STJ nega às empresas do setor hipermercadista o crédito sobre bens empregados na construção do prédio onde funciona o próprio hipermercado (STJ, Primeira Turma, REsp n $\mathrm{n}^{\circ}$ 860.701/MG, Relator Min. FRANCISCO FALCÃO, DJ 17.05.2007, p. 215; STJ, Primeira Turma, REsp no 1.077.242/MG, Relatora Min. DENISE ARRUDA, DJe 12.02.2009).
} 
fits, ou seja, utilizados como veículos particulares pelos empregados, que se valem dos carros não apenas para fins de trabalho, mas, também, para programas pessoais.

De lege ferenda, contudo, entendemos que o critério da proporcionalidade do crédito sobre automóveis para transporte pessoal seria mais adequado. Afinal, se o bem é da empresa é razoável presumir-se que em algum momento o automóvel será utilizado no transporte do empregado para o trabalho. A legislação poderia estabelecer um porcentual de utilização (v.g., cinqüenta por cento) para concessão parcial do direito ao crédito. Seria, a nosso sentir, uma política mais consentânea com a intenção manifestada da LC n ${ }^{\circ} 87 / 96$, qual seja a de conceder créditos sobre bens destinados ao ativo permanente.

De todo modo, a legislação do ICMS abre ensanchas para a prova em contrário, o que já é salutar, em que pese ser de difícil comprovação a forma pela qual se dá o uso do veículo automotor da empresa (se para fins pessoais ou profissionais).

\subsection{A MITIGAÇÃO DO CRÉDITO CONFERIDO SOBRE OS BENS DO A- TIVO PERMANENTE: CUMULATIVIDADE RESIDUAL DETERMINADA PELA} LEI.

\subsection{O CANCELAMENTO DOS CRÉDITOS REMANESCENTES APÓS O DECURSO DE QUATRO (LC No 102/00) OU CINCO ANOS (LC No 87/96).}

Tanto na regra originária da $\mathrm{LC} \mathrm{n}^{\circ} 87 / 96$ como na norma atual, veiculada pela LC $\mathrm{n}^{\mathrm{o}}$ 102/00 (aproveitamento do crédito fracionadamente sobre os bens do ativo, ao longo de 48 meses), uma vez findo o período fixado em lei (5 ou 4 anos), os créditos remanescentes e não aproveitados serão cancelados. Veja-se a LC no 87/96:

(a) em sua redação original:

“Art. 20. (...).

$\S 5^{\circ}$. Além do lançamento em conjunto com os demais créditos, para efeito da compensação prevista neste artigo e no anterior, os créditos resultantes de operações de que decorra entrada de mercadorias destinadas ao ativo permanente serão objeto de outro lançamento, em livro próprio ou de outra forma que a legislação determinar, para aplicação do disposto no art. $21, \S \S$ $5^{\circ}, 6^{\circ}$ e $7^{\circ}$.

(...)

$\S 8^{\circ}$. Ao fim do quinto ano contado da data do lançamento a que se refere o $\S 5^{\circ}$ do art. 20, o saldo remanescente do crédito será cancelado de modo a não mais ocasionar estornos." (destaques nossos)

(b) modificada pela LC no $102 / 00$ :

“Art. 20. (...). 
(...).

$\S 5^{\circ}$. Para efeito do disposto no caput deste artigo, relativamente aos créditos decorrentes de entrada de mercadorias no estabelecimento destinadas ao ativo permanente, deverá ser observado:

I - a apropriação será feita à razão de um quarenta e oito avos por mês, devendo a primeira fração ser apropriada no mês em que ocorrer a entrada no estabelecimento;

(...)

VII - ao final do quadragésimo oitavo mês contado da data da entrada do bem no estabelecimento, o saldo remanescente do crédito será cancelado." (destaques nossos)

A regra tem duas funções. Primeiramente, impõe um limite temporal à utilização do crédito. Se o contribuinte não fizer uso da faculdade que lhe é conferida pela legislação, uma vez decorrido o prazo legal (atualmente de quatro anos), decairá do direito de escriturar os créditos em sua conta gráfica. O procedimento é adequado pois, afinal, o ordenamento jurídico não deve abrigar direitos imprescritíveis. E o prazo fixado permite ao contribuinte a utilização integral dos créditos do ativo.

Contudo, tendo em vista que existe norma determinando o estorno proporcional dos créditos de ICMS em razão das saídas isentas e não-tributadas no período ${ }^{745}$, pode-se entender que o cancelamento determinado pela $\mathrm{LC}^{\circ}$ 87/96 (uma vez decorrido o prazo de quatro ou cinco anos) impede eventual pleito do contribuinte de escriturar, a posteriori, créditos que no passado foram estornados. Assim, o limite temporal se presta a impedir que o contribuinte se aproveite dos créditos de ICMS sobre os bens pertencentes ao seu ativo imobilizado, após decorrido o prazo legal. Além disso, ele se destina também a estancar, na origem, qualquer tentativa de utilização de créditos não aproveitados em sua integralidade por força da regra do estorno proporcional.

Como já dito, a legitimação do crédito físico pelo STF impede questionamentos acerca da constitucionalidade do prazo fixado na $\mathrm{LC} \mathrm{n}^{\circ} 87 / 96$, posto que, em se tratando de

\footnotetext{
${ }^{745}$ LC n' 87/96, redação original:

“Art. 21. (...).

$\S 4^{\circ}$. Em qualquer período de apuração do imposto, se bens do ativo permanente forem utilizados para produção de mercadorias cuja saída resulte de operações isentas ou não tributadas ou para prestação de serviços isentos ou não tributados, haverá estorno dos créditos escriturados (...).”

LC $n^{\circ}$ 87/96, modificada pela $\mathrm{LC} \mathrm{n}^{\circ} 102 / 00$ :

“Art. 20. (...).

$\S 5^{\circ} .(\ldots)$.

II - em cada período de apuração do imposto, não será admitido o creditamento de que trata o inciso I, em relação à proporção das operações de saídas ou prestações isentas ou não tributadas sobre o total das operações de saídas ou prestações efetuadas no mesmo período;"
} 
bens do ativo permanente, a liberdade do legislador quanto à autorização do creditamento é ampla.

\subsection{A ALIENAÇÃO DO ATIVO ANTES DE DECORRIDO O PRAZO LE- GAL E O ESTORNO DOS CRÉDITOS REMANESCENTES.}

Outra regra que ocasiona cumulatividade do ICMS sobre os bens destinados ao ativo permanente do estabelecimento é a aplicável na hipótese de alienação do ativo antes do prazo de quatro anos (necessário para aproveitamento dos créditos à razão de 1/48 por mês). O mesmo problema existia, ainda que de forma distinta, para os bens adquiridos para o imobilizado sob a égide da redação originária da LC no 87/96. Nesse caso, quando da venda do ativo se fazia necessário o estorno de $20 \%$ (vinte por cento) do crédito de ICMS por ano faltante para completar um qüinqüênio contado da entrada do bem no estabelecimento.

Tais disposições são combatidas pela doutrina, que afirma existir violação à nãocumulatividade ${ }^{746}$.

Entrementes, em atenção à corrente vencedora do crédito físico no STF, os argumentos constitucionais contra a vedação perdem força. Afinal, o crédito sobre ativo permanente não é direito subjetivo do contribuinte à luz da jurisprudência pretoriana. A legislação pode prevê-lo, pois ele se integra na não-cumulatividade - mas não pertence ao núcleo inatacável desta.

O que nos parece viável sustentar é o transporte do crédito remanescente para o estabelecimento destinatário, quando se tratar de transferência de ativo entre estabeleci-

\footnotetext{
${ }^{746}$ A. G. DE MATTOS, com esforço nas lições da doutrina especializada, averba:

“(...) Assim esclareceram e obtemperaram (...) José Cassiano Borges e Maria Lúcia Sá Motta Américo dos Reis:

'(...) Com a introdução do inciso $\mathrm{V}$ ao $\S 5^{\circ}$ do artigo 20 da Lei Complementar $\mathrm{n}^{\circ}$ 87, de 1996, foi criada mais uma restrição ao aproveitamento de créditos fiscais do ICMS, que não existia na redação anterior do artigo 20 da Lei Complementar nº 87, de 1996. Antes da inovação, o contribuinte era obrigado a estornar os créditos referentes a bens do ativo permanente que fossem alienados antes de decorrido o prazo de 5 (cinco) anos contados da data da respectiva aquisição, mas o estorno, no caso, correspondia apenas a $20 \%$ (vinte por cento) por ano ou fração que faltasse para completar o prazo de carência equivalente ao qüinqüênio. $\mathrm{O}$ inciso $\mathrm{V}$ reduz esse prazo para 4 (quatro) anos, mas não admite, a partir da data da alienação, o creditamento em relação à fração de tempo correspondente ao restante do quadriênio, o que convenhamos, ante a letra do disposto no artigo 155 , §2 $2^{\circ}$, inciso I da Constituição, que não contempla tais restrições, é um atentado ao direito à compensação assegurada ao contribuinte.'

Daí se infere que o estorno determinado pela Lei Complementar 102/00 no inc. V acima, no caso de alienação do bem adquirido para o ativo permanente antes de 48 (quarenta e oito) meses, fere, às escâncaras, o princípio da não-cumulatividade." (MATTOS, Aroldo Gomes de. ICMS - Comentários à Legislação Nacional. São Paulo: Dialética, 2006, pp. 306-7).
} 
mentos da mesma empresa. Afinal, o estorno exigido pela lei complementar é apenas no caso de alienação do bem, in verbis:

(a) $\mathrm{LC} \mathrm{n}^{\circ} 87 / 96$, redação original:

“Art. 21. (...).

$\S 1^{\circ}$. Devem ser também estornados os créditos referentes a bens do ativo permanente alienados antes de decorrido o prazo de cinco anos contado da data da sua aquisição, hipótese em que o estorno será de vinte por cento por ano ou fração que faltar para completar o qüinqüênio." (destaque nosso)

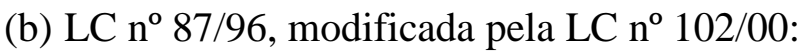

“Art. 20. (...).

$\S 5^{\circ} .(\ldots)$.

$\mathrm{V}$ - na hipótese de alienação dos bens do ativo permanente, antes de decorrido o prazo de quatro anos contado da data de sua aquisição, não será admitido, a partir da data da alienação, o creditamento de que trata este parágrafo em relação à fração que corresponderia ao restante do quadriênio;" (destaque nosso)

Ora, alienar significa "transferir para outrem o domínio de; tornar alheio; alhe$\operatorname{ar}^{, 747}$. Portanto, os dispositivos em comento somente são aplicáveis em se tratando de venda do ativo permanente a terceiros. A simples transferência entre estabelecimentos do mesmo titular, que inclusive não é fato gerador do $\mathrm{ICMS}^{748}$, não pode ensejar a perda do crédito em comento. O mais coerente e consonante com as regras ditadas pela $\mathrm{LC} \mathrm{n}^{\circ}$ 87/96 é transferir-se, junto com o bem, o valor remanescente do crédito, que será aproveitado pelo estabelecimento de destino observando-se as demais prescrições legais.

No Estado de Santa Catarina existe norma que permite a operação de que ora estamos tratando. O RICMS/SC ${ }^{749}$ isenta do imposto estadual a venda de bens para integração ao ativo imobilizado sempre que o destinatário estiver situado naquele Estado, pertença ele ou não à empresa titular do estabelecimento remetente (art. 35, I). Em se tratando de operações interestaduais, a isenção é concedida apenas quando o estabelecimento de destino pertencer à mesma empresa (art. 35, II, a). Apesar de a primeira isenção ir além do que seria devido (pois a mercadoria vendida para integrar o ativo imobilizado de terceiro gera débito do ICMS na saída), o RICMS/SC acerta quando isenta do ICMS as transferências de

\footnotetext{
${ }^{747}$ Dicionário Aurélio da Língua Portuguesa, versão eletrônica.

${ }^{748}$ Conforme a Súmula $\mathrm{n}^{\mathrm{o}} 166$ do STJ, a transferência de mercadorias entre estabelecimentos do mesmo titular não equivale a operação de circulação jurídica, afastando, por conseguinte, a incidência do ICMS em tais operações.

${ }^{749}$ Decreto Estadual n ${ }^{\circ} 2.870$, de 27 de agosto de 2001.
} 
ativo entre estabelecimentos do mesmo titular, ainda que interestaduais. Nesta hipótese, o RICMS/SC observa fielmente os ditames da precitada Súmula n ${ }^{\circ} 166$ do Superior Tribunal de Justiça ${ }^{750}$.

Pois bem. Uma vez concedida a isenção, o RICMS/SC dispõe exatamente na linha do que ora pugnamos. Confira-se:

"Art. 47. Poderá ainda ser transferido:

I - ao estabelecimento destinatário do bem, o crédito remanescente (...) no caso de transferência de bens do ativo permanente para outro estabelecimento do mesmo titular;" (destaques nossos)

Os procedimentos operacionais para a transferência do crédito remanescente são estabelecidos da seguinte forma (parágrafo único do art. 47 do RICMS/SC):

(a) no campo da nota fiscal denominado "Observações", será inserido o valor remanescente do crédito de ICMS sobre o bem do ativo que estiver sendo transferido;

(b) o estabelecimento de destino escriturará o crédito em seu Livro de Registro de Entradas;

(c) o estabelecimento de origem deverá estornar o crédito restante que lhe seria devido apropriar, mas que foi transferido juntamente com o bem do ativo permanente.

As regras em comento, a nosso sentir, são plenamente consentâneas com o regime ditado pela $\mathrm{LC}^{\circ}{ }^{\mathrm{1}}$ 102/00 para crédito sobre bens do ativo permanente. Ao revés, a obrigação de estorno dos créditos sem a sua transferência para o estabelecimento de destino, quando não se tem a alienação exigida pela lei é ilegal, merecendo, portanto, reparo por parte do Poder Judiciário.

\subsection{BENS CEDIDOS EM COMODATO: POSSIBILIDADE DE MANUTEN- ÇÃO DO CRÉDITO.}

Questão conexa com a analisada no item precedente refere-se à possibilidade de manutenção dos créditos de ICMS quando o bem é cedido em comodato a terceiros, no intuito de viabilizar a atividade empresarial do comodante.

Para melhor ilustrar o problema, analisar-se-á determinado caso que foi tratado pelo STJ. Uma empresa do ramo de alimentos tinha como prática ceder em comodato freezers para utilização pelos revendedores dos seus produtos (padarias, supermercados, restaurantes e bares). No freezer, que continha a pintura do logotipo da empresa, eram armazenados

750 "Não constitui fato gerador do ICMS o simples deslocamento de mercadoria de um para outro estabelecimento do mesmo contribuinte." 
os produtos fabricados pela comodante que necessitavam de refrigeração constante. Apesar de tal operação, o fabricante dos alimentos continuou se aproveitando dos créditos de ICMS referentes ao bem cedido ao seu parceiro comercial. Seu fundamento para exercer tal direito residia no argumento de que a cessão em comodato não importa em alienação do bem integrante do ativo imobilizado, que ensejaria, nos termos da $\mathrm{LC}^{\circ}$ 87/96, o estorno em questão. Todavia, o Fisco não entendeu desta forma, lavrando auto de infração ao fundamento de que a saída em comodato é não-tributada e, por tal razão, ensejaria o estorno do crédito da operação anterior, consoante determina não só a $L C$ n $^{\circ} 87 / 96$, mas a própria Constituição da República em matéria de ICMS.

Tendo perdido em primeira e segunda instâncias, a empresa não se resignou e levou a matéria ao Superior Tribunal de Justiça no qual, por maioria de votos, fez valer o seu direito ao crédito, anulando o auto de infração ${ }^{751}$.

Com carradas de razão o STJ. A saída em comodato não importa em alienação do ativo, que impediria a comodante de continuar aproveitando os créditos sobre o bem. Em verdade, o ativo continua sendo de sua propriedade e, ademais, utilizado em prol de sua atividade (no caso, a venda de produtos alimentícios, muitos dos quais necessitam de refrigeração constante). Dessa forma, seria indevido impedir-se o aproveitamento contínuo dos créditos em questão. Tampouco se poderia invocar a regra geral de estorno dos créditos do ICMS no caso de operações isentas ou não-tributadas. Afinal, a operação de circulação jurídica pressupõe translação da propriedade da mercadoria mediante celebração de negócio jurídico válido. A saída em comodato não se enquadra, portanto, em operação não-

\footnotetext{
${ }^{751}$ O raciocínio vencedor no STJ está exposto nos seguintes trechos do voto do Min. LUIZ FUX, Relator designado para o acórdão:

“(...) A Súmula no 573 do Supremo Tribunal Federal dispõe o seguinte:

'Não constitui fato gerador do imposto de circulação e mercadorias a saída física de máquinas, utensílios e implementos a título de comodato.'

(...)

Deveras, a transferência de bens do ativo permanente, no âmbito da mesma empresa, não constitui fato gerador do ICMS, sendo indevido o crédito relativos a eles.

A nossa jurisprudência também reconhece que, se não há um fato gerador e ainda que não o conhecesse, estamos submetidos à Súmula no 573.

Pelo que pude entender, o que o ilustre patrono sustentou da tribuna foi exatamente o fato de que, como não há circulação de mercadoria e em obediência ao princípio da não-cumulatividade, isso não pode ser contado como um crédito passível de estorno. Na verdade, até fez uma colocação muito simples que deu para entender a questão jurídica. Estamos acostumados a ver nas padarias freezeres com sorvetes e iogurtes, para gelar aqueles produtos, o que faz parte do ativo permanente da empresa, assim como as bombas de gasolina fazem parte do ativo permanente das empresas que fazem comodato com a exploração de posto de gasolina.

Tenho a impressão de que, (...) de acordo com a Súmula do Supremo Tribunal Federal e com a nossa jurisprudência, o pleito da parte é não ser instada a estornar (...)." (STJ, Primeira Turma, REsp n ${ }^{\circ}$ 791.491/MG, Relator p/ acórdão Min. LUIZ FUX, DJ 07.11.2006, p. 252).
} 
tributada, pois não é sequer operação de circulação jurídica, eis que a propriedade do ativo remanesce com o comodante.

Em outro caso, o Conselho de Contribuintes de Minas Gerais solucionou adequadamente a questão, evitando com isso que a lide desaguasse no Judiciário. Uma fabricante de automóveis havia celebrado contrato de comodato com diversos fornecedores de autopeças, cedendo-lhes ferramentas e moldes para utilização em sua produção. O fisco mineiro glosou tais créditos, com base nos argumentos acima referidos, a saber:

(a) a saída em comodato, não sendo tributada pelo ICMS, gera o dever de estornar os créditos acumulados e não os transfere para o adquirente;

(b) em todo caso, como houve alienação do ativo, cessa para o antigo titular o direito de continuar escriturando os créditos sobre o bem.

$\mathrm{O}$ auto de infração foi julgado improcedente, em decisão que recebeu a seguinte ementa no Conselho de Contribuintes de Minas Gerais:

“CRÉDITO DE ICMS. APROVEITAMENTO INDEVIDO. ATIVO PERMANENTE CEDIDO EM COMODATO.

Constatado que os bens cujos créditos foram estornados pelo Fisco são do ativo permanente afetos à atividade da Recorrente e, nesta condição, mesmo tendo sido cedidos em comodato a empresas que fabricam peças para a própria Recorrida, devem ser objeto de creditamento em cumprimento ao princípio da não-cumulatividade. Assim, não deve ser reformada a decisão recorrida." 752

As razões de decidir merecem transcrição, pela propriedade com que abordam o tema:

"Cabe aqui analisar se as saídas não tributadas ou isentas que impedem a manutenção do crédito do ICMS são aquelas definitivas, decorrentes de negócios jurídicos ou, ainda que meras saídas físicas, mas com transferência de titularidade, assim tratada diante da autonomia dos estabelecimentos, ou de modo diverso, quaisquer saídas sem tributação ensejam o imediato estorno dos créditos pelas entradas das mercadorias.

(...) Não é a mera saída física da mercadoria, em operação isenta ou não tributada, que determina o estorno do crédito relativo à sua aquisição, mas sim a saída definitiva do estabelecimento.

(...) A melhor interpretação para as normas relativas a matéria é de que o legislador constituinte ao prever a anulação do crédito de ICMS quando da saída de mercadoria beneficiada pela isenção ou não-incidência, referiu-se unicamente às saídas com tradição de propriedade, porquanto, somente assim, continuaria o ciclo de circulação da mercadoria.

752 Conselho de Contribuintes do Estado de Minas Gerais, PTA/AI no 01.000154669-55, Acórdão $\mathrm{n}^{\circ}$ 3.424/09/CE, DOE 18.06.2009. 
Registre-se que o comodato é um empréstimo para uso temporário, a título gratuito, de bem infungível, que deverá ser devolvido, após o uso ou dentro de prazo predeterminado, mediante contrato.

Assim, as peças e moldes de propriedade da Recorrida, que foram cedidos aos seus fornecedores a título de comodato, pertencem, na verdade, ao seu ativo imobilizado, o qual, ao tempo do período fiscalizado, gerava direito amplo e irrestrito ao crédito.

Resta configurado, portanto, que a utilização dos bens na hipótese presente dos autos não os caracteriza como alheios à atividade da empresa, também não se exigindo o estorno do crédito em razão da saída em comodato, devendo-se excluir as exigências pertinentes a tal estorno de crédito.",753

Dessa forma: mesmo cedido em comodato, o bem continua a integrar o ativo imobilizado do comodante. E, sendo empregado em fins não alheios à atividade empresarial, o crédito de ICMS continua sendo devido.

\subsubsection{CRÉDITO SOBRE SERVIÇOS DE TRANSPORTE E COMUNICAÇÃO.}

\subsection{HISTÓRICO NORMATIVO.}

Especificamente quanto aos serviços de comunicação e transporte, havia regra no Convênio ICM n ${ }^{\circ}$ 66/88 restringindo o direito ao crédito às hipóteses em que o estabelecimento tomador utilizasse tais serviços:

(a) na execução de atividades da mesma natureza;

(b) para a comercialização de mercadorias;

(c) na produção, extração, industrialização ou geração (inclusive de energia).

Em decorrência da $\mathrm{LC} \mathrm{n}^{\circ}$ 87/96, deixaram de existir as restrições do Convênio ICM $n^{\circ} 66 / 88$, passando-se, então, a ser autorizado o crédito sobre os serviços de comunicação e transportes desde que seu uso não se destinasse a fim alheio à atividade do estabelecimento:

“Art. 20. Para a compensação a que se refere o artigo anterior, é assegurado ao sujeito passivo o direito de creditar-se do imposto anteriormente cobrado em operações de que tenha resultado a entrada de mercadoria, real ou simbólica, no estabelecimento, inclusive a destinada ao seu uso ou consumo ou ao ativo permanente, ou o recebimento de serviços de transporte interestadual e intermunicipal ou de comunicação.

$\S 1^{\circ}$. Não dão direito a crédito as entradas de mercadorias ou utilização de serviços resultantes de operações ou prestações isentas ou não tributadas, ou que se refiram a mercadorias ou serviços alheios a atividade do estabelecimento."

753 Conselho de Contribuintes do Estado de Minas Gerais, PTA/AI n 0 01.000154669-55, Acórdão $\mathrm{n}^{\circ}$ 3.424/09/CE, DOE 18.06.2009. 
Com a LC $\mathrm{n}^{\circ} 102 / 00$, novas condicionantes foram trazidas para o creditamento dos serviços de comunicação. Confiram-se os termos da LC nº 87/96, em sua redação atual (modificada pela LC $\left.\mathrm{n}^{\circ} 102 / 00\right)$ :

“Art. 33. Na aplicação do art. 20 observar-se-á o seguinte:

(...)

IV - somente dará direito a crédito o recebimento de serviços de comunicação utilizados pelo estabelecimento:

a) ao qual tenham sido prestados na execução de serviços da mesma nature$\mathrm{za}$;

b) quando sua utilização resultar em operação de saída ou prestação para o exterior, na proporção desta sobre as saídas ou prestações totais; e

c) a partir de $1^{\circ}$ de janeiro de 2011 , nas demais hipóteses."

Assim, mesmo quando utilizados diretamente no processo de produção industrial, comercial ou de prestação de serviços de transporte, os serviços de comunicação não geram créditos aproveitáveis pelo tomador, à vista da vedação legal expressa trazida pela LC $\mathrm{n}^{\mathrm{o}} 102 / 00$.

Sendo essa a disposição normativa, cumpre analisar o tratamento do tema à luz da jurisprudência.

\subsection{O TRATAMENTO JURISPRUDENCIAL.}

À luz do Convênio ICM no 66/88, o STJ analisou a possibilidade de creditamento dos serviços de comunicação. Confira-se a seguinte ementa:

"PROCESSUAL CIVIL E TRIBUTÁRIO. ICMS. (...). PRINCÍPIO DA NÃO-CUMULATIVIDADE. (...). CREDITAMENTO. ART. 31, IV, DO CONVÊNIO ICM Nº 66/88. IMPOSSIBILIDADE.

(...)

2. A regra geral é que o ICMS pago pelo uso de serviços de telecomunicações não gera crédito compensável. Excepcionalmente, o art. 31, inciso IV, do Convênio ICM n ${ }^{\circ}$ 66/88 autoriza o creditamento do imposto quando houver demonstração de que o serviço foi utilizado em benefício da produção.

3. Recurso especial parcialmente conhecido e, nessa parte, provido." 754

No caso, uma empresa industrial pretendia creditar-se dos serviços de comunicação utilizados para viabilizar suas atividades. Tendo feito a prova necessária e havendo, à épo-

${ }^{754}$ STJ, Segunda Turma, REsp no 523.520/RS, Relator Min. JOÃO OTÁVIO DE NORONHA, DJ 06.02.2007, p. 280. 
ca, autorização convenial para o creditamento dos serviços utilizados na produção, comercialização ou industrialização, o pleito do contribuinte foi atendido.

Por outro lado, quando não provada a utilização nos fins do estabelecimento tomador do serviço - tarefa que competia ao contribuinte - não se reconhecia o direito ao creditamento:

"RECURSO ESPECIAL. TRIBUTÁRIO. ICMS. CREDITAMENTO. ART. 31, IV, DO CONVÊNIO 66/88. SERVIÇOS DE COMUNICAÇÃO. AUSÊNCIA DE COMPROVAÇÃO PELA CONTRIBUINTE. RECURSO PARCIALMENTE PROVIDO.

(...)

2. $O$ art. 31, IV, do Convênio 66/88, prevê a possibilidade de creditamento de ICMS incidente sobre o uso dos serviços de telecomunicação e de transporte, condicionando, porém, o referido benefício à utilização desses serviços para fins de produção ou comercialização.

3. Para que o contribuinte faça jus ao creditamento de ICMS de que trata o dispositivo supracitado, deve provar que os serviços de transporte e comunicação foram empregados diretamente na consecução de suas finalidades comerciais e/ou industriais. Assim, o ônus probatório pertence àquele que pretende se beneficiar com a aquisição do crédito.,"755

Interessante notar que o acórdão menciona acerca da possibilidade de se creditar dos serviços de transporte e comunicação utilizados em prol da industrialização ou comercialização. Com acerto. Isso porque o art. 31, IV autorizava expressamente o crédito de ICMS sobre serviços de comunicação ou de transportes utilizados em processo de industrialização ou na comercialização de mercadorias.

Entretanto, como a regra era o não-creditamento dos serviços de transporte e comunicação, a prova do enquadramento nas hipóteses do art. 31, IV do Convênio ICM nº 66/88 era conditio sine qua non para o exercício do direito ao crédito.

Sob a égide da LC $n^{\circ} 87 / 96$, em sua redação originária, o creditamento tornou-se regra geral. Todavia, por força do $\S 1^{\circ}$ do art. 20 da referida lei, os serviços de comunicação e transporte deveriam ser utilizados na atividade precípua do estabelecimento, fato este que também deveria ser provado pelo contribuinte. É ver a seguinte ementa, que tratou do crédito relativo aos serviços de comunicação:

“TRIBUTÁRIO. ICMS. SERVIÇOS DE (...) TELECOMUNICAÇÕES. CREDITAMENTO.

1. Segundo a jurisprudência do STJ, o ICMS incidente sobre as contas de (...) serviços de telecomunicações não podia ser creditado como espécie de

${ }^{755}$ STJ, Primeira Turma, REsp n ${ }^{\text {o } 735.894 / R S, ~ R e l a t o r a ~ M i n . ~ D E N I S E ~ A R R U D A, ~ D J e ~ 24.04 .2008 . ~}$ 
insumo, quando utilizados em empresa com atividade de mero comércio segundo o DL 406/68 e o Convênio 66/88.

2. Com o advento da LC 87/96, a proibição se estendeu às hipóteses em que esses serviços (...) não são utilizados na atividade precípua do estabelecimento. $(\ldots)^{, 756}$

$\mathrm{O}$ aresto se equivoca ao interpretar o direito ao crédito à luz do Convênio ICM n ${ }^{\circ}$ 66/88, eis que seu art. 31, IV admitia o creditamento apenas quando o serviço de comunicação fosse utilizado em prol da comercialização. Não obstante, corretamente avalia o regramento à luz da LC no 87/96: se utilizado na finalidade precípua do estabelecimento, o serviço gera créditos de ICMS passíveis de aproveitamento.

Como não poderia deixar de ser, o mesmo entendimento foi assentado para o crédito sobre serviços de transporte à luz da $\mathrm{LC}^{\circ}$ 87/96. É ver:

“TRIBUTÁRIO. RECURSO ESPECIAL. ICMS. (...). SERVIÇO DE TRANSPORTE. DIREITO AO CRÉDITO. MOMENTO POSTERIOR À VIGÊNCIA DA LEI COMPLEMENTAR N. ${ }^{\circ} 87 / 96$ (LEI KANDIR). POSSIBILIDADE.

1. Pacificou-se nesta Corte entendimento no sentido de reconhecer o direito ao crédito de ICMS relativo à aquisição de bens destinados ao ativo imobilizado, material de uso e consumo, bem como ao recebimento de serviço de transporte, a partir da edição da LC 87/96 (Lei Kandir).

2. Recurso especial provido." 757 (destaques nossos)

A ação foi movida por um sindicato que atua na área de supermercados. Ao construir nova estrutura física para sua sede, utilizou-se de serviços de transporte tributados pelo ICMS. Em face da negativa do Fisco de lhe reconhecer os créditos, ingressou em juízo e obteve o amparo do STJ para tanto. Veja-se o trecho a seguir do voto da Min. ELIANA CALMON:

"Assim, como na presente hipótese restou incontroverso tratar-se de operações concernentes à aquisição e transporte de material destinado à construção de um novo prédio para o sindicato, que atua na área de supermercado, realizadas na vigência da referida LC 87/96, tem o recorrente direito ao creditamento propugnado (...)., ${ }^{, 758}$

\footnotetext{
${ }^{756}$ STJ, Segunda Turma, RMS no 19.176/SC, Relatora Min. ELIANA CALMON, DJ 12.09.2005, p. 259.

${ }^{757}$ STJ, Segunda Turma, REsp no 621.557/RS, Relatora Min. ELIANA CALMON, DJ 19.09.2005, p. 271.

${ }^{758}$ STJ, Segunda Turma, REsp no 621.557/RS, Relatora Min. ELIANA CALMON, DJ 19.09.2005, p. 271.
} 
Como o material transportado destinava-se à construção da sede do estabelecimento, entendeu o STJ que o serviço de transporte empregado geraria créditos do ICMS, pois estava vinculado à atividade do contribuinte.

O verdadeiro problema quanto ao creditamento reside na interpretação acerca do serviço realizado na finalidade do estabelecimento, condição trazida pelo art. $20, \S 1^{\circ}$ da LC n 87/96 para crédito do ICMS. Como já averbamos anteriormente, para nós, desde que o bem ou serviço seja utilizado, direta ou indiretamente, na consecução das atividades do estabelecimento, o direito ao crédito deve existir. Afinal, a LC $n^{\circ}$ 87/96 exige apenas que os bens ou serviços não sejam utilizados em fins alheios ao do estabelecimento (art. 20, $\S 1^{\circ}$ ). Contudo, pelo fato de o conceito ser um tanto vago, há margem para divergências, que efetivamente existem. Dessa forma, o Fisco defende as interpretação restritivas do direito ao crédito, como vimos quando da análise dos bens destinados ao ativo permanente alheios à atividade do contribuinte, à qual remetemos o leitor neste ponto (item 11.2.2.2.3).

Com a LC n ${ }^{\circ}$ 102/00, o regime dos serviços de comunicação foi modificado - mantendo-se incólume, todavia, o regramento dos serviços de transporte. Assim, o crédito seria admitido apenas quando o consumo da comunicação se desse pelas empresas de telecomunicações, em prol de atividades dessa natureza ou da exportação de mercadorias ou serviços (neste caso, apenas na proporção das exportações). Nas demais hipóteses - consumo por estabelecimentos comerciais, industriais e outros - o dies a quo para início do creditamento está postergado para 01.01.2011 (art. 33, IV da LC nº 87/96, modificada pela LC n ${ }^{\circ}$ 102/00). Refletindo a mudança legislativa, hodiernamente em vigor, decidiu o STJ:

"TRIBUTÁRIO. ICMS. CREDITAMENTO RELATIVO A (...) SERVIÇOS DE TELECOMUNICAÇÕES. ART. 33 (...), INCISO IV, 'A' [DA LEI COMPLEMENTAR] No 87/96. POSSIBILIDADE.

O contribuinte tem direito ao creditamento de ICMS se comprovar ter utilizado a energia elétrica 'no processo de industrialização' ou ter utilizado serviços de comunicação na 'execução de serviços da mesma natureza'.

Embargos de divergência providos." 759

A nosso sentir, a restrição ao crédito sobre os serviços de comunicação tal como plasmada na LC n ${ }^{\circ}$ 87/96 (em sua redação atual, dada pela LC $n^{\circ} 102 / 00$ ) fere o núcleo mínimo da não-cumulatividade predicado pelo Supremo Tribunal Federal. Isso porque a teoria do crédito físico somente é aplicável quando se trata de mercadorias. Em havendo

${ }^{759}$ STJ, Primeira Seção, EREsp n o 899.485/RS, Relator Min. HUMBERTO MARTINS, DJe 15.09.2008. 
consumição de serviços tributados pelo ICMS, por impossibilidade de ordem lógica, estes não poderão se agregar fisicamente ao produto final. Todavia, sendo essenciais à atividade comercial, industrial ou de prestação de serviços tributados, devem, por imperativo constitucional, ter o direito ao crédito reconhecido. Nessa hipótese, o serviço de comunicação deverá ser equiparado a um insumo (eis que a nomenclatura bem intermediário é exclusiva para as indústrias, como já visto). É impossível pensar-se em qualquer setor da atividade humana que, atualmente, possa funcionar sem a utilização dos serviços de comunicação. Por essa razão e pela determinação do STF acerca do crédito físico, que somente é aplicável ao ICM, mas não aos serviços tributados pelo imposto, a restrição imposta pelo art. 33, IV da LC no 87/96 em sua redação atual afigura-se inconstitucional.

\subsubsection{OS CRÉDITOS SOBRE A ENERGIA ELÉTRICA CONSUMIDA.}

A análise do direito ao crédito sobre a energia elétrica utilizada nos estabelecimentos comerciais, industriais e prestadores de serviço já foi realizada no item 11.2.2.1.

De todo modo, o atual regramento da matéria ( $L C n^{\circ} 87 / 96$, modificada pela LC $n^{\circ}$ 102/00) determina:

“Art. 33. Na aplicação do art. 20 observar-se-á o seguinte:

(...)

II - somente dará direito a crédito a entrada de energia elétrica no estabelecimento:

a) quando for objeto de operação de saída de energia elétrica;

b) quando consumida no processo de industrialização;

c) quando seu consumo resultar em operação de saída ou prestação para o exterior, na proporção destas sobre as saídas ou prestações totais; e

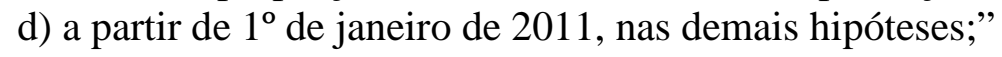

Como a energia é, para todos os fins, equiparada à mercadoria, não se pode aplicar a jurisprudência do STF (creditamento físico) para regê-la. Portanto, as restrições trazidas ao crédito da energia elétrica pela LC no 102/00 são, a priori, legítimas à luz da jurisprudência dominante.

Entrementes, quando a energia é utilizada por prestadores de serviço, as normas da LC $n^{\circ}$ 102/00 devem ser interpretadas à luz das especificidades do caso concreto. Notadamente no serviço de comunicação, a energia é insumo fundamental (o pulso eletromagnético que transmite a voz e os dados é a própria energia elétrica transformada).

É o que se demonstrará a seguir, em uma análise acerca dos serviços tributados pelo ICMS e da imperiosidade de uma adequação jurisprudencial ao alargamento da hipótese de 
incidência desse (incluindo os serviços de comunicação e de transporte interestadual e intermunicipal).

\subsection{A NÃO-CUMULATIVIDADE NA PRESTAÇÃO DE SERVIÇOS E A TEORIA DO CRÉDITO FÍSICO.}

Como se viu no Título II, a origem da teoria do crédito físico remonta ao vetusto imposto de consumo, sucedido pelo IPI. O STF, baseado em análise do processo industrial, concluiu que apenas os bens que se incorporam ao produto final ou são consumidos no processo industrial geram direito ao crédito. Entrementes, essa tese foi transplantada, sem uma discussão aprofundada, para o $\mathrm{ICM}^{760}$. Com a edição da Constituição de 1988 e a inclusão de dois serviços no raio de incidência do ICMS, as Cortes pátrias passaram a ter o dever de reanalisar o marco teórico da não-cumulatividade. Afinal, uma tese erigida para o setor industrial foi transposta para o comércio, sem adaptações, gerando, assim, diversas vicissitudes como vimos ao longo do trabalho. Neste momento, decorridos mais de 20 anos da Constituição de 1988 e, portanto, do novel ICMS, ainda não houve específica manifestação da Corte Suprema sobre o novo regramento da não-cumulatividade do imposto.

Desnecessário dizer que, levada às últimas conseqüências, a teoria do crédito físico invalidará a não-cumulatividade do ICMS nos setores de transporte e telecomunicações. Por essa razão, os insumos utilizados em tais atividades devem ter reconhecido seu direito ao crédito, pois será impossível que haja agregação ao produto final ou consumição em processo industrial, por se tratar do setor de serviços.

A interpretação das normas deve ser sempre feita de forma sistemática. Assim, ao se aplicar o crédito físico no segmento de prestação de serviços, anula-se por completo a não-cumulatividade assegurada pela Constituição.

Confiram-se, a seguir, algumas questões enfrentadas pelos prestadores de serviços de comunicação e transporte interestadual e intermunicipal para fazer valer a nãocumulatividade tributária, prevista na CR/88 e na $\mathrm{LC} \mathrm{n}^{\circ}$ 87/96.

\subsubsection{A PRESTAÇÃO DE SERVIÇOS DE TRANSPORTE INTERESTADUAL E INTERMUNICIPAL.}

\subsubsection{O DIREITO AO CRÉDITO SOBRE OS INSUMOS UTILIZADOS NO TRANSPORTE DE MERCADORIAS.}

\footnotetext{
${ }^{760}$ Vide Título II, Capítulo VI, Item 6.12, e Capítulo VII, Item 7.7.
} 
Os prestadores de serviço de transporte interestadual e intermunicipal utilizam diversos insumos em suas atividades, tais como gasolina, óleo diesel, lubrificantes, pneus e outros. Entretanto, inexiste uniformidade dos Fiscos estaduais no que tange à definição dos insumos que efetivamente geram crédito neste tipo de atividade.

O Estado de São Paulo reconhece, para o contribuinte optante pelo sistema normal de débitos e créditos $^{761}$, a possibilidade de aproveitamento dos créditos de ICMS suportados na aquisição de combustíveis (gasolina, óleo diesel e álcool) ${ }^{762}$. Por outro lado, nega o caráter de insumos aos pneus, lonas, peças para manutenção e óleos lubrificantes ${ }^{763}$. No que tange aos três primeiros itens, contudo, a SEFAZ/SP abre possibilidade para que o contribuinte aproveite os respectivos créditos de ICMS, desde que registre tais bens como integrantes do seu ativo imobilizado ${ }^{764}$. Para tanto, os bens deverão ter duração superior a 12 (doze) meses, além de se integrarem à estrutura física dos veículos transportadores - o que é impossível, v.g., no caso dos óleos lubrificantes.

O Estado do Rio de Janeiro, a seu turno, reconhece os combustíveis como insumos, autorizando o crédito integral e à vista para o transportador sujeito à apuração normal do

\footnotetext{
${ }^{761}$ Fazemos essa ressalva pois o Convênio ICMS n ${ }^{\circ}$ 106/96 permite que o transportador opte pela utilização de um crédito presumido de $20 \%$ (vinte por cento) sobre o valor do ICMS devido na prestação. No caso de transporte aéreo, o crédito presumido é de $8 \%$ (oito por cento) sobre o imposto a recolher. Optando pela sistemática convenial, o contribuinte deixa de fazer jus aos créditos regulares do ICMS. As normas do Convênio ICMS n ${ }^{\circ}$ 106/96 foram incorporadas pelo RICMS/SP (Decreto ${ }^{\circ}$ 45.490, de 30 de novembro de 2000), nos artigos 11 e 12 de seu Anexo III.

Frisa-se, contudo, que o STJ entende ser ilegítima a restrição ao aproveitamento dos créditos regulares do imposto por parte do transportador optante pela utilização de benefício fiscal. Sob a égide do Convênio ICMS no 38/89, que concedia redução de base de cálculo ao prestador do serviço de transporte, obrigando-o todavia a abandonar o regime de débitos e créditos escriturais, assentou-se pela possibilidade de cumulação do benefício com o sistema regular de apuração do imposto, ao contrário do que exigia o convênio (STJ, Segunda Turma, REsp no 466.832/RS, Relatora Min. ELIANA CALMON, DJ 05.06.2006, p. 245).

Data venia, entendemos que o STJ se equivocou no acórdão em comento. Somente haveria ferimento à nãocumulatividade se o contribuinte fosse obrigado a sair do regime débito-crédito do ICMS. Todavia, no caso era oferecida uma alternativa ao sistema regular da não-cumulatividade que, se eleita, teria como conseqüência a vedação do aproveitamento de créditos do imposto como contrapartida à redução da base de cálculo. Trata-se, portanto, de um acordo oferecido pelo Fisco aos contribuintes, que somente fariam a opção se esta, financeiramente, fosse mais vantajosa.

Analisando o mesmo convênio, o STF chegou a conclusão distinta do Superior Tribunal de Justiça, arrimado no fato de ser o benefício uma opção colocada à disposição do contribuinte e que implicaria, como conseqüência válida, a exclusão do regime de apuração de débitos e créditos (STF, Pleno, ADI-MC no 1.502/DF, Relator Min. ILMAR GALVÃO, DJ 14.11.1996, p. 44.467).
}

\footnotetext{
${ }^{762}$ Secretaria da Fazenda do Estado de São Paulo, Resposta à Consulta de Contribuinte no 038/1997.

${ }^{763}$ Secretaria da Fazenda do Estado de São Paulo, Resposta à Consulta de Contribuinte nº 038/1997.

${ }^{764}$ Secretaria da Fazenda do Estado de São Paulo, Resposta à Consulta de Contribuinte no 796/2003.
} 
ICMS $^{765}$. Todavia, condiciona esse direito à aquisição de combustível diretamente da distribuidora $^{766}$. Tal exigência é irregular haja vista que, segundo o art. 20 da LC n ${ }^{\circ}$ 87/96, basta ser a aquisição tributada para que surja o direito ao crédito. $O$ fato da compra ser feita diretamente da distribuidora, do posto de combustível, da refinaria ou de terceiros, é irrelevante para a operacionalização da não-cumulatividade tributária. Com relação aos lubrificantes, pneus e peças de reposição, a SEFAZ/RJ classifica-os como bens de uso e consumo, impassíveis de gerar créditos do ICMS por força da postergação ao seu aproveitamento imposta pelo art. 33, I da $\mathrm{LC} \mathrm{n}^{\circ} 87 / 96$, com a redação da $\mathrm{LC} \mathrm{n}^{\circ} 122 / 06^{767}$.

O Estado de Minas Gerais, por outro lado, assegura expressamente para o transportador optante pelo regime regular de apuração ${ }^{768}$, o direito ao crédito à vista (rectius, como insumos) de combustíveis, lubrificantes, pneus, câmaras-de-ar de reposição e materiais de limpeza, estritamente necessários à prestação do serviço de transporte ${ }^{769}$. Todavia, restringe tal direito aos insumos utilizados em veículos próprios, o que a nosso sentir fere a nãocumulatividade tributária. Afinal, se a mercadoria é essencial para o transporte, faz jus o transportador - seja o veículo de sua propriedade ou de terceiros - ao crédito do ICMS suportado na aquisição.

É possível dessumir dessa breve exposição que inexiste qualquer diretriz no tratamento conferido pelos Fiscos estaduais aos créditos de ICMS passíveis de aproveitamento pelo transportador contribuinte do imposto.

Para além dos materiais referidos acima, cujo tratamento é distinto em cada um dos Estados (à exceção dos combustíveis, estes sim reconhecidos unanimemente como insumos), os fiscos estaduais relutam em reconhecer os créditos sobre determinadas partes e peças dos veículos, tais como protetores e lonas, assim como sobre fluidos de freio e de direção - todos materiais imprescindíveis para o serviço de transporte. $\mathrm{Na}$ interpretação estatal, essas mercadorias (assim como outras) destinam-se ao uso e consumo dos transpor-

\footnotetext{
765 O Rio de Janeiro também oferece ao transportador o regime opcional do crédito presumido previsto no Convênio ICMS no 106/96 (incorporado pela Portaria da Superintendência de Tributação $n^{\circ}$ 162, de 6 de dezembro de 2004), que exclui o contribuinte da apuração regular do ICMS.

${ }^{766}$ RICMS/RJ (Decreto ${ }^{\circ}$ 27.427, de 17 de novembro de 2000), Livro IV, art. 26, § $3^{\circ}$.

${ }^{767}$ Perguntas e Respostas da SEFAZ/RJ (www.fazenda.rj.gov.br).

${ }^{768}$ À semelhança de SP e RJ, o Estado de Minas Gerais faculta a troca do sistema normal de débitos e créditos pelo crédito presumido do Convênio ICMS n 106/96 (incorporado no art. 75, V do RICMS/MG - Decreto $\mathrm{n}^{\circ} 43.080$, de 12 de dezembro de 2002).

${ }^{769}$ RICMS/MG, art. 66, VIII.
} 
tadores. Nessa toada, o crédito não seria permitido, seja sob a égide do Convênio ICM $\mathbf{n}^{\circ}$ 66/88, seja à luz da LC nº 87/96 (que vem postergando, desde sua edição, a autorização de creditamento sobre materiais de uso e consumo).

Mesmo recorrendo ao Judiciário, os transportadores não têm obtido sucesso no reconhecimento dos créditos sobre bens como peças de reposição, conserto e conservação dos veículos ${ }^{770}$. A jurisprudência funda-se, para tanto, na regra geral de distinção entre bens de uso e consumo e produtos intermediários (insumos), que se baseia nas seguintes premissas:

(a) os produtos intermediários são consumidos de forma imediata e integral no processo de prestação de serviços, sendo a este essenciais;

(b) os bens de uso e consumo, ainda que utilizados e consumidos na prestação do serviço, não são essenciais e imprescindíveis ao processo.

Ora, o fluido de freio não move o motor como a gasolina. Mas é possível prestar serviço de transporte sem freios? O mesmo vale para os pneus, lonas dos freios e outras partes e peças do veículo que, sendo consumidas em prazo inferior a 12 meses (logo, não qualificáveis como ativo permanente) e afigurando-se essenciais para o serviço do transporte, devem ter o direito ao crédito do ICMS reconhecido.

Das legislações examinadas, a mais benéfica aos contribuintes é a do Estado de Minas Gerais. Para logo, duas conclusões são possíveis: as normas paulista e fluminense ferem as regras da não-cumulatividade plasmadas na LC nº 87/96 ou, então, o Estado de Minas Gerais concedeu benefício fiscal (crédito fictício) à revelia do CONFAZ, devendo o art. 66, VIII do RICMS/MG ser declarado inconstitucional. A primeira opção, parece-nos, é a correta, sem prejuízo da necessidade de ampliação do rol de bens cujo creditamento é autorizado pelo RICMS/MG ${ }^{771}$.

${ }_{770}$ STJ, Primeira Turma, EDcl no REsp no ${ }^{\circ}$ 101.797/SP, Relator Min. HUMBERTO GOMES DE BARROS, DJ 15.09.1997, p. 44.288.

${ }^{771}$ A respeito da necessária amplitude que se deve conferir ao crédito de ICMS na prestação do serviço de transporte, SACHA CALMON e MISABEL DERZI, analisando a atividade de empresa ferroviária, assentaram:

“(...) Na prestação de serviços de transporte ferroviário de cargas, são apropriáveis, na condição de insumos, os créditos decorrentes da entrada de combustíveis, lubrificantes, fluido para freios, graxa, desengraxantes, aditivos, descarbonizantes, materiais de limpeza, energia elétrica e serviços de comunicação nas etapas operacionais. (...). Quanto ao ativo imobilizado, geram direito de crédito todas as mercadorias que, tendo vida útil superior a doze meses, destinem-se a garantir o funcionamento da empresa, como um todo." (COÊLHO, Sacha Calmon Navarro e DERZI, Misabel Abreu Machado. Intributabilidade do Serviço de Transporte Prestado a Si Mesmo e o Direito aos Créditos Relativos ao Imposto Pago na Aquisição de Insumos. Belo Horizonte, abr./2000, inédito). 


\subsubsection{O TRANSPORTE DE PRODUTOS NÃO-TRIBUTADOS NÃO AFETA O DIREITO AO CRÉDITO SOBRE INSUMOS UTILIZADOS NA PRESTAÇÃO DO SERVIÇO.}

É usual que os Fiscos exijam o estorno do crédito de ICMS incidente sobre o serviço de transporte quando a mercadoria transportada não é gravada pelo imposto estadual. Tal fato ocorre, por exemplo, quando se transportam mercadorias entre estabelecimentos sitos em cidades ou Estados distintos, porém pertencentes a um mesmo titular, assim como no transporte interestadual de combustíveis e lubrificantes destinados a outra unidade da federação. Na primeira hipótese, a operação refoge ao âmbito de aplicação da regra-matriz do imposto (não-incidência típica, inclusive reconhecida por força da Súmula no ${ }^{\circ}$ 166/STJ). Ao passo que na segunda existe imunidade de ICMS dos combustíveis e lubrificantes quando vendidos a adquirente estabelecido em outro Estado ${ }^{772}$.

Contudo, se estiverem presentes os requisitos erigidos pelo art. 20, caput e $\S \S 1^{\circ} \mathrm{e}$ art. $2^{\circ}$ da LC n ${ }^{\circ}$ 87/96, dar-se-á o creditamento. Tais requisitos são:

(a) a prestação do serviço de transporte foi tributada pelo ICMS e

(b) os bens transportados não são alheios à atividade do estabelecimento destinatário;

O entendimento contrário pugnado por alguns fiscos estaduais - que insistem em negar o crédito do ICMS sobre o frete de mercadoria não tributada - é insustentável em face do mais simples cotejo com as regras da $\mathrm{LC}^{\circ} 87 / 96$.

12.3.2. NÃO-CUMULATIVIDAdE E PRESTAÇÃO DE SERVIÇOS DE COMUNICAÇÃO.

\subsubsection{OS CRÉDITOS DE ENERGIA ELÉTRICA UTILIZADOS NA ÁREA O- PERACIONAL DAS EMPRESAS.}

As empresas de telecomunicações, assim como as de transporte interestadual e intermunicipal, com o advento da CR/88 passaram a serem contribuintes do ICMS.

\footnotetext{
${ }^{772} \mathrm{CR} / 88$ :

"Art. 155. (...).

$\S 2^{\circ}$. O [ICMS]:

(...)

X - não incidirá:

(...)

b) sobre operações que destinem a outros Estados petróleo, inclusive lubrificantes, combustíveis líquidos e gasosos dele derivados, e energia elétrica;"
} 
Os créditos aproveitáveis em decorrência do princípio da não-cumulatividade, partindo do pressuposto de que nos serviços inexiste matéria-prima (sendo impossível a incorporação física de qualquer mercadoria ao serviço prestado), são basicamente:

(a) oriundos das aquisições para o ativo permanente ${ }^{773}$;

(b) provenientes das compras de insumos.

A questão reside na conceituação de insumo quando se trata de prestador de serviço de comunicação. Alguns produtos, como o óleo diesel consumido em geradores elétricos nas centrais telefônicas, têm o crédito de ICMS reconhecido pelos fiscos estaduais e, quando necessário, pelo próprio Judiciário ${ }^{774}$. Nesses casos, tem-se o consumo imediato e integral, que se exige para a caracterização de bens intermediários. Por analogia, portanto, aplica-se a regra do creditamento das indústrias aos prestadores de serviço.

Contudo, outro insumo fundamental para as empresas de telecomunicações e que tem gerado acirrados debates desde a LC nº 102/00, é a energia elétrica. O Convênio ICM $n^{\circ}$ 66/88 restringia o direito ao crédito às hipóteses de consumo ocorridas na industrialização $^{775}$. Porém, quando a LC no $87 / 96$ foi editada, autorizou-se o crédito irrestrito sobre a energia elétrica consumida nos estabelecimentos do contribuinte ${ }^{776}$. Entrementes, a LC $\mathrm{n}^{\circ}$ 102/00 voltou a restringir o crédito de ICMS sobre a energia elétrica, autorizando-o apenas quando a mercadoria fosse consumida em processo de industrialização, utilizada para ex-

${ }^{773}$ Desde que haja autorização na legislação de regência, o que se tem a partir da LC nº 87/96.

${ }^{774}$ Confira-se o dispositivo da sentença prolatada na Ação Anulatória de Débito Fiscal no 001.04.047596-5 pelo Juiz RONNIE FRANK TORRES STONE, da Vara da Dívida Ativa Estadual do Amazonas (DJ 11.10.2005 - apelação do Estado aguardando julgamento pelo TJAM):

“(...) Entendo possível o aproveitamento do crédito decorrente da aquisição de óleo diesel utilizado nos grupos geradores que proporcionam a continuidade do serviço nos período de falha no fornecimento de energia elétrica. Isto por que verifico neste bem a natureza de insumo imprescindível para a prestação do serviço. Nos momentos de pane no fornecimento de energia elétrica, o óleo diesel é o insumo responsável pela geração da energia essencial para a manutenção do serviço. Isto é, está diretamente vinculado à prestação do serviço, restando nítida sua natureza de insumo."

${ }^{775}$ Convênio ICM nº 66/88:

“Art. 31. Não implicará crédito para compensação com o montante do imposto devido nas operações ou prestações seguintes:

(...)

II - a entrada de bens destinados a consumo ou à integração no ativo fixo do estabelecimento;

III - a entrada de mercadorias ou produtos que, utilizados no processo industrial, não sejam nele consumidos ou não integrem o produto final na condição de elemento indispensável a sua composição;"

${ }^{776}$ LC no 87/96, redação original:

“Art. 33. Na aplicação do art. 20 observar-se-á o seguinte:

I - somente darão direito de crédito as mercadorias destinadas ao uso ou consumo do estabelecimento, nele entradas a partir de $1^{\circ}$ de janeiro de 1998.

II - a energia elétrica usada ou consumida no estabelecimento dará direito de crédito a partir da entrada desta Lei Complementar em vigor." 
portação de produtos ou serviços ou para viabilizar a produção de energia elétrica ${ }^{777}$. Com isso, os créditos aproveitados pelas empresas do setor de telecomunicações sobre a energia elétrica consumida em suas centrais passou a ser glosado pelos Estados.

Em que pese o STF ter declarado em sede de medida cautelar (na ADI $n^{\circ}$ $2.325 / \mathrm{DF}^{778}$ ) que as modificações operadas pela LC $\mathrm{n}^{\circ} 102 / 00$ são constitucionais, parecenos que a restrição ao crédito sobre a energia elétrica (insumo tão fundamental à prestação de serviço) viola o núcleo mínimo da não-cumulatividade assegurado pelo prórpio STF. Expliquemo-nos.

A energia elétrica é o mais importante produto utilizado na prestação do serviço de comunicação. Na telefonia fixa, por exemplo, a voz é transmitida por meio de pulsos eletromagnéticos, que nada mais são do que a própria energia transformada. Na telefonia móvel, é também a energia elétrica que transporta o conteúdo transmitido, através das ondas eletromagnéticas. Essas ondas e pulsos eletromagnéticos, que transmitem os dados e a voz, são "a energia elétrica em movimento"779.

Nessa toada, negar o crédito à energia elétrica é fazer letra morta a nãocumulatividade tal como interpretada pelo STF. Afinal, à luz da teoria do crédito físico, tanto as matérias-primas como os produtos intermediários constituem o mínimo inatacável do direito ao crédito. Ao se vedar o crédito da energia para os prestadores de serviço de comunicação, estar-se-á tornando cumulativo um imposto que não o é ${ }^{780}$.

\footnotetext{
${ }^{777}$ LC n ${ }^{\text {o } 87 / 96, ~ m o d i f i c a d a ~ p e l a ~ L C ~ n o ~} 102 / 00$ :

"Art. 33. (...).

II - somente dará direito a crédito a entrada de energia elétrica no estabelecimento:

a) quando for objeto de operação de saída de energia elétrica;

b) quando consumida no processo de industrialização;

c) quando seu consumo resultar em operação de saída ou prestação para o exterior, na proporção destas sobre as saídas ou prestações totais; e

d) a partir de $1^{\circ}$ de janeiro de 2011, nas demais hipóteses (redação dada pela LC nº 122/06)."
}

${ }^{778}$ STF, Pleno, ADI-MC nº 2.325/DF, Relator Min. MARCO AURÉLIO, DJ 06.10.2006, p. 32.

${ }^{779}$ Laudo técnico elaborado pela AFAG Engenharia Ltda., com vistas a identificar o papel da energia elétrica na prestação dos serviços de comunicação. (SANTIAGO, Igor Mauler. Empresas de Telefonia Fixa e Móvel. Direito ao Creditamento do ICMS Incidente sobre a Energia Utilizada na Prestação dos Serviços de Comunicação. MOREIRA, André Mendes; RABELO FILHO, Antonio Reinaldo; CORREIA, Armênio Lopes (coord.). Direito das Telecomunicações e Tributação. São Paulo: Quartier Latin, 2006, p. 210).

${ }^{780}$ Confiram-se as lições de SANTIAGO:

“(...) A Constituição, ao formular o princípio da não-cumulatividade (mesmo que este seja entendido em sua forma mais restritiva, que só admite o crédito físico), garante o aproveitamento dos créditos por insumos integrados ao produto final ou ao resultado material do serviço ou consumidos na produção do primeiro ou na prestação do segundo.

Quanto a esse conteúdo mínimo da não-cumulatividade não existe espaço para dúvidas teóricas (...). 
Entretanto, como compatibilizar o que se está a dizer com a decisão do STF que legitimou, ainda que em sede de medida cautelar, as restrições ao crédito sobre a energia elétrica operadas pela LC $n^{\circ} 102 / 00$ ? A solução depende de uma interpretação, a ser feita pela própria Corte Suprema, quando do julgamento do mérito da ADI n 2.325/DF. Mesmo declarando constitucional o art. 33, II da LC $n^{\circ}$ 87/96, modificado pela LC $n^{\circ} 102 / 00$, a interpretação conforme à Constituição - carreada em diversas oportunidades pelo STF pode solucionar a questão ao indicar o sentido no qual o art acima deve ser entendido. Noutro giro verbal, é possível sustentar que a constitucionalidade do art. 33, II refere-se à limitação do crédito nas situações nele especificadas. Mas, se demonstrado que a energia consiste em insumo fundamental para atividade sujeita ao ICMS, o crédito será devido (conforme dispõe o art. 20, caput da $\mathrm{LC}^{\circ}$ 87/96, que prescreve a regra geral da nãocumulatividade $^{781}$. Do contrário, estar-se-ia permitindo ao legislador vedar até mesmo o crédito de insumos, o que nunca foi autorizado pela Corte Suprema desde o advento da não-cumulatividade por meio da EC no $18 / 65$.

Com efeito, admitir a restrição por lei ao direito de crédito quando a insumos essenciais seria negar qualquer conteúdo normativo ao dispositivo que institui a não-cumulatividade, submetendo-a ao inteiro alvedrio do legislador e esvaziando a decisão soberana do constituinte de dar-lhe status constitucional." (SANTIAGO, Igor Mauler. Empresas de Telefonia Fixa e Móvel. Direito ao Creditamento do ICMS Incidente sobre a Energia Utilizada na Prestação dos Serviços de Comunicação. MOREIRA, André Mendes; RABELO FILHO, Antonio Reinaldo; CORREIA, Armênio Lopes (coord.). Direito das Telecomunicações e Tributação. São Paulo: Quartier Latin, 2006, pp. 216-7).

${ }^{781}$ BOTTALLO e CARRAZZA chegam à mesma conclusão:

"I - Uma primeira leitura do art. 33, II, $b$ da Lei Complementar n $87 / 96$ (com a redação dada pela LC 102/00), pode levar ao entendimento de que o direito ao aproveitamento de créditos de ICMS, provenientes do consumo de energia elétrica, poderia ser reconhecido apenas a empresas industriais.

(...)

II - A expressão 'processo de industrialização' demanda adequação às diferentes variantes do ICMS, dentre as quais o que incide sobre a prestação dos serviços de telecomunicação.

(...)

Conseqüentemente, todos os insumos necessários ao desenvolvimento deste processo (prestação dos serviços de comunicação) geram direito de crédito, a exemplo do que ocorre com seus similares, no campo da industrialização em sentido estrito."

E arrematam, invocando o elevado grau de essencialidade da energia elétrica ao processo de prestação do serviço de telecomunicação:

"Note-se que, na prestação dos serviços de telecomunicação, a energia elétrica tem um elevadíssimo grau de essencialidade, já que, mais do que uma mera 'acionadora externa de equipamentos', integra a própria estrutura do processo de prestação dos serviços em pauta.” (BOTTALLO, Eduardo Domingos e CARRAZZA, Roque Antonio. Direito ao Crédito de ICMS pela Aquisição de Energia Elétrica Utilizada na Prestação de Serviços de Comunicação. Revista Dialética de Direito Tributário, no 119, ago./2005, pp. 76-7). 


\title{
12.3.2.2. O CRÉDITO SOBRE OS SERVIÇOS DE COMUNICAÇÃO UTILIZADOS NO CALL CENTER OBRIGATORIAMENTE MANTIDO PELA OPERADORA DE TELEFONIA.
}

A LC $\mathrm{n}^{\mathbf{o}}$ 102/00 também mitigou as possibilidades de aproveitamento dos créditos decorrentes da prestação de serviço de comunicação tomados pelo estabelecimento. Todavia, resguardou a possibilidade de crédito - o que, a nosso sentir, decorreria de qualquer forma do mínimo constitucional da não-cumulatividade - quando o seu consumo se der em prol da prestação de serviços da mesma natureza ${ }^{782}$.

No caso das empresas de telecomunicações a norma é essencial, haja vista que a interconexão de redes é fundamental para a prestação adequada do serviço ${ }^{783}$.

Entretanto, existe atualmente discussão quanto à possibilidade de as empresas de telecomunicação utilizarem os créditos de ICMS relativos aos serviços de call centers por elas contratados, necessários ao seu regular funcionamento. Expliquemos.

Toda empresa de telefonia fixa ou móvel é obrigada, pela Anatel, a manter gratuitamente, à disposição do usuário, um serviço de informação e de atendimento, sob pena de cassação ou caducidade da concessão ou autorização ${ }^{784}$. O usuário deve dispor de

\footnotetext{
${ }^{782}$ LC n $^{\circ} 87 / 96$, modificada pela LC no $102 / 00$ :

"Art. 33. (...).

IV - somente dará direito a crédito o recebimento de serviços de comunicação utilizados pelo estabelecimento:

a) ao qual tenham sido prestados na execução de serviços da mesma natureza;

b) quando sua utilização resultar em operação de saída ou prestação para o exterior, na proporção desta sobre as saídas ou prestações totais; e

c) a partir de $1^{\circ}$ de janeiro de 2011 , nas demais hipóteses." (destaques nossos)
}

\begin{abstract}
${ }^{783}$ A interconexão existe, pois as diversas companhias telefônicas não têm como instalar, em todo território nacional e internacional, redes de tráfego próprias para realizar, do início ao fim, todas as chamadas originadas em sua área de atuação. Nada mais natural, portanto, que convencionar um sistema uniforme que faça com que cada operadora possa dispor de toda a infra-estrutura de telefonia instalada.

O seguinte exemplo clarifica o que se está a tratar: o usuário de uma operadora (TIM, v.g.) realiza chamada para um usuário de outra operadora (VIVO). Para completar a chamada, a operadora de origem - TIM precisa utilizar os meios da operadora de destino - VIVO (há prestação de serviço de comunicação da VIVO para a TIM, no exemplo dado), mediante o pagamento de uma remuneração (exatamente a receita de interconexão da VIVO).

A Lei Geral de Telecomunicações (Lei no 9.472/97), além de tornar obrigatória a interconexão (art. 146, I), define-a como "a ligação entre redes de telecomunicações funcionalmente compatíveis, de modo que os usuários de serviços de uma das redes possam comunicar-se com usuários de serviços de outra ou acessar serviços nela disponíveis" (art. 146, parágrafo único).
\end{abstract}

${ }^{784}$ Assim prescreve o Regulamento do Serviço de Telefonia Fixa Comutado, veiculado como anexo à Resolução Anatel no 426, de 9 de dezembro de 2005:

“Art. 34. A Prestadora deve tornar disponível acesso gratuito à central de informação e de atendimento do Usuário, conforme previsto no PGMQ-STFC [Plano Geral de Metas de Qualidade do Serviço de Telefonia Fixo Comutado].

(...) 
um número para o qual ligará, sem custo, quando tiver reclamações ou solicitações a fazer. O custo da chamada, dessarte, será arcado pela operadora. Este serviço de call center, em regra, é feito por empresa terceirizada. Trata-se de atividade que envolve milhares de empregados.

Sendo assim, há um volume considerável de serviços de comunicação contratados pelas operadoras de telefonia, cujos créditos de ICMS as empresas tencionam aproveitar. O fundamento para tanto, com o qual concordamos, reside na obrigatoriedade de manutenção do call center, sob pena de multas e, no caso das empresas de telefonia móvel, até mesmo de perda da autorização para prestação do serviço ${ }^{785}$. Trata-se, dessarte, de serviço prestado às operadoras para a "execução de serviços da mesma natureza" (art. 33, IV, $a$ da LC no 87/96, modificado pela LC $\mathrm{n}^{\circ}$ 102/00). O direito ao crédito, sobre ser constitucional neste caso - pois se trata de insumo essencial para a atividade das companhias telefônicas - é ainda expressamente garantido pela legislação complementar.

Os fiscos se opõem ao creditamento em questão, sustentando que o art. 33, IV, $a$ da LC no 87/96 se restringe a assegurar os créditos de ICMS nas operações de interconexão, ou seja, quando o serviço for prestado para efetivamente completar a chamada originada de determinada operadora. Trata-se de posicionamento semelhante ao conferido para o crédito dos bens intermediários na indústria. Caso tais bens não sejam utilizados na linha principal de produção, o direito ao crédito será negado, com a anuência do STJ. Ora, como já averbamos anteriormente, desde que o produto seja essencial ao processo de produção ou à prestação do serviço, o direito ao crédito decorrerá da Constituição e da legislação complementar, sendo injurídicas as interpretações restritivas ao conceito de insumos que têm sido carreadas pelo STJ em determinados casos.

$\S 2^{\circ}$. O acesso à central de informação e de atendimento do Usuário deve oferecer grau de serviço compatível com o que determina o PGMQ-STFC."

Já Regulamento do Serviço Móvel Pessoal, anexo à Resolução Anatel nº 477, de 7 de agosto de 2007, prescreve:

“Art. 92. A prestadora deve tornar disponível ao Usuário o acesso telefônico gratuito ao Centro de Atendimento, bem como informar os endereços dos Setores de Atendimento.

$\S 1^{\circ}$. O acesso ao Centro de Atendimento deve oferecer grau de serviço compatível com o que determina o PGMQ-SMP [Plano Geral de Metas de Qualidade do Serviço Móvel Pessoal].

$\S 2^{\circ}$. A gratuidade prevista no caput inclui as chamadas originadas de estações fixas ou móveis de qualquer localidade dentro do território nacional."

${ }^{785}$ Confira-se a Lei n ${ }^{\circ}$ 9.472/97:

"Art. 140. Em caso de prática de infrações graves, de transferência irregular da autorização ou de descumprimento reiterado de compromissos assumidos, a Agência poderá extinguir a autorização decretando-lhe a caducidade." 
À luz do STF, a não-cumulatividade possui um núcleo mínimo. Sendo assim, não se pode coadunar com o posicionamento do STJ que intenta mitigar a garantia constitucional da não-cumulatividade com base em interpretações sem respaldo legal do conceito de insumos.

Em relação ao caso em tela, como o call center mantido pelas operadoras está diretamente ligado à prestação do serviço de comunicação, a conclusão a que se chega é pela legitimidade do aproveitamento dos créditos de ICMS na hipótese sub examine.

\subsection{O DIREITO DE TRANSFERÊNCIA A TERCEIROS DO SALDO CREDOR DE ICMS ACUMULADO.}

\subsubsection{A TRANSFERÊNCIA MANDATÓRIA EM DECORRÊNCIA DA EXPOR- TAÇÃO ${ }^{786}$ DE MERCADORIAS E SERVIÇOS.}

No Título II, Capítulo VII, Item 7.12 foi examinado o tratamento conferido pela Constituição aos créditos de ICMS quando da exportação de mercadorias e serviços. A regra atualmente inserta na Lei Maior imuniza do tributo estadual todas as exportações e, ademais, assegura "a manutenção e o aproveitamento do montante do imposto cobrado nas operações e prestações anteriores" ${ }^{, 787}$. A manutenção dos créditos ficava, anteriormente, a critério do legislador complementar, que tinha a faculdade de "prever casos de manutenção de crédito, relativamente à (...) exportação para o exterior, de serviços e de mercadorias" ${ }^{\text {"78 }}$. Hoje isso é dever estabelecido pela Constituição. Ademais, a EC nº 42/03 inovou ao exigir o aproveitamento dos créditos acumulados do ICMS em razão da exportação, previsão que inexistia na redação anterior da CR/88.

De todo modo, mesmo antes de se tornar mandatória por força da EC n ${ }^{\circ} 42 / 03$, a LC n ${ }^{\circ} 87 / 96$ já previa tanto a manutenção dos créditos na exportação (art. 32, II ${ }^{789}$ ) como a

\footnotetext{
${ }^{786} \mathrm{~A} \mathrm{LC} \mathrm{n}{ }^{\circ} 87 / 96$ (art. 3o parágrafo único) equipara à venda para o exterior a remessa de mercadoria com fim específico de exportação para:

(a) empresa comercial exportadora, inclusive trading;

(b) outro estabelecimento da mesma empresa;

(c) armazém alfandegado ou entreposto aduaneiro.

${ }^{787}$ Art. $155, \S 2^{\circ}, \mathrm{X}, a$, com a redação da $\mathrm{EC} \mathrm{n}^{\circ}$ 42/03, destaques nossos.

${ }^{788}$ Art. $155, \S 2^{\circ}$, XII, $f$, redação originária da CR/88.

${ }^{789}$ LC no 87/96:

“Art. 32. A partir da data de publicação desta Lei Complementar:

(...)

II - darão direito de crédito, que não será objeto de estorno, as mercadorias entradas no estabelecimento para integração ou consumo em processo de produção de mercadorias industrializadas, inclusive semi-elaboradas, destinadas ao exterior;"
} 
possibilidade de seu aproveitamento, mediante transferência a terceiros do saldo credor ${ }^{790}$ acumulado pelo exportador ${ }^{791}$, in verbis:

“Art. 25. (...).

$\S 1^{\circ}$. Saldos credores acumulados a partir da data de publicação desta Lei Complementar por estabelecimentos que realizem operações e prestações de [exportação] podem ser, na proporção que estas saídas representem do total das saídas realizadas pelo estabelecimento:

I - imputados pelo sujeito passivo a qualquer estabelecimento seu no Estado;

II - havendo saldo remanescente, transferidos pelo sujeito passivo a outros contribuintes do mesmo Estado, mediante a emissão pela autoridade competente de documento que reconheça o crédito." (destaques nossos)

De fato, a imunidade na exportação gera cumulatividade residual à míngua de uma forma efetiva de se utilizar os créditos acumulados. Muitos exportadores não realizam vendas para o mercado interno ou fazem-no em volume pouco significativo. Por isso, acumulam saldo credor do imposto suportado nas aquisições internas.

A regra plasmada na $\mathrm{LC} \mathrm{n}^{\circ} 87 / 96$ não é a ideal, pois o correto seria o ressarcimento em espécie ao exportador, como ocorre em determinadas situações no IVA-europeu ${ }^{792}$. Todavia, as impossibilidades financeiras dos Estados-membros impedem essa solução.

De todo modo, é importante registrar que o direito do exportador ao aproveitamento efetivo desses créditos decorre da Constituição. Portanto, sempre que houver necessida-

${ }^{790}$ A Secretaria da Fazenda de São Paulo assim define o "saldo credor" de créditos acumulados do ICMS: "O saldo credor constitui a mera diferença favorável ao contribuinte verificada entre todos os créditos e débitos apurados em determinado período. O crédito acumulado constitui espécie de crédito distinta dos demais quanto às respectivas formas de geração, apropriação e utilização. $O$ primeiro é apurado através do Livro Registro de Apuração do ICMS (RAICMS); o segundo, através do Demonstrativo de Geração de Crédito Acumulado, disciplinado na Portaria CAT-53/96." (SEFAZ/SP, Consulta $n^{\circ}$ 927-CT/SP, de 08.07.1999, Apud MATTOS, Aroldo Gomes de. ICMS - Comentários à Legislação Nacional. São Paulo: Dialética, 2006, p. 373).

${ }^{791}$ Reza a Súmula no 129 do STJ:

"O exportador adquire o direito de transferência de crédito do ICMS quando realiza a exportação do produto e não ao estocar a matéria-prima.”

Esse entendimento foi consolidado ainda sob a égide do DL n 406/68, que apenas em hipóteses tópicas assegurava o direito à manutenção e transferência dos créditos acumulados do ICM em decorrência da exportação. Alguns contribuintes pretenderam fazer uso dos créditos antes da exportação efetiva, o que gerou a jurisprudência em comento, que exige a efetiva saída das mercadorias do território nacional para que seja configurada a exportação, com os efeitos tributários dela decorrentes.

${ }^{792}$ A Diretiva 2006/112/CE do Conselho da União Européia prevê a possibilidade de ressarcimento em espécie ("reembolso") ao contribuinte que possua saldo credor de IVA acumulado, por qualquer razão:

"Artigo $183^{\circ}$

Quando o montante das deduções exceder o montante do IVA devido relativamente a um período de tributação, os Estados-Membros podem efectuar o reporte do excedente para o período seguinte, ou proceder ao respectivo reembolso nas condições por eles fixadas." 
de de atuação do Estado (mediante a emissão de "documento que reconheça o crédito", conforme dispõe o art. $25, \S 1^{\circ}$, II da LC $\mathrm{n}^{\circ}$ 87/96) para viabilizar a transferência do saldo credor, a providência em comento terá caráter estritamente burocrático-administrativo. Não pode o ente federado se recusar ou criar óbices à transferência em tela, arrimado na necessidade de emissão de documento de sua competência para tanto. O reconhecimento do crédito pela autoridade fiscal limita-se a verificar a origem do crédito e a correção do cálculo apresentado pelo contribuinte ${ }^{793}$. O direito do exportador é incondicionado e oriundo diretamente da Constituição.

Em passado não muito distante, os Estados e o Distrito Federal firmaram um Protocolo ( $\mathrm{n}^{\mathrm{o}} 30$, de 30 de setembro de 2005) por meio do qual se comprometeram a "não autorizar novas transferências de créditos de ICMS acumulados em decorrência de desoneração das exportações". A norma malferiu tanto o art. $25, \S 1^{\circ}$, II da LC n ${ }^{\circ} 87 / 96$, como o art. 155 , $\S 2^{\circ}, \mathrm{X}, a$ da $\mathrm{CR} / 88$ (com a redação da $\mathrm{EC} \mathrm{n}^{\circ} 42 / 03$ ), que não impõem limites materiais ao exercício do direito de transferência do saldo credor por parte dos contribuintes. Todavia, a vedação foi estabelecida como forma de pressão, dos Estados-membros, para que a União autorizasse a transferência de valores necessários à recomposição dos caixas estaduais em decorrência da não-incidência do ICMS nas exportações. Dessa maneira predica o Anexo da $\mathrm{LC} \mathrm{n}^{\circ}$ 87/96 (que, à época da edição do referido Protocolo, não estava sendo cumprido pela União).

Em face da jurisprudência que já se consolidara pela impossibilidade de restrição ao direito de transferência dos créditos do ICMS plasmado no art. $25, \S 1^{\circ}$, II da LC $\mathrm{n}^{\circ}$ $87 / 96^{794}$, assim como do compromisso da União de aportar os recursos necessários para a

${ }^{793}$ MACHADO, Schubert de Farias. A Lei Complementar 102/2000, a Autonomia dos Estabelecimentos e a Transferência de Crédito de ICMS. ROCHA, Valdir de Oliveira (coord.). O ICMS e a LC 102. São Paulo: Dialética, 2000, p. 233.

794 Confiram-se os seguintes excertos extraídos de ementas de acórdãos dos Tribunais de Justiça do Rio Grande do Sul e do Mato Grosso:

"Existente expressa previsão legal, autorizando a transferência dos créditos acumulados nas operações relativas à exportação, conforme o artigo $25, \S 1^{\circ}$, da LC 87/9, hipótese que se enquadra a impetrante, não pode a legislação estadual, hierarquicamente inferior, restringir o direito assegurado pela norma superior, de eficácia plena, para possibilitar a transferência dos saldos credores. Precedentes do TJRGS e STJ. Apelação a que se nega seguimento. Sentença confirmada em reexame necessário." (TJRS, 22 Câmara, AC n 70027000751, Relator Des. CARLOS EDUARDO ZIETLOW DURO, DJ 10.11.2008).

"III - O direito à transferência de créditos decorrentes das operações de exportação possui previsão na Constituição Federal em seu artigo 155, II, $\S 2^{\circ}, X$, 'a', bem como na Lei Complementar $n^{\circ}$ 87/96, sendo tal direito auto-aplicável, conforme posicionamento do STJ.

IV - Mostra-se ilegal a edição de Decreto Estadual que limita a utilização desses créditos, posto que ofende o princípio da hierarquia das leis.

V - Apelo improvido.” (TJMA, 1ª̂amara Cível, AC nº 52102007, Relator Des. JORGE RACHID MUBÁRACK MALUF, DJ 23.05.2008). 
reposição das perdas tributárias dos Estados e do Distrito Federal com as exportações, os próprios signatários do Protocolo n $30 / 05$ revogaram-no, meses depois, por meio do Protocolo $\mathrm{n}^{\circ} 40$, de 22 de dezembro de 2005.

Hodiernamente, portanto, todas as operações e prestações anteriores à exportação geram créditos de ICMS, que são lançados na escrita do exportador. Em havendo acúmulo de saldo credor, a empresa poderá:

(a) transferi-lo para outros estabelecimentos situados no mesmo Estado ${ }^{795}$; e

(b) em persistindo o saldo credor, transferi-lo a terceiros, dentro do Estado, observando os procedimentos formais ditados pelo ente estadual.

A transferência do crédito de ICMS-exportação a terceiros é direito subjetivo do contribuinte com estofo constitucional, logo impassível de restrição, seja por lei complementar, ordinária ou, menos ainda, por atos do Poder Executivo.

\subsubsection{A NORMA ESPECIAL PARA O SALDO CREDOR DECORRENTE DE EXPORTAÇÃO ACUMULADO ATÉ 31 DE DEZEMBRO DE 1999.}

Para os créditos acumulados até 31.12.1999, existe regra específica plasmada na própria LC no 102/00 (ou seja, não inserida na LC no 87/96), que permite ao Estado parcelar a compensação do saldo credor, além de estabelecer critérios para a transferência:

"Art. $4^{\circ}$. Os saldos credores acumulados na forma prevista nos $\S \S 1^{\circ}$ e $2^{\circ}$ do art. 25 da Lei Complementar $n^{\circ}$ 87, de 1996, existentes em 31 de dezembro de 1999 e ainda não compensados ou transferidos até a data da entrada em vigor desta Lei Complementar, podem ser, a requerimento do sujeito passivo e a critério de cada um dos Estados, transferidos a outros contribuintes

\footnotetext{
${ }^{795}$ Essa regra decorre do princípio da autonomia dos estabelecimentos. Sob a égide do DL no 406/68 (art. $6^{\circ}$, $\S 2^{\circ}$ ), cada estabelecimento era considerado autônomo pelos Estados. Se um estabelecimento apurasse saldo devedor e outro saldo credor, não se permitia a compensação dos montantes, devendo o contribuinte recolher o débito às burras estatais e transportar, naqueloutro estabelecimento, o crédito para as competências subseqüentes.

Com o advento da $\operatorname{LC} \mathrm{n}^{\circ}$ 87/96, o princípio da autonomia dos estabelecimentos foi reafirmado (art. 11, $\S 3^{\circ}$, II). Contudo, em face dos problemas que a sistemática anterior gerava, facultou-se à lei estadual permitir, no cálculo do imposto devido, a consideração do conjunto de débitos e créditos de todos os estabelecimentos do sujeito passivo no Estado (art. 25, §2º I).

Com a entrada em vigor da LC no 102/00, o caput do art. 25 da LC n 87/96 ganhou nova redação, determinando que "os débitos e créditos devem ser apurados em cada estabelecimento, compensando-se os saldos credores e devedores entre os estabelecimentos do mesmo sujeito passivo localizados no Estado". Em outros termos, aquilo que era uma faculdade a ser exercida pelos Estados-membros tornou-se a regra geral em matéria de ICMS.

Por essas razões, quando o art. $25, \S 1^{\circ}$, I permite ao exportador transferir para outros estabelecimentos de sua titularidade o saldo credor acumulado, não se trata mais de benefício concedido à exportação, pois a regra de apuração do tributo já prevê a compensação de créditos e débitos entre todos os estabelecimentos do contribuinte no Estado.
} 
do mesmo Estado, para compensação parcelada, mediante a emissão, pela autoridade competente, de documento que reconheça o crédito."

Em nossa opinião, a norma em comento não poderia retroagir, atingindo direito consolidado dos contribuintes. Se em 31.12.1999 inexistiam as restrições acima, não pode norma posterior prejudicar a situação do contribuinte. A irretroatividade das leis (art. $5^{\circ}$, XXXVI da CR/88) é garantia fundamental, não podendo prejudicar o contribuinte que, à luz da norma vigente no último dia do ano de 1999, fazia jus à transferência integral, à vista e sem qualquer óbice aos seus créditos.

Da mesma forma, os critérios aos quais alude o artigo, que serão ditados pelos entes estaduais, somente poderão ser de índole formal. Isso porque, a EC n ${ }^{\circ} 42 / 03$ constitucionalizou o direito ao aproveitamento dos créditos de ICMS acumulados em decorrência da exportação. Assim, a partir daquela, o legislador complementar não mais pode erigir obstáculos para a transferência dos créditos de ICMS-exportação a terceiros - tampouco podendo fazê-lo, por óbvio, os Estados-membros.

\subsubsection{AS TRANSFERÊNCIAS CONDICIONADAS PELA LEI.}

Além da exportação de mercadorias e serviços, diversas situações podem gerar acúmulo de créditos do ICMS, como por exemplo, a venda abaixo do preço de aquisição; a compra interna com alíquotas elevadas, seguida de revenda interestadual com destino a Estados cujas alíquotas sejam inferiores, entre outros.

Em tais hipóteses, não assiste ao contribuinte a garantia constitucional de aproveitamento dos créditos, que é restrita aos casos de exportação ${ }^{796}$. Entrementes, a LC nº 87/96 (art. 25, §2 , I e II) permite aos Estados estabelecerem, por leis próprias, condições para:

(a) transferência do saldo credor a outros estabelecimentos de titularidade do contribuinte no mesmo Estado;

(b) transferência do crédito acumulado a terceiros, dentro do Estado.

$\mathrm{Na}$ hipótese da alínea $a$, a "autorização" tornou-se desnecessária, pois desde a edição da LC n ${ }^{\circ}$ 102/00, que conferiu nova redação ao caput do art. 25 da LC n ${ }^{\circ}$ 87/96, a apu-

\footnotetext{
${ }^{796} \mathrm{CR} / 88$ :

"Art. 155. (...).

$\S 2^{\circ}$. O [ICMS]:

$\mathrm{X}$ - não incidirá:

a) sobre operações que destinem mercadorias para o exterior, nem sobre serviços prestados a destinatários no exterior, assegurada a manutenção e o aproveitamento do montante do imposto cobrado nas operações e prestações anteriores;"
} 
ração do ICMS obrigatoriamente considera os créditos e débitos de todos os estabelecimentos do contribuinte situados no Estado ${ }^{797}$.

Já no caso da alínea $b$, trata-se efetivamente de um benefício que os Estados podem, caso editem lei nesse sentido, conferir aos contribuintes. Ao contrário do que ocorre com os créditos acumulados em decorrência da exportação de mercadorias e serviços, inexiste direito subjetivo do contribuinte às transferências de saldo credor do ICMS acumulado em decorrência de outras razões. Portanto, somente se houver autorização estatal, poderá o contribuinte realizar a transferência nos exatos termos e condições em que o Estado autorizar.

\subsection{IDONEIDADE DA DOCUMENTAÇÃO E ESCRITURAÇÃO REGULAR: LIMITES FORMAIS PARA O CREDITAMENTO DO ICMS.}

Para exercer o direito ao crédito, o contribuinte deve apresentar documento fiscal comprovando a aquisição e a incidência do ICMS na etapa anterior. É certo que em caso de imunidade no período anterior à Emenda Passos Porto ${ }^{798}$, o STF chegou a reconhecer o direito ao crédito em hipótese na qual inexistia o documento fiscal ${ }^{799}$.

Todavia, a nota fiscal regular - ou seja, com todos os requisitos de validade exigidos pela lei - é condição essencial para a operacionalização da não-cumulatividade. É o documento fiscal que possibilitará ao adquirente provar a origem dos créditos compensáveis, que deverão estar devidamente destacados no preço da mercadoria ou serviço.

\footnotetext{
${ }^{797}$ É ver a LC n ${ }^{\text {o }} 87 / 96$, com a redação da $L C$ n ${ }^{\circ}$ 102/00:

"Art. 25. Para efeito de aplicação do disposto no art. 24, os débitos e créditos devem ser apurados em cada estabelecimento, compensando-se os saldos credores e devedores entre os estabelecimentos do mesmo sujeito passivo localizados no Estado."

Confira-se, ainda, a nota de rodapé no 187.
}

${ }^{798}$ Trata-se do período em que o STF concedia, à luz da CR/67-69 (ainda não modificada pela EC nº 23/83 Passos Porto), créditos presumidos de ICM quando da aquisição de produtos isentos ou imunes.

${ }^{799}$ O Supremo Tribunal Federal abordou o tema ao tratar das vendas feitas pelo extinto Instituto Brasileiro do Café (IBC). A autarquia era imune a impostos e desobrigada da emissão de nota físcal. Mesmo assim, praticava atos de comércio adquirindo café verde dos produtores rurais (que eram obrigados ao recolhimento do ICM na venda ao IBC) e revendendo para os exportadores ou torrefadores. Estes, sentindo-se prejudicados por não possuírem documento assecuratório de que o imposto fora cobrado (na operação produtor rural > IBC), recorreram ao Judiciário para legitimar a escrituração dos créditos, mesmo à míngua de documento fiscal. O STF, firme na convicção de garantir o creditamento sobre o imposto cobrado nas operações pretéri-

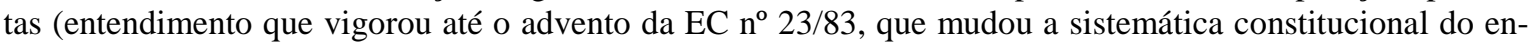
tão ICM), assentou jurisprudência em favor dos contribuintes, sumulada no seguinte verbete:

"Súmula 571. O comprador de café ao IBC, ainda que sem expedição de nota fiscal, habilita-se, quando da comercialização do produto, ao crédito do ICM que incidiu sobre a operação anterior."

Dessarte, mesmo nas hipóteses em que a nota inexiste, o direito ao crédito do imposto incidente nas etapas anteriores não resta prejudicado, sob pena de ferimento à não-cumulatividade. Essa é a importância do precedente para o estudo acerca das formalidades necessárias para o exercício do direito ao crédito. 
O Convênio $\mathrm{s} / \mathrm{n}^{\circ}$, de 15 de dezembro de 1970, instituidor do Sistema Nacional Integrado de Informações Econômico-Fiscais (SINIEF), estabelece que será considerado inidôneo o documento fiscal que:

(a) omita indicações;

(b) não seja o legalmente exigido para a respectiva operação;

(c) não guarde as exigências ou requisitos previstos no Convênio (que estabelece todos os detalhes acerca do preenchimento dos documentos fiscais);

(d) contenha declarações inexatas, esteja preenchido de forma ilegível ou apresente emendas ou rasuras que lhe prejudiquem a clareza.

Atento à importância da documentação para a não-cumulatividade tributária, a LC $\mathrm{n}^{\circ} 87 / 96$ positivou a seguinte regra:

"Art. 23. O direito de crédito, para efeito de compensação com débito do imposto, reconhecido ao estabelecimento que tenha recebido as mercadorias ou para o qual tenham sido prestados os serviços, está condicionado à idoneidade da documentação e, se for o caso, à escrituração nos prazos e condições estabelecidos na legislação."

Nada mais razoável. O adequado cumprimento dos deveres instrumentais pelos contribuintes é fundamental para o controle, por parte dos Fiscos, das obrigações principais, assegurando a arrecadação estatal. A obrigação acessória não é um fim em si mesmo, apenas existindo em decorrência do dever de pagar tributo. Todavia, nem por isso deixa de ser importante, sendo meio elementar para os trabalhos da fiscalização tributária.

Sendo certo, portanto, que o dever instrumental é meio para assegurar-se um fim maior, para logo é possível concluir que, inexistindo o documento fiscal, o contribuinte não fará jus ao crédito. Todavia, se provar que a operação efetivamente ocorreu, estando registrada nos demais instrumentos de controle fiscal (Livro de Registro de Saídas do vendedor e Livro de Registro de Entradas do adquirente), tendo ocorrido o pagamento do preço e o recebimento da mercadoria ou a prestação do serviço, fará jus o contribuinte ao crédito do ICMS. Todas essas provas serão produzidas no bojo de processo administrativo ou judicial, assegurada a ampla defesa e o contraditório. Além disso, uma vez denotada a efetividade da operação, possível será a escrituração na conta gráfica do crédito objurgado.

Portanto, pode-se concluir, $a b$ initio, que o documento fiscal regular é condição essencial para exercício do direito de crédito. Todavia, eventuais irregularidades ou mesmo a ausência da nota não impedem o contribuinte de provar, em processo administrativo ou 
judicial, a efetividade da operação que gerou o direito ao crédito. Confira-se a seguinte ementa do STJ, nesse sendeiro:

"2. A jurisprudência deste Superior Tribunal de Justiça pacificou-se no sentido de que o adquirente de boa-fé não pode ser responsabilizado pela inidoneidade de notas fiscais emitidas pela empresa vendedora, sendo certo que, nesse caso, é possível o aproveitamento de crédito de ICMS relativo às referidas notas fiscais. Todavia, para tanto, é necessário que o contribuinte demonstre, pelos registros contábeis, que a operação de compra e venda efetivamente se realizou, incumbindo-lhe, portanto, o ônus da prova."

Em outro caso paradigmático, o STJ reconheceu ao contratante do serviço de transporte o direito de escriturar o crédito de ICMS incidente sobre o frete, mesmo sem ter em mãos a primeira via do Conhecimento de Transporte Rodoviário de Cargas $\left(\mathrm{CTRC}^{801}\right)$. As legislações estaduais estabelecem como regra para o creditamento a apresentação da primeira via da nota fiscal (ou do CTRC, no caso de transporte rodoviário). Contudo, o contribuinte logrou provar que a prestação de serviço efetivamente ocorreu, mediante demonstração de lançamentos em seus livros fiscais e contábeis, pagamentos realizados a partir de sua conta bancária para a transportadora e até mesmo comprovantes de pagamento do ICMS pela transportadora ${ }^{802}$.

Da mesma forma, pequenas irregularidades formais na nota fiscal não têm o condão de torná-la irregular. Infelizmente, têm sido usuais casos em que a documentação acobertadora da operação é considerada inidônea pelo Fisco (acarretando a cobrança de pesadas multas, além do imposto devido). As justificativas para a desconsideração do documento pelo Fisco, absurdamente, são as mais variadas possíveis. Cita-se alguns exemplos: ausência de um dígito na inscrição estadual do estabelecimento destinatário; pela impressão, no

\footnotetext{
${ }^{800}$ STJ, Primeira Turma, REsp no 623.335/PR, Relatora Min. DENISE ARRUDA, DJ 10.09.2007, p. 187. Nesse mesmo sentido, cite-se: STJ, Segunda Turma, REsp no 470.633/MG, Relatora Min. ELIANA CALMON, DJ 11.10.2004, p. 268.

${ }^{801}$ O CTRC é o documento fiscal comprobatório do transporte interestadual ou intermunicipal. Contém o destaque do ICMS, tal como a nota fiscal, que é utilizada nas operações de circulação jurídica de mercadorias.

${ }^{802}$ Em face de todo o conjunto fático-probatório, averbou o STJ, pela pena do Min. LUIZ FUX:

“4. (...) A alegação da Fazenda Pública, no sentido da ausência de comprovação documental da materialidade do direito ao creditamento de ICMS, exigindo a apresentação da primeira via do CTRC, e tão-somente desta, ao argumento de que não serviriam para fins probatórios quaisquer das outras vias, demonstra extremado preciosismo, o que é repudiado pelo Direito, máxime em virtude de manifesta afronta à regra constitucional da não-cumulatividade.

5. Desta sorte, tem-se como infactível a referida exigência, que denota mera irregularidade formal, insuscetível de impedir o exercício de direito assegurado pela própria Constituição Federal." (STJ, Primeira Turma, AgRg no REsp no 883.821/DF, Relator Min. LUIZ FUX, DJe 15.12.2008).
} 
verso, da descrição completa das mercadorias, que não coube na frente da nota; pelo endereço incorreto do destinatário, muitas vezes com erro de um número.

Nessas hipóteses, entendemos que não se está diante de uma irregularidade passível de tornar o documento fiscal inidôneo, razão pela qual o contribuinte deveria ser intimado para retificar a nota ou prestar esclarecimentos. Porém nunca ser autuado pelo nãopagamento do principal acrescido de juros, além da penalidade pelo descumprimento da obrigação acessória.

Por derradeiro, vale lembrar que existem situações em que o remetente das mercadorias age em conluio com o comprador, no intuito de lesar o Fisco, emitindo notas fiscais em valores abaixo dos efetivamente praticados. Havendo conluio provado pelo Fisco, a operação deve ser desconsiderada, apenando-se os envolvidos, inclusive sob o prisma criminal.

Lado outro, muitas vezes o remetente está descumprindo com suas obrigações tributárias, porém continua a emitir regularmente notas fiscais. Nessas hipóteses, desde que a nota seja idônea - ou seja, não possua irregularidade passível de desqualificá-la (já que pequenos erros não têm o condão de invalidar o documento) - o comprador continuará fazendo jus ao crédito, que independe do efetivo pagamento do tributo pelo vendedor ${ }^{803}$. Se, eventualmente, o Fisco estadual decretar a inidoneidade daquele fornecedor, esse ato somente terá efeito quando publicado em veículo oficial e atingirá as notas fiscais emitidas posteriormente à publicação. A observação se aproposita pois esse tipo de procedimento é usual. Com muita freqüência, após declarar a inidoneidade e publicá-la em documento oficial, os Fiscos intentam impingir efeitos retroativos ao seu ato, atingindo os terceiros que adquiriram mercadorias ou serviços do fornecedor antes da publicação do ato que declarou a sua inidoneidade. Ora, se não for provado conluio entre comprador e vendedor, inexistirá motivo para apenar-se o adquirente de mercadorias ou serviços acobertados por notas fiscais regulares e emitidas por fornecedor que, à época, ainda não havia sido publicamente declarado inapto.

Incumbe ao Fisco, e não ao particular, a fiscalização da regularidade fiscal das empresas. À míngua de comunicação oficial pública da inidoneidade de determinado contribuinte, os que com este celebraram negócios de boa-fé não podem ser prejudicados. Nesse

${ }^{803}$ Sobre o tema, vide Título II, Capítulo VI, Item 6.3. 
sentido tem caminhado a jurisprudência do STJ, em posição uníssona de ambas as Turmas da Seção de Direito Público ${ }^{804}$.

A parte final do caput do art. 23 dispõe que o direito de crédito condiciona-se ainda, "se for o caso, à escrituração nos prazos e condições estabelecidos na legislação". Ora, a escrituração do crédito no Livro de Registro de Entradas é uma forma de se efetivar o direito de crédito, assim como o é o lançamento na conta gráfica do contribuinte. Todavia, tais questões meramente operacionais não poderão nunca afetar o direito material ao crédito, que decorre da própria não-cumulatividade. Como lembra MATTOS ${ }^{805}$, "se nem a lei complementar é instrumento hábil para restringir direito de crédito, muito menos seria a legislação subjacente, ainda mais por motivos meramente escriturais”.

\subsection{O LUSTRO DECADENCIAL PARA UTILIZAÇÃO DO CRÉDITO DO ICMS.}

O parágrafo único do art. 23 da LC no 87/96 estipula um terceiro e último requisito para o creditamento do ICMS (além da prova documental e da escrituração regular, referidas no item precedente), a saber:

\section{“Art. 23. (...).}

Parágrafo único. O direito de utilizar o crédito extingue-se depois de decorridos cinco anos contados da data de emissão do documento."

Trata-se de prazo decadencial, eis que se refere ao exercício de um direito potestativo do contribuinte. Haja vista que o ordenamento jurídico não comporta direitos imprescritíveis, e considerando que o prazo assinalado é razoável ${ }^{806}$, a norma em comento é, a nosso sentir, constitucional.

Um dado, contudo, é importante: ao se referir à utilização do crédito, a norma exige que o contribuinte registre-o em sua escrita fiscal, porém não pode - e não teria como fazê-

\footnotetext{
${ }^{804}$ STJ, Primeira Turma, REsp n ${ }^{\circ}$ 196.581/MG, Relator Min. GARCIA VIEIRA, DJ 03.05.1999, p. 108; STJ, Segunda Turma, REsp n 176.270/MG, Relatora Min. ELIANA CALMON, DJ 04.06.2001, p. 88.

${ }^{805}$ MATTOS, Aroldo Gomes de. ICMS - Comentários à Legislação Nacional. São Paulo: Dialética, 2006, p. 366.

${ }^{806} \mathrm{O}$ prazo em comento, ademais, busca igualar o tratamento entre Fisco e contribuinte. Isto porque o primeiro tem exatamente cinco anos, contados do fato gerador, para lançar eventuais débitos de ICMS não pagos. Nesse sentido, confira-se SOARES DE MELO:

"Embora o crédito se revista de natureza financeira, tendo em vista que a natureza tributária seja mais peculiar ao débito, o fato é que, fixando o mesmo lapso de tempo para a sua fruição - com manifesto objetivo isonômico -, o legislador confere-lhe característica tributária.” (MELO, José Eduardo Soares de. ICMS - Teoria e Prática, 10a ed. São Paulo: Dialética, 2008, p. 267).

Do autor discordamos apenas no ponto em que sustenta possuir o crédito natureza tributária. Seu caráter é estritamente financeiro e o fato de o prazo decadencial ser o mesmo para o lançamento do débito - este, sim, de cunho tributário - não tem, em nossa opinião, o condão de lhe modificar a natureza.
} 
lo - obrigá-lo a compensar o crédito com débitos do ICMS nesse mesmo período, sob pena de perda do direito. Afinal, inserido crédito na conta gráfica, o respectivo montante passa a integrar o patrimônio do contribuinte. Assim, se não houver débitos compensáveis durante um, cinco, dez ou trinta anos, sob nenhuma hipótese o crédito poderá ser estornado ao cancelado.

Dessa forma, teria andado melhor o legislador complementar se tivesse feito referência à escrituração do crédito - ao invés de sua utilização - dentro do qüinquiênio decadencial $^{807}$.

\subsection{O ESTORNO DOS CRÉDITOS INCENTIVADOS E O ART. $8^{\circ}$ DA LEI COM- PLEMENTAR No 24/75.}

No intuito de evitar as guerras fiscais em matéria de ICMS, a CR/88 determina, em seu art. $155, \S 2^{\circ}$, XII, $g$, que a lei complementar deverá "regular a forma como, mediante deliberação dos Estados e do Distrito Federal, isenções, incentivos e benefícios fiscais serão concedidos e revogados". A norma referida pela Lei Maior existe desde 1975: trata-se da Lei Complementar $n^{\circ} 24$, de 7 de janeiro daquele ano ${ }^{808}$.

A citada lei criou (em que pese não tê-lo assim nominado) o CONFAZ - Conselho Nacional de Política Fazendária, órgão presidido por uma autoridade do Governo Federal em que os 26 Estados da Federação e o Distrito Federal se fazem representar por meio de seus Secretários de Fazenda (ou outro delegado indicado pelo Governador). O quorum

${ }^{807}$ Nesse mesmo sendeiro são as lições de MATTOS, quando se refere ao parágrafo único do art. 23 da LC nº 87/96:

“(...) O verbo 'utilizar' nele empregado é, evidentemente, equivocado e só pode ser entendido como 'lançar', ou seja, registrar o crédito na escrita fiscal. Já o direito de 'utilizá-lo', no sentido de 'aproveitá-lo', não incorre em decadência, porque a sua perda entraria em testilha com o princípio maior da não-cumulatividade do tributo, que inadmite quaisquer restrições de ordem temporal." (MATTOS, Aroldo Gomes de. ICMS - Comentários à Legislação Nacional. São Paulo: Dialética, 2006, p. 367).

${ }^{808}$ Eis as matérias tratadas pela LC n ${ }^{\circ} 24 / 75$ :

"Art. $1^{\circ}$. As isenções do imposto sobre operações relativas à circulação de mercadorias serão concedidas ou revogadas nos termos de convênios celebrados e ratificados pelos Estados e pelo Distrito Federal, segundo esta Lei.

Parágrafo único. O disposto neste artigo também se aplica:

I - À redução da base de cálculo;

II - À devolução total ou parcial, direta ou indireta, condicionada ou não, do tributo, ao contribuinte, a responsável ou a terceiros;

III - À concessão de créditos presumidos;

IV - A quaisquer outros incentivos ou favores fiscais ou financeiro-fiscais, concedidos com base no imposto de circulação de mercadorias, dos quais resulte redução ou eliminação, direta ou indireta, do respectivo ônus;

V - Às prorrogações e às extensões das isenções vigentes nesta data." 
mínimo para instalação das reuniões é de 14 (quatorze) entes federados e as deliberações sobre os incentivos fiscais exigem a aprovação unânime de todos os Estados presentes ${ }^{809}$.

Dessarte, a implementação de todo e qualquer incentivo fiscal relativo ao ICMS deverá seguir os procedimentos ditados pela $\mathrm{LC} \mathrm{n}^{\circ} 24 / 75$, sob pena de invalidade. Em caso de seu descumprimento, prescreve o art. $8^{\circ}$, I da citada lei, na parte que nos toca:

“Art. 8. A inobservância dos dispositivos desta Lei acarretará, cumulativamente:

I - a nulidade do ato e a ineficácia do crédito fiscal atribuído ao estabelecimento recebedor da mercadoria;"

A norma estabelece que o adquirente das mercadorias não fará jus aos créditos de ICMS destacados na nota, quando o alienante estiver fruindo de algum benefício fiscal concedido à revelia das regras previstas na $\mathrm{LC}^{\circ}$ 24/75 (que, como visto, exige celebração de convênio com aprovação unânime dos Estados-membros presentes à reunião).

Para alguns autores ${ }^{810}$, o dispositivo não teria sido recepcionado pela Constituição de 1988, que somente admite o estorno dos créditos de ICMS nas hipóteses de isenção ou não-incidência (art. 155, §2º II).

${ }^{809}$ LC n ${ }^{\circ} 24 / 75$ :

“Art. $2^{\circ}$. Os convênios a que alude o artigo $1^{\circ}$, serão celebrados em reuniões para as quais tenham sido convocados representantes de todos os Estados e do Distrito Federal, sob a presidência de representantes do Governo Federal.

$\S 1^{\circ}$. As reuniões se realizarão com a presença de representantes da maioria das Unidades da Federação.

$\S 2^{\circ}$. A concessão de benefícios dependerá sempre de decisão unânime dos Estados representados; a sua revogação total ou parcial dependerá de aprovação de quatro quintos, pelo menos, dos representantes presentes."

${ }^{810}$ Nesse sentido propugna MELO, inicialmente retratando a situação jurídica nos Estados-membros:

"As legislações estaduais têm disposto que não se considera cobrado (para fins de consideração da não-cumulatividade), ainda que destacado em documento fiscal, o montante do imposto que corresponder à vantagem econômica decorrente da concessão de qualquer subsídio, redução da base de cálculo, crédito presumido ou outro incentivo ou benefício fiscal, em desacordo com o previsto no art. 155 , parágrafo $2^{\circ}$, inciso XII, alínea $g$, da CF."

Em seguida, delimita o poder de restrição dos créditos de ICMS pelos Estados:

"Entretanto, a CF estabelece uma excepcional restrição ao crédito de ICMS, aos exclusivos casos de isenção ou não-incidência (art. 155, parágrafo $2^{\circ}$ ), concedendo aos Estados (e DF) a faculdade de dispor em sentido diverso, ao estabelecer a exceção seguinte: 'salvo determinação em contrário da legislação'. Em decorrência, o que pode ocorrer é a legislação ordinária conceder o crédito, e nunca vedá-lo."

Para, ao fim, arrematar:

"Evidente que o art. $8^{\circ}$, inciso I, segunda parte, da LC no 24/75 não foi recepcionado pela CF/88, que somente não concede o direito ao crédito a casos de desoneração total do ICMS (isenção e nãoincidência). Nunca haverá vedação ao crédito em casos de distinta natureza jurídica." (MELO, José Eduardo Soares de. ICMS - Fato Gerador - Local da Ocorrência. Incentivos Fiscais e Créditos. ROCHA, Valdir de Oliveira (coord.). Grandes Questões Atuais do Direito Tributário, $11^{\circ}$ v. São Paulo: Dialética, 2007, pp. 237-8). 
Pensamos diferente. Toda norma deve, sempre que possível, ser interpretada de forma a ter validade. Na espécie em comento, o que se visa é evitar situações antiisonômicas decorrentes de incentivos inconstitucionais conferidos a determinados contribuintes em detrimento de seus concorrentes. Com isso, a glosa dos créditos aos quais o adquirente faria jus é um eficaz instrumento para restabelecimento do status quo ante, reequilibrando a concorrência entre os agentes econômicos.

Entretanto, considerando-se que a má-fé não se presume, o estorno dos créditos autorizado pelo art. $8^{\circ}$, I da LC $n^{\circ}$ 24/75 depende da edição de ato normativo do governo estadual, com ampla publicidade para todos os agentes econômicos e respeito ao princípio da não-surpresa. A resolução, portaria ou assemelhado deverá indicar quais mercadorias e serviços terão - a partir de uma data futura fixada no ato governamental - os créditos glosados e seus respectivos porcentuais (se integral ou apenas em parte). A única hipótese na qual entendemos que o estorno poderia ocorrer sem a publicação prévia do ato (que deve conferir prazo mínimo de noventa dias para que o contribuinte se adéqüe ${ }^{811}$ ) seria nas operações interestaduais entre empresas pertencentes ao mesmo grupo econômico. Nesse caso, é razoável presumir-se que o adquirente tinha ciência do benefício fiscal ilegítimo usufruído pelo alienante, razão pela qual não se poderia tratar a operação como uma compra-evenda entre partes não relacionadas.

A exigência do ato estatal prévio para aplicação do art. 8, I da LC n 87/96 alinhase com a jurisprudência do STJ, que exige a publicação da declaração de inidoneidade do contribuinte-alienante para desconsiderar os créditos oriundos das compras de suas mercadorias, como vimos no item 11.5. O princípio da não-surpresa ${ }^{812}$, do qual decorrem a anterioridade anual e a espera nonagesimal, respalda ainda a necessidade de se conferir um prazo mínimo para a adequação das atividades dos compradores às novas regras.

A aplicação irrestrita do art. $8^{\circ}$, I da $L C n^{\circ} 24 / 75$, como pretendem as fiscalizações estaduais, não nos parece consentânea com as normas jurídicas vigentes. Sobremais quando se recorda que os Governadores de Estado são partes legítimas para a propositura de Ações Diretas de Inconstitucionalidade, contra leis ou decretos de outros entes federados que firam o comando do art. $155, \S 2^{\circ}, \mathrm{XII}, g$ da CR/88. Diante de um benefício fiscal ilegí-

\footnotetext{
${ }^{811} \mathrm{O}$ prazo ora sugerido decorre de analogia com o princípio da espera nonagesimal insculpido no art. 150, III, $c$ da CR/88 (nesta acrescido pela EC no 42/03).

${ }^{812}$ Como leciona MANEIRA, “o princípio da não-surpresa da lei tributária é instrumento constitucional que visa a garantir o direito do contribuinte à segurança jurídica, essência do Estado de Direito, qualquer que seja a sua concepção". (MANEIRA, Eduardo. Direito Tributário - Princípio da Não-Surpresa. Belo Horizonte: Del Rey, 1994, p. 161).
} 
timo concedido por outro Estado da Federação, não pode o Estado prejudicado transferir o ônus da guerra fiscal para os adquirentes de mercadorias incentivadas. O munus fiscalizatório é estatal, não incumbindo ao contribuinte fazer uma investigação - de resto impossível - sobre a vida tributária dos seus parceiros comerciais. Compete ao Estado-membro, atingido pela norma inconstitucional, argüir a sua invalidade perante o Supremo Tribunal Federal. E, se assim desejar, editar normas internas que permitam, respeitando-se os princípios constitucionais da tributação, o não-reconhecimento dos créditos incentivados conferidos por outros Estados à margem da lei.

Sob esse prisma e feitas tais restrições, temos que o art. $8^{\circ}$, I da LC no 24/75 é válido, consistindo em importante instrumento para restabelecimento da isonomia em matéria fiscal. 


\section{PIS/COFINS INCIDENTES SOBRE A RECEITA BRUTA.}

\subsection{INTRÓITO.}

O mecanismo de apuração do quantum debeatur do PIS e da COFINS nãocumulativos é distinto daquele aplicado ao IPI e ao $\operatorname{ICMS}^{813}$. A não-cumulatividade das contribuições em tela consiste em mera técnica de quantificação do montante devido. Não há, portanto, translação jurídica do ônus fiscal ao contribuinte de facto. Afinal, o PIS e a COFINS não são tributos plurifásicos ${ }^{814}$, mas sim contribuições que gravam a receita bruta das empresas. A não-cumulatividade em comento consiste tão-somente na possibilidade de deduzir, do PIS/COFINS a pagar, créditos calculados sobre as despesas incorridas no período apuração. Não há abatimento do tributo pago em operações anteriores, como ocorre no IPI e no ICMS. Assim, eventuais referências nos tópicos seguintes às "etapas" ou "operações" anteriores do PIS/COFINS são feitas tão-somente para fins didáticos.

Outrossim, a não-cumulatividade das contribuições sociais é norma de eficácia limitada de princípio institutivo impositivo ${ }^{815}$. Trata-se de outra elementar diferença em relação ao IPI e ao ICMS. Nestes dois impostos, a eficácia da não-cumulatividade é plena, sendo mandatoriamente observada pelas suas leis de regência. Já o legislador do PIS/COFINS possui liberdade para implementar, se e quando quiser, a não-cumulatividade dessas contribuições ${ }^{816}$.

\subsection{ESCORÇO LEGISLATIVO DO PIS E DA COFINS.}

As sucessivas modificações das leis do PIS e da COFINS impõem a realização de uma resenha histórico-legislativa para se delinear a regra-matriz de incidência dessas contribuições. Em seqüência, será então possível proceder ao exame de sua nãocumulatividade. Vejamos.

\footnotetext{
${ }^{813}$ TORRES, Ricardo Lobo. A Não-Cumulatividade no PIS/COFINS. PEIXOTO, Marcelo Magalhães e FISCHER, Octavio Campos (coord.). PIS-COFINS - Questões Atuais e Polêmicas. São Paulo: Quartier Latin, 2005 , p. 72.

${ }^{814}$ Entendemos como plurifásicos os tributos que gravam diversas etapas do processo de produção/circulação de bens e riquezas, não sendo possível estender tal qualificação a contribuintes incidentes sobre um fato isolado, não encadeado em um processo, como é o caso da receita bruta. Para maiores detalhes, vide Título I, Capítulo III, Item 3.6.

${ }^{815}$ Vide Título II, Capítulo VII, Item 7.2.2.

${ }^{816}$ O legislador federal deverá, todavia, respeitar o conteúdo mínimo da não-cumulatividade plasmado na Constituição (vide Título II, Capítulo IX).
} 
A contribuição para o PIS foi instituída pela Lei Complementar $n^{\circ} 7$, de 7 de setembro de 1970, com o escopo de financiar o Programa de Integração Social (PIS), destinado a "promover a integração do empregado na vida e no desenvolvimento das empre-

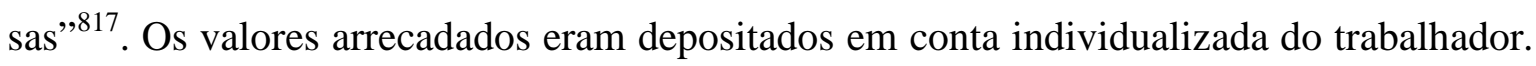
Quando do casamento ${ }^{818}$, aposentadoria, invalidez ou morte poderiam ser levantados, pelo interessado ou seus sucessores ${ }^{819}$, ou, ainda, serem utilizados pelo empregado para aquisição de sua casa própria ${ }^{820}$.

A alíquota inicial da contribuição para o PIS era de $0,15 \%$, porém a própria $\operatorname{LC} \mathrm{n}^{\circ}$ 7/70 já previa aumentos anuais sucessivos, tendo-se atingido a marca de 0,75\% em $1976^{821}$. Sua base de cálculo era o faturamento do sexto mês anterior ao da ocorrência do fato gerador ${ }^{822}$.

Análoga ao PIS, a contribuição para o Programa de Formação do Patrimônio do Servidor Público (PASEP) foi instituída pela Lei Complementar $\mathrm{n}^{\circ} 8$, de 3 de dezembro de 1970. A contribuição para o PASEP é devida pela União, Estados, Distrito Federal e Municípios, suas autarquias, fundações, sociedades de economia mista e empresas públicas. Visa a custear benefícios para o servidor público, como o auxílio para compra de casa própria e pagamento de valores quando do casamento, aposentadoria ou morte do funcionário $^{823}$. Sua base de cálculo é a receita das referidas pessoas jurídicas, com porcentuais variáveis conforme disposições da $\mathrm{LC} \mathrm{n}^{\circ} 8 / 70^{824}$.

\footnotetext{
${ }^{817} \mathrm{LC} \mathrm{n}^{\mathrm{o}} 7 / 70$, art. $1^{\mathrm{o}}$.

${ }^{818}$ A partir da CR/88 o saque por motivo de casamento foi vedado (art. $239, \S 2^{\circ}$ ).

${ }^{819} \operatorname{LC~n}^{\mathrm{o}} 7 / 70$, art. $9^{\circ}, \S 1^{\text {o. }}$.

${ }^{820} \mathrm{LC} \mathrm{n}^{\mathrm{o}} 7 / 70$, art. $9^{\circ}, \S 2^{\circ}$.

${ }^{820} \mathrm{LC} \mathrm{n}^{\mathrm{o}} 7 / 70$, art. $9^{\circ}, \S 2^{\circ}$.

${ }^{821}$ Segundo a Lei Complementar no 7/70, a alíquota do PIS seria de 0,15\% em 1971, 0,25\% em 1972, 0,4\% em 1973 e 0,5\% a partir de 1974. A Lei Complementar $n^{\circ} 17 / 73$ criou adicional de PIS à razão de 0,125\% em 1975 e de $0,25 \%$ a partir de 1976.

Deixa-se de considerar aqui - por irrelevante para o tema em discussão - o PIS-repique, equivalente a $5 \%$ do imposto de renda devido (ou como se devido fosse), instituído pelo art. $3^{\circ}$, $a$, e $\S \S 1^{\circ}$ a $3^{\circ}$ da Lei Complemen$\operatorname{tar} n^{\circ} 7 / 70$. Tal incidência foi suprimida pela Lei $n^{\circ} 9.715 / 98$, referida adiante no texto.

${ }^{822} \mathrm{LC} \mathrm{n}^{\mathrm{0}} 7 / 70$, art. $6^{\circ}$, parágrafo único.

${ }^{823} \mathrm{LC} \mathrm{n}^{\circ} 8 / 70$, art. $5^{\circ}$.

${ }^{824}$ Confiram-se as bases de cálculo e alíquotas estipuladas pela LC $\mathrm{n}^{\circ}$ 8/70:

“Art. $2^{\circ}$. A União, os Estados, os Municípios, o Distrito Federal e os Territórios contribuirão para o Programa, mediante recolhimento mensal ao Banco do Brasil das seguintes parcelas:
} 
O esteio constitucional das fontes de financiamento do PIS e do PASEP era o art. 165, V da CR/67-69, no qual se previa a instituição de contribuição que visasse a integrar o empregado "na vida e no desenvolvimento das empresas".

Os programas sociais intitulados PIS e PASEP foram unificados pela Lei Complementar $n^{\circ} 26$, de 11 de setembro de $1975^{825}$.

A sistemática das LCs $n^{\circ}$ s 7/70 e 8/70 - que foram expressamente recepcionadas pela Constituição de $1988^{826}$ - subsistiu até o advento Lei ${ }^{\circ} 9.715$, de 25 de novembro de $1998^{827}$. Esta unificou as contribuições para o PIS-PASEP, reduzindo suas alíquotas para 0,65\%, assim como definiu nova base de cálculo para o PIS: o faturamento do mês da o-

I - União: $1 \%$ (um por cento) das receitas correntes efetivamente arrecadadas, deduzidas as transferências feitas a outras entidades da Administração Pública, a partir de $1^{\circ}$ de julho de 1971; 1,5\% (um e meio por cento) em 1972 e $2 \%$ (dois por cento) no ano de 1973 e subseqüentes;

II - Estados, Municípios, Distrito Federal e Territórios: a) 1\% (um por cento) das receitas correntes próprias, deduzidas as transferências feitas a outras entidades da Administração Pública, a partir de $1^{\circ}$ de julho de 1971; 1,5\% (um e meio por cento) em 1972 e 2\% (dois por cento) no ano de 1973 e subseqüentes;

b) $2 \%$ (dois por cento) das transferências recebidas do Governo da União e dos Estados através do Fundo de Participações dos Estados, Distrito Federal e Municípios, a partir de $1^{\circ}$ de julho de 1971.

Parágrafo único. Não recairá, em nenhuma hipótese, sobre as transferências de que trata este artigo, mais de uma contribuição.

Art. $3^{\circ}$. As autarquias, empresas públicas, sociedades de economia mista e fundações, da União, dos Estados, dos Municípios, do Distrito Federal e dos Territórios contribuirão para o Programa com $0,4 \%$ (quatro décimos por cento) da receita orçamentária, inclusive transferências e receita operacional, a partir de $1^{\circ}$ de julho de 1971; 0,6\% (seis décimos por cento) em 1972 e $0,8 \%$ (oito décimos por cento) no ano de 1973 e subseqüentes.

${ }^{825}$ Assim dispôs a LC n ${ }^{\circ}$ 26/75:

“Art. $1^{\circ}$. A partir do exercício financeiro a iniciar-se em $1^{\circ}$ de julho de 1976, serão unificados, sob a denominação de PIS-PASEP, os fundos constituídos com os recursos do Programa de Integração Social (PIS) e do Programa de Formação do Patrimônio do Servidor Público (PASEP), instituídos pelas Leis Complementares no 7 e 8, de 7 de setembro e de 3 de dezembro de 1970, respectivamente."

O abono anual do PIS/PASEP foi criado pela LC $n^{\circ} 26 / 75$. Os participantes cadastrados nos programas há pelo menos 5 (cinco) anos, que percebiam remuneração igual ou inferior a 5 (cinco) vezes o salário-mínimo vigente, faziam jus ao recebimento, no mês de seu aniversário, de um salário-mínimo do governo federal (LC $\mathrm{n}^{\circ} 26 / 75$, art. $\left.3^{\circ}, \S^{\circ}\right)$.

Com a Constituição de 1988, o benefício passou a ser pago tão-somente aos trabalhadores que percebessem até 2 (dois) salários-mínimos mensais (art. 239, $3^{\circ}$ ).

${ }^{826} \mathrm{CR} / 88$ :

"Art. 239. A arrecadação decorrente das contribuições para o Programa de Integração Social, criado pela Lei Complementar $n^{\circ} 7$, de 7 de setembro de 1970, e para o Programa de Formação do Patrimônio do Servidor Público, criado pela Lei Complementar no 8, de 3 de dezembro de 1970, passa, a partir da promulgação desta Constituição, a financiar, nos termos que a lei dispuser, o programa do seguro-desemprego e o abono de que trata o $\S 3^{\circ}$ deste artigo."

${ }^{827}$ A Lei no 9.715/98 resultou da conversão da MP nº 1.212, inicialmente editada em 1995. 
corrência do fato gerador ${ }^{828}$ (em substituição ao faturamento do sexto mês anterior ao da ocorrência do fato gerador ${ }^{829}$ ).

O mesmo sistema foi mantido pela Lei $\mathrm{n}^{\circ} 10.637$, de 30 de dezembro de 2002, instituidora do PIS/PASEP não-cumulativos. Portanto, sempre que houver referência, nos tópicos seguintes, à contribuição para PIS, deve-se entender também abarcada a contribuição para o PASEP.

Já a contribuição para o Fundo de Investimento Social (FINSOCIAL), antecessora da Contribuição para Financiamento da Seguridade Social (COFINS), foi criada pelo Decreto-lei $\mathrm{n}^{\mathrm{o}} 1.940$, de 25 de maio de $1982^{830}$. Sua base de cálculo era a "receita bruta das vendas de mercadorias e serviços, com a dedução das vendas canceladas, das devolvidas e dos descontos incondicionais" ${ }^{831}$.

A COFINS propriamente dita foi instituída pela Lei Complementar $n^{\circ} 70$, de 30 de dezembro de 1991, à alíquota de $2 \%{ }^{832}$. Sua base de cálculo era "o faturamento mensal, assim considerado a receita bruta das vendas de mercadorias, de mercadorias e serviços e de serviço de qualquer natureza" ${ }^{\natural 33}$. A COFINS se fundava na redação original do art. 195, I da CR/88, que permitia a cobrança de contribuição sobre o faturamento das empresas ${ }^{834}$.

A unificação dos regimes do PIS e da COFINS foi feita pela Lei $n^{\circ} 9.718$, de 27 de novembro de 1998. O diploma, além de regulamentar a cobrança de ambas as contribui-

\footnotetext{
${ }^{828}$ É dizer, passou-se a calcular o PIS sobre o faturamento do mês imediatamente anterior ao do vencimento da contribuição.

${ }^{829}$ Como foi visto, em sua origem o PIS era devido sobre o que havia ingressado no caixa da empresa seis meses antes do surgimento da obrigação tributária.

${ }^{830}$ Modificado, dentro outros, pelo Decreto-lei no $2.397 / 87$.

${ }^{831}$ Sua alíquota era, inicialmente, de $0,5 \%$ (que foi sucessivamente elevada, após a promulgação da Constituição de 1988 , para $1 \%$ pelo art. $7^{\circ}$ da Lei $\mathrm{n}^{\circ}$ 7.787/89; para 1,2\% pelo art. $1^{\circ}$ da Lei $\mathrm{n}^{\mathrm{o}} 7.894 / 89$; e, finalmente, para $2 \%$ pelo art. $1^{\circ}$ da Lei $n^{\circ} 8.147 / 90$. Entretanto, o STF declarou, nos autos do RE $n^{\circ} 150.764 / P E$, a inconstitucionalidade, para as empresas comerciais, das majorações de alíquotas da contribuição para o FINSOCIAL, oriundas de leis posteriores ao advento da CR/88. Em face dessa decisão, todos os recolhimentos feitos pelos comerciantes em alíquotas superiores à de $0,5 \%$ foram considerados indevidos).

Os recursos do FINSOCIAL tinham a finalidade de "custear investimentos de caráter assistencial em alimentação, habitação popular, saúde, educação, justiça e amparo ao pequeno agricultor” (art. $1^{\circ}$ ).

${ }^{832} \mathrm{LC} \mathrm{n}^{\mathrm{o}} 70 / 91$, art. $2^{\mathrm{o}}$, caput.

${ }^{833}$ LC n $^{\circ} 70 / 91$, art. $2^{\circ}$, caput.

${ }^{834} \mathrm{CR} / 88$, redação original:

"Art. 195. A seguridade social será financiada por toda a sociedade, de forma direta e indireta, nos termos da lei, mediante recursos provenientes dos orçamentos da União, dos Estados, do Distrito Federal e dos Municípios, e das seguintes contribuições sociais:

I - dos empregadores, incidente sobre a folha de salários, o faturamento e o lucro." (destaque nosso)
} 
ções, majorou a alíquota da COFINS para 3\% (não dispondo sobre a do PIS, que continuou sendo de $0,65 \%$ por força da Lei $\left.n^{\circ} 9.715 / 98\right)$.

Predicou ainda a Lei $\mathrm{n}^{\circ}$ 9.718/98 a incidência do PIS/COFINS sobre o faturamento das empresas, tal como autorizado pela CR/88 (art. 195, I). Entretanto, ao conceituar faturamento, assim dispôs:

"Art. $3^{\circ}$. O faturamento a que se refere o artigo anterior corresponde à receita bruta da pessoa jurídica.

$\S 1^{\circ}$. Entende-se por receita bruta a totalidade das receitas auferidas pela pessoa jurídica, sendo irrelevantes o tipo de atividade por ela exercida e a classificação contábil adotada para as receitas." (destaques nossos)

Como se infere do dispositivo, apesar de referir-se inicialmente à incidência sobre o faturamento, em verdade a Lei $\mathrm{n}^{\circ}$ 9.718/98 determinou a cobrança do PIS/COFINS sobre a receita bruta das empresas.

Essa alteração na base de cálculo contrariou a autorização constitucional então em vigor. À época, a CR/88 permitia a instituição de contribuição apenas sobre o faturamento (entendido como o produto da venda de bens ou serviços) e não sobre a totalidade das receitas da pessoa jurídica. Tanto é verdade que a Constituição foi modificada logo após a edição da Lei $n^{\circ}$ 9.718/98: a EC n $n^{\circ} 20 / 98^{835}$ acresceu, ao lado do termo faturamento, a expressão "receita", permitindo a criação de contribuições sobre essa nova base de cálculo ${ }^{836}$.

Contudo, por ter sido editada antes da EC no 20/98, a Lei $n^{\circ} 9.718 / 98$ padecia de inconstitucionalidade no ponto em que ampliava a base de cálculo do PIS/COFINS. Afinal, como dito, a redação originária da Constituição (em vigor quando da publicação da referida lei) outorgava competência tão-somente para a criação de contribuição sobre o "faturamento". Não havia, até o advento da EC n ${ }^{\circ}$ 20/98, qualquer autorização para se tributar a "receita". Dessarte, para que a contribuição sobre a receita instituída antes da EC n 20/98 fosse válida, seria necessária a sua veiculação por lei complementar. Afinal, tratar-se-ia de tributo instituído com fincas na competência residual da União, pois sua base de cálculo

\footnotetext{
${ }^{835}$ Publicada em 16 de dezembro daquele ano, vinte dias após a Lei no 9.718/98.

${ }^{836}$ Após a modificação da EC n ${ }^{\circ}$ 20/98, a base de cálculo do PIS/COFINS restou assim prevista na CR/88:

"Art. 195. (...).

I - do empregador, da empresa e da entidade a ela equiparada na forma da lei, incidentes sobre:

(...)

b) a receita ou o faturamento."
} 
não estava prevista no art. 195 da CR/88. E o exercício da competência residual pressupõe, dentre outros requisitos, a utilização de lei complementar ${ }^{837}$.

Perfilhando esse entendimento, o STF declarou inconstitucional ${ }^{838}$ o alargamento da base de cálculo do PIS/COFINS operado pela Lei $n^{\circ} 9.718 / 98$, que determinava a incidência das aludidas contribuições sobre "a totalidade das receitas auferidas pela pessoa jurídica" ${ }^{839}$. Com isso, o PIS e a COFINS voltaram a incidir sobre o faturamento, entendido como o produto da venda dos bens e serviços da empresa ${ }^{840}$. Já os demais dispositivos da Lei $n^{\circ}$ 9.718/98 foram integralmente validados pela Suprema Corte. Com isso, o referido diploma continuou a reger o PIS e a COFINS, exceto no que tange à sua base de cálcu$10^{841}$.

A efetiva instituição do PIS e da COFINS sobre a receita bruta, tal como autorizado pela atual redação da $\mathrm{CR} / 88^{842}$, ocorreu respectivamente por meio das Leis $n^{\circ} \mathrm{s} 10.637$, de

${ }^{837} \mathrm{CR} / 88$ :

“Art. 195. (...).

$\S 4^{\circ}$. A lei poderá instituir outras fontes destinadas a garantir a manutenção ou expansão da seguridade social, obedecido o disposto no art. 154, I."

“Art. 154. A União poderá instituir:

I - mediante lei complementar, impostos não previstos no artigo anterior, desde que sejam nãocumulativos e não tenham fato gerador ou base de cálculo próprios dos discriminados nesta Constituição;"

${ }^{838}$ Confira-se a ementa de um dos quatro leading cases que foram julgados, conjuntamente, pelo Plenário do STF:

“CONSTITUCIONALIDADE SUPERVENIENTE. ARTIGO $3^{\circ}, \S 1^{\circ}$, DA LEI No 9.718, DE 27 DE NOVEMBRO DE 1998. EMENDA CONSTITUCIONAL No 20, DE 15 DE DEZEMBRO DE 1998. O sistema jurídico brasileiro não contempla a figura da constitucionalidade superveniente. (...). CONTRIBUIÇÃO SOCIAL. PIS. RECEITA BRUTA. NOÇÃO. INCONSTITUCIONALIDADE DO $\S 1^{\circ}$ DO ARTIGO $3^{\circ}$ DA LEI N 9.718/98. A jurisprudência do Supremo, ante a redação do artigo 195 da Carta Federal anterior à Emenda Constitucional no 20/98, consolidou-se no sentido de tomar as expressões receita bruta e faturamento como sinônimas, jungindo-as à venda de mercadorias, de serviços ou de mercadorias e serviços. É inconstitucional o $\S 1^{\circ}$ do artigo $3^{\circ}$ da Lei $n^{\circ}$ 9.718/98, no que ampliou o conceito de receita bruta para envolver a totalidade das receitas auferidas por pessoas jurídicas, independentemente da atividade por elas desenvolvida e da classificação contábil adotada." (STF, Plenário, RE no 390.840/MG, Relator Min. MARCO AURÉLIO, DJ 15.08.2006, p. 25).

${ }^{839} \mathrm{LC} \mathrm{n}^{\mathrm{o}} 9.718 / 98$, art. $3^{\mathrm{o}}, \S 1^{\text {o }}$.

${ }^{840}$ Declarada a inconstitucionalidade da incidência do PIS/COFINS sobre a receita prevista na Lei $\mathrm{n}^{\mathbf{0}}$ 9.718/98, voltaram a vigorar as LCs $\mathrm{n}^{\circ} \mathrm{s}$ 7/70 e 70/91 nas partes em que dispunham sobre a base de cálculo das referidas contribuições.

${ }^{841}$ Vide nota de rodapé anterior.

${ }^{842}$ Art. 195, I, $b$ da CR/88, com a redação da EC nº 20/98. 
30 de dezembro de 2002, e 10.833 , de 29 de dezembro de $2003^{843}$. Tais diplomas também instituíram a forma de cobrança não-cumulativa do PIS/COFINS. Todavia, alguns contribuintes permaneceram, por expresso desígnio da nova legislação, sob a égide das regras anteriores (PIS/COFINS cumulativos), veiculadas pela Lei $\mathrm{n}^{\circ}$ 9.718/98.

A sistemática não-cumulativa predica a utilização de alíquotas mais elevadas para cálculo das contribuições (7,6\% para a COFINS e 1,65\% para o PIS). Em contrapartida, reconhece-se o direito a créditos sobre algumas despesas incorridas pelas empresas, que são abatidos do quantum debeatur.

Dessarte, atualmente coexistem duas formas distintas de apuração das contribuições em comento:

(a) regime cumulativo, veiculado pela Lei $\mathrm{n}^{\circ}$ 9.718/98 para o PIS e a COFINS, com incidência sobre o faturamento ${ }^{844}$ mensal e alíquotas de $0,65 \%$ (PIS) e $3 \%$ (COFINS);

(b) regime não-cumulativo, instituído:

(b.1) para o PIS, pela Lei $\mathrm{n}^{\circ} 10.637 / 02$, tributando a totalidade das receitas auferidas pela empresa, no mês, à alíquota de 1,65\%, com possibilidade de abatimento de créditos calculados sobre as despesas incorridas no mesmo período;

(b.2) para a COFINS, pela Lei $\mathrm{n}^{\circ} 10.833 / 03$, também incidindo sobre a receita bruta das empresas, com alíquota de 7,6\% e, igualmente, direito ao desconto de créditos sobre as despesas do mês.

\subsection{A REGRA-MATRIZ DE INCIDÊNCIA DO PIS/COFINS NÃO- CUMULATIVOS.}

Com base na resenha legislativa feita alhures, pode-se agora delinear a regra-matriz do PIS e da COFINS não-cumulativos da seguinte forma:

\footnotetext{
${ }^{843}$ A base de cálculo do PIS e da COFINS não-cumulativos correspondem ao "total das receitas auferidas pela pessoa jurídica, independentemente de sua denominação ou classificação contábil" (art. $1^{\circ}$, caput, das Leis $\mathrm{n}^{\mathrm{s}} \mathrm{s} 10.637 / 02$ e 10.833/03).

${ }^{844} \mathrm{O}$ faturamento e a receita são realidades distintas, porém com um núcleo em comum. A receita possui espectro mais amplo, abarcando todas as entradas que importem em aumento do patrimônio da pessoa jurídica; o faturamento, a seu turno, adstringe-se à denominada receita bruta operacional, é dizer, àqueles ingressos oriundos da realização do objeto social da empresa (venda de mercadorias ou prestação de serviços). Esse foi o posicionamento adotado pelo Supremo Tribunal Federal ao tratar da inconstitucionalidade do art. $3^{\circ}, \S 1^{\circ}$ da Lei $\mathrm{n}^{\circ}$ 9.718/98, quando foram assentadas as definições de faturamento e receita bruta, sendo o primeiro a "receita derivada da venda de bens e/ou da prestação de serviços" e a segunda a "totalidade das receitas auferidas pela pessoa jurídica", que inclui "a receita bruta das vendas e serviços, gerais, administrativas e nãooperacionais” (RE nº 346.084/PR, Pleno, Relator Min. CEZAR PELUSO, DJ 01.09.2006).
} 


\begin{tabular}{|c|c|}
\hline Hipótese de incidência & Conseqüência jurídica \\
\hline $\begin{array}{l}\text { Aspecto material: auferimento de receita } \\
\text { bruta pela pessoa jurídica; } \\
\text { Aspecto temporal: momento da contabi- } \\
\text { lização da receita }^{845} \text {; } \\
\text { Aspecto espacial: em qualquer lugar do } \\
\text { território nacional; } \\
\text { Aspecto pessoal: pessoa jurídica que aufi- } \\
\text { ra receita tributável. }\end{array}$ & $\begin{array}{l}\text { Sujeito ativo: União Federal; } \\
\text { Sujeito passivo: pessoa jurídica que aufe- } \\
\text { re a receita tributável; } \\
\text { Base de cálculo: total das receitas auferi- } \\
\text { das pela pessoa jurídica, independente- } \\
\text { mente de sua classificação contábil }{ }^{846} \text {; } \\
\text { Alíquota: } 1,65 \% \text { para o PIS e } 7,6 \% \text { para a } \\
\text { COFINS; } \\
\text { Quanto pagar: valor da alíquota aplicado } \\
\text { sobre a receita do mês, deduzidos os crédi- } \\
\text { tos calculados sobre as despesas previstas } \\
\text { em lei e incorridas no mesmo período; } \\
\text { Como e onde pagar: previsto em normas } \\
\text { editadas pelo Poder Executivo Federal. }\end{array}$ \\
\hline
\end{tabular}

${ }^{845}$ Sobre o aspecto temporal convém esclarecer que a legislação adota, por analogia com a contabilidade, a regra de que o PIS e a COFINS são devidos por competência. Ou seja, uma vez faturado o valor e registrado na contabilidade, as contribuições passam a ser devidas. Entrementes, se a posteriori o montante faturado não ingressar no caixa da empresa por força de inadimplência do comprador, o contribuinte-vendedor fará jus, a nosso sentir, ao estorno dos débitos anteriormente escriturados na conta gráfica. Afinal, o PIS e a COFINS incidem sobre a receita, que pressupõe acréscimo patrimonial. Não auferida a receita, deixa de haver fundamento para a cobrança das contribuições. Esse tema está sob análise do Supremo Tribunal Federal, que já lhe reconheceu repercussão geral (STF, Plenário Virtual, RE nº 586.482/RS, Relator Min. MENEZES DIREITO, repercussão geral reconhecida em 07.06.2008).

${ }^{846}$ Há, contudo, algumas exceções taxativamente previstas na legislação relativas a ingressos que não são computados na base de cálculo do PIS/COFINS, a saber:

(a) receitas decorrentes de saídas isentas do PIS/COFINS ou sujeitas à alíquota zero;

(b) receitas decorrentes de vendas do ativo imobilizado (receitas não operacionais);

(c) receitas auferidas pelo revendedor na revenda de mercadorias em relação às quais as contribuições são recolhidas pelo vendedor no regime de substituição tributária (caso, por exemplo, dos fabricantes de veículos automotores, que recolhem, como substitutos tributários, o PIS/COFINS sobre os automóveis que fornecem a seus revendedores, os quais, portanto, estão desonerados de pagar as contribuições sobre as receitas oriundas das vendas de veículos);

(d) receitas de vendas de produtos sujeitos à incidência monofásica das contribuições (como é o caso dos derivados de petróleo, a teor da Lei $\mathrm{n}^{\circ}$ 9.990/00);

(e) receitas referentes a vendas canceladas e descontos incondicionais concedidos;

(f) receitas referentes a reversões de provisões e recuperações de créditos baixados como perda que não representem ingresso de novas receitas;

(g) receitas decorrentes de resultados positivos na avaliação de investimentos pelo valor do patrimônio líquido e de lucros e dividendos derivados de investimentos avaliados pelo custo de aquisição que tenham sido computados como receita;

(h) receitas decorrentes de venda dos créditos acumulados de ICMS-exportação (autorizada pelo art. 25, $\S 1^{\circ}$, II da LC no $\left.87 / 96\right)$. 
Assentadas essas premissas, passemos adiante.

\subsection{A NÃO-CUMULATIVIDADE DO PIS/COFINS.}

\subsubsection{NOTAS GERAIS.}

\subsubsection{A NATUREZA ESCRITURAL DOS CRÉDITOS DO PIS/COFINS.}

Já vimos que o ICMS e o IPI são apurados por meio de lançamentos a débito e a crédito, contabilmente escriturados em conta gráfica. Sendo meramente contábeis, os créditos de ICMS e IPI não tornam o contribuinte credor da Fazenda Pública. Trata-se tãosomente de um meio para se chegar ao quantum debeatur.

A não-cumulatividade do PIS/COFINS parte da mesma premissa: os créditos das referidas contribuições são meramente escriturais. Portanto, não geram dívida do Poder Público para com o contribuinte. Seu fim é puramente contábil, para nada mais se prestando, salvo se a lei dispuser em contrário (como ocorre com os exportadores, cujo saldo credor de PIS/COFINS pode ser até mesmo ressarcido em dinheiro ${ }^{847}$ ).

A regra geral posta na legislação, confirmando o que se está a expor, predica que o valor dos créditos de PIS/COFINS "não constitui receita bruta da pessoa jurídica, servindo somente para dedução do valor devido da contribuição" ${ }^{\text {" }} 48$.

\subsubsection{APURAÇÃO IMPOSTO-CONTRA-IMPOSTO, POR PERÍODO DE TEM- PO, COM TRANSPORTE DE SALDO CREDOR PARA COMPETENCIAS POS- TERIORES.}

A forma de apuração do PIS/COFINS é a imposto-contra-imposto ${ }^{849}$, ou melhor, “contribuição-contra-contribuição". Os débitos são calculados pela aplicação da alíquota sobre as receitas ${ }^{850}$, ao passo que os créditos se obtêm mediante a multiplicação das despesas pela mesma alíquota ${ }^{851}$. Assim, calcula-se primeiramente o tributo devido para, em um segundo momento, deduzir os créditos compensáveis, obtendo-se, ao cabo dessa operação - que é realizada em conta gráfica - o quantum a pagar.

\footnotetext{
${ }^{847}$ Vide Item 13.4.1.3, infra.

${ }^{848}$ Lei $\mathrm{n}^{\circ} 10.833 / 03$, art. $3^{\circ}, \S 10^{\circ}$. A disposição é aplicável ao PIS por força do art. 15 , II também da Lei $\mathrm{n}^{\circ}$ $10.833 / 03$.

${ }^{849}$ Para maiores detalhes sobre os métodos de apuração dos tributos não-cumulativos, vide Título I, Capítulo III, Item 3.3.1.

${ }^{850}$ Art. $2^{\circ}$, caput das Leis $n^{\circ}$ s $10.637 / 02$ e 10.833/03.

${ }^{851}$ Art. $3^{\circ}$ das Leis nos $10.637 / 02$ e $10.833 / 03$.
} 
Diferente seria se as despesas fossem deduzidas das receitas, multiplicando-se o resultado pela alíquota das contribuições. Nesse caso, ter-se-ia o método de apuração basecontra-base que, entretanto, não foi o escolhido pelo legislador.

Outrossim, o PIS/COFINS é apurado por competência mensal ${ }^{852}$. Caso haja acúmulo de créditos no mês, o saldo credor é transportado para os períodos subseqüentes ${ }^{853}$, até que surjam débitos a compensar. Todavia, se os créditos acumulados forem oriundos de despesas realizadas com o fito de exportar bens ou serviços, o exportador poderá compensá-los com outros tributos federais ou, até mesmo, pedir o ressarcimento do valor em dinheiro à Receita Federal do Brasil (RFB). É o que se verá a seguir.

\subsubsection{O DIREITO DO EXPORTADOR DE COMPENSAR OS CRÉDITOS DE PIS/COFINS COM DÉBITOS DE OUTROS TRIBUTOS FEDERAIS OU DE PEDIR O RESSARCIMENTO EM ESPÉCIE.}

As receitas oriundas da exportação de produtos e serviços são imunes ${ }^{854}$ de contribuições sociais e de intervenção no domínio econômico. Como o PIS e a COFINS são contribuições sociais, a legislação ${ }^{855}$ incorporou - como não poderia deixar de ser - a referida imunidade. Portanto, o PIS e a COFINS não incidem sobre receitas decorrentes de:

(a) exportação de mercadorias para o exterior (inclusive vendas a empresa comercial exportadora com fim específico de exportação);

(b) prestação de serviços para pessoa física ou jurídica domiciliada no exterior, com pagamento em moeda conversível ${ }^{856}$.

\footnotetext{
${ }^{852}$ Art. $1^{\circ}$, caput das Leis no ${ }^{\circ}$ 10.637/02 e 10.833/03.

${ }^{853}$ Art. $3^{\circ}, \S 4^{\text {o }}$ das Leis $n^{\text {os }} 10.637 / 02$ e $10.833 / 03$.

${ }^{854}$ Reza a CR/88:

"Art. 149. Compete exclusivamente à União instituir contribuições sociais, de intervenção no domínio econômico e de interesse das categorias profissionais ou econômicas, como instrumento de sua atuação nas respectivas áreas, observado o disposto nos arts. 146, III, e 150, I e III, e sem prejuízo do previsto no art. $195, \S 6^{\circ}$, relativamente às contribuições a que alude o dispositivo.

(...)

$\S 2^{\circ}$. As contribuições sociais e de intervenção no domínio econômico de que trata o caput deste artigo:

I - não incidirão sobre as receitas decorrentes de exportação;"

${ }^{855}$ Art. $^{\circ}$ da Lei $n^{\circ} 10.637 / 02$ e art. $6^{\circ}$ da Lei $n^{\circ} 10.833 / 03$.

${ }^{856}$ A nosso sentir, a exigência de ingresso de moeda estrangeira para caracterização da exportação é injurídica. Afinal, é possível que a empresa estrangeira possua aplicações financeiras no Brasil, optando por quitar a compra com os seus Reais. Nesse caso, deixaria de haver exportação? Temos que não. Todavia, a lei espelha o entendimento da Receita Federal do Brasil sobre o tema.
} 
Mesmo não havendo incidência do PIS/COFINS sobre as receitas de exportação, a pessoa jurídica sujeita ao regime não-cumulativo dessas contribuições fará jus a créditos calculados sobre suas despesas, para abatimento de débitos de PIS/COFINS oriundos das vendas no mercado interno, que são regularmente tributadas. Entretanto, se houver acúmulo de saldo credor - situação comum às empresas exportadoras, cujas vendas internas são nulas ou residuais - os créditos decorrentes de exportação poderão ser compensados com outros tributos administrados pela $\mathrm{RFB}^{857}$, na forma do art. 74 da Lei ${ }^{\circ} 9.430 / 96^{858}$.

Caso a existência de saldo credor perdure por um trimestre completo (significando, com isso, que nem mesmo a compensação com o IRPJ e a CSLL devidos foi suficiente para utilização integral dos créditos acumulados), o exportador poderá requerer o ressarcimento do montante em dinheiro à União Federal ${ }^{859}$.

Trata-se de norma idêntica à existente para o $\operatorname{IPI}^{860}$ e semelhante à do $\operatorname{ICMS}^{861}$ (neste imposto, entretanto, inexiste previsão para ressarcimento do exportador em dinheiro, sendo possível apenas a transferência para terceiros do saldo credor de ICMS acumulado em decorrência de exportação ${ }^{862}$ ).

A ratio essendi dessas regras que prescrevem formas de utilização efetiva dos créditos acumulados pelos exportadores é evitar a perda parcial de eficácia da imunidade das exportações de bens e serviços.

No caso em tela, o exportador efetivamente suporta o ônus fiscal do PIS/COFINS em suas aquisições no mercado interno ${ }^{863}$. À míngua da existência de normas prevendo a

\footnotetext{
${ }^{857}$ Art. $5^{\circ}, \S 1^{\circ}$, II da Lei $n^{\circ} 10.637 / 02$ e art. $6^{\circ}, \S 1^{\circ}$, II da Lei $n^{\circ} 10.833 / 03$.

${ }^{858} \mathrm{O}$ art. 74 da Lei $\mathrm{n}^{\circ}$ 9.430/96 permite a compensação de créditos do contribuinte com débitos de tributos federais, vincendos ou vencidos, na forma e condições estipuladas no artigo. Para maiores detalhes sobre o tema, confira-se: MOREIRA, André Mendes. Da Compensação de Tributos Administrados pela Receita Federal - Evolução Legislativa e Modalidades. Revista Dialética de Direito Tributário, no 95. São Paulo: Dialética, ago./2003, pp. 7-17.
}

${ }^{859}$ Art. $^{\circ}, \S 2^{\circ}$ da Lei $n^{\circ} 10.637 / 02$ e art. $6^{\circ}, \S 2^{\circ}$ da Lei $n^{\circ} 10.833 / 03$.

${ }^{860}$ Vide Capítulo XI, Item 11.4.3.5.

${ }^{861}$ Vide Capítulo XII, Item 12.4.1.

${ }^{862} \mathrm{LC} \mathrm{n}^{\mathrm{o}} 87 / 96$, art. $25, \S 1^{\circ}, \mathrm{II}$.

${ }^{863}$ Fazemos aqui uma ressalva pois os créditos de PIS/COFINS são calculados com base nas despesas do contribuinte. Assim, ao contrário do IPI e ICMS, cujo direito ao crédito advém do imposto pago nas operações anteriores, no PIS/COFINS inexiste essa relação direta (entre as contribuições incidentes nas "etapas pretéritas" - se é que se pode falar assim para tributos que gravam a receita bruta e não operações de circulação de mercadorias - e o crédito compensável). Portanto, apenas de forma indireta se pode afirmar que os 
utilização ou restituição em espécie do saldo credor dessas contribuições, os preços das mercadorias e serviços exportados seriam enfunados pelo custo do PIS e da COFINS.

Acertadas, portanto, as normas que asseguram a manutenção e utilização do saldo credor de PIS/COFINS acumulado pelo exportador ${ }^{864}$, posto que consentâneas com a imunidade das receitas de exportação insculpida no art. 149, §2 , I da CR/88.

\subsubsection{O ADQUIRENTE DE PRODUTOS E SERVIÇOS TRIBUTADOS PELO PIS/COFINS CUMULATIVOS (3,65\%) FAZ JUS AO CRÉDITO REGULAR $(9,25 \%)$ SOBRE AS SUAS DESPESAS.}

O crédito do PIS/COFINS é calculado sobre as despesas incorridas pelo contribuinte. Portanto, ao contrário do IPI/ICMS, não se credita o valor do tributo pago na etapa anterior. A situação é interessante pois permite, em certos casos, que o crédito seja maior que o valor pago anteriormente a título das referidas contribuições.

Para melhor ilustrar o ponto, tome-se como exemplo uma fábrica que se sujeita ao PIS/COFINS cumulativos, cuja alíquota é de $3,65 \%^{865}$; e, ainda, um comerciante que recolhe essas contribuições no regime não-cumulativo, a $9,25 \%{ }^{866}$. Quando esse comerciante adquire da referida fábrica produtos para revenda ${ }^{867}$, tem-se a seguinte situação:

(a) a fábrica recolhe $3,65 \%$ de PIS/COFINS sobre o valor da venda;

(b) o comerciante-adquirente credita-se de 9,25\% sobre esse mesmo montante.

Trata-se de um efeito decorrente da não-cumulatividade das contribuições sociais em tela. Afinal, se o cálculo é feito sobre as despesas e não sobre o PIS/COFINS pago nas etapas pretéritas, então é possível a ocorrência da situação acima descrita.

De fato, se houve incidência de PIS/COFINS na venda do bem ou serviço, ainda que em valor ínfimo, assiste ao adquirente o direito de se creditar regularmente. $\mathrm{O}$ valor

créditos de PIS/COFINS correspondem ao valor dessas contribuições suportadas pelo contribuinte nas compras de bens e serviços no mercado interno.

${ }^{864}$ Em suma, a legislação garante:

(a) a manutenção dos créditos de PIS/COFINS por parte do exportador (cujas receitas são imunes dessas contribuições); e

(b) a efetiva utilização de tais créditos, mediante:

(b.1) compensação com outros tributos administrados pela RFB (IRPJ e CSLL); ou

(b.2) ressarcimento do exportador em dinheiro.

${ }^{865} 3 \%$ da COFINS mais $0,65 \%$ da contribuição para o PIS.

$8667,6 \%$ da COFINS mais $1,65 \%$ da contribuição para o PIS.

${ }^{867}$ A aquisição de bens para revenda gera créditos de PIS/COFINS, consoante será demonstrado no Item 13.4.4.1, infra. 
superior do crédito em relação ao débito (da etapa anterior) não pode ser restringido pela lei - como de fato não o foi - sob pena de ferimento à não-cumulatividade.

A exigência de estorno dos créditos por parte do contribuinte-adquirente só é permitida pelo princípio da não-cumulatividade na hipótese de ausência de tributação das mercadorias e serviços adquiridos (salvo em se tratando de isenção concedida na etapa pretérita, quando o crédito do adquirente deverá ser preservado). Isso decorre da exigência constitucional de duas etapas tributadas em seqüência para que a não-cumulatividade opere os seus regulares efeitos.

É o que se demonstrará a seguir.

\subsubsection{A EXIGÊNCIA DE DUAS "ETAPAS" $" 868$ TRIBUTADAS E AS BENESSES DA NÃO-CUMULATIVIDADE LEGAL DO PIS/COFINS.}

Pela análise da jurisprudência do Supremo Tribunal Federal já se concluiu que a não-cumulatividade exige ao menos dois estádios tributados para sua operacionalização. Assim, a não-incidência em um dos elos da cadeia produtiva, sob a ótica do PIS/COFINS, impede o cálculo de créditos:

(a) sobre as despesas incorridas nas aquisições de bens e serviços não-tributados pelo contribuinte que aufere receitas tributadas;

(b) sobre as despesas incorridas nas aquisições de bens e serviços tributados pelo contribuinte que aufere receitas não-tributadas.

Sendo esse o conteúdo constitucional da não-cumulatividade, pode-se afirmar que a legislação do PIS/COFINS poderia vedar o aproveitamento e a transferência de créditos em ambas as situações acima, salvo na hipótese de a não-tributação decorrer de isenção.

Nos casos da alínea $a$ (aquisições não-tributadas e saídas tributadas), as leis efetivamente vedam o desconto do crédito, exceto se a aquisição for isenta.

Todavia, na situação descrita na alínea $b$ (aquisições tributadas e saídas nãotributadas) existe norma assegurando expressamente o crédito sobre as despesas incorridas pelo contribuinte não sujeito ao PIS/COFINS.

É ver.

\footnotetext{
${ }^{868}$ A referência entre aspas deve-se ao fato de que não consideramos a contribuição para o PIS e a COFINS tributos plurifásicos, consoante alertado no Item 13.1 do presente capítulo e visto, com maior vagar, no Título I, Capítulo V, Item 5.2.
} 


\subsection{A VEDAÇÃO DO CRÉDITO SOBRE AQUISIÇÕES NÃO- TRIBUTADAS PELO PIS/COFINS.}

Prescreve a legislação ${ }^{869}$ que as aquisições não sujeitas ao PIS/COFINS impedem a tomada de créditos pelo adquirente. Contudo, o comprador poderá se creditar dos bens ou serviços isentos dessas contribuições, exceto se aqueles forem revendidos ou utilizados como insumo em produtos ou serviços também isentos, não tributados ou sujeitos à alíquota zero.

Segue-se, portanto, a regra geral dos tributos não-cumulativos, vedando o crédito para o adquirente de bens ou serviços não alcançados pelas referidas exações. Todavia, resguarda a lei expressamente o crédito sobre a aquisição de produtos ou serviços isentos. Apenas na hipótese de a revenda do bem isento ser também isenta, não-tributada ou tributada à alíquota zero, ou então desse mesmo bem ser utilizado como insumo em produtos ou serviços sem tributação (por qualquer razão), inexistirá direito ao creditamento.

As normas em comento são, a nosso sentir, válidas à luz da CR/88.

A única hipótese em que haveria uma possível inconstitucionalidade seria na aquisição de bens isentos que saíssem do estabelecimento do contribuinte também ao abrigo da isenção e não fossem destinados ao consumidor final. Expliquemos.

Se a última operação isenta referida na lei for também a última do processo de circulação do bem ou serviço, a norma sub examine será aplicável, inexistindo direito ao crédito. Afinal, a isenção na venda ao consumidor final reduz a carga tributária nas exações não-cumulativas. Com isso, são plenamente alcançados os objetivos da norma isencional.

Contudo, se as duas incidências seguidas forem intercalares - é dizer, não representarem as derradeiras etapas do processo de circulação do bem ou serviço - a norma será inconstitucional. Isso porque a isenção intercalar nos tributos não-cumulativos majora o quantum a pagar. Assim, a isenção somente alcançará seus fins se a operação for considerada tributada, gerando direito ao desconto de créditos. Essa consideração é possível com base no posicionamento do STF que visualiza a isenção como causa excludente do dever de pagar tributo (pressupondo a prévia incidência da regra-matriz do tributo, com o conseqüente nascimento do dever de pagar a exação). Portanto, apenas nesse caso específico

${ }^{869}$ Art. $3^{\text {o }}, \S 2^{\text {o }}$, II das Leis n's $10.637 / 02$ e $10.833 / 03$. 
entendemos que deveria haver direito ao creditamento, sob pena de ferimento da nãocumulatividade.

Entrementes, é correta, em qualquer hipótese, a vedação do crédito para o adquirente de produto isento que seja revendido ou utilizado como insumo de bem ou serviço sujeito à alíquota zero ou não-tributado. Afinal, nesse caso inexistirá operação posterior sujeita ao PIS/COFINS. Portanto, mesmo se o produto isento em questão fosse efetivamente tributado não haveria direito ao crédito.

\subsection{DIREITO AOS CRÉDITOS DO PIS/COFINS QUANDO AS SAÍDAS FOREM ABRIGADAS PELA ISENÇÃO, SUSPENSÃO, ALÍQUOTA ZERO OU NÃO-INCIDÊNCIA.}

Situação inversa à tratada no item precedente consiste nas aquisições gravadas pelo PIS/COFINS seguidas de vendas não-tributadas. Nesses casos, salvo se a saída for isenta, não há garantia constitucional para manutenção dos créditos com base no princípio da nãocumulatividade.

Contudo, a Lei $\mathrm{n}^{\mathrm{o}} 11.033$, de 21 de dezembro de $2004^{870}$, trouxe em seu bojo dispositivo assecuratório do crédito aos contribuintes do PIS/COFINS cujas vendas sejam efetuadas com isenção, suspensão, alíquota zero ou não-incidência das aludidas contribuições. Em qualquer dessas hipóteses, faz jus a pessoa jurídica ao crédito de 9,25\% sobre as suas despesas.

À míngua do dispositivo legal em tela, os créditos seriam calculados apenas na proporção das saídas isentas, pelas razões já multicitadas ao longo do trabalho, a saber:

(a) o direito aos créditos de PIS/COFINS pelo vendedor de produtos ou serviços isentos é conditio sine qua non para a eficácia da norma isencional;

(b) o STF visualiza a isenção como dispensa legal de tributo devido. Assim, para haver isenção deve haver primeiramente a incidência da norma de tributação. Portanto, a isenção é equiparável ao pagamento do próprio tributo devido, gerando direito ao crédito tanto na etapa precedente como na subseqüiente.

${ }^{870}$ Lei $n^{\circ} 11.033 / 04$ :

"Art. 17. As vendas efetuadas com suspensão, isenção, alíquota 0 (zero) ou não incidência da Contribuição para o PIS/PASEP e da COFINS não impedem a manutenção, pelo vendedor, dos créditos vinculados a essas operações." 


\subsubsection{OS CONTRIBUINTES SUJEITOS À NÃO-CUMULATIVIDADE E AS EX- CEÇÕES À REGRA.}

\subsubsection{AS DISPOSIÇÕES LEGAIS.}

Estão sujeitas ao PIS/COFINS não-cumulativos as pessoas jurídicas que calculam o IRPJ pelo Lucro Real. Assim, salvo se o contribuinte apurar o IRPJ com base no Lucro Presumido ou Arbitrado, ou for optante do SIMPLES, deverá, em regra, recolher o PIS/COFINS com base na sistemática débito-crédito.

Entretanto, outras categorias de pessoas jurídicas - além das sujeitas ao SIMPLES, Lucro Presumido e Lucro Arbitrado - também permaneceram fora da sistemática nãocumulativa das conttibuições, a saber ${ }^{871}$ :

(a) bancos comerciais, bancos de investimentos, bancos de desenvolvimento, caixas econômicas, sociedades de crédito, financiamento e investimento, sociedades de crédito imobiliário, sociedades corretoras, distribuidoras de títulos e valores mobiliários, empresas de arrendamento mercantil e cooperativas de crédito;

(b) empresas de seguros privados;

(c) entidades de previdência privada, abertas e fechadas;

(d) empresas de capitalização;

(e) empresas de securitização de créditos imobiliários, financeiros e agrícolas;

(f) operadoras de planos de saúde;

(g) pessoas jurídicas imunes a impostos ${ }^{872}$;

(h) órgãos públicos, autarquias e fundações públicas estaduais, federais ou municipais;

(i) fundações de ensino e pesquisa cuja criação tenha sido autorizada por lei;

(j) sociedades cooperativas;

(k) pessoas jurídicas integrantes do Mercado Atacadista de Energia (MAE) que tenham optado pelo regime especial de apuração do PIS/COFINS ${ }^{873}$;

\footnotetext{
${ }^{871}$ Art. $8^{\circ}$ da Lei $n^{\circ} 10.637 / 02$ c/c art. 15, V da Lei $n^{\circ} 10.833 / 03$ e Art. $10^{\circ}$ da Lei $n^{\circ} 10.833 / 03$.

${ }^{872}$ As pessoas jurídicas que gozam de isenção de impostos, tais como associações civis sem fins lucrativos, sujeitam-se ao PIS/COFINS não-cumulativos quando auferirem receitas não derivadas de suas atividades próprias. De fato, como a lei sujeita ao PIS/COFINS cumulativos apenas os entes imunes, as entidades isentas não estão abarcadas pelo comando normativo. A $9^{a}$ Região Fiscal Receita Federal do Brasil, inclusive, já externou esse entendimento na Solução de Consulta $n^{\circ}$ 18/05:
}

“ASSOCIAÇÕES SEM FINS LUCRATIVOS. ISENÇÃO DAS RECEITAS DAS ATIVIDADES PRÓPRIAS. As associações civis sem fins lucrativos, que prestem os serviços para os quais houverem sido instituídas e os coloquem à disposição do grupo de pessoas a que se destinam, têm as receitas derivadas das atividades próprias isentas da Cofins e sujeitas à sistemática da nãocumulatividade as receitas derivadas das demais atividades." (PERES, Adriana Manni; ALMEIDA, Cristina Beatriz de Sousa; VIANA, Ivo Ribeiro; DINIZ, Marianita Ribeiro. Como Utilizar Créditos Fiscais do IPI, PIS/COFINS e ICMS/SP. São Paulo: IOB Thomson, 2005, p. 143). 
(1) parques temáticos.

Em todos esses casos, as pessoas jurídicas continuam a ser regidas pela sistemática cumulativa do PIS/COFINS, com alíquota global de 3,65\% e incidência sobre o faturamento, sem possibilidade de desconto de créditos (regime da Lei $\mathrm{n}^{\circ}$ 9.718/98).

Entretanto, além de excepcionar os contribuintes supra do novel regime, as Leis $\mathrm{n}^{\circ} \mathrm{s}$ 10.637/02 e 10.833/03 mantiveram determinadas receitas sob a égide do PIS/COFINScumulativos. Assim, sujeitam-se às disposições da Lei $n^{\circ}$ 9.718/98 as receitas:

(a) de venda de álcool para fins carburantes ${ }^{874}$;

(b) sujeitas à substituição tributária do PIS/COFINS;

(c) de venda de veículos usados adquiridos para revenda ou recebidos na troca por outro veículo (quando auferidas por empresas revendedoras de automóveis);

(d) decorrentes da prestação de serviço de telecomunicações;

(e) decorrentes da prestação de serviços das empresas jornalísticas e de rádio e TV abertas;

(f) decorrentes das vendas de jornais e periódicos;

(g) relativas a contratos com prazo superior a 1 (um) ano firmados anteriormente a 31 de outubro de $2003^{875}$ de:

(g.1) administradoras de planos de consórcios de bens móveis e imóveis autorizadas a funcionar pelo Banco Central;

(g.2) construção por empreitada;

(g.3) fornecimento, a preço predeterminado ${ }^{876}$, de bens ou serviços;

${ }^{873} \mathrm{O}$ regime especial é facultado pelo art. 47 da Lei $\mathrm{n}^{\circ} 10.637 / 02$.

${ }^{874}$ Trata-se da única receita sujeita à apuração monofásica do PIS/COFINS que ainda remanesce sob o regime da cumulatividade dessas contribuições. Contribuinte do PIS/COFINS monofásico sobre o álcool para fins carburantes é o seu distribuidor, sendo as alíquotas de 1,45\% para o PIS e 6,74\% para a COFINS (art. $5^{\circ}$ da Lei $n^{\circ}$ 9.718/98).

Os demais casos de monofasia do PIS/COFINS (combustíveis e lubrificantes derivados de petróleo, produtos farmacêuticos e de perfumaria, máquinas, veículos e autopeças, pneus e câmaras-de-ar de borracha, embalagens para água, refrigerantes e cervejas e determinados tipos de bebidas) estão, desde $1^{\circ}$ de agosto de 2004 (por força da Lei $\mathrm{n}^{\circ} 10.865 / 04$ ), submetidos ao regime não-cumulativo, sendo autorizado ao contribuinte monofásico o desconto de créditos dessas contribuições. Para maiores detalhes, vide Item 13.4.3, infra.

${ }^{875}$ Data de publicação da Medida Provisória nº 135 , que instituiu a COFINS não-cumulativa.

${ }^{876}$ A Receita Federal do Brasil entende que o contrato sujeito a preço predeterminado não pode conter cláusula de reajuste periódico dos valores. Do contrário, na primeira correção o preço deixaria de ser predeterminado, passando as receitas oriundas do contrato a se sujeitarem ao PIS/COFINS não-cumulativos. Esse entendimento foi externado por meio da Instrução Normativa no 468, de 8 de novembro de 2004.

Este entendimento é, a nosso sentir, injurídico. Afinal, o reajuste anual de valores pelos índices inflacionários não torna indeterminado o preço contratual. Ao revés, a preservação do valor da moeda apenas mantém o preço nos mesmos parâmetros em que inicialmente pactuado pelas partes. Ilegal, neste ponto, a IN/RFB $n^{\circ}$ 
(h) relativas a contratos de construção por empreitada ou de fornecimento, a preço predeterminado, de bens ou serviços contratados com pessoa jurídica de direito público, empresa pública, sociedade de economia mista ou suas subsidiárias, bem como os contratos posteriormente firmados decorrentes de propostas apresentadas, em processo licitatório, até aquela data;

(i) decorrentes de prestação de serviços de transporte coletivo rodoviário, metroviário, ferroviário e aquaviário de passageiros;

(j) decorrentes de serviços prestados por hospital, pronto-socorro, clínica médica, odontológica, fisioterápica e fonoaudiológica;

(k) decorrentes de serviços prestados por laboratório de anatomia patológica, citológica ou de análises clínicas;

(1) decorrentes de diálise, raios $\mathrm{X}$, radiodiagnóstico e radioterapia, quimioterapia e de banco de sangue;

(m) decorrentes de prestação de serviços de educação infantil, ensinos fundamental e médio e educação superior;

(n) decorrentes de venda de mercadorias realizadas por free-shops;

(o) decorrentes de prestação de serviço de transporte coletivo de passageiros, efetuado por empresas regulares de linhas aéreas domésticas, e as decorrentes da prestação de serviço de transporte de pessoas por empresas de táxi aéreo;

(p) decorrentes da edição de periódicos e de informações neles contidas, que sejam relativas aos assinantes dos serviços públicos de telefonia;

(q) decorrentes de prestação de serviços com aeronaves de uso agrícola inscritas no Registro Aeronáutico Brasileiro (RAB);

(r) decorrentes de prestação de serviços das empresas de call center, telemarketing, telecobrança e de teleatendimento em geral;

(s) decorrentes da execução por administração, empreitada ou subempreitada de obras de construção civil, até 31 de dezembro de 2010;

(t) decorrentes de serviços de hotelaria e de organização de feiras e eventos;

(u) decorrentes da prestação de serviços postais e telegráficos prestados pela Empresa Brasileira de Correios e Telégrafos;

468/04, como também apregoam SACHA CALMON e MISABEL DERZI (COÊLHO, Sacha Calmon Navarro e DERZI, Misabel Abreu Machado. PIS/Cofins. Regime de Crédito. Contratos de Longo Prazo. Instrução Normativa $n^{\circ}$ 468/04 da SRF. Ilegalidade. Revista Dialética de Direito Tributário, nº 114. São Paulo: Dialética, mar./2005, pp. 121-37). 
(v) decorrentes de prestação de serviços públicos de concessionárias operadoras de rodovias;

(w) decorrentes da prestação de serviços das agências de viagem e de viagens e turismo;

(x) decorrentes das atividades de desenvolvimento de software e o seu licenciamento ou cessão de direito de uso, bem como de análise, programação, instalação, configuração, assessoria, consultoria, suporte técnico e manutenção ou atualização de software, compreendidas ainda como softwares as páginas eletrônicas (salvo a comercialização, licenciamento ou cessão de direito de uso de software importado, cujas receitas se sujeitam ao PIS/COFINS não-cumulativos);

(y) relativas às atividades de revenda de imóveis, desmembramento ou loteamento de terrenos, incorporação imobiliária e construção de prédio destinado à venda, quando decorrentes de contratos de longo prazo firmados antes de 31 de outubro de 2003.

O número de exceções impressiona, todavia não surpreende. É que as alíquotas do PIS/COFINS não-cumulativos foram mal calibradas, resultando em aumento da carga fiscal. Assim, a sistemática cumulativa tornou-se mais atrativa para a maior parte dos contribuintes, posto que menos onerosa ${ }^{877}$.

Não bastasse o fato de o novel regime ter resultado em elevação do PIS/COFINS devidos, o principal critério de subsunção do contribuinte ao sistema não-cumulativo apuração do IRPJ com base no Lucro Real - é anti-isonômico, implicando a desequiparação de empresas em idêntica situação e, consequientemente, gerando desequilíbrio concorrencial.

É o que se demonstrará a seguir.

\subsubsection{A APURAÇÃO DO IRPJ PELO LUCRO REAL COMO CRITÉRIO PARA SUJEIÇÃO À NÃO-CUMULATIVIDADE DO PIS/COFINS: VIOLAÇÃO AO PRINCÍPIO DA ISONOMIA.}

A Constituição de 1988 permite que o legislador federal defina "os setores de atividade econômica" para os quais o PIS e a COFINS serão não-cumulativos ${ }^{878}$. O comando

\footnotetext{
${ }^{877}$ A onerosidade do novel regime atingiu principalmente os prestadores de serviço, cuja principal despesa mão-de-obra - não gera créditos de PIS/COFINS. Confira-se, para tanto, o Item 13.13, infra.

${ }^{878}$ Confira-se a CR/88, com a redação da Emenda Constitucional no 42, de 19 de dezembro de 2003:

“Art. 195. (...).
} 
deixa claro que os regimes cumulativo e não-cumulativo deverão coexistir, devendo o legislador eleger setores da economia para subsunção à não-cumulatividade.

Cumprindo o disposto na Constituição, as Leis nos 10.637/02 e 10.833/03 mantiveram diversas pessoas jurídicas na sistemática cumulativa do PIS/COFINS ${ }^{879}$. Tais contribuintes foram beneficiados, pois o pagamento das contribuições na forma cumulativa é mais benéfico para os contribuintes, haja vista as elevadas alíquotas do novel regime.

Até este ponto nenhuma inconstitucionalidade haveria, pois desde que todo um "setor da atividade econômica" (fator de discrímen pugnado pela Constituição) estivesse sujeito ao PIS/COFINS cumulativo, não se poderia falar em ferimento à isonomia. Afinal, nesse cenário, todas as empresas que concorressem entre si, vendendo mercadorias idênticas ou prestando serviços análogos, estariam sujeitas à mesma forma de apuração do PIS/COFINS (cumulativo ou não-cumulativo).

Entrementes, contrariando o critério determinado pela $\mathrm{CR} / 88$, o legislador elegeu $o$ regime de apuração do IRPJ pelo Lucro Real como principal elemento para subsunção da pessoa jurídica à não-cumulatividade do PIS/COFINS. Nessa toada, os contribuintes que calculam o IRPJ baseados no Lucro Presumido ou Arbitrado permaneceram submetidos ao PIS/COFINS cumulativos.

Ao proceder dessa forma o legislador incorreu, a nosso sentir, em inconstitucionalidade. O princípio da isonomia assegura que contribuintes em situações idênticas não poderão ser tributariamente diferençados ${ }^{880}$. Ora, a escolha do regime de apuração do Imposto sobre a Renda leva em consideração inúmeros fatores. Empresas cujas despesas sejam elevadas em relação ao seu faturamento preferem o Lucro Real, mesmo não sendo obrigadas a tanto $^{881}$; já empresas com altas margens de lucro optam, se puderem, pelo Lucro Presumido. Trata-se de uma escolha empresarial, resguardada pela liberdade que o contribuinte

$\S 12$. A lei definirá os setores de atividade econômica para os quais as contribuições incidentes na forma dos incisos I, $b$ [sobre receita ou faturamento] (...) do caput, serão não-cumulativas."

${ }^{879}$ Vide Item precedente.

${ }^{880} \mathrm{CR} / 88$, art. 150, II.

${ }^{881}$ São obrigadas à apuração do IRPJ pelo Lucro Real, dentre outras, as empresas cuja receita seja igual ou superior a quarenta e oito milhões de reais por ano (art. 14, I da Lei $n^{\circ}$ 9.718/98, modificado pela Lei $n^{\circ}$ 10.833/03). Entretanto, qualquer empresa pode optar por essa forma de apuração. Assim, o cálculo do Imposto de Renda da Pessoa Jurídica pelo Lucro Real, isoladamente considerado, não é indicativo de capacidade econômica. Muitas empresas de médio e até de pequeno porte preferem se sujeitar a esse regime, pois têm despesas elevadas e baixas margens de lucro. 
possui de estruturar os seus negócios - dentro da lei - da forma mais benéfica que lhe for possível.

Para clarificar o que se está a expor, tome-se como exemplo uma empresa prestadora de serviços de manutenção e limpeza. Como sua atividade não foi excepcionada do novel regime do PIS/COFINS, a empresa sujeitar-se-á:

(a) ao regime não-cumulativo, se optante pelo Lucro Real; ou

(b) ao regime cumulativo, se optante pelo Lucro Presumido.

Pois bem. Imagine-se que essa empresa possua elevadas despesas mensais, pelo que apura o IRPJ com base no Lucro Real (sujeitando-se, com isso, à não-cumulatividade do PIS/COFINS). A sua concorrente, contudo, possui uma lucratividade maior em decorrência de contratos mais bem negociados. Por essa razão, essa outra empresa opta pelo regime do Lucro Presumido (e, por conseguinte, paga o PIS/COFINS no regime cumulativo).

Nesse caso, ter-se-ão duas pessoas jurídicas, do mesmo segmento e concorrentes entre si, sujeitadas a regimes diversos de pagamento do PIS/COFINS.

Em hipóteses como tais exsurge com clareza o equívoco incorrido pelo legislador, que violou o princípio da isonomia quando da criação do PIS/COFINS não-cumulativos. Ademais, com o advento da EC n ${ }^{\circ} 42 / 03$, restou aclarado (desnecessariamente, a nosso sentir) que a coexistência entre o PIS/COFINS cumulativo e não-cumulativo somente seria possível caso setores completos da atividade econômica fossem submetidos ao novo regime. A EC n ${ }^{\circ} 42 / 03$ nunca autorizou - e mesmo assim não poderia, por ofensa à isonomia que o legislador subsumisse empresas do mesmo segmento de atuação, potencialmente concorrentes, a regimes diferenciados do PIS/COFINS.

Portanto, temos pela inconstitucionalidade do critério de apuração do IRPJ como fator de discrímen para sujeição ao PIS/COFINS não-cumulativos ${ }^{882}$. Vale dizer que o te-

${ }^{882}$ As considerações de GOSSON perfilham o mesmo entendimento:

"A adoção de um sistema híbrido de incidência da COFINS, composto por duas formas distintas de apuração da exação, resultou num desprestígio a alguns setores da economia e ofereceu tratamento antiisonômico a contribuintes em situação de equivalência, como é o caso do setor de prestação de serviços, formado por empresas optantes pelo lucro real, presumido e pelo lucro arbitrado.

(...)

$\mathrm{O}$ regime de apuração do imposto de renda, um dos critérios de discrímen indicados pela Lei $\mathrm{n}^{\circ}$ 10.833/03, não se mostra legítimo a permitir tratamento jurídico distinto a contribuintes de uma mesma atividade econômica. As pessoas jurídicas tributadas pelo lucro real não são reveladoras de maior capacidade contributiva de que aquelas tributadas pelo lucro presumido ou arbitrado, e viceversa.

A Lei ${ }^{\circ} 10.833 / 03$, no que diz respeito ao discrímen indicativo da sujeição à não-cumulatividade da COFINS, viola o princípio constitucional da isonomia, e por conseqüência, padece do vício da inconstitucionalidade, por estabelecer tratamento desigual a contribuintes em situação equivalente, além de suscitar divergências sociais e pôr em risco a livre iniciativa." (GOSSON, Grace Christine de Oliveira. COFINS na Prestação de Serviços: Violação do Princípio Constitucional da Isonomia. 
ma ainda não foi apreciado pelo STF, que, entretanto, já lhe reconheceu repercussão ge$\operatorname{ral}^{883}$.

\subsubsection{A MONOFASIA DO PIS/COFINS E A NÃO-CUMULATIVIDADE TRIBU-} TÁRIA.

\subsubsection{O REGIME MONOFÁSICO DAS CONTRIBUIÇÕES.}

Determinados contribuintes do PIS/COFINS sujeitam-se a um regime diferenciado de apuração, no qual há uma incidência única no início da cadeia produtiva, em alíquotas superiores às usuais.

O contribuinte monofásico é, em regra, o produtor ou o importador do bem. Os demais agentes da cadeia produtiva (distribuidores, atacadistas e varejistas) são tributados à alíquota zero (afinal, todo o PIS/COFINS devido é pago anteriormente). O fluxograma abaixo ilustra o instituto em comento:

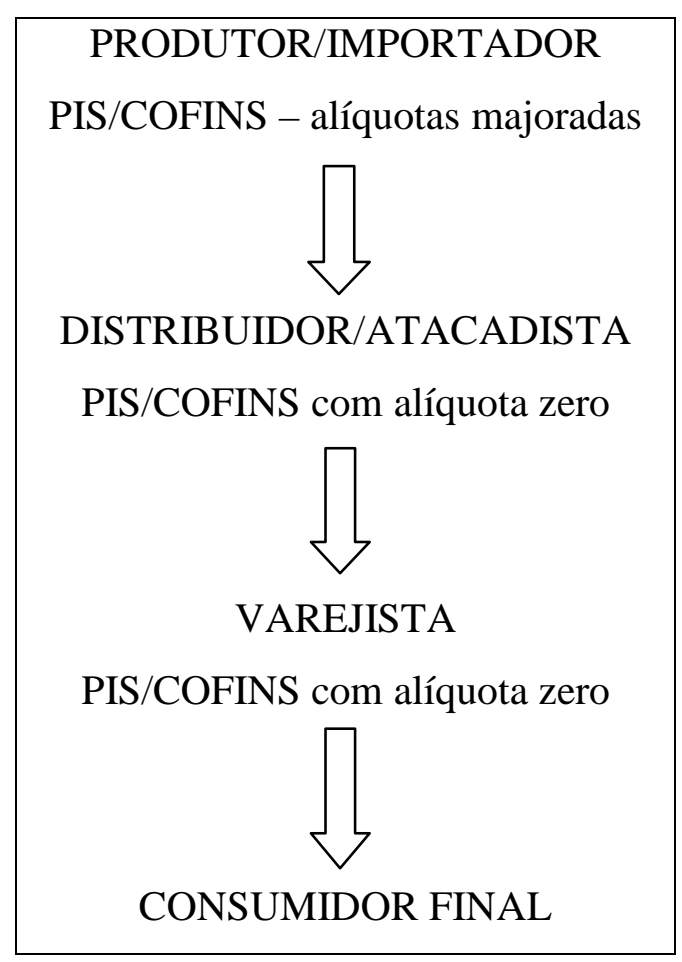

PEIXOTO, Marcelo Magalhães e FISCHER, Octavio Campos (coord.). PIS-COFINS - Questões Atuais e Polêmicas. São Paulo: Quartier Latin, 2005, pp. 469-70).

No mesmo sentido, confira-se: VERGUEIRO, Guilherme Von Müller Lessa. A Inconstitucionalidade da COFINS: Ofensa à Isonomia. PEIXOTO, Marcelo Magalhães e FISCHER, Octavio Campos (coord.). PISCOFINS - Questões Atuais e Polêmicas. São Paulo: Quartier Latin, 2005, pp. 395-410.

${ }^{883}$ STF, Plenário Virtual, RE n 570.122/RS, Relator Min. MARCO AURÉLIO, repercussão geral reconhecida em 23.02.2008. 
A monofasia do PIS/COFINS aplica-se aos produtores/importadores dos seguintes produtos:

(a) derivados de petróleo, tais como gás liquefeito de petróleo (GLP), querosene de aviação, gasolina e suas correntes, óleo diesel e suas correntes;

(b) medicamentos e produtos de perfumaria especificados pela legislação ${ }^{884}$;

(c) máquinas, veículos e autopeças especificados pela legislação ${ }^{885}$;

(d) pneus novos e câmaras-de-ar de borracha;

(e) embalagens para água, refrigerantes e cervejas;

(f) água, refrigerantes e cervejas.

Já o distribuidor de álcool para fins carburantes se sujeita ao pagamento do PIS/COFINS monofásico ${ }^{886}$, excepcionando a regra geral que impõe essa responsabilidade ao produtor ou importador.

É faculdade do legislador, a qualquer momento, sujeitar novos produtos à monofasia do PIS/COFINS, cujas alíquotas podem ser ad valorem (em porcentuais, forma mais usual) ou específicas (por unidade de medida, adotada para alguns derivados de petróleo e determinadas embalagens para água, refrigerantes e cervejas, assim como para a produção ou importação da própria água, dos refrigerantes e das cervejas).

Vale gizar que a apuração monofásica do PIS/COFINS não possui qualquer relação com o regime ao qual o contribuinte dessas exações está sujeito. Noutro giro verbal, a monofasia em tela se coaduna tanto com a cumulatividade como com a não-cumulatividade do PIS/COFINS. Compete apenas ao legislador sujeitar os contribuintes do PIS/COFINSmonofásico a uma ou outra das referidas formas de apuração.

É ver.

\subsubsection{A SUJEIÇÃO DOS CONTRIBUINTES MONOFÁSICOS À NÃO- CUMULATIVIDADE DO PIS/COFINS.}

Quando a não-cumulatividade do PIS/COFINS entrou a viger, os contribuintes sujeitos à monofasia foram mantidos na sistemática antiga (cumulativa). Com isso, mantevese o impedimento - já existente - de os produtores/importadores descontarem créditos sobre suas aquisições.

\footnotetext{
${ }^{884}$ Lei no 10.147 , de 21 de dezembro de 2000.

${ }^{885}$ Lei no 10.485 , de 3 de julho de 2002.

${ }^{886}$ Art. $5^{\circ}$ da Lei $n^{\circ} 9.718 / 98$.
} 
Entretanto, quando o PIS e a COFINS sobre a importação foram instituídos pela Lei $\mathrm{n}^{\mathrm{o}} 10.865 / 04$, a carga tributária sobre todos os contribuintes do PIS/COFINS-cumulativos foi majorada. Isso porque as contribuições devidas na importação só geram créditos se a pessoa jurídica estiver sujeita à apuração não-cumulativa do PIS/COFINS ${ }^{887}$.

Para que o PIS/COFINS-importação fosse melhor absorvido pelos contribuintes monofásicos (sujeitos até então à cumulatividade) ${ }^{888}$, a Lei $n^{\circ}$ 10.865/04 revogou o dispositivo que excepcionava a monofasia do regime não-cumulativo ${ }^{889}$. Essa medida resultou na subsunção dos contribuintes monofásicos às regras da não-cumulatividade, desde que apurassem o seu IRPJ pelo Lucro Real (e não se enquadrassem em nenhuma das demais exceções ao novel regime previstas na legislação).

Com essa modificação, as pessoas jurídicas obrigadas ao recolhimento monofásico do PIS/COFINS foram autorizadas a:

(a) descontar os créditos previstos no art. $3^{\circ}$ das Leis $n^{\circ}$ s 10.637/02 e 10.833/03 ${ }^{890}$;

(b) abater dos débitos de PIS/COFINS as contribuições pagas na importação de bens e serviços.

É interessante notar que, independentemente de a pessoa jurídica se sujeitar ao regime cumulativo ou não-cumulativo do PIS/COFINS, as alíquotas da tributação monofásica serão sempre as mesmas.

Portanto, pode-se concluir que os produtores/importadores que apurem o IRPJ pelo Lucro Real e estejam sujeitos ao PIS/COFINS-monofásico se subsumem, hoje, ao regime não-cumulativo das contribuições ${ }^{891}$. Com isso, fazem jus ao desconto de créditos sobre

\footnotetext{
${ }^{887}$ Para maiores detalhes sobre a não-cumulatividade do PIS/COFINS-importação, vide o Capítulo XIV, infra.

${ }^{888}$ Afinal, as alíquotas do PIS/COFINS-monofásico são substancialmente maiores do que as alíquotas regulares dessas contribuições.

${ }^{889} \mathrm{O}$ art. $1^{\mathrm{o}}, \S 3^{\circ}, \mathrm{IV}$ das Leis $\mathrm{n}^{\circ} \mathrm{s} 10.637 / 02$ e 10.833/03 excluía da não-cumulatividade os contribuintes do PIS/COFINS-monofásico. Tal dispositivo foi alterado pelos arts. 21 e 37 da Lei $n^{\circ} 10.865 / 04$, que incluiu esses contribuintes, com efeitos a partir de $1^{\circ}$ de agosto de 2004 , no regime não-cumulativo. Nesse primeiro momento, ficaram de fora da nova sistemática de tributação apenas os revendedores de álcool para fins carburantes e os produtores/importadores de água, refrigerantes e cervejas. Estes últimos, contudo, foram expressamente incluídos na não-cumulatividade pela Lei $\mathrm{n}^{\circ}$ 10.925/04 (cujo art. 16, II, $a$ revogou o art. 56 da Lei $\mathrm{n}^{\circ} 10.833 / 03$, com a redação da Lei $\mathrm{n}^{\circ} 10.865 / 04$, que mantinha fora da não-cumulatividade os produtores/importadores de água, refrigerantes e cervejas).

${ }^{890}$ Tais créditos são especificados, um a um, no Item 13.4.5, infra.

${ }^{891}$ Como já referido anteriormente, hoje apenas os distribuidores de álcool para fins carburantes são contribuintes monofásicos mandatoriamente excluídos do PIS/COFINS não-cumulativos (art. $5^{\circ}$ da Lei no 9.178/98 c/c art. $1^{\circ}, \S 3^{\circ}$, IV das Leis $n^{\circ}$ s $10.637 / 02$ e 10.833/03).
} 
suas despesas, assim como qualquer outro contribuinte sujeito à não-cumulatividade do PIS/COFINS ${ }^{892}$.

Já os distribuidores, atacadistas e varejistas que operam com produtos sujeitos à monofasia do PIS/COFINS - e se sujeitam à alíquota zero das contribuições nas vendas desses produtos - não podem descontar qualquer tipo de crédito, por expressa vedação legal $^{893}$.

Obviamente, se esses distribuidores, atacadistas ou varejistas auferirem receitas com a venda de produtos sujeitos à apuração regular (não-monofásica) do PIS/COFINS, poderão se creditar normalmente, bastando proporcionalizar suas despesas ${ }^{894}$, como inclusive já reconheceu a $\mathrm{RFB}^{895}$.

\subsubsection{EMPRESAS SUJEITAS AO REGIME MISTO (CUMULATIVO E NÃO- CUMULATIVO): APURAÇÃO DIRETA OU PROPORCIONAL DOS CRÉDITOS.}

Como visto, a legislação excepciona certas categorias de pessoas jurídicas e também de receitas da não-cumulatividade. Assim, como uma única empresa pode auferir receitas de origens distintas, é possível a sua sujeição ao pagamento do PIS e da COFINS em

${ }^{892}$ Confira-se a Solução de Consulta n $49 / 09$, da $4^{\text {a }}$ Região Fiscal (DOU de 02.04.2009):

"O sistema de tributação monofásica não se confunde com os regimes de apuração cumulativa e não-cumulativa das contribuições. $O$ enquadramento de uma pessoa jurídica e de suas receitas, que se dedique à venda de produtos sujeitos à tributação monofásica, ao regime de apuração cumulativa ou não-cumulativa segue as mesmas regras de enquadramento a que se sujeitam pessoas jurídicas que não comercializem produtos monofásicos. Caso a pessoa jurídica venha a estar submetida ao regime de apuração não-cumulativa das contribuições, a tributação monofásica dos produtos determinados também tem natureza não-cumulativa, permitindo à pessoa jurídica o aproveitamento de créditos de acordo com a regra geral." (destaques nossos)

${ }^{893}$ Art. $3^{\circ}, \mathrm{I}, b$ das Leis no ${ }^{\circ}$ 10.637/02 e 10.833/03.

${ }^{894}$ Vide Item 13.4.4, infra.

${ }^{895}$ Solução de Consulta n ${ }^{\text {o }} 351 / 07$, da $9^{\text {a }}$ Região Fiscal (DOU de 28.09.2007): "REVENDA DE PRODUTOS MONOFÁSICOS. CRÉDITOS POSSÍVEIS. INCIDÊNCIA PARCIAL DA NÃO-CUMULATIVIDADE. (...). Na tributação pela sistemática não-cumulativa da COFINS sobre a receita proveniente da revenda de produtos sujeitos à tributação concentrada, apesar da incidência de alíquota zero, podem ser descontados créditos referentes aos incisos IV a IX da Lei $\mathrm{n}^{\circ}$ 10.637/2002 e III a IX da Lei no 10.833/2003 (energia elétrica, aluguel etc.), sendo vedado o desconto de créditos relativos a bens sujeitos à tributação monofásica adquiridos para revenda, a bens e serviços usados como insumo e à depreciação de máquinas, equipamentos e outros bens incorporados ao ativo imobilizado. (...). O valor dos créditos, no caso de incidência parcial das receitas à cumulatividade e à não-cumulatividade, será determinado exclusivamente em relação aos custos, despesas e encargos vinculados à receita não-cumulativa e à parcela dos custos, despesas e encargos comuns, referentes à receita não-cumulativa, determinada alternativamente pelo método da apropriação direta ou do rateio proporcional. (...)." 
ambos os sistemas (cumulativo e não-cumulativo). Caso isso ocorra, seu direito ao crédito somente poderá ser exercido:

(a) sobre as despesas incorridas no auferimento de receitas tributadas pelo PIS/COFINS não-cumulativos; ou

(b) na proporção dos seus débitos de PIS/COFINS não-cumulativos.

Por exemplo: uma empresa que tenha faturamento mensal de $\mathrm{R} \$ 1.000 .000,00$, sendo R\$ 900.000,00 tributados pelo sistema cumulativo (alíquota global de 3,65\%) e R\$ 100.000,00 pelo não-cumulativo (alíquota global de 9,25\%), não poderá simplesmente aplicar 9,25\% sobre o total das suas despesas e aproveitar a integralidade dos créditos obtidos com esse cálculo. Afinal, caso isso fosse possível estar-se-ia conferindo créditos fictícios de PIS/COFINS ao contribuinte, o que anularia os débitos do regime nãocumulativo $^{896}$.

Dessarte, se apenas parte da receita do contribuinte é gravada pelo PIS/COFINS não-cumulativos, a legislação lhe confere o direito de escolha entre os métodos da apropriação direta (alínea $a$, supra) e do rateio proporcional (alínea $b$, supra) ${ }^{897}$ para cálculo de seus créditos. Vejamo-los.

A apropriação direta dos créditos da pessoa jurídica exige a identificação das despesas vinculadas à produção de receitas sujeitas à não-cumulatividade do PIS/COFINS. Os créditos serão integralmente aproveitados pelo contribuinte, porém seu cálculo recairá apenas sobre as despesas que geraram as receitas gravadas à alíquota de 9,25\%. Para que a apropriação direta seja possível, o contribuinte deverá possuir um sistema de contabilidade de custos integrado com a sua escrituração contábil. Somente dessa forma será viável a vinculação das despesas às receitas tributadas pelo PIS/COFINS não-cumulativos. Trata-se de um processo complexo e oneroso e, por essa razão, não tem sido utilizado pelos contribuintes sujeitos ao regime misto (cumulativo e não-cumulativo) para cálculo de seus créditos.

\footnotetext{
${ }^{896}$ É importante gizar que o contribuinte sujeito ao regime misto não tem o direito de compensar débitos do PIS/COFINS cumulativos com créditos do regime não-cumulativo dessas contribuições. Tratam-se de regimes jurídicos distintos, que não se confundem.

${ }^{897}$ Art. $3^{\circ}, \S \S 7^{\circ}$ e $8^{\circ}$ das Leis no ${ }^{\circ}$ 10.637/02 e 10.833/03.
} 
O método do rateio proporcional é o mais usual, exatamente por sua simplicidade. Nesse sistema calcula-se o porcentual das despesas que serão objeto de creditamento, por meio da seguinte operação aritmética ${ }^{898}$ :

Receita sujeita ao regime não-cumulativo x 100 $=$ Porcentual da receita sujeito ao regime Receita total não-cumulativo

Ou seja: se $10 \%$ da receita do contribuinte sujeitam-se ao regime não-cumulativo, ele poderá, pelo sistema do rateio proporcional, calcular créditos sobre $10 \%$ do total de suas despesas.

A opção por um dos métodos acima (apropriação direta ou rateio proporcional) será válida para todo o ano-calendário, somente podendo ser alterada no exercício subseqüente ${ }^{899}$.

\subsubsection{AS ESPÉCIES DE CRÉDITOS DO PIS/COFINS.}

A legislação prevê, em rol taxativo ${ }^{900}$, as despesas sobre as quais se permite o cálculo de créditos do PIS/COFINS. Todavia, o contribuinte somente fará jus a tais créditos se:

(a) os bens e serviços forem adquiridos de pessoa jurídica domiciliada no Brasil ${ }^{901}$; e

(b) os custos e despesas incorridos forem pagos a pessoa jurídica domiciliada no País ${ }^{902}$.

A restrição se justifica. Afinal, quando são feitas aquisições de empresas situadas no exterior, não há pagamento, pelo remetente dos bens ou prestador dos serviços, de PIS/COFINS sobre as receitas por eles auferidas. A operação, portanto, não é afetada pela incidência das referidas contribuições. Dessarte, a lei acerta ao vedar o cálculo de créditos sobre os custos de aquisição de produtos e serviços de empresas estrangeiras. Do contrário,

\footnotetext{
${ }^{898}$ PERES, Adriana Manni; ALMEIDA, Cristina Beatriz de Sousa; VIANA, Ivo Ribeiro; DINIZ, Marianita Ribeiro. Como Utilizar Créditos Fiscais do IPI, PIS/COFINS e ICMS/SP. São Paulo: IOB Thomson, 2005, p. 205.

${ }^{899}$ Art. $3^{\circ}, \S 9^{\circ}$ das Leis n ${ }^{\circ}$ s $10.637 / 02$ e $10.833 / 03$.

${ }^{900}$ Art. $3^{\circ}$ das Leis $n^{\circ}$ s $10.637 / 02$ e 10.833/03.

${ }^{901}$ Art. $3^{\circ}, \S 3^{\circ}$, I das Leis no ${ }^{\circ} 10.637 / 02$ e $10.833 / 03$.

${ }^{902}$ Art. $3^{\circ}, \S 3^{\circ}$, II das Leis $n^{\circ}$ s $10.637 / 02$ e $10.833 / 03$.
} 
estar-se-ia desequiparando as empresas nacionais, pois haveria um estímulo fiscal para a contratação de pessoas jurídicas forâneas.

Esclarece ainda a legislação ${ }^{903}$ que somente as despesas incorridas após o início da vigência da sistemática não-cumulativa do PIS/COFINS permitirão o desconto de créditos. A única exceção é a possibilidade de cálculo de créditos presumidos sobre o estoque de mercadorias existente na data de início de aplicação das regras da não-cumulatividade do PIS/COFINS ${ }^{904}$.

Vejamos, a seguir, as espécies de créditos do PIS/COFINS.

\subsubsection{OS CRÉDITOS DE BENS ADQUIRIDOS PARA REVENDA.}

Podem ser descontados créditos calculados à alíquota de $9,25 \%{ }^{905}$ sobre a aquisição de bens para revenda, exceto em relação a:

(a) produtos sujeitos à substituição tributária do PIS/COFINS;

(b) álcool para fins carburantes;

(c) produtos sujeitos à tributação monofásica do PIS/COFINS (álcool para qualquer finalidade quando revendido por produtor, importador ou distribuidor ${ }^{906}$; veículos automotores, cerveja, itens de perfumaria, dentre outros alcançados pela monofasia das aludidas contribuições ${ }^{907}$ ).

Os créditos serão calculados sobre o valor dos bens adquiridos no mês ${ }^{908}$.

Dúvida que assola os contribuintes é a inclusão dos valores de ICMS e IPI no custo de aquisição das mercadorias (base de cálculo dos créditos de PIS/COFINS).

No caso do ICMS, como este integra o preço do produto, seu valor deverá ser computado para fins de creditamento do PIS/COFINS. Trata-se de conseqüência do "cálculo por dentro" do referido imposto, que é destacado em nota fiscal apenas para fins de contro$1 \mathrm{e}^{909}$.

\footnotetext{
${ }^{903}$ Art. $3^{\circ}, \S 3^{\circ}$, III das Leis no ${ }^{\text {s }} 10.637 / 02$ e $10.833 / 03$.

${ }^{904}$ Item 13.4.4.12, infra.

$9057,6 \%$ relativos à COFINS e $1,65 \%$ do PIS.

${ }^{906}$ Art. $2^{\circ}, \S 1^{\circ}$-A das Leis $n^{\circ}$ s $10.637 / 02$ e $10.833 / 03$.

${ }^{907}$ Art. $2^{\mathrm{o}}, \S 1^{\mathrm{o}}$ das Leis $\mathrm{n}^{\mathrm{o}} \mathrm{s} 10.637 / 02$ e $10.833 / 03$.

${ }^{908}$ Art. $3^{\circ}, \S 1^{\circ}$, I das Leis n ${ }^{\text {o }}$ 10.637/02 e 10.833/03.

${ }^{909}$ Sobre o cálculo “por dentro” do ICMS, confira-se o Título II, Capítulo VI, Item 6.19.1.
} 
Já o IPI é calculado "por fora”. Seu valor é inclusive cobrado em apartado no documento fiscal (não sendo destacado "apenas para fins de controle", como no caso do ICMS).

Assim, no caso do IPI, duas situações são possíveis:

(a) quando o adquirente da mercadoria for contribuinte do IPI e conseguir repassar o ônus do imposto ao próximo agente da cadeia de produção, inexistirá direito ao creditamento de PIS/COFINS. Afinal, o IPI não integrará o valor do bem adquirido no mês;

(b) caso o adquirente seja contribuinte de facto do IPI, caracterizando-se como consumidor final para o referido imposto, a situação é distinta. Nesse caso, o ônus fiscal será efetivamente suportado pelo adquirente da mercadoria. Como o imposto não poderá ser juridicamente repassado ao próximo elo da cadeia produtiva, passará a integrar o valor pago pela mercadoria, gerando créditos de PIS/COFINS ${ }^{910}$.

\subsubsection{BENS E SERVIÇOS UTILIZADOS COMO INSUMOS.}

É permitido o crédito de PIS/COFINS sobre a compra de insumos para utilização ${ }^{911}$ :

(a) na produção de bens e serviços destinados à venda

(b) na prestação de serviços.

Para chegar-se ao montante do crédito, aplica-se a alíquota $(9,25 \%)$ sobre o valor dos insumos adquiridos no mês ${ }^{912}$.

Trata-se da primeira vez em que a legislação brasileira expressamente predica o crédito sobre insumos. Dada a sua amplitude, temos que o vocábulo foi corretamente empregado pela legislação do PIS/COFINS. Afinal, sendo as contribuições incidentes sobre a

${ }^{910}$ Nesse sentido dispõe a IN/RFB no 404/04:

"Art. $8^{\circ}$ Do valor apurado na forma do art. $7^{\circ}$, a pessoa jurídica pode descontar créditos, determinados mediante a aplicação da mesma alíquota, sobre os valores:

I - das aquisições efetuadas no mês:

a) de bens para revenda

(...)

$\S 3^{\circ}$. Para efeitos do disposto no inciso I, deve ser observado que:

I - o Imposto sobre Produtos Industrializados (IPI) incidente na aquisição, quando recuperável, não integra o valor do custo dos bens; e

II - o Imposto sobre Operações Relativas à Circulação de Mercadorias e sobre Prestação de Serviços de Transporte Interestadual e Intermunicipal e de Comunicação (ICMS) integra o valor do custo de aquisição de bens e serviços."

${ }^{911}$ Art. $3^{\circ}, \S 2^{\circ}$ das Leis $n^{\text {os }} 10.637 / 02$ e $10.833 / 03$.

${ }^{912}$ Art. $3^{\circ}, \S 1^{\text {o }}$, I das Leis n ${ }^{\text {o }}$ 10.637/02 e 10.833/03. 
receita, todo tipo de pessoa jurídica (industrial, comercial, prestadora de serviço, inter alii) se sujeita ao seu pagamento. Portanto, o crédito sobre os insumos reflete, com acerto, o extenso rol das atividades abarcadas pelo PIS/COFINS.

Com o intuito de regulamentar as Leis nº 10.637/02 e 10.833/03, a Receita Federal editou a Instrução Normativa $n^{\circ}$ 404, de 12 de março de 2004. Dentre as definições trazidas pela norma está a de insumo, que é inicialmente conceituado à luz da indústria, consistindo:

(a) nas matérias-primas;

(b) nos produtos intermediários;

(c) nos materiais de embalagem; e

(d) em quaisquer outros bens que sofram alterações, tais como o desgaste, o dano ou a perda de propriedades físicas ou químicas, em função de contato direto com o produto em industrialização.

Essas definições consistem em importante avanço relativamente à legislação do IPI e do ICMS. Afinal, ao se permitir, ao lado dos produtos intermediários, os créditos sobre quaisquer outros bens que se desgastem na produção, a norma em comento corretamente interpreta o conceito de insumo (que é lato). A nosso sentir, a IN/RFB nº 404/04 apenas pecou ao exigir que os outros bens se consumam "em função de contato direto com o produto em industrialização".

A ação direta sobre o produto em fabricação foi exigência posta, por primeira vez, pelo Parecer Normativo CST n ${ }^{\circ}$ 181/74 para caracterização dos produtos intermediários em matéria de IPI. Posteriormente, o Parecer Normativo CST nº 65/79 - também relativo ao IPI - buscou reforçar a necessidade do contato direto entre o produto final e o bem intermediário. Com essas medidas o Fisco intentou estatuir um novo requisito - não previsto nas normas do IPI - para fruição do crédito sobre bens intermediários. A restrição, sobre ser injurídica, leva a conclusões absurdas como a consideração de que a energia elétrica não é um produto intermediário (afinal, apesar de consumida no processo industrial, ela não entra em contato direto com o produto fabricado).

Ora, o conceito de insumo é econômico. Trata-se, em síntese, de toda e qualquer aquisição (input) destinada à consecução do objeto social da empresa. Apesar de inexistente na lei, a jurisprudência, em matéria de IPI e ICMS, trata o termo como sinônimo de matérias-primas e produtos intermediários. E o conceito de bem intermediário, como já visto para o IPI e para o ICMS, não exige contato físico direto com produto em fabricação. Ora, o sistema jurídico é uno. Para que a norma editada pela RFB seja coerente, o requisito do 
contato direto deveria ser abolido dos outros bens. Do contrário, os produtos intermediários, tal e qual interpretados pela jurisprudência, já abarcarão - com sobras - os materiais que a IN no 404/04 pretendeu indicar ao erigir a quarta categoria (quaisquer outros bens) de insumos geradores de crédito do PIS/COFINS.

Já no que tange à prestação de serviços, a IN/RFB nº 404/04 considera insumos:

(a) os bens aplicados ou consumidos na prestação de serviços, desde que não estejam incluídos no ativo imobilizado; e

(b) os serviços prestados por pessoa jurídica domiciliada no País, aplicados ou consumidos na prestação do serviço.

Trata-se de definição que serve de exemplo para os mais diversos Regulamentos do ICMS do País, que restringem sobremaneira os créditos dos prestadores de serviços de comunicação e de transporte interestadual e intermunicipal. De forma bastante sagaz, a RFB se apercebeu da distinção fundamental entre indústria e prestadores de serviços em matéria de tributos não-cumulativos. Portanto, o advento do PIS/COFINS não-cumulativos lança luzes sobre o tratamento tributário dos insumos aplicados na prestação de serviços, merecendo loas por essa razão.

\subsubsection{ENERGIA TÉRMICA E ELÉTRICA.}

Ab initio, cumpre notar que a energia consiste em insumo, na modalidade bem intermediário, sendo essencial às indústrias e a alguns prestadores de serviço. Portanto, ainda que não houvesse previsão expressa a esse respeito, o desconto de créditos de PIS/COFINS sobre o custo da energia utilizada no setor operacional das empresas já estaria assegurado pela existência dos créditos sobre insumos, vistos no item precedente.

De todo modo, o legislador houve por bem ampliar o crédito de PIS/COFINS sobre os dispêndios com energia, seja ela utilizada na área operacional ou administrativa das empresas. As leis do PIS/COFINS ${ }^{913}$ prevêem, sem qualquer ressalva, o direito ao creditamento sobre a energia elétrica ou térmica, inclusive sob a forma de vapor, consumida nos estabelecimentos das pessoas jurídicas. $\mathrm{O}$ crédito se calcula pela aplicação da alíquota de $9,25 \%$ sobre o valor da energia consumida no mês ${ }^{914}$.

\footnotetext{
${ }^{913}$ Art. $^{\circ}$, IX da Lei n ${ }^{\circ} 10.637 / 02$ e art. $3^{\circ}$, III da Lei no $10.833 / 03$.

${ }^{914}$ Art. $3^{\circ}, \S 1^{\circ}$, II das Leis no ${ }^{\circ}$ 10.637/02 e 10.833/03.
} 
A amplitude do direito concedido pela lei - que ampliou o crédito para além da energia-insumo utilizada na área operacional das empresas - tem sido confirmado pela Receita Federal do Brasil, em respostas a consultas de contribuintes ${ }^{915}$.

\subsubsection{ALUGUÉIS DE PRÉDIOS, MÁQUINAS E EQUIPAMENTOS.}

O aluguel de prédios, máquinas e equipamentos gera créditos do PIS/COFINS ${ }^{916}$, desde que ${ }^{917}$ :

(a) o locador seja pessoa jurídica ${ }^{918}$;

(b) os prédios, máquinas ou equipamentos sejam utilizados nas atividades da empresa (não importando, contudo, se o uso é para fins administrativos ou operacionais).

Baseando-se na norma em comento, a Receita Federal já reconheceu a possibilidade de se descontar créditos de PIS/COFINS:

(a) em relação a terreno alugado sobre o qual a empresa construiu edificação utilizada em suas atividades ${ }^{919}$;

(b) sobre a locação de veículos utilizados para transporte de engenheiros e funcionários de empresa de engenharia para execução de serviços nas obras contratadas ${ }^{920}$.

\subsubsection{LEASING (ARRENDAMENTO MERCANTIL).}

O pagamento das prestações de arrendamento mercantil celebrado com pessoa jurídica - exceto as optantes pelos SIMPLES - gera créditos de PIS/COFINS ${ }^{921}$, calculados sobre os valores pagos no mês ${ }^{922}$.

\footnotetext{
${ }^{915}$ Confira-se a Solução de Consulta n ${ }^{\circ}$ 95, da $8^{\text {a }}$ Região Fiscal (DOU de 05.06.2003): "ENERGIA ELÉTRICA CONSUMIDA NOS ESTABELECIMENTOS DA PESSOA JURÍDICA. A partir de $1^{\circ}$ de fevereiro de 2003 , pode ser descontado, do valor da contraprestação para o PIS/PASEP, crédito calculado em relação à energia elétrica consumida em todas as dependências do(s) estabelecimento(s) utilizado(s) pela pessoa jurídica em sua atividade." (PERES, Adriana Manni; ALMEIDA, Cristina Beatriz de Sousa; VIANA, Ivo Ribeiro; DINIZ, Marianita Ribeiro. Como Utilizar Créditos Fiscais do IPI, PIS/COFINS e ICMS/SP. São Paulo: IOB Thomson, 2005, p. 186).

${ }^{916}$ Calculados sobre os alugueres pagos no mês (art. $3^{\text {o }}, \S 1^{\text {o }}$, II das Leis $n^{\text {os }} 10.637 / 02$ e 10.833/03).

${ }^{917}$ Art. $3^{\circ}$, IV das Leis n's $10.637 / 02$ e 10.833/03.

${ }^{918}$ A exigência é justificada, pois a pessoa física não é contribuinte do PIS/COFINS.

${ }^{919}$ Solução de Consulta n ${ }^{\text {o }}$ 217/02, $9^{\text {a }}$ Região Fiscal, DOU 09.01.2003.

${ }^{920}$ Solução de Consulta no 206/04, $9^{\text {a }}$ Região Fiscal, DOU 10.08.2004.

${ }^{921}$ Art. $3^{\circ}$, V das Leis no ${ }^{\circ}$ 10.637/02 e 10.833/03.

${ }^{922}$ Art. $3^{\circ}, \S^{\circ}$, II das Leis $n^{\text {os }} 10.637 / 02$ e 10.833/03.
} 
Não há qualquer exigência quanto à utilização do bem arrendado nas atividades operacionais da empresa.

\subsubsection{BENS DO ATIVO IMOBILIZADO.}

É permitido o desconto de créditos sobre a depreciação das máquinas, equipamentos e outros bens integrantes do ativo imobilizado da empresa, que tenham sido adquiridos pela pessoa jurídica ou fabricados para locação a terceiros, quando forem utilizados ${ }^{923}$ :

(a) na produção de bens destinados à venda; ou

(b) na prestação de serviços.

Neste caso, somente serão considerados os ativos utilizados na produção de bens para comercialização ou na prestação de serviços.

O crédito será calculado mediante aplicação da alíquota regular $(9,25 \%)$ sobre o valor dos encargos de depreciação do bem incorridos no mês ${ }^{924}$. Opcionalmente, o contribuinte poderá se creditar ao longo de 4 (quatro) anos, à razão de 1/48 por mês, tomando-se como base o valor de aquisição do bem ${ }^{925}$.

\subsubsection{EDIFICAÇÕES E BENFEITORIAS EM IMÓVEIS.}

A depreciação das edificações e benfeitorias realizadas pela pessoa jurídica, em imóveis próprios ou de terceiros, também gera créditos de PIS/COFINS. Diferentemente do que a lei exige para os bens do ativo imobilizado, basta que as edificações e benfeitorias sejam realizadas em imóveis "utilizados nas atividades da empresa" para que haja o direito ao crédito. Assim, obras realizadas no setor administrativo, no estacionamento de veículos ou na área de lazer dos empregados possibilitarão, igualmente, o desconto dos créditos.

Para cálculo do montante a creditar, aplica-se a alíquota de 9,25\% sobre a depreciação ou amortização dos imóveis incorrida no mês ${ }^{926}$.

\subsubsection{BENS RECEBIDOS EM DEVOLUÇÃO.}

\footnotetext{
${ }^{923}$ Art. $3^{\circ}$, VI das Leis n's $10.637 / 02$ e 10.833/03.

${ }^{924}$ Art. $3^{\mathrm{o}}, \S 1^{\mathrm{o}}$, III das Leis no ${ }^{\mathrm{o}} 10.637 / 02$ e $10.833 / 03$.

${ }^{925}$ Art. $3^{\circ}, \S 14^{\circ} \mathrm{c} / \mathrm{c}$ art. 15 , II da Lei $\mathrm{n}^{\mathrm{o}} 10.833 / 03$.

${ }^{926}$ Art. $3^{\text {o }}, \S 1^{\text {o }}$, III das Leis no ${ }^{\text {s }} 10.637 / 02$ e $10.833 / 03$.
} 
Regra comum aos tributos não-cumulativos é a que predica o estorno dos débitos via lançamento de créditos - quando há devolução de produtos ao estabelecimento de origem.

A legislação do PIS/COFINS segue a regra geral, autorizando o desconto de créditos sobre bens recebidos em retorno. Erige, para tanto, dois requisitos ${ }^{927}$ :

(a) a receita da venda deve ter integrado o faturamento do mês da devolução ou de mês anterior;

(b) a receita deve ter sido tributada.

O crédito corresponderá à aplicação da alíquota sobre o valor dos bens devolvidos no mês ${ }^{928}$.

\subsubsection{ARMAZENAGEM DE MERCADORIA E FRETE NA OPERAÇÃO DE} VENDA.

Quando da aquisição de mercadorias para revenda o contribuinte faz jus ao crédito de PIS/COFINS, como já foi visto. O mesmo ocorre na compra de insumos empregados na produção de bens ou prestação de serviços.

Custos acessórios a essas atividades, como os decorrentes da armazenagem das mercadorias adquiridas ou produzidas (que aguardam venda ou revenda), assim como do frete na operação de venda, podem ser objeto de creditamento do PIS/COFINS. A única exigência feita pela legislação é que o ônus, no caso, seja suportado pelo contribuintevendedor $^{929}$.

\subsubsection{VALE-TRANSPORTE, VALE-ALIMENTAÇÃO OU REFEIÇÃO, UNI- FORMES E FARDAMENTOS FORNECIDOS POR EMPRESA PRESTADORA DE SERVIÇOS DE CONSERVAÇÃO, LIMPEZA E MANUTENÇÃO AOS SEUS EM- PREGADOS.}

A casuística da legislação do PIS/COFINS chega ao extremo quando assegura créditos sobre vale-transporte, vale-refeição ou vale-alimentação, fardamento ou uniforme fornecidos aos empregados por pessoa jurídica que explore as atividades de prestação de serviços de limpeza, conservação e manutenção.

\footnotetext{
${ }^{927}$ Art. $3^{\circ}$, VIII da Lei ${ }^{\circ} 10.833 / 03$.

${ }^{928}$ Art. $3^{\circ}, \S 1^{\text {o }}$, IV das Leis n ${ }^{\circ}$ s $10.637 / 02$ e $10.833 / 03$.

${ }^{929}$ Art. $3^{\circ}$, IX c/c art. 15, II da Lei no $10.833 / 03$.
} 
A norma é clara. Porém, a razão de sua positivação - carga tributária excessiva que a não-cumulatividade do PIS/COFINS gerou para os prestadores de serviço - merece maior atenção das autoridades ${ }^{930}$.

\subsubsection{IMÓVEIS PRONTOS E EM CONSTRUÇÃO: FORMA DE CREDITA- MENTO.}

A pessoa jurídica que adquirir imóvel para revenda, promover desmembramento ou loteamento de terrenos, incorporação imobiliária ou construção de prédio destinado a venda, fará jus a créditos de PIS/COFINS calculados sobre o custo da unidade construída ou em construção ${ }^{931}$. Neste último caso, tomar-se-á como custo o valor orçado total da obra em andamento ${ }^{932}$ (o crédito será presumido, ou melhor, antecipado).

O desconto efetivo do crédito é permitido a partir da venda da unidade imobiliária $^{933}$ e na proporção do auferimento da receita relativa à venda da unidade imobiliária ${ }^{934}$.

Tal como se prescreve para as mercadorias, no caso de devolução de unidades imobiliárias em decorrência de cancelamento do negócio deverá haver o estorno dos créditos $\operatorname{aproveitados}^{935}$.

\footnotetext{
${ }^{930}$ Confira-se, para tanto, o Item 13.13, infra.
}

${ }^{931}$ Art. $4^{\circ}$ da Lei ${ }^{\circ} 10.833 / 03$.

${ }^{932}$ Nesta hipótese, como a tributação se dará sobre um valor estimado, ao fim da obra serão necessários ajustes na tributação, para que esta recaia sobre a receita efetivamente auferida. A esse respeito, assim prescreve a Lei $\mathrm{n}^{\circ} 10.833 / 03$ :

"Art. $4^{\circ}$. (...).

$\S 5^{\circ}$. A pessoa jurídica que utilizar o crédito presumido de que trata este artigo determinará, na data da conclusão da obra ou melhoramento, a diferença entre o custo orçado e o efetivamente realizado, apurados na forma da legislação do imposto de renda, com os ajustes previstos no $\S 2^{\mathrm{o}}$ :

I - se o custo realizado for inferior ao custo orçado, em mais de 15\% (quinze por cento) deste, considerar-se-á como postergada a contribuição incidente sobre a diferença;

II - se o custo realizado for inferior ao custo orçado, em até $15 \%$ (quinze por cento) deste, a contribuição incidente sobre a diferença será devida a partir da data da conclusão, sem acréscimos legais; III - se o custo realizado for superior ao custo orçado, a pessoa jurídica terá direito ao crédito correspondente à diferença, no período de apuração em que ocorrer a conclusão, sem acréscimos.

$\S 6^{\circ}$. A diferença de custo a que se refere o $\S 5^{\circ}$ será, no período de apuração em que ocorrer a conclusão da obra ou melhoramento, adicionada ou subtraída, conforme o caso, no cálculo do crédito a ser descontado (...), devendo ainda, em relação à contribuição considerada postergada, de acordo com o inciso I, ser recolhidos os acréscimos referentes a juros de mora e multa, de mora ou de ofício, calculados na forma da legislação que rege a cobrança da contribuição não paga."

\footnotetext{
${ }^{933}$ Art. $4^{\circ}$, caput, in fine da Lei ${ }^{\circ} 10.833 / 03$.

${ }^{934}$ Art. $4^{\circ}, \S 3^{\circ}$ da Lei $n^{\circ} 10.833 / 03$.

${ }^{935}$ Art. $4^{\circ}, \S 9^{\circ}$ da Lei $n^{\circ} 10.833 / 03$.
} 


\subsubsection{CRÉDITOS PRESUMIDOS SOBRE O ESTOQUE DE ABERTURA.}

\subsection{AS PREVISÕES LEGAIS.}

Quando da instituição do PIS/COFINS não-cumulativos, a legislação concedeu um crédito presumido sobre os bens em estoque (mercadorias para revenda e insumos) na data de início da nova sistemática de cobrança das referidas contribuições ${ }^{936}$.

Tal crédito correspondeu à aplicação da alíquota do PIS/COFINS cumulativos $(3,65 \%)$ sobre o estoque de abertura. O aproveitamento se deu em 12 (doze) parcelas mensais, iguais e sucessivas ${ }^{937}$.

A regra consistia em norma de transição, cujo intuito era mitigar os impactos da alteração do regime de cobrança.

Todavia, mesmo atualmente é possível que empresas sujeitas ao PIS/COFINS cumulativos se tornem contribuintes do sistema forma não-cumulativa. Isso pode ocorrer nos casos de pessoas jurídicas tributadas com base no Lucro Presumido (ou optantes pelo SIMPLES) que passem a ser tributadas pelo Lucro Real. Elas passarão a recolher o PIS/COFINS à alíquota de $9,25 \%{ }^{938}$, fazendo jus, todavia, ao crédito sobre o estoque existente na data de mudança do regime de tributação do IRPJ ${ }^{939}$. Neste caso, o crédito presumido poderá ser aproveitado à vista, pois a lei não prevê a necessidade de parcelamento ao longo de 12 (doze) meses.

Em qualquer hipótese, os bens recebidos em devolução após a mudança do regime - porém anteriormente tributados pelo PIS/COFINS cumulativos - são considerados integrantes do estoque de abertura para fins de cálculo dos créditos em tela ${ }^{940}$.

Apesar de a legislação considerar os créditos sobre estoque de abertura como presumidos - ou seja, decorrentes de uma benesse da União - alguns contribuintes entenderam que haveria um direito, decorrente da não-cumulatividade, de se calcular o aludido crédito com base na alíquota de $9,25 \%$ (e não de $3,65 \%$, como predica a lei).

Vejamos esse tema a seguir, assim como a posição dos Tribunais sobre a matéria.

\footnotetext{
${ }^{936}$ Art. 12 da Lei no $10.833 / 03$.

${ }^{937}$ Art. $12, \S 2^{\circ}$ da Lei $n^{\circ} 10.833 / 03$.

938 O PIS/COFINS não-cumulativos são devidos pelas empresas sujeitas à apuração do IRPJ pelo Lucro Real, salvo se as suas atividades ou receitas estiverem excepcionadas do regime da não-cumulatividade.

${ }^{939}$ Art. $12, \S 5^{\circ} \mathrm{c} / \mathrm{c}$ art. 16, parágrafo único da Lei $\mathrm{n}^{\mathrm{o}} 10.833 / 03$.

${ }^{940}$ Art. $12^{\circ}, \S 6^{\circ} \mathrm{c} / \mathrm{c}$ art. 16, parágrafo único da Lei $\mathrm{n}^{\circ} 10.833 / 03$.
} 


\subsection{A DISCUSSÃO JUDICIAL ACERCA DA ALÍQUOTA APLICÁVEL AOS CRÉDITOS SOBRE O ESTOQUE DE ABERTURA.}

Como a alíquota do regime não-cumulativo gera débitos da ordem de 9,25\% sobre as receitas, alguns contribuintes passaram a sustentar que o crédito presumido sobre o estoque de abertura deveria incidir às mesmas alíquotas dos novos débitos de PIS/COFINS (e não a 3,65\%, como predica a legislação). O fundamento seria a não-cumulatividade: como o débito é calculado a 9,25\%, o crédito deveria sê-lo, inclusive sobre o estoque de abertu$r a$, nesse mesmo montante.

A nosso sentir, tal entendimento não merece prosperar. Afinal, o legislador é livre para, a partir de uma data previamente fixada, modificar o regime de tributação, transferindo o contribuinte do sistema cumulativo para o não-cumulativo. $\mathrm{O}$ direito ao desconto de créditos somente surgirá com as despesas incorridas após o início da vigência do novo regime. A data de cobrança das novas contribuições para o PIS/COFINS consiste em um marco jurídico, a partir do qual o contribuinte passa a se subsumir às novas regras. Contudo, as despesas incorridas no passado - dentre elas as que permitiram a formação do estoque de abertura - não geram, a priori, direito ao crédito.

Por essa razão as Leis $\mathrm{n}^{\circ} \mathrm{s}$ 10.637/02 e 10.833/03 classificaram como presumido o crédito sobre o estoque de abertura. De fato, essa é a sua natureza. Trata-se de um favor concedido pelo legislador no intuito de minimizar os impactos da alteração do regime de tributação, que importou na majoração de alíquotas do PIS/COFINS.

Não há direito adquirido contra a tributação. Se a lei mudou, o novel regime deve ser aplicado a partir da data de sua vigência inicial. Regras de transição como a sub examine são desejáveis, mas não consistem em direito subjetivo do contribuinte.

Nesse sendeiro, temos que não existe fundamento para se pleitear a aplicação de alíquotas superiores às previstas na lei $(3,65 \%)$ para cálculo do crédito presumido em comento.

Confirmando o posicionamento aqui esposado, o STJ decidiu ser ilegal a aplicação da alíquota de 7,6\% sobre os estoques que foram objeto de recolhimento de COFINS à alíquota de $3 \%{ }^{941}$. Por óbvio, as conclusões são extensíveis à contribuição para o PIS.

\footnotetext{
${ }^{941}$ Confira-se a ementa:

“TRIBUTÁRIO. RECURSO ESPECIAL. COFINS. NÃO-CUMULATIVIDADE. ESTOQUE EXISTENTE EM 01/02/2004. CREDITAMENTO SOB A ALÍQUOTA DE 7,6\%. DESCABIMENTO. AUTORIZAÇÃO LEGAL PARA A ALÍQUOTA DE 3\%. NECESSIDADE DE CORRESPONDÊNCIA COM O VALOR EFETIVAMENTE RECOLHIDO NA OPERAÇÃO ANTERIOR DE AQUISIÇÃO DOS BENS. RECURSO ESPECIAL CONHECIDO E NÃO-PROVIDO.
} 
O Supremo Tribunal Federal, a seu turno, está em vias de reconhecer a repercussão geral da matéria ${ }^{942}$. A nosso sentir, mesmo se houver análise do mérito pela Suprema Corte, a tendência é a manutenção do posicionamento pelo STJ, pelas razões vistas acima.

\subsection{O ESTOQUE DE ABERTURA DOS CONTRIBUINTES SUJEITOS À APURAÇÃo MONOFÁSICA DO PIS/COFINS QUE PASSARAM, A PARTIR DA

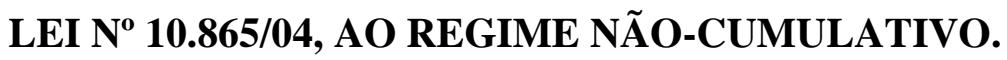

A partir de $1^{\circ}$ de agosto de 2004 , por força da Lei $n^{o} 10.865 / 04^{943}$, os contribuintes do PIS/COFINS-monofásico (produtores e importadores) passaram a se sujeitar ao regime não-cumulativo dessas contribuições ${ }^{944}$. Em razão disso, estendeu-se a eles o direito ao creditamento sobre o estoque de abertura ${ }^{945}$.

O crédito nesse caso foi calculado com alíquota de $9,25 \%{ }^{946}$, devendo também ser parcelado ao longo de doze meses ${ }^{947}$. Todavia, ressalvou a legislação que no caso de aquisições isentas, não-tributadas ou sujeitas à alíquota zero o contribuinte não faria jus ao crédito sub examine.

1. Trata-se de recurso especial fundado na alínea 'a' do permissivo constitucional interposto por
COPESUL - Cia Petroquímica do Sul em autos de mandado de segurança preventivo impetrado
contra o Delegado da Delegacia da Receita Federal de Porto Alegre contra acórdão que, em síntese,
vedou a aplicação de crédito presumido ao patamar de $7,6 \%$ sobre os estoques anteriores à vigência
da Lei $10.833 / 03$, em $1^{\circ}$ de fevereiro de 2004 .
2. O inconformismo, todavia, não merece acolhida, porquanto a inserção de novo procedimento para
o recolhimento da COFINS, de cumulatividade para não-cumulatividade, instituído pela Lei
10.833/03, não poderia resultar na obtenção de receita fiscal indevida. Com efeito, não é legalmente
possível que se permita que sobre os estoques que foram objeto de recolhimento de COFINS à alí-
quota de $3 \%$, aplica-se a alíquota de $7,6 \%$ para efeito de creditamento.
3. Recurso especial conhecido e não-provido." (STJ, Primeira Turma, REsp no $1.005 .598 / R S$, Rela-
tor Min. JOSÉ DELGADO, DJe 23.06 .2008 ). No mesmo sentido: STJ, Primeira Turma, REsp n 1.071.061/RS, Relator Min. FRANCISCO FALCÃO, DJe 01.10.2008.

${ }^{942}$ STF, Plenário Virtual, RE no 587.108/RS, Relator Min. RICARDO LEWANDOWSKI, reconhecimento da repercussão geral em discussão (já contando com 5 votos favoráveis, incluindo o Relator).

${ }^{943}$ Vale lembrar que os produtores/importadores de água, refrigerantes e cervejas somente passaram ao regime não-cumulativo a partir de $1^{\circ}$ de novembro de 2004, por força da Lei ${ }^{\circ} 10.925 / 04$. Dessarte, a data a ser considerada para fins de cálculo do crédito do estoque de abertura é a aqui referida e não a de $1^{\circ}$ de agosto de 2004.

${ }^{944}$ Sobre monofasia do PIS/COFINS e não-cumulatividade vide Item 13.4.3, supra.

${ }^{945}$ Art. $11, \S 5^{\circ}$ da Lei $n^{\circ} 10.637 / 02$ c/c art. $12, \S 7^{\circ}$ da Lei $n^{\circ} 10.833 / 03$.

${ }^{946}$ Art. $11, \S 7^{\circ}$ da Lei $n^{\circ} 10.637 / 02$ c/c art. $12, \S 9^{\circ}$ da Lei $n^{\circ} 10.833 / 03$.

${ }^{947}$ Art. $11, \S 2^{\circ}$ da Lei $n^{\text {o }} 10.637 / 02$ c/c art. $12, \S 2^{\circ}$ da Lei $n^{\circ} 10.833 / 03$. 


\subsubsection{O CRÉDITO PRESUMIDO NAS SUBCONTRATAÇÕES FEITAS PELAS EMPRESAS DE TRANSPORTE DE CARGAS.}

As empresas de transporte de cargas subsumem-se ao regime não-cumulativo do PIS/COFINS (ao contrário do setor de transporte de passageiros, que permaneceu sujeito à sistemática cumulativa das referidas contribuições).

É usual, no transporte de cargas, que haja subcontratação de outros transportadores para levar-se o bem até o seu destino final.

Se o subcontratado for pessoa jurídica, a contratante fará jus ao crédito sobre insumos, previsto no art. $3^{\circ}$, II das Leis n ${ }^{\circ}$ s $10.637 / 02$ e 10.833/03.

Entretanto, parte considerável dos subcontratados para transporte de cargas é de pessoas físicas (motoristas autônomos), cujos serviços não geram créditos de PIS/COFINS. Assim, dada a peculiaridade do setor, as empresas de transporte sofreram substancial majoração do valor devido a título de PIS/COFINS com a mudança para o regime nãocumulativo.

Em atenção a essa realidade, a legislação criou um crédito presumido a ser calculado sobre o valor pago às pessoas físicas subcontratadas por empresas de transporte de carga. Esse crédito equivale a $75 \%$ daquele ao qual a empresa faria jus se tivesse subcontratado uma pessoa jurídica para realização da mesma atividade ${ }^{948}$.

Outrossim, a lei ${ }^{949}$ dispõe que as subcontratações de pessoas jurídicas optantes pelo SIMPLES também geram créditos compensáveis de PIS/COFINS. Tendo em vista que o cômputo desses créditos já é autorizado pela legislação ${ }^{950}$, tal previsão seria, a nosso sentir, desnecessária $^{951}$.

\subsubsection{O ESTORNO DE CRÉDITOS.}

Tal como predicam as normas do $\operatorname{ICMS}^{952}$ e do $\operatorname{IPI}^{953}$, é devido o estorno de créditos do PIS/COFINS relativo a bens adquiridos para revenda ou utilizados como insumos na

\footnotetext{
${ }^{948}$ Art. $3^{\circ}, \S \S 19$, I e 20 c/c art. 15 , II da Lei $n^{\circ} 10.833 / 03$.

${ }^{949}$ Art. $3^{\circ}, \S 19$, II da Lei $n^{\circ} 10.833 / 03$.

${ }^{950}$ Vide Capítulo XV, Item 15.1.2.

${ }^{951}$ Por ser decorrente do regime normal da não-cumulatividade do PIS/COFINS, o crédito sobre os serviços prestados por empresas do SIMPLES não pode ser considerado presumido (ao contrário do crédito concedido às empresas de transporte de cargas pelas despesas incorridas com a subcontratação de motoristas autônomos).

${ }^{952}$ Art. 21, IV da LC no 87/96.
} 
prestação de serviços e na produção ou fabricação de bens ou produtos destinados à venda, que tenham sido furtados ou roubados, inutilizados ou deteriorados, destruídos em sinistro ou, ainda, empregados em outros produtos que tenham tido a mesma destinação ${ }^{954}$.

Trata-se de consectário lógico da exigência de duas operações tributadas em sequiência para que se faça jus ao crédito dos tributos não-cumulativos, já criticada anteriormente ${ }^{955}$ porém respaldada pela jurisprudência das Cortes Superiores.

\subsubsection{CRÉDITOS EXPRESSAMENTE VEDADOS PELA LEGISLAÇÃO.}

Apesar de os créditos de PIS/COFINS serem numerus clausus, o legislador houve por bem explicitar duas situações em que o creditamento é proibido ${ }^{956}$ :

(a) na aquisição de bens ou serviços não sujeitos ao pagamento da contribuição, inclusive no caso de isenção, esse último quando revendidos ou utilizados como insumo em produtos ou serviços sujeitos à alíquota zero, isentos ou não alcançados pela contribuição; e

(b) sobre as despesas com mão-de-obra paga a pessoa física.

O impedimento constante da alínea $a$ já foi tratado no item 13.4.1.5, supra, ao qual remetemos o leitor.

Já a vedação constante da alínea $b$ funda-se no fato de apenas as pessoas jurídicas serem contribuintes do PIS/COFINS, o que gera a não-incidência das contribuições sobre os valores recebidos pelas pessoas físicas. Tanto é que a mão-de-obra contratada de pessoa jurídica gera créditos, mediante autorização legal expressa ${ }^{957}$.

A impossibilidade de cômputo de créditos sobre o valor da mão-de-obra paga a pessoas físicas atinge em especial os prestadores de serviço. Estes foram os maiores penalizados pela novel sistemática de apuração do PIS/COFINS, consoante se verá no próximo tópico.

\footnotetext{
${ }^{953}$ RIPI/02, art. 193, IV.

${ }^{954}$ Art. $3^{\circ}, \S 13$ e art. 15 , II da Lei $n^{\circ} 10.833 / 03$.

${ }^{955}$ Confira-se: Título II, Capítulo VI, Item 6.12.

${ }^{956}$ Art. $3^{\circ}, \S 2^{\circ}$, I e II das Leis no s $10.637 / 02$ e 10.833/03.

${ }^{957}$ Predica o art. $3^{\circ}$, II das Leis n's 10.637/02 e 10.833/03 o cômputo de créditos sobre "serviços utilizados como insumo na prestação de serviços e na produção ou fabricação de bens ou produtos destinados à venda" - partindo da premissa, contudo, que tais serviços são prestados por pessoas jurídicas.
} 


\subsubsection{AS VICISSITUDES DA NÃO-CUMULATIVIDADE DO PIS/COFINS PARA OS PRESTADORES DE SERVIÇO: UMA PROPOSTA DE LEGE FERENDA. 13.4.8.1. A PROPOSTA.}

A experiência no Brasil e noutras plagas demonstra que a não-cumulatividade pode, se mal implementada, gerar um aumento intolerável da carga tributária sobre os prestadores de serviço. Afinal, o principal insumo desse segmento é a mão-de-obra de pessoas físicas (funcionários das empresas), que não gera créditos de PIS/COFINS por expressa vedação legal $^{958}$. Ademais, a curta extensão do ciclo produtivo dos prestadores de serviço - em comparação com o setor industrial, v.g. - restringe, sobremaneira, a possibilidade de aproveitamento e transferência de créditos escriturais.

As considerações se justificam pois a alíquota de um tributo não-cumulativo é sempre superior à do cumulativo ${ }^{959}$ (os abatimentos de créditos, típicos do regime nãocumulativo, geram a necessidade de elevação da alíquota para manter-se a arrecadação fiscal).

Dessarte, considerando-se o seu curto ciclo produtivo, a impossibilidade de desconto de créditos sobre despesas com mão-de-obra e a majoração de alíquota que a nãocumulatividade demanda, temos os prestadores de serviço submetidos à incidência nãocumulativa do PIS/COFINS deveriam sujeitar-se a alíquotas inferiores às atualmente vigentes.

A análise dos fatos a seguir corrobora o que se está a propor.

\subsubsection{A JUSTIFICATIVA.}

Quando a contribuição para o PIS e a COFINS foram sujeitadas à sistemática nãocumulativa, as alíquotas saltaram de $0,65 \%$ para $1,65 \%$ (PIS) e de $3 \%$ para $7,6 \%$ (COFINS).

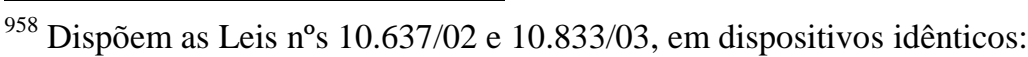

"Art. $3^{\circ}$. (...).

$\S 2^{\circ}$. Não dará direito a crédito o valor:

I - de mão-de-obra paga a pessoa física;"
}

959 Quando a Emenda Constitucional no 18/65 foi editada, o antigo Imposto sobre Vendas e Consignações (IVC), tributo cumulativo e incidente em cascata, foi substituído pelo ICM, criado à imagem dos impostos europeus sobre o valor acrescido. Apesar da salutar modificação, a alíquota passou de 5\% no IVC para $18 \%$ no ICM - ou seja, mais que triplicou. Todavia, por ser restrito às operações com circulação de mercadorias não abarcando os prestadores de serviço - o ICM, passado o impacto negativo inicial da mudança de alíquotas, revelou-se um imposto mais adequado à economia do que o avelhantado IVC. 
Como todos os segmentos da economia foram atingidos, aqueles que se utilizam de mão-de-obra própria com maior intensidade (como as empresas de call center, estabelecimentos de ensino, hospitais e prestadores de serviço em geral) pleitearam, junto ao Congresso Nacional, a sua exclusão do novel regime. Tal resultou em uma lista de mais de vinte exceções à sistemática não-cumulativa do PIS/COFINS.

$\mathrm{O}$ acolhimento do pleito pelos congressistas foi salutar, na medida em que os prestadores de serviço, quando sujeitados a alíquotas mais elevadas das contribuições, sofreram substancial aumento na tributação, dado o reduzido - ou nulo - número de créditos de PIS/COFINS aos quais fazem jus. Isso decorre, como já dito, da proibição do desconto de créditos sobre a mão-de-obra e da curta extensão do ciclo de prestação de serviço ${ }^{960}$.

Dessarte, a permanência no regime cumulativo do PIS/COFINS, antes de ser uma penalização, foi um benefício para o setor de serviços.

Contudo, somente os segmentos que se organizaram e conseguiram fazer valer sua vontade junto ao Congresso Nacional foram beneficiados pela medida. Diversas outras empresas do ramo - tais como as de conservação e limpeza - continuaram sujeitas à forma de apuração não-cumulativa ${ }^{961}$. Isso tem gerado desequilíbrio no mercado e conseqüente estímulo à sonegação.

O aumento da carga foi tão acima do razoável que alguns contribuintes ingressaram em juízo pleiteando a sua exclusão do sistema não-cumulativo do PIS/COFINS, fulcrados no princípio do não-confisco ${ }^{962}$.

${ }^{960}$ Confiram-se as conclusões de GOSSON, na mesma linha do que se está a expor:

"A aplicação da não-cumulatividade ao setor de prestação de serviços tem gerado conseqüências danosas, uma vez que a curta extensão do ciclo produtivo, a discriminação contra os salários e a elevação da alíquota implicaram em um considerável aumento da carga tributária." (GOSSON, Grace Christine de Oliveira. COFINS na Prestação de Serviços: Violação do Princípio Constitucional da Isonomia. PEIXOTO, Marcelo Magalhães e FISCHER, Octavio Campos (coord.). PIS-COFINS Questões Atuais e Polêmicas. São Paulo: Quartier Latin, 2005, p. 469).

${ }^{961}$ Vale aqui lembrar que apenas as empresas sujeitas ao cálculo do IRPJ com base no Lucro Real pagam PIS/COFINS não-cumulativo. A opção pelo Lucro Presumido ou Arbitrado, se e quando possível, leva o contribuinte de volta ao regime da cumulatividade das referidas contribuições sociais. O critério de discrímen é, a nosso sentir, inconstitucional (vide item 13.4.2.2). Entretanto, a matéria ainda não foi apreciada pelo $\mathrm{STF}$, pelo que se deve presumir a validade da lei para fins didáticos.

962 Confira-se o seguinte acórdão do Tribunal Regional Federal da $4^{\text {a }}$ Região, que deferiu o pleito de empresa prestadora de serviços:

“TRIBUTÁRIO. PIS. COFINS. REGIME NÃO-CUMULATIVO. PRESTADORA DE SERVIÇOS. DUPLICAÇÃO DA CARGA TRIBUTÁRIA. PRINCÍPIOS DA RAZOABILIDADE, DA CAPACIDADE CONTRIBUTIVA, DA ISONOMIA E DA LIVRE CONCORRÊNCIA.

(...)

No caso específico da Autora, que tem por objetivo social principal a prestação de serviços, a submissão ao novo regime não-cumulativo implicou um aumento de mais de $100 \%$ no ônus tributário 
Assim é que a diferenciação de alíquotas por categorias de contribuintes seria uma solução simples que restauraria a isonomia e o respeito à capacidade contributiva. De ressaltar, outrossim, que a diferenciação ora proposta é expressamente autorizada pela Constituição, em seu art. $195, \S 9^{\circ 963}$.

Por fim, ressalte-se que, em sua forma atual, a legislação do PIS/COFINS se assemelha a uma colcha de retalhos. Para além dos já useiros problemas das leis, como polissemia e obscurantismo, tem-se in casu um emaranhado de normas recortadas e coladas. Estas exigem muitas vezes que o intérprete recorra a três ou quatro leis distintas para aclarar o sentido de um único artigo. As inserções de novas regras a cada dia para adaptar as Leis $n^{\circ}$ s 10.637/02 e 10.833/03 às necessidades prementes dos prestadores de serviço ${ }^{964}$ que foram os mais atingidos pela mudança do regime - contribuem para o incremento da complexidade do PIS/COFINS e, conseqüentemente, dos custos envolvidos na apuração e controle desses tributos, o que é indesejável.

decorrente da incidência do PIS e da COFINS. Isso porque, como empresa prestadora de serviços, os créditos que pode apurar não são significativos.

O acréscimo do ônus tributário, não corresponde a aumento da capacidade contributiva da Autora, que não teve alteração.

(...)

Direito da autora de permanecer recolhendo as contribuições pelo regime comum (cumulativo) relativamente às suas receitas provindas da prestação de serviços e de compensar os valores pagos a maior." (TRF da $4^{a}$ Região, Segunda Turma, AC n 2004.71.08.010633-8/RS, Relator Des. Federal LEANDRO PAULSEN, DJ 26.04.2007).

${ }^{963}$ Reza a CR/88:

“Art. 195. (...).

$\S 9^{\circ}$. As contribuições sociais previstas no inciso I do caput deste artigo [sobre folha-de-salários, receita ou faturamento e lucro] poderão ter alíquotas ou bases de cálculo diferenciadas, em razão da atividade econômica, da utilização intensiva de mão-de-obra, do porte da empresa ou da condição estrutural do mercado de trabalho."

${ }^{964}$ Por exemplo, cite-se a Lei $\mathrm{n}^{\mathrm{o}} 11.898$, de 8 de janeiro de 2009 , que acresceu o inciso $\mathrm{X}$ ao art. $3^{\circ}$ da Lei $\mathrm{n}^{\mathrm{o}}$ 10.833/03 para assegurar aos prestadores de serviço de limpeza, conservação e manutenção o crédito sobre as despesas com vale-transporte, vale-refeição, vale-alimentação, fardamento e uniformes fornecidos aos seus empregados. A casuística seria até admissível em um decreto regulamentar, mas nunca na legislação de regência do tributo, como, indevidamente, ocorre na espécie. 


\section{PIS/COFINS INCIDENTES SOBRE A IMPORTAÇÃO DE BENS E SERVIÇOS.}

\subsection{A REGRA-MATRIZ DE INCIDÊNCIA DO PIS/COFINS-IMPORTAÇÃO.}

A Emenda Constitucional n ${ }^{\circ}$ 42, de 19 de dezembro de 2003, autorizou a criação de contribuições sociais e de intervenção no domínio econômico sobre a importação de bens e serviços do exterior. Trata-se de medida de isonomia. Afinal, se os bens e serviços produzidos no Brasil sujeitam-se ao pagamento dessas contribuições, nada mais justo que também submeter os produtos e serviços estrangeiros ao seu pagamento.

Assim, com esforço no art. $149, \S 2^{\circ}$ e no art. 195, IV da CR/88 (acrescidos pela aludida EC $n^{\circ} 42 / 03^{965}$ ) foi editada a Lei $n^{\circ} 10.865$, de 30 de abril de $2004^{966}$, instituidora da contribuição para o PIS e da COFINS sobre a importação de bens e serviços do exterior.

O fato gerador do PIS/COFINS-importação é:

(a) a entrada de bens estrangeiros no território nacional; ou

(b) o pagamento, o crédito, a entrega, o emprego ou a remessa de valores a residentes ou domiciliados no exterior como contraprestação por serviço prestado ${ }^{967}$.

No que se refere à importação de serviços, a lei exige, para a incidência do PIS/COFINS, que aqueles sejam executados no País. Se prestados no exterior, ao menos seu resultado deverá ser verificável no Brasil ${ }^{968}$. Assim, serviços contratados por empresas

${ }^{965} \mathrm{CR} / 88$, modificada pela EC n ${ }^{\circ}$ 42/03:

“Art. 149. Compete exclusivamente à União instituir contribuições sociais (...).

(...)

$\S 2^{\circ}$. As contribuições sociais e de intervenção no domínio econômico de que trata o caput deste artigo:

(...)

II - incidirão também sobre a importação de produtos estrangeiros ou serviços;

(...)

Art. 195. A seguridade social será financiada por toda a sociedade, de forma direta e indireta, nos termos da lei, mediante recursos provenientes dos orçamentos da União, dos Estados, do Distrito Federal e dos Municípios, e das seguintes contribuições sociais:

(...)

IV - do importador de bens ou serviços do exterior, ou de quem a lei a ele equiparar."

${ }^{966}$ A exposição de motivos constante da MP no 164/04, que originou a Lei no $10.865 / 04$, confirma a intenção do legislador de equiparar a tributação dos bens importados aos nacionais:

"As contribuições ora instituídas dão tratamento isonômico entre a tributação dos bens produzidos e serviços prestados no País, que sofrem a incidência da Contribuição para o PIS-Pasep e da Contribuição para o Financiamento da Seguridade Social (COFINS), e os bens e serviços importados de residentes ou domiciliados no exterior, que passam a ser tributados às mesmas alíquotas dessas contribuições."

${ }^{967}$ Art. $3^{\text {o }}$ da Lei $n^{\circ} 10.865 / 04$.

${ }^{968}$ É o que dispõe o art. $1^{\text {o }}, \S 1^{\text {o }}$, I e II da Lei $n^{\text {o }} 10.865 / 04$ : 
brasileiras que são prestados no exterior e têm resultados exclusivamente auferidos no estrangeiro refogem ao espectro de incidência das exações em comento.

Contribuinte na importação de bens é a pessoa física ou jurídica importadora ${ }^{969}$. Já no caso de contratação de serviços de empresas situadas no exterior, é contribuinte:

(a) em regra, a pessoa física ou jurídica contratante dos serviços ${ }^{970}$;

(b) excepcionalmente o beneficiário dos serviços, caso o contratante também seja residente ou domiciliado no exterior ${ }^{971}$.

A base de cálculo do PIS/COFINS sobre a importação de serviços é o valor efetivamente pago ao prestador estrangeiro, acrescido do ISSQN e das próprias contribuições $^{972}$.

Já a base imponível na importação de bens é, consoante determina a Constituição ${ }^{973}$, o valor aduaneiro. Este é definido pelo Regulamento Aduaneiro, com base no Acordo Geral de Tarifas e Comércio (GATT), como o valor da mercadoria importada $a$ crescido dos custos de transporte, carga, descarga, manuseio e seguro ${ }^{974}$. Contudo, a Lei $\mathrm{n}^{\circ}$ 10.865/04 dispôs que integram o valor aduaneiro o ICMS e o próprio PIS/COFINS-

“Art. $1^{\circ}$. Ficam instituídas a Contribuição para os Programas de Integração Social e de Formação do Patrimônio do Servidor Público incidente na Importação de Produtos Estrangeiros ou Serviços PIS/PASEP-Importação e a Contribuição Social para o Financiamento da Seguridade Social devida pelo Importador de Bens Estrangeiros ou Serviços do Exterior - COFINS-Importação, com base nos arts. 149, $\S 2^{\circ}$, inciso II, e 195, inciso IV, da Constituição Federal, observado o disposto no seu art. $195, \S 6^{\circ}$.

$\S 1^{\circ}$. Os serviços a que se refere o caput deste artigo são os provenientes do exterior prestados por pessoa física ou pessoa jurídica residente ou domiciliada no exterior, nas seguintes hipóteses:

I - executados no País; ou

II - executados no exterior, cujo resultado se verifique no País.”

969 A lei equipara ao importador o destinatário de remessa postal internacional indicado pelo remetente e o adquirente de mercadoria entrepostada (art. 5, I e parágrafo único da Lei nº 10.865/04).

${ }^{970}$ Art. $5^{\circ}$, II da Lei no $10.865 / 04$.

${ }^{971}$ Art. $^{\text {o }}$, III da Lei n ${ }^{\mathbf{o}} 10.865 / 04$.

${ }^{972}$ Art. $7^{\circ}$, II da Lei no $10.865 / 04$.

${ }^{973} \mathrm{CR} / 88$, art. $149, \S 2^{\circ}$, III, $a$.

${ }^{974}$ Prescreve o Regulamento Aduaneiro (Decreto $\mathrm{n}^{\circ}$ 6.759, de 5 de fevereiro de 2009):

"Art. 77. Integram o valor aduaneiro, independentemente do método de valoração utilizado:

I - o custo de transporte da mercadoria importada até o porto ou o aeroporto alfandegado de descarga ou o ponto de fronteira alfandegado onde devam ser cumpridas as formalidades de entrada no território aduaneiro;

II - os gastos relativos à carga, à descarga e ao manuseio, associados ao transporte da mercadoria importada, até a chegada aos locais referidos no inciso I; e III - o custo do seguro da mercadoria durante as operações referidas nos incisos I e II." 
importação. Ao fazê-lo, incorreu em inconstitucionalidade ${ }^{975}$, posto que o legislador tributário não pode modificar os conceitos de direito privado utilizados pela Lei Maior para fins de definição de competências tributárias ${ }^{976}$.

As alíquotas são de 7,6\% para a COFINS e de 1,65\% para o PIS, podendo, em casos especiais, ser diferenciadas em razão do produto $^{977}$.

975 A EC no $42 / 03$ não deixou ao arbítrio do legislador ordinário definir a base de cálculo do PIS/COFINS-
importação, enunciando-a rigidamente ao delimitar a sua hipótese de incidência. Assim, estabeleceu:
"Art. 149. Compete exclusivamente à União instituir contribuições sociais (...);
(...)
$\$ 2^{\circ}$. As contribuições sociais (...) de que trata o caput deste artigo:
(...)
III - poderão ter alíquotas:
a) ad valorem, tendo por base o faturamento, a receita bruta ou o valor da operação e, no caso de
importação, o valor aduaneiro;" (destaques nossos) Contudo, a base de cálculo do PIS/COFINS-importação extrapolou os limites estabelecidos pela CR/88 (modificada pela EC $\left.n^{\circ} 42 / 03\right)$, fazendo com que a incidência se desse sobre valores outros que não se incluem no conceito de "valor aduaneiro". Confira-se:

"Art. $7^{\circ}$. A base de cálculo será:

I - o valor aduaneiro, assim entendido, para os efeitos desta Lei, o valor que servir ou que serviria de base para o cálculo do imposto de importação, acrescido do valor do Imposto sobre Operações Relativas à Circulação de Mercadorias e sobre Prestação de Serviços de Transporte Interestadual e Intermunicipal e de Comunicação - ICMS incidente no desembaraço aduaneiro e do valor das próprias contribuições, na hipótese do inciso I do caput do art. $3^{\circ}$ desta Lei;" (destaques nossos)

Ao acrescentar à base de cálculo o valor do ICMS incidente no desembaraço aduaneiro, esse dispositivo legal também incluiu, nessa mesma base, de forma indireta, o valor do imposto de importação, do imposto sobre produtos industrializados, do IOF, de "quaisquer outros impostos, taxas, contribuições e despesas aduaneiras”, bem como das próprias contribuições para o PIS/PASEP e COFINS. Tal disposição vai além do conceito de valor aduaneiro (que encontra guarida no Acordo GATT de 1994, assinado pelo Brasil, assim como em nosso Regulamento Aduaneiro). O conceito vigente no ordenamento jurídico de valor aduaneiro inclui, além do custo da mercadoria importada, tão-somente as despesas com carga, descarga, manuseio e seguro (sem inclusão de quaisquer tributos).

IVES GANDRA e SOUZA confirmam o exposto, averbando que a incidência do PIS e da COFINS na importação "deveria se limitar ao valor aduaneiro e não, ao valor aduaneiro, acrescido do II, do PIS/PASEPImportação e da COFINS-Importação, e, principalmente, do ICMS". (MARTINS, Ives Gandra da Silva e SOUZA, Fátima Fernandes Rodrigues de. PIS/PASEP e COFINS Importação: Inconstitucionalidades. PEIXOTO, Marcelo Magalhães e FISCHER, Octavio Campos (coord.). PIS-COFINS - Questões Atuais e Polêmicas. São Paulo: Quartier Latin, 2005, p. 170).

Sobre o tema, confira-se também: MACHADO SEGUNDO, Hugo de Brito e MACHADO, Raquel Cavalcanti Ramos. Breves Anotações sobre a Incidência do PIS e da COFINS na Importação. GAUDÊNCIO, Samuel Carvalho e PEIXOTO, Marcelo Magalhães (coord). Fundamentos do PIS e da COFINS e o Regimento Jurídico da Não-Cumulatividade. São Paulo: MP Editora, 2007, pp. 260-65.

${ }^{976}$ Assim dispõe o Código Tributário Nacional:

"Art. 110. A lei tributária não pode alterar a definição, o conteúdo e o alcance de institutos, conceitos e formas de direito privado, utilizados, expressa ou implicitamente, pela Constituição Federal, pelas Constituições dos Estados, ou pelas Leis Orgânicas do Distrito Federal ou dos Municípios, para definir ou limitar competências tributárias."

${ }^{977}$ Para importação de determinados bens e serviços a Lei $\mathrm{n}^{\circ}$ 10.865/04 estabelece alíquotas diferenciadas. Certas máquinas e veículos, v.g., são tributadas a $2 \%$ pelo PIS e a 9,6\% pela COFINS (art. $2^{\circ}$, §3º; já a importação de determinados tipos de papel destinado à impressão de periódicos é gravada a 0,8\% pelo PIS e a $3,2 \%$ pela COFINS (art. $2^{\circ}, \S 10^{\circ}$ ). Alguns produtos, todavia, sujeitam-se à alíquota zero do PIS/COFINSimportação, como no caso dos livros importados (art. $\left.2^{\circ}, \S 12, \mathrm{XII}\right)$.

Outrossim, em dispositivo de duvidosa constitucionalidade (art. $2^{\circ}, \S 11$ ), a Lei ${ }^{\circ} 10.865 / 04$ permite ao Poder Executivo reduzir a zero e posteriormente restabelecer as alíquotas sobre certas categorias de produtos quí- 
Com espeque no art. $195, \S 12$ da $\mathrm{CR} / 88^{978}$, o legislador atribuiu às contribuições em comento a nota da não-cumulatividade. Assim, o PIS/COFINS-importação poderá ser abatido do PIS/COFINS devido pelo importador nas vendas internas ${ }^{979}$. Entretanto, somente poderá promover o referido abatimento o contribuinte-importador sujeito à nãocumulatividade do PIS/COFINS incidentes sobre a receita bruta ${ }^{980}$.

Com base no exposto, é possível bosquejar a regra-matriz de incidência da contribuição para o PIS e da COFINS incidentes na importação:

\begin{tabular}{|c|c|}
\hline Hipótese de incidência & Consequiência jurídica \\
\hline $\begin{array}{l}\text { Aspecto material: importação de bens e } \\
\text { contratação de serviços de empresas es- } \\
\text { trangeiras cujo resultado seja verificável } \\
\text { no Brasil; } \\
\text { Aspecto temporal: momento do desem- } \\
\text { baraço aduaneiro na importação de bens; } \\
\text { momento da remessa dos valores ao es- } \\
\text { trangeiro na importação de serviços; } \\
\text { Aspecto espacial: qualquer local do terri- } \\
\text { tório nacional; } \\
\text { Aspecto pessoal: importador do bem ou } \\
\text { serviço, pessoa física ou jurídica. }\end{array}$ & $\begin{array}{l}\text { Sujeito ativo: União Federal; } \\
\text { Sujeito passivo: pessoa física ou jurídica } \\
\text { importadora das mercadorias e serviços; } \\
\text { Base de cálculo: valor aduaneiro do bem } \\
\text { importado; valor pago pelo serviço a em- } \\
\text { presa estrangeira, acrescido do ISSQN e } \\
\text { das próprias contribuições; } \\
\text { Alíquota: } 1,65 \% \text { para o PIS e 7,6\% para a } \\
\text { COFINS em regra, podendo ser majorada } \\
\text { ou minorada para produtos específicos; } \\
\text { Quanto pagar: valor da alíquota aplicado } \\
\text { sobre a base de cálculo; } \\
\text { Como e onde pagar: previsto em normas } \\
\text { editadas pelo Poder Executivo Federal. }\end{array}$ \\
\hline
\end{tabular}

Esquadrinhadas as características essenciais do PIS/COFINS-importação, passemos agora ao deslinde das nuanças da não-cumulatividade aplicada a essas exações.

micos e farmacêuticos, assim como de produtos utilizados em hospitais, clínicas, laboratórios, consultórios médicos e odontológicos e campanhas de saúde promovidas pelo Poder Público.

${ }^{978} \mathrm{CR} / 88$, modificada pela $\mathrm{EC} \mathrm{n}^{\mathrm{o}}$ 42/03:

“Art. 195. (...).

$\S 12$. A lei definirá os setores de atividade econômica para os quais as contribuições incidentes na forma dos incisos (...) IV do caput [sobre importação de bens e serviços], serão não-cumulativas.”

979 As receitas decorrentes de vendas para o exterior são imunes de contribuições sociais (CR/88, art. 149, $\S 2^{\circ}$, I).

${ }^{980}$ Dessarte, para as empresas obrigadas ao pagamento do PIS/COFINS na sistemática cumulativa, as contribuições em comento são novos tributos que majoram a tributação das importações de bens e serviços. 


\subsection{A NÃO-CUMULATIVIDADE DO PIS/COFINS-IMPORTAÇÃO.}

\subsubsection{O ABATIMENTO DO PIS/COFINS-IMPORTAÇÃO SOMENTE É PERMI- TIDO AOS CONTRIBUINTES DO PIS/COFINS NÃO-CUMULATIVO: RESTRI- ÇÃO QUE FERE A ISONOMIA.}

Consoante prescreve a legislação, o desconto de créditos do PIS/COFINSimportação é limitado às pessoas jurídicas que apurem o PIS/COFINS no sistema nãocumulativo $^{981}$.

Trata-se de restrição compreensível ${ }^{982}$. Afinal, o sistema débito-crédito não se coaduna com o PIS/COFINS cumulativos. Portanto, não é possível a concessão de créditos escriturais para abatimento do valor devido dessas contribuições, sob pena de desnaturálas, transformando-as em não-cumulativas ${ }^{983}$.

Entretanto, o importador sujeito ao PIS/COFINS não-cumulativo terá vantagens tributárias sobre aquele que apura essas contribuições no sistema cumulativo. Um simples cálculo demonstra o fato. Tome-se uma importação de mercadoria no valor de $\mathrm{R} \$ 100,00$, que é revendida internamente por $\mathrm{R} \$ 200,00$. O importador submetido ao PIS/COFINS não-cumulativo pagará9 ${ }^{984}$ :

(a) $\mathrm{R} \$$ 9,25 a título de PIS/COFINS-importação;

(b) $\mathrm{R} \$ 18,50$ a título de PIS/COFINS não-cumulativo.

Todavia, como no caso é possível a compensação do PIS/COFINS com o PIS/COFINS-importação, o valor final a recolher ao erário será de $\mathrm{R} \$ 9,25$.

Já o importador sujeito ao PIS/COFINS cumulativo pagará:

(a) $\mathrm{R} \$ 9,25$ a título de PIS/COFINS-importação;

(b) $\mathrm{R} \$ 3,65$ a título de PIS/COFINS cumulativo.

Como não poderá descontar os créditos das contribuições recolhidas na importação, sua carga fiscal será de $\mathrm{R} \$ 12,90$.

\footnotetext{
${ }^{981}$ Art. 15 da Lei $\mathrm{n}^{\circ}$ 10.865/04.

${ }^{982}$ Vide Título II, Capítulo VII, Item 7.4.

${ }^{983}$ No mesmo sentido é a opinião de PEREIRA, para quem "a unificação do direito ao crédito contrariaria a sistemática dos tributos nas situações em que, por força da lei, são cumulativos". (PEREIRA, João Luis de Souza. PIS/COFINS na Importação: Necessidade de Alíquotas Variáveis em Homenagem ao Princípio da Capacidade Contributiva. GAUDÊNCIO, Samuel Carvalho e PEIXOTO, Marcelo Magalhães (coord). Fundamentos do PIS e da COFINS e o Regimento Jurídico da Não-Cumulatividade. São Paulo: MP Editora, 2007, p. 303).

${ }^{984} \mathrm{O}$ cálculo foi feito da forma mais simples possível, para melhor visualização. Não corresponde, portanto, ao valor exato do PIS/COFINS-importação devidos.
} 
Ora, não é possível conferir-se tratamento tributário diferenciado para empresas que se dedicam à mesma atividade, salvo se for para atender ao princípio da capacidade contributiva. Entretanto, recolher PIS/COFINS cumulativo ou não-cumulativo não pode ser invocado como fator de discrímen para identificação da capacidade contributiva. Pode-se, portanto, afirmar que a restrição ao creditamento do PIS/COFINS-importação às empresas do regime não-cumulativo do PIS/COFINS consiste em elemento desequiparador de contribuintes que se encontram em situações semelhantes ${ }^{985}$.

De fato, o PIS/COFINS-importação consiste, para os contribuintes sujeitos à apuração não-cumulativa do PIS/COFINS, em uma antecipação destas contribuições, que seriam devidas apenas quando do auferimento de receita pela venda interna das mercadorias importadas. Já para os contribuintes do sistema cumulativo do PIS/COFINS, trata-se de um custo adicional às importações, que refletirá no preço de seus produtos ou serviços oferecidos no mercado brasileiro ${ }^{986}$.

De mais a mais, considerando-se isoladamente o PIS/COFINS-importação, tem-se que o critério mais adequado para imposição de eventuais diferenças na tributação seria $o$ próprio bem ou serviço estrangeiro - e não a sujeição do importador a este ou aquele regime de tributação ${ }^{987}$.

985 IVES GANDRA e SOUZA perfilham o mesmo sendeiro:

“(...) Ao atribuir um crédito a algumas empresas e deixar de atribuir o mesmo tratamento a outras, que se encontram em situação equivalente - ou seja, àquelas que se vêem na circunstância de estarem obrigadas a importar bens e serviços para a consecução de suas atividades sociais - a Lei 10.865/04 viola a isonomia consagrada no art. 150, II da CF, que impede a lei de estabelecer tratamento desigual a contribuintes que se encontrem em situação equivalente." (MARTINS, Ives Gandra da Silva e SOUZA, Fátima Fernandes Rodrigues de. PIS/PASEP e COFINS Importação: Inconstitucionalidades. PEIXOTO, Marcelo Magalhães e FISCHER, Octavio Campos (coord.). PISCOFINS - Questões Atuais e Polêmicas. São Paulo: Quartier Latin, 2005, p. 165).

${ }^{986}$ BENÍCIO, Sérgio Gonini e BENÍCIO JR., Benedicto Celso. As Principais Questões do PIS e COFINS Não-Cumulativos e sua Incidência sobre as Importações. PEIXOTO, Marcelo Magalhães e FISCHER, Octavio Campos (coord.). PIS-COFINS - Questões Atuais e Polêmicas. São Paulo: Quartier Latin, 2005, p. 753.

${ }^{987}$ AMARAL e YAMASHITA predicam:

"O produto estrangeiro é o único critério válido de discriminação. Critérios de sujeição ou não ao regime não-cumulativo, tais como o ramo de atividade da empresa e até mesmo a receita bruta, não guardam nenhuma relação de pertinência com os produtos estrangeiros importados. Por isso, tais critérios não são inválidos como fatores de distinção entre os importadores sujeitos às novas contribuições em discussão." (AMARAL, Antonio Carlos Rodrigues do e YAMASHITA, Douglas. PIS e COFINS sobre a Importação de Produtos: Ilegalidades e Inconstitucionalidades. PEIXOTO, Marcelo Magalhães e FISCHER, Octavio Campos (coord.). PIS-COFINS - Questões Atuais e Polêmicas. São Paulo: Quartier Latin, 2005, p. 284).

E, ao cabo, arrematam:

"Aliás, ainda que o produto estrangeiro não fosse o único critério válido de diferenciação entre importadores, certo é que o art. 150, II da CF/88 expressamente veda a distinção em razão da ocupação profissional ou função exercida por contribuintes, critérios esses que, uma vez contidos na sujeição ou não ao regime não-cumulativo, implicam na discriminação do produto estrangeiro." (AMARAL, 
Patente, na hipótese, a afronta a isonomia, que leva à inconstitucionalidade da cobrança do PIS/COFINS-importação de contribuintes sujeitos à apuração cumulativa do PIS/COFINS.

A legitimação da cobrança das exações em comento, a nosso sentir, exigiria o estabelecimento de alíquotas reduzidas do PIS/COFINS-importação para os contribuintes do PIS/COFINS cumulativos. Tal medida poderia restaurar o primado da igualdade, atualmente quebrantado pela cobrança indiscriminada da alíquota de $9,25 \%$ na importação ${ }^{988}$.

\subsubsection{OS CRÉDITOS DO PIS/COFINS-IMPORTAÇÃO.}

\subsubsection{ORIGEM DOS CRÉDITOS.}

Apenas as importações de bens e serviços taxativamente previstas na lei permitirão ao contribuinte o cálculo de créditos para abatimento do PIS/COFINS não-cumulativo. São elas $^{989}$ :

(a) importação de bens para revenda;

(b) importação de bens e serviços utilizados como insumos ${ }^{990}$ :

(b.1) na prestação de serviços; e

(b.2) na produção ou fabricação de bens ou produtos destinados à venda;

(c) energia elétrica consumida nos estabelecimentos da pessoa jurídica;

(d) aluguéis e contraprestações de arrendamento mercantil de prédios, máquinas e equipamentos, embarcações e aeronaves, utilizados na atividade da empresa;

Antonio Carlos Rodrigues do e YAMASHITA, Douglas. PIS e COFINS sobre a Importação de Produtos: Ilegalidades e Inconstitucionalidades. PEIXOTO, Marcelo Magalhães e FISCHER, Octavio Campos (coord.). PIS-COFINS - Questões Atuais e Polêmicas. São Paulo: Quartier Latin, 2005, p. 284).

Pela imbricação do PIS/COFINS-importação com o PIS/COFINS não concordamos que o produto importado seja o "único" critério válido de discriminação. Entretanto, é certo que, dentre o critério da natureza do produto e o do regime tributário ao qual se sujeita o importador (este, o eleito pela Lei $\mathrm{n}^{\circ} 10.865 / 04$ ) o primeiro é mais adequado.

988 Conforme exposto no item 14.1, in fine, alguns produtos possuem alíquotas diferenciadas do PIS/COFINS-importação, expressamente previstas no art. $8^{\circ}$ da Lei no $10.865 / 04$.

${ }^{989}$ Art. 15 da Lei no $10.865 / 04$.

${ }^{990}$ Os direitos autorais pagos pela indústria fonográfica a artistas estrangeiros são expressamente considerados insumos pelo art. $15, \S 6^{\circ}$ da Lei $\mathrm{n}^{\circ}$ 10.865/04. Assim, desde que tenha havido pagamento do PIS/COFINS-importação sobre os direitos autorais, o importador que os utilize como insumos fará jus aos créditos das referidas contribuições. 
(e) máquinas, equipamentos e outros bens incorporados ao ativo imobilizado, adquiridos para locação a terceiros ou para utilização na produção de bens destinados à venda ou na prestação de serviços.

É pressuposto para os créditos em questão que tenha havido a incidência do PIS/COFINS na importação dos bens e serviços listados ${ }^{991}$.

Todas as hipóteses acima referidas também geram créditos aproveitáveis de PIS/COFINS. Portanto, as considerações que fizemos sobre cada uma delas no capítulo anterior - ao qual remetemos o leitor que deseje maiores informações sobre esses pontos se aplicam, in totum, ao PIS/COFINS-importação.

\subsubsection{O CÁlCULO DO CRÉDITO.}

O crédito é calculado pela aplicação da alíquota do PIS/COFINS não-cumulativo ${ }^{992}$ sobre a base de cálculo do PIS/COFINS-importação, acrescida do IPI quando este for integrante do valor de aquisição do produto (é dizer, quando o adquirente-importador não puder se recuperar, via lançamento a crédito em sua conta gráfica, do IPI que gravou o bem importado $)^{993}$.

No caso de importações de bens para o ativo imobilizado, o crédito será apurado mediante a aplicação da alíquota do PIS/COFINS não-cumulativos sobre o valor da depreciação ou amortização contabilizada a cada mês. Todavia, faculta-se ao contribuinte optar pelo creditamento em quatro anos, à razão de $1 / 48$ por mês, calculado sobre o valor de aquisição do ativo ${ }^{994}$.

\subsubsection{O TRANSPORTE DO SALDO CREDOR PARA OS PERÍODOS SUBSE- QUENTES.}

Como é regra nas exações não-cumulativas, o crédito de PIS/COFINS-importação não aproveitado em determinado mês poderá sê-lo nas competências subsequientes ${ }^{995}$.

\footnotetext{
${ }^{991}$ Art. $15, \S 1^{\circ}$ da Lei ${ }^{\circ} 10.865 / 04$.

${ }^{992}$ A alíquota é de $7,6 \%$ para a COFINS e 1,65\% para o PIS, totalizando os $9,25 \%$ aos quais nos referimos em diversas oportunidades.

${ }^{993}$ Art. $15, \S 3^{\circ}$ da Lei no $10.865 / 04$.

${ }^{994}$ Art. $15, \S \S 4^{\circ}$ e $5^{\circ}$ da Lei $n^{\circ} 10.865 / 04$.

${ }^{995}$ Art. $15, \S 2^{\circ}$ da Lei ${ }^{\circ} 10.865 / 04$.
} 


\subsubsection{IMPORTAÇÕES ISENTAS E DIREITO AO CRÉDITO.}

As importações efetuadas ao abrigo de isenção $^{996}$ do PIS/COFINS-importação geram créditos para o contribuinte. As únicas ressalvas feitas pela legislação referem-se:

(a) à importação de produtos ou insumos isentos para serem revendidos ou utilizados na produção de bens sujeitos à alíquota zero, isentos ou não-tributados ${ }^{997}$;

(b) à importação de bens sob o regime aduaneiro especial de drawback, na modalidade de isenção ${ }^{998}$.

\subsubsection{IMPORTAÇÕES POR CONTA E ORDEM DE TERCEIROS.}

Nas importações por conta e ordem de terceiros, os créditos do PIS/COFINSimportação serão aproveitados pelo encomendante e não pela empresa importadora ${ }^{999}$.

Nesse tipo de operação, a importadora promove o despacho aduaneiro em nome próprio. Todavia, as mercadorias estrangeiras são, em verdade, adquiridas pela "encomendante", que é a importadora de facto ${ }^{1000}$. Assim, a importadora por conta e ordem de tercei-

${ }^{996}$ O art. $9^{\circ}$ da Lei n ${ }^{\circ}$ 10.865/04 predicam os casos de isenção do PIS/COFINS-importação:

“Art. $9^{\circ}$. São isentas das contribuições de que trata o art. $1^{\circ}$ desta Lei:

I - as importações realizadas:

a) pela União, Estados, Distrito Federal e Municípios, suas autarquias e fundações instituídas e mantidas pelo poder público;

b) pelas Missões Diplomáticas e Repartições Consulares de caráter permanente e pelos respectivos integrantes;

c) pelas representações de organismos internacionais de caráter permanente, inclusive os de âmbito regional, dos quais o Brasil seja membro, e pelos respectivos integrantes;

II - as hipóteses de:

a) amostras e remessas postais internacionais, sem valor comercial;

b) remessas postais e encomendas aéreas internacionais, destinadas a pessoa física;

c) bagagem de viajantes procedentes do exterior e bens importados a que se apliquem os regimes de tributação simplificada ou especial;

d) bens adquiridos em loja franca no País;

e) bens trazidos do exterior, no comércio característico das cidades situadas nas fronteiras terrestres, destinados à subsistência da unidade familiar de residentes nas cidades fronteiriças brasileiras;

f) bens importados sob o regime aduaneiro especial de drawback, na modalidade de isenção;

g) objetos de arte, classificados nas posições 97.01, 97.02, 97.03 e 97.06 da NCM, recebidos em doação, por museus instituídos e mantidos pelo poder público ou por outras entidades culturais reconhecidas como de utilidade pública; e

h) máquinas, equipamentos, aparelhos e instrumentos, e suas partes e peças de reposição, acessórios, matérias-primas e produtos intermediários, importados por instituições científicas e tecnológicas e por cientistas e pesquisadores, conforme o disposto na Lei n ${ }^{\circ} 8.010$, de 29 de março de 1990."

${ }^{997}$ Art. $16, \S 1^{\circ}$ da Lei no $10.865 / 04$.

${ }^{998}$ Art. $16, \S 2^{\circ}$ c/c art. $9^{\circ}$, II, $f$ da Lei n ${ }^{\circ} 10.865 / 04$.

${ }^{999}$ Art. 18 da Lei no $10.865 / 04$.

${ }^{1000}$ Art. $1^{\circ}$ da IN SRF n ${ }^{\text {o }} 225 / 02$ c/c art. $12, \S 1^{\circ}$, I, da IN SRF n ${ }^{\circ} 247 / 02$. 
ro, embora possa cuidar de todos os detalhes da importação - até mesmo da negociação comercial e, eventualmente, da realização de pagamentos ${ }^{1001}$ - age sempre como mandatária da adquirente, que dispõe da capacidade econômica e dos recursos para viabilizar a transação internacional.

Dessarte, a regra que prescreve o aproveitamento dos créditos de PIS/COFINSimportação pela "encomendante" na importação por conta e ordem de terceiros é salutar, pois a importadora, em que pese possuir amplos poderes, nunca age em nome próprio nessa hipótese. Trata-se de mera prestadora de serviços, no mais das vezes sem capacidade econômica para suportar a aquisição realizada pelo adquirente de facto.

Fazemos apenas um reparo na terminologia eleita pelo legislador do PIS/COFINSimportação: melhor teria sido referir-se a adquirente no lugar de encomendante para definição do titular dos créditos quando da importação por conta e ordem de terceiro. Nesse tipo de operação, têm-se três partes envolvidas: o adquirente (e não o encomendante), o importador e o alienante. $\mathrm{O}$ termo encomendante remete à importação por encomenda, que não se confunde com a importação por conta e ordem e não é abrigada pela disposição em comento.

Nas importações por encomenda, os partícipes são: o encomendante predetermina$d o$, o importador e o alienante. A aquisição do bem no estrangeiro é feita diretamente pelo importador, que deve possuir disponibilidade financeira para tanto (ao contrário da importação por conta e ordem de terceiro). Quando o bem adentra em território nacional, o importador o revende ao encomendante predeterminado. Assim, para todos os efeitos legais, o importador é efetivamente aquele que traz as mercadorias do exterior. Portanto, na hipótese de importação por encomenda, aplica-se a regra geral da Lei ${ }^{\circ} 10.865 / 04$ : os créditos de PIS/COFINS são de titularidade da pessoa jurídica que promove a importação.

\footnotetext{
${ }^{1001} \mathrm{O}$ pagamento da importação por conta e ordem pode ser feito pela encomendante ou pela importadora, conforme opção facultada pelo Regulamento do Mercado de Câmbio e Capitais Internacionais (Título 1, Capítulo 12, Seção 2) do Banco Central do Brasil. De todo modo, mesmo quando o pagamento for feito pela importadora ele o será, em regra, com dinheiro da encomendante, que é a verdadeira adquirente e detentora da capacidade financeira para realização do negócio.
} 


\section{TEMAS COMUNS À NÃO-CUMULATIVIDADE DO IPI, ICMS E PIS/COFINS.}

\subsection{OPERAÇÕES COM EMPRESAS SUJEITAS AO SIMPLES NACIONAL.}

15.1.1. A REGRA GERAL: VEDAÇÃO DE APROVEITAMENTO E TRANSFERÊNCIA DE CRÉDITOS PELAS EMPRESAS OPTANTES DO SIMPLES.

O "Regime Especial Unificado de Arrecadação de Tributos e Contribuições devidos pelas Microempresas e Empresas de Pequeno Porte" (SIMPLES Nacional) consiste em um método alternativo de pagamento de tributos federais (IRPJ, CSLL, IPI, PIS/COFINS e Contribuição Previdenciária Patronal), do ICMS e do ISSQN.

O regime em vigor foi instituído pela Lei Complementar $n^{\circ} 123$, de 14 de dezembro de $2006^{1002}$. Seu antecessor era o SIMPLES Federal, veiculado pela revogada Lei $\mathrm{n}^{\circ}$ 9.317/96. A diferença fundamental entre o SIMPLES Federal e o Nacional reside na amplitude que este possui, posto que abarca, além dos tributos federais, o ICMS e o ISSQN ${ }^{1003}$.

Podem optar pelo SIMPLES Nacional as microempresas ou empresas de pequeno porte ${ }^{1004}$ que atendam às condições estipuladas pela LC n ${ }^{\circ} 123 / 06^{1005}$. Feita a opção, o con-

${ }^{1002}$ Por se tratar de regime especial que agrega impostos de competência dos Estados (ICMS) e dos Municípios (ISSQN), foi necessária a inserção de cláusula autorizativa na Constituição de 1988, por meio da EC $n^{\circ}$ 42/03, permitindo a criação dessa novel sistemática pelo legislador complementar:

"Art. 146. Cabe à lei complementar:

(...)

III - estabelecer normas gerais em matéria de legislação tributária, especialmente sobre:

d) definição de tratamento diferenciado e favorecido para as microempresas e para as empresas de pequeno porte, inclusive regimes especiais ou simplificados no caso do imposto previsto no art. 155, II, das contribuições previstas no art. 195, I e $\S \S 12$ e 13, e da contribuição a que se refere o art. 239. Parágrafo único. A lei complementar de que trata o inciso III, $d$, também poderá instituir um regime único de arrecadação dos impostos e contribuições da União, dos Estados, do Distrito Federal e dos Municípios, observado que:

I - será opcional para o contribuinte;

II - poderão ser estabelecidas condições de enquadramento diferenciadas por Estado;

III - o recolhimento será unificado e centralizado e a distribuição da parcela de recursos pertencentes aos respectivos entes federados será imediata, vedada qualquer retenção ou condicionamento;

IV - a arrecadação, a fiscalização e a cobrança poderão ser compartilhadas pelos entes federados, adotado cadastro nacional único de contribuintes."

${ }^{1003}$ Sob a égide da Lei no 9.317/96 era possível que o ICMS e o ISSQN fossem incluídos no SIMPLES Federal. Todavia, tal medida dependia da autorização dos Estados e dos Municípios, por meio de convênios firmados com a União Federal. Dadas as dificuldades ínsitas às negociações políticas, o SIMPLES Federal acabou fazendo jus ao nome e se restringindo, na maior parte dos casos, apenas aos tributos de competência da própria União.

${ }^{1004}$ A LC n ${ }^{\text {o }}$ 123/06 define a microempresa como o empresário, a pessoa jurídica, ou a ela equiparada, que aufira, em cada ano-calendário, receita bruta igual ou inferior a $\mathrm{R} \$ 240.000,00$ (duzentos e quarenta mil reais). Já a empresa de pequeno porte é conceituada como o empresário, a pessoa jurídica, ou a ela equiparada, que aufira, em cada ano-calendário, receita bruta superior a $\mathrm{R} \$ 240.000,00$ (duzentos e quarenta mil reais) e igual ou inferior a $\mathrm{R} \$ 2.400 .000,00$ (dois milhões e quatrocentos mil reais). 
tribuinte passa a se sujeitar às regras do sistema favorecido de tributação. Dentre essas, interessam-nos as insculpidas no art. 23 da $\operatorname{LC~}^{\circ}$ 123/06, que assim dispõe em seu caput:

"Art. 23. As microempresas e as empresas de pequeno porte optantes pelo SIMPLES Nacional não farão jus à apropriação nem transferirão créditos relativos a impostos ou contribuições abrangidos pelo SIMPLES Nacional."

A regra já existia no vetusto SIMPLES Federal, que vedava a apropriação ou transferência de créditos relativos ao IPI e ao ICMS ${ }^{1006}$ pela empresa optante. Atualmente, como se infere do caput do art. 23 da LC n 123/06, a proibição se estende também aos créditos das contribuições abrangidas pelo SIMPLES Nacional.

A norma foi duramente combatida quando de sua edição, principalmente na parte em que proíbe a transferência de créditos de impostos e contribuições para os terceiros que celebram negócios com as empresas optantes pelo SIMPLES. Com razão as críticas.

A vedação de transferência de créditos a terceiros quebranta a não-cumulatividade, ferindo a norma constitucional assecuratória do crédito do IPI, do ICMS e até mesmo do PIS/COFINS ${ }^{1007}$. Afinal, essas exações, quando devidas, são efetivamente pagas pelas empresas no âmbito do SIMPLES. Apenas o valor recolhido é menor. Sendo assim, a opção pelo regime especial de tributação não pode atingir os adquirentes de produtos e serviços de empresas do SIMPLES. Negar-se a estas o direito ao aproveitamento de créditos sobre suas próprias aquisições é perfeitamente admissível. Afinal, trata-se de um regime de tributação opcional, ao qual a empresa pode ou não aderir. Todavia, impedir-se o desconto dos créditos ${ }^{1008}$ pelos terceiros que adquirem bens e serviços das empresas do SIMPLES consiste em patente violação à não-cumulatividade tributária ${ }^{1009}$.

\footnotetext{
1005 Algumas atividades, tais como as dos bancos de investimentos, assim como determinadas formas de pessoas jurídicas, como as sociedades por ações, não são admitidas no SIMPLES Nacional.

1006 Vale lembrar que a inclusão do ICMS no SIMPLES Federal (Lei no 9.317/96) não era automática. Dependia de convênio entre a União e o Estado (art. $4^{\circ}, \S 4^{\circ} \mathrm{c} / \mathrm{c}$ art. $5^{\circ}, \S 5^{\circ}$ da Lei $\mathrm{n}^{\circ}$ 9.317/96). Assim, a vedação de transferência e apropriação de créditos de ICMS por empresa optante do SIMPLES Federal somente se aplicava quando o ICMS estive incluído no sistema favorecido de tributação.
}

${ }^{1007}$ Dentro do núcleo mínimo da não-cumulatividade se insere o direito de creditamento do tributo pago na etapa anterior.

${ }^{1008}$ No caso do IPI e do ICMS o crédito equivale ao montante do imposto pago na etapa anterior. Já no caso do PIS/COFINS o crédito é calculado sobre as despesas incorridas pelo próprio contribuinte no período de apuração.

1009 O mesmo entendimento é partilhado por MARINS e BERTOLDI:

"Ainda que se admita que o contribuinte optante pelo SIMPLES Nacional possa, facultativamente, aceitar a cobrança em regime especial cumulativo por se afigurar mais vantajoso que o geral, não cumulativo, essa opção não pode contaminar o direito ao creditamento do contribuinte não-optante." 
Assim, pode-se afirmar que o artigo analisado:

(a) é constitucional ao restringir o direito à apropriação dos créditos de impostos e contribuições pela empresa optante do SIMPLES Nacional. Afinal, trata-se de regime facultativo, razão pela qual a saída da sistemática débito-crédito somente ocorrerá mediante opção do contribuinte;

(b) fere a não-cumulatividade do IPI, do ICMS e do PIS/COFINS quando veda a transferência dos créditos decorrentes do ICMS e do IPI aos terceiros adquirentes de bens e serviços das empresas do SIMPLES. Aqueles ficam também proibidos, pelo dispositivo, de calcular créditos de PIS/COFINS sobre as despesas incorridas na aquisição de produtos e serviços de contribuintes optantes pelo SIMPLES.

As vedações em tela afetaram sobremaneira as empresas optantes, que perderam importante diferencial competitivo nas vendas para contribuintes sujeitos à sistemática débito-crédito do IPI, ICMS e PIS/COFINS.

\subsubsection{OS CRÉDITOS DE PIS/COFINS.}

Com o intuito de solucionar o problema da vedação de transferência de créditos, ao menos no que tange ao PIS/COFINS, a Receita Federal editou o Ato Declaratório Interpretativo $\mathrm{n}^{\mathrm{o}} 15$, de 26 de setembro de 2007. Por meio desse, as empresas adquirentes de produtos e serviços de contribuintes optantes pelo SIMPLES passaram a fazer jus, novamente, ao cálculo de créditos (à alíquota de 9,25\%) sobre as despesas incorridas com tais aquisições.

Louvável a atitude da Receita Federal, restabelecendo a isonomia concorrencial em matéria de PIS/COFINS para as empresas optantes pelo SIMPLES.

\subsubsection{A NÃO-CUMULATIVIDADE DO ICMS.}

No que tange ao ICMS, o próprio legislador se encarregou de mitigar os efeitos cumulativos trazidos pelo art. 23 da LC n 123/06. A Lei Complementar no 128/08 permitiu, a partir de $1^{\circ}$ de janeiro de 2009 , que as empresas optantes pelo SIMPLES transferissem créditos de ICMS a alguns de seus adquirentes não-optantes, destacando o valor do imposto em suas notas fiscais. Para tanto foram acrescidos os $\S \S 1^{\circ}$ a $6^{\circ}$ ao art. 23 da $\mathrm{LC}^{\circ}$ $123 / 06$.

(MARINS, James e BERTOLDI, Marcelo M. Simples Nacional - Estatuto da Microempresa e da

Empresa de Pequeno Porte Comentado. São Paulo: Revista dos Tribunais, 2007, p. 155). 
Com a modificação legal, o creditamento do ICMS passou ser permitido às pessoas jurídicas que adquirirem mercadorias de empresas do SIMPLES para fins de comercialização ou industrialização. Apesar de ter representado um avanço, a norma olvidou-se dos serviços gravados pelo ICMS. Afinal, não há garantia de crédito na aquisição de serviços tributados pelo ICMS das empresas optantes. Tampouco se autoriza o creditamento quando mercadorias são compradas para permitir a prestação de serviços gravados pelo imposto estadual $^{1010}$.

O valor do crédito de ICMS transferido ao adquirente será o efetivamente pago pelo contribuinte do SIMPLES, devendo ser destacado em documento fiscal ${ }^{1011}$. Nesse caso, por óbvio, haverá uma substancial diferença entre os créditos de ICMS oriundos de aquisições de empresas não-optantes (dado que a alíquota do imposto gira em torno de 18\%) e de pessoas jurídicas optantes pelo SIMPLES (que pagam entre 1\% e 4\% de ICMS sobre o valor da mercadoria).

A novel LC no 128/08 também permitiu aos Estados e ao Distrito Federal autorizarem, por meio de deliberação conjunta, o desconto de créditos pela própria empresa optante quando da aquisição de insumos para a industrialização ${ }^{1012}$. Os créditos equivaleriam ao exato montante de ICMS destacado nas notas fiscais de compra de produtos pelas empresas do SIMPLES. Todavia, até o momento essa benesse não foi concedida pelos entes federados.

Não poderão transferir créditos do ICMS as empresas do SIMPLES que ${ }^{1013}$ :

(a) estiverem sujeitas ao pagamento do imposto em valores fixos mensais;

(b) forem isentas do ICMS; e

(c) fizerem a opção pelo pagamento desse imposto com base no regime de caixa (após o auferimento dos valores que lhe são devidos por seus clientes) em detrimento do

$\overline{1010}$ Confira-se a LC n ${ }^{\circ} 123 / 06$, modificada pela LC n ${ }^{\circ} 128 / 08$ :

"Art. 23. (...).

$\S 1^{\circ}$. As pessoas jurídicas e aquelas a elas equiparadas pela legislação tributária não optantes pelo SIMPLES Nacional terão direito a crédito correspondente ao ICMS incidente sobre as suas aquisições de mercadorias de microempresa ou empresa de pequeno porte optante pelo SIMPLES Nacional, desde que destinadas à comercialização ou industrialização e observado, como limite, o ICMS efetivamente devido pelas optantes pelo SIMPLES Nacional em relação a essas aquisições.”

${ }^{1011}$ Conforme estipulado pelo Comitê Gestor do SIMPLES Nacional por meio da Resolução no 53 , de 22 de dezembro de 2008, o valor do crédito deverá ser inserido pela empresa optante no campo "informações complementares" da nota fiscal.

${ }^{1012}$ Art. $23, \S 5^{\circ}$ da LC no $123 / 06$, modificada pela $\operatorname{LC~n}{ }^{\circ} 128 / 08$.

${ }^{1013}$ Art. $23, \S 4^{\circ}$ da $\operatorname{LC~n}^{\circ} 123 / 06$, modificada pela $\operatorname{LC} \mathrm{n}^{\mathrm{o}} 128 / 08$. 
recolhimento do ICMS por competência (no qual o débito é escriturado no momento de emissão da nota fiscal).

De qualquer modo, ainda que a LC $\mathrm{n}^{\circ}$ 128/08 tenha mitigado a inconstitucional cumulatividade imprimida ao ICMS pelo art. 23 da LC n ${ }^{\circ}$ 123/06, a solução não adveio por completo. Foram ignorados os prestadores de serviços tributados pelo ICMS, que não adquirem mercadorias para comercialização ou industrialização, mas sim para utilização na prestação do serviço de comunicação ou de transporte interestadual e intermunicipal. Ademais, a aquisição de serviços tributados pelo ICMS das empresas do SIMPLES não gera créditos para os não-optantes. Apenas a compra de mercadorias das pessoas jurídicas optantes foi contemplada pela novel legislação.

De todo modo, temos que a restrição inserta no caput do art. 23 à transferência de créditos para empresas não-optantes que celebrem negócios jurídicos com contribuintes do SIMPLES é inconstitucional. Como já dito, vedar-se a apropriação de créditos pela pessoa jurídica optante é uma faculdade da lei, pois o regime não é obrigatório. Contudo, os terceiros que comerciam com as empresas do SIMPLES não podem ter seu direito ao crédito atingido. A vedação atenta contra a não-cumulatividade tributária.

\subsubsection{A PROBLEMÁTICA DO IPI.}

Neste ponto, vale lembrar que o art. 23 da LC n ${ }^{\circ}$ 123/06 manteve (e ampliou, para as contribuições) a regra vigente desde a Lei $\mathrm{n}^{\circ}$ 9.317/96, que proibia a apropriação e a transferência de créditos de IPI e ICMS ${ }^{1014}$ por empresa inscrita no SIMPLES.

Sob o pálio da legislação pretérita, entendeu a Corte Superior de Justiça pela legitimidade da restrição ao aproveitamento de créditos do IPI pelas empresas optantes ${ }^{1015}$. Tal entendimento é correto. O SIMPLES é um regime especial de tributação ao qual as empresas podem ou não aderir. Caso adiram, sabem de antemão que, dentre as conseqüências do seu ato, está a restrição ao aproveitamento de créditos de IPI.

\footnotetext{
${ }^{1014}$ Assim dispunha a antiga lei do SIMPLES Federal:

"Art. $5^{\circ} .(\ldots)$.

$\S 5^{\circ}$. A inscrição no SIMPLES veda, para a microempresa ou empresa de pequeno porte, a utilização ou destinação de qualquer valor a título de incentivo fiscal, bem assim a apropriação ou a transferência de créditos relativos ao IPI e ao ICMS."

1015 STJ, Primeira Turma, EDcl no Ag. no 940.592/PR, Relatora Min. DENISE ARRUDA, DJ 17.12.2007, p. 143; STJ, Segunda Turma, REsp nº 843.291/PR, Relatora Min. ELIANA CALMON, DJe 07.04.2008.
} 
Entretanto, o STJ também sustentou a impossibilidade de creditamento do IPI pelos terceiros não-optantes que adquirem mercadorias de empresas do SIMPLES ${ }^{1016}$. É neste ponto que reside a ilegitimidade do caput do art. 23 da LC n ${ }^{\circ} 123 / 06$ (e residia a do art. $5^{\circ}$, $\S 5^{\circ}$ da Lei $n^{\circ}$ 9.317/96). Afinal, não se pode tolher o direito assegurado pela Constituição ${ }^{1017}$ e pelo CTN ${ }^{1018}$ de abatimento do IPI pago nas operações anteriores. O recolhimento do IPI por qualquer contribuinte, optante ou não por regime especial, deve, obrigatoriamente, gerar créditos aproveitáveis para o adquirente de suas mercadorias (desde que este também seja contribuinte do IPI, do contrário arcará com o ônus do imposto na qualidade de contribuinte de facto). Trata-se de premissa basilar da não-cumulatividade tributária, integrante de seu núcleo mínimo desde sempre resguardado pelo Supremo Tribunal Federal.

\subsection{RESTITUIÇÃO DO INDÉBITO VERSUS CREDITAMENTO ESCRITURAL: PRAZOS PRESCRICIONAIS.}

\subsubsection{O CTN E A REPETIÇÃO DO INDÉBITO NOS TRIBUTOS SUJEITOS A LANÇAMENTO POR HOMOLOGAÇÃO.}

Uma vez pago indevidamente o tributo, exsurge para o contribuinte o direito de repetir o indébito ou, alternativamente, pleitear a compensação do montante pago a maior. O pedido pode ser feito administrativamente ou em juízo.

O fundamento constitucional do direito à restituição do tributo indevidamente pago radica no direito de propriedade insculpido no art. $5^{\circ}$, XXII da CR/88 ${ }^{1019}$. Essa garantia fundamental veda a apropriação ou confisco de bens econômicos dos contribuintes sem causa jurídica.

No plano infraconstitucional, o CTN regulamenta a restituição de tributos em seus arts. 165 a 169.

\footnotetext{
1016 STJ, Primeira Turma, AgRg no REsp no 1.066.597/PR, Relator Min. FRANCISCO FALCÃO, DJe 29.10.2008.

${ }^{1017} \mathrm{CR} / 88$, art. $153, \S 3^{\circ}, \mathrm{II}$.

${ }^{1018}$ CTN, art. 49.

${ }^{1019}$ Constituição de 1988:

“Art. $5^{\circ}$. Todos são iguais perante a lei, sem distinção de qualquer natureza, garantindo-se aos brasileiros e aos estrangeiros residentes no País a inviolabilidade do direito à vida, à liberdade, à igualdade, à segurança e à propriedade, nos termos seguintes:

(...)

XXII - é garantido o direito de propriedade;"
} 
O art. 168 do Código Tributário ${ }^{1020}$ cura do prazo para se pleitear a devolução dos tributos indevidamente pagos. Esse direito extingue-se com o prazo de 05 anos contados:

(a) da data da extinção do crédito tributário, quando o pagamento a maior pelo sujeito passivo tenha decorrido de erro de fato ou de direito;

(b) da data em que se tornar definitiva a decisão administrativa ou que transitar em julgado decisão judicial que tenha anulado, reformado, revogado ou rescindido o auto de infração/decisão condenatória.

Quando se prescreve que o prazo para repetição do indébito expira em 05 anos contados da extinção do crédito tributário nas hipóteses de pagamento indevido pelo sujeito passivo (alínea $a$, supra), somos remetidos ao art. 156 do CTN, cujos incisos I e VII predicam:

“Art. 156. Extinguem o crédito tributário:

I - o pagamento;

(...)

VII - o pagamento antecipado e a homologação do pagamento, nos termos do disposto no art. 150 e seus $\S \S 1^{\circ}$ e $4^{\circ}$."

Nos tributos lançados de ofício (IPTU e IPVA, v.g.), o pagamento extinguirá o crédito tributário, nos termos do art. 156, I CTN. Assim, o prazo para propositura de eventual ação de repetição de indébito inicia-se a partir da data de recolha dos valores ao erário.

Já nos tributos sujeitos a lançamento por homologação (IPI, ICMS, PIS/COFINS, et caterva), a extinção do crédito tributário se dará com o pagamento antecipado e a homologação do pagamento, nos termos do art. 156, VII do CTN. Nessa hipótese, duas interpretações são possíveis:

(a) feito o pagamento, o crédito se extingue e o prazo de cinco anos passa a correr;

(b) ainda que pago o tributo, a extinção do crédito somente ocorre com a homologação do pagamento, que se dá - tacitamente - cinco anos após a ocorrência do fato gerador nos tributos sujeitos a lançamento por homologação (art. 150, $\S 4^{\circ}$ do $\mathrm{CTN}^{1021}$ ).

${ }^{1020}$ Código Tributário Nacional:

"Art. 168. O direito de pleitear a restituição extingue-se com o decurso do prazo de 5 (cinco) anos, contados:

I - nas hipóteses dos incisos I e II do artigo 165, da data da extinção do crédito tributário;

II - na hipótese do inciso III do artigo 165, da data em que se tornar definitiva a decisão administrativa ou passar em julgado a decisão judicial que tenha reformado, anulado, revogado ou rescindido a decisão condenatória."

${ }^{1021}$ CTN:

“Art. 150. O lançamento por homologação, que ocorre quanto aos tributos cuja legislação atribua ao sujeito passivo o dever de antecipar o pagamento sem prévio exame da autoridade administrativa, 
Assim, o dies a quo para contagem do prazo prescricional em questão seria a data da homologação tácita do pagamento ${ }^{1022}$.

Inicialmente, o Superior Tribunal de Justiça entendia que o referido prazo de 5 anos (para pleitear-se a repetição/compensação nos tributos sujeitos a lançamento por homologação) se iniciava na data do pagamento antecipado ${ }^{1023}$. Contudo, em março de 1995, nos autos dos Embargos de Divergência no REsp n $n^{\circ} 42.720 / \mathrm{RS}^{1024}$, o STJ pacificou entendimento em sentido diverso. Prevaleceu, a partir de então, a tese de que o prazo prescricional para a propositura da ação de repetição/compensação do indébito é de 10 anos nos tributos sujeitos a lançamento por homologação. O decênio é resultante dos 5 anos contados da extinção do crédito tributário, que se dá (por força da homologação tácita) 5 anos após a ocorrência do fato gerador do tributo.

Com a edição da Lei Complementar $n^{\circ} 118$, de 09 de fevereiro de 2005, a regra posta no CTN acerca do prazo para repetição do indébito nos tributos sujeitos a lançamento por homologação foi "interpretada" pelo legislador da seguinte forma:

“Art. $3^{\circ}$. Para efeito de interpretação do inciso I do art. 168 da Lei no 5.172, de 25 de outubro de 1966 - Código Tributário Nacional, a extinção do crédito tributário ocorre, no caso de tributo sujeito a lançamento por homologação, no momento do pagamento antecipado de que trata o $\S 1^{\circ}$ do art. 150 da referida Lei."

O dispositivo objetivava modificar o entendimento do STJ acerca da contagem do prazo prescricional para a propositura da ação de repetição de indébito. Ao argumento de se tratar de norma interpretativa (que, portanto, retroagiria para atingir fatos geradores pretéritos ${ }^{1025}$ ), o legislador complementar dispôs que o prazo de 5 anos contar-se-ia do paga-

opera-se pelo ato em que a referida autoridade, tomando conhecimento da atividade assim exercida pelo obrigado, expressamente a homologa.

$\S 1^{\circ}$. O pagamento antecipado pelo obrigado nos termos deste artigo extingue o crédito, sob condição resolutória da ulterior homologação ao lançamento.

(...)

$\S 4^{\circ}$. Se a lei não fixar prazo a homologação, será ele de cinco anos, a contar da ocorrência do fato gerador; expirado esse prazo sem que a Fazenda Pública se tenha pronunciado, considera-se homologado o lançamento e definitivamente extinto o crédito, salvo se comprovada a ocorrência de dolo, fraude ou simulação."

${ }^{1022}$ A homologação expressa quase não existe. Todavia, se ocorrer, consistirá no dies a quo para a contagem do prazo prescricional de compensação/repetição do indébito.

${ }^{1023}$ STJ, Primeira Turma, REsp no 44.265/RS, Relator Min. DEMÓCRITO REINALDO, DJ 27.06.1994, p. 16.913.

${ }^{1024}$ STJ, Primeira Seção, EREsp no 42.720/RS, Relator Min. HUMBERTO GOMES DE BARROS, DJ 17.04.1995, p. 9.551 .

${ }^{1025}$ A retroatividade da lei tributária interpretativa é predicada pelo art. 106, I do CTN. 
mento antecipado (e não da homologação do pagamento, como havia sido assentado pelo STJ ao interpretar o CTN).

Contra a regra adveio forte reação por parte da doutrina ${ }^{1026}$. Afinal, nada havia a ser interpretado. A jurisprudência se encontrava há muito pacificada no sentido de que o prazo prescricional para propositura da ação de repetição de indébito nos tributos sujeitos a lançamento por homologação contava-se da homologação do pagamento, ou seja: a regra era a do prazo decenal (conhecida como a tese dos "cinco mais cinco").

Sensibilizado, o Superior Tribunal de Justiça, por sua Corte Especial, decidiu que a norma veiculada pela LC $n^{\circ} 118 / 05$ não era interpretativa. A hermenêutica do CTN, na parte atingida pela referida lei complementar, já havia sido realizada pelo Poder Judiciário, ao qual incumbe a interpretação das leis. Portanto, o comando inserto no art. $3^{\circ}$ da $\mathrm{LC} \mathbf{n}^{\circ}$ 118/05 consistia em modificação legislativa. Dessarte, o novel dispositivo somente produziria efeitos para os fatos geradores ocorridos após o início de sua vigência, iniciada em 9 de junho de $2005^{1027}$.

Assim, atualmente a regra que vigora para os pleitos de restituição/compensação do indébito tributário nos tributos sujeitos a lançamento por homologação é:

(a) prazo decenal para fatos geradores ocorridos antes de 9 de junho de 2005;

(b) prazo qüinqüenal para fatos gerados após 9 de junho de 2005 (sendo que o dies a quo é a data do pagamento e não a de ocorrência do fato tributável).

Pois bem. Sendo o IPI, o ICMS e o PIS/COFINS tributos sujeitos a lançamento por homologação, o prazo para ações que busquem a restituição/compensação do indébito dessas exações se sujeita às regras acima.

Todavia, nenhuma dessas regras é aplicável quando se trata de ação que pleiteie o direito à escrituração de créditos de tributos não-cumulativos, como se verá a seguir.

\footnotetext{
${ }^{1026}$ Inter alii, sugerimos a leitura do seguinte texto: COÊLHO, Sacha Calmon Navarro e LOBATO, Valter. Reflexões Sobre o Art. $3^{\circ}$ da Lei Complementar 118. Segurança Jurídica e a Boa-fé como Valores Constitucionais. As Leis Interpretativas no Direito Tributário Brasileiro. Revista Dialética de Direito Tributário, $\mathrm{n}^{\circ}$ 117. São Paulo: Dialética, jun./2005, pp.108-23.

1027 STJ, Corte Especial, AI nos EREsp n 644.736/PE, Relator Min. TEORI ZAVASCKI, DJ 27.08.2007, p. 170.
} 


\subsubsection{O DECRETO $\mathrm{N}^{\circ}$ 20.910/32 E O CREDITAMENTO ESCRITURAL DE IPI, ICMS E PIS/COFINS NÃO-CUMULATIVOS.}

Nas hipóteses em que o pleito do contribuinte restringe-se à escrituração de créditos cujo reconhecimento é negado pelo Fisco, a regra do art. 168 do CTN é afastada. Isso porque o direito ao crédito, decorrente do princípio da não-cumulatividade, não se confunde com o direito à compensação ou restituição do tributo pago a maior.

Assim, se o contribuinte que não escriturou determinado crédito de IPI, ICMS ou PIS/COFINS, posto que o Fisco não lhe reconhecia esse direito, não há que se falar em aplicação do prazo previsto no art. 168 do Código para eventual ação contra a Fazenda Pública. As hipóteses - pleito de creditamento escritural e de compensação/repetição do indébito - são distintas. E o CTN, como se viu no item precedente, regulamenta tãosomente a restituição (ou compensação) do indébito tributário.

Em face do vácuo legal, o Superior Tribunal de Justiça ${ }^{1028}$ aplica o Decreto $\mathrm{n}^{\circ}$ 20.910, de 6 de janeiro de 1932, às ações de reconhecimento do direito a créditos escriturais de tributos não-cumulativos. O referido decreto prevê a prescrição qüinqüenal de todas as dívidas passivas da União, Estados e Municípios, assim como de todo direito ou ação contra a Fazenda Federal, Estadual ou Municipal, seja qual for a sua natureza ${ }^{1029}$.

A solução adotada pelo STJ é correta. Afinal, a escrituração de créditos de impostos não-cumulativos é inconfundível com o pleito de repetição do indébito fiscal, esse sim regulamentado pelo CTN. Tanto é que o art. 166 do Código Tributário ${ }^{1030}$ é inaplicável aos

${ }^{1028}$ Confira-se:

“TRIBUTÁRIO. PROCESSUAL CIVIL. IPI. CRÉDITOS ESCRITURAIS. PRESCRIÇÃO. INCIDÊNCIA DO DECRETO-LEI N. 20.910/32. (...).

1. É cediço, nesta Corte, o entendimento jurisprudencial no sentido da aplicabilidade da regra inserta no Decreto-Lei n. 20.910/32 da prescrição do direito ao creditamento do IPI, e não o disposto no CTN, por não se tratar de pagamento indevido. Quanto à prescrição, é pacífico nesta Corte o entendimento de que 'a prescrição dos créditos fiscais visando ao creditamento do IPI é qüinqüenal, contada a partir do ajuizamento da ação’ (REsp 530.182/RS, Rel. Min. Castro Meira, DJ 25.10.2004).

Recurso especial parcialmente conhecido, e nessa parte, parcialmente provido, apenas para reconhecer a incidência da prescrição qüinqüenal, nos termos do Decreto-Lei no 20.910/32." (STJ, Segunda Turma, REsp n ${ }^{\circ}$ 746.440/MG, Relator Min. HUMBERTO MARTINS, DJ 04.05.2007, p. 426).

No mesmo sentido, cite-se: STJ, Primeira Turma, REsp n 866.697/MG, Relatora Min. DENISE ARRUDA, DJe 23.04.2008.

${ }^{1029}$ Decreto n $^{\mathbf{o}} 20.910 / 32$ :

“Art. $1^{\circ}$. As dívidas passivas da União, dos Estados e dos Municípios, bem assim todo e qualquer direito ou ação contra a Fazenda Federal, Estadual ou Municipal, seja qual for a sua natureza, prescrevem em cinco anos contados da data do ato ou fato do qual se originarem."

${ }^{1030} \mathrm{O}$ art. 166 do CTN exige a prova da não-repercussão jurídica para os pedidos de repetição de indébito de tributos não-cumulativos stricto sensu, quais sejam, ICMS e IPI. 
casos em que o contribuinte pugna pelo reconhecimento de créditos escriturais ${ }^{1031}$. Noutro giro verbal, a compensação do indébito não se confunde com a compensação em conta gráfica das exações não-cumulativas. Dessarte, à míngua de regramento pelo Código Tributário, é acertada a utilização do Decreto n 20.910/32 para regular a prescrição das ações de reconhecimento de créditos escriturais do IPI, ICMS e PIS/COFINS nãocumulativos $^{1032}$.

\subsection{PRAZO DECADENCIAL PARA ESCRITURAÇÃO, EM CONTA GRÁFICA, DE CRÉDITOS DE IPI, ICMS E PIS/COFINS.}

O ICMS possui regra própria ${ }^{1033}$ que estipula o prazo de 5 (cinco) anos para a utilização (leia-se escrituração) pelo contribuinte dos créditos do imposto, contados da data de emissão da nota fiscal que suporta esse creditamento.

Já o IPI e o PIS/COFINS não possuem tal previsão em suas leis de regência. Todavia, como o ordenamento jurídico não abriga direitos imprescritíveis, aplica-se analogicamente à hipótese o já referido Decreto no 20.910/32. Assim, é de 5 (cinco) anos o prazo para escrituração dos créditos decorrentes dessas exações, sob pena de decadência do direito do contribuinte. O dies a quo para a contagem do lustro decadencial, no caso do IPI, será a data de emissão da nota fiscal, tal como no ICMS. Já para o PIS/COFINS será a data em que o contribuinte incorreu na despesa geradora do crédito que pretenda aproveitar.

\subsection{A CORREÇÃO MONETÁRIA DOS CRÉDITOS ESCRITURAIS ${ }^{1034}$.}

\footnotetext{
${ }^{1031}$ Interplures, veja-se a ementa infra:

"TRIBUTÁRIO. ICMS. CREDITAMENTO EXTEMPORÂNEO. INSUMOS, MATERIAL INTERMEDIÁRIO E DE EMBALAGEM. ART. 166 DO CTN. INAPLICABILIDADE.

1. A não-contabilização de crédito de ICMS relativo a matérias primas, produtos intermediários e material de embalagem (ou a contabilização a menor) não implica repasse do ônus correspondente nas operações de saída realizadas pela contribuinte, dentro da sistemática da não-cumulatividade. Inaplicabilidade do disposto no art. 166 do CTN a essa hipótese de creditamento extemporâneo. Precedentes do STJ. (...)." (STJ, Segunda Turma, AgRg no Ag no 1.022.174/SP, Relator Min. HERMAN BENJAMIN, DJe 19.03.2009).
}

\footnotetext{
${ }^{1032}$ A legislação regente do PIS/COFINS não-cumulativos (art. 15, II c/c art. $3^{\circ}, \S 10^{\circ}$ da Lei $n^{\circ} 10.833 / 03$ ) deixa claro que os créditos dessas contribuições - utilizados para fins de apuração do quantum debeatur - são meramente escriturais, assim como o são os créditos de IPI e ICMS, que possuem a mesma finalidade.

${ }^{1033}$ LC no 87/96, art. 23, parágrafo único.

${ }^{1034}$ Os créditos escriturais do IPI e ICMS e a problemática acerca da sua correção, não se confundem com a atualização monetária do indébito tributário oriundo de pagamento a maior ou indevido de tributo.

Em se tratando de repetição de indébito do ICMS ou IPI, a jurisprudência da Corte Suprema remete a questão da atualização dos valores à legislação infraconstitucional. Pugna o STF, no entanto, pela ampliação (por
} 
Como já visto à saciedade, o IPI, o ICMS e o PIS/COFINS devem ser apurados pelo sistema de conta gráfica, lançando-se créditos e débitos para, ao cabo, obter-se o quantum debeatur a ser recolhido às burras estatais. Todavia, é possível que em determinada competência o contribuinte apure mais créditos do que débitos a compensar, podendo transportar o saldo credor para os períodos subseqüentes. Em situações como tais, exsurge a seguinte indagação: os créditos não aproveitados na competência em que lançados ${ }^{1035}$ devem ser monetariamente corrigidos quando transferidos para os períodos seguintes?

Temos que sim. Afinal, a atualização monetária nada mais é que a manutenção do poder de compra da moeda. Especialmente em períodos inflacionários, a ausência de correção poderá levar à perda de significativa parcela do direito de crédito - o que contraria a regra da não-cumulatividade.

Em que pese a acaciana simplicidade da questão, o STF entendeu de forma diversa. A Corte Suprema assentou que a correção monetária dos créditos escriturais não integra o núcleo constitucional da não-cumulatividade. Assim, trata-se de matéria que fica ao inteiro alvedrio do legislador infraconstitucional. Portanto, salvo disposição em contrário, não há direito à correção dos créditos escriturais desses impostos. Tal entendimento tem como fundamento a natureza meramente contábil dos créditos lançados na conta gráfica do contribuinte. Como aqueles se prestam tão-somente para fins de apuração do quantum debeatur, não representando um direito oponível ao Fisco, não haveria razão para assegurar-se ao contribuinte a sua correção com fundamento no princípio da não-cumulatividade - posicionamento do qual discordamos veementemente ${ }^{1036}$.

analogia) das hipóteses em que a correção seria devida, quando tal medida se afigure possível em face das leis estaduais e federais. Nessa toada, confira-se a seguinte ementa:

"ICM. CORREÇÃO MONETÁRIA EM REPETIÇÃO DE INDÉBITO FISCAL.

Já se firmou a orientação do STF no sentido de que, com base na aplicação analógica admitida pelo artigo 108 do CTN, é cabível a correção monetária." (STF, Segunda Turma, RE nº 84.353/SP, Relator Min. MOREIRA ALVES, DJ 26.04.1976).

No caso, a legislação paulista previa a correção monetária na ação de repetição de indébito quando o contribuinte depositasse judicialmente os valores. Entretanto, caso pagasse o imposto e ajuizasse a repetitória, a lei estadual era omissa quanto à correção. Utilizando-se da analogia, estendeu o STF a regra que predicava a atualização do indébito também para as hipóteses nas quais o contribuinte optasse pelo solve et repete. No mesmo sentido, inter alii: STF, Primeira Turma, RE $n^{\circ} 81.456 / \mathrm{SP}$, Relator Min. ANTONIO NEDER, DJ 13.03.1981, p. 11.731; STF, Segunda Turma, RE $\mathrm{n}^{\circ}$ 86.327/SP, Relator Min. MOREIRA ALVES, DJ 17.03.1978, p. 1.417 .

1035 A competência (período de apuração) é em regra mensal nos tributos não-cumulativos, mas pode ser quinzenal ou até mesmo decendial, como ocorre com o IPI em alguns casos.

${ }^{1036}$ Os acórdãos a seguir mencionados tratam da correção de créditos do ICMS, já sob a luz da Constituição de 1988. Neles, o STF reafirma que as questões atinentes à atualização monetária de tributos são matéria infraconstitucional. Outrossim, denotam ser impossível extrair-se do princípio da não-cumulatividade o direito à correção monetária dos créditos escriturais: STF, Primeira Turma, AI-AgR nº 181.138/RS, Relator Min. 
A exceção à regra, ainda de acordo com o Supremo Tribunal Federal, ocorre apenas nas hipóteses em que o contribuinte deixa de aproveitar o crédito por força de óbice criado pelo próprio Estado. Em tais situações, o Tribunal assegura a correção monetária dos créditos escriturais, ao fundamento de evitar o locupletamento ilícito do Fisco. Resguarda-se, assim, a não-cumulatividade contra fato criado pelo próprio Fisco (em clássica utilização da máxima venire contra factum proprium non potest $)^{1037}$.

O STJ, como não poderia deixar de ser, perfilha o mesmo entendimento da Suprema Corte Co38 $^{103}$.

Assim, pode-se afirmar - com base na jurisprudência remansosa de nossas Cortes Superiores - que não há direito à correção monetária dos créditos escriturais do IPI, do ICMS e do PIS/COFINS não-cumulativos.

Todavia, se houver óbice estatal ao creditamento, os créditos de IPI e do PIS/COFINS não-cumulativos sofrerão a incidência da SELIC ${ }^{1039}$. Já os relativos ao ICMS

MOREIRA ALVES, DJ 18.04.1997, p. 13.775; STF, Segunda Turma, RE no 213.583/RS, Relator Min. MAURÍCIO CORREA, DJ 14.04.2000, p. 54.

Nesse sentido, confira-se ainda a seguinte decisão Plenária do Supremo Tribunal, em sede de embargos de divergência:

"Embargos de divergência. Inadmissibilidade. Tributo. ICMS. Correção monetária de créditos escriturais. Não-incidência. Recurso extraordinário provido. Violação ao princípio da legalidade. Matéria constitucional não prequestionada. Acórdão que, ademais, reflete a jurisprudência da Corte. Recurso não conhecido. Aplicação do art. 332 do RISTF. Não se conhece de embargos de divergência que argúem matéria constitucional não prequestionada e impugnam acórdão proferido de acordo com jurisprudência assentada do Supremo." (STF, Pleno, Embargos de Divergência no RE no 213.583/RS, Relator Min. CEZAR PELUSO, DJ 06.06.2008, p. 93).

Digno de registro, todavia, o voto vencido do Min. MARCO AURÉLIO, que pugnava pela rediscussão da matéria no âmbito da Corte, in verbis:

“(...) Peço vênia para admitir a rediscussão do tema, tendo em conta até mesmo o que não consigo conceber: o enriquecimento sem causa por parte do Estado.

Quando, ante o princípio da não-cumulatividade, ao término do mês de apuração do que devido a título de ICMS, o contribuinte tem crédito, o transporte - principalmente em época de inflação (...) para o mês seguinte, com a perda do poder aquisitivo da moeda, implica transgressão ao princípio, implica enriquecimento sem causa do próprio Estado, implica majoração, portanto, do tributo. É um tema que, a meu ver, merece reflexão maior." (STF, Pleno, Embargos de Divergência no RE no 213.583/RS, Relator Min. CEZAR PELUSO, DJ 06.06.2008, p. 93).

${ }^{1037}$ É o que se extrai do voto do Min. MARCO AURÉLIO, quando da relatoria do RE nº 168.752/MG:

"Relativamente à correção monetária, assentada a premissa segundo a qual, em razão da atividade desenvolvida pelo Fisco, não foi possível a feitura do crédito (...) na época oportuna, forçoso é concluir pela necessidade de atualização, sob pena de advir, do congelamento, a ineficácia do princípio da não-cumulatividade." (STF, Segunda Turma, RE n 168.752/MG, Relator Min. MARCO AURÉLIO, DJ 20.03.1998, p. 15).

${ }^{1038}$ Inter alii, cite-se: STJ, Primeira Seção, EREsp no 605.921/RS, Relator Min. TEORI ZAVASCKI, DJe 24.11.2008 (trata de IPI, mas se aplica igualmente ao PIS/COFINS e ao ICMS).

${ }^{1039}$ Art. 13 da Lei $n^{\circ} 9.065$, de 20 de junho de 1995, c/c art. 39, $\S 4^{\circ}$ da Lei $n^{\circ} 9.250$, de 26 de dezembro de 1995.

As leis em comento não são específicas para a correção monetária dos créditos escriturais. Em verdade, elas regem a atualização dos débitos de tributos federais e, também, do indébito decorrente do seu pagamento 
serão corrigidos pelos índices previstos nas leis estaduais para a atualização dos créditos do próprio Fisco, consoante predica a orientação pretoriana.

indevido. Todavia, consoante predicam o STF e o STJ, os aludidos diplomas legais fundamentam a atualização dos créditos escriturais de IPI e PIS/COFINS não-cumulativos sempre que o Fisco não reconhecer a legitimidade desses créditos, erigindo óbices para a sua escrituração. 


\section{CONCLUSÕES}

Ao longo do trabalho, tivemos a oportunidade de abordar diferentes temas que se amalgamam em torno de um só núcleo, edificando o conceito teórico e aplicado da nãocumulatividade tributária.

Iniciando os estudos, a Parte I, que compreende os Capítulos I a V, cuidou de estremar os institutos da tributação indireta e da não-cumulatividade.

Foi visto nos Capítulos I e II que tributo indireto, para o ordenamento jurídico pátrio, é aquele criado para trasladar juridicamente o ônus fiscal ao elo seguinte da cadeia produtiva. O principal elemento tipificador da exação indireta é a existência de dois contribuintes (de jure e de facto), que deverão estar conectados por um negócio jurídico. Outrossim, o destaque em documento fiscal do valor do tributo é forte indício da sua natureza indireta, em que pese - por se tratar de uma formalidade - não poder ser erigido como conditio sine qua non para a classificação proposta.

Prosseguindo, os requisitos da não-cumulatividade foram assentados no Capítulo III, a saber:

(c) plurifasia necessária, o que implica a incidência sobre negócios jurídicos encadeados que objetivem a circulação de riquezas (bens e serviços);

(d) direito ao crédito sobre o valor do tributo recolhido em fases anteriores do processo de produção ou prestação do serviço (método imposto-contra-imposto, adotado pela Constituição de 1988 para o IPI e o ICMS).

Em seguida, o Capítulo IV se ocupou de associar os conceitos estudados nos capítulos precedentes, tendo-se concluído que:

(a) a não-cumulatividade não é requisito para caracterização do tributo indireto. Ela provavelmente estará presente em boa parte das exações indiretas, mas não é imprescindível a estas. A incidência indireta pode ser monofásica ou plurifásica. Se for monofásica, não haverá condições para que a não-cumulatividade opere. Sendo plurifásica, poderá ser cumulativa ou não;

(b) por outro lado, todo tributo não-cumulativo será indireto, desde que incida sobre operações de circulação de riquezas. Entretanto, se a não-cumulatividade for aplicada a gravames que incidem sobre outras materialidades (como a receita, no caso do PIS/COFINS) não se poderá concluir da mesma forma. Nesse caso, a nãocumulatividade estará sendo utilizada em função diversa daquela para a qual foi concebida, não tendo o condão de tornar indireta, per se, a exação. 
O Capítulo V, que encerra a Parte I da tese, propõe a seguinte classificação à luz da Constituição da República:

(a) tributos não-cumulativos stricto sensu: ICMS e IPI. Nestes, a não-cumulatividade opera em sua função precípua, possibilitando a translação do ônus fiscal ao contribuinte de facto e tornando indireta a exação;

(b) tributos não-cumulativos lato sensu: PIS/COFINS. Como essas contribuições não são plurifásicas (pois não gravam negócios jurídicos encadeados ao longo do processo de produção do bem ou prestação do serviço), a não-cumulatividade a elas aplicada não torna indiretos os tributos em comento.

À luz dessa divisão, afirmou-se ainda que os impostos e contribuições residuais deverão observar a não-cumulatividade somente quando forem plurifásicos. Assim, um imposto residual que grave a propriedade de aeronaves e embarcações, v.g., não se subsume à exigência da não-cumulatividade para o exercício da competência residual.

Na Parte II da tese, que compreende os Capítulos VI a X, as normas constitucionais da não-cumulatividade foram analisadas, à luz da jurisprudência do Supremo Tribunal Federal. Restou assentado que, para o IPI e o ICMS, a não-cumulatividade é norma de eficácia plena; já para o PIS/COFINS, é norma de eficácia limitada de princípio institutivo facultativo (significando que compete ao legislador decidir se irá ou não adotá-la). No que tange ao conteúdo material da não-cumulatividade, concluiu-se que:

(a) a tendência atual da Suprema Corte é a exigência de ao menos duas etapas gravadas pelo tributo, sob pena de estorno dos créditos dos estádios anteriores e, igualmente, vedação de transporte de créditos para os estádios subseqüentes. Tal determinação, alertamos, deve ser amalgamada com a apuração por período de tempo - o que ainda não foi feito pelo STF. Afinal, uma única empresa pode realizar vendas tributadas e não-tributadas. Em tal hipótese, negar-se o crédito ao fundamento de que as saídas não são tributadas - sendo certo que outras o são - consiste em olvidar a apuração por período de tempo, que pressupõe a imputação indiscriminada de créditos e débitos na conta gráfica. $\mathrm{O}$ tema em questão não se refere ao ICMS, regido por regra da CR/88 que determina o estorno dos créditos sempre que houver operação ou prestação isenta ou nãotributada;

(b) o STF tem sustentado, em matéria de IPI, que deve haver estorno dos créditos escriturados em decorrência da aquisição de insumos tributados para produtos cujas saídas são isentas. Todavia, em verdadeira contradição, tem reconhecido 
o direito a créditos presumidos para os adquirentes de insumos isentos que realizam saídas tributadas pelo IPI. A antinomia deve ser solucionada. Em nossa opinião, a norma isencional, para ter eficácia nos tributos não-cumulativos, exige a manutenção e o transporte dos créditos tributários cujo pagamento foi dispensado. Do contrário, ter-se-á majoração da carga tributária ao invés de sua redução (salvo se a isenção for concedida na última etapa do ciclo de produção, que não é o caso em análise pelo STF);

(c) sendo apurado saldo credor em determinada competência, é direito do contribuinte transportá-lo para o período de apuração subseqüente. Portanto, serão inconstitucionais leis federais (no caso do IPI e do PIS/COFINS) ou estaduais (ICMS) que impeçam o carregamento dos créditos escriturais acumulados;

(d) outrossim, o contribuinte faz jus à manutenção integral de seus créditos mesmo quando revende mercadorias por preço inferior ao de custo. Portanto, leis que limitem o valor do crédito ao do débito gerado pela saída do produto são inválidas em face da não-cumulatividade;

(e) os contribuintes sujeitos ao diferimento fazem jus à manutenção de seus créditos, pois suas saídas são tributadas, porém de forma postergada;

(f) na substituição tributária (ST) para frente, o STF legitimou a tese de que a restituição do tributo pago a maior somente é devida se o fato gerador presumido não ocorrer sob nenhuma hipótese, como se tem, v.g., quando a mercadoria perece antes da venda pelo substituído. Tal entendimento, firmado na ADI $\mathrm{n}^{\circ}$ 1.851/AL, está contudo em fase de revisão por meio da ADI n ${ }^{\circ} 2.777 / \mathrm{SP}$;

(g) de todo modo, as pautas fiscais que têm sido erigidas por Estados-membros, fulcradas na decisão prolatada na ADI no 1.851/AL, são inconstitucionais. Afinal, substituição tributária para frente não se confunde com pauta fiscal, que desde os primórdios da implantação da não-cumulatividade no País foi acertadamente repelida pela jurisprudência da Suprema Corte. Na substituição tributária a presunção do valor de venda ao consumidor final - que consistirá na base de cálculo do ICMS-ST - deve ser consentânea com a realidade. Disparidades constantes entre o preço presumido e o praticado transmudam a ST em pauta fiscal, deslegitimando-a;

(h) o STF construiu a teoria do crédito físico sob a égide do Imposto de Consumo, tendo-a transplantado sucessivamente para o IPI, ICM e ICMS sem maiores reflexões. De todo modo, estando a referida teoria sedimentada há meio século, 
resta aos contribuintes discutir o seu alcance, à luz das normas infraconstitucionais editadas acerca da não-cumulatividade.

Para analisar o último ponto e, ainda, verificar o tratamento conferido pela legislação aos demais ditames da não-cumulatividade, a Parte III da tese foi elaborada.

Nos seus quatro primeiros capítulos (XI a XIV) abordou-se, respectivamente, a legislação do IPI, do ICMS, do PIS/COFINS sobre receitas e sobre importação de bens e serviços. O capítulo derradeiro (XV) tratou de institutos comuns aos referidos tributos nãocumulativos.

O Capítulo XI esmiúça o regramento da não-cumulatividade do IPI, sendo importante ressaltar, dentre os temas abordados, que:

(a) a legislação do IPI veda a apropriação de créditos sobre bens do ativo imobilizado, autorizando-a apenas em relação a matérias-primas, produtos intermediários e materiais de embalagem;

(b) o conceito de produto intermediário (espécie do gênero insumo, que abriga também as matérias-primas) foi definido por primeira vez para o IPI. Todavia, nunca houve na lei ou nos regulamentos do IPI qualquer exigência de contato físico do bem intermediário com o produto final. Esse requisito, que chegou a ser cogitado por alguns poucos arestos do STJ, não possui, dessarte, base normativa.

No Capítulo XII as diversas normas e problemas da não-cumulatividade do ICMS foram abordados, tendo-se concluído que:

(a) a $\mathrm{LC} \mathrm{n}^{\circ} 87 / 96$ autorizou o creditamento financeiro, porém de forma mitigada (dada a postergação do direito ao crédito sobre os bens de uso e consumo). Seu alcance foi reduzido pela $\mathrm{LC}^{\circ} 102 / 00$, que, dentre outros pontos, restringiu o crédito sobre a energia elétrica e os serviços de comunicação (insumos fundamentais para qualquer empresa na atualidade);

(b) atualmente, os créditos básicos do ICMS são os provenientes de mercadorias adquiridas para revenda, bens do ativo imobilizado, matérias-primas e produtos intermediários;

(c) são matérias-primas as que se agregam fisicamente ao produto final, ao passo que os bens intermediários são os consumidos no processo de produção ou prestação do serviço. Não se exige, para a qualificação do bem como intermediário, que o consumo seja instantâneo, tampouco que haja contato direto com o produto final. Todavia, bens que possuem durabilidade superior a um ano são 
legalmente considerados (pelas normas do Imposto de Renda) integrantes do ativo imobilizado do contribuinte;

(d) entrementes, não há um conceito claro de insumos geradores de crédito para os prestadores de serviço sujeitos ao ICMS. À míngua de definições legais e jurisprudenciais a esse respeito, remanesce a critério de cada Estado conceder ou não direito ao crédito em relação à maior parte dos insumos utilizados pelos prestadores de serviço de comunicação e transporte interestadual e intermunicipal, gerando verdadeira algaravia tributária;

(e) bens alheios à atividade do estabelecimento não ensejam o creditamento, por expressa vedação legal. Contudo, bem alheio é aquele totalmente estranho às atividades empresariais. Se determinada mercadoria possui uso indireto no processo produtivo ou de prestação do serviço, o direito ao crédito deverá ser assegurado. Todavia, a jurisprudência do STJ tem restringido sobremaneira o crédito em tais hipóteses - indevidamente, a nosso sentir - exigindo a aplicação direta do bem na produção;

(f) nos casos de ativo imobilizado cedido em comodato para parceiros comerciais, o comodante faz jus ao aproveitamento dos créditos de ICMS sobre os bens cedidos (desde que o uso conferido ao ativo pelo comodatário seja relacionado com as atividades de ambas as empresas);

(g) o transporte interestadual ou intermunicipal de mercadorias não-tributadas gera crédito aproveitável pelo contratante do serviço, desde que os bens transportados sejam vinculados à sua atividade empresarial;

(h) os prestadores de serviço de comunicação possuem direito inatacável aos créditos de ICMS sobre a energia elétrica consumida em suas áreas operacionais, pois a comunicação é viabilizada pela própria energia transformada em pulsos ou ondas eletromagnéticas. Assim, as vedações ao crédito da energia trazidas pela LC $n^{\circ} 102 / 00$ são inoponíveis às empresas de telecomunicações;

(i) a exigência de nota fiscal para aproveitamento dos créditos de ICMS não é definitiva, podendo ser substituída por prova, feita pelo contribuinte em processo administrativo ou judicial, de que a operação ou prestação efetivamente ocorreu. Outrossim, meros erros formais não tornam inidôneo o documento fiscal, devendo ser oportunizado ao contribuinte o direito de retificá-lo.

O Capítulo XIII cura da não-cumulatividade legal do PIS/COFINS incidente sobre a receita bruta das empresas. O seu regramento pela legislação se assemelha ao do ICMS e 
do IPI, com apuração em conta gráfica por período de tempo. Nesse sendeiro, são apontados os diversos créditos de PIS/COFINS calculados sobre as despesas incorridas pelos contribuintes dessas exações. Dentre aqueles, impende destacar que a legislação assegura de forma expressa o creditamento sobre insumos, utilizando o referido termo por primeira vez na legislação brasileira. Todavia, a Receita Federal buscou restringir o alcance da lei por meio de instrução normativa, no que laborou em equívoco. Exigiu a RFB que os outros bens geradores de crédito (para além das matérias-primas e produtos intermediários) deveriam ser consumidos em contato direto com o produto final (retomando o vetusto e injurídico requisito do contato físico para legitimação do creditamento). De todo modo, a referida instrução normativa deixa claro que o termo insumos resguarda os créditos dos prestadores de serviço, no que se tem importante evolução acerca da matéria, que poderia ser neste ponto - incorporada pelas normas do ICMS.

As vicissitudes do regime não-cumulativo do PIS/COFINS quando aplicado aos prestadores de serviço são também abordadas. Afinal, estes possuem ciclo produtivo mais curto e poucos créditos aproveitáveis, já que as despesas com mão-de-obra de pessoas físicas não autorizam o creditamento do PIS/COFINS. À vista desse cenário propõe-se, de lege ferenda, que os prestadores de serviço se sujeitem a alíquotas minoradas do PIS/COFINS não-cumulativos, com o intuito de restabelecer a igualdade e a observância da capacidade contributiva.

Outrossim, o Capítulo XIII trata ainda da violação à isonomia decorrente:

(a) da sujeição dos contribuintes que apurem o IRPJ com base no Lucro Real ao PIS/COFINS não-cumulativos;

(b) da manutenção das empresas cujo Imposto de Renda seja calculado pelo Lucro Presumido no PIS/COFINS cumulativos.

Conclui-se que o fator de discrímen eleito pela legislação é inadequado, pois sujeita empresas em idêntica situação - muitas vezes concorrentes entre si - a formas distintas de tributação (sendo que o regime não-cumulativo do PIS/COFINS é, em regra, mais gravoso que o cumulativo).

O Capítulo XIV, ao tratar do PIS/COFINS-importação, salienta que existe inconstitucionalidade, por ferimento à isonomia, na autorização concedida apenas aos contribuintes do PIS/COFINS não-cumulativos para desconto dos créditos referentes àquelas exações. Com isso, majora-se a carga tributária das empresas sujeitas à cumulatividade do PIS/COFINS que realizem importações de bens e serviços. Outrossim, o capítulo remete às considerações já feitas (e acima sumariadas) sobre o PIS/COFINS não-cumulativos. 
Por fim, o Capítulo XV assenta, para o IPI, ICMS e PIS/COFINS, que:

(a) a lei do SIMPLES não pode vedar o transporte de créditos para os adquirentes de produtos das empresas optantes. Se o imposto foi pago pela pessoa jurídica inscrita no SIMPLES, o crédito é devido na etapa subseqüente, por força do princípio da não-cumulatividade;

(b) o direito ao ajuizamento de ações pleiteando a escrituração de créditos não reconhecidos pelo Fisco é distinto do direito à repetição/compensção do indébito tributário. Este caso é regido pelos arts. 165 a 168 do CTN, ao passo que o primeiro se sujeita, no que tange ao prazo prescricional, ao Decreto ${ }^{\circ}$ 20.910/32;

(c) a legislação não prevê a correção monetária dos créditos escriturais de IPI, ICMS e PIS/COFINS, no que agride o direito de propriedade dos contribuintes, com o beneplácito acomodatício das Cortes Superiores.

São essas, em apertada síntese, as principais conclusões da tese, cuja abordagem da não-cumulatividade à luz da sua teoria geral, da Constituição e das leis, pretendeu delinear um panorama amplo desse instituto que, no ano passado, completou meio século de existência no País. 


\section{BIBLIOGRAFIA}

ALBUQUERQUE, Marcos Cintra Cavalcanti. A Verdade sobre o Imposto Único. São Paulo: LCTE, 2003.

ALEXY, Robert. Teoria da Argumentação Jurídica: a Teoria do Discurso Racional como Teoria da Justificação Jurídica, $2^{\mathrm{a}}$ ed. Trad. por SILVA, Zilda Hutchinson Schild. São Paulo: Landy, 2001.

ALEXY, Robert. Teoria de los Derechos Fundamentales. Madrid: Centro de Estudios Constitucionales, 1993.

ALLIX, Edgard e LECERCLÉ, Marcel. L'Impôt sur Le Revenú, Impôts Cédulaires et Impôt Général. Les Nouvelles Dispositions Législatives, v. I. Paris: Rousseau, 1926.

ALMEIDA, Cristina Beatriz de Sousa; PERES, Adriana Manni; VIANA, Ivo Ribeiro; DINIZ, Marianita Ribeiro. Como Utilizar Créditos Fiscais do IPI, PIS/COFINS e ICMS/SP. São Paulo: IOB Thomson, 2005.

ALVES, José Carlos Moreira. Direito Romano, 14ª ed. Rio de Janeiro: Forense, 2007.

AMARAL, Antonio Carlos Rodrigues do e YAMASHITA, Douglas. PIS e COFINS sobre a Importação de Produtos: Ilegalidades e Inconstitucionalidades. PEIXOTO, Marcelo Magalhães e FISCHER, Octavio Campos (coord.). PIS-COFINS - Questões Atuais e Polêmicas. São Paulo: Quartier Latin, 2005, pp. 273-86.

ATALIBA, Geraldo. Conflitos entre ICMS, ISS e IPI. Revista de Direito Tributário, nº 7/8, jan.-jun./1979, pp. 105-31.

ATALIBA, Geraldo. Estudos e Pareceres de Direito Tributário, v. I. São Paulo: Revista dos Tribunais, 1978.

ATALIBA, Geraldo. Hipótese de Incidência Tributária, 6ª ed. São Paulo: Malheiros, 2006.

ÁVILA, Humberto. Teoria dos Princípios - da Definição à Aplicação dos Princípios Jurídicos, $8^{\text {a }}$ ed. São Paulo: Malheiros, 2008. 
BALEEIRO, Aliomar. Direito Tributário Brasileiro, $11^{\mathrm{a}}$ ed. Atualizado por MISABEL ABREU MACHADO DERZI. Rio de Janeiro: Forense, 2001.

BALEEIRO, Aliomar. Uma Introdução à Ciência das Finanças, 16 ${ }^{\mathrm{a}}$ ed. Atualizado por DEJALMA DE CAMPOS. Rio de Janeiro: Forense, 2006.

BECKER, Alfredo Augusto. Teoria Geral do Direito Tributário, $4^{\mathrm{a}}$ ed. São Paulo: Noeses, 2007.

BENÍCIO, Sérgio Gonini e BENÍCIO JR., Benedicto Celso. As Principais Questões do PIS e COFINS Não-Cumulativos e sua Incidência sobre as Importações. PEIXOTO, Marcelo Magalhães e FISCHER, Octavio Campos (coord.). PIS-COFINS - Questões Atuais e Polêmicas. São Paulo: Quartier Latin, 2005, pp. 741-66.

BERLIRI, Antonio. Corso Istituzionale di Diritto Tributario, t. I. Milano: Giuffrè, 1965.

BERLIRI, Antonio. L'Imposta sul Valore Aggiunto. Milano: Giuffrè, 1971.

BERTOLDI, Marcelo M. e MARINS, James. Simples Nacional - Estatuto da Microempresa e da Empresa de Pequeno Porte Comentado. São Paulo: Revista dos Tribunais, 2007

BOBBIO, Norberto. Teoria do Ordenamento Jurídico, 10ª ed. Brasília: UnB, 1999.

BODIN, Jean-Paul; EBRILL, Liam; KEEN, Michael; SUMMERS, Victoria. The Modern VAT. Washington: International Monetary Fund, 2001.

BORGES, José Cassiano e REIS, Maria Lúcia Américo. O IPI ao Alcance de Todos. Rio de Janeiro: Revista Forense, 1999.

BORGES, José Souto Maior. Crédito do IPI Relativo a Insumo Isento. Revista Dialética de Direito Tributário, no 48. São Paulo: Dialética, set./1999, pp. 159-171.

BORGES, José Souto Maior. Isenções Tributárias. São Paulo: Sugestões Literárias, 1969.

BOTTALLO, Eduardo. IPI - Princípios e Estrutura. São Paulo: Dialética, 2009.

BOTTALlO, Eduardo Domingos. Restituição de Impostos Indiretos. Revista de Direito Público, no 22. São Paulo: Revista dos Tribunais, out.-dez./1972, pp. 314-327. 
BOTTAllo, Eduardo Domingos e CARRAZZA, Roque Antonio. Direito ao Crédito de ICMS pela Aquisição de Energia Elétrica Utilizada na Prestação de Serviços de Comunicação. Revista Dialética de Direito Tributário, n 119, ago./2005, pp. 70-9.

BOTTALlo, Eduardo Domingos e MELO, José Eduardo Soares de. Comentários às Súmulas Tributárias do STF e do STJ. São Paulo: Quartier Latin, 2007.

BOUCHER, Hércules. Estudo da Mais-Valia no Direito Tributário Brasileiro, tomo I. Rio de Janeiro: Freitas Bastos, 1964.

BRITO, Edvaldo. ICMS: Restrições à Compensação do ICMS - Bens do Ativo e Bens Destinados a Consumo do Estabelecimento. ROCHA, Valdir de Oliveira (coord.). O ICMS e a LC 102. São Paulo: Dialética, 2000, pp. 21-64.

CANARIS, Claus-Wilhelm. Pensamento Sistemático e Conceito de Sistema na Ciência do Direito, $2^{\mathrm{a}}$ ed. Trad. por CORDEIRO, Antonio Menezes. Lisboa: Fundação Calouste Gulbenkian, 1996.

CANOTILHO, J. J. Gomes. Direito Constitucional e Teoria da Constituição, $2^{\mathrm{a}}$ ed. Coimbra: Almedina, 1998.

CANTO, Gilberto de Ulhôa. A Repetição do Indébito. MARTINS, Ives Gandra da Silva (coord.). Caderno de Pesquisas Tributárias, nº 8 - Repetição do Indébito. São Paulo: Resenha Tributária, 1983, pp. 1-16.

CARRAZZA, Roque Antonio. Curso de Direito Constitucional Tributário, $23^{\mathrm{a}}$ ed. São Paulo: Malheiros, 2007.

CARRAZZA, Roque Antonio. ICMS, 10ª ed. São Paulo: Malheiros, 2005.

CARrAZZA, Roque Antonio e BOTTALlo, Eduardo Domingos. Direito ao Crédito de ICMS pela Aquisição de Energia Elétrica Utilizada na Prestação de Serviços de Comunicação. Revista Dialética de Direito Tributário, nº 119, ago./2005, pp. 70-9.

CARVAlHO, Paulo de Barros. A Definição da Base de Cálculo como Proteção Constitucional do Contribuinte. ASOREY, Rubén O. (org.). Protección Constitucional de Los Contribuyentes. Madrid: Marcial Pons, 2000, pp. 65-70. 
CARVALHO, Paulo de Barros. A Regra-matriz do ICM. Tese de Livre-Docência. São Paulo: PUC, 1981.

CARVALHO, Paulo de Barros. Curso de Derecho Tributario. Madrid, Barcelona, Buenos Aires: Marcial Pons, 2007.

CARVALHO, Paulo de Barros. Curso de Direito Tributário, $17^{\mathrm{a}}$ ed. São Paulo: Saraiva, 2005 .

CARVAlHO, Paulo de Barros. Direito Tributário - Fundamentos Jurídicos da Incidência, $4^{\mathrm{a}}$ ed. São Paulo: Saraiva, 2006.

CARVALHO, Paulo de Barros. Direito Tributário, Linguagem e Método. São Paulo: Noeses, 2008.

CARVALHO, Paulo de Barros. Formalização da Linguagem - Proposições e Fórmulas. Direito - Revista do Programa de Pós-Graduação em Direito, PUC/SP. São Paulo: Max Limonad, 1995, pp. 143-154.

CARVALHO, Paulo de Barros. Isenções Tributárias do IPI, em face do Princípio da NãoCumulatividade. Revista Dialética de Direito Tributário, $\mathrm{n}^{\circ}$ 33. São Paulo: Dialética, jun./1998, pp. 142-66.

CARVALHO, Paulo de Barros. Teoria da Norma Tributária. São Paulo: Lael, 1974.

CASSONE, Vittorio. A Não-Cumulatividade no Direito Brasileiro e no Direito Italiano. MARTINS, Ives Gandra da Silva (coord.). Caderno de Pesquisas Tributárias ${ }^{\circ} 10$ (nova série) - O Princípio da Não-Cumulatividade. São Paulo: Revista dos Tribunais/Centro de Extensão Universitária, 2004, pp. 422-46.

CASSONE, Vittorio. Direito Tributário, 17ª ed. São Paulo: Atlas, 2006.

COCIVERA, Benedeto. Principi di Diritto Tributario, v. I. Milano: Giuffrè, 1959.

COELHO, Carlos Nayro de Azevedo. Uma Análise Econômica do Imposto sobre o Valor Adicionado no Brasil. Brasília: Comissão de Financiamento da Produção, 1980. 
COÊLHO, Sacha Calmon Navarro. A Lei Complementar $n^{\circ} 116 / 03$, os Profissionais Liberais e as suas Sociedades. Revista Dialética de Direito Tributário, nº 99. São Paulo: Dialética, dez./2003, pp. 102-11.

COÊLHO, Sacha Calmon Navarro. Comentários à Constituição de 1988 - Sistema Tributário, $6^{\mathrm{a}}$ ed. Rio de Janeiro: Forense, 1996.

COÊLHO, Sacha Calmon Navarro. Curso de Direito Tributário Brasileiro, $7^{\mathrm{a}}$ ed. Rio de Janeiro: Forense, 2004.

COÊLHO, Sacha Calmon Navarro. Curso de Direito Tributário Brasileiro, $9^{\mathrm{a}}$ ed. Rio de Janeiro: Forense, 2007.

COÊLHO, Sacha Calmon Navarro. Liminares e Depósitos antes do Lançamento por Homologação - Decadência e Prescrição, 2a ed. São Paulo: Dialética, 2002.

COÊLHO, Sacha Calmon Navarro. O IVA Brasileiro. SARAIVA FILHO, Oswaldo Othon; VASQUES, Sérgio; GUIMARÃES, Vasco Branco (org.). IVA para o Brasil - Contributos para a Reforma da Tributação do Consumo. São Paulo: Fórum, 2007, pp. 553-86.

COÊLHO, Sacha Calmon Navarro. Prescrição e Decadência no Direito Tributário. Revista de Direito Tributário, no 71. São Paulo: Malheiros, 1998, pp. 84-93

COÊLHO, Sacha Calmon Navarro. Teoria Geral do Tributo e da Exoneração Tributária. São Paulo: Revista dos Tribunais, 1982.

COÊLHO, Sacha Calmon Navarro e DERZI, Misabel Abreu Machado. ICMS - Direito ao Creditamento - Princípio da Não-Cumulatividade. Revista Dialética de Direito Tributário, n 102. São Paulo: Dialética, mar./2004, pp. 141-56.

COÊLHO, Sacha Calmon Navarro e DERZI, Misabel Abreu Machado. Intributabilidade do Serviço de Transporte Prestado a Si Mesmo e o Direito aos Créditos Relativos ao Imposto Pago na Aquisição de Insumos. Belo Horizonte, abr./2000, inédito.

COÊLHO, Sacha Calmon Navarro e DERZI, Misabel Abreu Machado. O Direito ao Aproveitamento dos Créditos de ICMS, PIS e COFINS Relativos a Materiais e Serviços Utiliza- 
dos na Exploração, Desenvolvimento e Produção do Petróleo Bruto. Belo Horizonte, ago./2008, inédito.

COÊLHO, Sacha Calmon Navarro e DERZI, Misabel Abreu Machado. O Direito do Sujeito Passivo do ICMS de Compensar o Imposto Pago a Maior, em Razão da Técnica da Substituição Tributária Progressiva. Revista Dialética de Direito Tributário, no 101. São Paulo: Dialética, fev./2004, pp. 115-35.

COÊLHO, Sacha Calmon Navarro e DERZI, Misabel Abreu Machado. PIS/Cofins. Regime de Crédito. Contratos de Longo Prazo. Instrução Normativa no 468/04 da SRF. Ilegalidade. Revista Dialética de Direito Tributário, no 114. São Paulo: Dialética, mar./2005, pp. 121-37.

COÊLHO, Sacha Calmon Navarro e LOBATO, Valter. Reflexões Sobre o Art. $3^{o}$ da Lei Complementar 118. Segurança Jurídica e a Boa-fé como Valores Constitucionais. As Leis Interpretativas no Direito Tributário Brasileiro. Revista Dialética de Direito Tributário, $\mathrm{n}^{\circ}$ 117. São Paulo: Dialética, jun./2005, pp. 108-23.

COÊLHO, Sacha Calmon Navarro e MANEIRA, Eduardo. Os Retrocessos da Lei Complementar $n^{o}$ 102, de 11.07.2000. ROCHA, Valdir de Oliveira (coord.). O ICMS e a LC 102. São Paulo: Dialética, 2000, pp. 207-22.

CONSELHO DE IMPOSTOS DA FRANÇA. XIX Relatório ao Presidente da RepúblicaImposto sobre o Valor Agregado. Trad. por DERZI, Misabel Abreu Machado e LOBATO, Valter de Souza. Revista Internacional de Direito Tributário $n^{\circ} 2$. Belo Horizonte: Del Rey, jul.-dez./2004, pp. 395-598.

COSTA, Alcides Jorge. ICM na Constituição e na Lei Complementar. São Paulo: Resenha Tributária, 1978.

COSTA, Alcides Jorge. O Decreto-lei $n^{o} 491 / 1969$ Não Cria Incentivos, Apenas Remove Obstáculos. Crédito-Prêmio de IPI - Estudos e Pareceres III. Barueri: Manole, 2005, pp. 115-30.

COSTA, José Manuel Moreira Cardoso da. Curso de Direito Fiscal, $2^{\mathrm{a}}$ ed. Coimbra: Almedina, 1972. 
DENARI, Zelmo. Curso de Direito Tributário, 2a ed. Rio de Janeiro: Forense, 1991.

DERZI, Misabel Abreu Machado. A Necessidade da Instituição do IVA no Sistema Constitucional Tributário Brasileiro. BALTHAZAR, Ubaldo César (org.). Reforma Tributária e Mercosul - a Instituição do IVA no Direito Brasileiro. Belo Horizonte: Del Rey, 1999, pp. 17-30.

DERZI, Misabel Abreu Machado. Construindo o Direito Tributário na Constituição Uma Análise da Obra do Ministro Carlos Mário Velloso. Belo Horizonte: Del Rey, 2004.

DERZI, Misabel Abreu Machado. Direito Tributário, Direito Penal e Tipo. São Paulo: Revista dos Tribunais, 1988.

DERZI, Misabel Abreu Machado. Modificações da Jurisprudência no Direito Tributário. São Paulo: Noeses, 2009.

DERZI, Misabel Abreu Machado. Quebras da Livre Concorrência no ICMS, no IPI e PISCOFINS: Corporativismo, Informalidade, Ampla Cumulatividade Residual e Substituição Tributária. Revista Internacional de Direito Tributário nº 3. Belo Horizonte: Del Rey, jan.jun./2005, pp. 103-17.

DERZI, Misabel Abreu Machado e COÊLHO, Sacha Calmon Navarro. ICMS - Direito ao Creditamento - Princípio da Não-Cumulatividade. Revista Dialética de Direito Tributário, $n^{\circ}$ 102. São Paulo: Dialética, mar./2004, pp. 141-56.

DERZI, Misabel Abreu Machado e COÊLHO, Sacha Calmon Navarro. Intributabilidade do Serviço de Transporte Prestado a Si Mesmo e o Direito aos Créditos Relativos ao Imposto Pago na Aquisição de Insumos. Belo Horizonte, abr./2000, inédito.

DERZI, Misabel Abreu Machado e COÊLHO, Sacha Calmon Navarro. O Direito ao Aproveitamento dos Créditos de ICMS, PIS e COFINS Relativos a Materiais e Serviços Utilizados na Exploração, Desenvolvimento e Produção do Petróleo Bruto. Belo Horizonte, ago./2008, inédito.

DERZI, Misabel Abreu Machado e COÊLHO, Sacha Calmon Navarro. O Direito do Sujeito Passivo do ICMS de Compensar o Imposto Pago a Maior, em Razão da Técnica da 
Substituição Tributária Progressiva. Revista Dialética de Direito Tributário, nº 101. São Paulo: Dialética, fev./2004, pp. 115-35.

DERZI, Misabel Abreu Machado e COÊLHO, Sacha Calmon Navarro. PIS/Cofins. Regime de Crédito. Contratos de Longo Prazo. Instrução Normativa no 468/04 da SRF. Ilegalidade. Revista Dialética de Direito Tributário, no 114. São Paulo: Dialética, mar./2005, pp. 121-37.

DERZI, Misabel Abreu Machado e SANTIAGO, Igor Mauler. A Harmonização dos IVAs no Brasil para o Desenvolvimento Produtivo. SARAIVA FILHO, Oswaldo Othon; VASQUES, Sérgio; GUIMARÃES, Vasco Branco (org.). IVA para o Brasil - Contributos para a Reforma da Tributação do Consumo. São Paulo: Fórum, 2007, pp. 527-51.

DIAMANTE, Flávio. ICM - Introdução à Análise da Sistemática - Uma Abordagem Estruturalista, $2^{\mathrm{a}}$ ed. Belo Horizonte: MAI, 1974.

DINIZ, Maria Helena. Conflito de Normas, $7^{\mathrm{a}}$ ed. São Paulo: Saraiva, 2007.

DINIZ, Marianita Ribeiro; ALMEIDA, Cristina Beatriz de Sousa; PERES, Adriana Manni; VIANA, Ivo Ribeiro. Como Utilizar Créditos Fiscais do IPI, PIS/COFINS e ICMS/SP. São Paulo: IOB Thomson, 2005.

DWORKIN, Ronald. Levando os Direitos a Sério. Trad. por BOEIRA, Nelson. São Paulo: Martins Fontes, 2002.

DUE, John F. Indirect Taxation in Developing Economies. Baltimore, London: Johns Hopkins, 1970.

EBRILL, Liam; KEEN, Michael; BODIN, Jean-Paul; SUMMERS, Victoria. The Modern VAT. Washington: International Monetary Fund, 2001.

ESTURILIO, Regiane Binhara. A Seletividade no IPI e no ICMS. São Paulo: Quartier Latin, 2008.

FALCÃO, Amílcar de Araújo. Fato Gerador da Obrigação Tributária, $2^{\mathrm{a}}$ ed. Atualizado por GERALDO ATALIBA. São Paulo: Revista dos Tribunais, 1971. 
FERRAZ JR., Tércio Sampaio. Crédito-Prêmio de IPI e Incentivo Fiscal Setorial: da Inaplicabilidade do Art. 41 do ADCT da CF/1988. Crédito-Prêmio de IPI - Estudos e Pareceres III. Barueri: Manole, 2005, pp. 33-52.

FERRAZ JR., Tércio Sampaio. Introdução ao Estudo do Direito - Técnica, Decisão, Dominação, $5^{\text {a }}$ ed. São Paulo: Atlas, 2007.

FERREIRO LAPATZA, José Juan. Curso de Derecho Financiero Español, 12a ed. Madrid: Marcial Pons, 1990.

FERREIRO LAPATZA, José Juan. Direito Tributário - Teoria Geral do Tributo. Barueri: Manole; Madrid: Marcial Pons, 2007.

FONROUGE, Carlos María Giuliani. Conceitos de Direito Tributário. Trad. por ATALIBA, Geraldo e GRECO, Marco Aurélio. São Paulo: Lael, 1973.

FONROUGE, Carlos María Giuliani. Derecho Financiero, v. I, $8^{\mathrm{a}}$ ed. Buenos Aires: Depalma, 2003.

GAMA, Tácio Lacerda. Competência Tributária - Fundamentos para uma Teoria da Nulidade. São Paulo: Noeses, 2009.

GARCÍA BELSUNCE, Horacio A. El Concepto de Crédito en la Doctrina y en el Derecho Tributario. Buenos Aires: Depalma, 1967.

GIANNINI, Achille Donato. I Concetti Fondamentali del Diritto Tributario. Torino: Torinese, 1956.

GOSSON, Grace Christine de Oliveira. COFINS na Prestação de Serviços: Violação do Princípio Constitucional da Isonomia. PEIXOTO, Marcelo Magalhães e FISCHER, Octavio Campos (coord.). PIS-COFINS - Questões Atuais e Polêmicas. São Paulo: Quartier Latin, 2005, pp. 448-70.

GRECO, Marco Aurélio. A Não-Cumulatividade das Contribuições COFINS/PIS. Revista de Estudos Tributários, no 41. Porto Alegre: Síntese, jan.-fev./2005, pp. 125-40. 
GRIZIOTTI, Benvenuto. Principios de Ciencia de las Finanzas. Buenos Aires: Depalma, 1959.

GUIMARÃES, Vasco Branco. A Responsabilidade Civil da Administração Fiscal Emergente da Obrigação de Pagar Imposto. Belo Horizonte: Fórum, 2007.

GUIMARÃES, Vasco Branco. A Tributação do Consumo no Brasil - uma Visão Européia. SARAIVA FILHO, Oswaldo Othon; VASQUES, Sérgio; GUIMARÃES, Vasco Branco (org.). IVA para o Brasil - Contributos para a Reforma da Tributação do Consumo. São Paulo: Fórum, 2007, pp. 37-68.

HENSEL, Albert. Diritto Tributario. Trad. para o italiano de Dino Jarach. Milano: Giuffrè, 1956.

HURD, Heidi M. Interpretando as Autoridades. MARMOR, Andrei (coord.). Direito e Interpretação. São Paulo: Martins Fontes, 2004, pp. 609-50.

JARACH, Dino. El Hecho Imponible, 2a ed. Buenos Aires: Abeledo-Perrot, 1971.

KEEN, Michael; EBRILL, Liam; BODIN, Jean-Paul; SUMMERS, Victoria. The Modern VAT. Washington: International Monetary Fund, 2001.

KELSEN, Hans. Teoria Pura do Direito, $7^{\mathrm{a}}$ ed. Trad. por MACHADO, João Baptista. São Paulo: Martins Fontes, 2006.

KELSEN, Hans. Teoria Geral do Direito e do Estado, 4ª ed. Trad. por BORGES, Luís Carlos. São Paulo: Martins Fontes, 2005.

LAFERRIÉRE, Julien e WALINE, Marcel. Traité Élémentaire de Science et de Législation Financiéres. Paris: Librairie generale de droit et de jurisprudence, 1952.

LECERCLÉ, Marcel e ALLIX, Edgard. L'Impôt sur Le Revenú, Impôts Cédulaires et Impôt Général. Les Nouvelles Dispositions Législatives, v. I. Paris: Rousseau, 1926.

LIPO, Luiz Francisco e MELO, José Eduardo Soares de. A Não-Cumulatividade Tributária (ICMS, IPI, ISS, PIS e COFINS), $2^{\text {a }}$ ed. São Paulo: Dialética, 2004. 
LOBATO, Valter e COÊLHO, Sacha Calmon Navarro. Reflexões Sobre o Art. $3^{\circ}$ da Lei Complementar 118. Segurança Jurídica e a Boa-fé como Valores Constitucionais. As Leis Interpretativas no Direito Tributário Brasileiro. Revista Dialética de Direito Tributário, $\mathrm{n}^{\circ}$ 117. São Paulo: Dialética, jun./2005, pp. 108-23.

LUNARDELLI, Pedro Guilherme Accorsi. A Não-Cumulatividade do ICMS - uma Aplicação da Teoria sobre as Regras do Direito e as Regras dos Jogos. São Paulo: Quartier Latin, 2009.

LUNARDELLI, Pedro Guilherme Accorsi. Operações com Energia Elétrica e Serviços de Comunicação - Retorno ao Tema dos Créditos Físicos e Financeiros. ROCHA, Valdir de Oliveira (coord.). O ICMS e a LC 102. São Paulo: Dialética, 2000, pp. 179-94.

MACHADO, Brandão. Repetição do Indébito no Direito Tributário. MACHADO, Brandão (coord.). Direito Tributário - Estudos em Homenagem ao Prof. Ruy Barbosa Nogueira. São Paulo: Saraiva, 1984, pp. 61-106.

MACHADO, Hugo de Brito. Imposto Indireto, Restituição do Indébito e Imunidade Subjetiva. Revista Dialética de Direito Tributário, no 2. São Paulo: Dialética, nov./1995, pp. 325.

MACHADO, Hugo de Brito. Repetição do Indébito Tributário. MARTINS, Ives Gandra da Silva (coord.). Caderno de Pesquisas Tributárias, $n^{\circ} 8$ - Repetição do Indébito. São Paulo: Resenha Tributária, 1983, pp. 231-51.

MACHADO, Hugo de Brito. Virtudes e Defeitos da Não-Cumulatividade no Sistema Tributário Brasileiro. MARTINS, Ives Gandra da Silva (coord.). Caderno de Pesquisas Tributárias $n^{\circ} 10$ (nova série) - O Princípio da Não-Cumulatividade. São Paulo: Revista dos Tribunais/Centro de Extensão Universitária, 2004, pp. 68-104.

MACHADO, Raquel Cavalcanti Ramos e MACHADO SEGUNDO, Hugo de Brito. Breves Anotações sobre a Incidência do PIS e da COFINS na Importação. GAUDÊNCIO, Samuel Carvalho e PEIXOTO, Marcelo Magalhães (coord). Fundamentos do PIS e da COFINS e o Regimento Jurídico da Não-Cumulatividade. São Paulo: MP Editora, 2007, pp. 247-65. 
MACHADO, Schubert de Farias. A Lei Complementar 102/2000, a Autonomia dos Estabelecimentos e a Transferência de Crédito de ICMS. ROCHA, Valdir de Oliveira (coord.). O ICMS e a LC 102. São Paulo: Dialética, 2000, pp. 225-35.

MACHADO SEGUNDO, Hugo de Brito e MACHADO, Raquel Cavalcanti Ramos. Breves Anotações sobre a Incidência do PIS e da COFINS na Importação. GAUDÊNCIO, Samuel Carvalho e PEIXOTO, Marcelo Magalhães (coord). Fundamentos do PIS e da COFINS e o Regimento Jurídico da Não-Cumulatividade. São Paulo: MP Editora, 2007, pp. 247-65.

MANEIRA, Eduardo. Considerações sobre o art. 166 do CTN e a Não-cumulatividade das Contribuições ao PIS e à COFINS. Revista Dialética de Direito Tributário, $\mathrm{n}^{\circ} 124$. São Paulo: Dialética, jan./2006, pp. 42-7.

MANEIRA, Eduardo. Da Substituição Tributária Para a Frente no ICMS. Revista Dialética de Direito Tributário, nº 95. São Paulo: Dialética, ago./2003, pp. 56-64.

MANEIRA, Eduardo. Direito Tributário - Princípio da Não-Surpresa. Belo Horizonte: Del Rey, 1994.

MANEIRA, Eduardo e COÊLHO, Sacha Calmon Navarro. Os Retrocessos da Lei Complementar $n^{o}$ 102, de 11.07.2000. ROCHA, Valdir de Oliveira (coord.). O ICMS e a LC 102. São Paulo: Dialética, 2000, pp. 207-22.

MARINS, James e BERTOLDI, Marcelo M. Simples Nacional - Estatuto da Microempresa e da Empresa de Pequeno Porte Comentado. São Paulo: Revista dos Tribunais, 2007.

MARION, José Carlos. Contabilidade Básica. 9. ed. São Paulo: Atlas, 2008.

MARTINS, Ives Gandra da Silva. O Princípio da Não-Cumulatividade do ICM. A Imunidade Constitucional para a Exportação de Produtos Industrializados. A Interpretação Extensiva do Instituto. O Direito ao Aproveitamento dos Créditos Escriturais. Parecer. Estudos Outros Tributos, nº 2: IR - IPI - ICM - IMP. - EXP. - IOF. São Paulo: Resenha Tributária, mar./91, pp. 11-70. 
MARTINS, Ives Gandra da Silva. O Princípio da Não-Cumulatividade e os Princípios da Subvenção Pública e da Neutralidade. MACHADO, Hugo de Brito (coord.). NãoCumulatividade Tributária. São Paulo: Dialética; Fortaleza: ICET, 2009, pp. 241-52.

MARTINS, Ives Gandra da Silva. O Princípio da Não-Cumulatividade - O Direito à Compensação Periódica de ICMS nas Operações Próprias e de Substituição Tributária. Revista Dialética de Direito Tributário, nº 14. São Paulo: Dialética, nov./1996, pp. 76-87.

MARTINS, Ives Gandra da Silva. O Sistema Tributário na Constituição, $6^{\text {a }}$ ed. São Paulo: Saraiva, 2007.

MARTINS, Ives Gandra da Silva e SOUZA, Fátima Fernandes Rodrigues de. PIS/PASEP e COFINS Importação: Inconstitucionalidades. PEIXOTO, Marcelo Magalhães e FISCHER, Octavio Campos (coord.). PIS-COFINS - Questões Atuais e Polêmicas. São Paulo: Quartier Latin, 2005, pp. 149-73.

MATTOS, Aroldo Gomes de. ICMS - Comentários à Legislação Nacional. São Paulo: Dialética, 2006.

MAXIMILIANO, Carlos. Hermenêutica e Aplicação do Direito, $19^{\mathrm{a}}$ ed. Rio de Janeiro: Forense, 2002.

MAYER, Otto. Deutsches Verwaltungsrecht, v. I, $3^{\mathrm{a}}$ ed. Miinchen: Duncker \& Humblot, 1914.

MELO, José Eduardo Soares de. ICMS - Teoria e Prática, 10ª ed. São Paulo: Dialética, 2008 .

MELO, José Eduardo Soares de e BOTTALLO, Eduardo Domingos. Comentários às Súmulas Tributárias do STF e do STJ. São Paulo: Quartier Latin, 2007.

MELO, José Eduardo Soares de e LIPO, Luiz Francisco. A Não-Cumulatividade Tributária (ICMS, IPI, ISS, PIS e COFINS), 2a ed. São Paulo: Dialética, 2004.

MENDONÇA, Christine. A Não-Cumulatividade do ICMS. São Paulo: Quartier Latin, 2005. 
MERCIER, Jean-Yves e PLAGNET, Bernard. Les Impôts em France, 29a ed. Levallois: Francis Lefebvre, 1997.

MILL, John Stuart. Principles of Political Economy. New York: Prometheus Books, 2004.

MIRANDA, Jorge. Teoria do Estado e da Constituição. Rio de Janeiro: Forense, 2007.

MOREIRA, André Mendes. Da Compensação de Tributos Administrados pela Receita Federal - Evolução Legislativa e Modalidades. Revista Dialética de Direito Tributário, ${ }^{\circ}$ 95. São Paulo: Dialética, ago./2003, pp. 7-17.

MORSHBACHER, José. Repetição do Indébito Tributário Indireto. São Paulo: Revista dos Tribunais, 1984.

MORSHBACHER, José. Repetição do Indébito Tributário Indireto, $3^{\mathrm{a}}$ ed. São Paulo: Dialética, 1998.

NABAIS, José Casalta. Direito Fiscal, 2a ed. Coimbra: Almedina, 2004.

NEVIANI, Tarcísio. Repetição do Indébito. MARTINS, Ives Gandra da Silva (coord.). Caderno de Pesquisas Tributárias, no 8 - Repetição do Indébito. São Paulo: Resenha Tributária, 1983, p. 303-37.

NOGUEIRA, Ruy Barbosa. Curso de Direito Tributário, 10ª ed. São Paulo: Saraiva, 1990.

NOGUEIRA, Ruy Barbosa. Direito Tributário Comparado. São Paulo: Saraiva, 1971.

OGLEY, Adrian. Principles of Value Added Tax - a European Perspective. London: Interfisc Publishing, 1998.

OLIVEIRA, Ricardo Mariz de. Visão Geral sobre a Cumulatividade e a Nãocumulatividade (Tributos com Incidência Única ou Múltipla), e a "Não-cumulatividade" da Cofins e da Contribuição ao PIS. MACHADO, Hugo de Brito (coord.). São Paulo: Dialética; Fortaleza: ICET, 2009, pp. 423-48.

OLIVEIRA, Waldemar de. Regulamento do Imposto sobre Produtos Industrializados. São Paulo: FISCOSoft, 2008. 
PALMA, Clotilde Celorico. A Harmonização Comunitária do Imposto sobre o Valor Acrescentado: Quo Vadis. SARAIVA FILHO, Oswaldo Othon; VASQUES, Sérgio; GUIMARÃES, Vasco Branco (org.). IVA para o Brasil - Contributos para a Reforma da Tributação do Consumo. São Paulo: Fórum, 2007, pp. 175-220.

PEREIRA, João Luis de Souza. PIS/COFINS na Importação: Necessidade de Alíquotas Variáveis em Homenagem ao Princípio da Capacidade Contributiva. GAUDÊNCIO, Samuel Carvalho e PEIXOTO, Marcelo Magalhães (coord). Fundamentos do PIS e da COFINS e o Regimento Jurídico da Não-Cumulatividade. São Paulo: MP Editora, 2007, pp. 295-309.

PERES, Adriana Manni; ALMEIDA, Cristina Beatriz de Sousa; VIANA, Ivo Ribeiro; DINIZ, Marianita Ribeiro. Como Utilizar Créditos Fiscais do IPI, PIS/COFINS e ICMS/SP. São Paulo: IOB Thomson, 2005.

PÉREZ DE AYALA, José Luis. Explicación de la Técnica de los Impuestos, $3^{\mathrm{a}}$ ed. Madrid: Editoriales de Derecho Reunidas, 1981.

QUESNAY, François. The Economical Table. Honolulu: University Press of the Pacific, 2004.

RABELLO FILHO, Francisco Pinto. Consideração do ISS como Imposto Direto ou Indireto, para Efeito de Repetição do Indébito Tributário: Breve Revisitação do Tema. Revista Tributária e de Finanças Públicas, nº 55. São Paulo: Revista dos Tribunais, mar.-abr./2004, pp. $145-57$.

RACTZ, Juliana. A Inclusão da Energia Elétrica na Base de Cálculo do Crédito Presumido do IPI. BRASIL JR., Vicente (coord.). IPI - Questões Atuais. Curitiba: Juruá, 2008, pp. 117-32.

RÁO, Vicente. O Direito e a Vida dos Direitos, $6^{\mathrm{a}}$ ed. São Paulo: Revista dos Tribunais, 2004.

REIS, Maria Lúcia Américo e BORGES, José Cassiano. O IPI ao Alcance de Todos. Rio de Janeiro: Revista Forense, 1999. 
RIBEIRO, José Joaquim Teixeira. Lições de Finanças Públicas, $5^{\mathrm{a}}$ ed. Coimbra: Coimbra Editora, 1995.

ROSA JR., Luiz Emygdio F. da. Manual de Direito Financeiro e Direito Tributário, $18^{\mathrm{a}}$ ed. Rio de Janeiro: Renovar, 2005.

ROSEN, Harvey S. Public Finance, $4^{\mathrm{a}}$ ed. Chicago: Irwin, 1995.

SAINZ DE BUJANDA, Fernando. Lecciones de Derecho Financiero, $6^{\mathrm{a}}$ ed. Madrid: Facultad de Derecho Universidad Complutense, 1998.

SANTIAGO, Igor Mauler e DERZI, Misabel Abreu Machado. A Harmonização dos IVAs no Brasil para o Desenvolvimento Produtivo. SARAIVA FILHO, Oswaldo Othon; VASQUES, Sérgio; GUIMARÃES, Vasco Branco (org.). IVA para o Brasil - Contributos para a Reforma da Tributação do Consumo. São Paulo: Fórum, 2007, pp. 527-51.

SANTIAGO, Igor Mauler. Empresas de Telefonia Fixa e Móvel. Direito ao Creditamento do ICMS Incidente sobre a Energia Utilizada na Prestação dos Serviços de Comunicação. MOREIRA, André Mendes; RABELO FILHO, Antonio Reinaldo; CORREIA, Armênio Lopes (coord.). Direito das Telecomunicações e Tributação. São Paulo: Quartier Latin, 2006, pp. 210-19.

SILVA, José Afonso da. Aplicabilidade das Normas Constitucionais, $7^{\mathrm{a}}$ ed. São Paulo: Malheiros, 2007.

SELIGMAN, Edwin Robert Anderson. The Shifting and Incidence of Taxation, $3^{\text {rd }}$ ed. New York: Columbia University Press, 1910.

SILVA, Paulo Roberto Coimbra. A Substituição Tributária Progressiva nos Impostos Plurifásicos e Não-cumulativos. Belo Horizonte: Del Rey, 2001.

SILVEIRA, Lindemberg da Mota. Repetição do Indébito. MARTINS, Ives Gandra da Silva (coord.). Caderno de Pesquisas Tributárias, no 8 - Repetição do Indébito. São Paulo: Resenha Tributária, 1983, pp. 59-86.

SMITH, Adam. Uma Investigação sobre a Natureza e Causas da Riqueza das Nações, $2^{\mathrm{a}}$ ed. Trad. por LIMA, Norberto de Paula. São Paulo: Hemus, 1981, p. 475. 
SUMMERS, Victoria; EBRILL, Liam; KEEN, Michael; BODIN, Jean-Paul. The Modern VAT. Washington: International Monetary Fund, 2001.

SZKLAROWSKY, Leon Frejda. Repetição do Indébito. MARTINS, Ives Gandra da Silva (coord.). Repetição do Indébito - Caderno de Pesquisas Tributárias, ${ }^{\circ}$ 8. São Paulo: Resenha Tributária, 1983, pp. 18-57.

TEBECHRANI, Alberto. Novo Regulamento do Imposto de Renda, v. I. São Paulo: Resenha Gráfica, 1999.

TOLEDO, José Eduardo Tellini. IPI - Incidência Tributária e Princípios Constitucionais. São Paulo: Quartier Latin, 2006.

TÔRRES, Heleno Taveira. O IVA na Experiência Estrangeira e a Tributação das Exportações no Direito Brasileiro. SARAIVA FILHO, Oswaldo Othon Pontes de; VASQUES, Sérgio; GUIMARÃES, Vasco Branco (org.). IVA para o Brasil - Contributos para a Reforma da Tributação do Consumo. Belo Horizonte: Fórum, 2007, pp. 69-88.

TORRES, Ricardo Lobo. A Não-Cumulatividade no PIS/COFINS. PEIXOTO, Marcelo Magalhães e FISCHER, Octavio Campos (coord.). PIS-COFINS - Questões Atuais e Polêmicas. São Paulo: Quartier Latin, 2005, pp. 53-74.

TORRES, Ricardo Lobo. É Possível a Criação do IVA no Brasil?. SARAIVA FILHO, Oswaldo Othon Pontes de; VASQUES, Sérgio; GUIMARÃES, Vasco Branco (org.). IVA para o Brasil - Contributos para a Reforma da Tributação do Consumo. Belo Horizonte: Fórum, 2007, pp. 19-36.

TORRES, Ricardo Lobo. Restituição dos Tributos, $1^{\text {a }}$ ed. Rio de Janeiro: Forense, 1983.

VERGUEIRO, Guilherme Von Müller Lessa. A Inconstitucionalidade da COFINS: Ofensa à Isonomia. PEIXOTO, Marcelo Magalhães e FISCHER, Octavio Campos (coord.). PISCOFINS - Questões Atuais e Polêmicas. São Paulo: Quartier Latin, 2005, pp. 395-410.

VIANA, Ivo Ribeiro; DINIZ, Marianita Ribeiro; ALMEIDA, Cristina Beatriz de Sousa; PERES, Adriana Manni. Como Utilizar Créditos Fiscais do IPI, PIS/COFINS e ICMS/SP. São Paulo: IOB Thomson, 2005. 
VILLEGAS, Hector Belisario. Curso de Finanzas, Derecho Financiero y Tributario, $8^{\mathrm{a}}$ ed. Buenos Aires: Astrea, 2003.

VOLKWEISS, Roque Joaquim. Direito Tributário Nacional, $2^{\mathrm{a}}$ ed. Porto Alegre: Livraria do Advogado, 1998.

WALINE, Marcel e LAFERRIÉRE, Julien. Traité Élémentaire de Science et de Législation Financiéres. Paris: Librairie generale de droit et de jurisprudence, 1952.

WONNACOT, Ronald e WONNACOT, Paul. Introdução à Economia. Trad. por CRUSIUS, Yeda e CRUSIUS, Carlos Augusto. São Paulo: McGraw-Hill do Brasil, 1985.

WONNACOT, Paul e WONNACOT, Ronald. Introdução à Economia. Trad. por CRUSIUS, Yeda e CRUSIUS, Carlos Augusto. São Paulo: McGraw-Hill do Brasil, 1985.

XAVIER, Alberto Pinheiro. Direito Tributário Internacional do Brasil, $4^{\mathrm{a}}$ ed. Rio de Janeiro: Forense, 1998.

XAVIER, Alberto Pinheiro. Regime Constitucional das Isenções e Incentivos Fiscais às Exportações: o Caso do ICMS. Do Direito à Utilização Integral de Saldo Acumulado de Créditos de ICMS como corolário da Imunidade das Exportações. TORRES, Heleno Taveira (coord.). Tratado de Direito Constitucional Tributário: estudos em homenagem a Paulo de Barros Carvalho. São Paulo: Saraiva, 2005, pp. 597-623.

YAMASHITA, Douglas e AMARAL, Antonio Carlos Rodrigues do. PIS e COFINS sobre a Importação de Produtos: Ilegalidades e Inconstitucionalidades. PEIXOTO, Marcelo Magalhães e FISCHER, Octavio Campos (coord.). PIS-COFINS - Questões Atuais e Polêmicas. São Paulo: Quartier Latin, 2005, pp. 273-86.

ZANOBINI, Guido. Corso di Diritto Amministrativo, v. IV. Milano: Giuffrè, 1955. 